\title{
Philo of Alexandria's Exposition of the Tenth Commandment
}

Hans Svebakken

Loyola University Chicago

Follow this and additional works at: https://ecommons.luc.edu/luc_diss

Part of the Biblical Studies Commons

\section{Recommended Citation}

Svebakken, Hans, "Philo of Alexandria's Exposition of the Tenth Commandment" (2009). Dissertations. 244.

https://ecommons.luc.edu/luc_diss/244

This Dissertation is brought to you for free and open access by the Theses and Dissertations at Loyola eCommons. It has been accepted for inclusion in Dissertations by an authorized administrator of Loyola eCommons. For more information, please contact ecommons@luc.edu. (c) (i) $\Theta \Theta$

This work is licensed under a Creative Commons Attribution-Noncommercial-No Derivative Works 3.0 License. Copyright @ 2009 Hans Svebakken 
LOYOLA UNIVERSITY CHICAGO

PHILO OF ALEXANDRIA'S EXPOSITION OF THE TENTH COMMANDMENT

\author{
A DISSERTATION SUBMITTED TO \\ THE FACULTY OF THE GRADUATE SCHOOL \\ IN CANDIDACY FOR THE DEGREE OF \\ DOCTOR OF PHILOSOPHY
}

PROGRAM IN THEOLOGY

BY

HANS RICHARD SVEBAKKEN

CHICAGO, ILLINOIS

DECEMBER 2009 
Copyright by Hans R. Svebakken, 2009

All rights reserved. 


\section{ACKNOWLEDGEMENTS}

Work on this project began in earnest during my year as a Schmitt Dissertation Fellow (2004 - 2005). I want to thank both the Arthur J. Schmitt Foundation for its financial support and the Graduate School of Loyola University Chicago for awarding the fellowship.

Many people have helped me through my years at Loyola. First, I want to thank the faculties of Classical Studies and Theology for generously sharing their expertise and equipping me to complete a doctoral dissertation. (Two Professors no longer at Loyola, David E. Aune and John L. White, deserve thanks as well.) In particular, I want to thank my two readers, Professors Robert Di Vito and James Keenan, who taught me much in the course of my studies and thoughtfully reviewed my work. Most of all, I want to thank Professor Thomas Tobin, S.J., the director of my dissertation, whose Hellenistic Judaism seminar sparked my interest in Philo. At every critical juncture of the process, his expert

guidance has invariably steered me toward a better outcome. I want to thank also my graduate student colleagues, too many to name, whose friendship and conversation have encouraged me professionally and personally. Finally, I want to thank Catherine Wolf, Administrative Assistant for the Theology Department, 
for having a friendly answer to all of my questions, and the Interlibrary Loan staff of Cudahy Library for greatly facilitating my research.

I have a large extended family, and each member-in his or her own way-deserves a personal word of thanks. But for the sake of brevity l'll mention only my family of origin, who first welcomed me into the world. My brother, Pete, and sister, Khris, my first and oldest friends, have never questioned my choice of a meandering academic career, and I appreciate their confidence. My father, Gene, has also been a great encouragement, and I will remember fondly the extra time we spent together as a result of my education in the Chicago area. My mother, Kay, gave me a gift of love that continues to shape my life. Sadly, she did not live to see me complete this degree, but I can well imagine her happy words and congratulations.

Two people inspire everything I do. My wife, Mary Jane, graciously welcomed Philo into our lives and supported this project in every possible way. I cannot begin to express the value of her unfailing encouragement. Our son, Elias, arrived in the course of chapter four, and the extraordinary joy he brought into our lives helped carry me over the finish line.

This has been a long journey, and I consider its completion a great blessing. Unsure of how to express my deepest sense of gratitude, I'll let Philo have the last word, in honor of our many hours together: "It is for God to give benefits and for mortals to give thanks, since they have nothing else to give in return" (Plant. 130). 
Behold me daring, not only to read the sacred messages of Moses, but also in my love of knowledge to peer into each of them and unfold and reveal what is not known to the multitude.

Philo of Alexandria, De specialibus legibus 3.6 


\section{TABLE OF CONTENTS}

ACKNOWLEDGEMENTS iii

LIST OF TABLES viii

LIST OF ABBREVIATIONS IX

CHAPTER ONE: INTRODUCTION

PHILO'S COMMENTARY ON MOSAIC LEGISLATION 2

PHILO'S EXPOSITION OF THE TENTH COMMANDMENT 9

THE VALUE OF PHILO'S EXPOSITION 13

HISTORY OF RESEARCH

Harry A. Wolfson $\quad 18$

Kathy L. Gaca 23

PLAN OF THE DISSERTATION 38

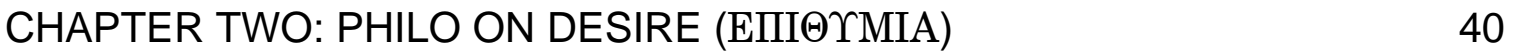

INTRODUCTION $\quad 40$

PhILO'S MIDDLE-PlatoniC CONTEMPORARIES

"IRRATIONAL" AND "NON-RATIONAL" IN MORAl PSYCHOLOGY

PLATONIC FOUNDATIONS $\quad 45$

Bipartition In MiddLE Platonism 48

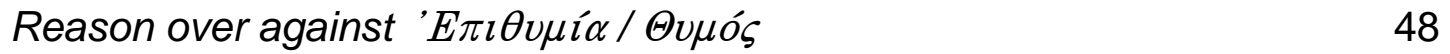

Reason over against Appetite (ö $\rho \xi l \varsigma) \quad 50$

Reason over against Impulse ( $\delta \rho \mu \eta)$

Reason over against Emotion ( $\pi \dot{\alpha} \theta 0 \varsigma) \quad 57$

Summary $\quad 59$

BIPARTITION IN PHILO's WRITINGS 60

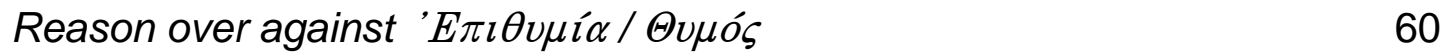

Reason over against Appetite (ö $\left.\rho \xi_{l \varsigma}\right) \quad 62$

Reason over against Impulse ( $о \rho \mu \eta) \quad 65$

Reason over against Emotion ( $\pi \alpha \dot{\theta} \theta \varsigma$ ) 69

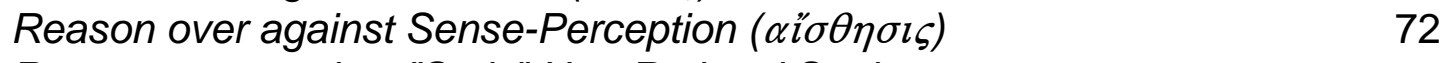

Reason over against "Stoic" Non-Rational Soul 75

Summary $\quad 77$

Problematic Malfunctions of Desire $\quad 79$

Passionate Desire ( $\ddot{\alpha} \mu \epsilon \tau \rho o \varsigma \dot{\varepsilon} \pi \imath \theta v \mu i ́ \alpha) \quad 79$

Tyrannical Desire (๕̋ $\rho \omega \varsigma) \quad 87$

"E $\rho \omega \varsigma$ as Advanced Grade of Desire $\quad 89$

Negative Impact of "E $\rho \omega \varsigma \quad 93$

$\begin{array}{ll}\text { CONCLUSION } & 98\end{array}$

CHAPTER THREE: PHILO ON SELF-CONTROL (ENKPATEIA) AND PRACTICE $(\mathrm{A} \Sigma \mathrm{KH} \Sigma \mathrm{I} \Sigma)$ 


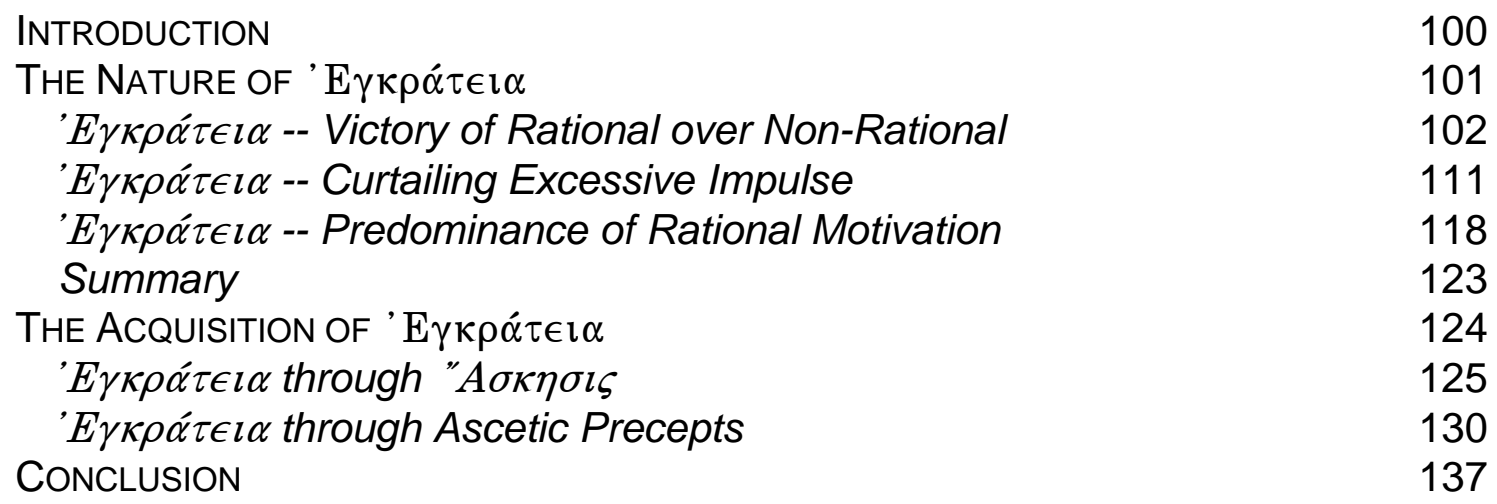

CHAPTER FOUR: PHILO'S EXPOSITION OF THE TENTH COMMANDMENT: TRANSLATION AND COMMENTARY 139

PHILO'S EXPOSITORY AGENDA 139

Traditional Interpretations of Clean and Unclean Animals 141

Contemporary Genres of Philosophical Literature 144

STRUCTURE OF PHILO'S EXPOSITION

TRANSLATION AND COMMENTARY 153

§78b: Introduction 153

§79: Problem: Every Passion 153

§79 Excursus: Parallel Material in Decal. 142-46 156

§§80 - 83: Overview of Tyrannical Desire 159

§§80 - 83 Excursus: Parallel Material in Decal. 146-50 164

§§84 - 91: Tyrannical Desire as "Source of All IIIs" 169

§§84 - 91 Excursus: Parallel Material in Decal. 151-53 174

§§92 - 94: Location of 'E $E \iota \theta \mu i \alpha \quad 175$

§§95 - 97: Overview of Moses' "Paradigmatic Instruction" 179

§§98 - 99: First Fruits 185

§100 - 102: Introduction to Clean and Unclean Animals 187

§§103 - 109: Land Animals 196

§§110 - 112: Aquatic Animals 207

§§113 - 115: "Reptiles" 209

§§116 - 117: Birds 215

§118: Conclusion of Clean and Unclean Animals 217

§§119 - 121: Dead Animals $\quad 220$

§\$122 - 125: Blood and Fat 224

§126 - 131: Concluding Moral Narrative 228

CHAPTER FIVE: CONCLUSION 236

SUMMARY 236

LINES OF FURTHER RESEARCH 240

$\begin{array}{ll}\text { BIBLIOGRAPHY } & 244\end{array}$

$\begin{array}{ll}\text { VITA } & 281\end{array}$ 


\section{LIST OF TABLES}

Table

Page

1. Variations of Bipartition in Middle Platonism

60

2. Variations of Bipartition in Philo's Writings 


\section{LIST OF ABBREVIATIONS}

Abbreviations of primary sources are those of The SBL Handbook of Style (ed. Patrick H. Alexander et al.; Peabody, Mass.: Hendrickson, 1999), with the following exceptions:

\section{PRIMARY SOURCES}

Colson $\quad$ English trans. of Spec. 4 by F. H. Colson in vol. 8 of Philo. Translated by F. H. Colson et al. 12 vols. Loeb Classical Library. Cambridge: Harvard University Press, 1929-1962.

Didask. Didaskalikos by Alcinous. English trans. cited by ch. and sec. in The Handbook of Platonism. Translated with intro. and comm. by John Dillon. Oxford: Clarendon, 1993. Gk. text cited in brackets by p. [ed. Hermann, 1853] and line in Enseignement des doctrines de Platon. Edited with intro. and comm. by John Whittaker. Translated by Pierre Louis. 2d ed. Paris: Belles Lettres, 2002 (e.g., Didask. 32.4 [186.14-18]).

DL Diogenes Laertius, Lives of Eminent Philosophers. Translated by R. D. Hicks. 2 vols. Loeb Classical Library. Cambridge: Harvard University Press, 1925.

Eclog. Eclogae Physicae et Ethicae by loannes Stobaeus. Cited by p. and line in vol. 2 of Ioannes Stobaeus. Anthologii libri duo priores. 2 vols. Edited by Curt Wachsmuth. Berlin: Weidmann, 1884.

ESE Epitome of Stoic Ethics by Arius Didymus. Cited by sec. in Epitome of Stoic Ethics. Edited by Arthur J. Pomeroy. Texts and Translations 44. Greco-Roman Series 14. Atlanta: Society of Biblical Literature, 1999.

Heinemann German trans. of Spec. 4 by Isaak Heinemann in vol. 2 of Die Werke Philos von Alexandria in Deutscher Übersetzung. Edited by L. Cohn, I. Heinemann, et al. 7 vols. Breslau, Berlin 1909-1964. 
LS A. A. Long and D. N. Sedley. The Hellenistic Philosophers. 2 vols. Cambridge: Cambridge University Press, 1987. Texts cited by section number and text letter (e.g., 25B).

Mazz. Claudio Mazzarelli, "Raccolta e interpretazione delle testimonianze e dei frammenti del medioplatonico Eudoro di Alessandria: Parte prima: Testo e traduzione delle testimonianze e dei frammenti sicuri," Rivista di filosofia neo-scolastica 77 (1985): 197-209.

Mosès $\quad$ French trans. of Spec. 4 by André Mosès in vol. 25 of Les œuvres de Philon D'Alexandrie. Edited by R. Arnaldez, J. Pouilloux, C. Mondésert. Paris, 1961-92.

PAPM Les œuvres de Philon D'Alexandrie. Edited by R. Arnaldez, J. Pouilloux, C. Mondésert. Paris, 1961-92.

$\mathrm{PCH} \quad$ Die Werke Philos von Alexandria in Deutscher Übersetzung. Edited by L. Cohn, I. Heinemann, et al. 7 vols. Breslau, Berlin 1909-1964.

PCW Philonis Alexandrini opera quae supersunt. Edited by L. Cohn, P. Wendland, S. Reiter. 6 vols. Berlin ,1896-1915.

Petit $\quad$ Philon D'Alexandrie: Quæstiones: Fragmenta Græca. Edited and translated by Françoise Petit. Les œvres de Philon d'Alexandrie 33. Paris: Cerf, 1978.

PHP De Placitis Hippocratis et Platonis by Galen. Cited by bk., ch., and sec. in On the Doctrines of Hippocrates and Plato. Edited and trans. with comm. by Phillip De Lacy. 3 vols. $2 d$ ed. Corpus Medicorum Graecorum 5.4.1.2. Berlin: Akademie-Verlag, 1980-84.

PLCL Philo in Ten Volumes (and Two Supplementary Volumes). Translated by F. H. Colson, G. H. Whitaker (and R. Marcus). 12 vols. Loeb Classical Library. Cambridge: Harvard University Press, 1929-1962.

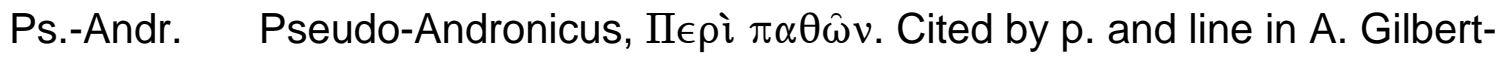
Thirry. Pseudo-Andronicus de Rhodes «IIEPI ПA $\Theta \Omega N »$ : Edition critique du texte grec et de la traduction latine médiévale. Corpus latinum commentariorum in Aristotelem graecorum. Supp. 2. Leiden: Brill, 1977. 
Ps.-Arch. Pseudo-Archytas, On Moral Education. Cited by p. [ed. Thesleff, 1965] and line in Pseudopythagorica Ethica: I trattati morali di Archita, Metopo, Teage, Eurifamo. Edited and translated by Bruno Centrone. Elenchos 17. Naples: Bibliopolis, 1990.

Ps.-Metop. Pseudo-Metopus, On Virtue. Cited by p. [ed. Thesleff, 1965] and line in Pseudopythagorica Ethica: I trattati morali di Archita, Metopo, Teage, Eurifamo. Edited and translated by Bruno Centrone. Elenchos 17. Naples: Bibliopolis, 1990.

Ps.-Theag. Pseudo-Theages, On Virtue. Cited by p. [ed. Thesleff, 1965] and line in Pseudopythagorica Ethica: I trattati morali di Archita, Metopo, Teage, Eurifamo. Edited and translated by Bruno Centrone. Elenchos 17. Naples: Bibliopolis, 1990.

SVF $\quad$ Stoicorum veterum fragmenta. $\mathrm{H}$. von Arnim. 4 vols. Leipzig, 1903-1924. Cited by vol., p., and line (e.g., III 113, 15).

TL Timaeus of Locri, On the Nature of the World and the Soul. Cited by paragraph in Timaios of Locri, On the Nature of the World and the Soul. Edited and trans. with notes by Thomas $\mathrm{H}$. Tobin. Texts and Translations 26. Greco-Roman Religion Series 8. Chico, Calif.: Scholars Press, 1985.

Troph. $^{\mathrm{B}} \quad \Pi \epsilon \rho \grave{\imath} \tau \rho \circ \phi \hat{\eta} \varsigma^{\mathrm{B}}$ by Musonius Rufus. Cited by $\mathrm{p}$. and line in Cora $\mathrm{E}$. Lutz. Musonius Rufus: The Roman Socrates. Yale Classical Studies 10. New Haven: Yale University Press, 1947.

\section{SECONDARY SOURCES}

AB

$A B D$

$A C P Q$

$A J P$

ALGHJ

AMMTC

AMP

ANRW

$A P$ ARGU ASE
Anchor Bible

Anchor Bible Dictionary. Edited by D. N. Freedman. 6 vols. New York, 1992.

American Catholic Philosophical Quarterly

American Journal of Philology

Arbeiten zur Literatur und Geschichte des hellensitischen Judentums

Ancient Mediterranean and Medieval Texts and Contexts Ancient and Medieval Philosophy

Aufstieg und Niedergang der römischen Welt: Geschichte und Kultur Roms im Spiegel der neueren Forschung. Edited by $\mathrm{H}$. Temporini and W. Haase. Berlin, 1972Ancient Philosophy Arbeiten zur Religion und Geschichte des Urchristentums Annali di storia dell'esegesi 


\begin{tabular}{|c|c|}
\hline$A S R$ & Annali di scienze religiose \\
\hline BBB & Bonner biblische Beiträge \\
\hline BEATAJ & $\begin{array}{l}\text { Beiträge zur Erforschung des Alten Testaments und des antiken } \\
\text { Judentum }\end{array}$ \\
\hline BJS & Brown Judaic Studies \\
\hline BThSt & Biblisch-Theologische Studien \\
\hline BU & Biblische Untersuchungen \\
\hline BZAW & Beihefte zur Zeitschrift für die alttestamentliche Wissenschaft \\
\hline CBQMS & Catholic Biblical Quarterly Monograph Series \\
\hline CCWJCW & $\begin{array}{l}\text { Cambridge Commentaries on Writings of the Jewish and Christian } \\
\text { World } 200 \mathrm{BC} \text { to } A D 200\end{array}$ \\
\hline CEC & Critical Essays on the Classics \\
\hline CJA & Christianity and Judaism in Antiquity \\
\hline$C Q$ & Classical Quarterly \\
\hline$C R$ & Classical Review \\
\hline CRINT & Compendia Rerum ludaicarum ad Novum Testamentum \\
\hline CSCP & Cornell Studies in Classical Philology \\
\hline CSP & Cornell Studies in Philosophy \\
\hline CUAPS & Catholic University of America Patristic Studies \\
\hline CWS & Classics of Western Spirituality. New York, 1978_- \\
\hline ELA & Études de littérature ancienne \\
\hline EPM & Études de philosophie médiévale \\
\hline ETL & Ephemerides Theologicae Lovanienses \\
\hline ETR & Études théologiques et religieuses \\
\hline EUSLR & Emory University Studies in Law and Religion \\
\hline FJCD & Forschungen zum jüdisch-christlichen Dialog \\
\hline GRBS & Greek, Roman, and Byzantine Studies \\
\hline GRRS & Greco-Roman Religion Series \\
\hline ABS & Herders Biblische Studien \\
\hline HCS & $\begin{array}{l}\text { Hellenistic Culture and Society. Anthony W. Bulloch, Erich S. } \\
\text { Gruen, A. A. Long, and Andrew F. Stewart, general editors. }\end{array}$ \\
\hline HPhQ & History of Philosophy Quarterly \\
\hline HSCP & Harvard Studies in Classical Philology \\
\hline HTR & Harvard Theological Review \\
\hline JACE & Jahrbuch für Antike und Christentum, Ergänzungsband \\
\hline$J B L$ & Journal of Biblical Literature \\
\hline JHS & Journal of Hellenic Studies \\
\hline$J J M L$ & Journal of Jewish Music and Liturgy \\
\hline JJS & Journal of Jewish Studies \\
\hline JLAS & Jewish Law Association Studies \\
\hline $\mathrm{JSH}$ & Journal of Sport History \\
\hline JSHRZ & Jüdische Schriften aus hellenistisch-römischer Zeit \\
\hline JSNT & Journal for the Study of the New Testament \\
\hline JSPSup & Journal for the Study of the Pseudepigrapha: Supplement Series \\
\hline JTS & Journal of Theological Studies \\
\hline
\end{tabular}




$\begin{array}{ll}\text { LTE } & \text { Library of Theological Ethics } \\ \text { MCL } & \text { Martin Classical Lectures } \\ \text { MSCRel } & \text { Mélanges de science religieuse } \\ \text { MdB } & \text { Le Monde de la Bible } \\ \text { MP } & \text { Museum Patavinum } \\ \text { NAWG } & \text { Nachrichten von der Akademie der Wissenschaften in Göttingen } \\ \text { NovT } & \text { Novum Testamentum } \\ \text { NovTSup } & \text { Supplements to Novum Testamentum } \\ \text { NTOA } & \text { Novum Testamentum et Orbis Antiquus } \\ \text { OBO } & \text { Orbis biblicus et orientalis } \\ \text { OPM } & \text { Oxford Philosophical Monographs } \\ \text { OTM } & \text { Oxford Theological Monographs } \\ \text { PA } & \text { Philosophia Antiqua } \\ \text { PASSV } & \text { Proceedings of the Aristotelian Society Supplementary Volume } \\ \text { PBACAP } & \text { Proceedings of the Boston Area Colloquium in Ancient Philosophy } \\ \text { Ph\&PhenR } & \text { Philosophy and Phenomenological Research } \\ \text { PhilSup } & \text { Philologus: Supplementband } \\ \text { PHR } & \text { Problèmes d'histoire des religions } \\ \text { REG } & \text { Revue des études grecques } \\ \text { REL } & \text { Revue des études latines } \\ \text { RKAM } & \text { Religion und Kultur der alten Mittelmeerwelt in Parallelforschungen } \\ \text { RM } & \text { Review of Metaphysics } \\ \text { RSR } & \text { Recherches de science religieuse } \\ \text { RTL } & \text { Revue théologique de Louvain } \\ \text { SA } & \text { Studia Anselmiana } \\ \text { SAP } & \text { Studien zur antiken Philosophie } \\ \text { SBLTT } & \text { Society of Biblical Literature Texts and Translations } \\ \text { SBS } & \text { Stuttgarter Biblestudien } \\ \text { ScES } & \text { Science et esprit } \\ \text { SCHNT } & \text { Studia ad corpus hellenisticum Novi Testamenti } \\ \text { ScrTh } & \text { Scripta Theologica } \\ \text { SF } & \text { Studi filosofici } \\ \text { SJPh } & \text { Southern Journal of Philosophy } \\ \text { SNTSMS } & \text { Society for New Testament Studies Monograph Series } \\ \text { SO } & \text { Symbolae Osloenses } \\ \text { SPh } & \text { Studia Philonica } \\ \text { SPhA } & \text { Studia Philonica Annual } \\ \text { SPhA } & \text { Studies in Philo of Alexandria } \\ \text { SPhAMA } & \text { Studies in Philo of Alexandria and Mediterranean Antiquity } \\ \text { SSEJC } & \text { Studies in Scripture in Early Judaism and Christianity } \\ \text { STA } & \text { Studia et Testimonia Antiqua } \\ \text { SUNT } & \text { Studien zur Umwelt des Neuen Testaments } \\ \text { TDNT } & \text { Theological Dictionary of the New Testament. Edited by G. Kittel } \\ & \text { and G. Friedrich. Translated by G. W. Bromily. 10 vols. Grand } \\ & \text { Rapids, 1964-1976. } \\ & \\ & \end{array}$




\begin{tabular}{|c|c|}
\hline TSAJ & Texte und Studien zum antiken Judentum \\
\hline TSHP & $\begin{array}{l}\text { New Synthese Historical Library: Texts and Studies in the History of } \\
\text { Philosophy }\end{array}$ \\
\hline TSP & Trivium: Special Publications \\
\hline TUGAL & $\begin{array}{l}\text { Texte und Untersuchungen zur Geschichte der altchristlichen } \\
\text { Literatur }\end{array}$ \\
\hline VC & Vigiliae Christianae \\
\hline VCSup & Supplements to Vigiliae Christianae \\
\hline VTSup & Supplements to Vetus Testamentum \\
\hline WMANT & Wissenschaftliche Monographien zum Alten und Neuen Testament \\
\hline WS & Wiener Studien: Zeitschrift für Klassische Philologie und Patristik \\
\hline WTS & Wijsgerige Teksten en Studies \\
\hline WUNT & Wissenschaftliche Untersuchungen zum Neuen Testament \\
\hline ZNW & $\begin{array}{l}\text { Zeitschrift für die neutestamentliche Wissenschaft und die Kunde } \\
\text { der älteren Kirche }\end{array}$ \\
\hline
\end{tabular}




\section{CHAPTER ONE}

\section{INTRODUCTION}

The Septuagint version of Exodus 20:17, translated literally, reads as

\section{follows:}

You shall not desire your neighbor's wife. You shall not desire your neighbor's house, nor his field, nor his male servant, nor his female servant, nor his ox, nor his beast of burden, nor any of his flock, nor anything that is your neighbor's. ${ }^{1}$

This is the last of the Ten Commandments, ${ }^{2}$ and although Philo of Alexandria (ca. 20 B.C. - A.D. 50) must have known the full biblical version, ${ }^{3}$ he cites the

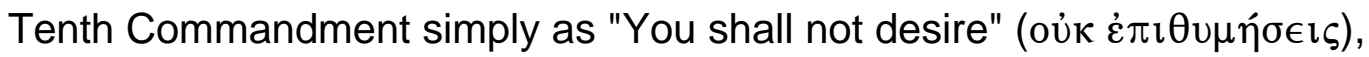

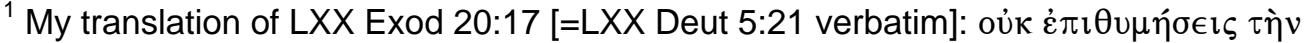

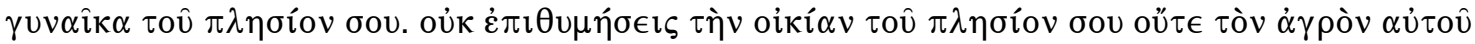

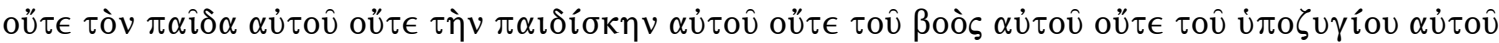

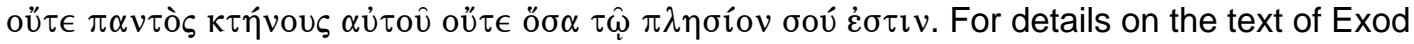
20:17, including ancient versions, see Innocent Himbaza, Le Décalogue et l'histoire du texte: Etudes des formes textuelles du Décalogue et leurs implications dans l'histoire du texte de l'Ancien Testament (OBO 207; Fribourg: Academic Press, 2004), 155-65 (cf. 68-72).

${ }^{2}$ Within the biblical canon, the Ten Commandments appear first in Exod 20:1-17 (cf. Deut 5:1-21) spoken by God and so become known as the "ten words," or in modern usage the

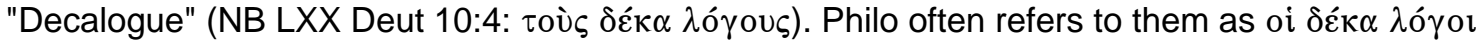

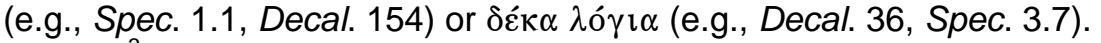

${ }^{3}$ Philo used the LXX, not the Hebrew Bible (see Valentin Nikiprowetzky, Le commentaire de l'écriture chez Philon d'Alexandrie [ALGHJ 11; Leiden: Brill, 1977], 50-96, esp. 51-52). No evidence for an abbreviated version of the Tenth Commandment exists in the MS tradition of the LXX. On the LXX Pentateuch, see the introductory essays in Le Pentateuque d'Alexandrie: text grec et traduction (ed. Cécile Dogniez and Marguerite Harl; Bible d'Alexandrie; Paris: Cerf, 2001), 31-130, including David Runia, "Philon d'Alexandrie devant le Pentateuque," 99-105.
} 
indicating that in his view the principle concern of this Commandment is desire itself $(\dot{\varepsilon} \pi \imath \theta u \mu i \alpha)$, not desire's object. ${ }^{4}$

This dissertation explains in detail Philo's exposition of the Tenth Commandment. As an introduction, this chapter (1) situates Philo's exposition within his larger corpus of works, (2) sketches in summary form the nature and content of the exposition, (3) explains the value of the exposition, (4) reviews prior research, and (5) outlines the plan of the dissertation.

PHILO'S COMMENTARY ON MOSAIC LEGISLATION

Philo describes the contents of the Pentateuch as a sequence of three topics: creation, history, and legislation. ${ }^{5}$ In a series of works known collectively

${ }^{4}$ In Spec. 4.78, Philo cites the Tenth Commandment as an abbreviated, two-word

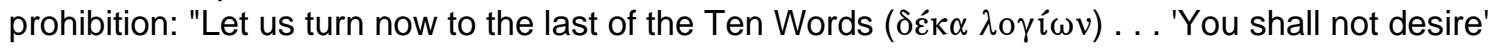

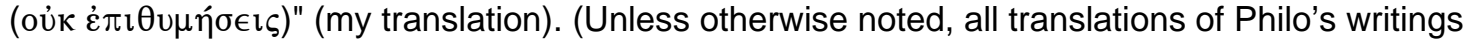
are from PLCL.) In Decal. 142, he clearly has this abbreviated version in mind: "Finally, he places a prohibition on desiring ( $\left.\tau \in \lambda \in v \tau \alpha \hat{\imath} o v \delta \delta^{\prime} \dot{\varepsilon} \pi \imath \theta u \mu \in \hat{\imath} v \dot{\alpha} \pi \alpha \gamma o \rho \in v \in \iota\right)$, knowing that desire ( $\tau \grave{\eta} v$

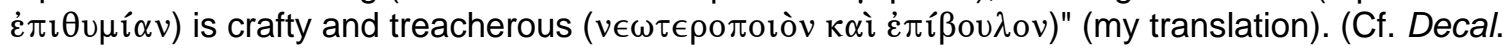

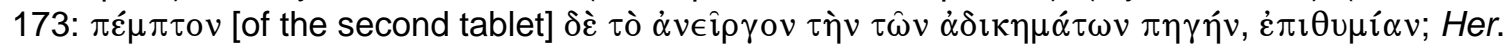

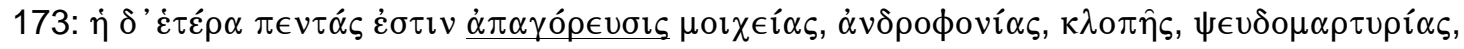

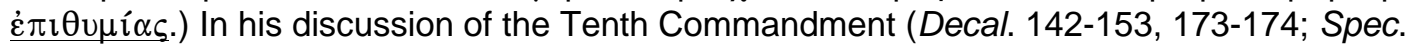
4.78b-131), Philo mentions none of the prohibited objects of desire listed in the LXX version

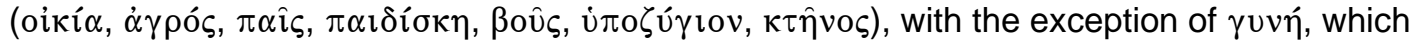
appears once in a list that includes also "reputation" ( $\left.\delta \delta^{\xi} \xi \alpha\right)$ and summarily "anything else that

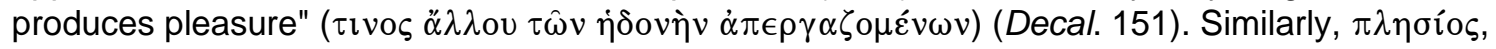

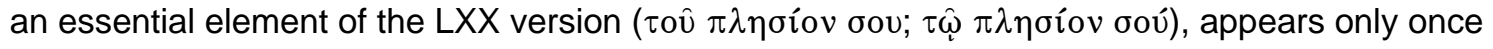
(Spec. 4.93), and there it involves Platonic psychology: the $\theta u \mu$ ó, or spirited part of the soul, is a "neighbor" to the $\lambda$ ó ${ }^{\circ} \varsigma$, or rational part.

5 "The oracles delivered through the prophet Moses are of three kinds ( $\tau \rho \in \hat{\imath} \varsigma$ i $\delta \varepsilon \varepsilon \alpha \varsigma$ ). The

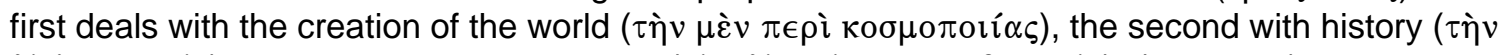

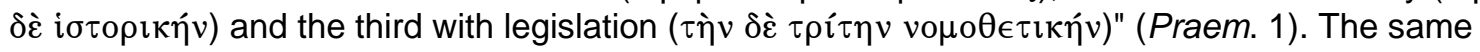
classification appears in Mos. 2.46-47, although Philo initially identifies only two parts: (1) the

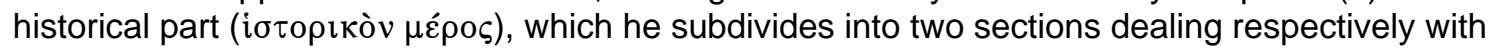

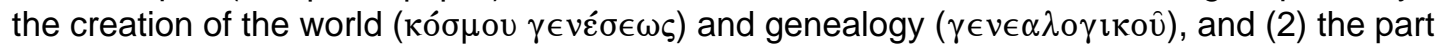
dealing with commands and prohibitions ( $\pi \epsilon \rho \grave{\imath} \pi \rho 0 \sigma \tau \dot{\alpha} \xi \in \imath \varsigma \kappa \alpha \grave{\imath} \dot{\alpha} \pi \alpha \gamma o \rho \in \dot{v} \sigma \epsilon l \varsigma)$. The part dealing with commands and prohibitions is equivalent to the third topic in Praem. 1, while the subdivisions of the first part are equivalent to the first two topics in Praem.1. (On the equivalence of

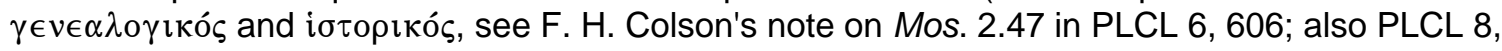
313, n. a.) This correlation of Praem. 1 and Mos. 2.46-47 is standard-see, for example, Peder 
as the Exposition of the Law, he offers an exegesis of the Pentateuch using these topics as his basic outline. ${ }^{6}$ The Exposition begins with a treatise on the creation of the world (De opificio mundi), continues with a set of treatises on the patriarchs (De Abrahamo and De losepho), ${ }^{7}$ and ends with a set of treatises on Mosaic legislation (De decalogo, De specialibus legibus 1-4, and De virtutibus). ${ }^{8}$ This last set dealing with legislation consists thematically of only two parts, despite its formal division into six treatises: the first comprises De decalogo and practically all of De specialibus legibus (1.1 - 4.132), the second comprises the

Borgen, "Philo of Alexandria," in Jewish Writings of the Second Temple Period (ed. M. E. Stone; vol. 2 of The Literature of the Jewish People in the Period of the Second Temple and the Talmud; CRINT 2; Assen: Van Gorcum, 1984), 233-82, 234, n. 5; Richard Hecht, "Preliminary Issues in the Analysis of Philo's De Specialibus Legibus," SPh 5 (1978): 1-56, 3; Leopold Cohn, "Einteilung und Chronologie der Schriften Philos," PhilSup 7 (1899): 387-436, 405-06.

${ }^{6}$ On the Exposition of the Law see esp. Peder Borgen, "Philo of Alexandria-A Systematic Philosopher or an Eclectic Editor? An Examination of his Exposition of the Laws of Moses," SO 71 (1996): 115-34; also Jenny Morris, "The Jewish Philosopher Philo," in Emil Schürer, The History of the Jewish People in the Age of Jesus Christ (175 B.C.-A.D. 135): A New English Version Revised and Edited by Geza Vermes, Fergus Millar, and Martin Goodman (vol. 3, part 2; Edinburgh: T\&T Clark, 1987), 809-89, 840-54.

${ }_{7}$ Originally, the set included treatises also on Isaac and Jacob (see los. 1), which are now lost. Most assign these treatises to the "history" portion of the creation-history-legislation triad of Praem. 1 (e.g., Peder Borgen, "Philo," 237). Some, however, assign them to the legislative portion, based on Philo's claim that the patriarchs themselves represent unwritten counterparts to the written laws he begins to consider in De decalogo (see Abr. 3). The historical portion, in this configuration, consists of Philo's Allegorical Commentary, a separate series of treatises covering most of Genesis (on which see Borgen, "Philo," 243-44; Morris, "Philo," 83040). Valentin Nikiprowetzky, for one, holds this view: see PAPM 23, 13, and Commentaire, 23435, n. 17. But if the correlation of Praem. 1 and Mos. 2.46-47 is correct, the legislative portion mentioned in Praem. 1 corresponds explicitly to "commands and prohibitions" in Mos. 2.46 and cannot reasonably include the lives of the patriarchs. For other problems with this view, see Cohn, "Einteilung und Chronologie," 406, n. 23; cf. Morris, "Philo," 845-46, n. 134.

${ }^{8}$ Another treatise, De praemiis et poenis, immediately follows Virt. and concludes the Exposition. In Praem. 2-3, Philo states that he has fully discussed (i.e., finished) the legislative section in the preceding treatises and is moving on to a new topic: "the rewards and punishments which the good and the bad have respectively to expect." De praemiis et poenis thus forms a fitting conclusion to the Exposition, insofar as the stipulated rewards and punishments are contingent on observance of the laws. But it does not form part of the legislative section proper, because it does not deal with the laws themselves. Philo's treatise on Moses, De vita Mosis 1-2, is closely connected with, but not part of, the Exposition (see Erwin R. Goodenough, "Philo's Exposition of the Law and His De Vita Mosis," HTR 26 [1933]: 109-25). 
remainder of De specialibus legibus (4.133-238) and De virtutibus. ${ }^{9}$ In both

parts, Philo cites laws then analyzes them, noting mostly their literal bearing on

practical and ethical matters. ${ }^{10}$ But the real commentary on Mosaic legislation in

Philo's Exposition is the first part (Decal. 1.1 - Spec. 4.132), which he frames as

a unified, systematic, and comprehensive exposition of Mosaic commands and

prohibitions, using an organizational scheme based entirely on the Ten

Commandments. ${ }^{11}$

For Philo, the Ten Commandments are absolutely preeminent, and their

arrangement and content determine the overall arrangement and content of his

legal commentary in Decal. 1.1 - Spec. 4.132. ${ }^{12}$ To establish their importance,

${ }^{9}$ Philo makes an obvious, explicit transition from one major topic to another in Spec.

4.132-34. For division of the same material into the same two parts, see points $B$ and $C$ on Peder Borgen's outline of the Exposition ("Philosopher or Editor?," 118).

${ }^{10}$ In Decal. 1.1 Philo announces that his investigation of the written laws will not neglect allegorical interpretations, when they are warranted, and indeed it does not (e.g., Spec. 2.29-32). Nevertheless, Philo's legal commentary tends to avoid allegory, in some instances offering only a literal treatment of laws read allegorically in the Allegorical Commentary (see Colson, PLCL 7, xiii, n. c, and Isaak Heinemann, PCH 2, 4, n. 1, for examples, such as Ebr. 14-95 vs. Spec. 2.232 on Deut 21:18-21). Samuel Sandmel ("Philo Judaeus: An Introduction to the Man, his Writings, and his Significance," ANRW 21.1:3-46, 10) thus goes too far in saying: "The treatises in [the 'Exposition of the Law'] are no less allegorical than those in the 'Allegory of the Law."'

${ }^{11}$ Praem. 2 suggests that part one (Decal. 1.1. - Spec. 4.132) represents, from Philo's perspective, the Pentateuch's "legislative part" proper (thus Borgen, "Philosopher or Editor?," 132-33; cf. Borgen, "Philo," 239-40). Part two (Spec. 4.133-238 and Virt.) has a different organizational scheme (categorization by virtues, not Commandments [see Spec. 4.133-35]) and is secondary to part one in terms of both length and design. Part one is roughly three times as large (ca. 277 vs. ca. 95 pages in PCW); but, more importantly, part one represents Philo's principal effort to organize all Mosaic precepts into a single logical system (on which see esp. Yehoshua Amir, "The Decalogue According to Philo," in The Ten Commandments in History and Tradition [ed. B.-Z. Segal and G. Levi; Jerusalem: Magnes Press, 1990], 121-60, 128-30; idem, "Philon und die jüdische Wirklichkeit seiner Zeit," in Die hellenistische Gestalt des Judentums bei Philon von Alexandrien [FJCD 5; Neukirchen-Vluyn: Neukirchener Verlag, 1983], 3-51, esp. 42-44 [="Das System der Gebote"]). In this respect, part two serves as a catchall, accommodating laws that do not fit neatly into Philo's primary scheme (see Amir, "Decalogue," 127; Morris, "Philo," 851).

${ }^{12}$ On the Decalogue in Philo, see esp. Amir, "Decalogue"; also Ulrich Kellermann, "Der Dekalog in den Schriften des Frühjudentums," in Weisheit, Ethos, und Gebot (ed. H.G.

Reventlow; BThSt 43; Neukirchen-Vluyn: Neukirchener, 2001), 147-226, esp. 161-70; Paul Kuntz, 
Philo begins his systematic study of Mosaic legislation with a distinction between

two categories of law:

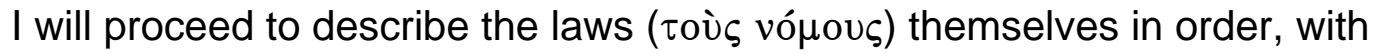
this necessary statement by way of introduction, that some of them (oùs $\mu \varepsilon \dot{v}$ ) God judged fit to deliver in His own person alone without employing any other, and some (oùc $\delta \varepsilon$ ) through His prophet Moses whom He chose as of all men the best suited to be the revealer of verities. Now we find that those which He gave in His own person and by His own mouth alone

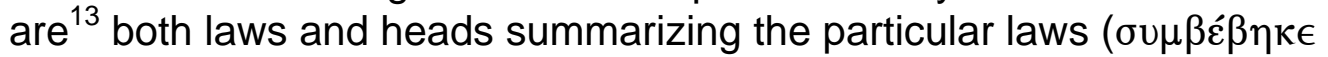

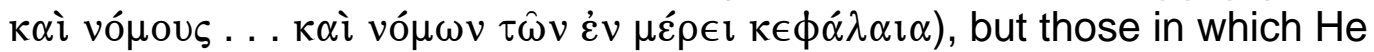
spoke through the prophet all belong to the former class. (Decal. 18-19)

Two key traits set the Ten Commandments apart. First, God delivered them personally to the Israelites without a human mediator. ${ }^{14}$ Second, each of the Ten Commandments has a unique dual significance: like any law, it stands on its own

\footnotetext{
"Philo Judaeus: A Decalogue in the Balance," in The Ten Commandments in History: Mosaic Paradigms for a Well-Ordered Society (ed. Thomas d'Evelyn; EUSLR; Grand Rapids: Eerdmans, 2004), 11-26; Miguel Lluch Baixauli, "El tratado de Filón sobre el Decálogo," ScrTh 29 (1997): 415-41; André Myre, "La loi et le Pentateuque selon Philon d'Alexandrie," ScEs 25 (1973): 20925, 222-24; Samuel Sandmel, "Confrontation of Greek and Jewish ethics: Philo: De Decalogo," in Judaism and Ethics (ed. Daniel J. Silver; New York: Ktav, 1970), 163-76. On the Decalogue as an organizational scheme, see in general Hecht, "Preliminary Issues," 3-17; for the scheme's presence in Decal. and Spec. see Borgen, "Philosopher or Editor?," 123-28; for details of the scheme see Daniel Jastram, Philo's Concept of Generic Virtue (Ph.D. diss., University of Wisconsin-Madison, 1989), 30-35, and Cristina Termini, "Taxonomy of Biblical Laws and ФI $O$ TEXNIA in Philo," SPhA 16 (2004): 1-29, esp. 1-10.

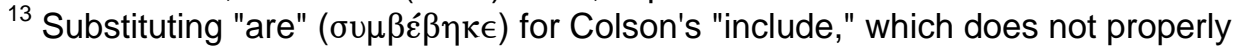
emphasize the dual nature of each Commandment. Cf. Nikiprowetzky, PAPM 23 ("sont non seulement des lois, mais aussi les principes qui commandent le détail des lois particulières"); Treitel, PCH 1 ("sind zugleich Gesetze und Grundprinzipien"); Francesca Calabi, Filone di Alessandria, De Decalogo (Philosophica 24; Pisa: ETS, 2005) ("sono leggi e principi delle leggi particolari").

${ }^{14}$ Cf. Spec. 2.189. Philo rejects an anthropomorphic concept of God speaking to the Israelites, developing instead the notion of a miraculous "divine voice" created especially for the occasion (Decal. 32-35; for analysis see Amir, "Decalogue," 135-48; also Reinhard Weber, Das"Gesetz" bei Philon von Alexandrien und Flavius Josephus: Studien zum Verständnis und zur Funktion der Thora bei den beiden Hauptzeugen des hellenistischen Judentums (ARGU 11; Frankfurt am Main: Lang, 2001), 68-77.
} 


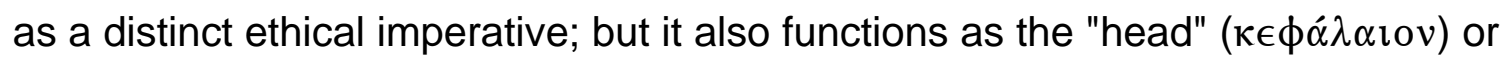

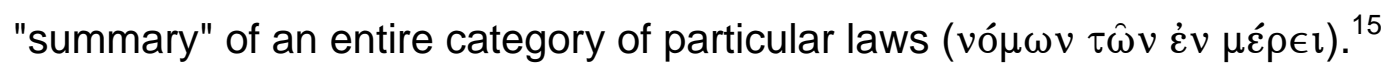

In Philo's view, God delivered each of the Ten Commandments "in the form of a summary,"16 stating succinctly what Moses spells out at length by means of additional laws found elsewhere in the Pentateuch. ${ }^{17}$ These other laws form a distinct set of subsidiary precepts, which—despite their individual variety-all express in some way the moral essence of their respective summary Commandment. To characterize this unique relationship of particular law(s) to summary Commandment, Philo uses a variety of terms and expressions. In terms of status, the particular laws are all subordinate to their respective "heads," as Philo's use of u̇ $\pi$ ó ("under") and related compounds clearly indicates. ${ }^{18}$ In

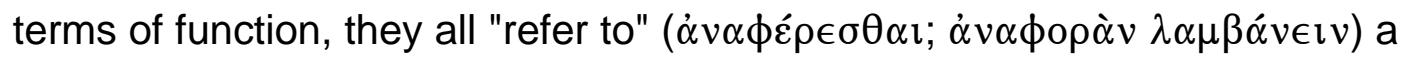

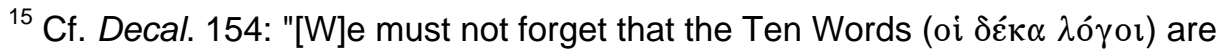
summaries of the special laws ( $\kappa \in \phi \dot{\alpha} \lambda \alpha \imath \alpha$ vó $\mu \omega v \in \dot{i} \sigma \grave{\imath} \tau \hat{\omega} v \dot{\varepsilon} v \in \mathfrak{l} \delta \in \imath$ ) which are recorded in the

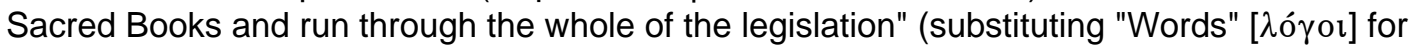

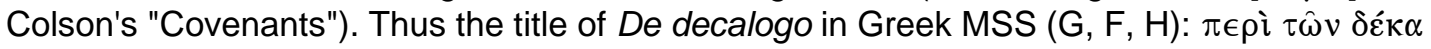

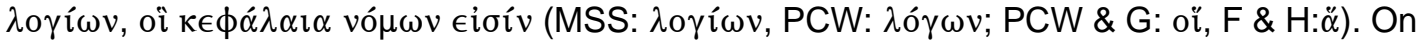
$\kappa \in \phi \alpha ́ \lambda \alpha$ lov, see Termini, "Taxonomy," 5-6.

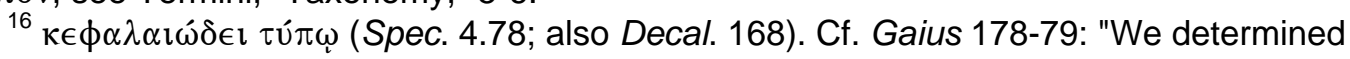

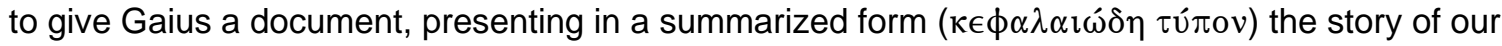

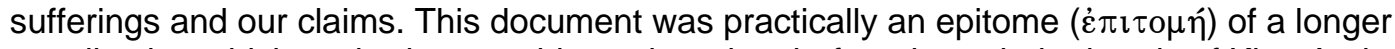
supplication which we had sent to him a short time before through the hands of King Agrippa."

${ }^{17}$ Decal. 175: "For it was in accordance with His nature that the pronouncements in

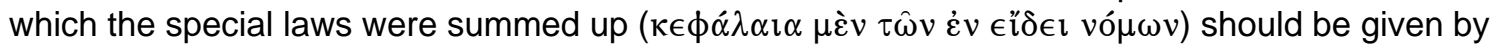

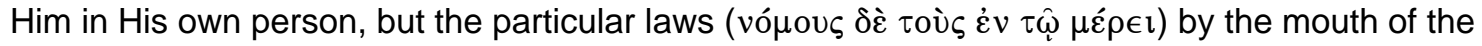
most perfect of the prophets whom He selected for his merits and having filled him with the divine spirit, chose him to be the interpreter of His sacred utterances." Cf. Cong. 120, where these ten are "general heads $(\gamma \in \nu \imath \kappa \grave{\alpha} \kappa \epsilon \phi \dot{\alpha} \lambda \alpha \iota \alpha)$, embracing the vast multitude of particular laws ( $\tau \hat{\omega} \nu \kappa \alpha \tau \grave{\alpha}$

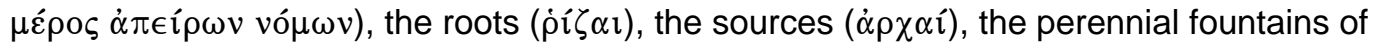
ordinances ( $\pi \eta \gamma \alpha \grave{\imath} \dot{\alpha} \varepsilon \dot{\alpha} \alpha o \imath \delta \imath \alpha \tau \alpha \gamma \mu \alpha \dot{\alpha} \omega \nu)$ containing commandments positive and prohibitive

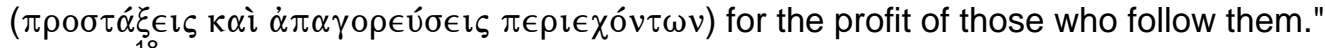

${ }^{18}$ For the particular laws as simply "under" (ن் $\pi$ ) their respective heads, see Decal. 170;

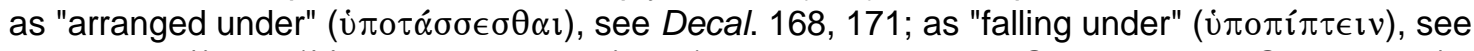

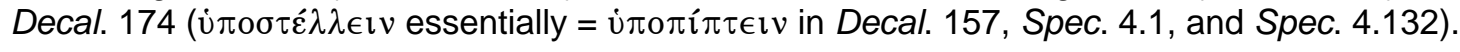


single summary command, serving or promoting its moral purpose in some way. ${ }^{19}$ But in abstract terms, Philo envisions the relationship between summary Commandment and particular law(s) as that of genus to species. ${ }^{20}$

The treatises De decalogo and De specialibus legibus represent, at least in part, Philo's painstaking and systematic attempt to illustrate this genus-species relationship. His treatise on the Ten Commandments deals with the ten genera, expounding each of the Commandments in sequence (Decal. 50-153) and introducing the idea of their summary function (Decal. 154-75). ${ }^{21}$ His treatise on the particular laws (Spec.) again expounds the ten genera, in even greater depth, but goes on to identify and comment on their respective species. The Pentateuch itself never uses a genus-species taxonomy to organize precepts into a coherent system, so Philo must construct the system himself. In other words, Philo must match species with genera, indicating which laws belong with which of the Ten

${ }^{19}$ E.g., Spec. 2.223: "I have now completed the discussion of the number seven [i.e., the fourth "head" (cf. Spec. 2.39)] and of matters connected with days and months and years that

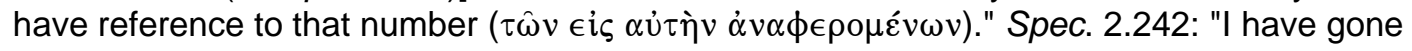
through the five heads of laws ( $\kappa € \phi \alpha \dot{\lambda} \alpha \alpha \alpha \nu$ vó $\mu \omega v$ ) that belong to the first table, along with whatever particular laws have reference to each of them (ö $\sigma \alpha \tau \hat{\omega} v \kappa \alpha \tau \grave{\alpha} \mu \varepsilon \dot{\varepsilon} \rho \varsigma \in i \zeta \check{\varepsilon} \kappa \alpha \sigma \tau o v$

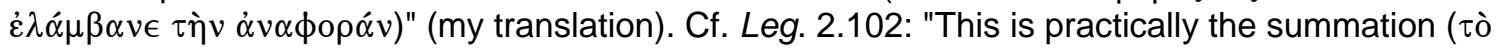
$\kappa \in \phi \dot{\alpha} \lambda \alpha \iota v)$ of the whole Song [of Moses], to which every other part refers ( $\dot{\varepsilon} \phi$ 'ò $\tau \dot{\alpha} \ddot{\alpha} \lambda \lambda \alpha \pi \dot{\alpha} v \tau \alpha$ $\dot{\alpha} v \alpha \phi \varepsilon \hat{\varepsilon} \rho \tau \alpha \mathrm{l}) "$ (my translation). In Hist. eccl. 2.18.5, Eusebius refers to De specialibus legibus as

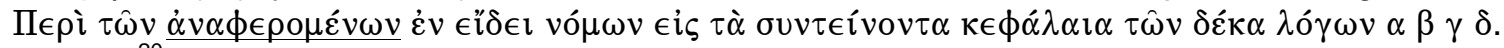

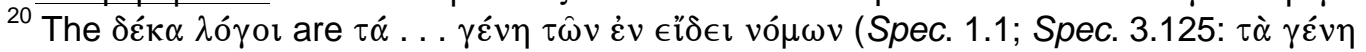

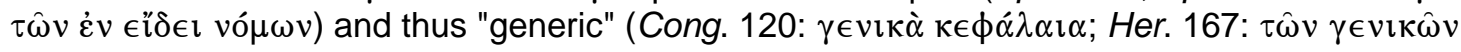

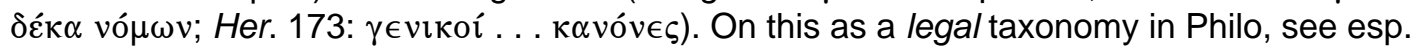
Jastram, Generic Virtue, 30-35. Jastram's remarks situate the legal taxonomy in the context of Philo's broader application(s) of the genus-species concept (see his chapter one, "Theory of Genus, Species, and Particular," 10-72). See also Termini, "Taxonomy." Termini argues that Philo's application of a genus-species taxonomy to Mosaic legislation is radically innovative, although his interest in the systematic organization of legal materials reflects contemporary trends in Roman jurisprudence.

${ }^{21}$ Philo first treats introductory questions such as why God delivered the Ten Commandments in the desert (§\$2-17), why there were ten (§§20-31), what voice announced the Commandments (§§32-35), and why the form of address was second-person singular (§§36-43). 
Commandments. ${ }^{22}$ When his work is finished, he leaves no doubt as to his purpose:

For if we are right in describing the main heads delivered by the voice of God as generic laws ( $\kappa \epsilon \phi \alpha \dot{\alpha} \alpha \_\alpha \gamma \varepsilon \dot{\varepsilon} v \eta$ vó $\mu \omega v$ ), and all particular laws of which Moses was the spokesman as dependent species ( $\epsilon \hat{\imath} \delta \eta)$, for accurate apprehension free from confusion scientific study was needed, with the aid of which I have assigned and attached to each of the genera what was appropriate to them throughout the whole legislation ( $\dot{\varepsilon} \kappa \alpha \dot{\sigma} \sigma \omega$

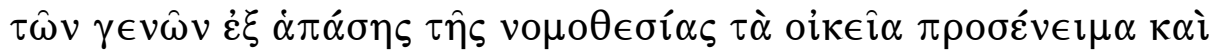
$\pi \rho \circ \sigma \varepsilon ́ \phi v \sigma \alpha)$. (Spec. 4.132) $)^{23}$

The scope of Philo's project is immense: considering each of the generic summaries in turn, he has scoured the Pentateuch in search of the corresponding specific precepts. In this respect, De specialibus legibus

${ }^{22}$ Despite disagreement over the originality of Philo's use of the Decalogue as a comprehensive taxonomic framework, consensus suggests that Philo at least did the work of matching species with genera. This consensus justifies the study of Philo's view of the Tenth Commandment, insofar as it allows for him to decide which laws logically pertain to the Tenth Commandment, based on his understanding of that Commandment. For a minimalist position, which concedes the originality of Philo's genus-species matching but otherwise attributes his basic taxonomy to traditional (rabbinic) Judaism, see Naomi Cohen, Philo Judaeus: His Universe of Discourse (BEATAJ 24; Frankfurt am Main: Peter Lang, 1995), 72-85, esp. 84-85. (On Philo's understanding of the Decalogue in relation to rabbinic tradition, see esp. Hecht, "Preliminary Issues," 3-17.) For a more generous position, which sees Philo as an innovator not only in his assignment of species to genus but also in his granting of a special inclusive status to the Decalogue, see Termini, "Taxonomy." Borgen, "Philosopher or Editor?," 126, has an intermediate position, which nevertheless approximates Cohen's: "Philo seems to develop in a more systematic fashion a notion also found in Palestinian tradition, that the Decalogue contained in nuce all the commandments of the Mosaic laws. Thus, Philo has a Jewish concept as organizing principle, but he has developed it into a broader systematic rewriting than found elsewhere in the contemporary Jewish sources."

${ }^{23}$ Substituting "genera" ( $\left.\gamma \in v \omega \hat{\omega} v\right)$ for Colson's "heads." On this passage, see also Termini, "Taxonomy," 8. Cf. Spec. 3.7: "Since out of the ten oracles which God gave forth Himself without a spokesman or interpreter, we have spoken of five, namely those graven on the first table, and

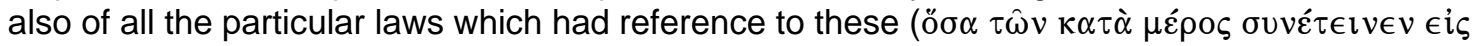
$\tau \alpha \hat{v} \tau \alpha$ ), and our present duty is to couple them with those of the second table as well as we can, I will again endeavour to fit the special laws into each of the genera ( $\pi \in \imath \rho \alpha \dot{\alpha} \sigma o \mu \alpha \imath \pi \dot{\alpha} \lambda_{\imath} v$

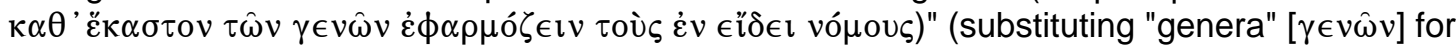
Colson's "heads"). 
complements De decalogo by presenting for each Commandment subsidiary laws that reflect its moral essence. ${ }^{24}$

Although the scope of Philo's project involves all of the Ten Commandments, his procedure makes it simple to extract the remarks devoted to any one of them. For the most part, he follows a rigid ten-point outline in both Decal. and Spec., introducing each Commandment, saying what he wants to say, then moving on to the next. ${ }^{25}$ As a result, both treatises have an embedded series of self-contained units, each with its own topic and structure, each dealing essentially with one of the Ten Commandments. Correlating the text unit devoted to a particular Commandment in Decal. with the text unit devoted to the same Commandment in Spec. provides material for a more or less self-contained exposition of that Commandment. ${ }^{26}$ Each exposition includes Philo's analysis of the Commandment itself (the genus), plus his treatment of the subordinate laws (the species).

\section{PHILO'S EXPOSITION OF THE TENTH COMMANDMENT}

Naturally, the last exposition embedded in Decal. and Spec. deals with the Tenth Commandment, which in Philo's Decalogue is the two-word prohibition oủ

${ }^{24}$ Cf. Morris on Spec. ("Philo," 847-48): "In this work Philo makes an extremely interesting attempt to bring the Mosaic special laws into a systematic arrangement according to the ten rubrics of the Decalogue."

${ }^{25}$ Structural outlines of the treatises reveal Philo's straightforward sequential movement through the list of Ten Commandments. For an outline of Decal., see Borgen, "Philosopher or Editor?," 124-25. For an outline of the four books of Spec., see Heinemann, PCH 2, 8-13 (although, as Heinemann's outline indicates, Philo in effect treats the First and Second Commandments as a single unit).

${ }^{26}$ For a schematic correlation of material from Decal. and Spec., see the outline of the Sixth through Tenth Commandments in André Mosès, PAPM 25, 15-16. 
$\dot{\varepsilon} \pi \imath \theta u \mu \eta \tilde{\sigma} \sigma \iota .^{27}$ Philo abbreviates the Septuagint version, which lists various aims of desire: a neighbor's wife, house, field, etc. ${ }^{28}$ Although he never explains or justifies this abbreviation, it makes good sense in light of his overall treatment of the Ten Commandments, especially the last five, which he views as a pentad containing basic prohibitions governing human affairs. ${ }^{29}$ Superficially, the abbreviation accomplishes a stylistic leveling, bringing the Tenth Commandment

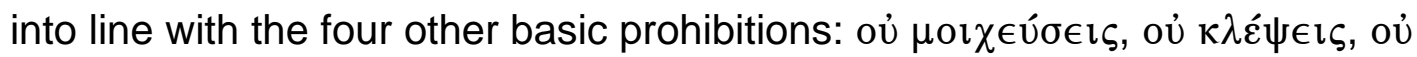

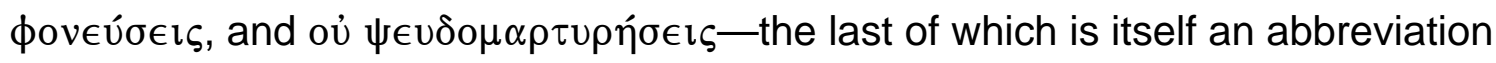
of the Ninth Commandment. ${ }^{30}$ More importantly, however, a specific formulation of the Tenth Commandment would contradict Philo's claim that the Commandments are comprehensive, generic summaries—or, as with oủ $\dot{\varepsilon} \pi \imath \theta v \mu \eta \dot{\eta} \sigma \in \iota \varsigma$, generic prohibitions. In his system of thought, limiting the scope of the Tenth Commandment to specific objects would blur the distinction between genus and species. Rather than a summary, the Commandment would read more like a short list of "particular laws." ${ }^{31}$ Philo does consider various objects of

${ }^{27}$ See above, n. 4.

${ }^{28}$ Cf. LXX Exod 20:17 [=LXX Deut 5:21]. See above, n. 1.

${ }^{29}$ Decal. 121: $\dot{\alpha} \pi \alpha \gamma o \rho \in \dot{\sigma} \sigma \epsilon \iota \varsigma \tau \hat{\omega} v \pi \rho o ̀ \varsigma ~ \dot{\alpha} \nu \theta \rho \omega ́ \pi$ ous. In Philo's view, these five prohibitions

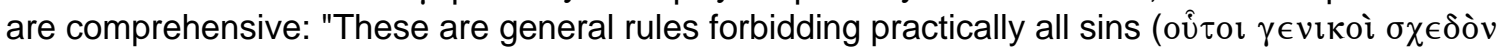
$\pi \dot{\alpha} \nu \tau \omega \nu \dot{\alpha} \mu \alpha \rho \tau \eta \mu \dot{\alpha} \tau \omega \nu \in i \sigma i ̀ ~ \kappa \alpha \nu o ́ v \in \varsigma)$, and to them the specific sins may in each case be referred

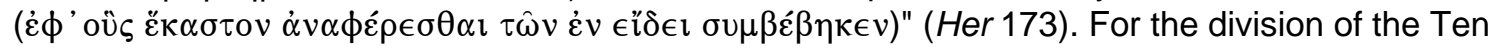
Commandments into pentads, see esp. Decal. 50-51 (also Her. 168).

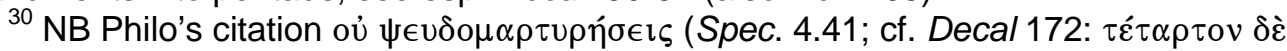

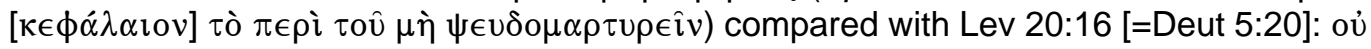

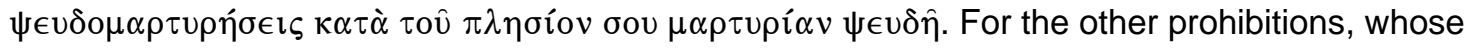
simple two-word expressions Philo adopts verbatim, see Lev 20:13-15 [=Deut 5:17-19]. Cf. Rom

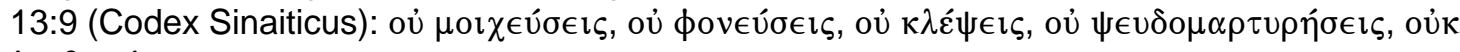
$\dot{\varepsilon} \pi \imath \theta u \mu \eta \dot{\sigma} \sigma \in \iota$.

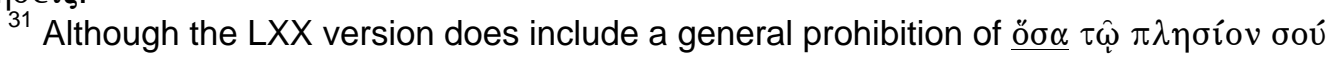

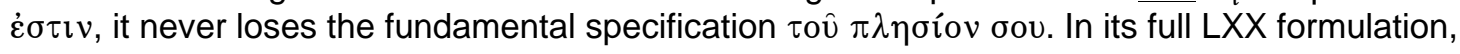


desire in his exposition, but only as concrete illustrations of the nature and function of desire itself, not restrictions on the Commandment's proscriptive range of objects. ${ }^{32}$

In its entirety, Philo's commentary on the Tenth Commandment consists of three text units: Decal. 142-53, Decal. 173-74, and Spec. 4.78b-131. The first of these units, Decal. 142-53, is the last installment in Philo's initial survey of the Ten Commandments (Decal. 50-153). Focusing on what the prohibition entails, this unit contains a sketch of the nature, mechanics, and potentially disastrous effects of desire, framed initially (§§142-46) as a review of the four cardinal

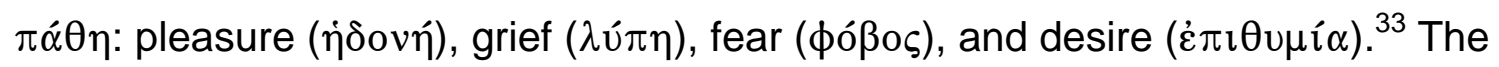

the Commandment does not proscribe, for example, the desire for a house per se, only the desire for a specific type of house-viz., the house of a neighbor.

${ }^{32}$ For example, in Spec 4.86-91 Philo wants to illustrate how desire "produces a change for the worse in all which it attacks" (§86) by listing various aims of desire and the respective vices associated with those aims. The aims are all quite general: "money" ( $\chi \rho \eta \mu \alpha \tau \alpha)$, "reputation"

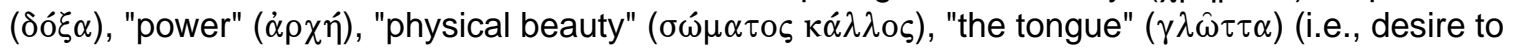
speak or keep silent), "the belly" ( $\gamma \alpha \sigma \tau \eta \dot{\rho} \rho)$ (i.e., desire for food and drink).

${ }^{33}$ On $\pi \dot{\alpha} \theta$ os as a philosophical term, see in general F.E. Peters, Greek Philosophical Terms: A Historical Lexicon (New York: New York University Press, 1967), 152-55. $\pi \dot{\alpha} \theta$ os refers essentially to something that happens to someone (i.e., an experience one undergoes), so "passion" bears literally the sense of its cognate "passive" despite its often active sense. (For an ancient [Platonic] discussion of active and passive connotations of $\pi \dot{\alpha} \theta$ os, see Galen, PHP 6.1.523; cf. Martin Elsky [trans.], "Erich Auerbach, 'Passio as Passion' ['Passio als Leidenshaft']" Criticism 43 [2001]: 288-308). As a psychological term, $\pi \dot{\alpha} \theta$ o $\varsigma$ refers to an experience undergone in one's soul; for example, the experience ("passion," "feeling," "emotion") of fear. Ancient moral philosophers proposed various definitions for both $\pi \dot{\alpha} \theta$ os per se and the individual $\pi \dot{\alpha} \theta \eta$, along with various strategies for how best to manage passion(s). On the four cardinal $\pi \dot{\alpha} \theta \eta$ see Simo Knuuttila and Juha Sihvola, "How the Philosophical Analysis of the Emotions was Introduced," in The Emotions in Hellenistic Philosophy (ed. J. Sihvola and T. Engberg-Pedersen; TSHP 46; Dordrecht: Kluwer, 1998), 1-19, esp. 14-16. For an explanation of the Stoic view of $\pi \dot{\alpha} \theta$ os over against the Platonic-Aristotelian view, see Michael Frede, "The Stoic Doctrine of the Affections of the Soul," in The Norms of Nature: Studies in Hellenistic Ethics (ed. Malcolm Schofield and Gisela Striker; Cambridge: Cambridge University Press, 1986), 93-110. On passion(s) in Philo see esp. Helmut Schmidt, Die Anthropoligie Philons von Alexandreia (Würzburg: Konrad Triltsch, 1933), 86-101; also David Charles Aune, "Mastery of the Passions: Philo, 4 Maccabees and Earliest Christianity," in Hellenization Revisited: Shaping a Christian Response within the GrecoRoman World (ed. Wendy E. Helleman; Lanham: University Press of America, 1994), 125-58, esp. 125-34; John Dillon, The Middle Platonists: 80 B.C. to A.D. 220 (rev. ed.; Ithaca, N.Y.: 
second unit, Decal. 173-74, briefly restates the pervasive ill effects of desire, then previews De specialibus legibus by noting the existence of "many ordinances which come under this head," without identifying any of those ordinances. The third unit, Spec. 4.78b-131 contains Philo's most comprehensive and sustained treatment of the Tenth Commandment and represents the exposition proper. ${ }^{34}$ Again he covers the nature, mechanics, and effects of desire, as in the first unit, but in much greater depth (Spec. 4.78b-94). Then, in fulfillment of his overarching program for Decal. and Spec., Philo cites and expounds the Mosaic dietary laws, which in his view are the "particular laws" that belong under the heading oủк $\dot{\varepsilon} \pi \imath \theta u \mu \eta ́ \sigma \epsilon \iota$ (Spec. 4.95-131). Together these three units amount to 374 lines of Greek text in PCW, and the exposition proper amounts to 301 lines, all devoted to Philo's understanding of the Tenth Commandment. In sheer quantity, Philo's

Cornell University Press, 1996), 151-52; Petra von Gemünden, "La culture des passions à l'époque du Nouveau Testament: une contribution théologique et psychologique," ETR 70 (1995): 335-48, esp. 339-42; Margaret Graver, "Philo of Alexandria and the Origins of the Stoic

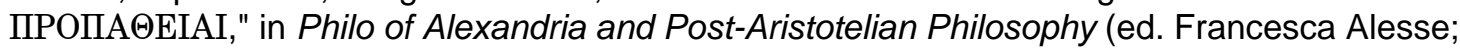
SPhA 5; Leiden: Brill, 2008), 197-221; repr. from Phronesis 44 (1999): 300-25; Carlos Lévy, "Philon d'Alexandrie et les passions," in Réceptions antiques: lecture, transmission, appropriation intellectuelle (ed. Lætitia Ciccolini et al.; ELA 16; Paris: Éditions Rue d'Ulm, 2006), 27-41; idem, "Philo's Ethics," in The Cambridge Companion to Philo (Cambridge: Cambridge University Press, 2009), 146-71, esp. 154-64 [="The Passions"]; Salvatore Lilla, Clement of Alexandria: A Study in Christian Platonism and Gnosticism (OTM; London: Oxford University Press, 1971), 84-92, esp. 92; Max Pohlenz, Philon von Alexandreia (NAWG 5; Göttingen: Vandenhoeck \& Ruprecht, 1942), 457-61; David Runia, Philo of Alexandria and the Timaeus of Plato (PA 44 ; Leiden: Brill, 1986), 299-301; Michel Spanneut, "Apatheia ancienne, apatheia chrétienne. lère partie: L'apatheia ancienne," ANRW 36.7: 4641-4717, 4701-04; Walther Völker, Fortschritt und Vollendung bei Philo von Alexandrien: Eine Studie zur Geschichte der Frömmigkeit (TUGAL 49.1; Leipzig: J.C. Hinrich, 1938), 80-95; David Winston, "Philo's Ethical Theory," ANRW 21.1:372-416, 400-05; idem, "Philo of Alexandria on the Rational and Irrational Emotions," in Passions and Moral Progress in Greco-Roman Thought (ed. John T. Fitzgerald; New York: Routledge, 2008), 201-20.

${ }^{34}$ Because it amounts to a self-contained treatise, the unit Spec. 4.79-135 receives the title "De concupiscentia" in some MSS (see PCW 5, xiv, xxvi), and-as Colson notes (PLCL 8, 56, n. 1)-Cohn "here begins a fresh numeration of chapters." Older studies sometimes refer to Spec. 4.79-135 using the Latin title and Cohn's fresh numeration (e.g., Emile Bréhier, Les idées philosophiques et religieuses de Philon d'Alexandrie [EPM 8; 3d ed.; Paris: J. Vrin, 1950], 253). 
exposition of oủк $\dot{\varepsilon} \pi \imath \theta u \mu \eta \dot{\sigma} \sigma \imath \varsigma$ stands on a par with some of his independent treatises_for example, De gigantibus (320 lines in PCW) and De sobrietate (353 lines in PCW). The importance of this exposition, however, lies in the material itself, first in its own right but also in its relation to other first-century treatments of the Tenth Commandment and key topics in Philo's ethical theory.

\section{The VAlue of Philo's EXPOSITION}

As a substantive, detailed analysis of the Tenth Commandment from arguably the best representative of Hellenistic Judaism in antiquity, Philo's exposition of oủк $\dot{\varepsilon} \pi \imath u \mu \eta \dot{\sigma} \sigma \iota \varsigma$ deserves a full and independent analysis. In his exposition, he considers in depth both the Commandment itself and the dietary laws that in his mind reflect its moral essence, so a careful reading should answer two fundamental questions:

1. In Philo's view, what does the Tenth Commandment prohibit? (All desire? A certain type? What type?)

2. In Philo's view, how is the Tenth Commandment observed? (What are the mechanics of its observance? What role do the dietary laws play in its observance?)

Answering these two questions also illuminates broader questions regarding Philo's unique fusion of Judaism and Hellenism. For example, how does a firstcentury Jew, who is fully committed to the literal observance of the Law of Moses, ${ }^{35}$ who is also an accomplished student of Greek philosophy, interpret the

${ }^{35}$ See Migr. 89-93, esp. 93: "Nay, we should look on all these outward observances as resembling the body $(\sigma \omega \mu \alpha \tau \iota)$, and their inner meanings as resembling the soul ( $\psi v \chi \hat{n})$. It follows that, exactly as we have to take thought for the body, because it is the abode of the soul, so we must pay heed to the letter of the laws ( $\tau \hat{\omega} v \dot{\rho} \eta \tau \hat{\omega} v \nu o ́ \mu \omega \nu \dot{\varepsilon} \pi \tau \mu \in \lambda \eta \tau \varepsilon$ ov). If we keep and observe these, we shall gain a clearer conception of those things of which these are the symbols; and 
significance of the Decalogue's prohibition of desire $(\dot{\varepsilon} \pi \imath \theta u \mu i \alpha)$, a function of the soul that Greek philosophers studied at length? How does an obscure set of dietary regulations, which placed observant Jews at odds with the broader culture, become the centerpiece of Moses' philosophical training program for the management of desire? ${ }^{36}$ Philo's exposition speaks to these and other issues. But Philo's work is important also for the comparative assessment of a broader first-century interest in the Tenth Commandment, attested by two of Philo's contemporaries, Paul and the author of 4 Maccabees. ${ }^{37}$ Both authors, like Philo, cite Greek versions of the Tenth Commandment and contemplate its moral significance. ${ }^{38} \mathrm{~A}$ full appreciation of the similarities and differences among these three treatments of the Tenth Commandment, as well as their relation to broader

besides that we shall not incur the censure of the many and the charges they are sure to bring against us."

${ }^{36}$ On the Jewish dietary laws in Philo's day, see John M.G. Barclay, Jews in the Mediterranean Diaspora: From Alexander to Trajan (323 BCE - 117 CE) (Edinburgh: T\&T Clark, 1996), 434-37; Katell Berthelot, "L'interprétation symbolique des lois alimentaires dans la Lettre d'Aristée: une influence pythagoricienne," JJS 52 (2001): 253-68; Christoph Heil, Die Ablehnung der Speisegebote durch Paulus: Zur Frage nach der Stellung des Apostels zum Gesetz (BBB 96; Weinheim: Beltz Athenäum, 1994), 23-123; Hermut Löhr, "Speisenfrage und Tora im Judentum des Zweiten Tempels und im entstehenden Christentum," ZNW 94 (2003): 17-37; James N. Rhodes, "Diet as Morality: Tracing an Exegetical Tradition" (M.A. thesis; Catholic University of America, 2000), esp. chs. three (Aristeas) and four (Philo); E.P. Sanders, "Purity, Food and Offerings in the Greek-Speaking Diaspora," in Jewish Law from Jesus to the Mishnah: Five Studies (London: SCM Press, 1990), 255-308, 272-83; Abraham Terian, "Some Stock Arguments for the Magnanimity of the Law in Hellenistic Jewish Apologetics," JLAS 1 (1985): 141-49.

${ }_{37}$ See Romans 7:7-25 and 4 Maccabees 2:4-6. The exact dates of the relevant texts cannot be determined, but their relative chronology can. The absolute terminus ad quem for Philo's exposition is his death, which by general consensus is hardly later than A.D. 50 (Peder Borgen, "Philo of Alexandria," ABD 5:333-42, 333). Paul's letter to the Romans probably was written between A.D. 55 and 60 (Joseph Fitzmyer, Romans: A New Translation with Introduction and Commentary [AB 33; New York: Doubleday, 1993], 85-88). 4 Maccabees probably was written near the end of the first century A.D. (Hans-Josef Klauck, 4. Makkabäerbuch [JSHRZ 3.1; Gütersloh: Gerd Mohn, 1989], 668-69).

${ }^{38}$ Paul's version, like Philo's, is oủк $\dot{\varepsilon} \pi \imath \theta u \mu \eta ́ \sigma \epsilon \iota \varsigma$ (Rom 7:7; cf. Rom 13:9). 4 Macc has an

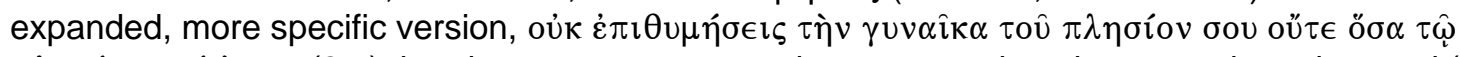
$\pi \lambda \eta \sigma i ́ v$ ooú $\dot{\varepsilon} \sigma \tau \imath v(2: 5)$, but the context suggests that a comprehensive scope is understood (NB

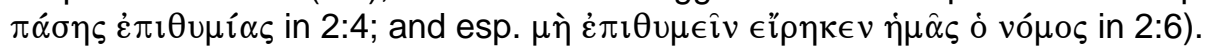


trends in biblical exegesis and ethical reflection, is impossible without a proper understanding of Philo's work—which is by far the most elaborate of the three. ${ }^{39}$ Finally, a comprehensive investigation of Philo's exposition of the Tenth Commandment promises a better understanding of key topics in Philo's ethical theory, which can in turn illuminate broader trends in Middle-Platonic ethical theory ${ }^{40}$ For example, Philo grounds his exposition in theoretical overviews of the $\pi \dot{\alpha} \theta \eta$, using a variety of technical terms and concepts. ${ }^{41}$ Clearly, he intends to establish at first a working model of $\dot{\varepsilon} \pi \imath \theta u \mu i \alpha$ as $\pi \dot{\alpha} \theta$ o $\zeta$ and then apply it to his

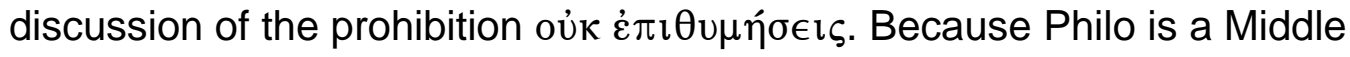
Platonist, his exposition offers valuable insight into the elements of a MiddlePlatonic theory of the "passions," insofar as it deals with passionate desire. ${ }^{42}$ The

${ }^{39}$ For an overview of these three treatments, see Thomas Tobin, Paul's Rhetoric in Its Contexts: The Argument of Romans (Peabody, Mass.: Hendrickson, 2004), 229-32. Tobin concludes that the three reflect "broader discussions within Hellenistic Judaism about the function of the law in relation to theories about the nature of the passions, particularly desire, in GrecoRoman philosophy" (232). See also Petra von Gemünden, "Der Affekt der $\dot{\varepsilon} \pi \imath u \mu i ́ \alpha$ und der vó $\mu$ os," in Das Gesetz im frühen Judentum und im Neuen Testament (ed. Dieter Sänger and Matthias Konradt; NTOA / SUNT 57; Göttingen: Vandenhoeck \& Ruprecht; Fribourg: Academic Press, 2006), 55-74; Stanley Stowers, "Paul and Self Mastery," in Paul in the Greco-Roman World: A Handbook (ed. J. Paul Sampley; Harrisburg, Pa.: Trinity Press International, 2003), 52450, 531-34 (cf. Stanley Stowers, A Rereading of Romans: Justice, Jews, and Gentiles [New Haven: Yale University Press, 1994], 58-65).

${ }^{40}$ On the fundamentally Platonic orientation of Philo's thought, see esp. Thomas $\mathrm{H}$. Billings, The Platonism of Philo Judaeus (Chicago: University of Chicago Press, 1919; repr., New York: Garland, 1979), made more useful by A.C. Geljon and D.T. Runia, "An Index Locorum to Billings, The Platonism of Philo Judaeus," SPhA 7 (1995): 169-85. On Philo as a Middle Platonist, see esp. Dillon, The Middle Platonists, 139-83; also "Special Section: Philo and Middle Platonism," SPhA 5 (1993): 95-155. In light of contemporary Middle-Platonic moral psychology, Philo's exposition of the Tenth Commandment looks like the work of a "de facto Middle Platonist," one of the six positions outlined in David Runia's typological spectrum (see "Was Philo a Middle Platonist? A Difficult Question Revisited," SPhA [1993]: 112-140, 125): "he does not belong to the school, but has a philosophical stance which is fundamentally Platonist and might well make him welcome in such circles."

${ }^{41}$ See esp. Decal. 142-46, Spec. 4.79.

${ }^{42}$ Simply put, Philo's exposition reflects a Middle-Platonic theory of the passions, insofar as it combines a fundamentally Platonic psychology (esp. Spec. 4.92-94) with Stoic technical 


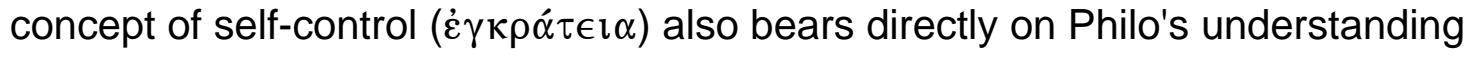
of the Tenth Commandment. ${ }^{43}$ When he begins his survey of the "particular

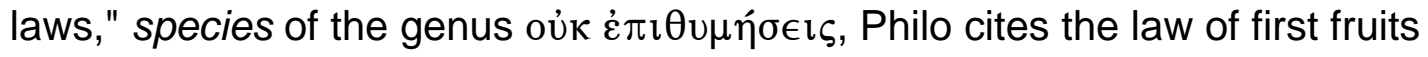
(Exod 23:19; Deut 18:4), which in his view exists "for the practice of self-control"

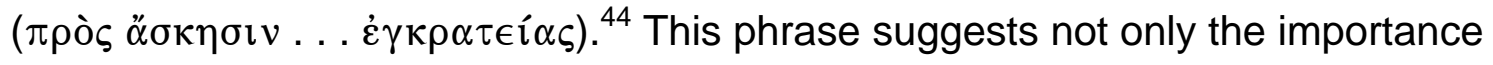
of $\dot{\varepsilon} \gamma \kappa \rho \dot{\alpha} \tau \epsilon \iota \alpha$, but also the relevance of another ethical concept, $\ddot{\alpha} \sigma \kappa \eta \sigma \iota \varsigma-$ specifically, how Mosaic laws regarding food and drink function as practice in the cultivation of self-control. ${ }^{45}$ Understanding Philo's exposition involves the clarification of these and other topics.

definitions of passion(s) (esp. Spec. 4.79; cf. Decal. 142)—a combination evident in other MiddlePlatonic texts (e.g., Didask. 32.1 [185.26]). Middle Platonists rework these Stoic definitions, enabling them to describe psychological phenomena whose existence "orthodox" (i.e., Chrysippean) Stoicism would deny (e.g., non-rational parts of the soul in conflict with a rational part). Evidence in Philo's exposition for this sort of reinvention exists but has not been properly assessed. For example, Philo in Spec. 4.79 adds to the Stoic definition of passion as "excessive

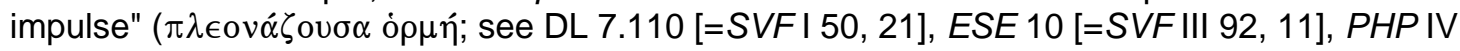

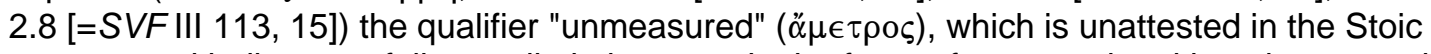
sources and indicates a failure to limit the quantitative force of a non-rational impulse-a notion incompatible with the Stoic understanding of impulse as a form of rational assent (on which see Brad Inwood, Ethics and Human Action in Early Stoicism [Oxford: Clarendon, 1985], esp. chs. 3 and 5, NB 167-68 on "excessive impulse": "no aspect of the theory [Stoic psychology] ... admits of the sort of variation of degree which would be needed for a more familiar quantitative sense of 'excessive'.").

${ }^{43}$ Spec. 4.97, 99, 101, 112 [х2], 124. For the explicit connection of $\dot{\varepsilon} \gamma \kappa \rho \dot{\alpha} \tau \epsilon \iota \alpha$ with the Tenth Commandment, see, for example, vol. 2 of Harry Austryn Wolfson, Philo: Foundations of Religious Philosophy in Judaism, Christianity, and Islam (2 vols; $2 \mathrm{~d}$ rev. print.; Cambridge, Mass.: Harvard University Press, 1948), 235-36; also Stowers, "Paul and Self Mastery," 532. For general considerations of $\dot{\varepsilon} \gamma \kappa \rho \alpha \dot{\tau} \tau \iota \alpha$ in Philo, see esp. Maren Niehoff, Philo on Jewish Identity and Culture (TSAJ 86; Tübingen: Mohr Siebeck, 2001), 94-110; also Stowers, "Paul and Self Mastery," 531-34 (cf. Stowers, Romans, 58-65).

${ }^{44}$ Spec. 4.99. Philo twice lists $\dot{\varepsilon} \gamma \kappa \rho \alpha \dot{\tau} \tau \epsilon \iota \alpha$ as one of many different kinds of $\ddot{\sigma} \sigma \kappa \eta \sigma \iota \varsigma$ (Her. 253, Leg. 3.18). Pierre Hadot uses Philo's two lists as a basis for his discussion of different "spiritual" exercises in antiquity, by which he means exercises of Greco-Roman philosophers pertaining to the soul, not exercises practiced in a religious setting (Pierre Hadot, "Spiritual Exercises," in Philosophy as a Way of Life: Spiritual Exercises from Socrates to Foucault [ed. w/intro. Arnold Davidson; trans. Michael Case; Malden, Mass.: Blackwell, 1995], 81-125, 84).

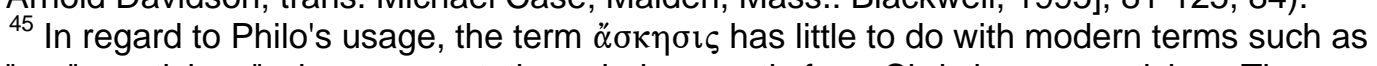
"ascetic" or "asceticism," whose connotations derive mostly from Christian monasticism. The Greek term has no intrinsic association with religious practice (see Hermigild Dressler, The Use 
Even an introductory survey of the nature and content of Philo's exposition of the Tenth Commandment commends it to further study. Moreover, Philo facilitates such study by neatly packaging his material: the structural layout of his broader Exposition of the Law makes his exposition of oủк $\dot{\varepsilon} \pi \imath u \mu \eta \dot{\eta} \sigma \in \iota$ a complete text in and of itself. Earlier studies of Philo have touched on this text in a variety of ways, from a variety of perspectives, with a variety of results.

\section{HISTORY OF RESEARCH}

Had Philo chosen to publish his exposition of the Tenth commandment as an independent work, it surely by now would have received more attention. But to date there is no comprehensive study of this important treatise, one that deals exclusively with Philo's view of the Tenth Commandment in light of his interests, his agenda, his organization of the material, and his understanding of the relevant topics—one that clearly and adequately answers the two basic questions of what the Commandment prohibits and how someone observes the Commandment. Translators of the units Decal. 142-53, 173-74 and Spec. 4.78b-

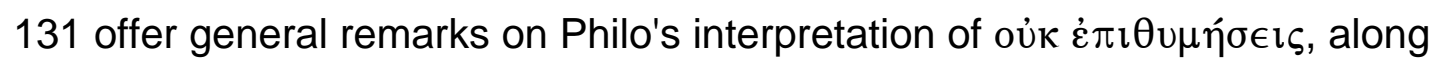
with commentary on specific passages, but the scope of their work is too broad and too sketchy to treat those units—especially the exposition proper-in sufficient depth. ${ }^{46}$ Similarly, a number of works whose aims lie elsewhere offer

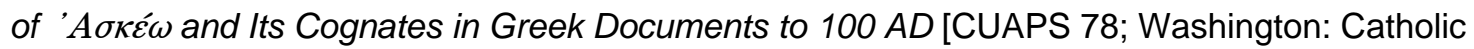

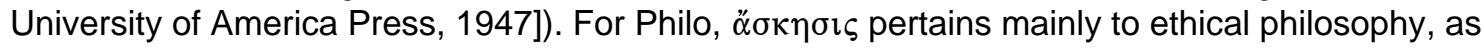
one of three ways to acquire virtue: nature, instruction, and practice (e.g., Abr. 52).

${ }^{46}$ Translations for the Decal. units (§§142-53, §§173-74) are in chronological order: Leopold Treitel, PCH 1 (1909); F. H. Colson, PLCL 7 (1937); Valentin Nikiprowetzky, PAPM 23 (1965); Francesca Calabi, Filone, Decalogo (2005); cf. Ronald Williamson, Jews in the Hellenistic 
incidental, often helpful, remarks on Philo's Tenth Commandment, but never in

an effort to explain his view in full. ${ }^{47}$ In fact, only two works offer sustained

treatments of the Tenth Commandment in Philo, and neither satisfies the need

for a comprehensive study.

Harry A. Wolfson

In an extensive work on Philo, Harry Wolfson devotes part of a chapter on

ethics to a study of the Tenth Commandment. ${ }^{48}$ The title of his brief analysis,

"The Virtue of the Control of Desire," reflects a broader aim on Wolfson's part to

explore the relationship between law and virtue, in particular where and how

Philo's understanding of Mosaic law incorporates terms and concepts derived

from Greek ethical theory (and/or Jewish tradition). ${ }^{49} \mathrm{He}$ does not intend to

World: Philo (CCWJCW 1.2; Cambridge: Cambridge University Press, 1989), 255-78. For the Spec. 4 unit (§§78b-131): Isaak Heinemann, PCH 2 (1910); F. H. Colson, PLCL 8 (1939); and André Mosès, PAPM 25 (1970).

${ }^{47}$ For example, Amir, "Decalogue," 158-59; Klaus Berger, Die Gesetzesauslegung Jesu (WMANT 40.1; Neukirchen-Vluyn: Neukirchener Verlag, 1972), 346-48; Erwin Goodenough, The Jurisprudence of the Jewish Courts in Egypt (New Haven: Yale University Press, 1929), 207-08;

Walther Houston, "Towards an Integrated Reading of the Dietary Laws of Leviticus," in The Book of Leviticus: Composition and Reception (ed. R. Rendtorff and R. Kugler; VTSup 93; FIOTL 3; Leiden: Brill, 2003), 142-61, 144-47; Kellermann, "Dekalog," 168; Lluch Baixauli, "Decálogo," 436-38; William Loader, "The Decalogue" in The Septuagint, Sexuality, and the New Testament (Grand Rapids, Mich.: Eerdmans, 2004), 5-25, 12-14; Anita Méasson, Du char ailé de Zeus à l'Arche d'Alliance: Images et mythes platoniciens chez Philon d'Alexandrie (Paris: Études Augustiniennes, 1987), 154; Thomas E. Phillips, "Revisiting Philo: Discussions of Wealth and Poverty in Philo's Ethical Discourse," JSNT 83 (2001): 111-21, 114-15; Alexander Rofé, "The Tenth Commandment in the Light of Four Deuteronomic Laws," in The Ten Commandments in History and Tradition (ed. B.-Z. Segal and G. Levi; Jerusalem: Magnes Press, 1990), 45-65, 4849; Torrey Seland, "The Moderate Life of the Christian paroikoi: A Philonic Reading of 1 Pet 2:11," in Philo und das Neue Testament (WUNT 172; Tübingen: Mohr Siebeck, 2004), 241-64, 259-63; Stowers, "Paul and Self-Mastery," 531-34 (cf. Stowers, Romans, 58-65); Tobin, Paul's Rhetoric, 231-32.

${ }^{48}$ Wolfson, Philo, 2:225-37.

${ }^{49}$ Before his discussion of the Tenth Commandment, Wolfson deals with the topics "'Under the Law' and 'In Accordance with Nature"' (165-200) and "Commandments and Virtues" (200-225). Topics in "The Virtue of the Control of Desire," listed in the table of contents as subheadings, are: "Control of actions and control of emotions, 225.-The treatment of the tenth commandment as dealing with the control of the pure emotion of desire in native Jewish tradition 
provide a comprehensive analysis of the contents of Philo's exposition. Instead, as part of a sweeping effort to reconstruct Philo's system of thought, he considers the significance within that system of a moral imperative aimed not at action(s) but at "pure emotion." ${ }^{10}$ Although limited, Wolfson's treatment nevertheless includes substantive claims about Philo's interpretation of oủк $\dot{\varepsilon} \pi \imath \theta u \mu \eta \dot{\sigma} \epsilon \iota \varsigma$.

Wofson's most valuable contribution comes at the end of his analysis, where he recognizes the central importance of $\dot{\varepsilon} \gamma \kappa \rho \dot{\alpha} \tau \in \imath \alpha$ in Philo's overall understanding of the Tenth Commandment. ${ }^{51}$ In particular, he recognizes that "[t]he negative tenth commandment is . . . a command to control one's desire." ${ }^{52}$ In other words, the negative prohibition implies a positive command to cultivate the virtue of $\dot{\varepsilon} \gamma \kappa \rho \alpha \dot{\tau} \tau \iota \alpha$, which-as Wolfson notes—is "the positive term . . . by which the control of excessive desire is to be described. ${ }^{53}$ But because his interests lie elsewhere, he only considers that this is true, not how this is true. He never answers the basic question of how someone observes the Tenth Commandment or how it in fact promotes $\dot{\varepsilon} \gamma \kappa \rho \alpha \dot{\tau} \tau \epsilon \iota$. Wolfson also realizes that, for Philo, other Mosaic laws work along with the Tenth Commandment to

and in Philo, 226.-Philo's diatribe against the emotions and the rabbis' diatribes against the evil yetzer, 229.-Similarity and difference between Philo on the one hand and Aristotle and the Stoics on the other in their treatment of the emotion of desire, 231.--'Continence' as the virtue opposed to the vice of 'desire,' 235."

${ }^{50}$ Wolfson, Philo, 2:225.

${ }^{51}$ Stanley Stowers (e.g., "Paul and Self Mastery," 532) similarly notes the importance of

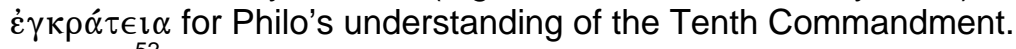

${ }^{52}$ Wolfson, Philo, 2:235.

${ }^{53}$ Wolfson, Philo, 2:235. 
promote $\dot{\varepsilon} \gamma \kappa \rho \dot{\alpha} \tau \in \iota \alpha .{ }^{54}$ But he never mentions the dietary laws, let alone explain

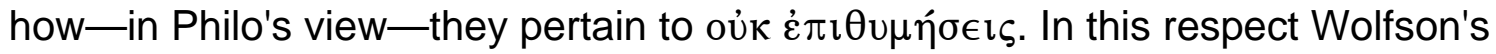
treatment, even where it does correctly characterize Philo's view of the Tenth Commandment, remains sketchy.

Although valuable for its emphasis on $\dot{\varepsilon} \gamma \kappa \rho \alpha ́ \tau \in \imath \alpha$, Wolfson's study misconstrues Philo's view of what the Commandment prohibits. He makes the unfounded assumption that Philo, with the Septuagint version in mind, understands the Tenth Commandment to be a prohibition only of desire for what belongs to another person. ${ }^{55}$ Wolfson does not acknowledge the generalizing

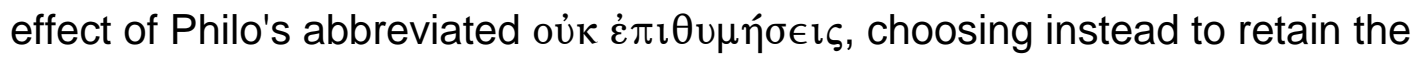
Septuagint version's specification "of your neighbor" ( $\tau$ ov $\pi \lambda \eta \sigma i ́ o v ~ \sigma o u) .{ }^{56} \mathrm{He}$ admits that this specification does not appear in Philo's commentary but assumes it nevertheless:

Though Philo speaks of desire in general, that is, of a desire for what we have not, and not of a desire for that which belongs to somebody else, still his discussion, in so far as it is a commentary upon the commandment, implies that the desire of which he speaks is that desire which the commandment explicitly describes as a desire for that which belongs to another person. (Wolfson, Philo, 2:228) ${ }^{57}$

54 "It is the virtue of 'continence' . . . that is taught by the tenth commandment as well as by all those special laws of which the purpose, as seen by [Philo], is to teach the control of desire" (Wolfson, Philo, 2:236).

${ }_{55}$ Wolfson, Philo, 2:228-29.

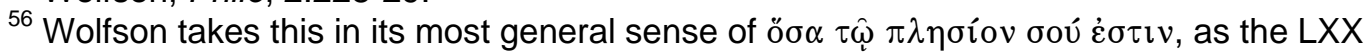
version stipulates. He cites and disagrees with Colson, whose assessment is correct: "The words 'thy neighbour's,' which are repeated so emphatically in the tenth commandment, as we have it and Philo also had it in the LXX, receive little attention from him" (PLCL 8, x).

${ }^{57}$ Also 2:229: "It is exactly the latter kind of desire, the desire for that which belongs to somebody else, that the tenth commandment as a law, and not a mere moral maxim, legally prohibits, according to Philo ...." Ibid.: "In his discussion of the legal prohibition not to desire that which belongs to one's neighbor, a prohibition, as we have said, of a mere desire for that which belongs to one's neighbor." 
The only evidence Wolfson offers in support of this view involves Philo's first example of an object of desire, namely money $(\chi \rho \eta \tilde{\eta} \mu \tau \alpha) .{ }^{58}$ He argues that, although Philo does not specify the money's source:

the subsequent statement that a desire for money leads to robbery and purse-cutting and house-breaking makes it quite evident that the desire for money spoken of was not a desire for money in general but rather for the money in the pocket or the purse or the house of one particular person. (Wolfson, Philo, 2:228)

But Wolfson fails to cite the entire passage, which goes on to associate the

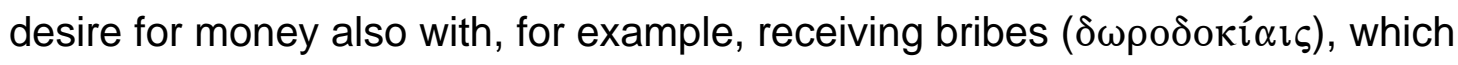
clearly involves greed per se and not desire for the money "of one particular person." Moreover, the other examples of desiderata on Philo's list, none of which Wolfson mentions, hardly make sense when construed strictly as belonging to another person. This is especially true in the case of desires for food and drink, which are, for Philo, governed by the Tenth Commandment's particular laws. $^{59}$

Wolfson's study suffers also from an outdated conception of Philo's relationship to Greek philosophy. As he investigates select details of Philo's "homily on the evils of desire," Wolfson considers Philo an eclectic who adopts any number of different philosophical positions ad hoc. Wolfson suggests that in most of his analysis of $\dot{\varepsilon} \pi \imath \theta u \mu i \alpha$ Philo chooses a Stoic position, but "[w]henever

${ }^{58}$ Spec 4.87: "If the desire is directed to money it makes men thieves and cut-purses, footpads, burglars, guilty of defaulting to their creditors, repudiating deposits, receiving bribes, robbing temples and of all similar actions."

${ }^{59}$ On Philo's association of the Tenth Commandment with dietary laws, Amir notes: "This association of ideas is possible only if the Commandment is shorn of its concluding words, 'anything that is your neighbor's'. For after all, kashrut has nothing to do with issues of ownership, of 'mine and thine'. An animal is not forbidden as food because it is stolen goods" ("Decalogue," 159). 
forced by certain native Jewish presuppositions, he departs from the Stoics and follows some other philosopher or presents a new view of his own." ${ }^{60}$ Wolfson is correct, generally speaking, when he matches various terms and concepts in Philo's commentary with the same terms and concepts in sources known to be, for example, Stoic. ${ }^{61}$ But he gives the misleading impression that Philo freely vacillates from one philosophical opinion to another, with no underlying commitment to one philosophical orientation over another. Philo's "eclectic" philosophical mix is instead best understood as a reflection of his Middle Platonism; but without this insight Wolfson's study cannot provide an adequate understanding of Philo's philosophical perspective. ${ }^{62}$

In sum, Wolfson offers a substantial discussion of the Tenth Commandment in Philo, but one whose breadth and depth are severely limited due to the relatively minor role it plays within a much larger and more broadly oriented work. His answer to the question of what, in Philo's view, the Tenth Commandment prohibits is incorrect, since he limits the scope of $\dot{\varepsilon} \pi \imath \theta u \mu i \alpha$ to

\footnotetext{
${ }^{60}$ Wolfson, Philo, 2:231. Wolfson initially emphasizes Stoic provenance: e.g., 2:230: "It is the Stoics . . . whom Philo follows here in the external formulation of his views." . . "He similarly follows the Stoics ...."

${ }^{61}$ E.g., Wolfson cites SVF for definitions of emotion comparable to Spec. 4.79, but he fails to note the significance of the non-Stoic $\ddot{\alpha} \mu \epsilon \tau \rho \circ \varsigma$ in Philo's definition (see above, n. 42).

${ }^{62}$ Cf. Dillon, Middle Platonists, 182: "My chief thesis (as against such an authority as H.A. Wolfson, for example) is that Philo was not so much constructing for himself an eclectic synthesis of all Greek philosophy, from the Presocratics to Posidonius, as essentially adapting contemporary Alexandrian Platonism, which was itself heavily influenced by Stoicism and Pythagoreanism, to his own exegetical purposes." For a fuller, yet still concise, statement of this position, in which Dillon rejects the misconceptions of (1) Philo as an "eclectic" who (2) merely uses philosophical language to serve exegetical aims, see his preface to Philo of Alexandria: The Contemplative Life, The Giants, and Selections (trans. and intro. David Winston; CWS; Mahwah, N.J.: Paulist, 1981), xii-xiii. See also David Winston's introduction (idem, 1-37), in which he accepts Philo's views as "Middle Platonist, that is, a highly Stoicized form of Platonism, streaked with Neopythagorean concerns" (3).
} 
only desire for what belongs to another person. Nor does he answer the question of how someone observes the Tenth Commandment, although he provides the proper context for an answer-namely, the acquisition, development, and exercise of $\dot{\varepsilon} \gamma \kappa \rho \alpha \dot{\tau} \tau \in \iota$. Finally, his comments on the nature and function of $\dot{\varepsilon} \pi \imath \theta v \mu i \alpha$, although helpful at times, fail to represent Philo's relationship with Greek philosophy properly.

Kathy L. Gaca

In her book The Making of Fornication, Kathy Gaca includes a chapter on Philo that deals in part with his understanding of the abbreviated Tenth Commandment. ${ }^{63}$ While the broad scope of her work precludes an exhaustive treatment of Philo's exposition, Gaca nevertheless presents a sustained and

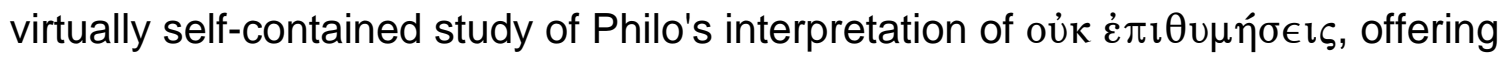
summary conclusions and a bold thesis about Philo's notion of forbidden desire. ${ }^{64}$ Taking all three of the relevant text units into account (Decal. 142-53, 173-74; Spec. 4.78b-131), she addresses not only the question of what, in Philo's view, the Commandment prohibits, but also but also how someone observes the Commandment, including an explanation of how the dietary laws promote its

${ }^{63}$ Chapter seven [="Philo's Reproductive City of God"] in The Making of Fornication: Eros, Ethics, and Political Reform in Greek Philosophy and Early Christianity (HCS 40; Berkeley: University of California Press, 2003), 190-217. Pages 193-99 deal directly with the Tenth Commandment.

${ }^{64}$ See esp. her section titled "Philo's Revolutionary Conception of Forbidden Desire" (Gaca, Making of Fornication, 194-204). The aim of her book is "to resolve an important philosophical and historical problem about the making of sexual morality in Western culture: Do the patristic sexual rules of second-century Christianity differ notably from the Greek philosophical sexual principles that the patristic writers used to help formulate their own? Alternatively, are these Christian rules in unison with the Greek philosophical basis that they claim to have" (1). Her interest in Philo lies mainly in his contribution to the sexual ethics of "Christian Platonism" (see 193-94, along with her study of Clement of Alexandria in 247-72). 
observance. $^{65}$ In one important general respect Gaca's work breaks new ground and sets a worthy standard: in her consideration of Philo's view of oủ $\dot{\varepsilon} \pi \imath \theta u \mu \eta \dot{\sigma} \sigma \iota \varsigma$, she takes seriously the idea that he is a Middle Platonist, consistently bearing in mind his debt to Plato and his acceptance of Platonic doctrines pertinent to an analysis of $\dot{\varepsilon} \pi \imath \theta u \mu i^{\prime}{ }^{66}{ }^{6}$ But in her analysis of Philo's view, Gaca misconstrues the textual data, misreading a number of passages and failing to mention others that would readily disprove her claims. ${ }^{67}$ For this reason, and because her study proposes a definitive-but incorrect-account of how Philo understands the Tenth Commandment, it deserves a detailed review. Stated in its broadest terms, Gaca's thesis is that Philo's explanation of the abbreviated Tenth Commandment combines two elements into one innovative "Jewish Middle Platonist notion of forbidden desire"—namely, (1) "the Hellenistic Jewish concern about the desire ( $\left.\dot{\varepsilon} \pi \imath \imath_{\imath} i \alpha\right)$ to disobey God's laws" and (2) "the Middle Platonist problem of excessive physical appetites ( $\dot{\varepsilon} \pi \theta u \mu i \alpha \imath)$

${ }^{65}$ Gaca does not quote Philo at length, but she does refer to passages from all three units of his exposition, indicating her awareness of the extent of his treatment. Her references take into account esp. Decal. 142, 173-174 and Spec. 4.78, 85, 87-96, 100-118.

${ }^{66}$ On Gaca's concept of Philo as a "Jewish Middle Platonist," see Making of Fornication, 191, n. 2. Although her conclusions are problematic, Gaca's approach is commendable in several respects. For example, she brings a Platonic psychological model to bear on the textual data of Philo's exposition, relating his discussion of $\dot{\varepsilon} \pi \imath \theta u \mu i \alpha$ to Plato's theory that there is in the soul a

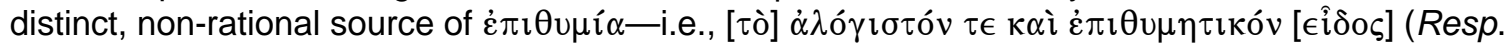
439 D; NB Spec. 4.92-94 [cf. Tim. 70 D-E]). Moreover, she notes key implications of Plato's theory, such as one's inability to remove appetitive $\dot{\varepsilon} \pi \imath \theta u \mu i \alpha$ entirely and the consequent importance of its moderation (e.g., Making of Fornication, 197). Gaca also understands that Philo's Middle Platonism involves the reinvention of Stoic terms and definitions: "The Stoic definitions of the passions that Philo uses are thus like a label that at first glance looks Stoic, but the contents have changed" (201). Gaca's understanding of exactly how Philo changes the contents is problematic, but this statement as such is correct.

${ }^{67}$ Cf. David Runia's review of The Making of Fornication in SPhA 17 (2005): 237-43, esp. 241-43. Runia's summary assessment of Gaca's study includes a caveat: "[B]ecause its method of analyzing and interpreting texts is flawed, it is to be used with caution" (243). 
for the pleasures of food, drink, and especially sexual activity, contrary to

reason's judicious sense of moderation. ${ }^{168}$ What this means is that Philo follows a broader exegetical trend within Hellenistic Judaism to treat the Tenth

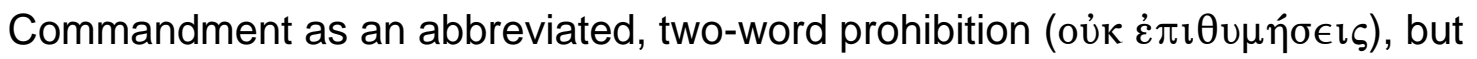

he does not follow the standard line of interpretation, which takes the prohibition

to mean "that it is wrong or sinful even to desire to act contrary to God's will." ${ }^{69}$

Instead, Philo follows Plato's conviction that uncontrolled appetitive desire, especially sexual desire, corrupts individuals and societies, and for this reason

${ }^{68}$ See Gaca, Making of Fornication, 194-95. Stated differently: "He reinterprets Platonic appetition-and sexual desire foremost-in light of the Hellenistic Jewish prohibition against the desire ( $\dot{\varepsilon} \pi \imath v \mu i \alpha)$ to disobey God's will" (197). Gaca frames her thesis as a matter of sexual ethics: "Philo's sexual principles are part of an innovative agenda for social order that borrows from Plato and the Pentateuch, makes sense only in relation to both, and yet represents neither without noteworthy transformation. This is especially true for Philo's reinterpretation of the problems Plato sees with sexual desire, which Philo presents in his take on the aphoristic version

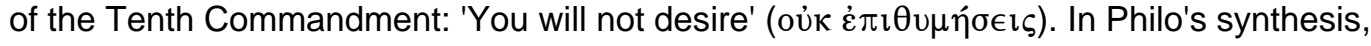
forbidden desire $(\dot{\varepsilon} \pi \imath \theta u \mu i \alpha)$ in the Hellenistic Jewish sense, which signifies any inclination to defy God's will, becomes primarily sexual in light of Plato's conviction that uncontrolled desire $(\dot{\varepsilon} \pi \imath v \mu i \alpha)$ for sexual pleasure is the single biggest source of individual and social corruption" (Gaca, Making of Fornication, 193).

${ }^{69}$ Gaca, Making of Fornication, 153. See 153-54 for Gaca's idea of a "Hellenistic Jewish variant on the Septuagint Tenth Commandment." In her discussion of Philo, Gaca speaks of "the Hellenistic Jewish Tenth Commandment in its two more traditional forms," by which she means (a) the LXX version itself (Exod 20:17 [=Deut 5:21]) and (b) the abbreviated version oü $\dot{\varepsilon} \pi \imath \theta u \mu \eta \dot{\eta} \in \iota \varsigma$, which omits the list of direct objects (198). She believes that Paul and Philo's citations of oủк $\dot{\varepsilon} \pi \imath \theta u \mu \eta \dot{\sigma} \sigma \iota \varsigma$ serve as evidence for a hypothetical tertium quid-namely, an exegetical tradition that influenced these two authors. Her supposition involves first the claim that prior to Philo, who in fact offers the earliest extant citation of oủк $\dot{\varepsilon} \pi \imath \theta u \mu \eta \dot{\eta} \sigma \in \iota \varsigma$ (see above, n. 37), one or more unidentified Hellenistic Jewish exegetes chose to make an abbreviated Tenth Commandment their object of inquiry. This is of course plausible, but the alternate supposition that Philo himself was the first to cite and interpret oủк $\dot{\varepsilon} \pi \imath \theta u \mu \eta \tilde{\sigma} \epsilon \varsigma$ is equally plausible and less speculative. After all, his is the most extensive extant commentary on the abbreviated version and-contingent on unknown facts regarding the publication of his Exposition of the Law-is as likely as any to have been the seminal work. Be that as it may, Gaca goes on to attribute a standard line of interpretation to this already hypothetical exegetical tradition. Oủк $\dot{\varepsilon} \pi \imath \theta u \mu \eta \dot{\eta} \sigma \iota \varsigma$, the "newer prohibition" offered by the tradition, means "that it is wrong or sinful even to desire to act contrary to God's will" (153). Gaca's view problematically requires Philo to creatively modify a tradition for which no evidence exists, at least in terms of an extant text that cites oủ $\dot{\varepsilon} \pi \imath \theta \mu \eta \tilde{\eta} \sigma \epsilon \iota \varsigma$, then explicitly offers the interpretive conclusion "that it is wrong or sinful even to desire to act contrary to God's will." (On 152 Gaca cites "a broader Hellenistic Jewish and early Christian trend that stresses the danger of rebellious impulses very stringently"; but this broader trend-even if it did exist—does not constitute evidence for the exegetical trend that Gaca posits.) 


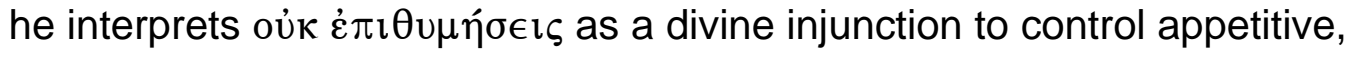
especially sexual, desire.

This last idea, that Philo's Tenth Commandment deals especially with sexual desire, deserves careful attention, since it in effect answers the question of what the Commandment prohibits. Ultimately, this idea derives from a reasonable but false assumption on Gaca's part that Philo imports without modification a certain concept of desire found in Plato's writings-a concept she outlines in an earlier chapter of her study. ${ }^{70}$ Taken for granted, this assumption drives an almost syllogistic logic that informs much of what Gaca has to say about Philo's view of the Tenth Commandment: (a) when Plato thinks of $\dot{\varepsilon} \pi \imath \theta v \mu i \alpha$ and its dangerous propensity for excess, he has in mind physical appetites, especially the sexual appetite; (b) when Philo thinks of the Commandment oủк $\dot{\varepsilon} \pi \imath \theta u \mu \eta \dot{\eta} \sigma \in \varsigma$, he has in mind Plato's concept of $\dot{\varepsilon} \pi \imath \theta u \mu i \alpha$ and its dangerous propensity for excess, therefore (c) Philo has in mind physical appetites, especially the sexual appetite. A number of sweeping claims ensue: Philo reinterprets this commandment in a Platonic spirit that is very much in keeping with "nothing in excess," as though oủк $\dot{\varepsilon} \pi \imath u \mu \eta \dot{\gamma} \sigma \in \iota \varsigma$ meant "you will restrain your physical appetites from becoming excessive," the

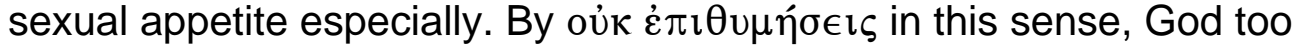
teaches the Platonic doctrine that depravity is grounded primarily in the

${ }^{70}$ See Gaca, Making of Fornication, 26-41, esp. 32-33. The accuracy of Gaca's reading of Plato on this point bears only secondary importance, since the question is what Philo has to say about desire in his exposition of the Tenth Commandment. Even if she has correctly understood Plato's concept of appetitive desire, this concept must not serve automatically as the

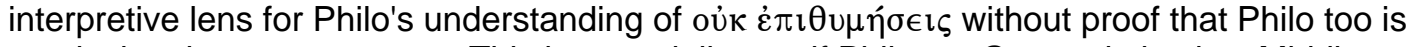
employing the same concept. This is especially true if Philo, as Gaca admits, is a Middle Platonist, which implies that he would have employed "Platonic" concepts that had been modified in significant respects in light of philosophical developments postdating Plato. 
unrestrained sexual appetite and its progeny of vices. (Gaca, Making of Fornication, 196)

Or similarly:

In God's social order these iniquities would become a thing of the past, so long as the people heed the commandment oủк $\dot{\varepsilon} \pi \imath \theta u \mu \eta ́ \sigma \in \iota \varsigma$ by getting their appetitive urges under control, especially sexual desire. (Idem) ${ }^{71}$

Gaca frames these statements carefully, avoiding the claim that oủк $\dot{\varepsilon} \pi \imath \theta u \mu \eta \dot{\sigma} \sigma \iota \varsigma$ deals exclusively with sexual desire. She does, after all, understand that the basic operation of Plato's $\dot{\varepsilon} \pi \imath u \mu \eta \tau \imath \kappa o ́ v$ involves desires also for food and drink. ${ }^{72}$ But in some instances there is no clear acknowledgement of the relevance of non-sexual desire(s) within the Commandment's purview: "Philo's Tenth Commandment is innovative as a Decalogue rule because it valorizes sexual desire as the main source of all wickedness. ${ }^{73}$ In other instances, particularly in concluding summaries of her argument, there is no indication that anything but sexual desire lies within the proscriptive range of oủк $\dot{\varepsilon} \pi \imath \cup \mu \eta \dot{\eta} \sigma \in \varsigma$ :

Though Philo supports Plato's argument that uncontrolled sexual desire is the primary and most incorrigible source of all vices, he identifies the

${ }^{71}$ The "iniquities" Gaca has in mind appear in Republic 575 B. In her view, Philo cites this passage in Spec. 4.87 (certainly an allusion, but Philo's $\chi \rho \epsilon \omega \kappa о \pi i \alpha \iota \varsigma \tau \epsilon \kappa \alpha \grave{\imath} \pi \alpha \rho \alpha \kappa \alpha \tau \alpha \theta \eta \kappa \hat{\nu} v$ $\dot{\alpha} \rho v \eta \dot{\sigma} \sigma \sigma \mathrm{l}$ has no parallel in the Republic passage) to illustrate "proliferating vices that he attributes to breaking his version of the Tenth Commandment" (196). But in Spec. 4.87, Philo explicitly considers desire directed at "money" ( $\chi \rho \eta \mu \alpha \tau \alpha)$, not sexual or even appetitive desire per se. Plato does consider $\chi \rho \eta \mu \alpha \tau \alpha$ an object of appetitive desire (see Resp. $580 \mathrm{E}$ ), but Philo's inclusion of other objects of $\dot{\varepsilon} \pi \imath u \mu i \alpha$, like "reputation" ( $\delta \hat{\xi} \xi \alpha$ ), which Plato does not associate with appetitive desire, proves that $\dot{\varepsilon} \pi \imath \theta u \mu i \alpha$ in his exposition must be conceived more broadly.

${ }^{72}$ E.g., Plato cites thirst to illustrate the distinction between rational and appetitive elements within the soul (see Resp. 439 A-E; cf. 437 D: "'[S]hall we say that the desires $(\dot{\varepsilon} \pi \imath \theta \mu \imath \hat{\omega} v)$ constitute a class and that the most conspicuous members of that class are what we call thirst and hunger?' 'We shall,' said he" [trans. Paul Shorey] [unless otherwise noted, all translations of Plato's writings are from the Loeb Classical Library]).

${ }^{73} \mathrm{Gaca}$, Making of Fornication, 198. Also: " Philo's version of oủк $\dot{\varepsilon} \pi \imath \theta u \mu \eta \tilde{\sigma \epsilon \iota \varsigma, ~ h o w e v e r, ~}$ prohibits unrestrained sexual desire as the primary religious defiance and corruption in the city of God" (198). 
Hellenistic Jewish notion of desiring to disobey God $(\dot{\varepsilon} \pi \imath \theta u \mu i \alpha)$ with the Platonic sexual appetite (i่ $\pi \imath \theta v \mu i \alpha)$. (Gaca, Making of Fornication, 297; emphasis added $)^{74}$

Gaca clearly has an answer to the question of what Philo's Tenth Commandment prohibits. Although she ostensibly points to "excessive appetitive desire," she in fact has appetitive sexual desire in mind. $^{75}$

But the idea that Philo's concept of desire in his exposition is exclusivelyor even primarily—sexual is incorrect, since Philo associates oủк $\dot{\varepsilon} \pi \imath \theta \mu \eta \dot{\sigma \epsilon \epsilon \iota}$ with a generic desire involving any number of different objects, none of which looms any larger than another in the Commandment's theoretically limitless

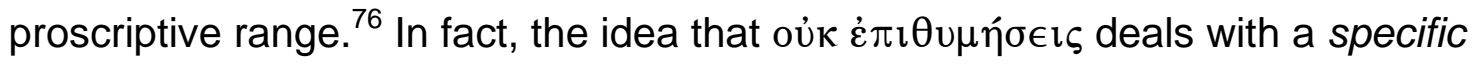
desire of any type is inherently implausible, because Philo believes that the Ten

${ }^{74}$ Cf. 216 , where Philo is said to identify "the Platonic notion of sexual desire ( $\left.\dot{\varepsilon} \pi \imath \theta u \mu i ́ \alpha\right)$ with the Hellenistic Jewish concern about the inherently wrongful impulse $(\dot{\varepsilon} \pi \imath \theta u \mu i \alpha)$ to transgress God's laws. He makes this identification most notably through his Jewish Middle

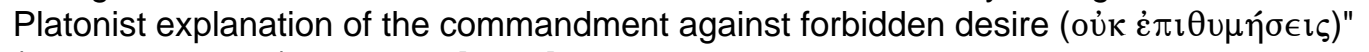
(emphasis added). Also 23: "[Plato] would have needed an interpreter to understand how the problems that he associates with uncontrolled sexual desire were written into the Tenth Commandment that Philo and Clement produced."

${ }^{75}$ This exclusive focus is confirmed by Gaca's construal of the Mosaic dietary laws, which in her view do not ultimately regulate appetitive desires for food and drink, but instead target the Tenth Commandment's real concern-sexual desire: "Philo regards Moses' dietary laws as the one sure regimen that reduces sexual desire and thereby subdues its offspring of vices" (Making of Fornication, 196).

${ }^{76}$ On this point there seems to be virtually unanimous agreement among commentators, with the exception of Gaca. For example, Colson (PLCL 7, 76, n. c): "Philo extends the meaning of the word from covetousness of what is another's to desire in general"; Mosès (PAPM 25, 17, n.1): Philo's version of the Tenth Commandment "n'admet pas de contenu veritable, puisque le désir est lui-même coupe de tout objet précis"; Williamson (Philo, 267): "Philo . . . extends the meaning of a desire to include its most general sense." Even Wolfson (2:228), who needlessly specifies "desire for that which belongs to another person," nevertheless acknowledges that "Philo speaks of desire in general, that is, of a desire for what we have not." On the concept of generic desire, note esp. Migr. 155: "It is this mixed multitude which takes delight not in a few

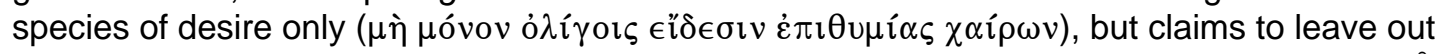
nothing at all, that it may follow after desire's entire genus ( $\gamma \varepsilon \dot{\varepsilon} v \varsigma)$, including all its species $(\hat{\omega} \pi \hat{\alpha} \nu$

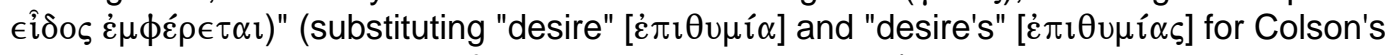
"lusting" and "lust's," neither of which the context supports). 
Commandments are all generic summaries. ${ }^{77}$ Philo's commentary consistently reflects his underlying belief in a prohibition of desire able to subsume any and all specific types. For example, in Spec. 4.80 Philo identifies this most troublesome

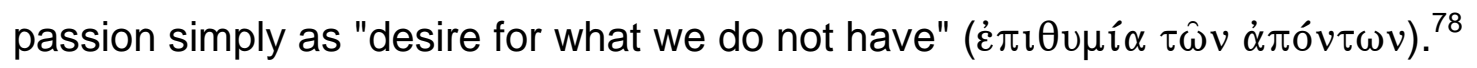
When Philo goes on to associate this desire with specific aims, he is merely illustrating its troublesome nature, noting that it creates savage hunger and thirst, "but not for something to fill the void in their bellies—-they hunger for money, fame, power, voluptuous bodies, or any of the countless other things that seem to them enviable and worthy of struggle" (Spec. 4.82; my translation) ${ }^{79}$ As this list indicates, sexual desire is not foremost in Philo's mind, nor even appetitive desire per se ${ }^{80}$ At most, sexual desire forms a part, but only a small part, of

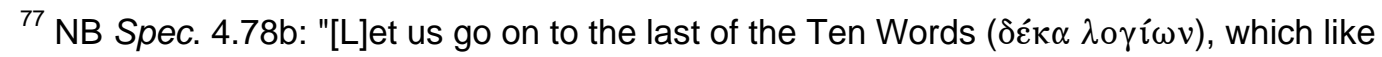

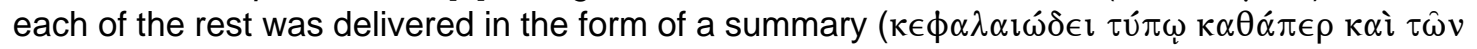

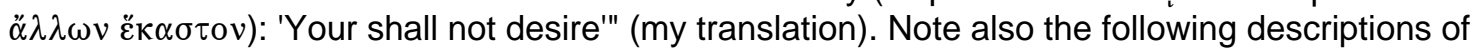

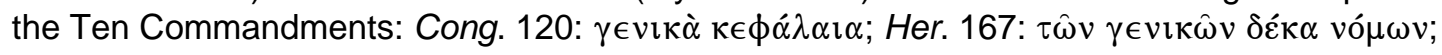

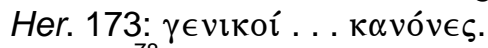

${ }^{78}$ Philo's immediate specification of "things which seem good, though they are not truly

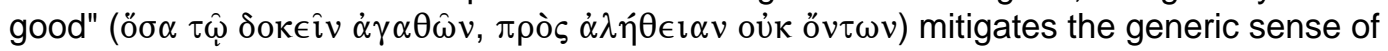
$\dot{\varepsilon} \pi \mathrm{\imath} \theta$ v $\mu i \alpha$ somewhat but still allows for most any particular "good" object (cf. the parallel passage

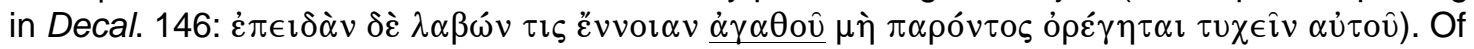
course, when Philo turns to the Tenth Commandment's particular laws (dietary laws) the desire for food and drink are singled out, but in a paradigmatic, not absolute, sense (see Spec. 4.96).

${ }^{79}$ Cf. Spec. 4.86-91.

${ }^{80}$ In fact, Gaca's proposal that $\dot{\varepsilon} \pi \imath \theta u \mu i \alpha$ in Philo's exposition refers specifically to

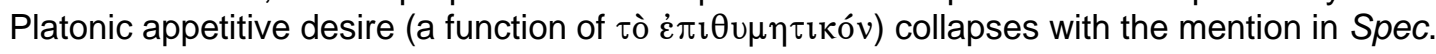

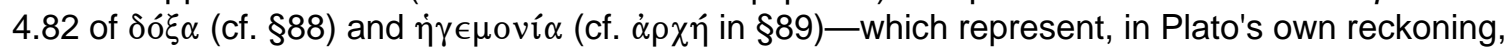

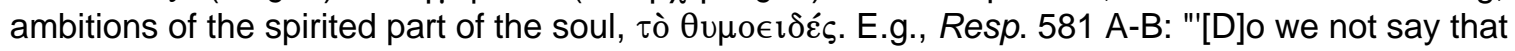

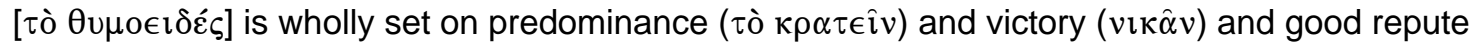

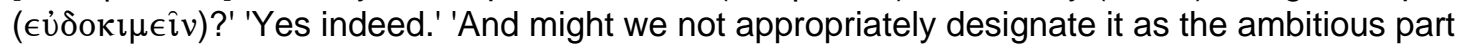

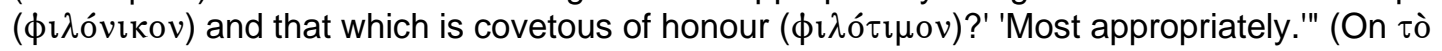
$\theta u \mu o € \imath \delta \varepsilon \varepsilon$ see John Cooper, "Plato's Theory of Human Motivation," in Reason and Emotion [Princeton: Princeton University Press, 1999], 118-37, esp. 130-36; repr. from HPhQ 1 [1984].) Schmidt, Anthropologie, 92-93, notes: "Als Gegenstand des Begehrens werden fast durchweg die Strebungen, die Platon von dem zweiten und dritten Sellenteil aussagt, zusammengefaßt." This

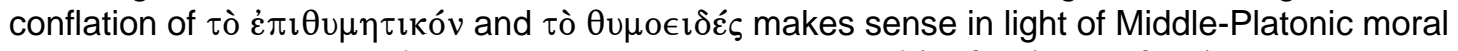
psychology, which was influenced by Aristotle's concept of $\dot{\varepsilon} \pi \imath u \mu i \alpha$ and $\theta u \mu o ́ s$ as two types of 
Philo's overall concept of desire with respect to the Tenth Commandment. ${ }^{81}$ Not only do Philo's words fail to support the claim that oủк $\dot{\varepsilon} \pi \imath \cup \mu \eta \dot{\eta} \sigma \in \iota \varsigma$ targets sexual desire-they positively refute it.

Naturally, this raises the question of where and how Gaca finds textual support for her idea that the desire proscribed by Philo's Tenth Commandment is primarily sexual. She asserts that "Philo accepts Plato's theory of the irrational physical appetites as well as his position that the sexual appetite is the most domineering and recalcitrant of the lot" (emphasis added), citing Spec. 4.92-94 to support her claim: ${ }^{82}$

Finally, they determined that desire must reside in the area around the

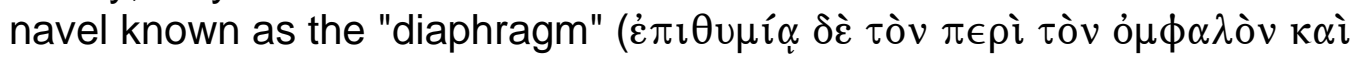
$\tau o ̀ ~ \kappa \alpha \lambda o u ́ \mu \epsilon v o v \delta i \alpha ́ \phi \rho \alpha \gamma \mu \alpha \chi \hat{\omega} \rho o v)$. Since desire has the least to do with

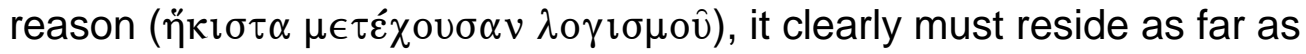
possible from reason's royal domain-practically at the outskirts. Naturally, the pasture of this most insatiable and licentious of beasts $(\pi \dot{\alpha} \nu \tau \omega \nu$

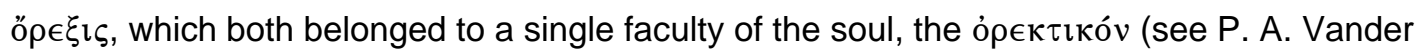
Waerdt: "The Peripatetic Interpretation of Plato's Tripartite Psychology," GRBS 26 [1985]: 283302 and "Peripatetic Soul-Division, Posidonius, and Middle Platonic Moral Psychology," GRBS 26 [1985]: 373-94; cf. Charles Kahn, "Plato's Theory of Desire," RM 41 [1987]: 77-103, 78-80).

${ }^{81}$ The passage in Philo's exposition that pertains to sexual desire appears in Spec. 4.89:

"If the object [of desire] is bodily beauty they are seducers ( $\phi \theta 0 \rho \in \hat{i} \varsigma$ ), adulterers ( $\mu$ ol $\chi 0 u ́ \varsigma)$, pederasts $(\pi \alpha \imath \delta \in \rho \alpha \sigma \tau \alpha \dot{\alpha})$ ), cultivators of incontinence and lewdness ( $\dot{\alpha} \kappa \circ \lambda \alpha \sigma i \alpha \varsigma \kappa \alpha i \lambda \lambda \alpha \gamma \nu \in i \alpha \varsigma$ $\zeta \eta \lambda \omega \tau \dot{\alpha} \varsigma)$, as though these worst of evils were the best of blessings." In Decal. 168-69, Philo has in mind the very same types of immoral sexual behavior, but he is commenting on a different

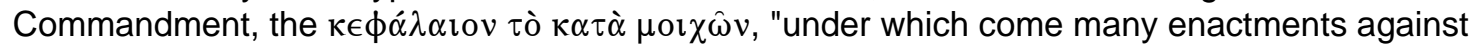

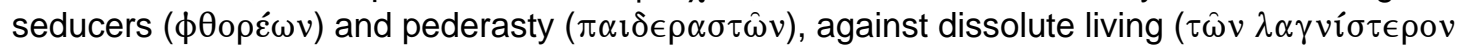

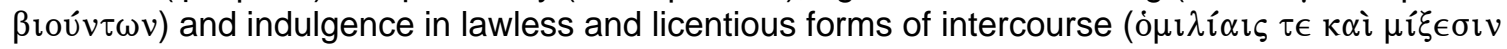

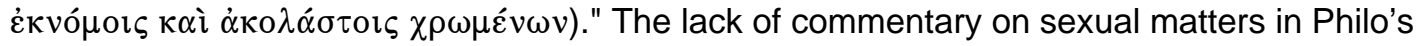
exposition of the Tenth Commandment is best explained by his having already dealt with such matters in his exposition of the Sixth Commandment, which governs the obviously sexual transgression of adultery. The preeminence of the Sixth Commandment, not the Tenth, in Philo's consideration of sexual ethics is correctly noted by Baudouin Decharneux, "Interdits sexuels dans l'œuvre de Philon d'Alexandrie dit 'Le Juif,'" Religion et Tabou Sexuel (ed. Jacques Marx; PHR 1; Bruxelles: Editions de l'Université de Bruxelles, 1990), 17-31, esp. 18-25.

${ }^{82}$ See Gaca, Making of Fornication, 195. Presumably, Spec. 4.92-94 is the textual evidence Gaca has in mind, since it is the only passage she cites in the paragraph other than Decal 173-74, which for her serves only to prove that "appetites are an unavoidable part of our human and animal nature." 


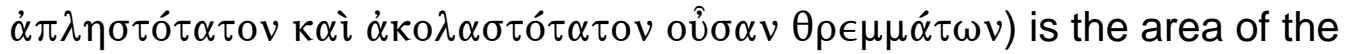

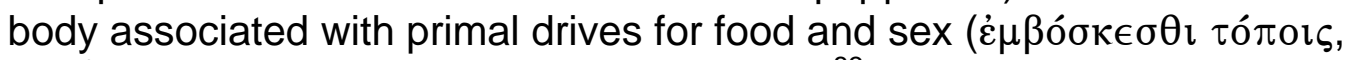

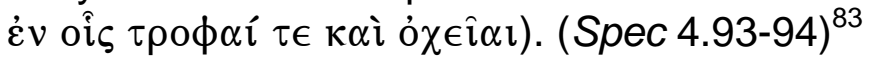

Philo clearly marks in this passage the Platonic $\dot{\varepsilon} \pi \imath \theta u \mu \eta \tau \imath \kappa o ́ v$ as the seat of primal drives for food and sex, but this is ultimately nothing more than an endorsement of Plato's tripartite psychology. ${ }^{84}$ By itself, this passage does not prove that Philo saw oủк $\dot{\varepsilon} \pi \theta u \mu \eta \dot{\sigma} \sigma \iota \varsigma$ primarily as a restriction of sexual desire. In fact, not one of the passages Gaca cites reflects a special emphasis on sexual appetite in Philo's exposition. She claims that he agrees with Plato that:

[t]he sexual appetite and reproductive urge, when fattened and left to their own devices, are the main root of depraved minds and social mores because they stimulate a proliferation of other passions. (Gaca, Making of Fornication, 195)

To support this claim, she cites Spec. 4.85 as follows: "Sexual eros is 'the

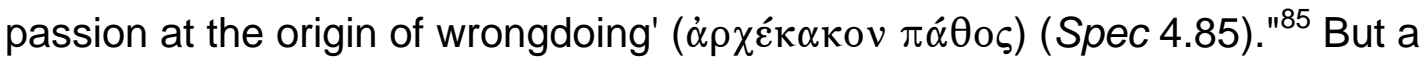
fuller citation shows that Gaca misreads Philo's statement:

For the passion to which the name of originator of evil can truly be given is

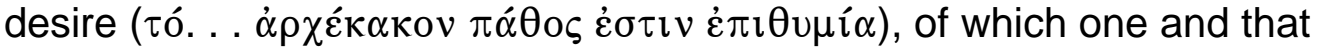

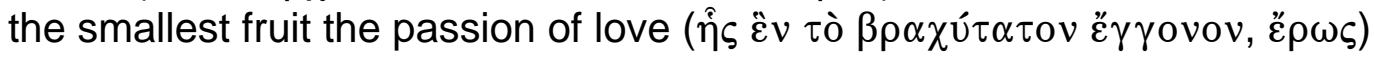
has not only once but often in the past filled the whole world with countless calamities ( $\sigma u \mu \phi о \rho \omega \hat{v})$... (Spec. 4.85)

\footnotetext{
${ }^{83}$ My translation. Cf. Tim. 70 D - 71 A. On the relation of Spec. 4.92-94 to the Timaeus account, see Runia, Philo and the Timaeus, 304.

${ }^{84}$ NB $\lambda o ́ \gamma o \varsigma, \theta u \mu o ́ s$, and $\dot{\varepsilon} \pi \imath \theta u \mu ́ \alpha$ in Spec. 4.92. Gaca may be justified in her suggestion that Philo here endorses "Plato's theory of the irrational physical appetites" (Gaca, Making of Fornication, 195), but Philo says nothing about "[Plato's] position that the sexual appetite is the most domineering and recalcitrant of the lot." Gaca assumes that a reference to the Platonic $\dot{\varepsilon} \pi \imath \theta u \mu \eta \tau \imath \kappa o ́ v$ mentioning its characteristic appetites proves ipso facto that Philo holds a highly sexualized concept of $\dot{\varepsilon} \pi \imath \theta u \mu i \alpha$ throughout his exposition.

${ }^{85}$ Gaca, Making of Fornication, 195.
} 
The $\dot{\alpha} \rho \chi \hat{\varepsilon} \kappa \alpha \kappa o v \pi \dot{\alpha} \theta$ o in this passage is clearly $\dot{\varepsilon} \pi \imath \theta u \mu i \alpha$ (desire involving any object), not "sexual eros" as Gaca states ${ }^{86}$ Philo does identify ह̌ $\rho \omega \varsigma$ as an

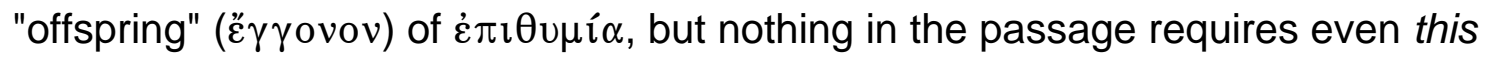
word to have a sexual connotation. ${ }^{87}$ Gaca also misconstrues the phrase

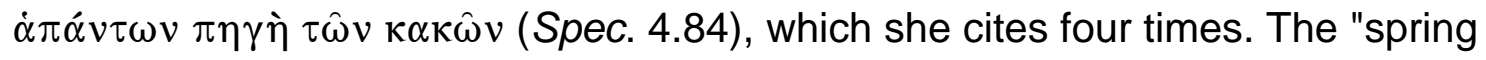
of all vices" is indeed $\dot{\varepsilon} \pi \imath \theta u \mu i \alpha$, but in light of Spec. 4.82 (esp. $\ddot{\alpha} \lambda \lambda \omega \nu \dot{\alpha} \mu \nu \theta \dot{\eta} \tau \omega \nu$ ) it must be understood as desire involving any number of possible objects-not sexual desire, or even appetitive desire per se. Gaca first misunderstands the sense when she states that "physical appetition in general" $(\dot{\varepsilon} \pi \imath \theta u \mu i \alpha)$ is "the origin of all wrongdoing, ${ }^{188}$ then she provides in each subsequent reference to Spec. 4.84 a different rendering of $\dot{\varepsilon} \pi \imath \theta v \mu i \alpha$ :

${ }^{86}$ Thus, for example, Méasson, Char ailé, 154: "Philon analyse d'abord le désir en luimême et, sans reference à aucun objet, le définit: $\dot{\alpha} \rho \chi \varepsilon ́ \kappa \alpha \kappa o v \pi \dot{\alpha} \theta \circ \varsigma$, «la passion qui est le

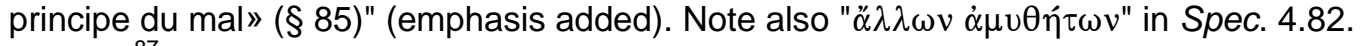

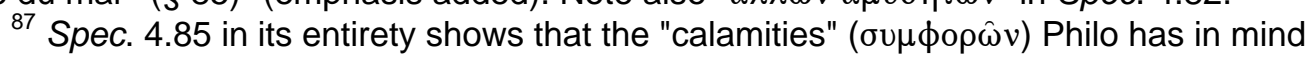
primarily involve warfare. A parallel passage in Decal. 152-53 also mentions "calamities" $(\sigma \cup \mu \phi о \rho \hat{\omega} v)$ involving warfare, and their source in that passage is the desire $(\dot{\varepsilon} \pi \imath \theta u \mu i \alpha)$ for

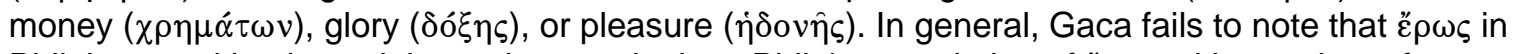
Philo's exposition is not inherently sexual, given Philo's association of है $\rho \omega \varsigma$ with a variety of objects, as in Decal. 151: "Consider the passion whether for money or a woman or glory or

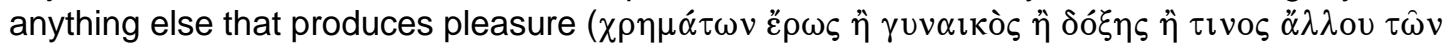

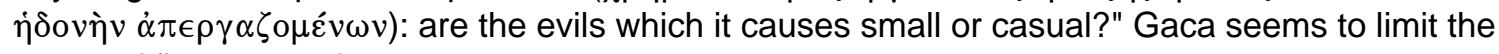
scope of $\tilde{\rho} \rho \omega \varsigma$, by definition, to sexual desire alone: "Uncontrolled sexual desire, or eros, is especially problematic for Philo and his predecessor Plato" (Gaca, Making of Fornication, 195). This is surprising, since Gaca in an earlier chapter on Platonic desire emphatically notes the difference between "sexual appetite" and "Platonic eros" (see Making of Fornication, 36-69). On $\varepsilon ̋ \omega \varsigma$ in Plato, including its orientation in theory toward any object, see David M. Halperin, "Platonic Erôs and What Men Call Love," AP 5 (1985): 161-204. Gaca faults Halperin's study for "diminish[ing] the opposition" between eros and sexual desire (Making of Fornication, 38, n. 53), when in fact he clearly and carefully notes the difference (Halperin, "Platonic Erôs," 170-76). Her citation of Halperin, intended to prove his conflation of eros and sexual appetite for sexual pleasure, fails to take into account his explicit distinction between the terms "appetite" and "desire" (see Halperin, "Platonic Erôs," 170). For the more general notion of है $\rho \omega \varsigma$ in Plato, see

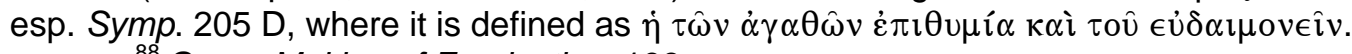

${ }^{88}$ Gaca, Making of Fornication, 198. 
• "sexual and other appetition" is "the origin of all wrongdoing"89

- "innate sexual desire" is "the origin of wrongdoing"90

• "eros" is "the origin of wrongdoing"191

The same word, $\dot{\varepsilon} \pi \imath \theta u \mu i \alpha$, from the same passage, receives a progressively more sexual connotation in the course of Gaca's study, without justification or explanation. Gaca can produce no clear evidence for an especially sexual connotation of $\dot{\varepsilon} \pi \imath \theta u \mu i \alpha$ in Philo's exposition because no such evidence exists. Moreover, the principal evidence she cites (three times) from elsewhere in Philo's corpus, Opif. 151-52, is inconclusive.$^{92}$ Although this passage deals with sexual attraction, it has little to say about the kind of $\dot{\varepsilon} \pi \imath \theta u \mu i \alpha$ Philo envisions when commenting on the Tenth Commandment. ${ }^{93}$ In fact, this passage does not even contain the word $\dot{\varepsilon} \pi \imath u \mu i \alpha$, contrary to Gaca's original citation:

"The irrational appetite" ( $\dot{\varepsilon} \pi \imath v \mu i \alpha)$, and the sexual appetite in particular, "is the beginning of wrongs and violations of the Law" (Opif 151-2). ${ }^{94}$

The relevant section in full reads:

And this desire begat bodily pleasure (ó $\delta \grave{\varepsilon} \pi$ ó $\theta$ o $\sigma \omega \mu \dot{\alpha} \tau \omega \nu \dot{\eta} \delta o v \grave{\eta} v \dot{\varepsilon} \gamma \varepsilon \dot{\varepsilon} v v \eta \sigma \epsilon v)$, that pleasure which is the beginning of

${ }^{89}$ Gaca, Making of Fornication, 198: "Philo, however, differs dramatically from Plato by insisting that sexual and other appetition is a 'great and excessive wickedness, truly the origin of all wrongdoing' (Spec 4.84)."

${ }^{90}$ Gaca, Making of Fornicataion, 200: "For Philo, however, the 'origin of wrongdoing' and 'of violation of the Law' (Spec 4.84, Opif 151-2) is innate sexual desire and its tendency to excessive pleasure...."

${ }^{91}$ Gaca, Making of Fornication, 216: "In support of Plato's political theory, Philo formulates a distinctively Jewish Platonist position that sexual desire is the primary root of rebellion against God. As he phrases this idea, eros is the 'origin of wrongdoing' and 'of violation of the Law' (Spec 4.84, Opif 151-2)."

${ }^{92}$ See Gaca, Making of Fornication, 198, 200, and 216.

${ }^{93}$ As part of his commentary on Genesis 1-3, Philo considers the nature and consequences of sexual है $\rho \omega \varsigma$ between Adam and Eve.

${ }_{94}$ Gaca, Making of Fornication, 198. 


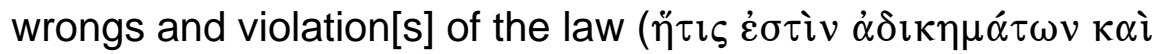

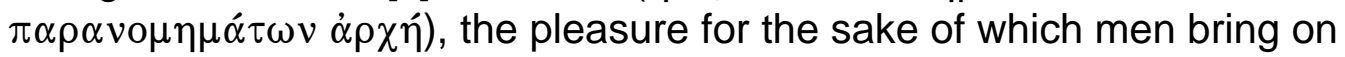
themselves the life of mortality and wretchedness in lieu of that of immortality and bliss. (Opif. 152) ${ }^{95}$

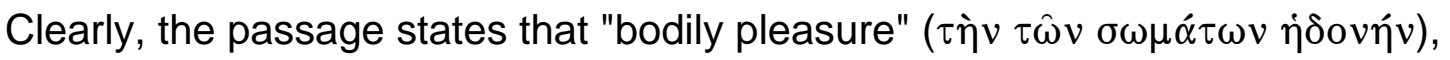

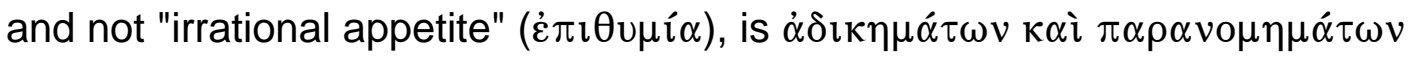

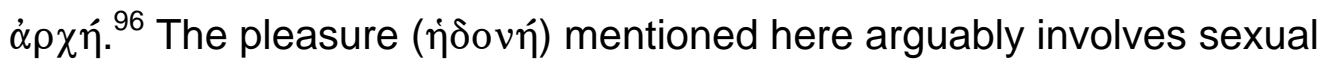
$\dot{\varepsilon} \pi \imath \theta u \mu i \alpha$, but the word $\dot{\varepsilon} \pi \imath \theta v \mu i \alpha$ simply does not appear, and applying this passage to Philo's commentary on the Tenth Commandment is unwarranted. Gaca is unable, with this or any other passage, to demonstrate that Philo sees

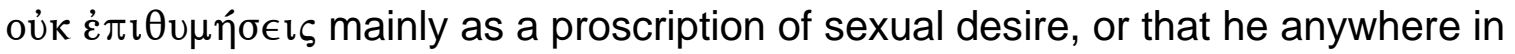
his exposition singles out sexual desire as especially problematic over against any other type.

Because her study misidentifies what the Commandment prohibits, its explanation of how someone observes the Commandment, particularly the role played by the dietary laws, is also incorrect. According to Gaca, and in keeping with her overall emphasis, the dietary laws for Philo ultimately target sexual

${ }^{95}$ The "desire" mentioned here is $\pi$ ó $\theta$ os, which—like $\varepsilon \rho \omega \varsigma$, also in Opif. 152—need not have a sexual connotation, although it clearly does in this case. Cf. Opif. 5: ع̋ $\rho \omega \tau \iota \kappa \alpha \grave{~} \pi$ ó $\theta \omega$

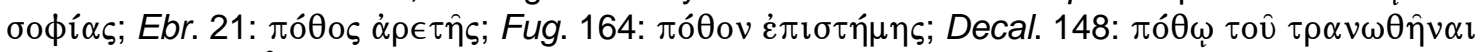

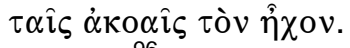

${ }^{96}$ Philo's comments in this passage reflect a much broader treatment, attested throughout his works, of pleasure (i்ovท́) as a moral danger. On Philo's view of pleasure, see esp. Alain Le Boulluec, "La place des concepts philosophiques dans la réflexion de Philon sur le plaisir," in Philon d'Alexandrie et le langage de la philosophie (ed. Carlos Lévy; Turnhout: Brepolis, 1998), 129-52; also Peter Booth, "The Voice of the Serpent: Philo's Epicureanism," in Hellenization Revisited: Shaping a Christian Response within the Greco-Roman World (ed. Wendy E. Helleman; Lanham: University Press of America, 1994), 159-72; Francesca Calabi, "II serpente e il cavaliere: piacere e 'sophrosyne' in Filone di Alessandria" ASR 8 (2003): 199-215; Schmidt, Anthropologie, 92-93; Graziano Ranocchia, "Moses against the Egyptian: The AntiEpicurean Polemic in Philo," in Philo of Alexandria and Post-Aristotelian Philosophy (ed. Francesca Alesse; SPhA 5; Leiden: Brill, 2008), 75-102, esp. 88-100. 
desire. ${ }^{97}$ Since a dangerous causal link exists between unrestrained eating and unrestrained sexual desire (which in turn causes a proliferation of other vices), dietary laws that restrict food intake restrict also sexual desire and thus limit the vicious behavior associated with sexual excess. ${ }^{98}$ But nowhere in Philo's discussion of the dietary laws (Spec. 4.96-131) is sexual desire mentioned, much less cited as the ultimate concern. This again calls into question Gaca's treatment of Philo's text—what does she claim to find and where. She refers to Spec. 4.96, where Philo states the rationale of the dietary laws from Moses' perspective, but she misinterprets his statement:

Moses thus "began to train and chastise the appetite centered on the belly" (Spec 4.96), because he knew God's people needed to put their "love-mad" sexual behavior on the right kind of diet (Spec 3.9-10). ${ }^{99}$

According to Philo, the reason Moses focused on training the desire "whose field

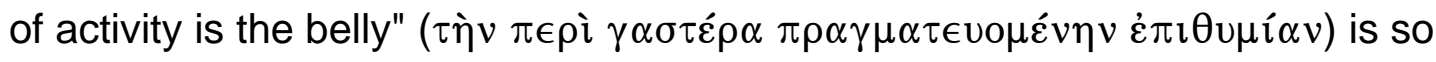
that "the other forms ( $\tau \grave{\alpha} \varsigma \ddot{\alpha} \lambda \lambda \alpha \varsigma$ ) will cease to run riot as before and will be restrained by having learnt that the senior and as it were the leader of their

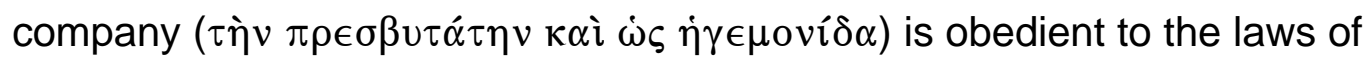
temperance" (Spec. 4.96). The desire for food and drink is preeminent and

97 "Restricting diet is an important part of taming sexual desire for both Philo and Plato. Philo regards Moses' dietary laws as the one sure regimen that reduces sexual desire and thereby subdues its offspring of vices" (Gaca, Making of Fornication, 196).

${ }_{98}$ Gaca elsewhere makes the connection between food and sexual desire without explicitly mentioning dietary laws: "Human beings must keep their appetites under rational guard by curbing their wild sexual desire through restricting the intake of food and drink" (Making of Fornication, 195). Also: "Sexual eros on Plato's view comes into its own as a raging tyrant once surplus nutriment fuels its voracity. The combined sexual appetite and reproductive urge, when fattened and left to their own devices, are the main root of depraved minds and social mores because they stimulate a proliferation of other passions. Philo fully agrees with Plato on this matter" (idem).

\footnotetext{
${ }^{99}$ Gaca, Making of Fornication, 196.
} 
serves as a "paradigmatic instruction" ( $\pi \alpha \rho \alpha \delta \epsilon \imath \gamma \mu \alpha \tau \imath \kappa \hat{n} \delta\left\llcorner\delta \alpha \sigma \kappa \alpha \lambda i i_{\text { }}\right.$ in 4.96), whose training is applicable to any other form of desire, including —but certainly neither limited nor especially pertinent to-sexual desire. Gaca omits the second half of Philo's sentence in Spec. 4.96, which contains his understanding of the rationale for training dietary desires, and substitutes a different rationale based on a passage from a different treatise, which has no direct application to Philo's discussion of the Tenth Commandment. ${ }^{100}$ As for prohibited animals, Gaca understands Philo to say that Moses "knew that the prohibited types of animal flesh, such as pork, are particularly laced with an aphrodisiac surplus (Spec 4.100-18)." ${ }^{101}$ But Philo says nothing of the sort in Spec. 4.100-18. He does say that Moses prohibited animals "whose flesh is the finest and fattest, thus titillating

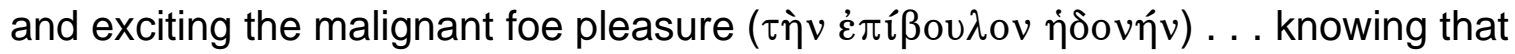
they set a trap for the most slavish of the senses, the taste $(\gamma \in \hat{v} \sigma \mathrm{v} v)$, and produce gluttony, an evil very dangerous both to soul and body" (Spec. 4.100). ${ }^{102}$ Without exploring here the full import of this statement for Philo's understanding of the dietary laws, it is enough to note that the sensory pleasure involved is gustatory, not sexual. ${ }^{103}$ Gaca notes also Philo's summary statement concerning Moses'

${ }^{100}$ Philo's comments in Spec. 3.9-10 pertain, as he explicitly states, to the Sixth Commandment, the first in the second table (see Spec. 3.1-8).

${ }^{101}$ Gaca, Making of Fornication, 196. Gaca essentially considers only Philo's discussion of prohibited animals (Spec. 4.100-18), leaving out Spec. 4.119-31, a section that also treats

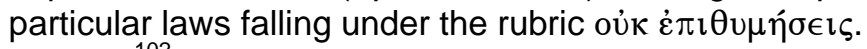

102 Presumably, this is the passage Gaca has in mind, since Philo immediately gives the example of pork in Spec. 4.101 and Gaca mentions pork explicitly when citing this passage.

${ }^{103}$ In any case, the context suggests that Philo's interest is in Moses' proscriptive

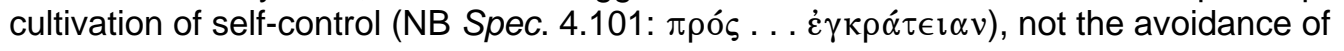
"aphrodisiac surplus." Isaak Heinemann, commenting on this passage, correctly notes this interest on Philo's part: "Nach SpL. IV 100 ff. will Moses durch seine Speisegesetze vor allem zur 
prohibition of various animals, that "by this as by the withdrawal of fuel from a fire

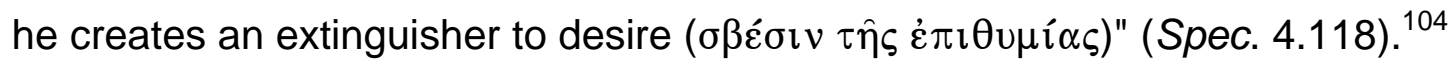
But this has no explicit bearing on sexual desire, unless the term $\dot{\varepsilon} \pi \imath \theta u \mu i \alpha$ is presumed to have an especially sexual connotation in Spec. 4.96-131, which it does not. In fact, due to an overemphasis on sexual desire, Gaca overlooks the fundamental role of the dietary laws from Philo's perspective, which is to promote

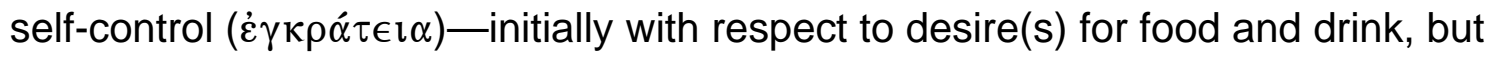
ultimately with respect to desires of any type. ${ }^{105}$

Despite their respective contributions, the studies of Wolfson and Gaca,

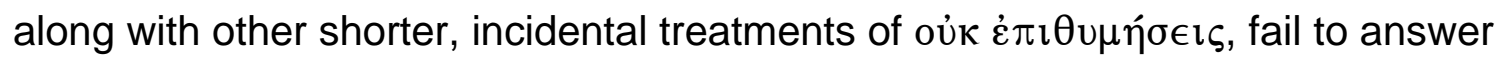
with sufficient depth or accuracy the fundamental interpretive questions surrounding Philo's exposition of the Tenth Commandment. As a result, this important aspect of Philo's thought remains obscure.

Selbstbeherrschung anregen; daher sind gerade besonders wohlschmeckende Tiere verboten, wie das Schwein" (Philons Griechische und Jüdische Bildung [Darmstadt: Wissenschaftliche Buchgesellschaft, 1962], 163).

${ }_{104}$ Gaca, Making of Fornication, 196.

105 Other considerations of the dietary laws in Philo, which to various extents emphasize the importance of $\dot{\varepsilon} \gamma \kappa \rho \alpha \dot{\tau} \tau \epsilon \alpha$ without finding any special concern with sexual desire on his part, include Norman Bentwich, Philo-Judaeus of Alexandria (Philadelphia: Jewish Publication Society of America, 1910), 123-24; Peder Borgen, Philo of Alexandria: An Exegete for His Time (NovTSup 86; Leiden: Brill, 1997), 168-69; Mireille Hadas-Lebel, Philon D'Alexandrie: Un penseur en diaspora (Paris: Fayard, 2003), 159-62; Richard Hecht, "Patterns of Exegesis in Philo's Interpretation of Leviticus," SPh 6 (1979-80): 77-155, esp.108-15; Heinemann, Bildung, 155-66; Houston, "Dietary Laws," 144-47; Alan Mendelson, Philo's Jewish Identity (BJS 161; Atlanta: Scholars Press, 1988), 67-71; Niehoff, Philo on Jewish Identity, 105-06; James Rhodes, "Diet and Desire: The Logic of the Dietary Laws According to Philo," ETL 79 (2003): 122-33; Karl Olav Sandnes, Belly and Body in the Pauline Epistles (SNTSMS 120; Cambridge: Cambridge University Press, 2002), 128-29; Cristina Termini, "Philo's Thought within the Context of Middle Judaism," in The Cambridge Companion to Philo (Cambridge: Cambridge University Press, 2009), 95-123, esp. 119-21 [="The Dietary Laws"]; Giovanni Maria Vian, "Purità e culto nell'esegesi giudaico-ellenistica," ASE 13 (1996): 67-84, esp. 78-80. 


\section{PLAN OF THE DisseRTATION}

Chapters two and three of this dissertation do not deal directly with Philo's exposition of the Tenth Commandment. Instead, they offer an introductory survey of terms and concepts that Philo uses in that exposition, situating his moral psychology within the philosophical context of Middle Platonism. ${ }^{106}$ Chapter two treats Philo's concept of desire ( $\dot{\varepsilon} \pi \theta v \mu i \alpha)$, including explanations of its source, nature, function, and problematic malfunction. Chapter three treats Philo's

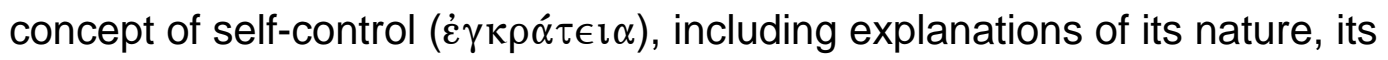

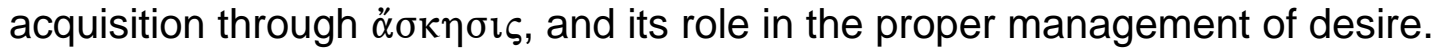

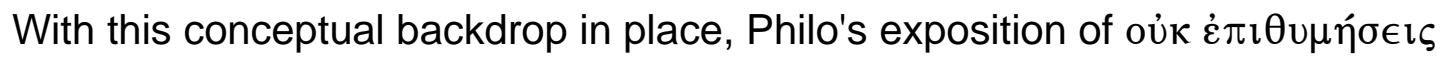
emerges more clearly as a thoughtful, coherent statement of his ethical theory.

Chapter four focuses directly on Philo's exposition of the Tenth Commandment, Spec. 4.78b-131, although Decal. $142-53$ and 173-74 receive consideration in connection with relevant sections of the exposition proper. The goals of this chapter are to provide (1) an outline of the contents of Philo's exposition, (2) a fresh translation of the PCW text, (3) notes on select passages, and (4) commentary on each distinct unit of text.

Chapter five summarizes the results of the dissertation by providing direct and concise answers to the basic questions regarding Philo's exposition:

${ }^{106}$ Without assuming or suggesting that Philo intends to write as a systematic philosopher, chapters two and three nevertheless demonstrate the existence of coherent strands of thought running throughout his exegetical works. Multiple attestation, based on a broad reading of Philo's works, confirms the reliability of these strands as accurate representations of his thought. 
1. In Philo's view, what does the Tenth Commandment prohibit? (All desire? A certain type? What type?)

2. In Philo's view, how is the Tenth Commandment observed? (What are the mechanics of its observance? What role do the dietary laws play in its observance?)

Chapter five also suggests lines of further research based on the results of this investigation. 


\section{CHAPTER TWO

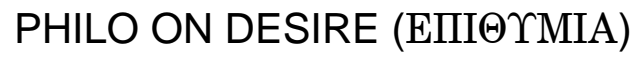

INTRODUCTION

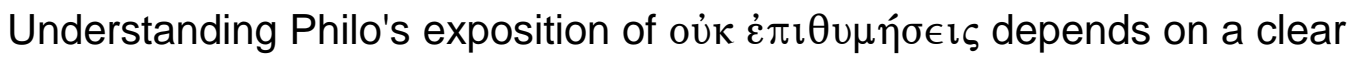
understanding of his concept of $\dot{\varepsilon} \pi \imath \theta u \mu i \alpha$, including its source, nature, function, and problematic malfunction. Philo's concept of $\dot{\varepsilon} \pi \imath \theta u \mu i \alpha$ depends in turn on his broader concept of the soul, in particular his moral psychology—his understanding of how various elements of the soul's structure and function relate to questions of morality. This chapter begins with a survey of the basic moral psychology of Philo's Middle-Platonic contemporaries, especially their concept of a fundamental bipartition between rational and non-rational components within the soul and their concept of various non-rational capacities whose normal operation includes instances of $\dot{\varepsilon} \pi \imath \theta u \mu i \alpha$. Next comes a survey of Philo's moral psychology, with a special emphasis on the correspondence between contemporary Middle-Platonic views and his own understanding of both bipartition and the various capacities involved with $\dot{\varepsilon} \pi \imath \theta u \mu i \alpha$. The chapter ends with a consideration of how Philo views the malfunction of $\dot{\varepsilon} \pi \imath v \mu i \dot{\alpha}$ in the soul, identifying two grades of problematic desire-passionate and tyrannical desireanalyzed in light of contemporary Middle Platonism. 


\section{PHILO'S MIDDLE-PLATONIC CONTEMPORARIES}

As a de facto Middle Platonist, Philo reflects the views of his Middle-

Platonic contemporaries, in particular Eudorus of Alexandria (fl. ca. 25 B.C.) and

his associates. ${ }^{1}$ As representatives of a movement known for its renewed interest

in the doctrines of Plato, Middle Platonists naturally derived fundamental

convictions from the writings of Plato himself, but to rely solely on Plato and

project his views onto later Platonists without qualification ignores centuries of

philosophical activity postdating Plato. ${ }^{2}$ For this reason, Middle-Platonic evidence

${ }^{1}$ On the notion of a "de facto Middle Platonist," see above, page 15, n. 40. In the afterward to his 1996, revised edition of The Middle Platonists, John Dillon reviews his position on the relation between Philo and Eudorus: "Despite my cautionary remarks, I have been repeatedly accused (or worse, commended), for presenting Philo as a pupil of Eudorus, and as a Middle Platonist. Let me make it clear once again that I wish to make neither claim. There is no evidence that Philo had ever heard of Eudorus (though I regard it as very probable that he did). All I would claim is that Philo shows the influence of a brand of Platonism that is in many ways close to that of Eudorus, and the he constitutes good evidence for prevailing trends in contemporary Platonism." (Middle Platonists, 438-39; emphasis added). On the relation between Philo and the Alexandrian Platonism of Eudorus, see also Mauro Bonazzi, "Towards Transcendence: Philo and the Renewal of Platonism in the Early Imperial Age," in Philo of Alexandria and Post-Aristotelian Philosophy (ed. Francesca Alesse; SPhA 5; Leiden: Brill, 2008), 233-51. On Eudorus himself, see John Dillon, Middle Platonists, 115-35, 436-39; also Heinrich Dörrie, "Der Platoniker Eudorus von Alexandreia," in Platonica Minora (STA 8; München: W. Fink, 1976), 297-309. For fragments of his work, see esp. Mazz.

${ }_{2}^{2}$ For example, Middle Platonists adapted Stoic technical terms, infusing them with new meaning for use within their fundamentally different system of thought, and a failure to appreciate this leads to a false impression of their incoherent adoption of the Stoic principles underlying those terms. When Eudorus expounded a dogmatic Platonism in the first century B.C. (after the Academy's skeptical phase), an elaborate lexicon of Stoic terms and definitions, with an accompanying conceptual vocabulary, had already been systematically formulated. Rather than creating de novo an alternative system, with its own terms, definitions, etc., Middle Platonists chose to revise the system at hand, creating distinctively Platonic understandings of Stoic philosophical language. This was especially true in the field of ethics (e.g., the topic of "passions" $[\pi \dot{\alpha} \theta \eta]$, including $\dot{\varepsilon} \pi \imath \theta u \mu i \alpha)$ and moral psychology. On this aspect of Middle-Platonic ethics, note Dörrie, "Eudorus," 301-03 (e.g., 302: "Der Platonismus konnte hier [Ethik] nirgends aus dem Vollen schöpfen wie in der Physik und der Theologie"; 303: "Die bloße Einteilung der Ethik konnte niemanden befriedigen-jetzt galt es, den neuen platonischen Inhalt in diese alte Form zu gießen"); also Giovanni Reale, The Schools of the Imperial Age (vol. 4 of A History of Ancient Philosophy; ed. and trans. John R. Catan; Albany: State University of New York Press, 1990), 233: "The eclectic character of Middle Platonic ethics has frequently been emphasized, for in addition to Platonic tenets Middle Platonists saw no difficulty in accepting Aristotelian as well as 
must act as a guide_-confirming, supplementing, and modifying what can be otherwise known from the Platonic dialogues. And enough evidence exists to reconstruct the basic moral psychology and corresponding concept of $\dot{\varepsilon} \pi \imath \theta u \mu i \alpha$ held by Alexandrian Middle Platonists of Philo's day, based-in addition to the extant fragments from Eudorus himself (Mazz.)—on the following sources:

\begin{abstract}
ARIUS DIDYMUS ${ }^{3}$ (b. ca. 75 B.C.): Arius was a Stoic philosopher, probably a native of Alexandria and personal acquaintance of Eudorus. ${ }^{4} \mathrm{He}$ composed surveys of contemporary philosophical views, including Eudorus and certain "Platonic philosophers" (oi $\kappa \alpha \tau \grave{\alpha} \Pi \lambda \alpha \dot{\tau} \omega \nu \alpha$

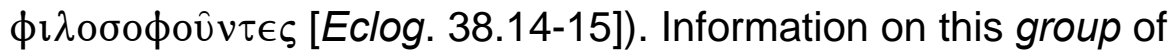
philosophers (Eclog. 37.18 - 38.15) bears special importance, since it most likely depicts contemporary Alexandrian (Middle-)Platonists, and it summarizes principal tenets of their moral psychology, providing crucial evidence for an otherwise unattested aspect of Eudoran Middle Platonism. ${ }^{5}$
\end{abstract}

\footnotetext{
Stoic doctrines. A great deal of evidence could be brought forward as proof of this assertion. Nevertheless, that the Middle Platonists only rarely accepted the results after Plato which are opposed to the Platonic spirit has not been adequately appreciated. In fact, in the great majority of cases they reinterpret and ground again the new results according to the Platonic spirit" (original emphasis). Cf. Inwood, Ethics and Human Action, 132: "so many of the innovators who looked back beyond Stoic monism to the psychological observations made by Plato and Aristotle continued to use the terminology of the Stoic theory in setting forth their own doctrines"; John Whittaker, "Platonic Philosophy in the Early Centuries of the Empire," ANRW 36.1: 81-123, 116: "We may in fact conclude that the Stoic element in Middle Platonism, both in the 'Didaskalikos' and elsewhere, is generally of a superficial nature and indicates rather a generous disposition toward Stoic concepts and terminology than a whole-hearted attempt to accommodate Platonism to a Stoic mould."

${ }^{3}$ See David E. Hahm, "The Ethical Doxography of Arius Didymus," ANRW 36.4: 29353055, 3234-43 (indices).

${ }^{4}$ Hahm, "Arius Didymus," 3035-41.

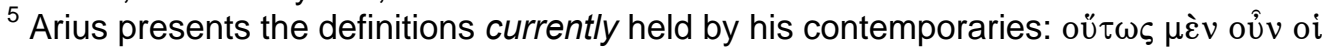

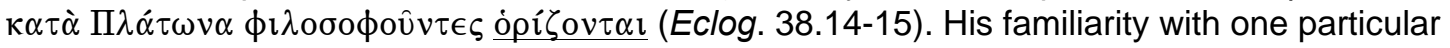
Middle-Platonic philosopher from first-century B.C. Alexandria (Eudorus) implies some familiarity with other "Platonic philosophers" from the same milieu (whose views he cites, presumably, in Eclog. 37.18 - 38.15). The doxographical nature of Arius' report concerning the moral psychology of these "Platonic philosophers" suggests that the attested views were standard, which in turn suggests that these would have been the views of Eudorus. Without considering the question of Eudorus, P. A. Vander Waerdt nevertheless holds that Eclog. $37.18-38.15$ represents good evidence for Middle Platonism (see "Moral Psychology," 378).
} 
Pseudo-Timaeus, ${ }^{6}$ ON THE NATURE OF THE WORLD AND THE SOUL [=TL]: Probably composed in the late first century B.C. or the first century A.D., this treatise arguably represents Eudoran Middle Platonism, based on its distinct profile of agreements with Eudorus on a number of points. ${ }^{7}$ Purportedly written by Timaeus of Locri (of Plato's Timaeus), in an affected Doric dialect, the treatise generally reads like an epitome of Timaeus $27 \mathrm{C}-92 \mathrm{C}$, although it offers scholastic Middle-Platonic elaborations on key topics.

Pseudo-Metopus, ${ }^{8}$ ON VIRTUe [=Ps.-Metop.]: This treatise, probably composed in the first century B.C., in a Doric similar to TL, is one of many Pseudo-Pythagorean ethical writings that arguably reflect Eudoran Middle Platonism. ${ }^{9}$ The clearly didactic aim of On Virtue suggests a handbook, which in turn suggests conventional ethical doctrines. ${ }^{10}$

PlUTARCH (b. ca. A.D. 45): Plutarch was a Middle Platonist who knew the works of Eudorus. ${ }^{11}$ Furthermore, Plutarch's teacher Ammonius was both a contemporary of Philo and a native of Alexandria. ${ }^{12}$ Assuming Plutarch

${ }^{6}$ See Timaios of Locri, On the Nature of the World and the Soul (text, trans., notes, Thomas H. Tobin; SBLTT 26; GRRS 8; Chico, Calif.: Scholars Press, 1985); also the commentary of Matthias Baltes, Timaios Lokros, Über die Natur des Kosmos und der Seele (PA 21; Leiden: Brill, 1972).

${ }^{7}$ On the date of TL, see Tobin, Timaios of Locri, 3-7. On the agreements between TL and Eudorus, see Baltes, Timaios Lokros, 22-26. Baltes does not believe that Eudorus himself composed TL, but that the work is more likely "ein Produkt aus der Schule des Eudor" (25). Tobin notes some problems with Baltes' position (Timaios of Locri, 6) but nevertheless affirms the likelihood of some connection between TL and Eudorus: "One can probably say that the TL came after Eudorus and that the author of the TL was aware of his work" (7).

${ }^{8}$ See Pseudopythagorica Ethica: I trattati morali di Archita, Metopo, Teage, Eurifamo (text, trans., comm., Bruno Centrone; Elenchos 17; Naples: Bibliopolis, 1990), esp. 87-94 (text), 193-216 (comm.).

${ }^{9}$ On the date of Ps.-Metopus, see Centrone, Pseudopythagorica Ethica, 41-44; on the connection with Eudorus, see ibid., 17, n. 10. Centrone suggests that Philo made use of these Pseudo-Pythagorean ethical writings (ibid., 30-34, 43-44); cf. David Runia, "Why Does Clement Call Philo "The Pythagorean?,"' in Philo and the Church Fathers: A Collection of Papers (VCSup 32; Leiden: Brill, 1995), 54-76; repr. from VC 49 (1995): 1-22.

${ }^{10}$ Cf. Centrone, Pseudopythagorica Ethica, 193: "Il trattato di Metopo sulla virtù presenta, in forma sintetica e condensate, una serie di loci classici della dossografia etica, amalgamate in maniera più o meno felice."

${ }^{11}$ On Plutarch as a Middle Platonist, see Dillon, Middle Platonists, 184-230. Plutarch cites Eudorus by name in De animae procreatione in Timaeo (An. procr.) 1013 B, 1019 E, and $1020 \mathrm{C}$.

${ }^{12}$ On Ammonius see C.P. Jones, "The Teacher of Plutarch," HSCP 71 (1967), 205-13; also Dillon, Middle Platonists, 189-92. Jones suggests approximate dates for Ammonius of A.D. 20 to A.D. 70-80 ("Teacher of Plutarch," 208; cf. Dillon, Middle Platonists, 191: "Ammonius was probably dead by about A.D. 80"). Dillon calls Ammonius "a product of Alexandrian Platonism" (Middle Platonists, 190), although he taught and died in Athens. John Glucker believes,

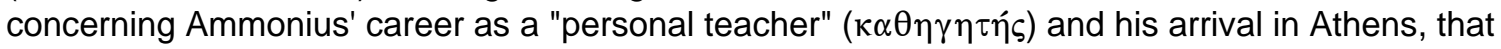


did not radically depart from his teacher on basic ethical theory, his views-especially insofar as they corroborate the testimony of Arius, Ps.Timaeus, and Ps.-Metopus-reflect standard views among Philo's MiddlePlatonic contemporaries. ${ }^{13}$

For the most part, the identification of this material with Eudorus rests on reasonable conjecture, not demonstrable fact. But in any case, this material does represent Middle-Platonic thought, as general consensus and corroborating evidence from, for example, Alcinous' doctrinal handbook the Didaskalikos attest. ${ }^{14}$ Therefore, while the comparison of Philo to Arius Didymus, Ps.-Timaeus, Ps.-Metopus, and Plutarch probably illustrates his relation to Eudoran Middle Platonism, it certainly illustrates Philo's relation to general trends in MiddlePlatonic thought.

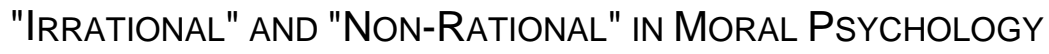

The most fundamental question to ask about $\dot{\varepsilon} \pi \imath \theta u \mu i \alpha$ in Middle-Platonic

moral psychology involves the Greek word ״ँ $\lambda_{0} \gamma \circ \varsigma$, which has two radically

"[w]hatever philosophy he knew he had already learnt in Egypt" (Antiochus and the Late Academy [Hypomnemata 56; Göttingen: Vandernhoeck \& Ruprecht, 1978], 133). Jean Daniélou suggests that Philo and Plutarch have a similar "platonisme éclectique" because Philo and Ammonius were educated in the same Alexandrian philosophical environment (Philon D'Alexandrie [Paris: A. Fayard, 1958], 58-59).

${ }^{13}$ Among Plutarch's works, De virtute morali (Virt. mor.) bears special significance, because of its summary representation of a Middle-Platonic (over against Stoic) stance on moral psychology and passion(s). Moreover, the moral psychology of Virt. mor. reflects Plutarch's broader commitment to a fundamentally Platonic understanding of the soul, such as he elaborates in An. procr. (see Jan Opsomer, "L'âme du monde et l' âme de l'homme chez Plutarque," in Estudios sobre Plutarco: Ideas religiosas: Actas del III Simposio Internacional sobre Plutarco, Oviedo 30 de abril a 2 de mayo de 1992 [ed. Manuela García Valdés; Madrid: Ediciones Clásicas, 1994], 33-49). Also important are five ethical treatises-De curiositate (Curios.), De cohibenda ira (Cohib. ira)), De garrulitate (Garr.), De vitioso pudore (Vit. pud.), and De laude ipsius (De laude) - that pertain directly to moral virtue, in particular the role of "practice"

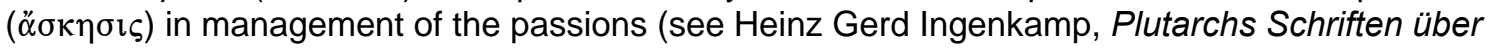
die Heilung der Seele [Hypomnemata 34; Göttingen: Vandernhoeck \& Ruprecht, 1971]).

${ }^{14}$ On which see Alcinous: The Handbook of Platonism (trans., comm. John Dillon; Oxford: Clarendon, 1993); Alcinoos: Enseignement des doctrines de Platon (ed., comm. John Whittaker; trans. Pierre Louis; 2d ed.; Paris: Belles Lettres, 2002). 


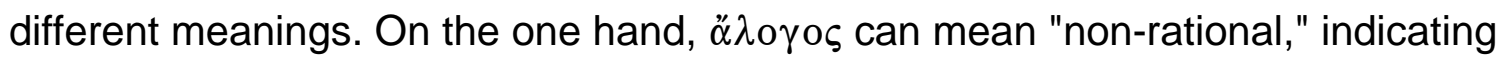

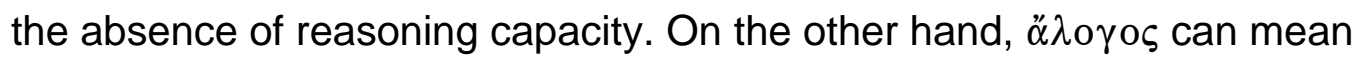
"irrational," indicating the corruption or malfunction of a reasoning capacity that nevertheless exists. In a treatise that defends a Platonic view of the passions over against the Stoic view of Chrysippus, Galen explains the distinction:

[S]ometimes the $\alpha$ negates the meaning of the word to which it is prefixed, and sometimes it does not. And I find the word $\ddot{\alpha} \lambda$ o all the ancients and by men of today. When a person says that a fish or a

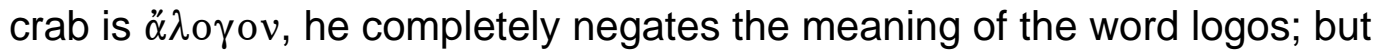
when men criticize a particular statement of a particular person by saying that it is $\ddot{\alpha} \lambda$ o yov, they do not give it this name because it has no logos, but because it is blameworthy and faulty. (PHP IV 4.13-15) $)^{15}$

Philo understands the same distinction just as clearly:

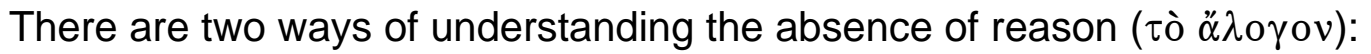
it means either defying the dictates of logos, as when people call the senseless man "irrational" ( $\alpha \lambda$ o $\gamma \circ v)$, or having no logos at all, as with the

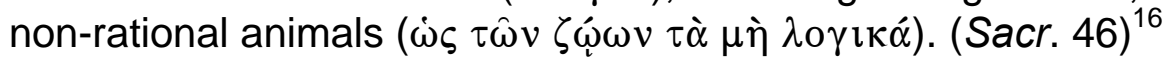

Do Philo and his Middle-Platonic contemporaries see $\dot{\varepsilon} \pi \imath u \mu i ́ \alpha$ as an "irrational" ( $\alpha \lambda \circ \gamma \circ \varsigma)$ or a "non-rational" ( $\alpha \lambda \circ \gamma \circ \varsigma)$ function of the soul? Plato himself offers the best place to begin answering this critical question.

\section{PLATONIC FOUNDATIONS}

Plato believed that the human soul has three essential components: one

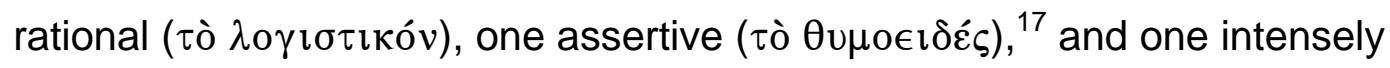

${ }^{15}$ Trans. De Lacey (slightly modified).

${ }^{16}$ My translation. In De animalibus, Philo argues at length that beasts are non-rational (see $\S \S 77-100)$, a position he consistently holds throughout his works: e.g., $\zeta \hat{\omega} \alpha \ddot{\alpha} \lambda \mathrm{o} \gamma \alpha$ in Opif. 73, Spec. 2.89, and Virt. 160; or simply $\ddot{\alpha} \lambda \mathrm{o} \gamma \alpha$, as in Spec. 1.260.

17 "Assertive" captures the essence of this component of the soul. Cf. John Cooper, "Human Motivation," 133-34: "the motivations that Plato classifies under the heading of spirit are 


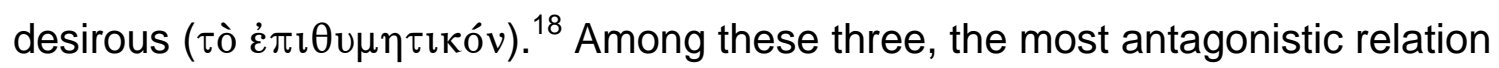

exists between reason and desire. In fact, Plato establishes the independence of

desire from reason by noting its capacity for diametric and simultaneous

opposition to reason, granting desire independent agency as a distinct source of

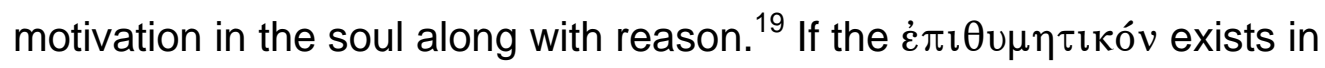

contradistinction to reason, it must also operate apart from reason, so Platonic

to be understood as having their root in competitiveness and the desire for self-esteem and (as a normal presupposition of this) esteem by others."

${ }^{18}$ Resp. 580 D-E: "But the third part, owing to its manifold forms ( $\delta i \grave{\alpha} \pi 0 \lambda v \in \imath \delta i \alpha \nu$ ), we could not easily designate by any one distinctive name, but gave it the name of its chief and

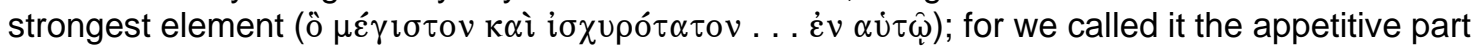
( $\dot{\varepsilon} \tau \theta v \mu \eta \tau \imath \kappa o ́ v)$ because of the intensity of its appetites concerned with food and drink and love

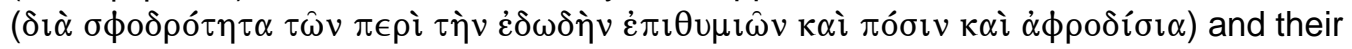

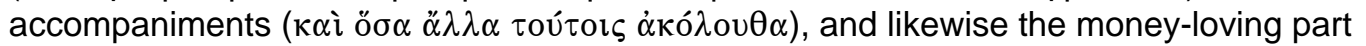
( $\phi \imath \lambda \sigma \chi \rho \eta \eta \alpha \tau \sigma v)$, because money is the chief instrument for the gratification of such desires ( $\delta i \grave{\alpha}$

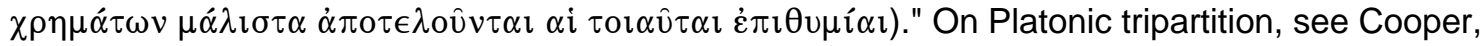
"Human Motivation." On Plato's general theory of desire, see Charles Kahn, "Plato's Theory of Desire." On appetitive desire, see esp. Hendrik Lorenz, The Brute Within: Appetitive Desire in Plato and Aristotle (OPM; Oxford: Clarendon Press, 2006). Lorenz's work outlines the basic model of $\dot{\varepsilon} \pi \imath v \mu i i_{\alpha}$ developed by Plato and appropriated in large part by Aristotle. This basic model was formative in Middle-Platonic moral psychology and so helps to explain many aspects of Philo's thought. For a later Platonist's concept of the $\dot{\varepsilon} \pi \imath \theta u \mu \eta \tau \iota \kappa o ́ v$ covering the fundamental data from Plato's writings, see Phillip De Lacy, "The Third Part of the Soul," in Le Opere Psicologiche di Galeno: Atti del Terzo Colloquio Galenico Internazionale, Pavia, 10-12 Settembre 1986 (ed. Paola Manuli and Mario Vegetti; Elenchos 13; Naples: Biblipolis, 1988), 43-63.

${ }^{19}$ In the Republic (436 B), Plato posits an axiom that shapes his moral psychology, considering it obvious $(\delta \hat{\eta} \lambda \circ v)$ that "the same thing ( $\tau \alpha \dot{\tau} \tau o ́ v)$ will never do or suffer opposites

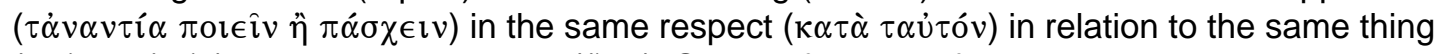
( $\pi \rho o ̀ \varsigma \tau \alpha \dot{u} \tau o ́ v)$ and at the same time $(\ddot{\alpha} \mu \alpha)$. So that if ever we find these contradictionsin the functions of the [soul] ( $\dot{\varepsilon} v \alpha \dot{v} \tau o \hat{\zeta} \zeta$; cf. $\check{\varepsilon} \kappa \alpha \sigma \tau \alpha$ in $436 \mathrm{~A}$ ) we shall know that it was not the same thing functioning (oủ $\tau \alpha \cup ̉ \tau o ́ v$ ) but a plurality $(\pi \lambda \in i \omega)$ " (substituting "soul" for Shorey's "mind" [cf.

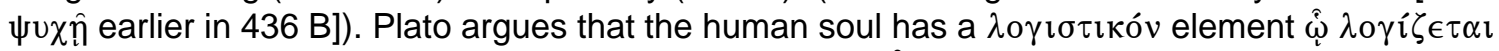

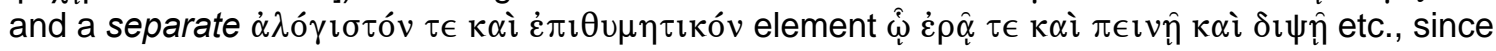
it is otherwise impossible to explain an agent who at the same time desires a drink (via the $\dot{\varepsilon} \pi \imath \theta u \mu \eta \tau \imath \kappa o ́ v)$ but for whatever reason counteracts that desire and abstains from drinking (via

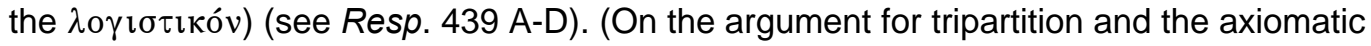
"Principle of Opposites," see Lorenz, Brute Within, 18-34.) Middle Platonists continued to assert the probative force of this axiom as well as the validity of Plato's proof (e.g., Plutarch Virt. mor.

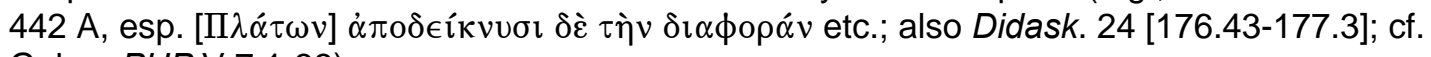

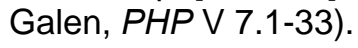




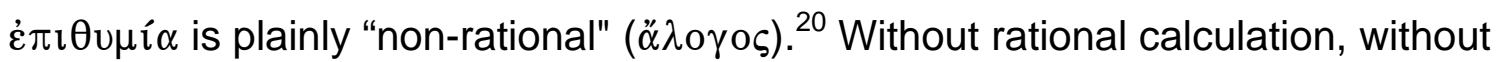
deliberating on the best course of action, $\dot{\varepsilon} \pi \imath \theta u \mu i \alpha$ impulsively pursues pleasure (ं்ovท́) as its ultimate aim (most notably via food, drink, and sex) whenever stimulated by the appropriate thought or sensory impression. ${ }^{21}$ Reason's task is to manage desire, as a rational human being would manage a non-rational animal, ensuring that desire's myopic pursuits serve, rather than subvert, the greater good, which requires the rational pursuit of the best overall course of life..$^{22}$

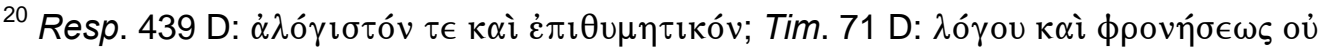

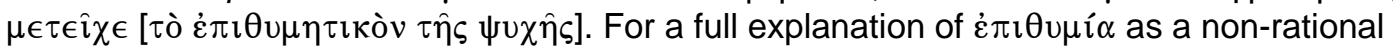
phenomenon, see Lorenz, Brute Within, e.g. 9: "The notion of a part of the soul that is incapable of reasoning, but capable of giving rise to episodes of behaviour, even to episodes of human behaviour, sets the scene for the book's central theme: the idea, shared by Plato and Aristotle, that while reason can, all by itself, motivate a person to act, parts or aspects of the soul other than reason are equipped with non-rational cognitive resources that are sufficient for the generation of fully formed motivating conditions." For explanations of how desire manages to operate without the capacity to reason, see esp. Lorenz, Brute Within, 55-95 [="Belief and Appearance in Plato"] and 113-86 [="Phantasia and Non-Rational Desire in Aristotle"], esp. 11973; also Cooper, "Reason, Virtue, Value," esp. 255-64 [="Non-Rational Desires"]; and idem, "Some Remarks on Aristotle's Moral Psychology," in Reason and Emotion (Princeton: Princeton University Press, 1999), 237-52, esp. 241-44; repr. from SJPh supp. (1988): 25-42; cf. the discussion of "sense-appetite" in N. J. H. Dent, "Varieties of Desire," PASSV 50 (1976): 153-75, esp. 154-58.

${ }^{21}$ On the connection between $\dot{\varepsilon} \pi \imath \theta u \mu i ́ \alpha$ and $\dot{\eta} \delta o v \eta ́$, see e.g. Resp. 439 D: $\tau \grave{c} . \ldots$

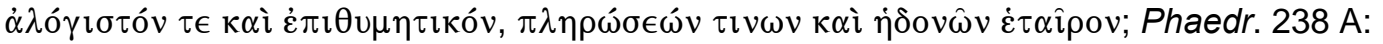

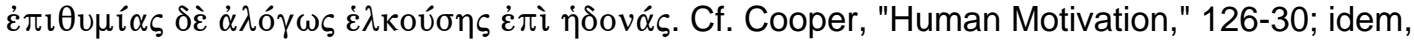
"Reason, Moral Virtue, and Moral Value," in Reason and Emotion (Princeton: Princeton University Press, 1999), 253-70; repr. from pages 81-114 in Rationality in Greek Thought (ed. M. Frede and G. Striker; Oxford: Clarendon, 1996); David Halperin, "Platonic Erôs," 172; Lohrenz, Brute Within, passim, e.g. 2: "Appetite's stubborn and inflexible attachment to whatever happens to give a person pleasure renders psychological conflict ineliminable. ... Appetite's attachment to what in fact gives us pleasure is unreformable"). Later philosophers recognized this association in Plato's writings and formulated it with greater precision (e.g., Aristotle, De an. 414 b 5-6: $\dot{\eta} \dot{\varepsilon} \pi \imath \theta u \mu i \alpha \cdot \tau o \hat{v}$

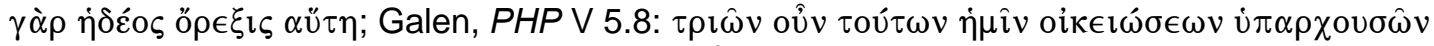

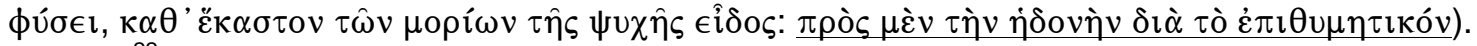

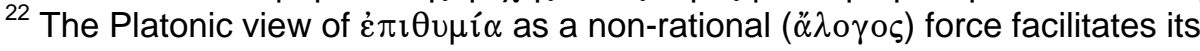
comparison to a non-rational animal, leading to the Platonic imagery of desire as "beast"; see

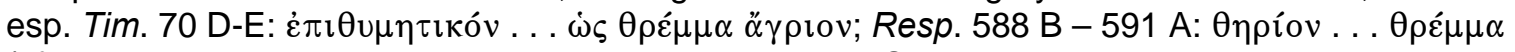
(cf. Urs Dieraur, Tier und Mensch im Denken der Antike: Studien zur Tierpsychologie, 
BIPARTITION IN MIDDLE PLATONISM

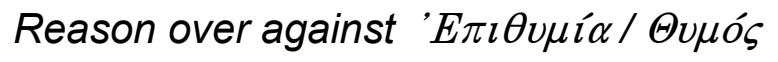

Like other Middle Platonists, Ps.-Timaeus endorses Platonic tripartition,

but in a distinctly modified version:

With regard to human souls ( $\dot{\alpha} v \theta \rho \omega \pi i v \alpha \varsigma \psi v \chi \alpha \hat{\alpha} \varsigma)$, one part is reasonable

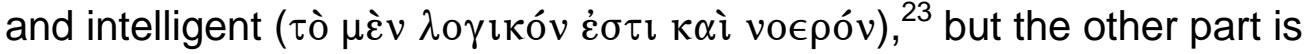

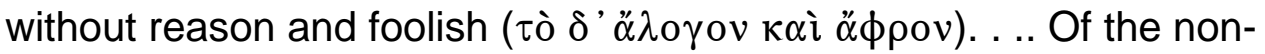
rational part ( $\left.\tau \hat{\omega} \delta \delta^{\prime} \dot{\alpha} \lambda \sigma^{\prime} \gamma \omega \mu \varepsilon \dot{\varepsilon} \rho \in \varsigma\right)$ ), the irascible element is located around

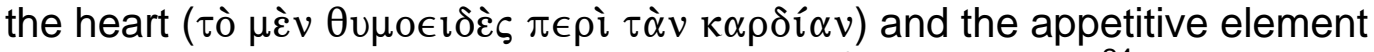

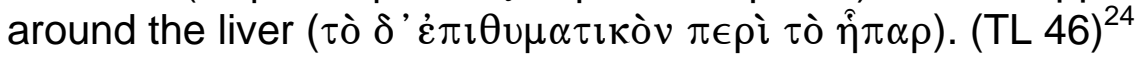

Although he clearly identifies each of Plato's three "parts," including its respective location in the body, Ps.-Timaeus frames this tripartition in dualistic terms: the soul, it seems, really has just two parts—-the rational and the non-rational ( $\tau \grave{\text { ò }} \mu \grave{\varepsilon} v$

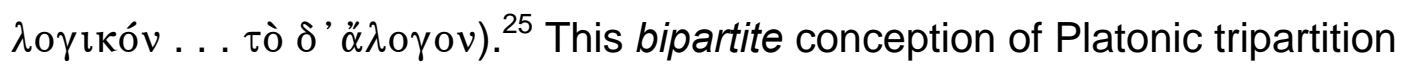
subsumes the spirited and desiderative parts under a single "non-rational part"

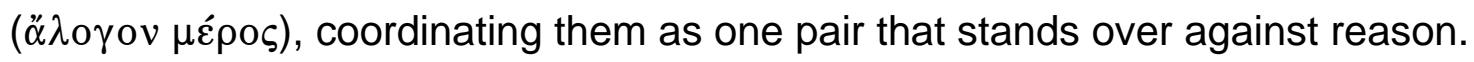

Anthropologie und Ethik [SAP 6; Amsterdam: Grüner, 1977], 66-89 [="Hinweise auf Tiere in der Anthropologie und Ethik Platons"]). This comparison of the $\dot{\varepsilon} \pi \imath \theta u \mu \eta \tau \imath \kappa o ́ v(\dot{\varepsilon} \pi \imath \theta u \mu i \alpha)$ to a beast

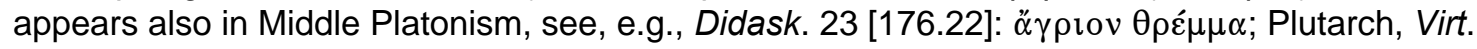

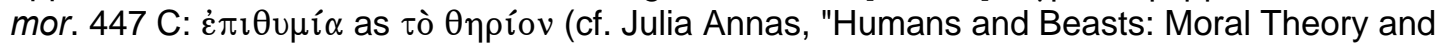
Moral Psychology," in Platonic Ethics, Old and New [CSCP 57; Ithaca: Cornell University Press, 1999], 117-36, esp. 134-36).

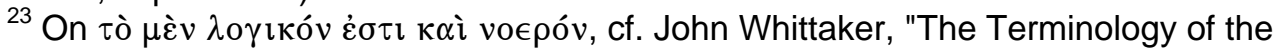
Rational Soul in the Writings of Philo of Alexandria," SPhA (1996): 1-20.

${ }^{24} \mathrm{Cf}$. TL 82: "Music and philosophy, its guide, which were established by the gods and the laws for the correction of the soul, accustom, persuade, and sometimes even coerce the non-

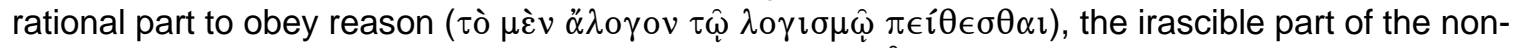
rational soul to be tame ( $\tau \hat{\omega} \delta \delta^{\prime} \dot{\alpha} \lambda \hat{\gamma} \gamma \omega \theta v \mu \grave{o} v \mu \grave{\varepsilon} v \pi \rho \hat{\alpha} o v \in \hat{\imath} \mu \epsilon \nu$ ), and the appetitive part ( $\left.\dot{\varepsilon} \pi \imath \imath_{\imath} \mu_{\boldsymbol{i}} \alpha \nu \delta \grave{\varepsilon}\right)$ to remain quiet when the mind summons it either to action or to enjoyment." (Unless otherwise noted, all translations of TL are from Tobin, Timaios of Locri.)

${ }^{25}$ Arius Didymus provides evidence for bipartite psychology among "Platonic

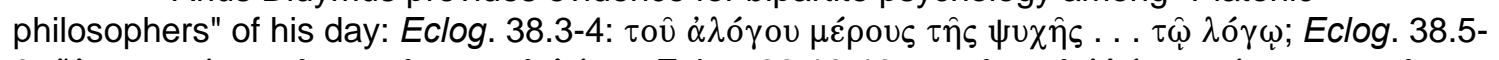

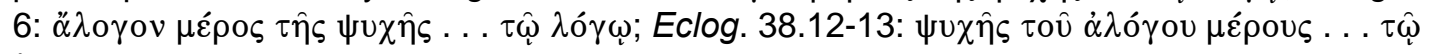
$\lambda о \gamma \iota \kappa \hat{\omega}$. 
Plato did not formulate tripartition in this way. ${ }^{26}$ Aristotle, to facilitate his discussion of ethics, endorsed a simple dichotomy in the soul between "rational"

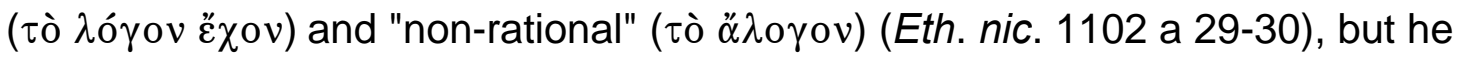
did not use this dichotomy as a frame for Platonic tripartition. ${ }^{27}$ Instead, this formulation derives from an early and highly influential Peripatetic rendering of Plato's tripartite psychology, first attested in the Magna Moralia. ${ }^{28}$ Peripatetic philosophers superimposed Aristotle's dichotomy onto Platonic tripartition, making his rational part (

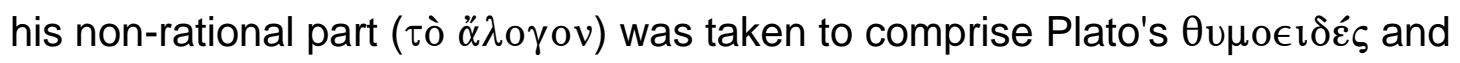
$\dot{\varepsilon} \pi \imath \theta u \mu \eta \tau \imath \kappa o ́ v$ (or $\theta u \mu \iota \kappa o ́ v^{29} / \theta u \mu o ́ \varsigma$ and $\dot{\varepsilon} \pi \imath \theta u \mu i \alpha$ ). This hybrid version of Platonic tripartition, which pits rational against non-rational, became a standard model for moral psychology among Middle Platonists. ${ }^{30}$

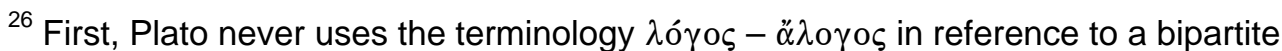
division of the soul (see Vander Waerdt, "Peripatetic Interpretation," 283-86). Second, Plato's

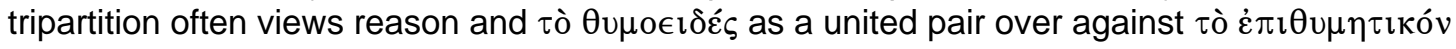
(e.g., Resp. 441 A; Phaedr. 253 D - 254 E). But the absence of a particular formulation of tripartition as bipartition does not mean that Plato never ascribes bipartition to the soul (see e.g. D. A. Rees, "Bipartition of the Soul in the Early Academy," JHS 77 [1957]: 112-18).

${ }^{27}$ Vander Waerdt, "Peripatetic Interpretation," esp. 286-87. Cf. idem, "Aristotle's Criticism of Soul-Division," AJP 108 (1987): 627-43.

${ }^{28}$ Vander Waerdt, "Peripatetic Interpretation." On the appropriation of this Peripatetic rendering in Middle Platonism, see Vander Waerdt, "Moral Psychology."

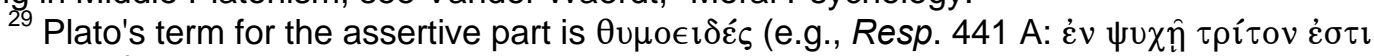

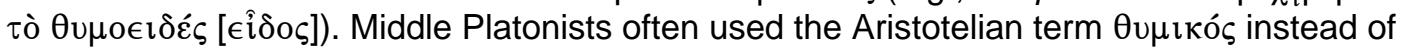

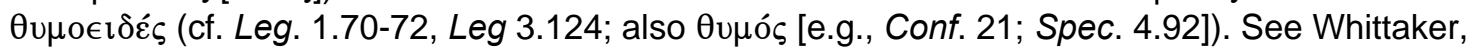
Alcinoos, 87, n. 73 (NB his citation of Leg. 3.115); Vander Waerdt, "Peripatetic Interpretation," 286, n. 9; also Jean Bouffartigue, "La structure de l'âme chez Philon: terminologie scolastique et metaphors," in Philon d'Alexandrie et le langage de la philosophie (ed. Carlos Lévy; Turnhout: Brepolis, 1998), 59-75, 60, n. 3 (on Leg. 3.115)

${ }^{30}$ Vander Waerdt, "Moral Psychology," 378-81, notes six representative examples of Middle-Platonic sources that "harmonize bipartition and tripartition in accordance with Peripatetic doctrine by collapsing the $\theta u \mu \iota \kappa o ́ v$ and $\dot{\varepsilon} \pi \imath \theta u \mu \eta \tau \imath \kappa o ́ v$ into a single $\ddot{\alpha} \lambda o \gamma o v$ and by opposing this to a reasoning faculty" (377): Arius Didymus' epitome, the Didaskalikos, Apuleius, Plutarch, Philo, 
Reason over against Appetite (ö $\rho \epsilon \xi \varsigma$ )

Although Middle-Platonic bipartition appears simply to reconfigure Plato's

three soul parts, and thus appears to leave Plato's conception of those parts

intact, it actually owes much to Aristotle's theory of desire, which differed from

Plato's in significant respects. ${ }^{31}$ Unlike Plato, who envisioned three distinct soul

parts, each with its own sorts of desires ( $\dot{\varepsilon} \pi \imath \theta v \mu i \alpha \imath)$, Aristotle acknowledged just

one appetitive faculty of the soul, which generates three different sorts of appetite

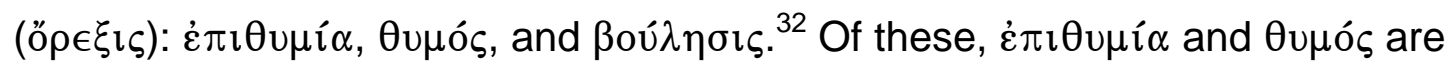

non-rational ỏ $\rho \varepsilon \xi \in ı \zeta \varsigma$ analogous to the motivations generated by Plato's

$\dot{\varepsilon} \pi \imath \theta u \mu \eta \tau \imath \kappa o ́ v$ and $\theta u \mu o \in \imath \delta \varepsilon \varsigma_{.}{ }^{33}$ For example, Aristotle understood $\theta u \mu o ́ \varsigma$ to be

the sort of non-rational motivation at work when people get angry, mirroring

Plato's concept of the $\theta u \mu \circ \in \downarrow \delta \varepsilon$ s, which is-among other things—the seat of

and Clement. To this list may be added TL 46, 82, and Ps.-Metop. 118.1-5: $\tau \hat{\alpha} \varsigma \psi v \chi \hat{\alpha} \varsigma \delta$ óo $\mu \varepsilon \dot{\varepsilon} \in \alpha$,

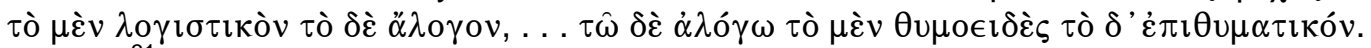

${ }^{31}$ On the fundamental revision of Plato's theory of desire resulting from a bipartite conception of tripartition, see Vander Waerdt, "Peripatetic Interpretation," esp. 286-87 and 291-

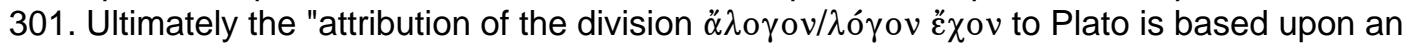
interpretation of tripartition in the terms of Aristotle's doctrine of o $\rho \epsilon \xi ı \varsigma^{\prime \prime}$ (286).

${ }^{32}$ See, for example, Resp. $580 \mathrm{D}$ and $D e$ an. 414 b 2. On Aristotle's theory of desire, see esp. Cooper's essays "Aristotle's Moral Psychology" and "Reason, Virtue, Value." "O $\rho \in \xi$ ic in Aristotle serves as the generic term for "appetite," of which there are several specific types. Plato, who had no corresponding notion of "generic appetite," never uses the term ö $\rho \xi \xi$ ic. (The term itself derives from ó $\rho \dot{\varepsilon} \gamma \omega$ : reach, stretch [LSJ, s.v.], which Plato does use in the context of moral psychology: e.g., Resp. 439 B: ó $\rho \varepsilon ́ \gamma \epsilon \sigma \theta \alpha$ [ [reach after].) Because ő $\rho \in \xi ı$ ऽ only becomes a term of moral psychology with Aristotle, its use among Middle Platonists demonstrates their appropriation of terms and concepts postdating Plato.

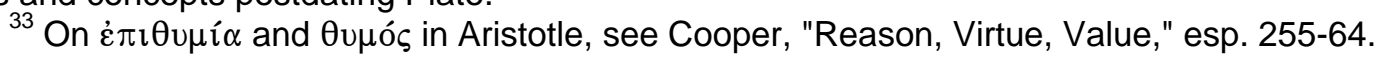
NB 257: "Aristotle seems throughout his career to have accepted from Plato's account of the human soul in the Republic the division of our non-rational desires into two types, appetitive and spirited (epithumia and thumos)." 
anger in the soul. ${ }^{34}$ In addition, Aristotle associated $\dot{\varepsilon} \pi \imath \theta v \mu i \alpha$ with "bodily" desires for food, drink, and sex-the three desires that characterize Plato's $\dot{\varepsilon} \pi \imath \theta u \mu \eta \tau \imath \kappa o ́ v .{ }^{35}$ But in two key respects, the Aristotelian conception of $\theta u \mu o ́ \varsigma$ and $\dot{\varepsilon} \pi \imath \theta u \mu i \alpha$ underlying Middle-Platonic bipartition differs from that of Plato.

First, what for Plato are acquisitive aims of the $\theta v \mu o \in \imath \delta \varepsilon ́ \varsigma$-things like victory, honor, and fame-lose all association with "assertive appetite" ( $\theta u \mu o ́ \varsigma)$ and become simply additional objects of "acquisitive appetite" ( $\dot{\varepsilon} \pi \imath v \mu i \alpha)$, along with food, drink, and sex. ${ }^{36}$ In other words, Aristotle followed Plato in viewing $\dot{\varepsilon} \pi \imath \theta u \mu i \alpha$ as a non-rational desire for pleasure, but he expanded the scope of $\dot{\varepsilon} \pi \imath \theta u \mu i ́ \alpha$ to include the intangible—but nevertheless pleasurable—objects of

\footnotetext{
${ }^{34}$ Plato, in fact, argues for the distinct function of the $\theta u \mu o \in l \delta \varepsilon \varepsilon$ over against the $\dot{\varepsilon} \pi \imath \theta u \mu \eta \tau \imath \kappa o ́ v$ by citing the story of Leontius, whose anger against his own repugnant desire to view corpses demonstrates the separation of $\theta u \mu$ ó $\varsigma$ and $\dot{\varepsilon} \pi \imath \theta u \mu i \alpha$ within the soul (see Resp. 439

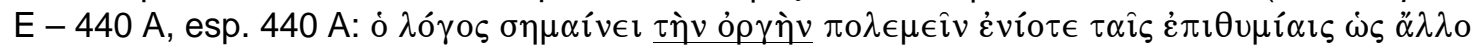

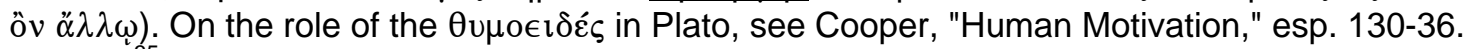

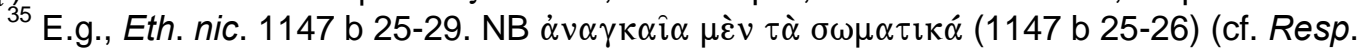

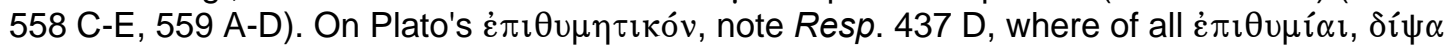

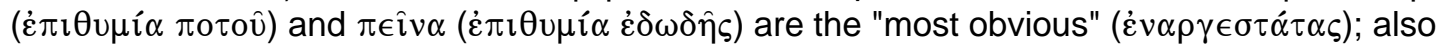

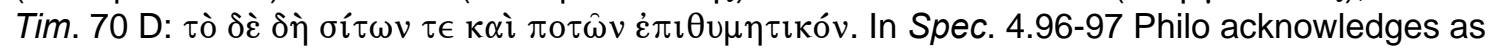
chief of all desires $\tau \grave{\eta} \nu \pi \epsilon \rho \grave{~} \gamma \alpha \sigma \tau \varepsilon \rho \alpha \pi \rho \alpha \gamma \mu \alpha \tau \epsilon v o \mu \varepsilon \dot{\varepsilon} v \eta v \dot{\varepsilon} \pi \imath \theta v \mu i \alpha \nu$, which concerns $\dot{\varepsilon} \delta \omega \delta \grave{\eta} \kappa \alpha \grave{\imath}$

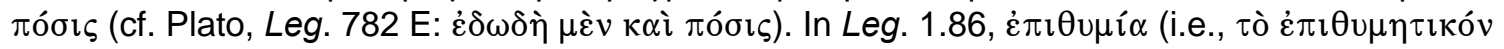

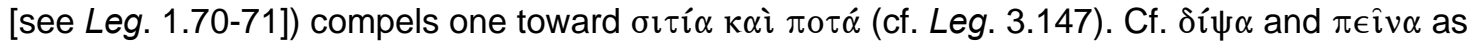
"harsh mistresses" in Mos. 1.191, Spec. 4.82, Virt. 130, Contemp. 37. The desire for sexual

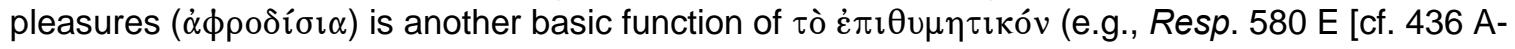
$\mathrm{B}]$ ). In fact, desires for food, drink, and sex often appear together as the primal triumvirate of appetites (e.g., Leg. 782 E; Phaed. 81 B). Although closely tied to bodily requirements and

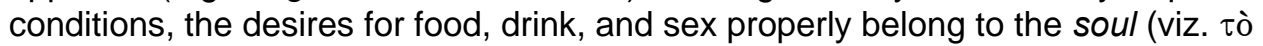
$\dot{\varepsilon} \pi \imath \theta u \mu \eta \tau \imath \kappa o ́ v)$ - there are, for Plato, no desires of the body, only "bodily desires," desires of the soul bearing a unique connection to the body (see e.g. R. Hackforth, Plato's Examination of Pleasure [Cambridge: Cambridge University Press, 1945], 61; cf. 79, n. 4; 112, n. 2; 140, n. 2).

${ }^{36} \mathrm{Cf}$. Cooper, "Reason, Virtue, Value," 263: "In the Republic Plato gives this intermediate kind of desire [sc. $\theta u \mu o ́ c]$ its own special object of pursuit, victory, and/or esteem or honor (timē), corresponding to appetite's [sc. $\dot{\varepsilon} \pi \imath \theta u \mu i \alpha$ ] pursuit of pleasure. As we have already seen, Aristotle rejects this identification: according to him, akratic lovers of honor and victory are incontinently pursuing a pleasure and so are inappropriately subject not to spirited desire but to certain appetites, appetites for victory and honor."
} 
victory, honor, and fame.$^{37}$ This broader concept of $\dot{\varepsilon} \pi \imath \theta u \mu i \alpha$ strips $\theta v \mu o ́ \varsigma$ of all acquisitive aims, leaving it almost exclusively associated with anger and aggression in Middle-Platonic thought. ${ }^{38}$ In other words, Middle Platonists continued to associate $\dot{\varepsilon} \pi \imath \theta u \mu i \alpha$ with a particular component of the Platonic soul, but they conceived it more broadly as the one source for all non-rational appetites, pursuing its aim of pleasure through any number of possible objects. Second, since Aristotle assigned both $\theta u \mu o ́ \varsigma$ and $\dot{\varepsilon} \pi \imath \vartheta \mu$ í $\alpha$ to a single ỏ $\rho \in \kappa \tau \imath \kappa o ́ v$ faculty of the soul, and since $\theta u \mu o ́ \varsigma$ and $\dot{\varepsilon} \pi \imath \theta u \mu i \alpha$ constitute the soul's $\ddot{\alpha} \lambda \circ \gamma \circ v$

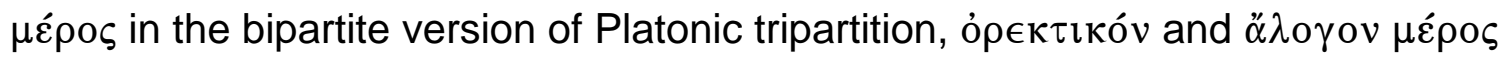
become interchangeable in Middle-Platonic moral psychology. Attesting this

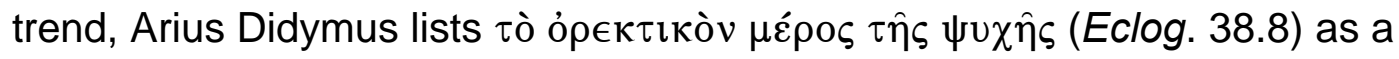
variant Middle-Platonic designation for the soul's non-rational part over against its rational part. ${ }^{39}$ In fact, Middle-Platonic ethical theory in general, which deals

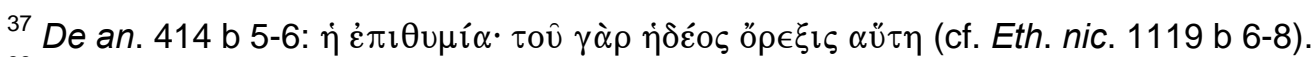

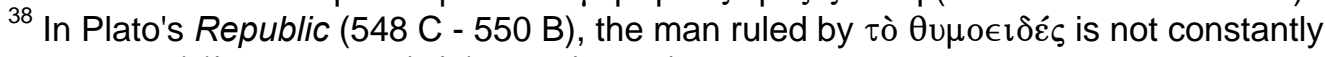
angry: he is rather $\phi i ́ \lambda \alpha \rho \chi 0 \varsigma$ and $\phi \imath \lambda o ́ \tau \imath \mu о \varsigma$ (549 A)—he wants power and honor. The MiddlePlatonic conception (following Aristotle) would identify a $\phi i \lambda \alpha \rho \chi 0 \varsigma$ or $\phi \imath \lambda o ́ \tau \imath \mu \circ \varsigma$ as one ruled by

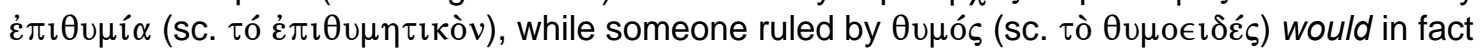
be irascible. When Ps.-Timaeus considers training of the soul (TL 82), in particular the obedience

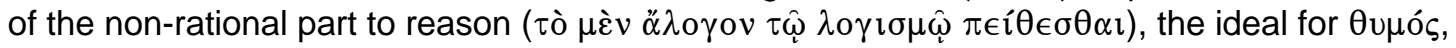
which constitutes the non-rational part along with $\dot{\varepsilon} \pi \imath \theta u \mu i \alpha$, is that it be "tame" ( $\tau \hat{\omega} \delta$ ' $\dot{\alpha} \lambda \dot{\gamma} \gamma \omega$ $\theta u \mu o ̀ v ~ \mu \grave{\varepsilon} v \pi \rho \hat{\alpha} o v \in \hat{\imath} \mu \in v$ ) —in other words, Ps.-Timaeus envisions $\theta u \mu o ́ s$ primarily as an irascible

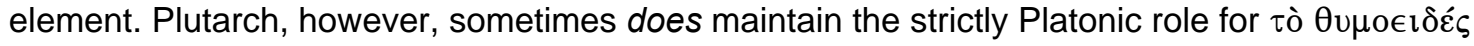
as the motivating force for reckless ambition (see Tim Duff, Plutarch's Lives: Exploring Virtue and Vice [Oxford: Clarendon Press, 1999], 83-89).

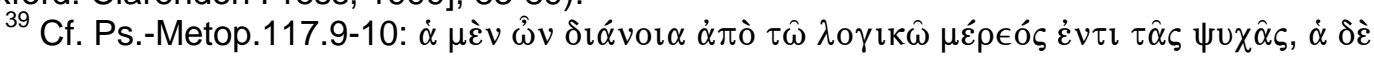
ő $\rho \xi_{1 \varsigma} \dot{\alpha} \pi o ̀ ~ \tau \hat{\omega} \dot{\alpha} \lambda o ́ \gamma \omega$ (also Ps.-Theag. 193.13-14: $\dot{\alpha} \delta \grave{\varepsilon}$ ő $\left.\rho \epsilon \xi_{1 \varsigma} \tau \hat{\omega} \dot{\alpha} \lambda o ́ \gamma \omega\right)$ ); Didask. 29.2 [182.2935] (note the association of $\alpha i$ o $\rho \varepsilon \varepsilon \xi \in l \zeta$ with non-rational over against rational): $\sigma \omega \phi \rho o \sigma u ́ v \eta=$

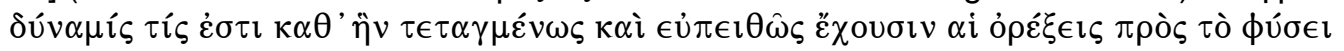

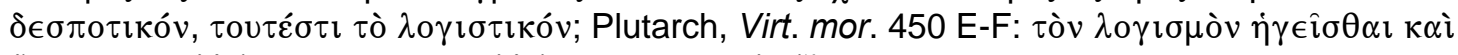

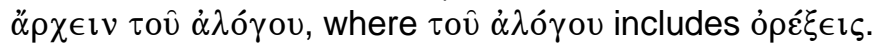


with reason's management of non-rational forces in the soul, and which must

systematically conceptualize the nature and function of those non-rational forces

in need of management, takes full advantage of $\ddot{\alpha} \lambda \circ \gamma o v \mu \varepsilon \dot{\varepsilon} \rho \varsigma_{\varsigma}$ as a heuristic

device, making it the locus not only of appetite (ő $\rho \in \xi i \varsigma)$ but also of impulse

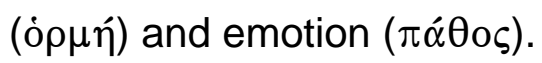

\section{Reason over against Impulse ( $\dot{\rho} \mu \eta \eta)$}

"Appetite" (ő $\rho \in \xi i \varsigma)$, generally speaking, bears a close relation to "impulse"

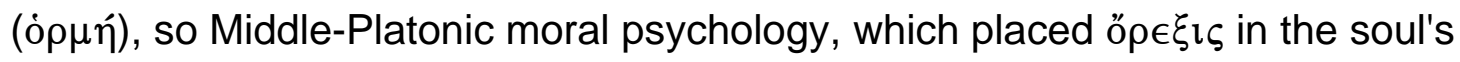

non-rational part, naturally placed ó $\mu \eta \eta \dot{~ t h e r e ~ a s ~ w e l l . ~}{ }^{40}$ The term ó $\rho \mu \eta \dot{~ d e n o t e s ~}$

above all directed movement within the soul. ${ }^{41}$ Thus ő $\rho \xi \xi \varsigma$, as a type of impulse,

denotes directed movement toward something, and $\dot{\varepsilon} \pi \imath \theta u \mu i \alpha$, more specifically,

denotes movement toward pleasure, a pursuit—other types of impulses denote

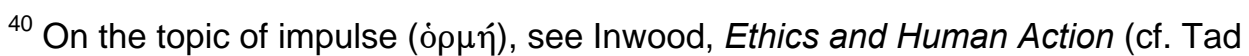
Brennan, "Stoic Moral Psychology," in The Cambridge Companion to the Stoics [ed. Brad Inwood; Cambridge: Cambridge University Press, 2003], 265-69). Inwood considers primarily the Stoic view (esp. 42-101 [="The Psychology of Action"]), but also the less technical views of Plato and Aristotle (see 242-49 [="Hormê in Plato, Aristotle, and the Magna Moralia"]). For Plato, neither ó $\rho \mu \eta$ nor ő $\rho \xi \xi \iota \varsigma$ are technical terms (the latter does not appear in his writings), so their precise relation cannot be determined. For Aristotle, the terms were more or less interchangeable, which allowed for their conflation among later philosophers, as Inwood notes: "For although one was the central theoretical term for the Stoa [ó $\rho \mu \eta$ ] and the other for Aristotle [ö $€ \xi \xi \varsigma]$, they could be blended together by those who were not interested in or did not understand the difference between the two psychological theories. This process continued to the point where ... the desiderative part of the soul could be called to hormêtikon rather than to orektikon" (245). For the Stoics, op $\epsilon \xi_{1 \zeta}$ was a type of impulse: namely, a rational impulse toward the apparent good (see Inwood, Ethics and Human Action, 235-37; cf. 114-15, 227-28).

${ }^{41}$ According to the generic Stoic definition, an impulse is simply "a motion of the soul

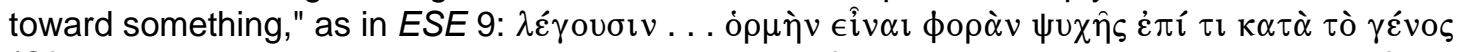
(Cf. Inwood, Ethics and Human Action, 32: "In most of our sources impulse is explicitly defined as a kind of change, movement or activity of the soul"). Stoics considered this definition broad

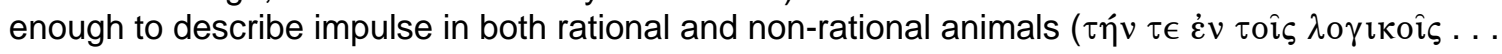

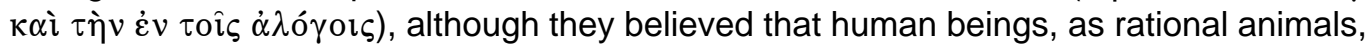

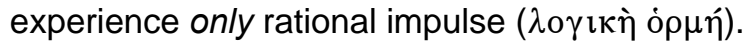


other types of directed movement. ${ }^{42}$ The issue dividing Stoics and Middle

Platonists was not how to describe the phenomenon of impulse, since both could

acknowledge the experience of directed movement within the soul. They

disagreed over where in the soul (in a theoretical sense) impulse occurred and

what role reason played in the generation of impulse. Arius Didymus notes that

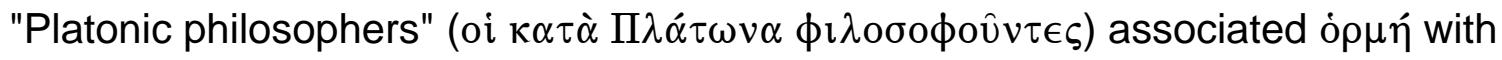

the non-rational part of the soul ( $\ddot{\alpha} \lambda \circ \gamma o v \mu \varepsilon \dot{\varepsilon} \rho \varsigma \tau \hat{\eta} \varsigma \psi \nu \chi \hat{\eta} \varsigma)$ over against the

rational part $(\tau \hat{\omega} \lambda \partial \gamma \kappa \kappa \hat{\omega}) .{ }^{43}$ This same association appears in other writings with

"Eudoran" affinities (Ps.-Timaeus, Ps.-Metopus, Plutarch) and arguably in the

extant fragments of Eudorus himself. ${ }^{44}$ By locating impulse in the non-rational

\footnotetext{
${ }^{42}$ Pleasure (i்ovท́), for example, as an impulse denotes directed movement upward—an "elevation" ("̈ $\pi \alpha \rho \sigma \iota \varsigma)$ of the soul (ESE 10b; DL 7.114).

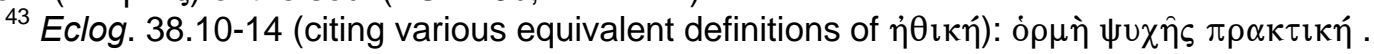

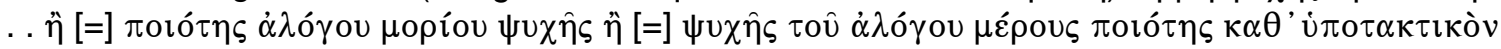

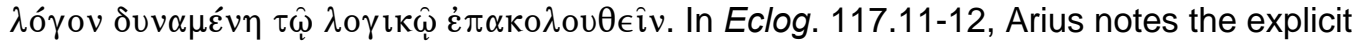

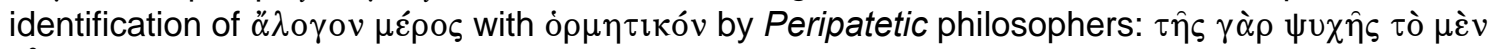

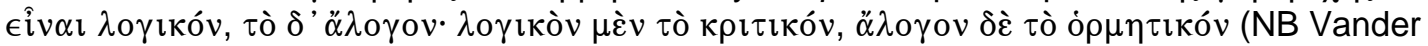

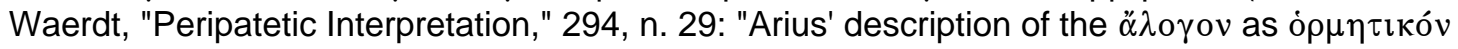
contravenes Stoic doctrine and appears to represent a Peripatetic adaptation of the Stoic theory of $\left.\dot{\rho} \mu \eta^{\prime \prime}\right)$. Middle Platonists surely made the same identification, given their readiness to adopt Peripatetic models in moral psychology (e.g., tripartition as bipartition). But even without an

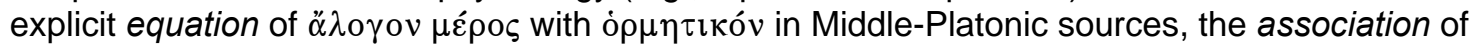

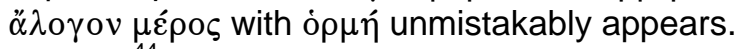

${ }_{44}$ See esp. Mauro Bonazzi, "Eudorus' Psychology and Stoic Ethics," in Platonic Stoicism - Stoic Platonism: The Dialogue between Platonism and Stoicism in Antiquity (ed. Mauro Bonazzi and Christoph Helmig; AMP 39; Leuven: Leuven University Press, 2007), 109-32. On the basis of a distinction between $\theta \epsilon \omega \rho i ́ \alpha$ and ó $\rho \mu \eta$ in Eclog. 42.13-23 [=Mazz. 1.4-10], Bonazzi convincingly argues for Eudorus' acknowledgement of non-rational impulse in the context of a Platonic bipartition between rational and non-rational parts of the soul. The association between o $\rho \mu \eta$ and

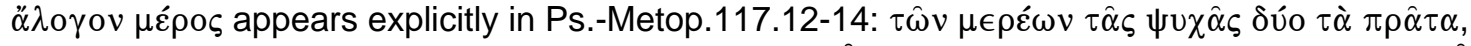

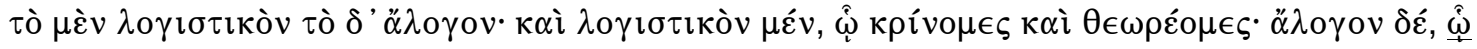

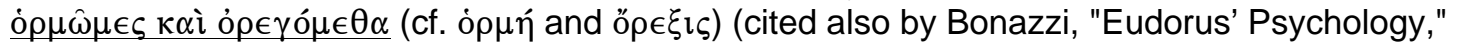
125). Ps.-Timaeus has the association, but not as clearly: e.g., TL 71, where the soul's hormetic faculty ( $\dot{\rho} \rho \mu \tau \imath \kappa \hat{\alpha} \varsigma)$ is listed separately from its rational faculty $(\lambda \circ \gamma \imath \kappa \hat{\alpha} \varsigma)$, indicating its non-

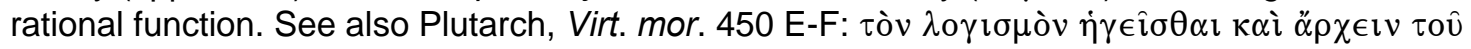


part of the soul, which stands over against reason, Middle Platonists affirmed the existence of non-rational impulses in adult human beings. For them, impulses capable of motivating human action could arise, subsist, and desist wholly apart from reason, without reason's assent or authorization. ${ }^{45}$ Such impulses are thus capable of genuinely opposing, or even usurping, reason. In sharp contrast, the Stoics flatly denied the possibility of non-rational impulse in adult human

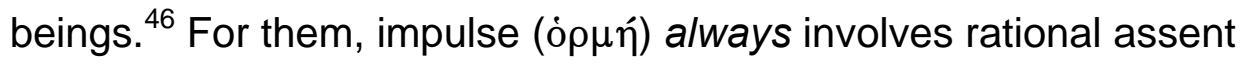

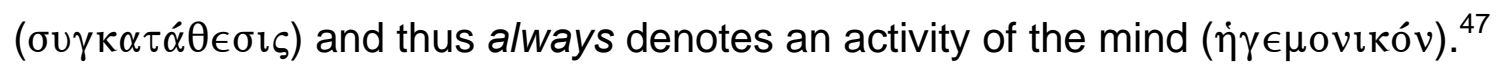

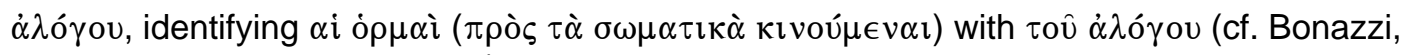
"Eudorus' Psychology," 125-26).

${ }^{45}$ Just as non-rational animals, who have no capacity for reason, nevertheless operate according to impulse. For an explanation of the role of impulse in animal behavior, see Inwood, Ethics and Human Action, 66-91, esp. 72-82.

${ }^{46}$ See, for example, Inwood, Ethics and Human Action, 224-42 [=Appendix 2: "The Kinds of Impulse"], esp. 225. Commenting on Arius Didymus' detailed summary of the Stoic classification of impulse (see Eclog. 86.17 - 88.7), Inwood notes the Stoic attribution of nonrational impulse to non-rational animals, while noting also that for rational animals (i.e., human beings) the concept of non-rational impulse simply does not apply (225). Cf. Julia Annas, Hellenistic Philosophy of Mind (HCS 8. Berkeley: University of California Press, 1992), 106: "Our normal talk of 'irrational' impulses suggests that they are not rational at all; but for the Stoics ordinary language is just wrong here, for there can be no such thing as a totally nonrational impulse, at least not in undefective humans. We grasp the phenomenon, but it is not what we think it is, namely, reason versus something devoid of reason, but rather good reason versus bad, inadequate reason."

${ }^{47}$ The relation between impulse and assent stands as part of the broader Stoic psychology of action (see Inwood, Ethics and Human Action, 42-101). Following Inwood (Ethics

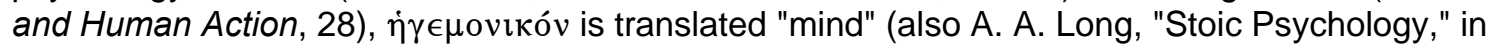
The Cambridge History of Hellenistic Psychology [ed. Keimpe Algra et al.; Cambridge: Cambridge University Press, 1999], 560-84, esp. 572-83 [="Rationality and the faculties of the mind"]).

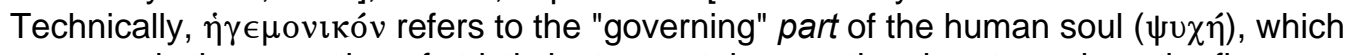
commands the operation of strictly instrumental non-rational parts such as the five senses ( $\alpha i \sigma \theta \eta \sigma \epsilon i \varsigma$ ), the faculty of speech, and the faculty of reproduction-thus in Stoic theory, the soul has eight parts (see Inwood, Ethics and Human Action, 27-41; cf. Long, "Stoic Psychology," esp.

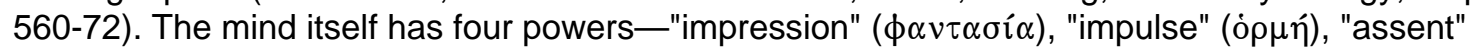

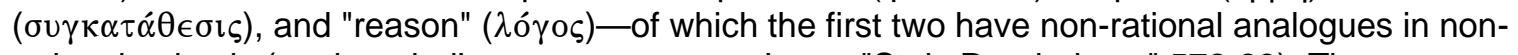
rational animals (on the mind's powers, see esp. Long, "Stoic Psychology," 572-83). The presence of reason in Man, however, influences the operation of the entire mind, making all of its functions distinctly rational: "[O]ur sources are correct, but misleading, when they say that the mind or 'governing part' of the human psuchē has the four faculties, impression, assent, impulse, reason. The Stoics' model of the mind would be better rendered by saying that there are three 
Stoics, in other words, considered impulse a rational function, precluding on theoretical grounds the idea of impulse opposing, much less usurping, reason. ${ }^{48}$ The Middle-Platonic discussion of impulse certainly owed much to the Stoics, insofar as the Stoics brought the topic into prominence by emphasizing the role of impulse in moral theory, but the difference in their respective understandings of the origin and nature of impulse could not be starker. Simply put, the Stoics conceived impulse as an exclusively rational function, while Middle Platonists conceived impulse as a non-rational function, appropriately located in the soul's non-rational part. ${ }^{49}$

mental faculties-rational impression, rational impulse, and rational assent. Reason is not something over and above the other three. It is the mind in its entirety. Hence reason (logos), mind (nous), and thought (dianoia) are all terms that refer to the distinctive nature of a human being's psuchē" (Long, "Stoic Psychology," 575).

${ }^{48}$ For the Stoics, a moment of rational assent is always the direct cause of human behavior, whether or not the agent is consciously aware of that moment. The idea of an internal, non-rational force causing or determining behavior clearly and flatly contradicts the Stoic theory of human action. (Cf. Inwood, Ethics and Human Action, 139: "[A]t no time do we experience impulses or passions which are produced independently of our assenting reason or which conflict with and resist it.") This reflects the Stoic "monistic" psychology, which holds that the human psyche stands united under one arbiter-reason. Thus no psychic power other than reason (i.e., no non-rational power) can ultimately determine the course of human action, which always proceeds on the basis of an autonomous agent's rational decision. As Inwood explains (idem, 33), Stoic monism did not preclude the existence of soul parts ( $\mu \varepsilon \dot{\rho} \eta)$, only the possibility of opposition among those parts.

${ }^{49}$ The acknowledgement of non-rational impulses ( $\ddot{\alpha} \lambda$ o $\gamma$ or ó $\left.\rho \mu \alpha i ́\right)$ in adult human beings serves in itself as a criterion for distinguishing Middle-Platonic from Stoic moral psychology, including the moral psychology of the Stoic Posidonius (ca. 130 - 50 B.C.). While Posidonius did acknowledge non-rational forces in the soul analogous to Platonic $\dot{\varepsilon} \pi \imath v \mu i \alpha$ and $\theta \dot{v} \mu \varsigma_{\text {, }}$, he did

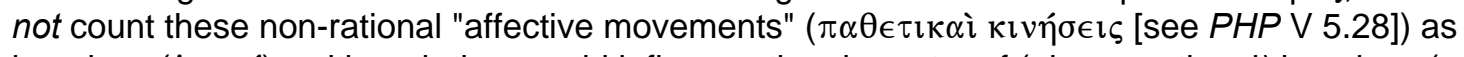
impulses ( $\dot{\rho} \mu \alpha \hat{i})$-although they could influence the character of (always rational) impulses (see John Cooper, "Posidonius on Emotions," in Reason and Emotion: Essays on Ancient Moral Psychology and Ethical Theory [Princeton: Princeton University Press, 1999], 449-84, esp. 46768, 474-75; repr. from pages 71-111 in The Emotions in Hellenistic Philosophy [ed. J. Sihvola and T. Engberg-Pedersen; TSHP 46; Dordrecht: Kluwer, 1998]). In other words, Posidonius need not muddle the clear and radical difference between Middle Platonists (including Philo) and Stoics on the question of non-rational impulses in adult human beings-or, for that matter, on the question of $\pi \dot{\alpha} \theta \eta$, which both groups analyzed ultimately as a type of impulse: for Middle Platonists a type of non-rational impulse, for Stoics a type of (ir)rational impulse. 
Reason over against Emotion ( $\pi \dot{\alpha} \theta 0 \varsigma)$

Along with ő $\rho \xi \xi \varsigma$ and $\dot{\rho} \mu \eta$, Middle Platonists placed also emotion $(\pi \dot{\alpha} \theta o \varsigma)$ in the non-rational part of the soul: feelings of dejection, fear, elation, desire—can all arise, subsist, and desist apart from the rational faculty. ${ }^{50}$ Arius Didymus confirms that "Platonist philosophers" (Eclog. 38.14-15) considered the

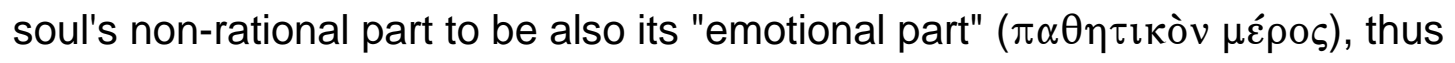
indicating that emotions are essentially non-rational phenomena. ${ }^{51}$ Similarly, in

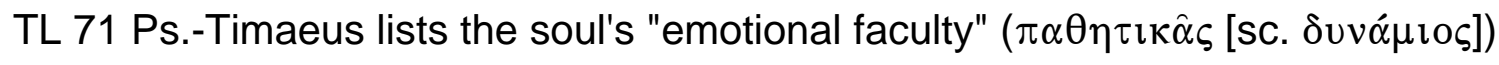

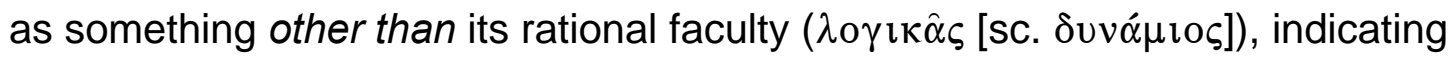
that emotions occur apart from reason. Along with the Stoics, Middle Platonists

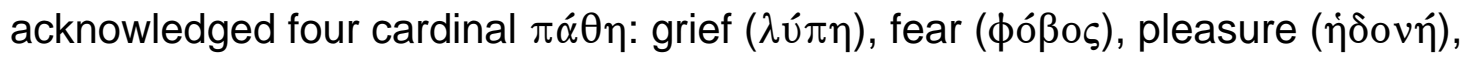
and desire $\left(\dot{\varepsilon} \pi \imath \theta v \mu \imath^{\prime} \alpha\right) .{ }^{52}$ But agreement between the two groups virtually ends

${ }^{50}$ The term $\pi \dot{\alpha} \theta 0 \varsigma$ bears various translations, and a comparison of Middle-Platonic over against Stoic ethical theory demands the subtle yet crucial distinction between "emotion" ( $\pi \dot{\alpha} \theta$ o $\varsigma)$ and "passion" $(\pi \dot{\alpha} \theta \circ \varsigma)$. Emotion $(\pi \dot{\alpha} \theta \circ \varsigma)$ is a strictly amoral function of normal human life, while passion $(\pi \dot{\alpha} \theta 0 \varsigma)$ is an immoral function of abnormal human life. These different connotations led to semantic confusion and charges of equivocation (see Plutarch, Virt. mor. 449 A-C).

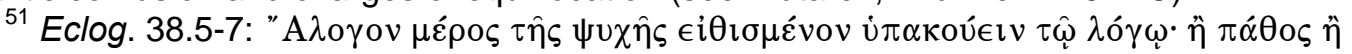

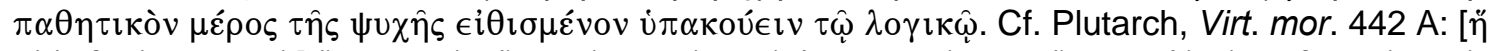

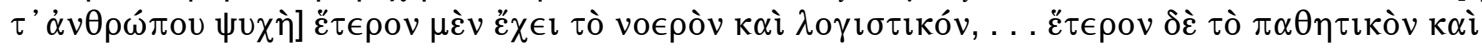
$\ddot{\alpha} \lambda$ o yov (Virt. mor. represents in large part Plutarch's polemic against the Stoics, who refuse to acknowledge that passions are something other than reason, not-as they claim-aberrant manifestations of reason; see 441 C [the Stoic view], 443 B, 446 F - 447 C, 448 D); also Didask.

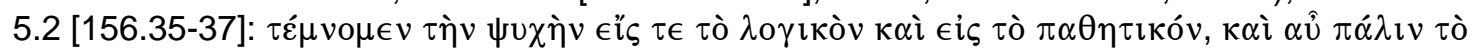

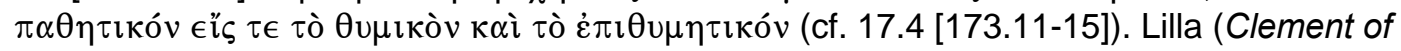
Alexandria, 87) suggests that a general tenet of the Middle-Platonic doctrine of $\pi \dot{\alpha} \theta$ o $\varsigma$ is: "the tendency to consider it as produced by the irrational [i.e., non-rational] parts of the soul."

${ }^{5}$ On the four cardinal passions, see Inwood, Ethics and Human Action, 144-45. The four

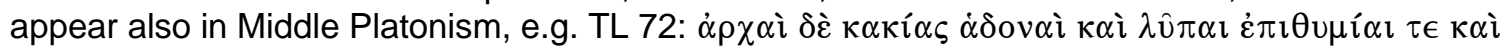

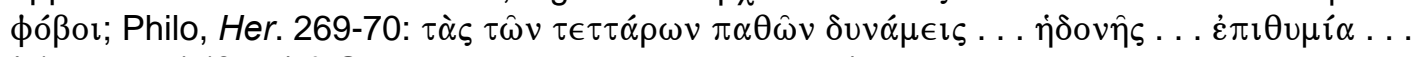

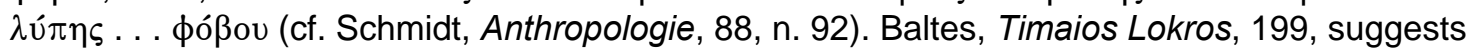
that the doctrine of four cardinal passions attested in TL 72 formed (for Middle Platonists) part of "ein neues ethisches Lehrgebäude." 
with this taxonomy. In the first place, Stoics considered these four passions to be

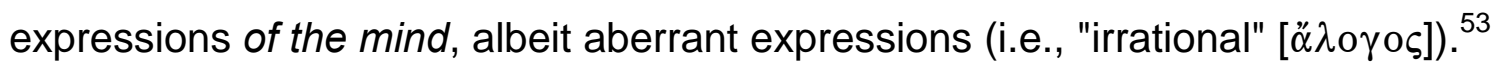

This follows from the Stoic conviction that (a) passions are a type of impulse and (b) every impulse derives from reason. By claiming that passions arise independently from the rational faculty, Middle Platonists reject Stoic theory unequivocally. ${ }^{54}$ In addition, Stoics considered these four $\pi \dot{\alpha} \theta \eta$ to be always and inherently bad—-thus passions and not just emotions. Middle Platonists, by contrast, considered the cardinal $\pi \dot{\alpha} \theta \eta$ an amoral part of normal human existence: their non-rational energy provides essential motivation for human activity, including virtuous human activity, and they become problematic only when they overstep the dictates of reason. ${ }^{55}$ So Middle Platonists endorsed as

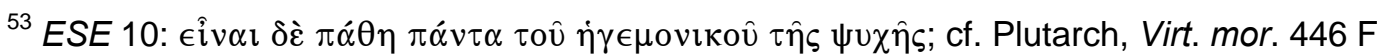

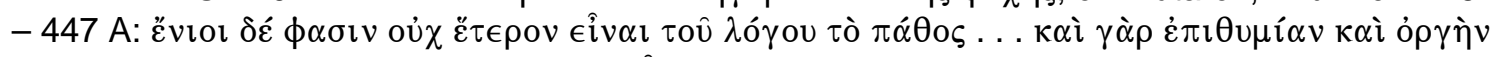

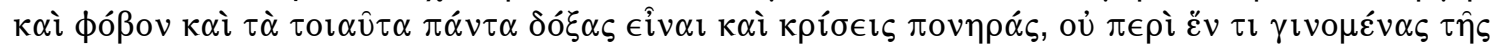

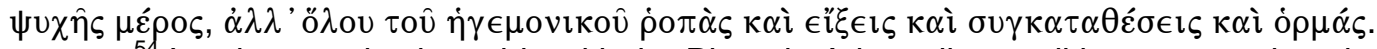

${ }^{54}$ In other words, they side with the Platonic-Aristotelian tradition over against the Stoic. For a discussion of the radical difference between the Platonic-Aristotelian concept of $\pi \dot{\alpha} \theta$ o $\varsigma$ (as non-rational) and the Stoic concept (as [ir]rational), see Frede, "Stoic Affections," esp. 94-100.

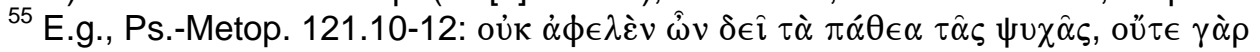

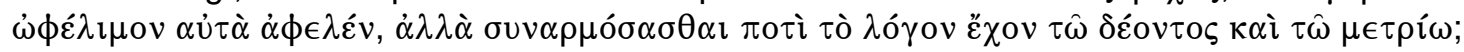

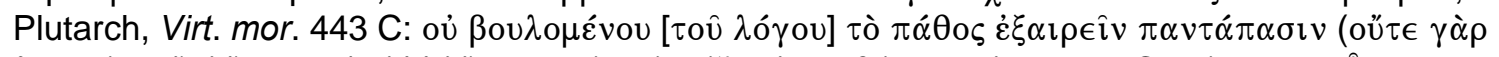

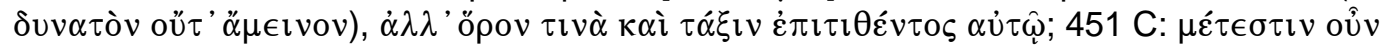

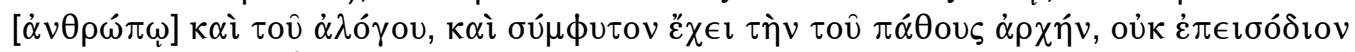

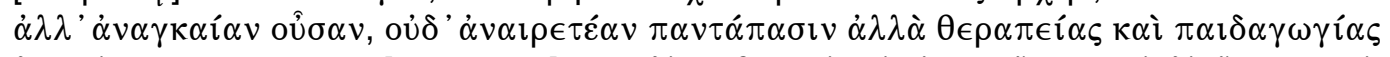

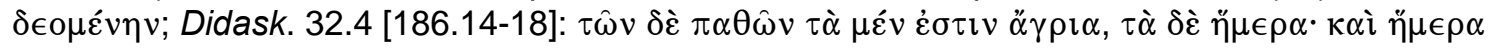

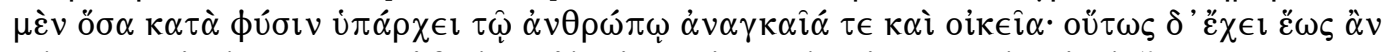

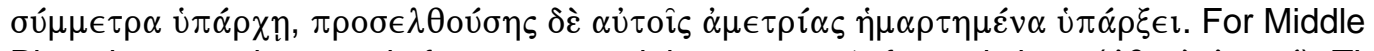

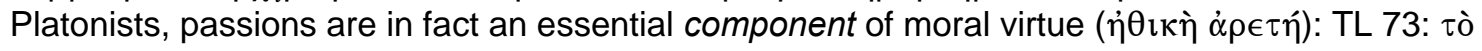

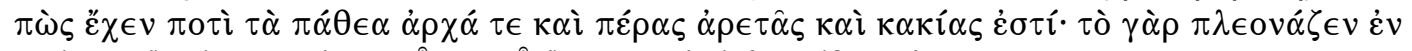

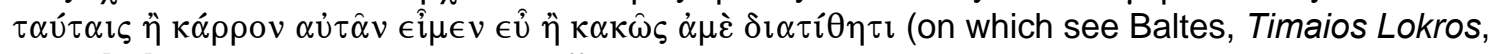
206: "[W]ie bei Platon . . . sind die Affekte an sich noch nicht schlecht, sie werden es erst durch

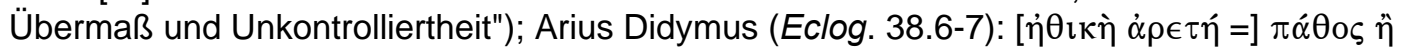

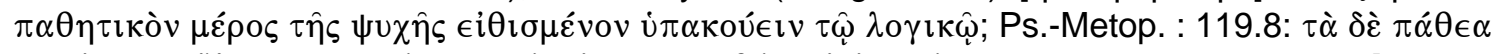

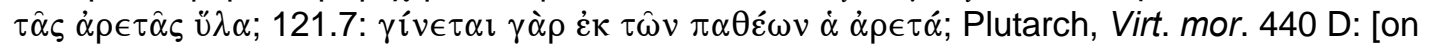

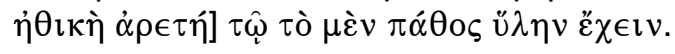


an ethical norm the moderation of emotion. ${ }^{56}$ This emphasis on moderation stems directly from Middle-Platonic convictions about the soul: a non-rational component, the locus of emotion, simply exists as a matter of fact; and its existence calls for active management on the part of reason. ${ }^{57}$

\section{Summary}

According to Alexandrian Middle Platonism, the human soul consists of two essentially different parts: a rational part and a non-rational part. Although the non-rational part represents in theory a composite of Platonic $\theta u \mu$ ó $\varsigma$ and $\dot{\varepsilon} \pi \imath \theta u \mu i ́ \alpha$, this representation involves dramatic modifications of Plato's views. Along with expanding the scope of acquisitive desire ( $\dot{\varepsilon} \pi \imath \theta \mu i \alpha)$, this representation of tripartition as bipartition facilitates a unitary conception of the

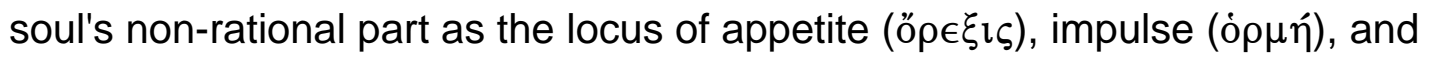
emotion ( $\pi \dot{\alpha} \theta$ o $\varsigma$ - -which all are conceived as non-rational capacities in accordance with their non-rational origin. In sum, Middle Platonists understand "rational" over against "non-rational" to be the one overarching paradigm for

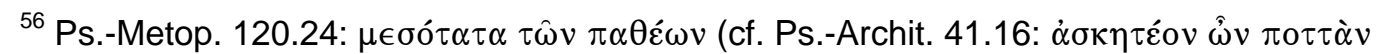

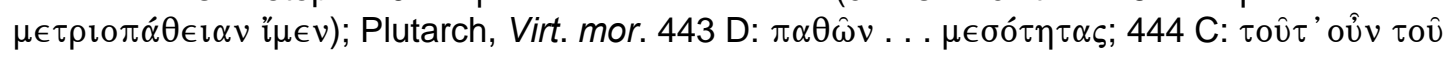

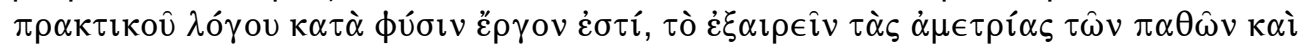

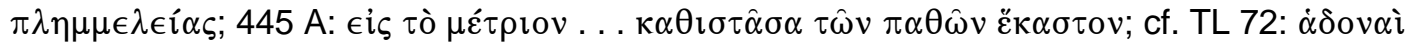
$\ddot{\alpha} \mu \epsilon \tau \rho o i ́$. Cf. Claudio Moreschini, "Considerazioni sulla dottrina del pathos nel Medioplatonismo, SF 8-9 (1985-86), 23-33, 24: "il medioplatonismo . . . sostiene l'eccellenza della dottrina della metriopatheia." See also Lilla, Clement of Alexandria, 92-103; John Dillon, "Metriopatheia and Apatheia: Some Reflections on a Controversy in Later Greek Ethics," in Essays in Ancient Greek Philosophy II (ed. John Anton and Anthony Preus; Albany: SUNY Press, 1983), 508-17; repr. in The Golden Chain: Studies in the Development of Platonism and Christianity; CS 333; Aldershot, Hampshire; Brookfield, Vt.: Variorum, 1990.

${ }^{57}$ Cf. Dillon, "Metriopatheia and Apatheia," 515: "the controversy about metriopatheia and apatheia, which generated such heat in later Greek philosophy, is properly one between the concept of a bipartite or tripartite soul, in which the lower part [or] parts can never be eradicatedat least while the soul is in the body-but must constantly be chastised, and that of a unitary one." 
moral psychology, although that paradigm accommodates a number of different conceptual models:

Table One: Variations of Bipartition in Middle Platonism

\begin{tabular}{|c|c|c|c|c|}
\hline & TRIPARTITION & APPETITE (ő $\rho € \xi ı \varsigma)$ & IMPULSE (ó $\rho \mu \eta ́)$ & EMOTION $(\pi \dot{\alpha} \theta 0 \varsigma)$ \\
\hline RATIONAL & & & & \\
\hline 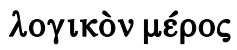 & $\lambda o \gamma \iota \kappa o ̀ v ~ \mu \varepsilon ́ \rho о \varsigma$ & 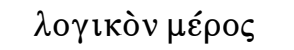 & 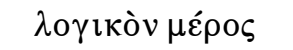 & 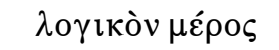 \\
\hline NON-RATIONAL & & & & \\
\hline 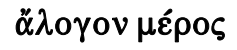 & 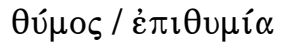 & 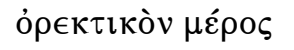 & 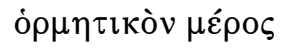 & $\pi \alpha \theta \eta \tau \imath \kappa o ̀ v ~ \mu \varepsilon ́ \rho \circ$ \\
\hline
\end{tabular}

This variety naturally allows for variant conceptions of desire $(\dot{\varepsilon} \pi \imath \theta u \mu i \alpha)$, depending on the model in question. For Middle Platonists, the term $\dot{\varepsilon} \pi \imath \theta u \mu i \alpha$ can denote either an enduring "part" of the soul or an intermittent function of

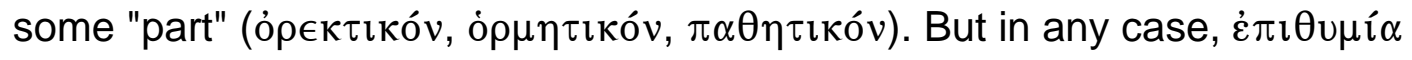
represents a non-rational force within the soul in need of reason's management.

\author{
BIPARTITION IN PHILO'S WRITINGS

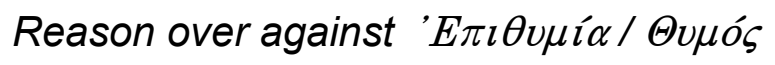

Philo consistently maintains the bipartite psychological model of his

Middle-Platonic contemporaries: ${ }^{58}$

${ }^{58}$ Generally speaking, studies of Philo's work identify the bipartition of rational and nonrational (often "irrational") as the model held most consistently: e.g., Billings, Platonism of Philo, 52: "The one distinction which persists throughout is the one . . . between the rational and the irrational parts of the soul"; Dillon, Middle Platonists, 174-75: "[F]or Philo each of these divisions expresses some aspect of the truth, but the most basic truth remains the division into rational and irrational" (175); Runia, Philo and The Timaeus, 468: "Philo regarded the main thrust of Plato's psychology as tending towards a bipartition of the soul into a rational and an irrational part" [cf. 304-05]); Schmidt, Anthropologie, 50: "Trotzdem Philon zwischen den verschiedenen Einteilungen ... hin- und herschwankt ...., dominiert doch entsprechend seiner dualisischen Grundhaltung die Zweiteilung der Seele." Cf. Hermann S. Schibli, "Xenocrates' Daemons and the 
Since our soul is bipartite ( $\psi v \chi \hat{\eta} \varsigma \dot{\eta} \mu \hat{\omega} v \delta \imath \mu \epsilon \rho o \hat{\varsigma} \varsigma \dot{u} \pi \alpha \rho \chi o v ́ \sigma \eta \varsigma)$, having

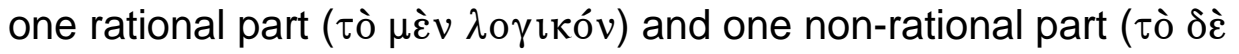
$\ddot{\alpha} \lambda \circ \gamma \circ v)$, there is a virtue associated with each part ....(Congr. 26) $)^{59}$

\title{
Furthermore, Philo uses this bipartite model to accommodate Platonic tripartition,
}

\author{
again in agreement with contemporary Middle Platonism:
}

[Esau] was wild and indocile, brimful of fierce temper and desire ( $\theta u \mu \circ \hat{0}$

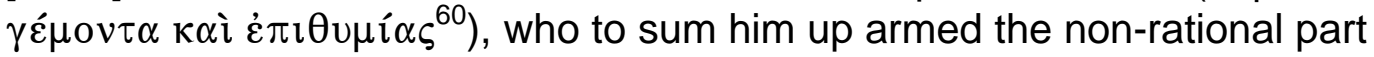

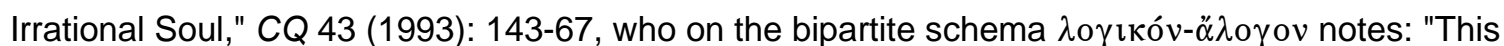
was the working model for Philo of Alexandria in the first century A.D., probably following Eudorus" (161). For a helpful collection of Philonic material on the soul, in outline form and arranged under rubrics relevant to moral psychology, see Gretchen Reydams-Schils, "Philo of Alexandria on Stoic and Platonist Psycho-Physiology: The Socratic Higher Ground," in Philo of Alexandria and Post-Aristotelian Philosophy (ed. Francesca Alesse; SPhA 5; Leiden: Brill, 2008), 169-95; repr. from AP 22 (2002): 125-47. In addition to assembling and collating data (175-87 [="Philo's Psychology, Nuts and Bolts"]), Reydams-Schils considers "which psychological model Philo prefers in his analysis of rational behavior and the passions" (169-70) and so seeks to explain the data (see esp. 169-75, 187-95). She concludes that Philo-despite skepticism regarding the precise nature of the soul-consistently maintains an overarching "Socratic" notion of soul-body opposition able to accommodate psychological models of both Platonic and Stoic provenance, which Philo can them deploy in various forms according to exegetical need (esp. 190: "A return to the Socratic position of a struggle between soul and body" etc.). Her thesis, however, does not address the question of whether or not Philo holds a consistent view of the soul itself, since in the end a "soul-body" dichotomy only affirms the existence of a soul over against the body, which both Platonists and Stoics acknowledged. The bipartition espoused by Middle Platonists (rational over against non-rational) accommodates all of Reydams-Schils' data within one working model of the soul and so it provides what the soul-body dichotomy cannot: an overarching paradigm for moral psychology. The soul-body dichotomy more likely belongs not to Philo's moral psychology but to his moral rhetoric, in which the body (esp. the belly) serves as a foil for loftier pursuits of the soul (see Sandnes, Belly and Body, esp. 35-60 [="The belly in ancient moral philosophy"], 97-107 [="The belly-topos in Jewish-Hellenistic sources"], and 108-35 [="The belly in Philo's writings"]). On Philo's various formulations of the soul (along with a proposal of

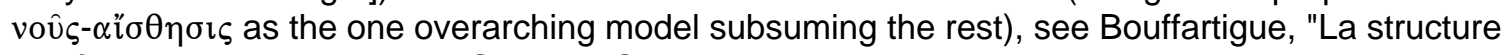
de l'âme chez Philon," 59-75. See also Schmidt, Anthropologie, 49-67.

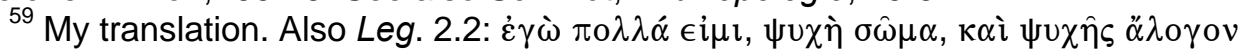

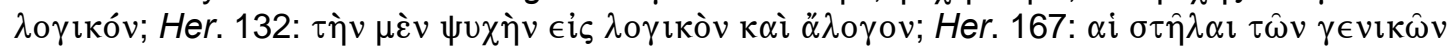

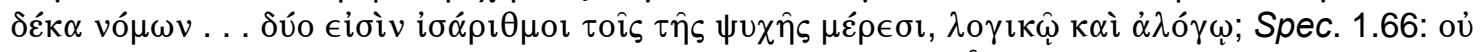

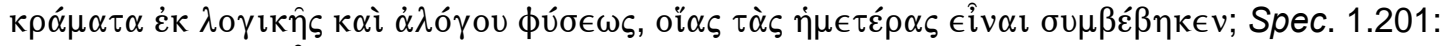

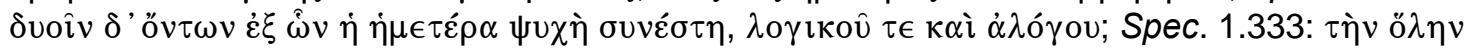

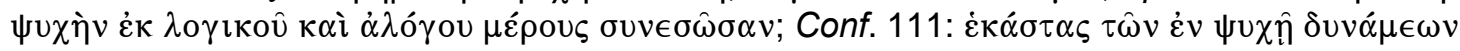

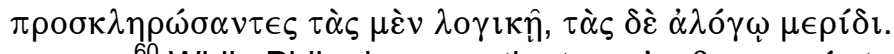

${ }^{60}$ While Philo does use the term $\dot{\varepsilon} \pi \imath \theta u \eta \tau \imath \kappa o ́ v$ to refer to the desiderative element of the tripartite soul in Leg. 1.70-72 and Leg. 3.115, he elsewhere uses the term $\dot{\varepsilon} \pi \mathrm{l} \theta u \mu i \alpha$ (cf. $\theta u \mu o ́ c$ for $\theta u \mu o \in \mathfrak{l} \delta \varepsilon$ ), as loannes Leisegang notes (Indices ad Philonis Alexandrini Opera [= vol. 7 of PCW], s.v. at no. 1, "tertia pars animae"): Conf. 21; Spec. 4.92; Spec. 1.146-50, cf. 206 ff.; Virt. 13; Migr. 67; Her. 64; Spec. 4.10. 


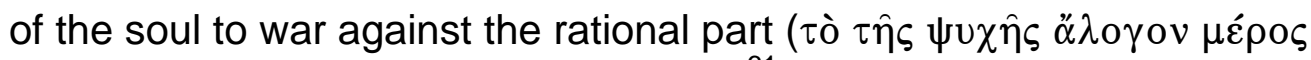
$\dot{\varepsilon} \pi \imath \tau \epsilon \tau \in \chi \imath \kappa o ́ \tau \alpha \tau \hat{\omega} \lambda$ o $\gamma \imath \kappa \hat{\omega})$. (Praem. 59) ${ }^{61}$

Reflecting the full range of variant models endorsed by Middle Platonists, Philo

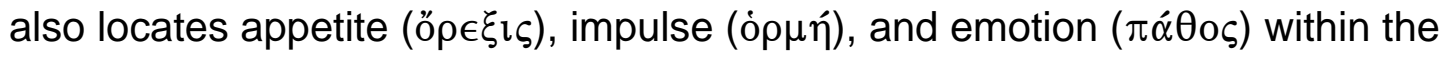
non-rational part of the soul.

\section{Reason over against Appetite (ö $\epsilon \xi \xi l)$}

In agreement with his Middle-Platonic contemporaries, Philo locates ő $\rho \xi \xi \downarrow$ in the non-rational part of the soul:

Our soul is tripartite ( $\tau \rho \jmath \epsilon \rho \hat{\eta})$ : one part is rational ( $\mu \varepsilon \dot{\varepsilon} \rho \varsigma \mu \grave{\varepsilon} \nu \tilde{\varepsilon} \nu$

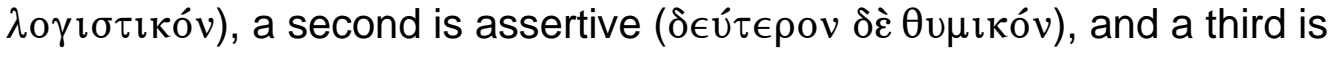

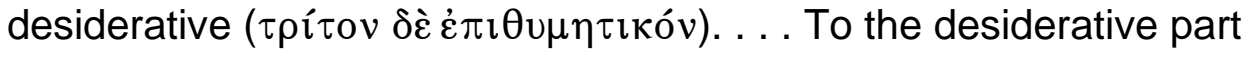
[philosophers have assigned] the area around the abdomen and belly,

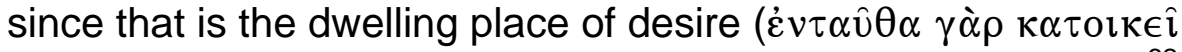
$\dot{\varepsilon} \pi \imath \theta u \mu i \alpha)$, non-rational appetite (ő $\epsilon \xi \xi \varsigma \ddot{\alpha} \lambda o \gamma o \varsigma)$. (Leg. 3.115)

Philo indicates in Leg. 3.116 that he views this tripartite Platonic model in MiddlePlatonic terms, as a bipartite dichotomy: ò $\lambda o ́ \gamma o \varsigma$ over against ò $\theta u \mu o ́ \varsigma$ and $\dot{\eta}$

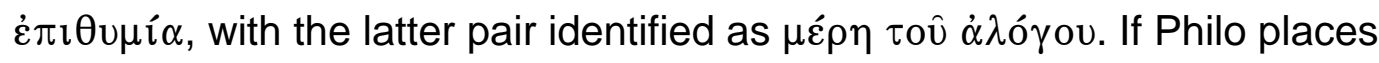
$\dot{\varepsilon} \pi \imath \theta u \mu i \alpha$ in the soul's non-rational part, then his equation of $\dot{\varepsilon} \pi \imath \theta u \mu i \alpha$ with

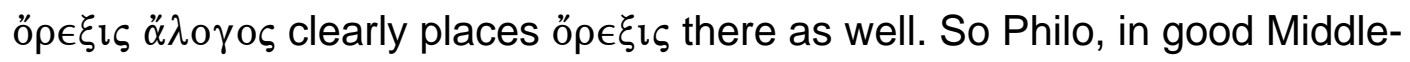
Platonic fashion, sees ő $\rho € \xi ı$ ऽ operating apart from reason as a non-rational force within the soul in a distinct, non-rational part. This flatly contradicts the Stoics,

${ }^{61}$ Substituting "desire" for Colson's "lust"; "non-rational" for "unreasoning." Cf. Migr. 66: $\dot{o}$

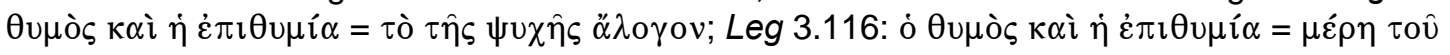

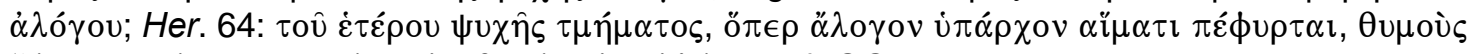

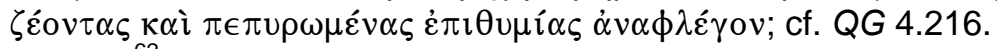

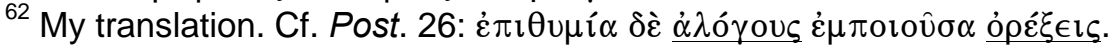




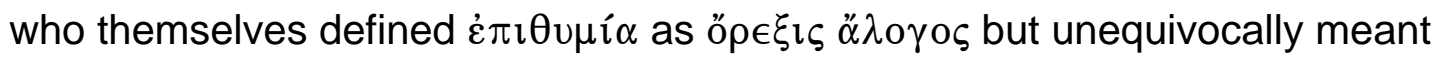
"irrational appetite," a malfunction of the rational faculty. ${ }^{63}$

Philo's identification of $\dot{\varepsilon} \pi \imath \theta u \mu i \alpha$ as öp $\epsilon \xi \iota \varsigma \ddot{\alpha} \lambda o \gamma o \varsigma$ derives ultimately from

Aristotle, and Philo's overall use of the term ő $\rho \in \xi i \varsigma$ further reflects the Aristotelian modifications of Platonic theory inherent in Middle-Platonic bipartition. Plato had understood pleasure (i்oví) to be the ultimate aim of $\dot{\varepsilon} \pi \imath \theta v \mu i \alpha$, and Aristotle

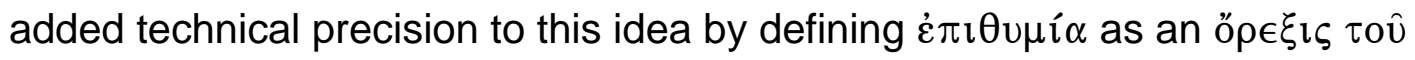

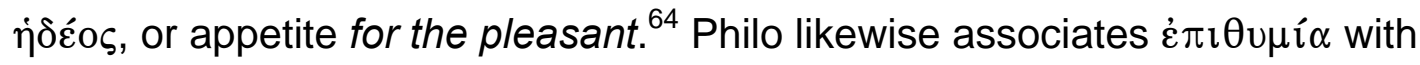

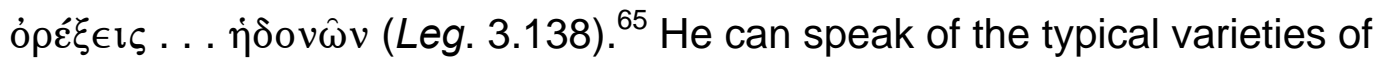

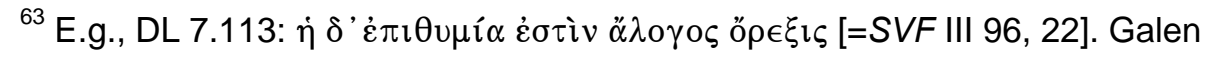
understands both the ambiguity of $\ddot{\alpha} \lambda$ o $\gamma$ o $\varsigma$ and the clear intention of Chrysippus to mean "irrational" in his definition of $\dot{\varepsilon} \pi \imath \theta u \mu i \alpha$ : "[l]n his definition of desire ( which he calls irrational appetite (ő $\rho \xi \xi \iota \ddot{\alpha} \lambda \circ \gamma o v)$ ), he touches in a way, verbally at least, on the non-rational power in the soul; but here too he departs from it in his explanation, since even the appetite $(\dot{\eta}$ ő $\rho \xi \xi \varsigma)$ that he includes in the definition belongs to the rational power ( $\tau \hat{\eta} \varsigma \lambda \circ \gamma \iota \kappa \hat{\eta} \varsigma$

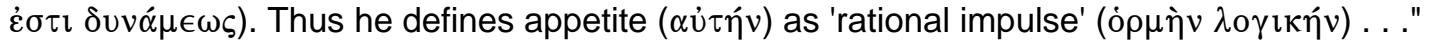
(PHP IV 4.2-3; trans. De Lacey, slightly modified). Schmidt, Anthropologie, 89, citing Leg. 3.115

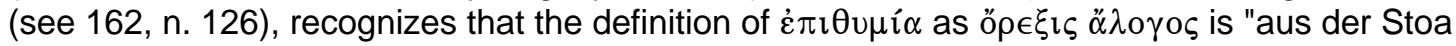
wörtlich übernommene," but also that the words by themselves mean very little ("inhaltlich recht leere"). The meaning must be supplied, either through explicit commentary or through clear contextual cues, such as Philo provides via the framework of Platonic tripartition, in which $\dot{\varepsilon} \pi \imath \theta u \mu i \alpha$ explicitly resides outside of the reasoning faculty and is thus non-rational.

${ }^{64}$ E.g., De an. 414 b 5-6; Eth. nic. 1119 b 6-8.

65 "We have already mentioned that pleasure goes not only on its breast ( $\dot{\varepsilon} \pi \mathrm{\imath} \tau \hat{\omega} \sigma \tau \dot{\imath} \theta \in \mathfrak{l}$ )

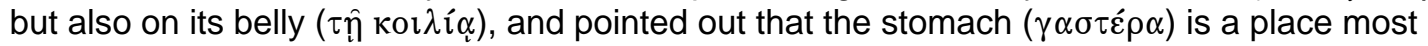
appropriate to pleasure, for we may almost describe it as a reservoir of all the pleasures ( $\sigma \chi \in \delta o ̀ v$

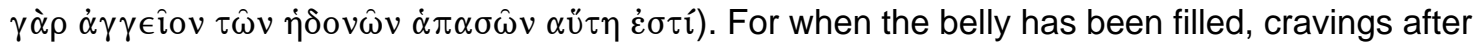

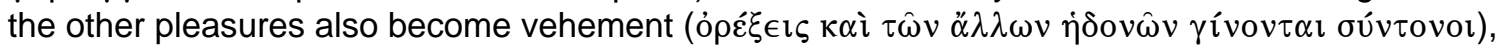
but when it has been emptied, theses are quieted and become more still ( $\eta_{\rho} \epsilon \mu \alpha \hat{\imath} \alpha \iota \kappa \alpha i$

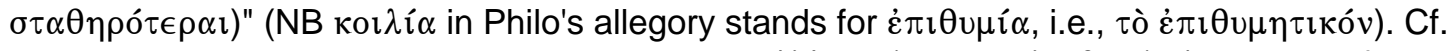

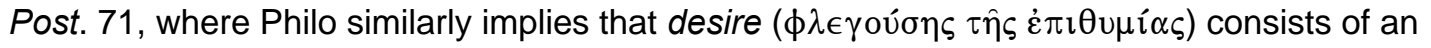

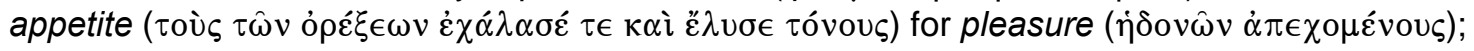

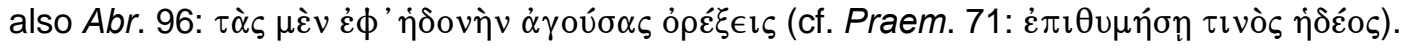


Platonic $\dot{\varepsilon} \pi \imath \theta \mu i ́ \alpha$ (for food, drink, sex) in terms of ő $\rho \xi \xi \varsigma$, as did Aristotle ${ }^{66}$ But more importantly, his concept of the non-rational appetite for pleasure expands to include, as it did for Aristotle, objects that Plato had associated with the soul's assertive function, not its appetitive function-objects like victory, honor, and fame. ${ }^{67}$ So for Philo, as for other Middle Platonists, $\dot{\varepsilon} \pi \imath \theta v \mu i ́ \alpha$ encompassed the

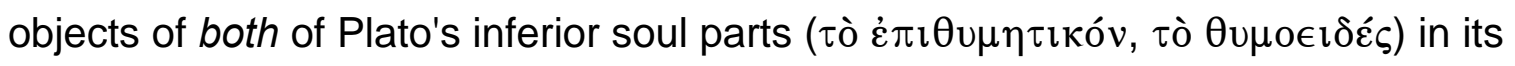
pursuit of pleasure. ${ }^{68}$ This "expansion" of the role of $\dot{\varepsilon} \pi \imath \theta v \mu i \alpha$ in turn casts $\theta u \mu o ́ s$ more exclusively as the non-rational agent of anger ${ }^{69}$ Philo does not often use the term ő $€ \xi \downarrow \iota$, but his use does reflect standard trends within Middle-Platonic moral psychology. ${ }^{70}$

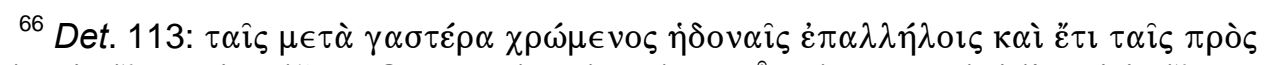

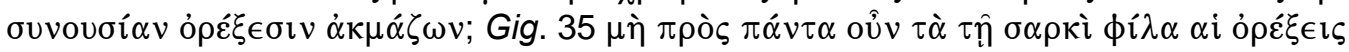

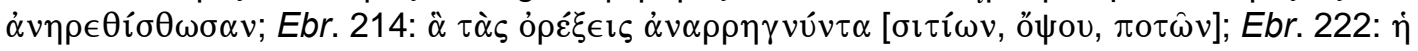

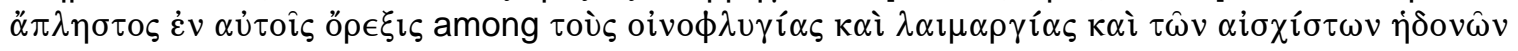

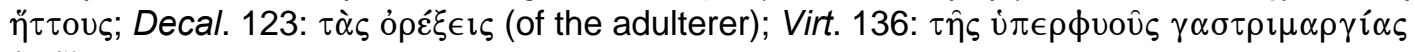
ó $\tilde{\xi} \xi \in i \varsigma$.

${ }^{67}$ Philo attests this view explicitly only in Post. 116, but the passage is telling. Philo has in

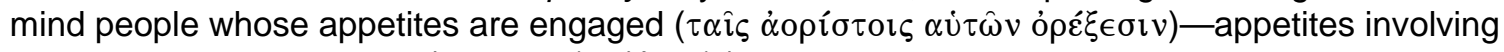

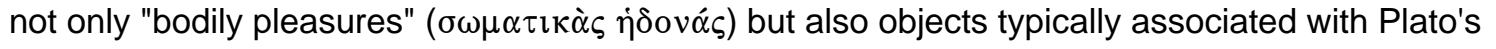

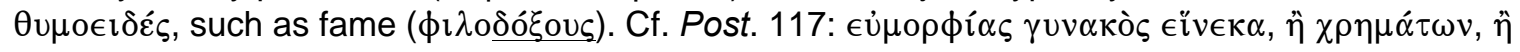

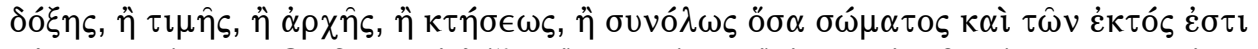

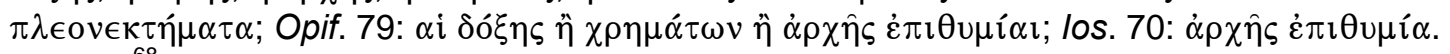

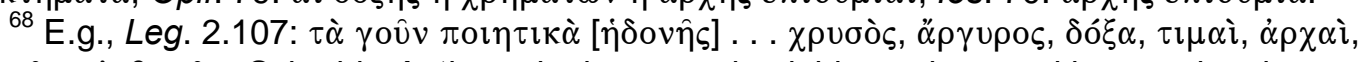
$\alpha i \hat{v} \lambda \alpha \imath \tau \hat{\omega} v \alpha i \sigma \theta \eta \tau \hat{\omega} v$. Schmidt, Anthropologie, recognized this tendency, without noting the historical developments in moral psychology that account for it: "Als Gegenstand des Begehrens werden fast durchweg die Strebungen, die Platon von dem zweiten und dritten Sellenteil aussagt, zusammengefaßt" (92-93).

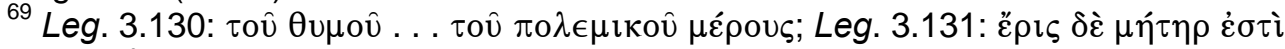

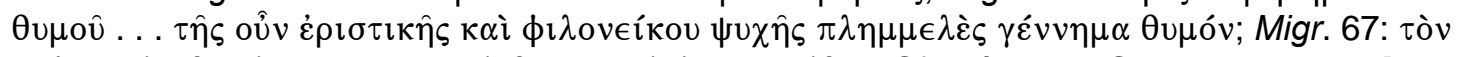

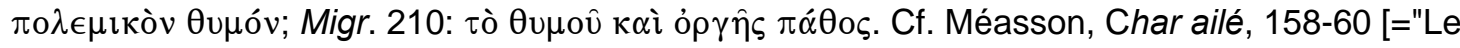
«thumos» chez Platon et chez Philon"].

${ }^{70}$ Compare the instances of ő $\rho \in \xi ı \varsigma$ (15) and $\dot{\varepsilon} \pi \imath \theta u \mu i \alpha$ (218) (see Philo Index, s.v.).

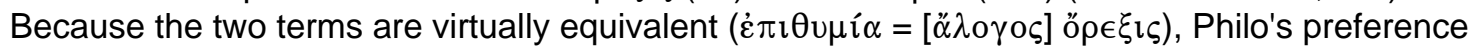
for $\dot{\varepsilon} \pi \imath \theta \mu i \alpha$ over ő $\rho \xi \xi ı$ may come from a conviction that ő $\rho \epsilon \xi ı$ in most cases amounts to needless technical jargon. 


\section{Reason over against Impulse ( $\dot{\rho} \mu \eta)$}

Siding with his Middle-Platonic contemporaries against the Stoics, Philo believes that the soul's non-rational part can generate non-rational impulses (óp $\mu \alpha \hat{\imath})$, whose independent origin allows them genuinely to oppose, or even usurp, reason. ${ }^{71}$ Philo's acceptance of non-rational impulse as a factor in human moral psychology derives from broader convictions about the relation between animal and human souls. Following standard formulations of the so-called scala naturae, which ranks various forms of existence according to natural endowment,

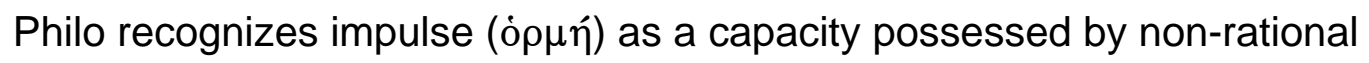

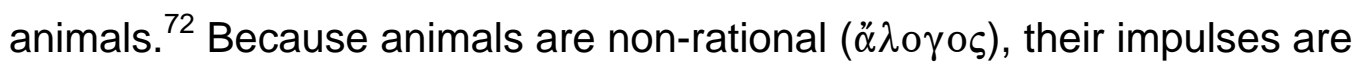
likewise non-rational ( $\alpha \lambda \circ \gamma \circ \varsigma)$, generated by a reflexive mechanism every time an appropriate stimulus appears, without the authorization or assent of reason. ${ }^{73}$ Occupying a higher rank on the scale, human beings have not only the capacity

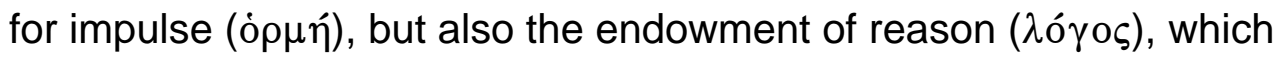
distinguishes them as a more advanced type of soul. But in Stoic theory, reason is not just one additional endowment among others. In other words, a human soul in no way amounts to simply the capacities of an animal soul, as they

\footnotetext{
${ }^{71}$ Philo acknowledges also rational impulses in human beings (e.g., Praem. 104: $\tau \grave{\alpha} \varsigma$ $\dot{o} \rho \mu \grave{\alpha} \varsigma \delta \imath \alpha$ voí $\alpha$ ). But the issue is not whether mind can generate impulses or not (it can), but whether or not there are also non-rational parts of the soul that can generate impulses. On ó $\rho \mu \eta$ in Philo's writings, including rational óp $\mu$, , see Schmidt, Anthropologie, 86-87.

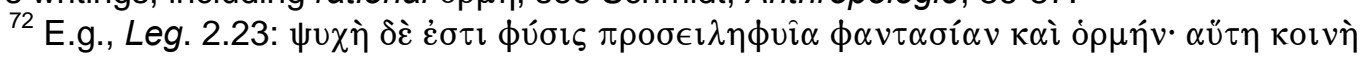

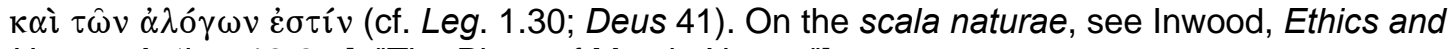
Human Action, 18-27 [="The Place of Man in Nature"].

${ }^{73}$ For a discussion of how impulse works in non-rational animals, see Inwood, Ethics and Human Action, 66-91 [="Human and Animal Action"].
} 
function in animals (i.e., non-rationally), with reason added on as a distinct new element. ${ }^{74}$ Reason transforms the very nature of the human soul, making its capacities thoroughly rational. So human beings, for the Stoics, experience only rational impulses. In Philo's view, by contrast, the capacities of the animal soul, as they function in animals (i.e., non-rationally), remain intact within the human soul, coexisting with reason in what amounts to an animal soul superintended by reason:

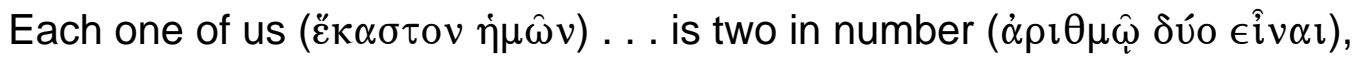

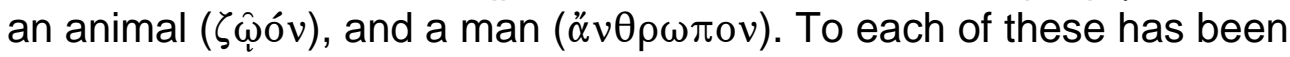
allotted an inner power akin to the qualities of their respective life-

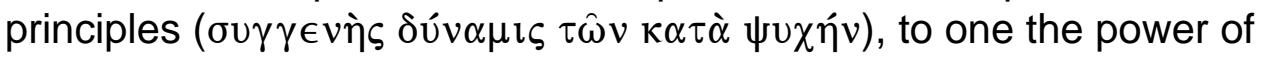
vitality ( $\dot{\eta} \zeta \omega \tau \imath \kappa \eta \dot{\eta})$, in virtue of which we are alive, to the other the power of reasoning $(\dot{\eta} \lambda \circ \gamma \imath \kappa \eta \dot{)}$, in virtue of which we are reasoning beings. Of the power of vitality the non-rational creatures ( $\tau \dot{\alpha} \ddot{\alpha} \lambda \mathrm{o} \gamma \alpha$ ) partake with us . ... $\left(\right.$ Det. 82) ${ }^{75}$

This Middle-Platonic understanding of the scala naturae gives Plato's basic image of the "beast within" a more sophisticated theoretical basis—one that has profound implications for Philo's moral psychology. In particular, Philo considers the same mechanism of non-rational impulse found in animals to operate also in

${ }^{74}$ See Long, "Stoic Psychology," esp. 574-75.

75 Substituting "each" for Colson's "either"; "non-rational" for Colson's "irrational." For

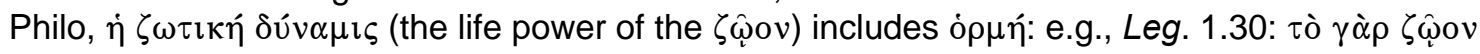

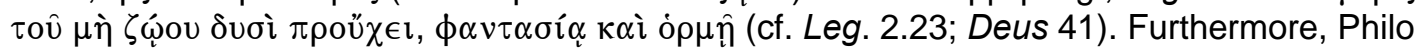
states that $\dot{\eta} \zeta \omega \tau \iota \kappa \dot{\eta} \delta \dot{v} \alpha \mu \iota \varsigma$, including ó $\rho \mu \dot{\eta}$, retains its distinct nature within the human soul,

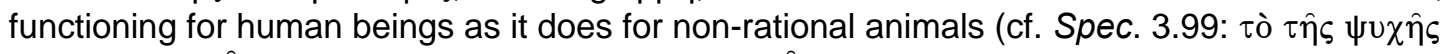

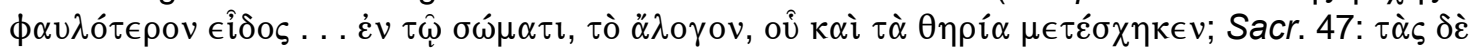

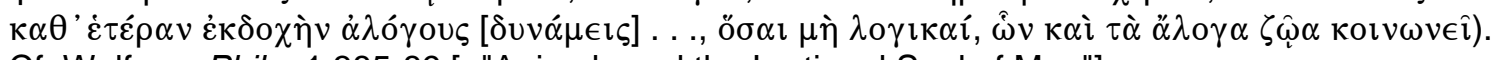
Cf. Wolfson, Philo, 1:385-89 [="Animals and the Irrational Soul of Man"]. 
human beings. Just like non-rational animals, human beings experience non-

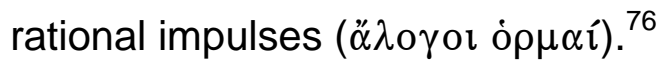

In his description of Moses, Philo presents an idealized portrait of reason's management of non-rational impulse(s):

He did not . . . allow the lusts of adolescence ( $\tau \grave{\alpha} \varsigma \mu \epsilon \rho \imath \alpha \kappa \imath \omega ́ \delta \epsilon \iota \varsigma$ $\dot{\varepsilon} \pi \imath \theta u \mu i \alpha \varsigma)$ to go unbridled, . . .. But he kept a tight hold on them with the reins, as it were, of temperance and self-control, and forcibly pulled them

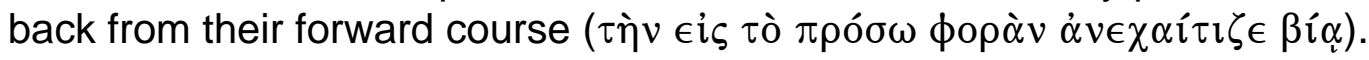

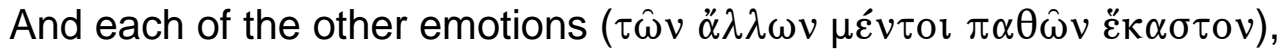
which rage so furiously if left to themselves, he tamed and assuaged and reduced to mildness; . . . and in general he watched the first directions and

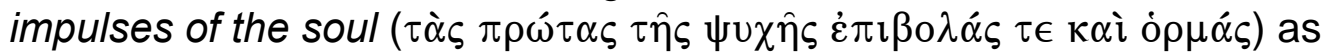

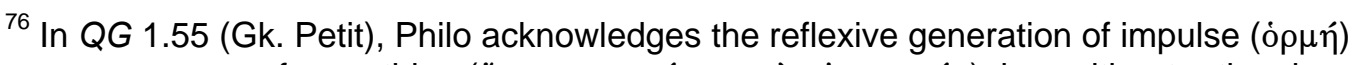

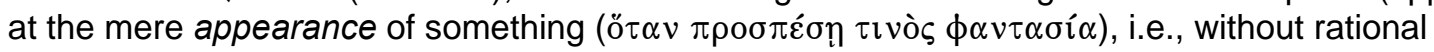
assent. In other words, he describes a mechanism of non-rational impulse in human beings. Commenting on the Armenian version of this passage, Margaret Graver correctly notes: "Here the 'impulse ... of which the appearance is the cause' cannot be the usual Stoic ó $\rho \mu \eta$, since in adult humans $\dot{\alpha} \rho \eta \eta^{\prime}$ is always caused by assent, never by the presentation itself" ("Stoic

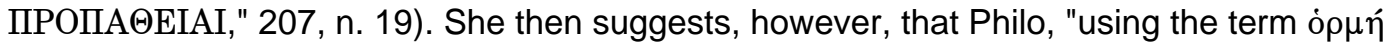
loosely," has in mind the Stoic technical term $\pi \rho 0 \pi \dot{\alpha} \theta \epsilon \iota \alpha$. But Philo more likely speaks with precision: he refers in this case to a non-rational ó $\mu \eta$ (neither the rational ó $\mu \eta$ of the Stoics, nor a $\pi \rho \circ \pi \dot{\alpha} \theta \epsilon \iota \alpha)$. The suggestion that $\pi \rho 0 \pi \dot{\alpha} \theta \epsilon \iota \alpha \imath$ played a meaningful role in Philo's theory of the passions presumes that rational assent ( $\sigma \nu \gamma \kappa \alpha \tau \dot{\alpha} \theta \epsilon \sigma \iota)$ ) played a meaningful role as well: "Philo . . . assumes that $\pi \rho 0 \pi \alpha \dot{\theta} \theta \epsilon \alpha \imath$ can be called upon to explain away apparent exceptions to the posited incompatibility of virtue and emotion, taking advantage of a theoretical time-lag between impression and assent" (ibid., 200-01); "Philo employs [the appeal to the $\pi \rho 0 \pi \dot{\alpha} \theta \epsilon \iota \alpha$ l] only where there is some textual warrant for positing a time-lag between impression and assent" (205-06; cf. 208: "the gap between impression and assent"). Philo, however, in keeping with his MiddlePlatonic affinities, nowhere brings $\sigma 0 \gamma \kappa \alpha \tau \dot{\alpha} \theta \epsilon \sigma \iota \zeta$ into his understanding of $\pi \dot{\alpha} \theta$ o $\zeta$ (see Pohlenz, Philon, 456, n. 1). He would have had precedent for his view of non-rational impulse in the Academic tradition, since Arcesilaus (ca. 316-240 B.C.), in dispute with the Stoics and using Stoic terminology, claimed that in human beings impulses reflexively occur in response to the appropriate sensory impression. See e.g. LS 53S [=Plutarch, Stoic. rep. 1057 A (=SVF III 42, 22-

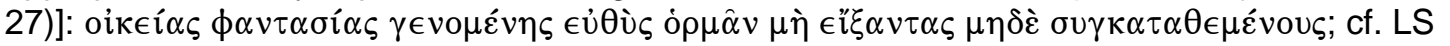
69A and commentary: "In effect, Arcesilaus applies to human action the Stoics' account of nonrational animal behaviour" (LS 1:456) (see also Inwood, Ethics and Human Action, 86-88). For

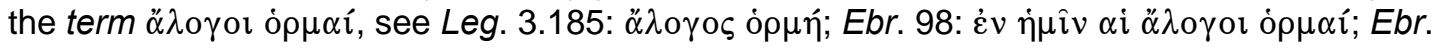

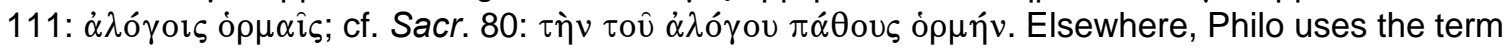

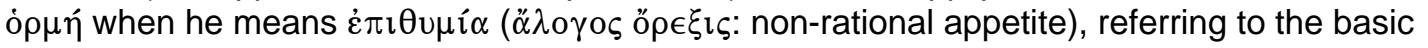

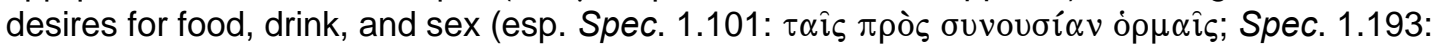

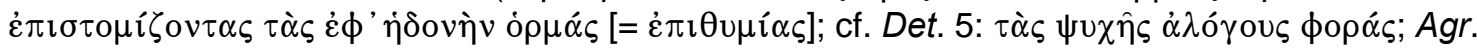

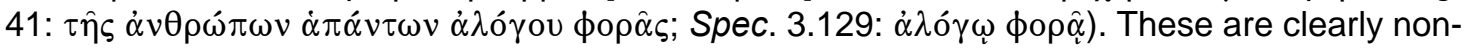
rational impulses ( $\alpha \lambda$ oyor o $\rho \mu \alpha i)$, the kind common to both human beings and animals. 


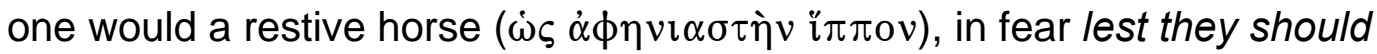

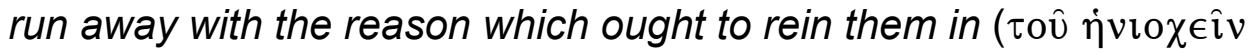

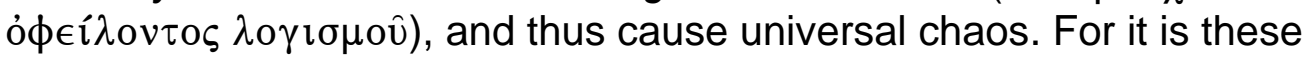

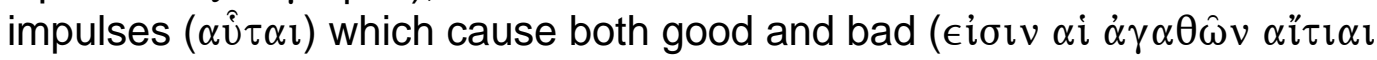
$\kappa \alpha \grave{\imath} \kappa \alpha \kappa \hat{\omega} v$ )—good when they obey the guidance of reason (ö $\tau \alpha \nu \dot{\eta} \gamma \in \mu o ́ v \imath$ $\lambda \sigma \gamma(\omega \pi \in \imath \theta \alpha \rho \chi \hat{\omega} \sigma \mathrm{l})$, bad when they turn from their regular course into anarchy ( $\dot{\alpha} v \alpha \rho \chi i \alpha v)$. (Mos. 1.25-26; emphasis added)

The characterization here of reason's relation to impulse illustrates the MiddlePlatonic perspective evident throughout Philo's writings. ${ }^{77}$ The "primary impulses" ( $\pi \rho \hat{\omega} \tau \alpha \iota \dot{o} \rho \mu \alpha \hat{)}$ ) clearly arise apart from reason, since reason must act upon them, actively managing them as a rational human being would manage a non-

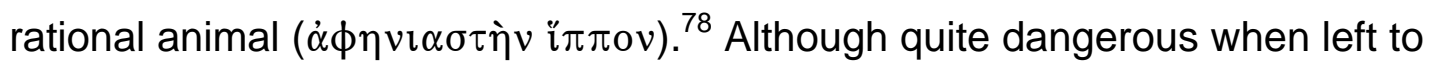
themselves, these impulses are not inherently bad. Their moral import lies entirely in their relation to reason-i.e., whether or not they obey its commanding

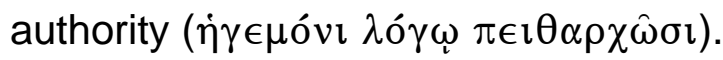

Philo does not name in this passage the source of the impulses, but clearly desire $(\dot{\varepsilon} \pi \imath \theta u \mu i \alpha)$ and the "other emotions" ( $\pi \dot{\alpha} \theta \eta)$ derive from the same

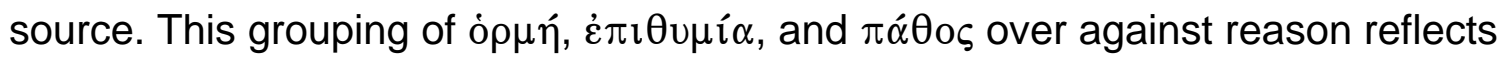
the Middle-Platonic dichotomy between "rational part" (

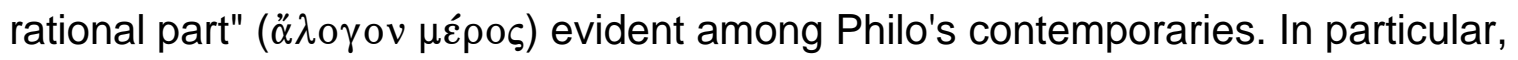

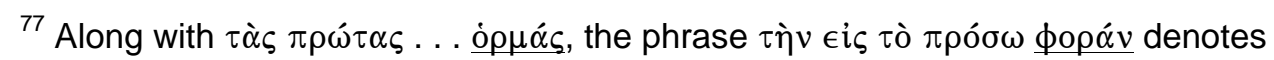

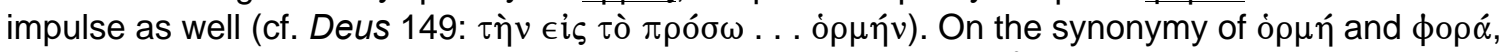

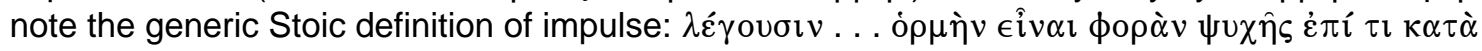

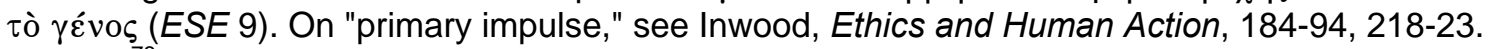

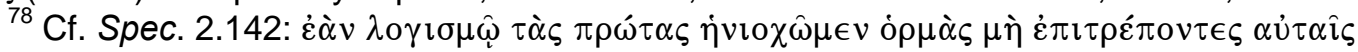

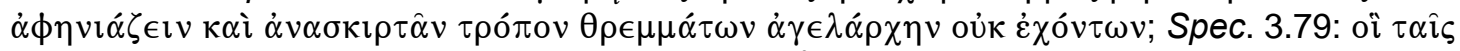

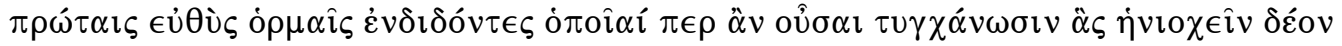
$\dot{\alpha} \chi \alpha \lambda \imath v \omega \dot{\tau} \tau$ ous $\dot{\varepsilon} \hat{\omega} \sigma \iota v$. 
the placement of emotion within the soul's non-rational part bears special significance for Philo's moral theory.

Reason over against Emotion ( $\pi \dot{\theta} \theta \circ \varsigma)$

Philo agrees with his Middle-Platonic contemporaries, against the Stoics, when he locates emotion ( $\pi \dot{\alpha} \theta$ os) outside of the rational faculty within the nonrational part of the soul. ${ }^{79}$ Most clearly in Leg. 3.114-16, Philo identifies the two

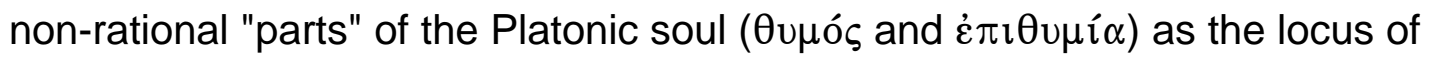
emotion $(\pi \dot{\alpha} \theta o \varsigma):^{80}$

If, therefore, $\mathrm{O}$ mind, thou art ever inquiring what quarter pleasure (i்oví) has for her portion, do not consider the place occupied by the head, where the reasoning faculty resides (ö $\pi$ ou $\tau$ ò $\lambda$ o $\gamma \imath \sigma \tau \imath \kappa o ́ v)$, for thou wilt assuredly not find it there (oủ $\gamma \grave{\alpha} \rho \mu \grave{\eta} \in \dot{v} \rho \eta \tilde{\sigma} \sigma \varsigma$ ), since reason is at war with emotion ( $\mu \alpha \dot{\alpha} \in \tau \alpha \mathrm{l} \dot{o} \lambda \sigma_{\gamma} \sigma \varsigma \tau \hat{\omega} \pi \dot{\alpha} \theta \epsilon \mathrm{l}$ ), and cannot remain in the same place with it

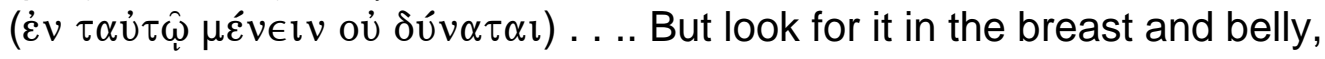

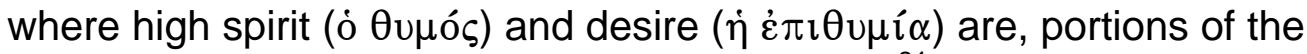

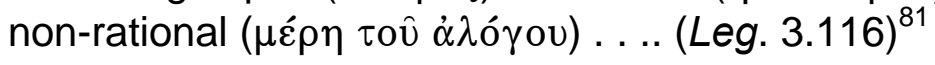

Stoics, by contrast, invariably located the $\pi \dot{\alpha} \theta \eta$ within the mind, identifying them

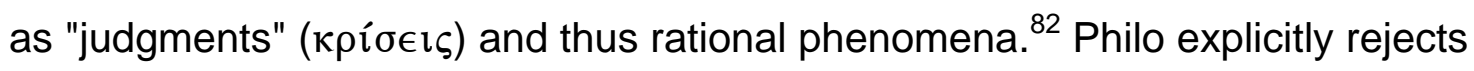
this view:

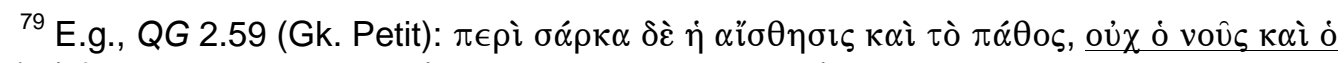

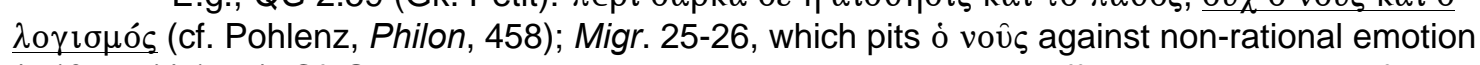
( $\pi \dot{\alpha} \theta$ ous $\dot{\alpha} \lambda o ́ \gamma o v)$. Cf. Schmidt, Anthropologie, 88: "Er weist . . . die Affekte dem unvernünftigen Seelenteile zu und lehnt ausdrücklich ihren Platz im Kopf, d.h. am Sitz des vernünftigen Seelenteils, ab, während sie nach stoischer Anschauung sich gerade im Hegemonikon vollziehen sollen."

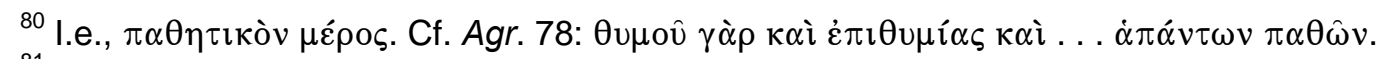

${ }^{81}$ Emphasis added; substituting "emotion" for Colson's "passion" and "non-rational" for

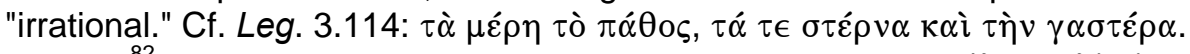

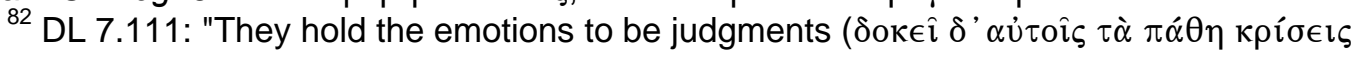

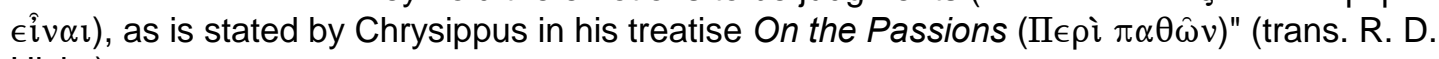
Hicks). 
The non-rational part of the soul consists of sense-perception and its offspring the emotions, which are also non-rational-especially if they are

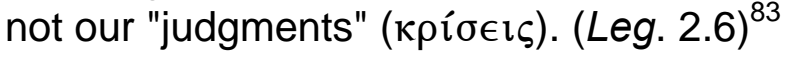

As part of the non-rational equipment of the soul, emotions are simply an endowment of human nature. ${ }^{84}$ In this respect, emotions are like a natural faculty ( $\delta \dot{v} v \alpha \mu \varsigma$ ), comparable to other faculties like sense-perception. ${ }^{85}$ Philo acknowledges the natural occurrence of non-rational $\pi \dot{\alpha} \theta \eta$ most clearly in Congr.

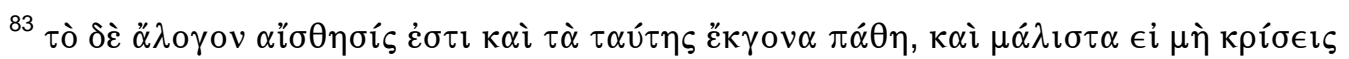
$\epsilon$ iøìv $\dot{\eta} \mu \varepsilon \dot{\tau} \tau \in \rho \alpha \mathrm{l}$. The translation (my own) clearly offers an interpretation of the Greek, but the obscurity of the construction calls for it. Despite Philo's wording, his meaning is clear, given the broader context of the passage (Leg. 2.1-8). In the course of his allegorical exegesis of Gen 2:8, Philo establishes the following points: the soul is divided into rational ( $\lambda \circ \gamma \iota \kappa o ́ v)$ and non-rational

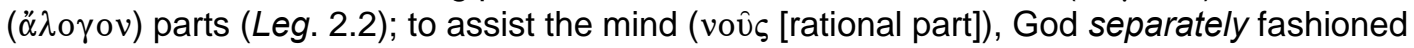
sense-perception ( $\alpha$ ľ $\sigma \eta \eta \iota \varsigma)$ and passions $(\pi \dot{\alpha} \theta \eta)$ as "helpers" (Leg. 2.5); the "ruling part" of the

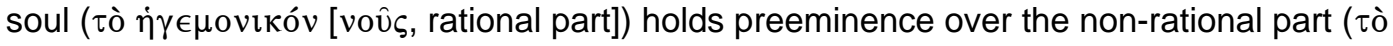
$\ddot{\alpha} \lambda$ o yov), which consists of the "helpers" sense-perception and passion, which together represent a distinct, inferior order of creation (Leg. 2.6); mind, sense-perception, and the passions are distinct "parts" ( $\mu \varepsilon ́ \rho \eta)$ of one soul ( $\psi \nu \chi \eta ́)$ (Leg. 2.8). Philo clearly affirms Middle-Platonic

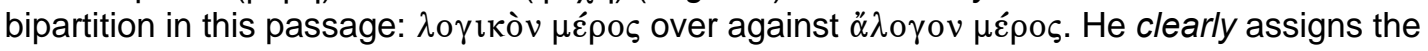
$\pi \dot{\alpha} \theta \eta$ to the soul's non-rational part, identifying them as something other than reason and therefore not functions of reason. There cannot be any real question in Philo's mind as to whether or not the passions are judgments, because he repeatedly and unmistakably claims that they are not, insofar as he identifies them as something distinctly other than the rational faculty. By using

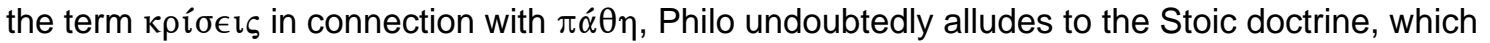
he cites only to reject. Commentators who understand Leg. 2.6 in this way include Bréhier, Idées philosophiques et religieuses, 263; Le Boulluec, "Philon sur le plaisir," 137; Pohlenz, Philon, 45859; Schmidt, Anthropologie, 88. Alcinous, in his Middle-Platonic treatment of the passions,

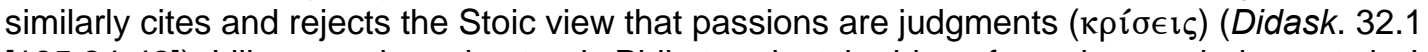
[185.24-42]). Lilla not only understands Philo to reject the idea of passions as judgments in Leg. 2.6 (Clement of Alexandria, 92) but also more generally identifies the "refusal to regard [ $\pi \dot{\alpha} \theta o \zeta]$ as a wrong judgement of reason" as one of three principal tenets in the Middle-Platonic doctrine of $\pi \dot{\alpha} \theta$ os (idem, 87). Cf. Alain Le Boulluec, "La place des concepts philosophiques dans la réflexion de Philon sur le plaisir," in Pages in Philon d'Alexandrie et le langage de la philosophie (ed. Carlos Lévy; Turnhout: Brepolis, 1998), 129-152, 131: "Une altération sensible consiste à dissocier «passion» . . . et capacité intellectuelle."

${ }^{84}$ And, for that matter, an endowment of animal nature. Just as human beings have within them a mechanism of non-rational impulse analogous to the mechanism within non-rational animals, they also have within them a mechanism of emotion (which consists of non-rational impulses) analogous to the emotional mechanism of non-rational animals. For a consideration of the nature of animal emotion, see Juha Sihvola, "Emotional Animals: Do Aristotelian Emotions Require Beliefs?," in Psychology and Ethics (ed. Lloyd P. Gerson; vol. 3 of Aristotle: Critical Assessments; London: Routledge, 1999), 50-82.

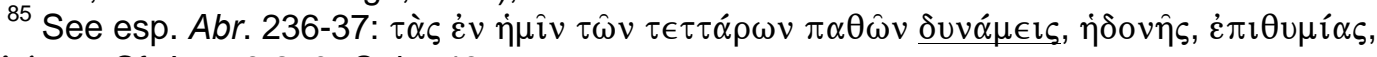

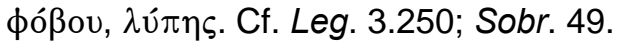


81 , where he notes that before the onset of mature rational calculation

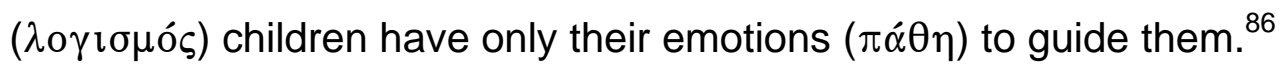

Because they are not intrinsically immoral, these emotions can provide

non-rational motivation for perfectly natural, ethically appropriate behavior. ${ }^{87}$

Philo accordingly asserts that God created the emotions as "helpers" ( $\beta$ ¡ $\theta$ oí) for

the human race:

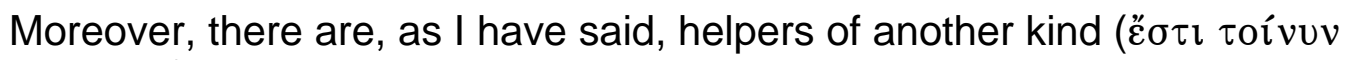
$\ddot{\varepsilon} \tau \epsilon \rho o v \in \hat{i} \delta \circ \varsigma \beta o \eta \theta \hat{\omega} v)$, namely the emotions ( $\tau \grave{\alpha} \pi \dot{\alpha} \theta \eta)$. For pleasure ( $\dot{\eta} \delta o v \eta)$ and desire $(\dot{\varepsilon} \pi \imath \theta u \mu i \alpha)$ contribute to the permanence of our kind: pain ( $\lambda u ́ \pi \eta)$ and fear ( $\phi o ́ \beta o \varsigma)$ are like bites or stings warning the soul to treat nothing carelessly: anger (ỏ $\rho \gamma \eta$ ) is a weapon of defense, which has conferred great boons on many: and so with the other emotions ( $\kappa \alpha i$ $\tau \hat{\alpha} \lambda \lambda \alpha \tau \alpha u ́ \tau \eta)$. (Leg. 2.8) 88

The emotion of $\dot{\varepsilon} \pi \imath \theta u \mu i \alpha$, for example, can be especially useful, and in fact

necessary, as a non-rational motivator for the procurement of food and drink,

${ }^{86}$ See esp. Congr. 81-82, on which Le Boulluec ("Philon sur le plaisir," 131) notes:

"Prises en elles-mêmes, les quatre «passions» principales, chagrin, peur, désir, plaisir, semblent selon Philon moralement neutres."

${ }^{87}$ Cf. Williamson, Philo, 203-04.

${ }^{88}$ Substituting "emotion" for Colson's "passion." Philo's allegorical exegesis of Gen 2:19 (see Leg. 2.9) equates the $\pi \dot{\alpha} \theta \eta$ with the "beasts" ( $\tau \dot{\alpha} \theta \eta \rho i \alpha)$ God created then presented to Adam as "helpers." Because he considers the emotions morally dangerous, Philo qualifies this identification (see Leg. 2.10-11), but he never denies it outright. In Plant. 43, he similarly equates $\theta \eta \rho i \alpha$ with $\pi \dot{\alpha} \theta \eta$, acknowledging their ferocity but nevertheless admitting that they are a necessary component of life in the body (NB $\dot{\varepsilon} \xi \dot{\alpha} v \alpha \dot{\gamma} \gamma \kappa \eta$; cf. Praem. 88). On Philo's allegorical equation of beasts with emotions, see Carl Siegfried, Philo von Alexandria als Ausleger des Alten Testaments (Jena: Hermann Dufft, 1875), 182-84, esp. 182: "Die Thiere, insofern sie vernunftlose Wesen sind, werden Symbole der Leidenschaften, welche ebenfalls das ä $\lambda$ o darstellen" (emphasis added). A similar Middle-Platonic understanding of the emotions appears in Didask. 32.4 [186.14-29], where Alcinous discusses "wild" and "tame" emotions: $\tau \hat{\omega} v \delta \grave{\varepsilon} \pi \alpha \theta \hat{\omega} v$

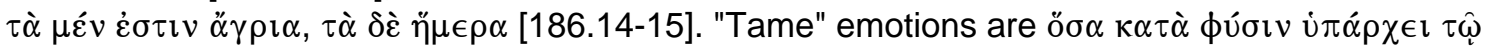

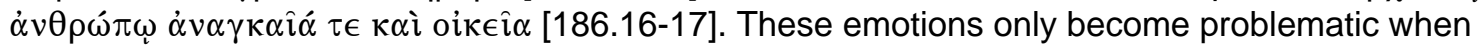
they exhibit a lack of moderation ( $\dot{\alpha} \mu \epsilon \tau i \alpha \varsigma)$ [186.18]. 
both of which are obviously necessary for survival. ${ }^{89}$ So, for example, in the case of desire for food, virtue requires not the eradication of $\dot{\varepsilon} \pi \imath \theta u \mu i \alpha$ but its proper management by reason. In general, Philo promotes the value of restraint by endorsing the moderation of emotion $(\mu \epsilon \tau \rho \iota \pi \tilde{\alpha} \theta \epsilon \iota \alpha)$ as an ethical norm, although he admits the theoretical possibility of a perfect sage becoming free from the influence of emotion $(\dot{\alpha} \pi \dot{\alpha} \theta \epsilon \iota \alpha) .{ }^{90}$

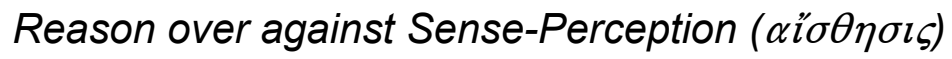

Philo holds yet another conception of the soul's bipartition between

rational and non-rational—one closely related to the reason-emotion dichotomy-

${ }^{89}$ Plato, Resp. 558 D-E: "[D]esires that we cannot divert or suppress may be properly called necessary $(\dot{\alpha} v \alpha \gamma \kappa \alpha \hat{\imath} \alpha)$, and likewise those whose satisfaction is beneficial to us

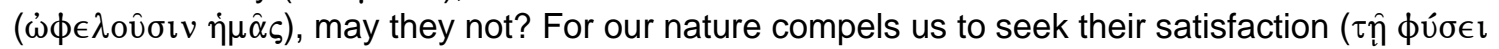

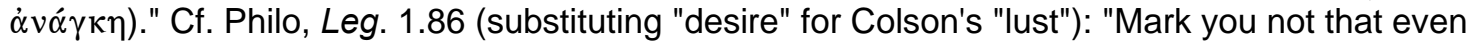

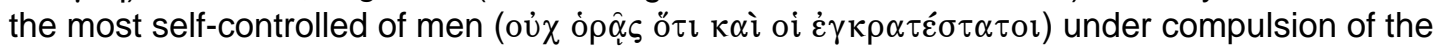

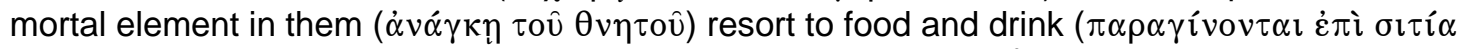

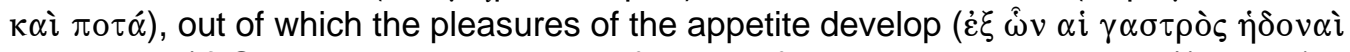
$\sigma \cup v \in \sigma \tau \hat{\alpha} \sigma l v)$ ? So we must be content to face and fight desire as a principle ( $\dot{\alpha} \gamma \alpha \pi \eta \tau o ̀ v$ oủv $\dot{\varepsilon} \sigma \tau \imath v$

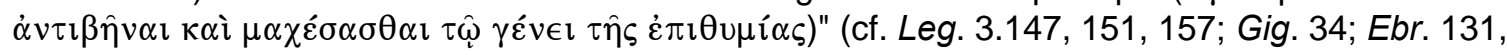
214; Mos. 1.28; Contemp. 37).

${ }^{90}$ Philo in fact endorses both $\mu \in \tau \rho \imath ⿻ \pi \dot{\alpha} \theta \epsilon \iota \alpha$ and $\dot{\alpha} \pi \dot{\alpha} \theta \epsilon \iota \alpha$, as the respective goals for intermediate and advanced stages of ethical development (see esp. Lilla, Clement of Alexandria, 92-106; also Richard Sorabji, Emotion and Peace of Mind: From Stoic Agitation to Christian Temptation: The Gifford Lectures (Oxford: Oxford University Press, 2000), 385-86; Spanneut, "Apatheia," 4701-04; Williamson, Philo, 205-07; Winston, "Philo's Ethical Theory," 400-05). But since $\dot{\alpha} \pi \dot{\alpha} \theta \epsilon \imath \alpha$ presumes a sort of moral perfection, $\mu \epsilon \tau \rho \imath o \pi \dot{\alpha} \theta \epsilon \iota \alpha$ becomes, practically

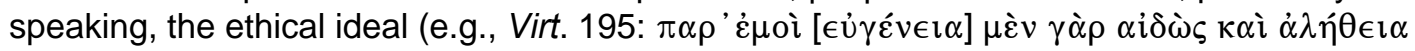

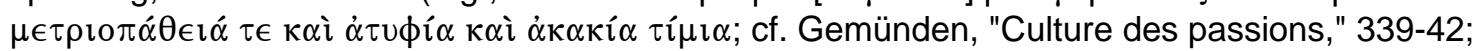
Williamson, Philo, 206). Philo's concept of $\dot{\alpha} \pi \dot{\alpha} \theta \epsilon \iota \alpha$ differs from the Stoic concept of $\dot{\alpha} \pi \dot{\alpha} \theta \epsilon \iota \alpha$, in accordance with his rejection of Stoic monistic psychology. Whereas the Stoics envision a mind that avoids false assessments of value and thus avoids passions, Philo envisions a mind so divorced from the sensible world, and so immersed in the intelligible world, that it operates free

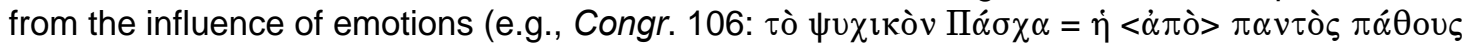

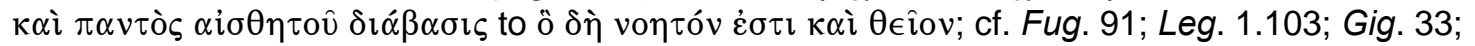
Ebr. 99-103). Plutarch endorses a similar Middle-Platonic notion of $\dot{\alpha} \pi \dot{\alpha} \theta \epsilon \iota \alpha$, while at the same time endorsing $\mu \epsilon \tau \rho \imath \tau \alpha \dot{\alpha} \theta \epsilon \iota \alpha$, as Christopher Gill notes in his comment on Virt. mor. 444 C-D: "[T]here are two ideals: apatheia for the mind as the vehicle of abstract thought and knowledge and metriopatheia for the body-based emotions as regulated by practical reason" (The Structured Self in Hellenistic and Roman Thought [Oxford: Oxford University Press, 2006], 238). 
which despite a relative lack of attestation among his contemporaries still bears

Middle-Platonic affinities: a bipartition of mind (voûs) over against sense-

perception ( $\alpha$ lı $\sigma \eta \sigma \imath \varsigma) .{ }^{91}$ Xenocrates (396 - 314 B.C.), third scholarch of Plato's

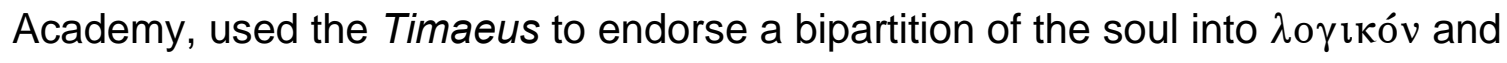

$\alpha i \sigma \theta \eta \tau \imath \kappa o ́ v$, indicating a dichotomy between parts of the soul geared respectively

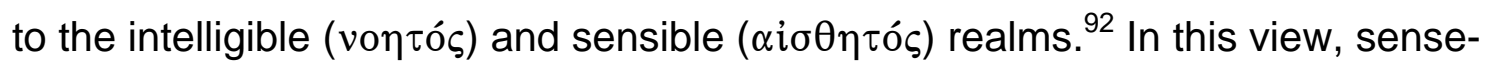

perception, a non-rational component of the soul, stems from embodiment and

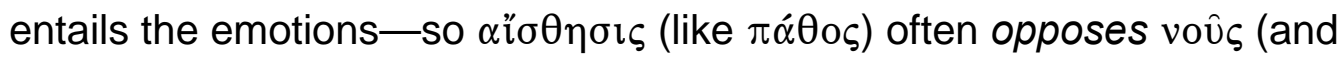

intelligible realities) through its attachment to the sensible realm. ${ }^{93}$ Philo affirms

the non-rationality of $\alpha$ lı $\theta \eta \sigma \iota \varsigma,{ }^{94}$ its close association with the emotions, ${ }^{95}$ its link

${ }^{91}$ On Philo's dichotomy between mind and sense-perception in the context of Middle Platonism, see esp. Bouffartigue, "Structure de l'âme chez Philon," esp. 62-73; also Runia, Philo and the Timaeus, 262-66; Thomas H. Tobin, The Creation of Man: Philo and the History of Interpretation (CBQMS 14; Washington: Catholic Biblical Association of America, 1983), 148-49; cf. Gérard-Henry Baudry, "Le péché original chez Philon d'Alexandrie," MScRel 50 (1993): 99115; Petra von Gemünden, "La femme passionnelle et l'homme rationnel? Un chapitre de psychologie historique," Biblica 78 (1997): 457-80, 468-70.

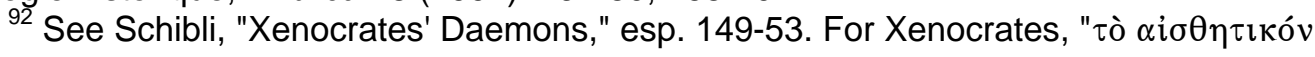
points to that part of the soul which links the psyche to the material, sensate world (the $\alpha i \sigma \theta \eta \tau \eta$ oúoí $\alpha$ ); as such it merely serves as the conduit for sensations and operates without reason. The

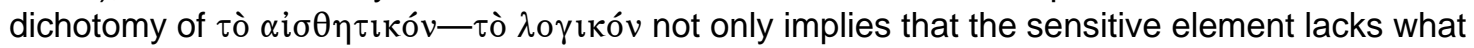
its counterpart possesses, but it conceivably also points to the antithetical dimension of the two divisions, in so far as the sensible part may give rise to affections and passions that militate against reason, and that reason in turn must conquer" (153).

${ }_{93}$ See esp. Tim. 42 A-B (cf. Didask. 16.2 [172.2-19]). On $\alpha$ ľ $\sigma \eta \eta \sigma r \varsigma$ and embodiment, see

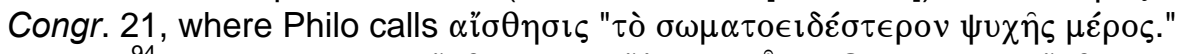

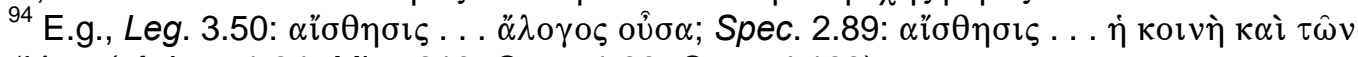
$\dot{\alpha} \lambda o ́ \gamma \omega \nu \zeta \omega \omega v$ (cf. Leg. 1.24; Migr. 213; Spec. 1.33; Spec. 4.123).

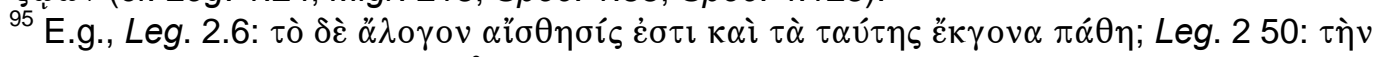

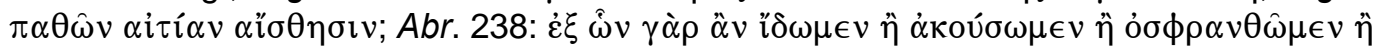

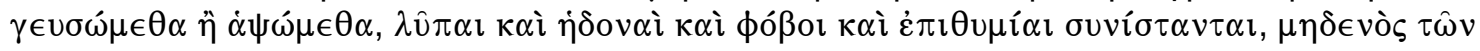

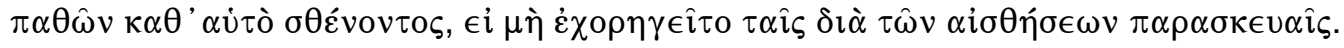


to the sensible over against intelligible realm, ${ }^{96}$ and particularly its capacity to oppose voûs:

Now the younglings $(\theta \rho \epsilon \mu \mu \alpha \tau \omega \nu)$ that are reared among the herd are tame and docile, because they are guided by the care of the herdsman

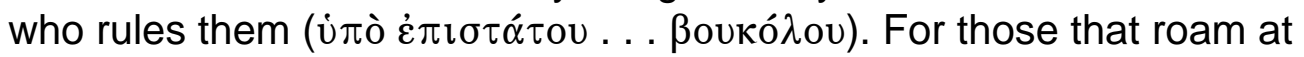
large and in liberty become wild ( $\dot{\varepsilon} \xi \alpha \gamma \rho \imath \alpha i v \in \tau \alpha \imath)$ for want of one to tame them, but those who are led by goatherd, neat-herd, shepherd, and the like, the herdsman, that is, who tends whatever kind of animal it may be, must needs be tame and gentle $(\dot{\eta} \mu \in \rho o \hat{\tau} \tau \alpha \mathrm{l})$. So then, the senses also as

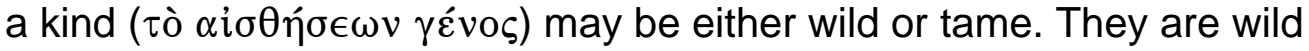
( $\dot{\alpha} \tau \dot{i} \theta \alpha \sigma o v)$ when, throwing off the control of their herdsman the mind

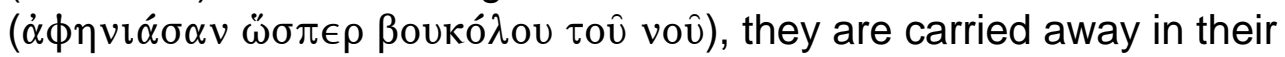
unreason $(\dot{\alpha} \lambda \hat{\gamma} \gamma \omega \varsigma)$ into the outer sphere of things perceptible by them

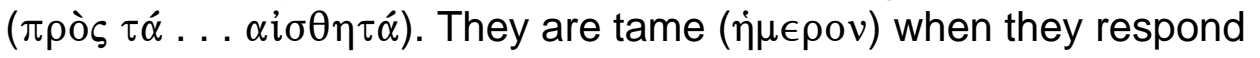
submissively to reflection $(\lambda \circ \gamma \imath \sigma \mu \hat{\omega})$, the ruling element in our compound nature, and accept its guidance and control. (Sacr. 104-06) ${ }^{97}$

Here Philo casts $\alpha$ i̋ $\theta \eta \sigma \iota \varsigma$ as a non-rational animal in need of a rational ruler

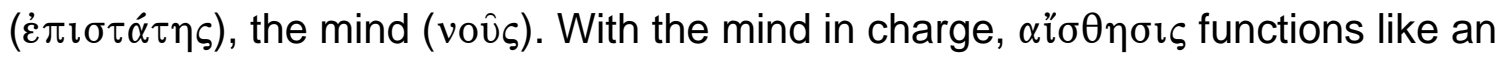

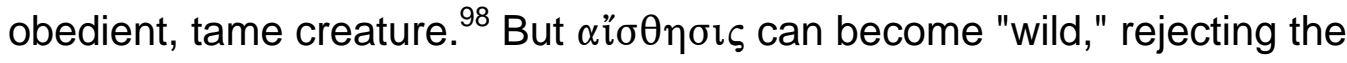

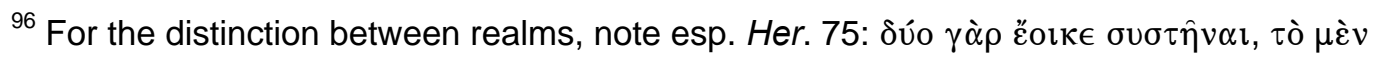

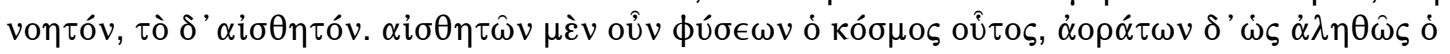

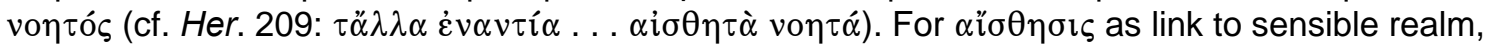

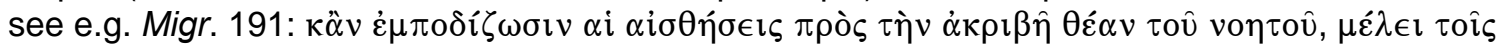

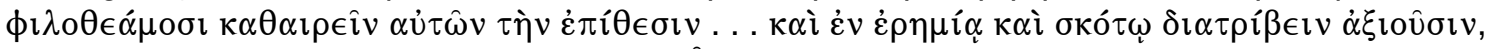

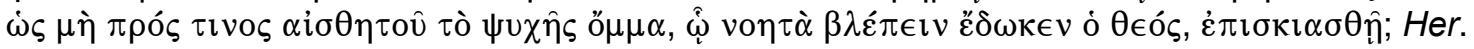

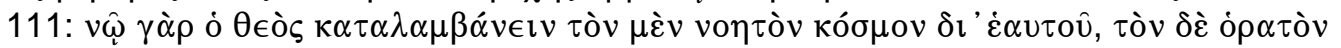

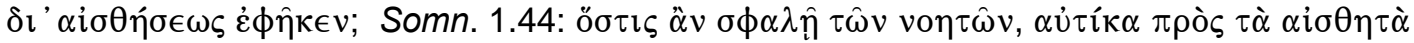

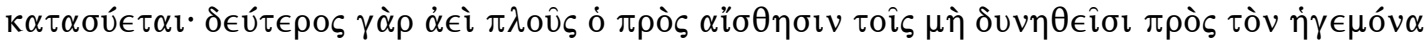
voûv $\in \dot{u} \pi \lambda o \eta \hat{\sigma} \alpha$. Cf. David Runia, "A Brief History of the Term Kosmos Noetos from Plato to Plotinus," in Traditions of Platonism: Essays in Honour of John Dillon (ed. John J. Cleary; Aldershot: Ashgate, 1999), 151-71.

${ }^{97}$ Cf. Alcinous' "tame" and "wild" emotions (Didask. 32.4 [186.14-18]).

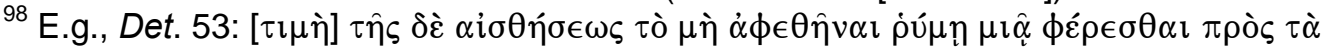

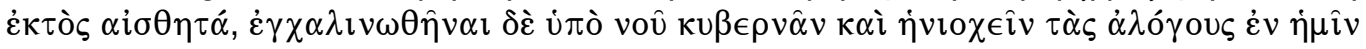

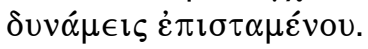


authority of reason and bringing destructive chaos to the soul. ${ }^{99}$ This sort of relation between voûs and $\alpha \imath ̋ \sigma \theta \eta \sigma \iota \varsigma$ fits Philo's general characterization of Middle-Platonic bipartition: a rational element placed over a non-rational element, one capable of opposing or even usurping reason's hegemony. This emphasis on

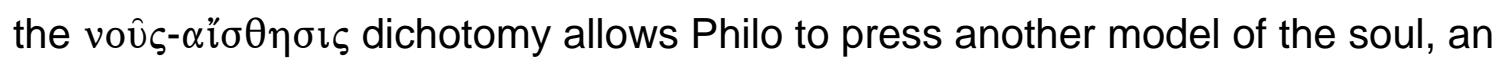
otherwise Stoic model, into Middle-Platonic service.

\section{Reason over against "Stoic" Non-Rational Soul}

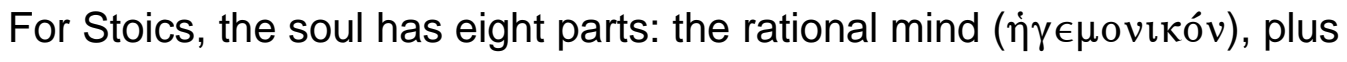
the five senses, the faculty of speech, and the faculty of reproduction. ${ }^{100}$ On the surface, this Stoic model resembles Philo's Middle-Platonic dichotomy of voûs-

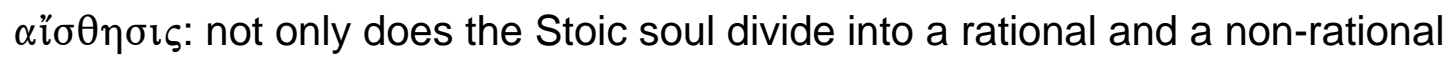
component ( $\dot{\eta} \gamma \in \mu$ ovıкóv plus collective seven), but the senses account for five of the seven non-rational parts. So a loose description of both models as rational mind over non-rational sense-perception fits the data reasonably well. In terms of moral psychology, however, the two models are fundamentally incompatible. The

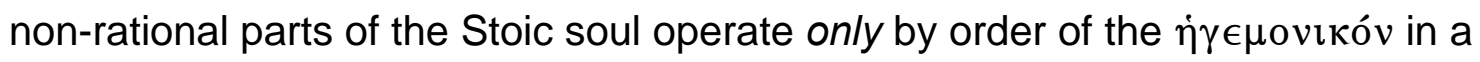
strictly instrumental capacity. ${ }^{101}$ Under no circumstances would-or could-

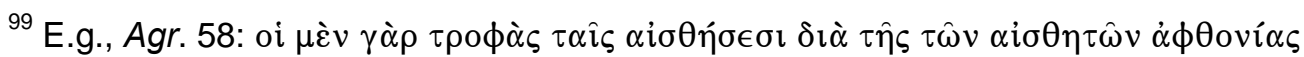

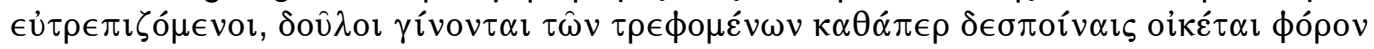

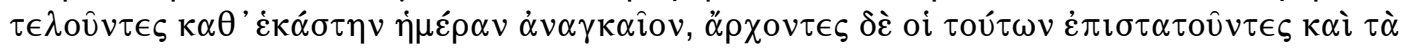

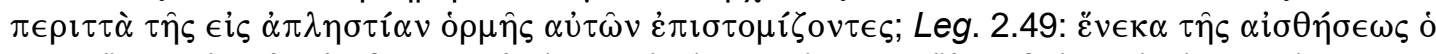

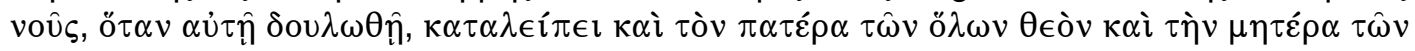

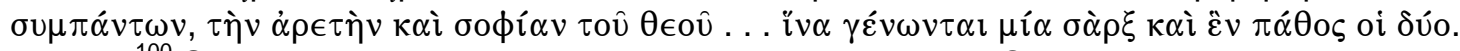

100 See Inwood, Ethics and Human Action, 27-41; Long, Stoic Psychology, esp. 560-72.

101 Inwood, Ethics and Human Action, 33. 


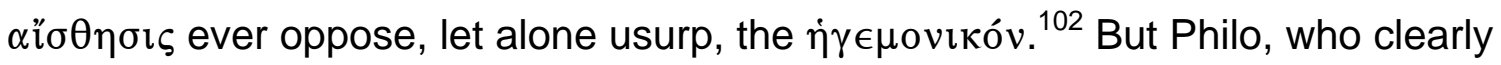
knows and cites the Stoic eight-part model, ${ }^{103}$ nevertheless characterizes its nonrational component as an antagonist of reason, able not only to oppose but even to supplant and enslave its rightful sovereign:

[S]ix of [the faculties within us] wage ceaseless and continuous war on land and sea, namely the five senses ( $\alpha i \imath \tau \epsilon \pi \dot{v} v \tau \epsilon \alpha i \sigma \theta \eta \dot{\eta} \sigma \epsilon \iota)$ ) and speech

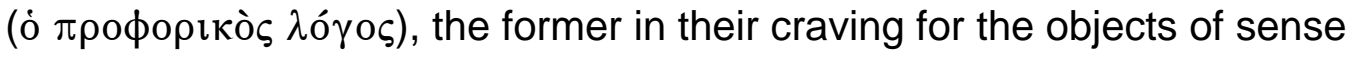
( $\alpha i \mu \grave{\varepsilon} v \pi \delta \dot{\theta} \theta \omega \alpha i \sigma \theta \eta \tau \hat{\omega} v$ ), deprivation of which is painful to them, speech because with unbridled mouth ( $\dot{\alpha} \chi \alpha \lambda i v \omega \sigma \tau o ́ \mu \alpha \tau \imath)$ it perpetually gives utterance where silence is due. But the seventh faculty is the dominant

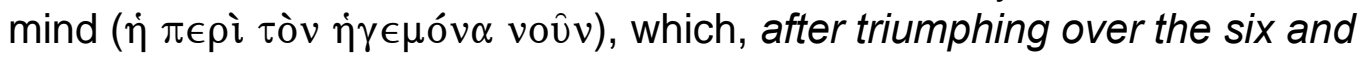

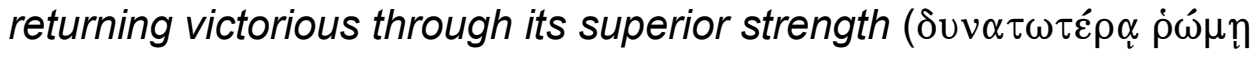
$\kappa \alpha \tau \alpha \kappa \rho \alpha \tau \eta \sigma \alpha \varsigma$ ), welcomes solitude and rejoices in its own society. (Abr. 28-30) ${ }^{104}$

Philo's omission here of the faculty of reproduction, making a soul of seven parts instead of the canonical eight, illustrates his general practice of co-opting the Stoic model and forcing it into a Middle-Platonic mold. ${ }^{105} \mathrm{He}$ has no real

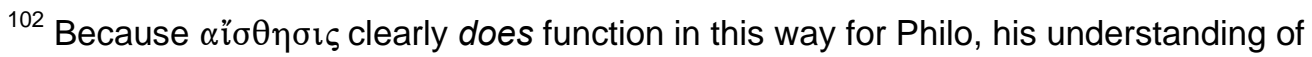

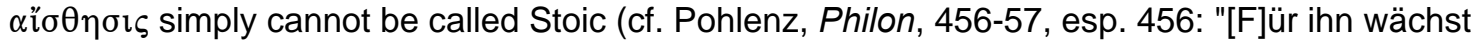
die Aisthesis weit über die Rolle hinaus, die ihr nach der Stoa zukommen kann. Sie wird zu einem selbständigen seelischen Vermögen, das dem Nus wohl unentbehrlich für die Erkenntnis der Außenwelt ist und inm damit gute Dienste tut, aber zugleich, da es auch die sinnlichen Triebe umfaßt, sein ständiger Widerpart wird und an die Stelle tritt, die in der griechischen Philosophie das Alogon einnimmt."

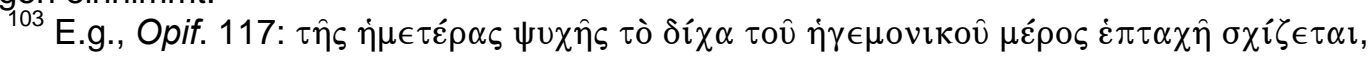

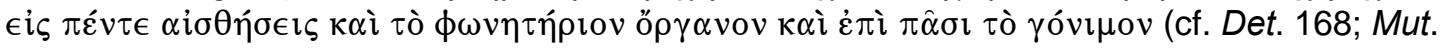
111; Her. 232; Leg. 1.11).

${ }^{104}$ Emphasis added. Bouffartigue ("Structure de l'âme chez Philon," 61) also recognizes Philo's reference here to the Stoic model.

${ }^{105}$ Philo knows all seven of the Stoic non-rational parts, he simply chooses to omit one

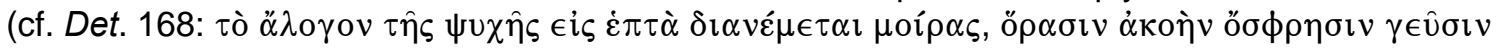
$\dot{\alpha} \phi \eta ̀ v ~ \lambda o ́ \gamma o v$ yóvırov; also Mut. 111, Leg. 1.11; on antagonism between the reproductive faculty and reason, see Det. 100-103, esp. 102, 170-74, esp. 174). For another example of Philo's recasting of the Stoic model as Middle-Platonic bipartition, see Agr. 30-34. On Philo's use of the Stoic model, see also Carlos Lévy, "'Le concept de doxa des Stoïciens à Philon d'Alexandrie: essai d'étude diachronique" in Passions and Perceptions (ed. J. Brunschwig and M. Nussbaum; Cambridge, 1992), 250-84, esp. 275-84. 
commitment to the Stoic doctrine, but he does insist on the Middle-Platonic bipartition of rational over against non-rational, with the patently non-Stoic assumption of antagonism between the two components. The Stoic formulation simply gives Philo more options when speaking of the soul's non-rational part: reason's non-rational antagonist can be $\alpha \imath ̋ \sigma \theta \eta \sigma \iota \varsigma$ (as in the Middle-Platonic voûs-

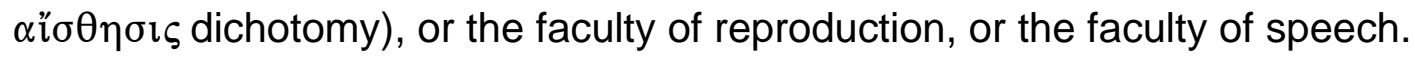
Philo does not endorse a Stoic understanding of the soul-he merely superimposes Middle-Platonic bipartition onto a Stoic formulation, always presuming a moral psychology incompatible with Stoic monism.

\section{Summary}

Despite a variety of formulations, Philo ultimately endorses one basic model of the soul, setting rational over against non-rational in an often antagonistic bipartition:

Table Two: Variations of Bipartition in Philo's Writings

\begin{tabular}{|c|c|c|c|c|c|c|}
\hline & $\begin{array}{l}\text { "PLATONIC" } \\
\text { THREE PARTS }\end{array}$ & APPETITE & IMPULSE & EMOTION & $\begin{array}{c}\text { SENSE- } \\
\text { PERCEPTION }\end{array}$ & $\begin{array}{c}\text { "STOIC" } \\
\text { EIGHT PARTS }\end{array}$ \\
\hline RATIONAL $^{106}$ & 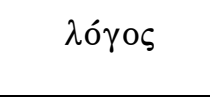 & 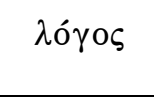 & 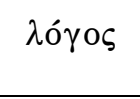 & 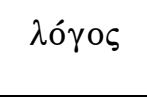 & 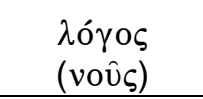 & $\begin{array}{c}\lambda o ́ \gamma o \varsigma \\
(\dot{\eta} \gamma \in \mu \text { ovıкóv) }\end{array}$ \\
\hline $\begin{array}{c}\text { NON- } \\
\text { RATIONAL }\end{array}$ & $\begin{array}{c}\text { } \theta \dot{u} \mu \circ \varsigma \\
\dot{\varepsilon} \pi \imath \theta u \mu i \alpha\end{array}$ & $o ̋ \rho \in \xi_{\imath} \iota$ & $\dot{\alpha} \rho \mu \eta ́$ & $\pi \dot{\alpha} \theta$ o $\varsigma$ & $\alpha \imath ̋ \sigma \theta \eta \sigma \iota \varsigma$ & 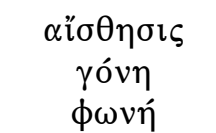 \\
\hline
\end{tabular}

${ }^{106}$ On Philo's various designations for the soul's rational part, note especially Schmidt, Anthropologie, 49-50: "Für dieses oberste Vermögen, wodurch sich der Mensch von den Tieren unterscheidet, verwendet Philon nun außer Seele und Nus noch gleichbedeutend $\delta \imath \alpha \dot{v o l} \alpha$,

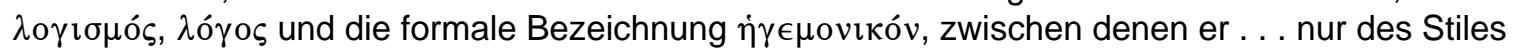
wegen wechselt." Schmidt offers extensive evidence for the interchangeability of various terms on pages $139-42[=n .14]$. 
Philo's Middle-Platonic contemporaries offered him various ways of framing his discourse on $\dot{\varepsilon} \pi \imath \theta u \mu i ́ \alpha$. Undoubtedly, Plato's conviction that the soul contains an independent, enduring source of non-rational desire exerts a powerful influence: the term $\dot{\varepsilon} \pi \imath \theta u i \alpha$ stands often as a reference to either the Platonic faculty of

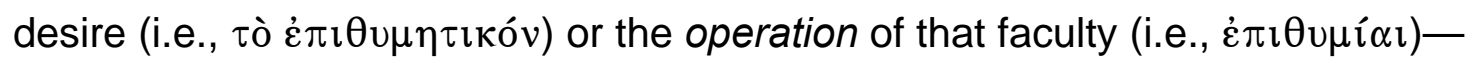
either, to use Platonic imagery, the beast itself or the beast in action. ${ }^{107}$ Philo's Middle-Platonic moral psychology, however, allows for greater technical precision and more sophisticated, variant conceptions of the phenomenon of desire. Philo can, for example, identify $\dot{\varepsilon} \pi \imath \theta u \mu i \alpha$ as an $\ddot{\alpha} \lambda o \gamma o \varsigma$ ó $\rho \in \xi ı$ ı. In addition, he

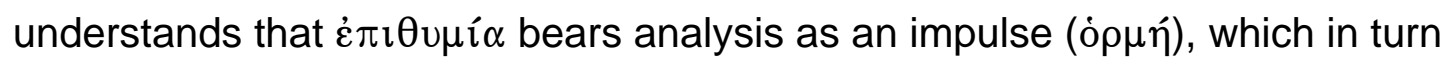
allows him to speak of transient instances of desire in the more abstract technical language of impulse. Or Philo can speak of $\dot{\varepsilon} \pi \imath \theta u \mu i \alpha$ as an emotion ( $\pi \dot{\alpha} \theta$ os), although he sides with contemporary Middle Platonists by asserting that the emotion of desire, as a function of the non-rational, "emotional" part of the soul,

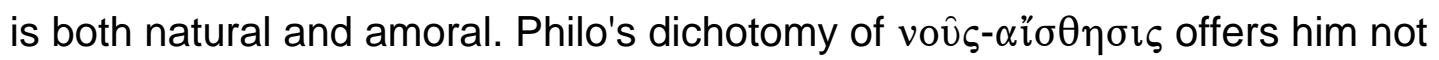
only another model of bipartition, but also another way of envisioning desire: nonrational $\alpha$ i̋ $\theta \eta \sigma \iota \varsigma$ yearning for the attractions of the sensible world. ${ }^{108}$ Using this

${ }^{107}$ For Philo's Platonic identification of $\tau o ̀ ~ \dot{\varepsilon} \pi \imath \theta u \mu \eta \tau \imath \kappa o ́ v ~(\dot{\varepsilon} \pi \imath \theta u \mu i ́ \alpha)$ as a beast, see esp.

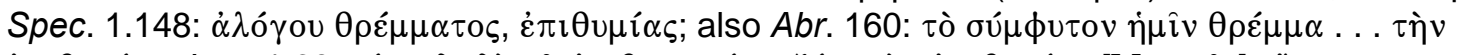

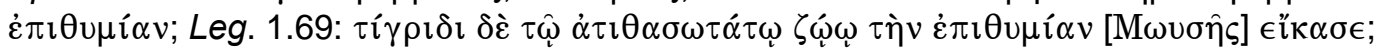

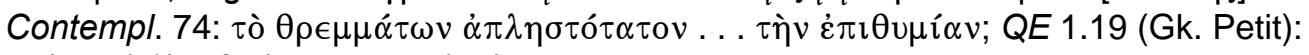

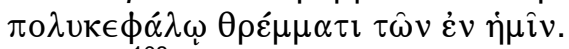

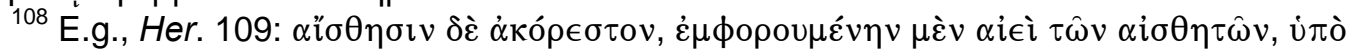

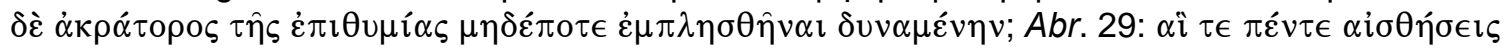

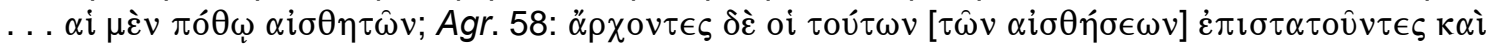

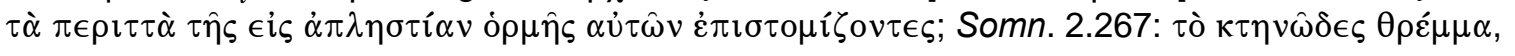


same notion of non-rational $\alpha i ̋ \theta \eta \sigma \iota \varsigma$, but adding the two non-rational faculties of reproduction and speech, Philo used a reworked Stoic model for his MiddlePlatonic moral psychology, facilitating, for example, his discussion of the desire to speak and the desire to keep silent. ${ }^{109}$ All of these various conceptions of the soul and its faculties make it possible for Philo to understand and describe any given instance of desire in a variety of equivalent ways. But no instance of $\dot{\varepsilon} \pi \imath \theta u \mu i \alpha$, however described, necessarily represents for Philo an ethical problem or malfunction of the soul. When Philo wants to speak of desire as an aberration, he turns to other conceptual models.

\section{PRoblematic Malfunctions of Desire

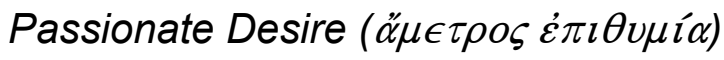

In Philo's view, the term $\dot{\varepsilon} \pi \imath \theta u \mu i \alpha$ can refer also to "passionate desire," meaning non-rational desire that has overstepped the bounds of reason. For Middle Platonists, as for Plato, $\dot{\varepsilon} \pi \imath \theta u \mu i \alpha$ as such was normal and morally unobjectionable—an inevitable, often useful, ingredient of human life. But certainly there were problematic manifestations of $\dot{\varepsilon} \pi \imath \theta u \mu i ́ \alpha$, so Plato's heirs needed a precise model for explaining the mechanics of problematic desire to match the elaborate moral psychology of the Stoics. For the Stoics, problematic movements of the soul belonged categorically under one rubric, "passion"

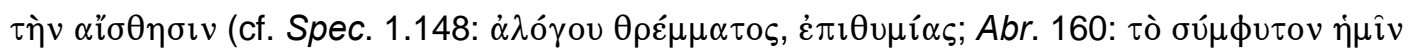

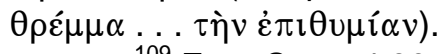

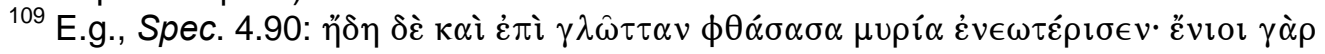

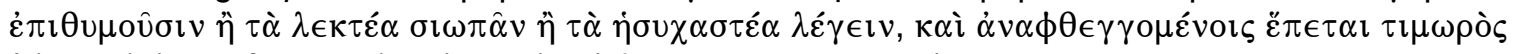

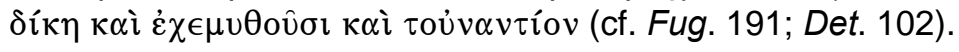


( $\pi \dot{\alpha} \theta$ os): the passions $(\pi \dot{\alpha} \theta \eta)$, including $\dot{\varepsilon} \pi \imath \theta u \mu i \alpha$, were always and inherently bad. But for Middle Platonists, the term $\pi \dot{\alpha} \theta$ os did not bear such an exclusively negative meaning. So despite the appeal—from the standpoint of systematic moral theory—of having one designated class of problematic phenomena, the label $\pi \dot{\alpha} \theta$ o $\varsigma$ by itself simply would not work (as it did for the Stoics) because of its moral ambiguity. The technical Stoic definition of $\pi \dot{\alpha} \theta$ os, however, was more promising, especially the designation of $\pi \dot{\alpha} \theta$ o $\varsigma$ as "excessive impulse"

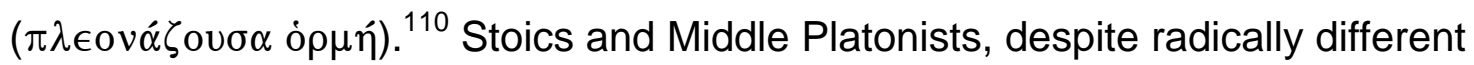
views of the human soul, could agree that (1) the soul generates impulses

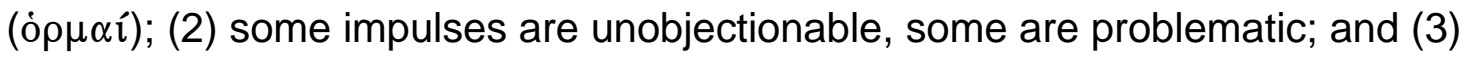
human appetition, generally speaking, bears analysis as either an unobjectionable or a problematic impulse. Middle Platonists, then, could preserve the analytic value of the Stoic category $\pi \dot{\alpha} \theta$ o $\varsigma$ (despite the ambiguity of the term from a Platonic perspective) by focusing on the term ó $\rho \mu \eta$ and endorsing-albeit

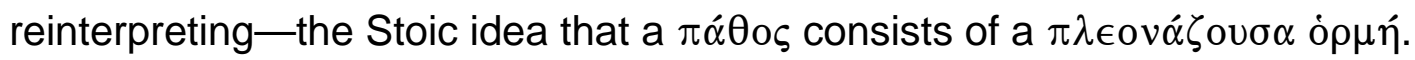

What did the Stoics mean by "excessive impulse"? In accordance with Stoic psychology, the impulse had to be a rational impulse, a function of the mind, because the Stoics denied the existence of non-rational impulses in adult human beings. But in what sense is the impulse "excessive"? ${ }^{111}$ Ultimately, the excess lies in a faulty—but nevertheless reasoned—assessment of something's

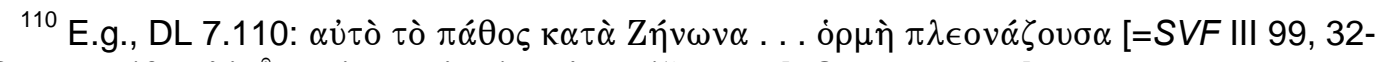

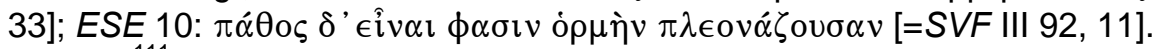

${ }^{111}$ On this question, see Inwood, Ethics and Human Action, 165-73. 
value: an excessive, exorbitant appraisal. ${ }^{112}$ The notion is strictly qualitative: an excessive impulse differs in quality from a non-excessive impulse in the same way that strict alternatives like "correct" and "incorrect" differ from one another. In this qualitative model, the only way to eliminate an "excessive impulse" is to abandon an incorrect rational assessment and make a different (correct) rational assessment. Nothing in the Stoic sources suggests a quantitative notion of excess: the idea that an impulse, whose essential nature never changes, proceeds along an incremental scale of measurement until at some point it goes too far, becoming too powerful, too intense, too big. On the contrary, the term

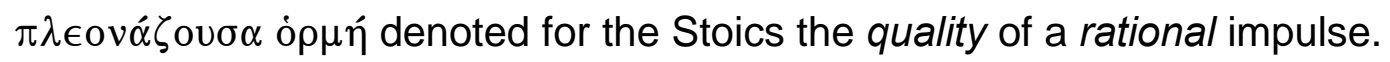

The earliest extant evidence for a Middle-Platonic definition of $\pi \dot{\alpha} \theta$ os using the Stoic terms $\pi \lambda \epsilon o v \alpha ́ \zeta o v \sigma \alpha \dot{o} \rho \mu \eta$ comes from Eudorus of Alexandria. ${ }^{113}$ Unfortunately, no explanation survives from Eudorus of what he meant by that definition. If he simply meant what the Stoics meant, he would have endorsed the

${ }^{112}$ Cf. Frede, "Stoic Affections," 107: Due to their faulty assessments of objects, moral agents "feel impelled towards them or away from them, with an intensity which stands in no comparison to their real value, and which hence is excessive."

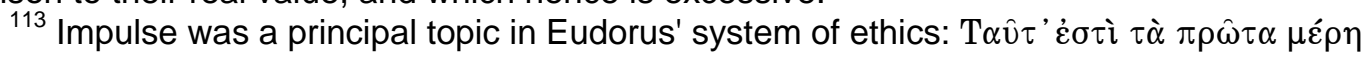

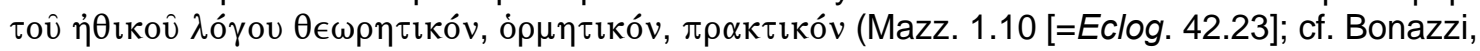
"Eudorus' Psychology"). He took an interest in both the taxonomy of impulse ( $€$ ío $\varsigma$ ) and the relation between impulse and passions, in particular the notion of passion as an "excessive

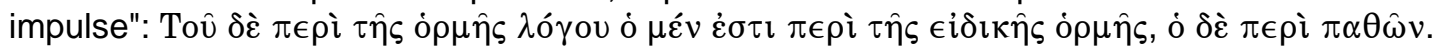

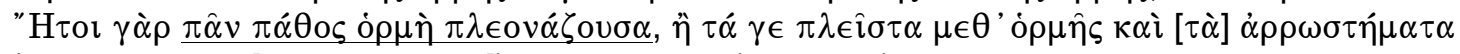
(Mazz. 1.23-24 [=Eclog. 44.3-6]). Ps.-Timaeus (TL 73-74) similarly attests a Middle-Platonic use of Stoic terminology $(\pi \lambda \epsilon o v \dot{\alpha} \zeta \epsilon v \ldots \dot{o} \rho \mu \alpha \dot{\alpha} \varsigma)$ with reference to the passions $(\tau \grave{\alpha} \pi \dot{\alpha} \theta \epsilon \alpha)$, which both Tobin (Timaios of Locri, 79, n. 35) and Baltes (Timaios Lokros, 206-07) identify as an

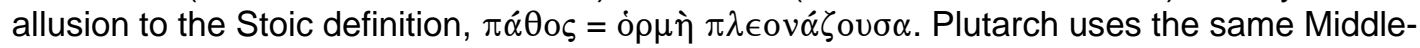

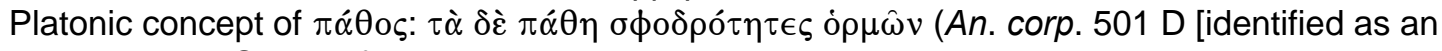
allusion to the Stoic definition also by Francesco Becchi, "Plutarco tra Platonismo e Aristotelismo:

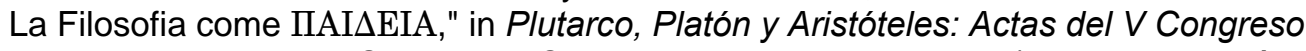
Internacional de la I.P.S. : Madrid-Cuenca, 4-7 de mayo de 1999 (ed. Aurelio Peréz Jiménez et al.; Madrid: Ediciones Clásicas, 1999), 25-43, 32] cf. Virt. mor. 444 B-C). 
Stoic theory of impulse, which in turn implies an endorsement of Stoic monistic psychology. In that case, his association with Middle Platonism, which disagreed so sharply with the Stoics on the fundamentals of moral psychology, becomes difficult to explain. A more likely conjecture would have Eudorus revising the Stoic definition in accordance with the tenets of Middle-Platonic moral psychology ${ }^{114}$ Given Middle Platonism's strong association of impulse with the non-rational part of the soul, the impulse in question would most certainly be a

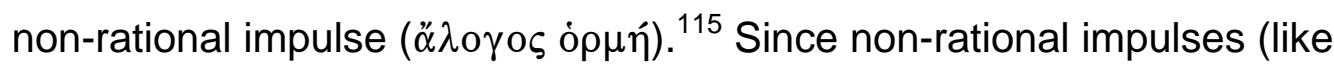
emotions) are not problematic as such, but only become problematic when they overstep the bounds of reason, "excessive" would then denote a non-rational impulse whose measure exceeds proper limits and becomes "immoderate" in a quantitative sense. When the bounds of reason are transgressed-precisely at that moment-an otherwise benign impulse of emotion (say, fear or desire) becomes a passion, a morally problematic, injurious force within the soul. In other words, based on what is otherwise known of Middle-Platonic moral psychology, a Middle Platonist speaking of $\pi \dot{\alpha} \theta$ o $\varsigma$ as $\pi \lambda \epsilon o v \alpha ́ \zeta o v \sigma \alpha$ ó $\rho \mu \eta$ would almost certainly have meant the excessive quantity of a non-rational impulse, not

${ }^{114}$ Cf. Dillon, Middle Platonists, 122: "Eudorus' terminology is as fully Stoic as that of Antiochus [of Ascalon], although, like Antiochus, he would not have admitted that it was distinctively Stoic, but would claim it as the normal current language of philosophic discourse. We, from our perspective, attach too much importance to ferreting out Stoic, and even Epicurean, terms, in Platonic writers. By Eudorus' time, the technical language of philosophy was very largely uniform. Only the meanings given to certain terms by the various schools might differ" (emphasis added). For an example of Eudorus' revision of Stoic formulations in the area of physics, see Mauro Bonazzi, "Eudoro di Alessandria alle origini del platonismo imperiale," in L'eridità platonica: studi sul platonismo da Arcesilao a Proclo (ed. Mauro Bonazzi and Vincenza Celluprica; Elenchos 45; Naples: Bibliopolis, 2005), 117-60, esp. 127-49.

${ }^{115}$ Cf. Bonazzi, "Eudorus' Psychology." 
the aberrant quality of a rational impulse ${ }^{116}$ Exactly this sort of Middle-Platonic reinvention of Stoic ideas appears in the writings of Philo.

In his most obvious citation of the Stoic definition, Philo adds one qualifying term, as if to clarify precisely what he means:

On the one hand, every "passion" ( $\pi \dot{\alpha} \theta 0 \varsigma$ ) is reprehensible ( $\dot{\varepsilon} \pi \hat{\imath} \lambda \eta \pi \tau o v)$, since we are responsible (i $\pi \alpha i \tau \imath o \varsigma)$ for every unmeasured "excessive

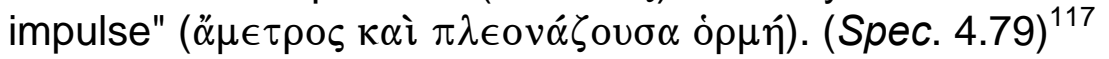

Philo grants, along with the Stoics, that a passion is an "excessive impulse"—but

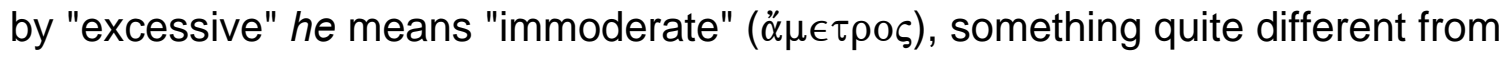

what the Stoics had in mind. The term $\ddot{\alpha} \mu \epsilon \tau \rho \varsigma$ denotes quantitative excess: going beyond the proper measure ( $\mu \varepsilon \dot{\tau} \rho \rho \nu$ ) imposed by reason. ${ }^{118}$ As a natural

${ }^{116}$ John Dillon, Middle Platonists, 77 , entertains this idea as a possibility but does not explore it further or mention it in connection with Eudorus. Speaking of Antiochus of Ascalon, he writes: "Antiochus, then, accepted the Stoic ideal of apatheia (freedom from passion) as opposed to the Academic-Peripatetic metriopatheia (moderation in the passions). It is not impossible, however, that Antiochus took the Stoic term and gave it a meaning consonant with Peripateticism. After all, he could argue, a passion is defined as an 'immoderate impulse' (hormê pleonazousa); if an impulse is under the control of moderation, it is not pleonazousa, and therefore not a passion 'within the meaning of the Act'. There were, after all, in Stoic theory, so-called 'equable states' (eupatheiai) corresponding to all of the pathê (except Distress, of which there could be no reasonable form), and it would not have been beyond the wit of Antiochus to equate these with the Peripatetic 'means'. The difference, he might well say, is more verbal than real." Just such a connection between the Peripatetic notion of mean ( $\mu \varepsilon \dot{\varepsilon} \sigma o v)$ and the term $\pi \lambda \epsilon o v \alpha \dot{\zeta} \zeta \in \mathfrak{l} v$ appears in

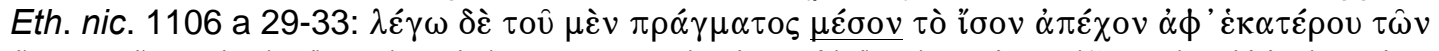

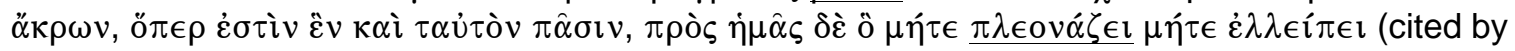
Francesco Becchi, "Platonismo medio ed etica Plutarchea," Prometheus 7 (1981): 125-45 [part one], 263-84 [part two], 275, in the context of Middle-Platonic theories of virtue).

${ }^{117}$ My translation. Cf. Virt. mor. 444 B-C. Inwood, Ethics and Human Action, cites Virt. mor. 450 E - 451 B \& 444 C (304, n. 193) understanding Plutarch to mean that "excessiveness of impulse" is "a reference to the exceeding of some ideal and moderate degree of emotion in the soul" (170).

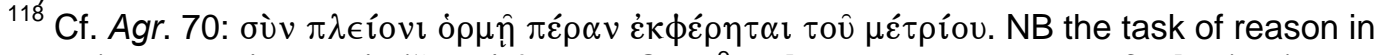

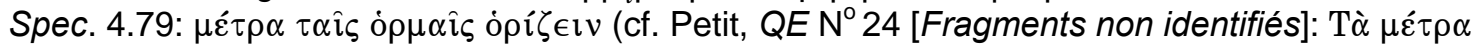

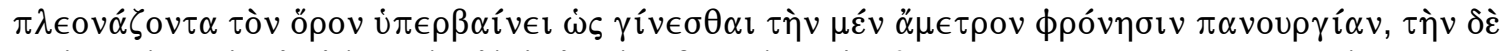

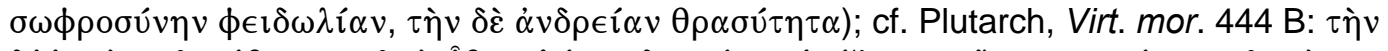

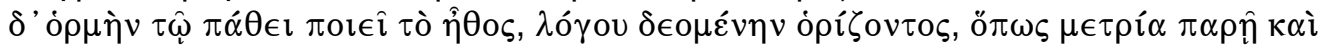

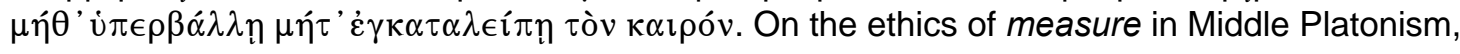




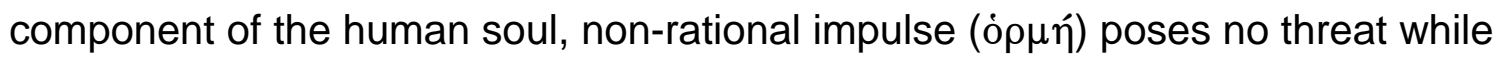
it operates within the bounds of reason. If, however, an impulse exceeds those bounds (i.e., if the non-rational force usurps reason's control), it becomes morally problematic (a "passion"). For a Middle Platonist like Philo, the term $\ddot{\alpha} \mu \epsilon \tau \rho \circ \varsigma$ best captured what was actually going wrong with the impulse; but the Stoic technical

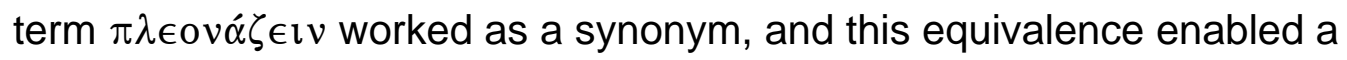
deliberate pressing of the Stoic definition of "passion" into Middle-Platonic service. ${ }^{119}$

This Middle-Platonic reinvention of Stoic technical terminology allowed Philo to speak with greater precision about problematic desire over against amoral desire. Desire itself-understood variously as the Platonic $\dot{\varepsilon} \pi \imath \theta u \mu \eta \tau \imath \kappa o ́ v$,

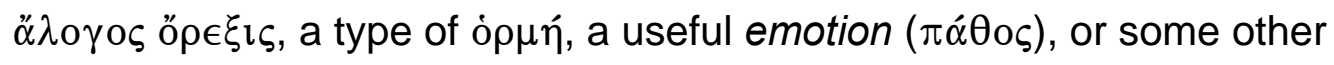

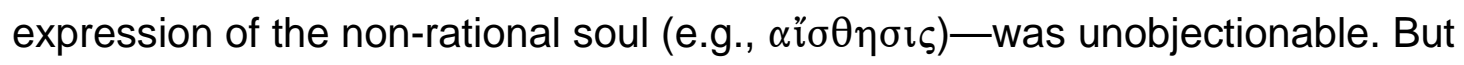
passionate desire—understood as an excessive (i.e., immoderate) desiderative impulse, and thus a "passion" by Stoic definition—was unquestionably a moral problem. In Her. 245, among the "deadly and irreconcilable enemies of the soul,"

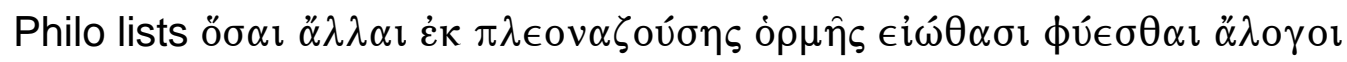

see Opsomer, "L'âme du monde et l' âme de l'homme," esp. 45-49 (cf. idem, "Plutarch's Platonism Revisited," in L'eridità platonica: studi sul platonismo da Arcesilao a Proclo (ed. Mauro Bonazzi and Vincenza Celluprica; Elenchos 45; Naples: Bibliopolis, 2005), 163-200, esp. 180-83 [="Moral psychology and ethics"].

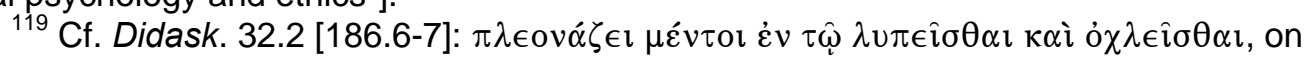
which Whittaker, Alcinoos, 148, n. 519: "Le terme stoïcien $\pi \lambda \epsilon 0 \nu \alpha ́ \zeta \omega$ (cf. SVF I. 205 et III. 479, etc.) a été adopté tant par les Moyen-platoniciens (cf. Eudore d'Alexandrie ap. Stobée, Anth. II. 44. 5 W.; Philon d'Alexandrie, De spec. leg. IV. 79; Plutarque, De virt. mor. 441 C; Timée de Locres 222. 14 M.) que par les Péripatéticiens (cf. Arius Didyme ap. Stobée, Anth. II. 38. 18-24 W.)." 
$\dot{\varepsilon} \pi \imath \theta u \mu i \alpha \mathrm{l}$, stating plainly that $\ddot{\alpha} \lambda \sigma \gamma o \imath \dot{\varepsilon} \pi \imath \theta v \mu i \alpha \iota$ stem from "excessive impulse"

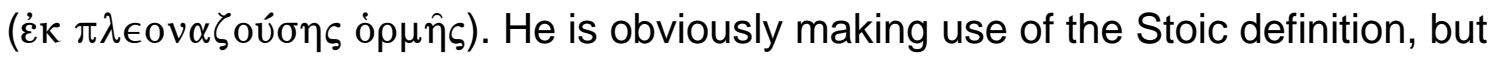
in Stoic theory an "excessive" desiderative impulse would simply be $\dot{\varepsilon} \pi \imath \vartheta \mu i \alpha^{\alpha}$ :

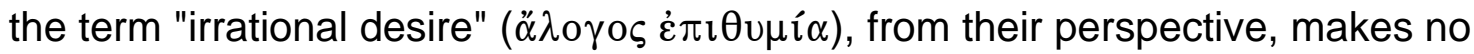
sense, because $\dot{\varepsilon} \pi \imath \theta \mu i \alpha$ is always irrational-there is no other type. For a Middle Platonist, however, the term $\dot{\varepsilon} \pi \imath \theta u \mu$ í by itself denotes the non-rational desire inherent in the soul, whose presence and operation do not necessarily result in irrational behavior, provided that reason stays in control. Only when the impulse of non-rational desire oversteps the bounds of reason does desire become "irrational": a non-rational desire usurps reason and becomes a dangerous force, capable of motivating a rational being to act contrary to reason (i.e., irrationally). So for Philo, as Her. 245 illustrates, $\ddot{\alpha} \lambda o \gamma o \varsigma \dot{\varepsilon} \pi \imath \theta u \mu i \alpha$ designates "irrational desire"-in other words, problematic desire, which appears only when an otherwise natural desiderative impulse oversteps reason and

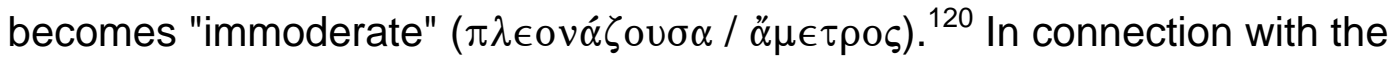

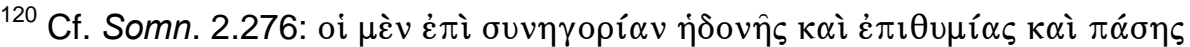

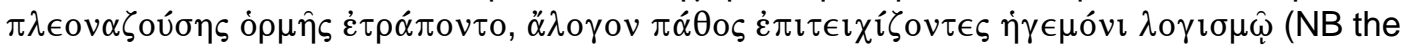

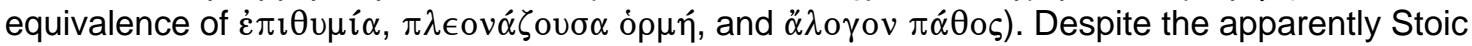

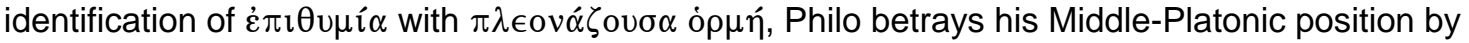
referring to this as an $\ddot{\alpha} \lambda$ o yov $\pi \dot{\alpha} \theta$ os. For the Stoics every $\pi \dot{\alpha} \theta$ o $\varsigma$ was irrational, so the term $\ddot{\alpha} \lambda$ o $\gamma$ ov $\pi \dot{\alpha} \theta$ o $\varsigma$ would strike them as redundant. But for a Middle-Platonist, who believes that nonrational $\dot{\varepsilon} \pi \imath \theta u \mu i \alpha$ need not be "irrational," the term $\ddot{\alpha} \lambda$ o yov $\pi \dot{\alpha} \theta$ o $\varsigma$ makes perfect sense: an excessive desiderative impulse represents an otherwise useful emotion ( $\pi \dot{\alpha} \theta$ o $\varsigma$ ) that has become problematic and thus "irrational" ( $\alpha \lambda \circ \gamma o v$ ) This is precisely the idea underlying Philo's use of $\ddot{\alpha} \lambda$ o $о \varsigma \varsigma \dot{\varepsilon} \pi \imath \theta u \mu i \alpha$ in Her. 245. In other words, a non-rational force no longer under the control of reason, operating contrary to reason, is "irrational." Cf. $\epsilon u ̉ \lambda o \gamma o v \pi \alpha \dot{\theta} \theta \varsigma_{\text {in }} \mathrm{Her} 192$, in reference to a non-rational emotion that is not irrational (opposed to reason) but "eurational" (obedient to reason). This is the Middle-Platonic version of Stoic $\epsilon \dot{v} \pi \dot{\alpha} \theta \epsilon \iota \alpha$ (see also Plutarch, Virt. mor. 448

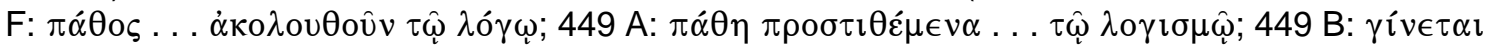




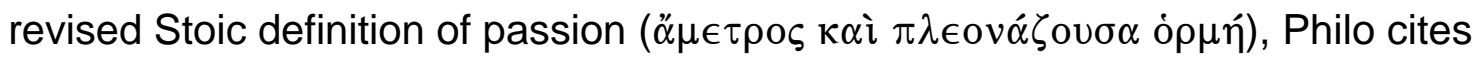

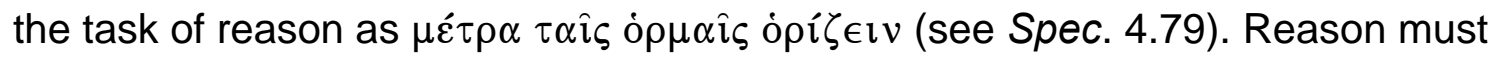

impose boundaries on non-rational desire as such ( $\left.\dot{\varepsilon} \pi \imath \theta u \mu i^{\alpha}\right)$, lest it become

passionate desire $(\ddot{\alpha} \mu \in \tau \rho \circ \varsigma \dot{\varepsilon} \pi \imath \theta v \mu i \alpha){ }^{121}$ This Middle-Platonic revision of Stoic

terminology underlies expressions such as $\mu \varepsilon \dot{\varepsilon} \tau \rho \alpha \tau \alpha \hat{\imath} \varsigma \dot{\varepsilon} \pi \imath \theta u \mu i ́ \alpha \iota \varsigma \pi \epsilon \rho \imath \theta \hat{\imath} v \alpha \iota$

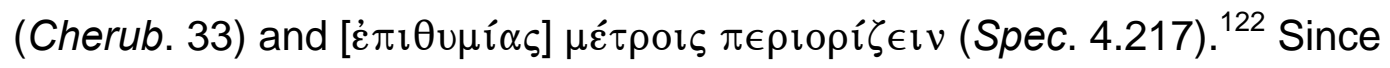

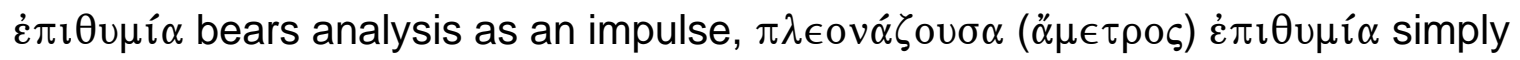

represents a more specific instance of $\pi \lambda \epsilon o v \alpha \dot{\alpha} \zeta o v \sigma \alpha(\ddot{\alpha} \mu \epsilon \tau \rho \circ \varsigma)$ ò $\mu \eta \dot{\eta}$, both of

which are morally problematic. With the concept of "immoderation" ( $\dot{\alpha} \mu \in \tau \rho i \alpha)$,

Philo was able to clearly distinguish passionate desire from amoral desire, using

a reinvented Stoic definition of passion. ${ }^{123}$

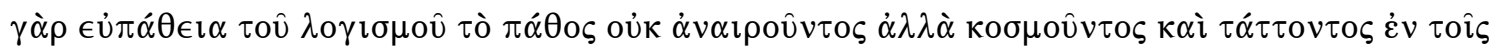
$\sigma \omega \phi \rho o v o v o(v)$. Philo's Middle-Platonic take on Stoic $\epsilon \dot{v} \pi \dot{\alpha} \theta \epsilon \iota \alpha$ explains his willingness to defy the Stoic doctrine of no rational counterpart to grief by naming $\delta \eta \gamma \mu$ ó $\varsigma$ in QG 2.57 as the "good emotion" corresponding to $\lambda u ́ \pi \eta$ (see John Dillon and Abraham Terian, "Philo and the Stoic

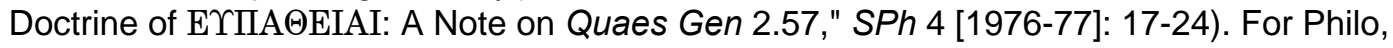
$\delta \eta \gamma \mu$ ó $\varsigma$ would indicate the emotion of grief properly measured by reason. Rather than "a significant modification in basic Stoic doctrine" (ibid., 18), Philo offers a fundamental Middle-

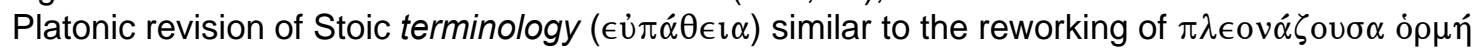

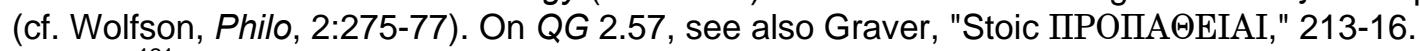

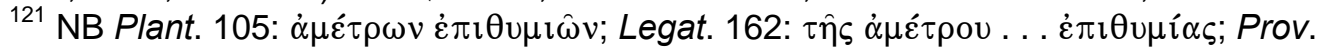

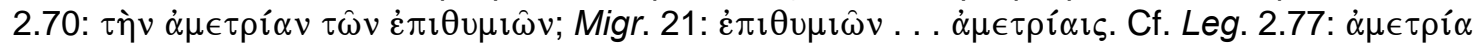

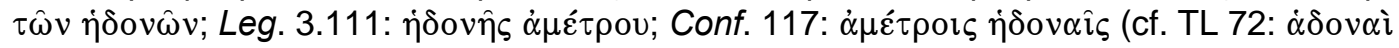
$\ddot{\alpha} \mu \in \tau \rho \circ \imath)$.

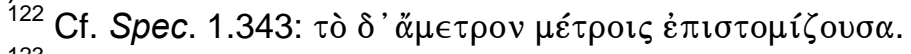

${ }^{123}$ And since $\dot{\varepsilon} \pi \imath \theta u \mu i^{\alpha}$ bears analysis as also a useful emotion ( $\pi \dot{\alpha} \theta 0 \varsigma$ ), the MiddlePlatonic use of $\ddot{\alpha} \mu \epsilon \tau \rho \varsigma$ terminology to analyze non-rational impulse applies also to the analysis of non-rational emotion, particularly in connection with the idea of "moderate" emotion

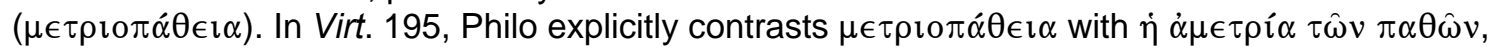
"immoderation of the emotions" (cf. Migr. 18: $\tau \dot{\alpha} \varsigma \ldots \pi \alpha \theta \hat{\omega} v \dot{\alpha} \mu \epsilon \tau \rho i \alpha \varsigma ;$ Migr. 21: $\pi \alpha \theta \hat{\omega} v$ $\dot{\alpha} \mu \epsilon \tau \rho i \alpha l \varsigma ;$ Mut. 143: $\pi \alpha \theta \hat{\omega} v \dot{\alpha} \mu \epsilon \tau \rho i \alpha \varsigma ;$ Spec. 3.209: $\tau \dot{\alpha} \varsigma \dot{\alpha} \mu \epsilon \tau \rho i \alpha \varsigma \tau \hat{\omega} v \pi \alpha \theta \hat{\omega} v)$. For Middle Platonists, the need to distinguish between emotion $(\pi \dot{\alpha} \theta$ o $\varsigma)$ and passion $(\pi \dot{\alpha} \theta$ o $\zeta)$ posed an obvious terminological problem. So they often denoted passion by using terms that ascribed excess or lack of measure to emotion: $\dot{\alpha} \mu \epsilon \tau \rho i \alpha \tau \hat{\omega} \nu \pi \alpha \theta \hat{\omega} v$ designates a "passionate emotion," 
Tyrannical Desire (ž $\rho \omega \varsigma)$

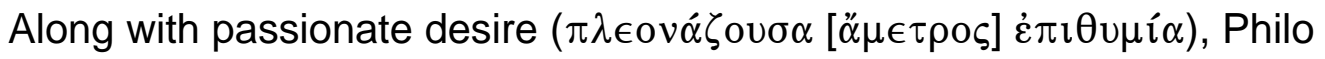
recognizes a second and even worse type of problematic desire, a "tyrannical

desire" (๕̋ $\rho \omega)$, which does not simply overstep the bounds of reason, but instead takes control of the entire soul. Philo's characterization of tyrannical desire relies not on reinvented Stoic terminology but on the writings of Plato himself, who believed that $\varepsilon^{\prime} \rho \omega \varsigma$ can operate as a consuming, injurious, relentless desire for a single beloved object. He describes this type of desire in Books VIII - IX of the Republic through his portrait of the "tyrannical soul."124 Just as governments

an amoral, potentially useful emotion $(\pi \dot{\alpha} \theta 0 \varsigma)$ that exceeds rational bounds and become morally

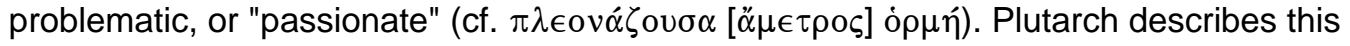
phenomenon in Virt. mor. $444 \mathrm{C}$, where he associates $\tau \grave{\alpha} \varsigma \dot{\alpha} \mu \epsilon \tau \rho \dot{\alpha} \alpha \varsigma \tau \hat{\omega} \nu \pi \alpha \theta \hat{\omega} v$ with an impulse

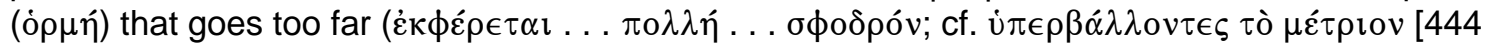
$\mathrm{B}]$ ). Evidence of the terminological problem faced by Middle Platonists appears in Didask. 30.5-6 [184.20-36], where Alcinous uses the terms $\dot{\alpha} \mu \epsilon \tau \rho \imath \tau \alpha \theta \dot{\eta} \varsigma$ and $\dot{v} \pi \epsilon \rho \pi \alpha \theta \eta \dot{\gamma}$ to designate

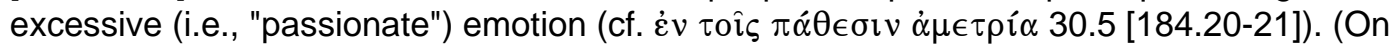
$\dot{\alpha} \mu \epsilon \tau \rho i ́ \alpha$ in Middle Platonism [including Virt. 195], see Whittaker, Alcinoos, 62, n. 504, who cites Resp. $486 \mathrm{D}$ and Phileb. $52 \mathrm{C}$ in connection with the term; cf. Dillon, Alcinous, 188-89.)

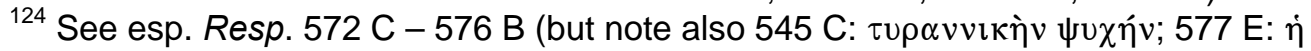

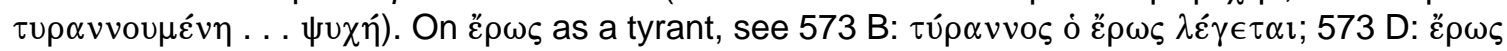

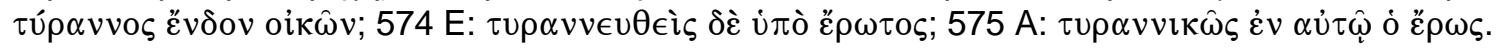
This clearly negative image of $\varepsilon \rho \omega \varsigma$ from the Republic corresponds with a similar image in Phaedr. $237 \mathrm{D}-238 \mathrm{C}$, where Socrates defines $\tilde{\varepsilon} \rho \omega \varsigma$ as an $\dot{\varepsilon} \pi \imath \theta u \mu i \alpha$ that usurps reason and becomes tyrant (238 B: $\tau u \rho \alpha \nu v \in v ́ \sigma \alpha \sigma \alpha$; cf. $238 \mathrm{~A}: \dot{\varepsilon} \pi \imath \theta u \mu i \alpha \varsigma$. . $\dot{\alpha} \rho \xi \dot{\alpha} \sigma \eta \varsigma \dot{\varepsilon} v \dot{\eta} \mu \hat{\imath} v ; 238 \mathrm{~B}$ : [sc. $\dot{\varepsilon} \pi \imath \theta v \mu i \alpha \varsigma] \delta v v \alpha \sigma \tau \epsilon v o u ́ \sigma \eta \zeta . . . \kappa \rho \alpha \tau \eta ́ \sigma \alpha \sigma \alpha \dot{\varepsilon} \pi \imath \theta u \mu i \alpha \alpha$. Plato's positive image of $\tilde{\varepsilon} \rho \omega \varsigma$, by contrast, sees it as a means by which the soul of the philosopher ascends to the realm of true beauty and goodness (see Symp. 210 A - 212 C; Phaedr. 245 B - 257 B). Philo employs also this positive understanding of है $\rho \omega \varsigma$ in his writings (e.g. Contempl. 11-12; Praem. 84: ن $\pi$ '

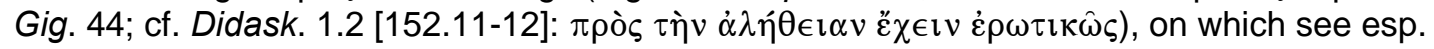
Dieter Zeller, Charis bei Philon und Paulus (SBS 142; Stuttgart: Verlag Katholisches Bibelwerk, 1990), 75-79 [="Der himmlische Eros"] (cf. Peder Borgen, "Heaven Ascent in Philo: An Examination of Selected Passages," in The Pseudepigrapha and Early Biblical Interpretation [ed. James Charlesworth and Craig Evans; JSPSup 14; SSEJC 2; Sheffield: JSOT Press, 1993], 24668, esp. 253-56; Holger Thesleff, "Notes on Eros in Middle Platonism," Arctos 28 [1994]: 115-28, esp. 119-20). Both views ascribe to है $\rho \omega \varsigma$ a consuming motivational power capable of directing the course of one's life (cf. Post. 157). On Platonic है $\rho \omega \varsigma$ in general, see Halperin, "Platonic Erôs"; idem, "Plato and the Metaphysics of Desire," PBACAP 5 (1989): 27-52. 
degenerate stepwise from a best to a worst type, souls can degenerate from a best to a worst type, with tyranny representing the worst of both states and souls. The "tyrannical soul" suffers under the hegemony of an overgrown desire $(\dot{\varepsilon} \pi \imath \theta u \mu i \alpha)$-a preeminent, tyrannical desire $(\varepsilon \tilde{\varepsilon} \rho \varsigma)$ that dominates not only other competing desires but also the collective operation of the entire soul. ${ }^{125}$ Without explicitly citing Plato's text, Philo nevertheless clearly demonstrates a familiarity with Plato's description of soul tyranny in the Republic. ${ }^{126}$ In particular, he incorporates Plato's notion of tyrannical desire ( $\varepsilon \rho \omega \varsigma)$ into his moral psychology to describe the ultimate victory of non-rational desire $(\dot{\varepsilon} \pi \imath \theta u \mu i \alpha)$ over reason $(\lambda o ́ \gamma \circ \varsigma){ }^{127}$

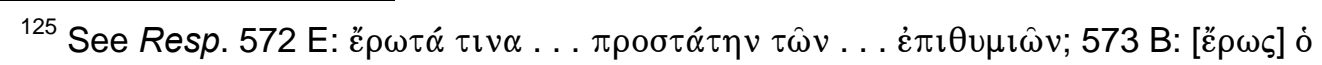

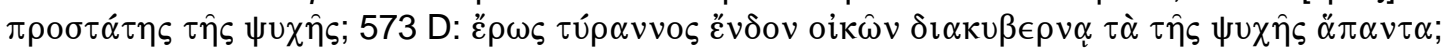

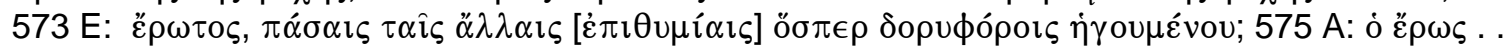

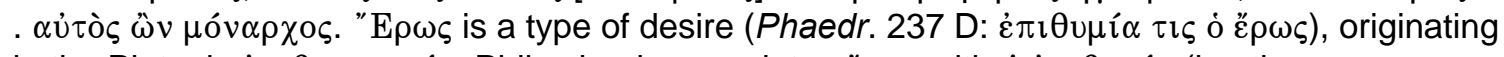
in the Platonic $\dot{\varepsilon} \pi \imath \theta u \mu \eta \tau \imath \kappa o ́ v$. Philo clearly associates $\varepsilon \rho \omega \varsigma$ with $\dot{\eta} \dot{\varepsilon} \pi \imath \theta u \mu i \alpha$ (i.e. the $\dot{\varepsilon} \pi \imath \theta u \mu \eta \tau \imath \kappa o ́ v)$ in Conf. 21. Cf. the scholium on Didask. 34.3 [188.30-35] from the ninth-century codex Parisinus Graecus 1962 (see Whittaker, Alcinoos, 167), which correlates the various

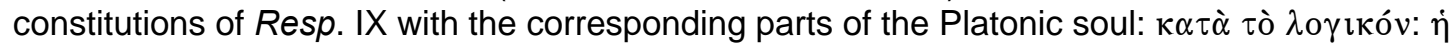

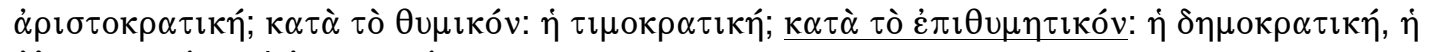

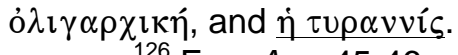

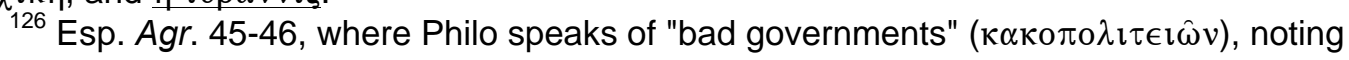

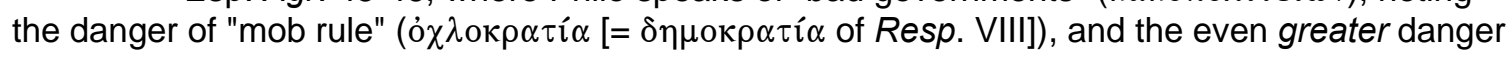
of an arising tyrant ( $\tau \dot{\rho} \rho \alpha \nu v o \varsigma$ ), which in cities involves a man ( $\pi$ ó $\lambda \in \omega \nu \mu \varepsilon \grave{\varepsilon} \nu \ddot{\alpha} \nu \theta \rho \omega \pi \circ \varsigma$ ), but in

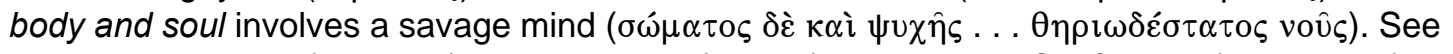

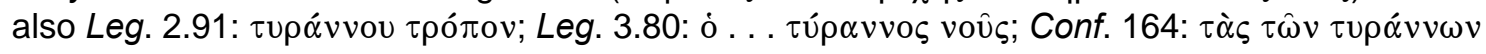

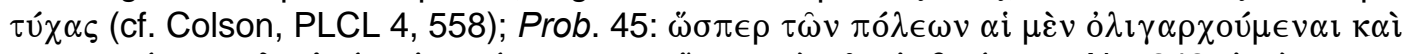

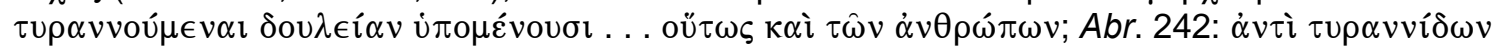

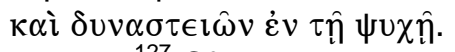

${ }^{127}$ Cf. Emma Wasserman, The Death of the Soul in Romans 7 (WUNT 256; Tübingen: Mohr Siebeck, 2008), 60-76 [="The Death of the Soul in Philo of Alexandria"]. Wasserman similarly notes the influence of Resp. VIII and IX on Philo's Platonic notion of an inferior part of the soul utterly defeating reason, but she does not explore this connection in terms of $\tilde{\varepsilon} \rho \omega \varsigma$ (tyrannical desire). Instead, she suggests a link between Philo's motif of "soul death" (e.g., Leg. 1.105-107) and the "extreme immorality" (broadly conceived) represented by Plato's image of tyranny in the Republic (see 67-76 [="Extreme Immorality in Platonic Discourse"], esp. 67-70). 
"E $\rho \omega \varsigma$ as Advanced Grade of Desire

Unlike useful desire, which dutifully submits to reason's command, passionate desire and tyrannical desire both counteract reason, but to different extents, and in different ways. Generally speaking, passionate desire and tyrannical desire correspond to the ethical categories of "lack of self-control"

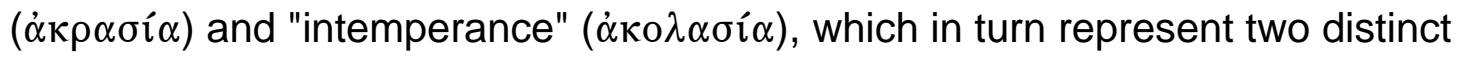
dynamic relations between non-rational desire $(\dot{\varepsilon} \pi \imath \theta u \mu i \alpha)$ and reason ( $\left.\lambda \sigma_{\gamma} \sigma \varsigma\right)$ within the soul. ${ }^{128}$ In the case of passionate desire, $\dot{\varepsilon} \pi \imath \theta u \mu i \alpha$ impulsively counteracts the dictates of reason-overstepping the bounds of reason (becoming $\ddot{\alpha}-\mu \epsilon \tau \rho \circ \varsigma$ )—despite reason's attempt to enforce those dictates. In other words, desire forcibly asserts its inclination over against the inclination of reason in a contest of power. ${ }^{129}$ The moral agent simply does not have the

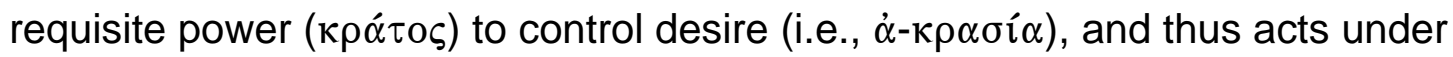
compulsion "against his or her will." In the case of tyrannical desire, however, the moral agent no longer experiences internal conflict, because desire has defeated reason entirely. Desire has become the undisputed ruler of the soul, a tyrant

${ }^{128}$ In descending order of moral value, the four relations are "self-mastery" ( $\left.\sigma \omega \phi \rho \circ \sigma u ́ v \eta\right)$, in which reason enjoys uncontested dominion over compliant desire; "self-control" ( $\dot{\gamma} \gamma \kappa \rho \alpha \tilde{\tau} \tau \mathfrak{\imath} \alpha)$, in which reason asserts contested control over opposing desire; "lack of self-control" ( $\dot{\alpha} \kappa \rho \alpha \sigma i \alpha)$, in which desire asserts contested control over opposing reason; and "intemperance" ( $\dot{\alpha} \kappa o \lambda \alpha \sigma i \alpha)$, in which desire enjoys uncontested dominion over compliant reason. The ethical theory underlying this scale of morality comes from Book VII of Aristotle's Nicomachean Ethics (see Helen North, Sophrosyne: Self-Knowledge and Self-Restraint in Greek Literature [CSCP 35; Ithaca: Cornell University Press, 1966], 203). For the scale from a Middle-Platonic perspective similar to Philo's, see Plutarch Virt. mor. $445 \mathrm{~B}-446 \mathrm{C}$.

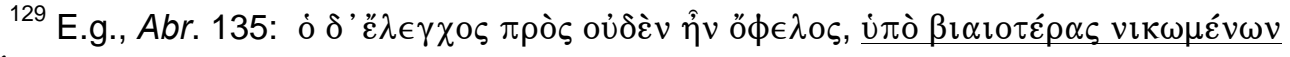
$\dot{\varepsilon} \pi \imath \theta \mu i \alpha \varsigma$. 
whose agenda determines the overall orientation and course of life. ${ }^{130}$ The moral

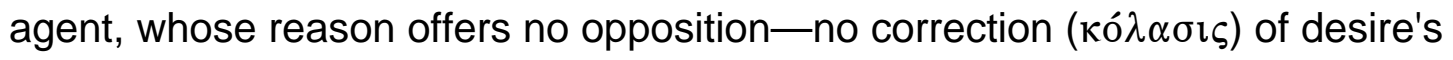
errant ways (i.e., $\dot{\alpha}$-ко $\lambda \alpha \sigma i \alpha$ )—acts as the compliant slave of desire. ${ }^{131}$ In terms of moral psychology, what this means is that the invariable, sole aim of $\dot{\varepsilon} \pi \imath \theta \mu i \dot{ } \alpha$, which the Platonic tradition identifies as pleasure (jंovvr), has become the invariable, sole aim of the moral agent, who thus becomes a "Lover of Pleasure" $(\phi \imath \lambda \eta ́ \delta 0 v o \varsigma){ }^{132}$

Just as $\dot{\varepsilon} \pi \imath \theta u \mu i \alpha$ can invariably seek pleasure through a variety of means (food, money, fame), tyrannical desire ( $\varepsilon \rho \omega)$ can invariably represent "love of pleasure" ( $\phi \imath \lambda \eta \delta o v i ́ \alpha)$ despite a variety of distinct means to pleasure. Philo speaks of the trouble caused by:

${ }^{130}$ Cf. Annas, "Humans and Beasts," on Resp. VIII - IX: "[T]he 'tyrannical' man is the only one to have lost all overall control, once a master desire has been implanted within him" (129).

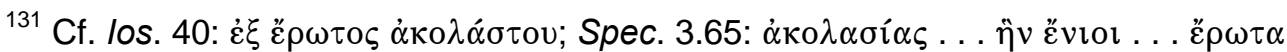

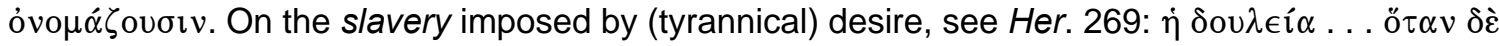

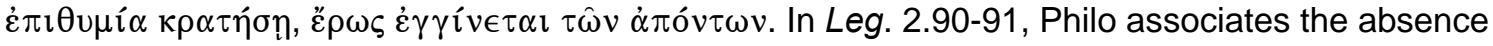
of discipline ( $\pi \alpha \imath \delta \in i \alpha$ [cf. $\kappa o ́ \lambda \alpha \sigma \imath \varsigma])$ with the eventual rise of tyranny in the soul.

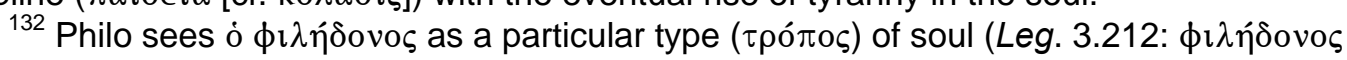

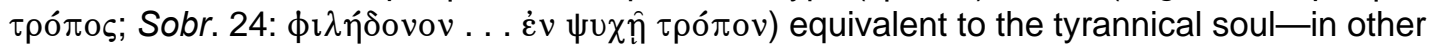

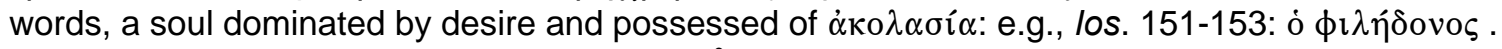

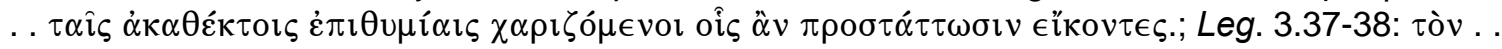

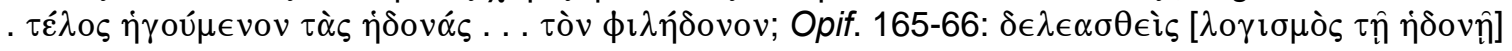

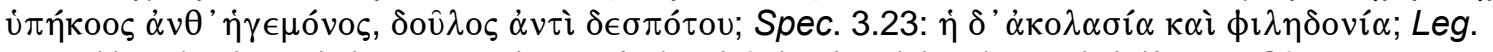
2.90: $\dot{\varepsilon} \dot{\alpha} \nu ~ \gamma \grave{\alpha} \rho \dot{\eta} \psi v \chi \grave{\eta} \alpha \underline{\alpha} \pi 0 \rho \rho \psi \eta \eta \eta$ "Anti-Epicurean Polemic," 93: "Philo never tires of attacking in his writings the 'pleasure-seeker'

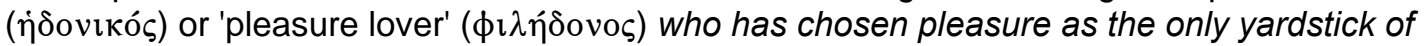
judgment and has made it his supreme rule of life" (emphasis added). Philo's disdain for the

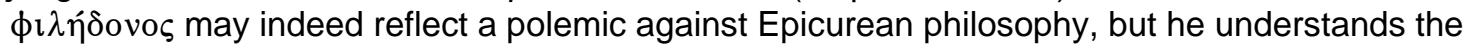
moral psychology of hedonism along fundamentally Platonic lines. (On the Epicurean notion of pleasure as "the good," see LS 21A-X, esp. 21B, line 2 [from Epicurus, Letter to Menoeceus]: $\tau \grave{\eta} v$

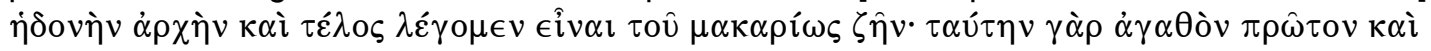

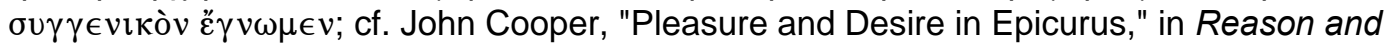
Emotion: Essays on Ancient Moral Psychology and Ethical Theory [Princeton: Princeton University Press, 1999], 485-514.) 


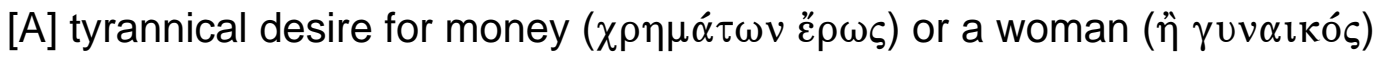

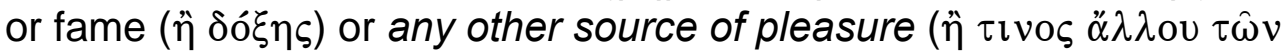

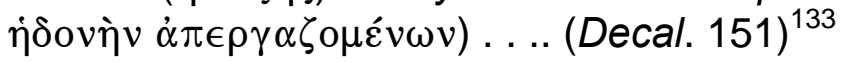

Plato's general theory of $\tilde{\varepsilon} \rho \omega \varsigma$ makes a distinction between the object and the aim of है $\rho \omega \varsigma$, which explains for tyrannical desire (है $\rho \omega \varsigma)$ the relation between

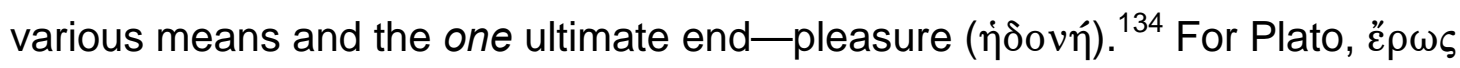
engages the rational mind, whose scope includes the convictions and aspirations of the moral agent, not just the impulsive activity of a non-rational element within the soul. ${ }^{135}$ "E $\rho \omega \varsigma$ fundamentally involves a passionate pursuit of the Beautiful

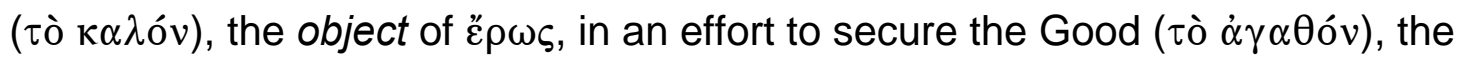
ultimate aim of $\tilde{\varepsilon} \rho \omega \varsigma^{136}$ By properly evaluating reflections of the Beautiful manifested in a variety of sources in the sensible realm, the student of philosophy can ultimately ascend to the one source of those reflections in the intelligible realm, the Beautiful itself, in order to secure the Good itself, which

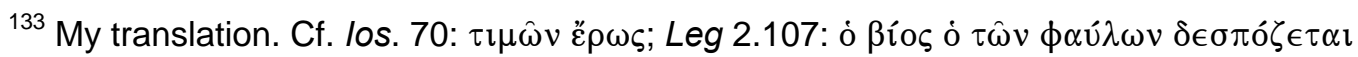

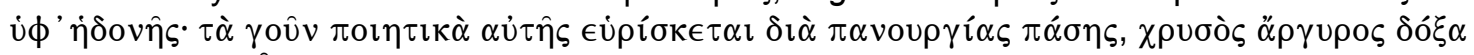

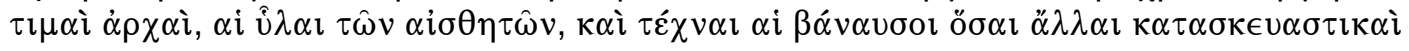

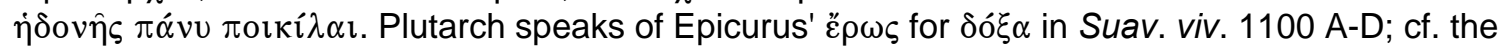

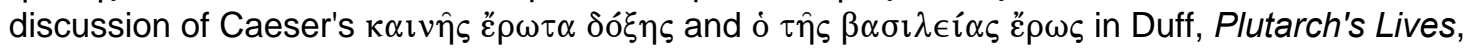
86-87.

${ }^{134}$ On this distinction, see Halperin, "Platonic Erôs, esp. 176-82.

${ }^{135}$ Cf. J. M. E. Moravcsik, "Reason and Eros in the 'Ascent'-Passage of the Symposium," in Essays in Ancient Greek Philosophy (ed. J. P. Anton and G. L. Kustas; Albany: State University of New York Press, 1971), 283-302, 290: "Plato is using 'eros' in a wide sense, including any over-all desire or wish for what is taken to be good. The qualification 'over-all' is needed, for Plato is not talking about momentary impulses but about wishes, desires, aspirations that determine the ultimate goals of one's life. Thus eros is not blind passion; it is the wish or desire . . . for things deemed on account of their nature to be worthy of having their attainment become a man's

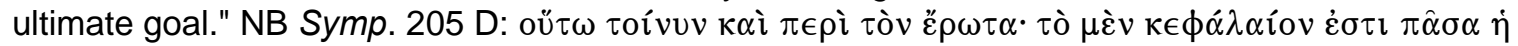

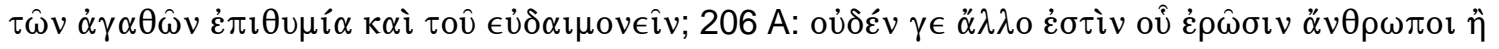

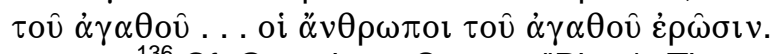

${ }^{136}$ Cf. Gerasimos Santas, "Plato's Theory of Eros in the Symposium," in Plato and Freud: Two Theories of Love (Oxford: Basil Blackwell, 1988), 14-57, esp. 32-34 [="Generic Desire: Desire for the Good to be One's Own Forever"]. 
results in happiness $(\epsilon \dot{\delta} \delta \alpha \imath \mu$ oví $\alpha)$. But this philosophical use of $\varepsilon \rho \omega \varsigma$ presumes that the moral agent values as good what is truly good. In the case of tyrannical desire, the moral agent operates under the erroneous conviction that pleasure (ं்oví) is good and thus worthy of pursuit. ${ }^{137}$ Enamored of a false good, the moral agent vehemently pursues objects that secure the "good"-pursues, in other words, objects capable of producing pleasure. The moral agent focuses only on what is "good" for non-rational desire, which has commandeered all faculties of the soul—including the rational faculty—to serve its pursuit of pleasure. ${ }^{138}$ Tyrannical desire (है $\left.\rho \omega \varsigma\right)$ thus represents the terminal stage of a disastrous process that begins with reason outmatched by $\dot{\varepsilon} \pi \imath \theta u \mu i \alpha$ and ends with reason enslaved by $\dot{\varepsilon} \pi \imath \theta u \mu \alpha^{\alpha}{ }^{139}$

Philo emphasizes the distinct nature of $\varepsilon^{\prime} \rho \omega \varsigma$ as an advanced grade of desire by representing passionate desire (and thus $\dot{\alpha} \kappa \rho \alpha \sigma i \alpha$ ) as a preliminary condition that engenders tyrannical desire (and thus $\dot{\alpha} \kappa \circ \lambda \alpha \sigma i \alpha$ ):

When desire prevails within the soul (ö $\alpha \nu \nu \delta \dot{\varepsilon} \dot{\varepsilon} \pi \imath \theta u \mu i \alpha \kappa \rho \alpha \tau \eta ் \sigma \eta)$, a tyrannical desire arises for things one does not have ("̋ $\rho \omega \varsigma \dot{\varepsilon} \gamma \gamma \dot{v} \in \epsilon \alpha \alpha \tau \hat{\omega} v$ $\dot{\alpha} \pi o ́ v \tau \omega v)$-a tyrannical desire that racks the soul on unmet expectation as

${ }^{137}$ Cf. Leg. 3.60-62. Pleasure appears to be good and thus has a deceptive charm that leads people to embrace it as good (see esp. Jessica Moss, "Pleasure and Illusion in Plato," Ph\&PhenR 72 [2006]: 503-35).

138 Tyrannical desire has made pleasure "the good" (cf. Symp. 205 D).

${ }^{139} \mathrm{Cf}$. Kahn, "Plato's Theory of Desire," 88: "If reason is able to rule in the soul, it will specify the life of virtue (the life of philosophy) as the good to be aimed at. If it does not succeed in doing so, that is because it has been so 'overpowered' by spirit or appetite that it mis-identifies the good. Since it is only the rational part that can form any conception of the good, even an erroneous conception, the domination of the other parts has the consequence of causing reason to make a mistake in its recognition of the ends to be pursued. That is what it means for reason to be enslaved" (original emphasis) (see also Cooper, "Human Motivation," 132, n. 18; Lorenz, Brute Within, 46: "the rule of the appetitive part consists in the fact that its central object of desire has become the person's central object of desire ..."). 


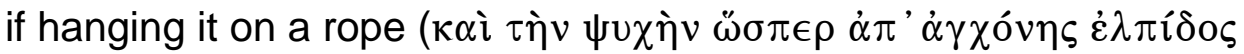
$\dot{\alpha} \tau \in \lambda$ ov̂ $\varsigma \dot{\varepsilon} \kappa \rho \varepsilon \tilde{\varepsilon} \mu \sigma \epsilon)$. Always thirsty, yet never able to drink, such a soul suffers the awful fate of Tantalus ( $\delta \imath \psi \hat{n} \mu \grave{\varepsilon} v \gamma \dot{\alpha} \rho \dot{\alpha} \in \hat{\imath}, \pi \imath \in \hat{\imath} v \delta \grave{\varepsilon} \dot{\alpha} \delta v v \alpha \tau \in \hat{\imath}$

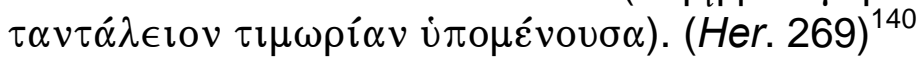

In order for tyrannical desire to come into existence, $\dot{\varepsilon} \pi \imath \theta u \mu i \alpha$ must first

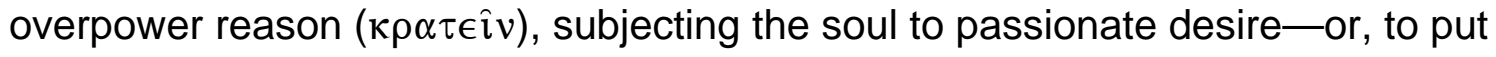
it differently, tyrannical desire is born only in souls predisposed to its genesis by passionate desire and the accompanying state of incontinence $(\dot{\alpha} \kappa \rho \alpha \sigma i \alpha)$. Advancement to this terminal grade of desire invariably brings disaster.

Negative Impact of "E $\rho \omega \varsigma$

Once established, tyrannical desire's hegemony ravages the soul by imposing the "fate of Tantalus" (Her. 269). For Tantalus, this meant the torturous circumstance of being always thirsty yet never able to take a drink. ${ }^{141}$ Framed as a more general predicament, this means suffering under an insatiable desire: always wanting something yet never able to get it. ${ }^{142}$ This experience of chronic insatiability ( $\dot{\alpha} \pi \lambda \eta \sigma \tau i \alpha)$ distinguishes tyrannical desire ( $(\tilde{\rho} \omega \varsigma)$ from all other types. ${ }^{143}$ In fact, only the abject defeat of reason ( $\left.\dot{\alpha} \kappa \circ \lambda \alpha \sigma i \alpha\right)$ presupposed by tyrannical desire can explain the phenomenon of chronic insatiability. Unlike a physical receptacle such as the stomach, whose physical limits can be reached

${ }^{140}$ My translation. For the same idea of passionate desire as a preliminary condition engendering $\check{\varepsilon} \rho \omega \varsigma$, see Spec. 4.80-81.

${ }^{141}$ See Od. 11.582-92.

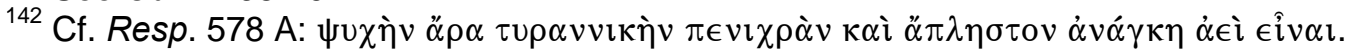
See Halperin, "Metaphysics of Desire," esp. 36-43 [="Eros: Suffering Without Satisfaction"].

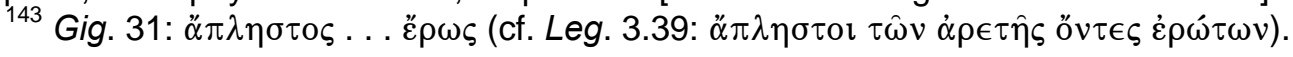


to induce satiety, desire itself $\left(\dot{\varepsilon} \pi \imath \theta \mu i{ }^{\alpha} \alpha\right)$-as a function of the soul—has no inherent limit. Philo explains:

[T]he craving of the soul that is out of control is not restricted as the bodily

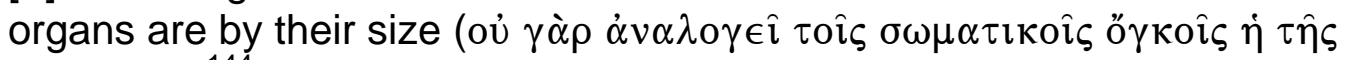
$\left.\dot{\alpha} \kappa \rho \dot{\alpha} \tau о \rho о \varsigma^{144} \psi v \chi \hat{\eta} \varsigma \dot{\varepsilon} \pi \imath \theta u \mu i ́ \alpha\right)$. These are vessels of a fixed capacity

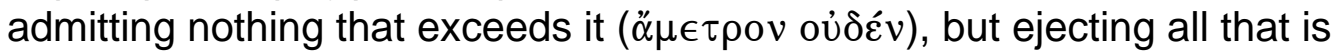
superfluous. Desire is never filled up ( $\dot{\eta} \delta \grave{\varepsilon} \dot{\varepsilon} \pi \imath \theta u \mu i \alpha^{\prime} \pi \lambda \eta \rho o v i \tau \alpha \mu \grave{\varepsilon} \nu$

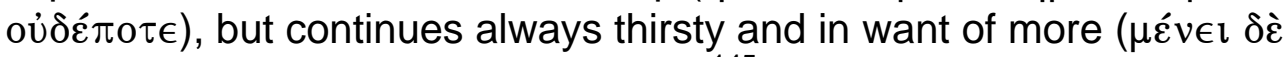
$\dot{\varepsilon} v \delta \in \grave{\eta} \varsigma \kappa \alpha \grave{\imath} \delta \imath \psi \alpha \lambda \varepsilon \dot{\alpha} \alpha \dot{\alpha} \in \hat{\imath})$. (Leg. 3.149) ${ }^{145}$

Once activated in the soul, desire impulsively extends toward its object, with nothing to limit it other than reason. In the virtuous soul, reason imposes limits, allowing desire to pursue its object only so far as that pursuit serves a rational end: to secure, for example, something necessary or useful. But in the soul under tyrannical desire $(\varepsilon \rho \omega \varsigma)$, reason never exercises its limiting capacity, so nothing counteracts this appetitive extension. The moral agent consumed with tyrannical desire continually holds the object of desire in mind, causing non-rational desire to pursue reflexively the pleasure afforded by that object, which in turn leads to the unending frustration of insatiable desire in a soul racked with longing. Although Philo alludes to this phenomenon in a variety of passages, he finds it

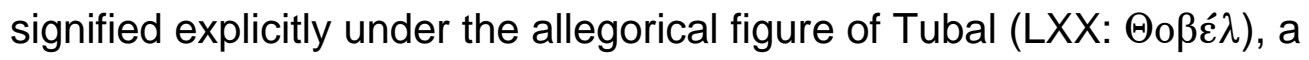

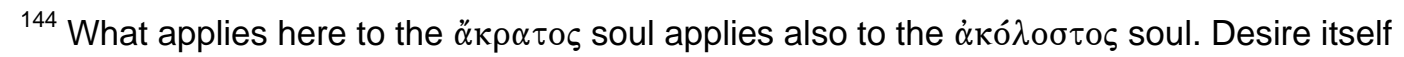
is insatiable, whether the absence of restraining reason is temporary $(\dot{\alpha} \kappa \rho \alpha \sigma i \alpha)$ or chronic $(\dot{\alpha} \kappa \circ \lambda \alpha \sigma i \alpha)$.

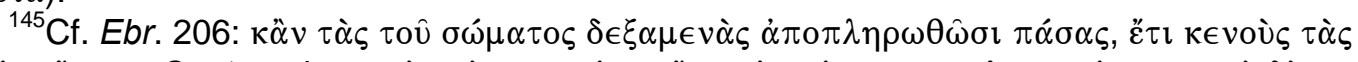

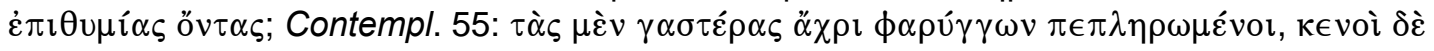

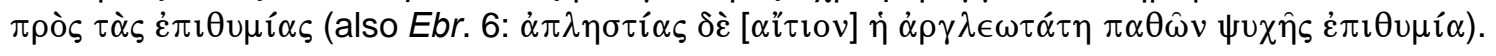


descendant of Cain mentioned in Gen 4:22. ${ }^{146}$ Tubal represents for Philo the torturous extension of a soul consumed by a tyrannical desire $\left(\varepsilon^{\prime} \rho \omega \varsigma\right)^{147}$ for the

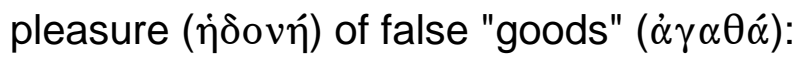

$[T]$ he soul of someone vexed by the pleasures derived from either bodily

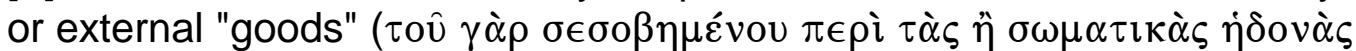

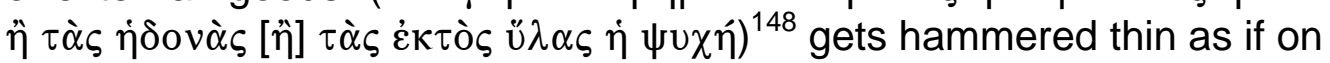
an anvil, driven by the long and cavernous extensions of its desires

${ }^{146}$ On Philo's etymological interpretation, see Lester L. Grabbe, Etymology in Early Jewish Interpretation: The Hebrew Names in Philo (BJS 115; Atlanta: Scholars Press, 1988). On

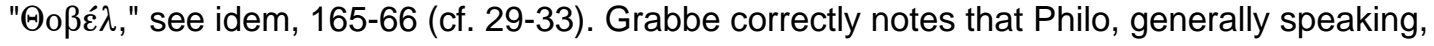
does not so much draw meaning as inject meaning: "Philo has a definite philosophical and theological system in mind. While certain modifications have been made to accommodate it to Judaism, this system is still evidently a representative of Middle Platonism. Philo is not in reality exegeting the biblical text, any more than the Stoic allegorists exegeted the text of Homer. He is only building an extensive bridgework between the Jewish sacred text and his philosophicotheological system. Although Philo probably would not have thought consciously in such terms, his question is, ultimately, not what the text means but how can he funnel his philosophical system into it" (116). See also David Runia, "Etymology as an Allegorical Technique in Philo of Alexandria," SPhA 16 (2004): 101-21.

${ }^{147}$ Although the term ع̋ $\rho \omega \varsigma$ does not appear in Post. 116, Philo clearly has $\tilde{\varepsilon} \rho \omega \varsigma$ in mind: (1) the broader context of the passage (Post. 113: esp. $\left.\dot{\omega} \varsigma \delta \iota^{\prime} \dot{\alpha} v \alpha \beta \alpha \theta \mu \hat{\omega} v\right)$ alludes to Plato's teaching on ع̋ $\rho \omega \varsigma$ in the Symposium (211 C: esp. $ّ \sigma \pi \epsilon \rho \dot{\varepsilon} \pi \alpha \nu \alpha \beta \alpha \theta \mu o i \varsigma$; cf. Arnaldez, PAPM 6, 110, n.3); (2) Philo links the term $\sigma \in \sigma o \beta \eta \mu \varepsilon \dot{v}$ ov, which Colson translates as "vehemently

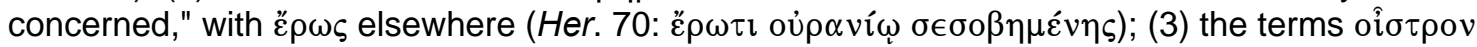

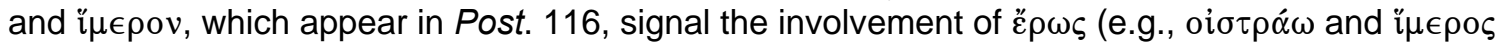
in Phaedr. $251 \mathrm{C}-\mathrm{E})$. Philo describes a person whose state of mind is characterized by $\check{\varepsilon} \rho \omega \varsigma$, although distinct instances of desire still bear description with terms like $\dot{\varepsilon} \pi \imath \theta u \mu i \alpha$ and ő $\rho \in \xi ı$, which are both found in Post. 116.

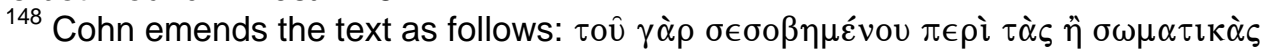

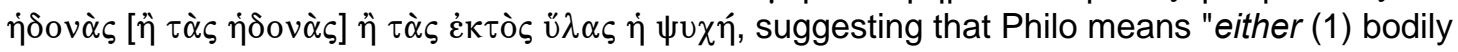

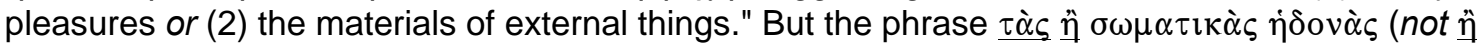
$\tau \grave{\alpha} \varsigma \sigma \omega \mu \alpha \tau \iota \kappa \grave{\alpha} \varsigma \dot{\eta} \delta o v \grave{\alpha} \varsigma)$ suggests that Philo has in mind one type of pleasure over against

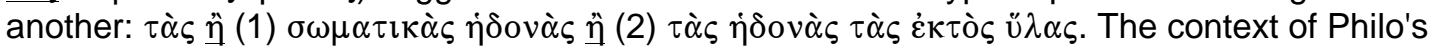
statement (Post. 112-15) clearly shows that he has in mind two classes of false "goods," those related to the body (e.g., health) and those related to the external world (e.g., wealth): "Sella" is a

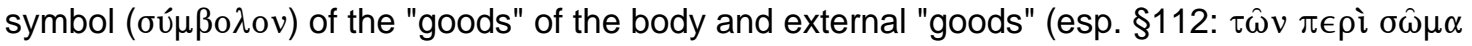

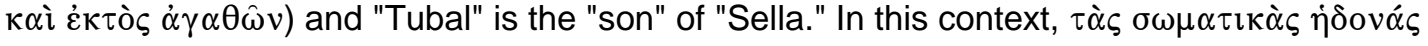

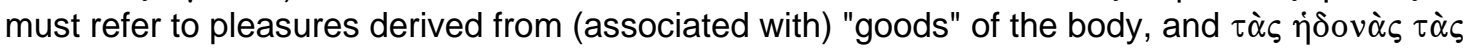
$\dot{\varepsilon} \kappa \tau o ̀ \varsigma ~ u ̌ \lambda \alpha \varsigma$, although an awkward expression, must refer to pleasures derived from (associated

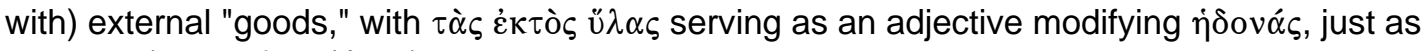
$\sigma \omega \mu \alpha \tau \imath \kappa \alpha ́ \varsigma$ modifies $\dot{\eta} \delta o v \alpha ́ \varsigma$. This emphasis on pleasure complements Philo's subsequent

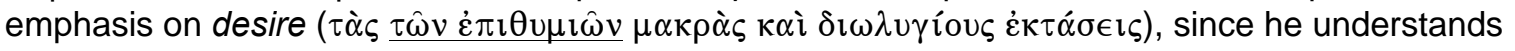

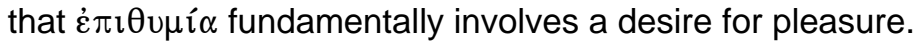




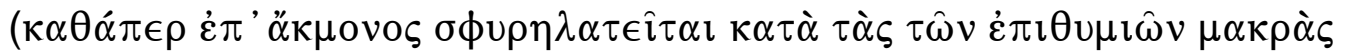

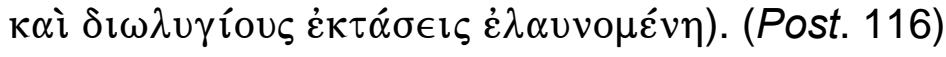

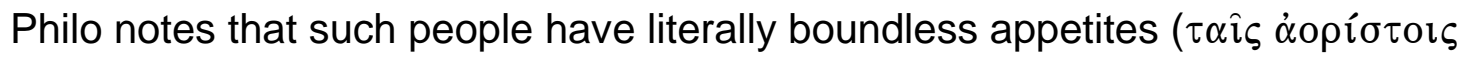

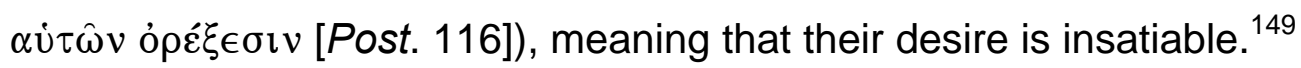

Tyrannical desire harms not only the individual, but also the community at large through the individual, whose obsessive pursuit of pleasure via false "goods" leads to lawless behavior and violent conflict. Plato associates tyrannical desire with lawlessness in the Republic, in his portrait of the tyrannical man:

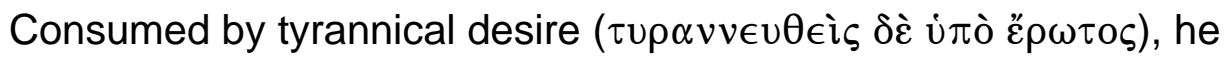
regularly becomes by day the sort of person he scarcely dreamed of becoming at night. He will kill anyone, eat anything, do anything, because

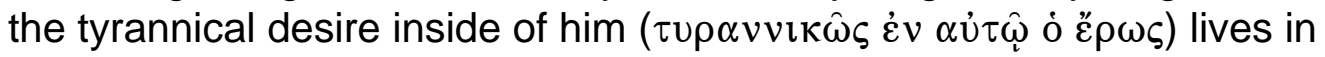
absolute anarchy and lawlessness ( $\dot{\varepsilon} v \pi \dot{\alpha} \sigma \eta \eta \dot{\alpha} v \alpha \rho \chi i \dot{\alpha} \alpha \alpha \dot{\imath} \dot{\alpha} v o \mu i \alpha)$. As the

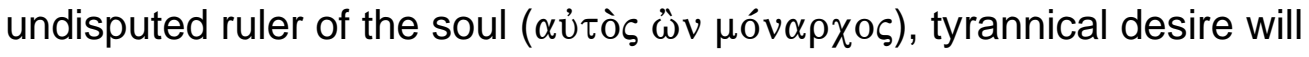
drive $(\ddot{\alpha} \xi \in \imath)$ its host, its subject "city" ( $\pi \hat{\prime} \lambda \iota v)$, to dare anything ( $\dot{\varepsilon} \pi \grave{\imath} \pi \hat{\alpha} \sigma \alpha \nu$ $\tau o ́ \lambda \mu \alpha v) \ldots(\text { Resp. } 574 \mathrm{E}-575 \mathrm{~A})^{150}$

Philo also links inner tyranny with lawless behavior, in a clear allusion to Plato's

Republic:

Anarchy $(\dot{\alpha} v \alpha \rho \chi i \alpha)$.. . is not our only danger. We have to dread also the uprising of some aspirant to sovereign power, forcibly setting law at

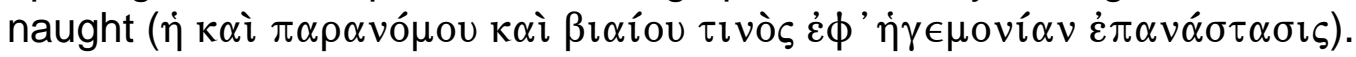

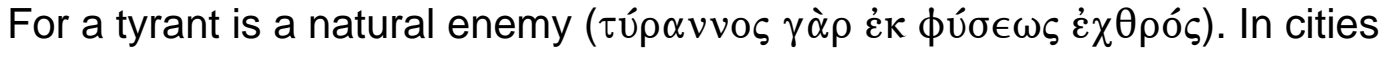
this enemy is man ( $\pi \lambda^{\lambda} \in \omega \nu \mu \grave{\varepsilon} \nu \ddot{\alpha} \nu \theta \rho \omega \pi \circ \varsigma$ ); to body and soul and all the interests of each of these ( $\sigma \omega \hat{\omega} \mu \alpha \tau o \zeta \delta \grave{\varepsilon} \kappa \alpha \grave{\imath} \psi \nu \chi \hat{\eta} \varsigma \kappa \alpha \grave{\imath} \tau \hat{\omega} \nu \kappa \alpha \theta^{\prime} \dot{\varepsilon} \kappa \alpha ́ \tau \epsilon \rho o \nu$ $\pi \rho \alpha \gamma \mu \alpha \tilde{\tau} \tau \omega)$, it is an utterly savage mind, that has turned our inner citadel

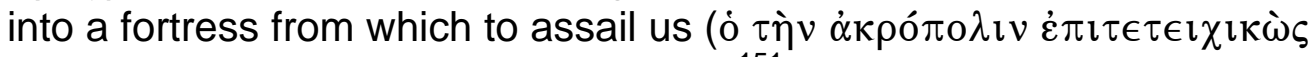

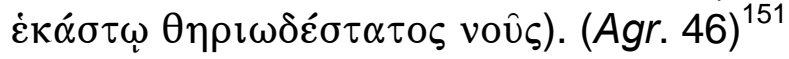

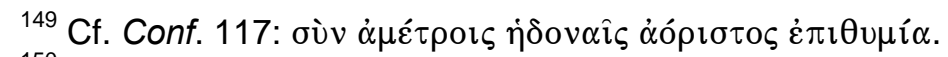

150 My translation.

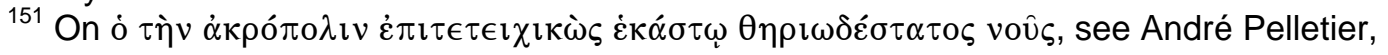
"Les passions à l'assaut de l'âme d'après Philon," REG 78 (1965): 52-60, 56. Cf. Leg. 3.79-80:

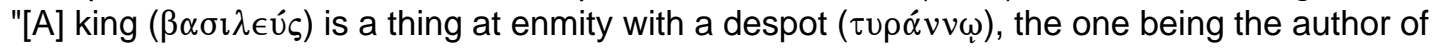

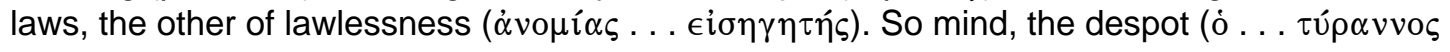


People consumed by tyrannical desire will do anything to get what they want: nothing deters them, not even the law. For instance, Philo in Spec. 4.7 speaks of someone "crazed with a tyrannical desire for what belongs to others" (है $\rho \omega \tau \imath \tau \hat{\omega} v$

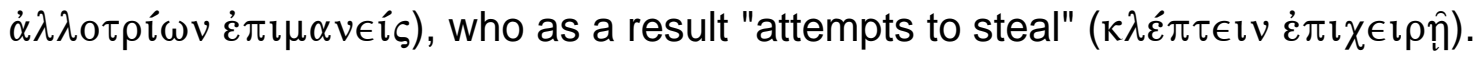

As in Agr. 46, the tyrannical desire for possessions has "set law at naught." Tyrannical desire leads not only to individual acts of lawlessness, but also to violent conflict among entire groups of people. Philo states this most clearly in his exposition of the Tenth Commandment:

[A]mong the passions, only passionate desire deserves the name "Master

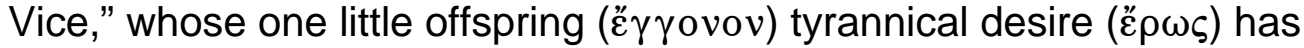
repeatedly filled the world with unspeakable disasters-which, too numerous for land, have spilled out into the sea. Everywhere the vast watery expanse has been filled with ships of war and all the terrible inventions of war. Charging out to sea, their violence runs its course then crashes back like a tide upon the shores of home. (Spec. 4.85$)^{152}$

This same idea appears in Philo's allegorical reading of Tubal, who represents the soul consumed by tyrannical desire ( $\left(\rho^{\prime} \omega\right)^{153}$ and thus all "war makers"

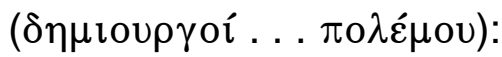

[A]nd that is why they are said to be workers in iron and bronze,${ }^{154}$ and these are the instruments with which wars are waged ( $\delta \imath^{\prime}{ }^{\hat{\omega}} \nu$ oi $\pi$ ó $\left.\lambda \in \mu o \imath\right)$. For any who are looking into the matter would find, that the greatest quarrels both of men individually and of states corporately, have arisen in the past, and are going on now, and will take place in the future, either for

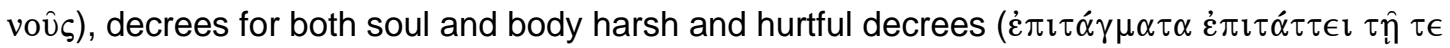

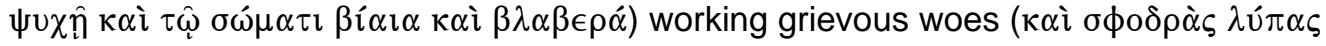

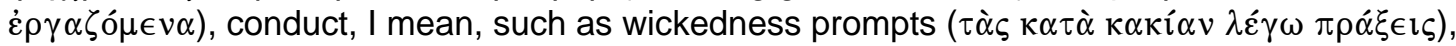
and free indulgence of the passions ( $\tau \grave{\alpha} \varsigma \tau \hat{\omega} \nu \pi \alpha \theta \hat{\omega} \nu \dot{\alpha} \pi \mathrm{o} \lambda \alpha \hat{v} \sigma \epsilon \iota \varsigma) "$ (also Abr. 242).

${ }^{152}$ My translation. Cf. Decal. 151-53.

153 On ع̈ $\rho \omega \varsigma$ in Post. 116-17, see above, n. 142.

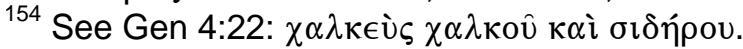


a woman's beauty (

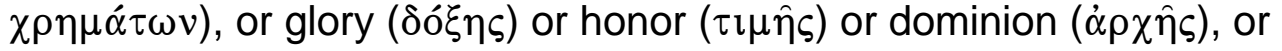
acquisition ( $\kappa \tau \eta \tilde{\sigma} \sigma \omega \varsigma)$, or, in a word, to gain advantages pertaining to the

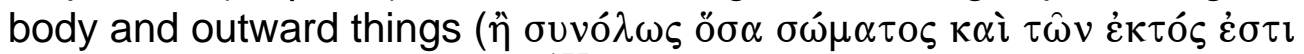
$\pi \lambda \in o v \in \kappa \tau \eta \mu \alpha \tau \alpha)$. (Post. 117) $)^{155}$

Tyrannical desire (๕̋ $\rho \omega \varsigma)$ thus poses a unique threat to both individual and society, representing the maximum ill effect of unrestrained $\dot{\varepsilon} \pi \imath \theta u \mu i \alpha$.

CONCLUSION

Philo holds a coherent, consistently Middle-Platonic theory of $\dot{\varepsilon} \pi \imath \theta u \mu i \alpha$, involving a great variety of terms and concepts. Philo consistently locates $\dot{\varepsilon} \pi \imath \theta u \mu i \alpha$ in the non-rational part of the soul, but he uses different terms to describe that part. This makes $\dot{\varepsilon} \pi \imath \theta u \mu i \alpha$ a fundamentally non-rational phenomenon, which operates according to a non-rational mechanism of stimulus (pleasurable object) and response (pursuit). Discrete instances of $\dot{\varepsilon} \pi \imath \theta u \mu i \alpha$ may

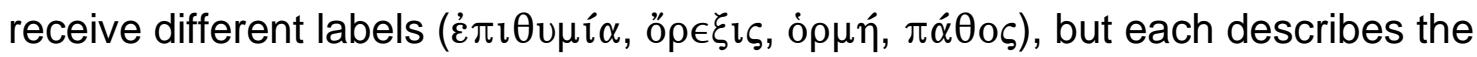
same phenomenon, only from a different conceptual perspective. Desire serves a variety of useful purposes for human beings_most notably the necessary desire for food and drink-and so forms an integral part of life. If not properly managed by reason, however, desire can become an injurious force. Passionate desire signals the partial victory of non-rational desire over reason, in which desire forcibly oversteps the bounds of reason, despite the moral agent's knowledge of what reason requires. Tyrannical desire (ह̋ $\rho \omega \varsigma)$ signals the complete defeat of reason by non-rational desire, in which desire enslaves reason, compelling the

${ }^{155}$ Cf. Conf. 45-50. 
entire soul to pursue desire's single aim of pleasure. So the non-rational desire $(\dot{\varepsilon} \pi \imath \theta \mu i \alpha)$ found in every human soul poses a latent threat, and tyrannical desire (ह̋ $\rho \omega \varsigma)$ represents the absolute realization of that threat. Instead of a useful source of non-rational motivation, desire becomes an awful tyrant, whose despotic rule harms both the individual and the surrounding community.

Clearly, effective management of the threat posed by non-rational desire requires preemptive intervention, an effort to contain the threat before it ever matures. Since the terminal state of intemperance ( $\dot{\alpha} \kappa \circ \lambda \alpha \sigma i \alpha)$ accompanying tyrannical desire always develops from a prior lack of self-control ( $\dot{\alpha} \kappa \rho \alpha \sigma i ́ \alpha)$, preemptive therapeutic intervention must target the preliminary state and the passionate desire associated with it. If non-rational desire always remains within rational bounds, then passionate desire can never emerge, which in turn removes the precondition for tyrannical desire and so precludes its development. The moral quality necessary for keeping non-rational desire in check is self-

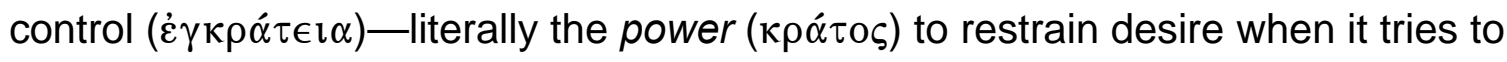
usurp the dictates of reason. So a complete system of practical ethics must

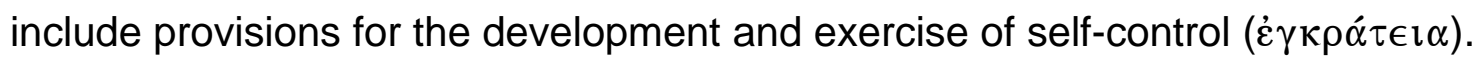




\title{
CHAPTER THREE
}

\section{PHILO ON SELF-CONTROL (EГKPATEIA) AND PRACTICE (A $\Sigma K H \Sigma I \Sigma)$}

\author{
INTRODUCTION
}

Philo considers non-rational desire $(\dot{\varepsilon} \pi \imath \theta u \mu i \alpha)$ a necessary, even useful component of human life, but its innate and invariable tendency to pursue

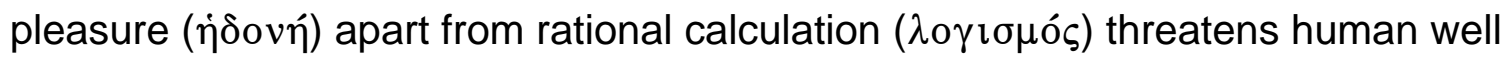
being. The initial danger lies in the ability of $\dot{\varepsilon} \pi \imath \theta u \mu i \alpha$ to oppose and overpower the dictates of reason, to compel moral agents to pursue pleasure against their better judgment in an instance of $\dot{\alpha} \kappa \rho \alpha \sigma i \alpha$ ("lack of self-control"). When an otherwise benign emotion overpowers reason in this way, it becomes a malignant passion, and Middle Platonists conceptualized this transformation as an impulse

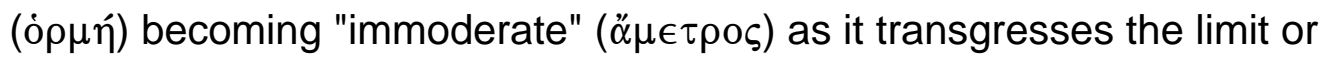
"measure" ( $\mu \varepsilon ́ \tau \rho o v)$ set by reason. Passionate desire unquestionably harms the soul, but the ultimate danger of $\dot{\varepsilon} \pi \imath \theta u \mu i \alpha$ lies not so much in its ability to get the occasional upper hand as in its ability to usurp reason entirely, to rule the moral

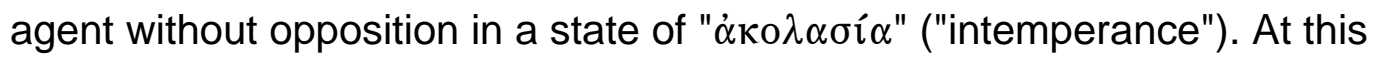
terminal stage, $\dot{\varepsilon} \pi \imath \theta v \mu i \alpha$ becomes an all-consuming tyrannical desire ( $\left.\varepsilon^{\prime} \rho \omega \varsigma\right)$ and the moral agent becomes thoroughly corrupt. 
Self-control ( $\dot{\varepsilon} \gamma \kappa \rho \alpha \dot{\tau} \tau \epsilon \alpha)$ involves the moral agent's ability to assert the dictates of reason over against the demands of desire whenever the two conflict, and by preventing desire from ever getting the upper hand, $\dot{\varepsilon} \gamma \kappa \rho \alpha ́ \tau \epsilon \iota \alpha$ eliminates the risk of tyrannical desire entirely. Recognizing its critical importance for the overall health of the soul, Philo speaks highly of $\dot{\varepsilon} \gamma \kappa \rho \dot{\alpha} \tau \in \iota \alpha$ and gives it a prominent role in his ethical theory. ${ }^{1}$ This chapter explains Philo's concept of $\dot{\varepsilon} \gamma \kappa \rho \alpha \dot{\tau} \epsilon \iota \alpha$ in light of Middle-Platonic moral psychology, addressing in turn the fundamental questions of what $\dot{\varepsilon} \gamma \kappa \rho \alpha \dot{\tau} \epsilon \iota \alpha$ is and how to acquire it.

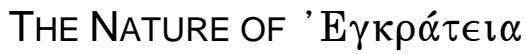

Philo has a coherent but multi-faceted concept of $\dot{\varepsilon} \gamma \kappa \rho \alpha \dot{\tau} \tau \epsilon \alpha$, whose character emerges best by considering three of its aspects. First, $\dot{\varepsilon} \gamma \kappa \rho \alpha ́ \tau \epsilon \iota \alpha$ simply involves a power dynamic, in which reason engages and overpowers a

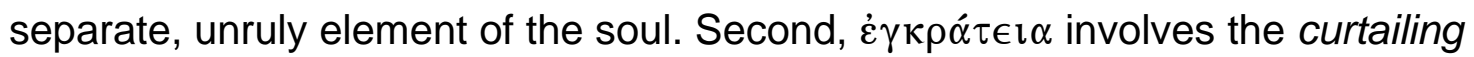
of excessive impulse, and so it figures prominently in a Middle-Platonic theory of passion, especially through the Platonic image of reason as charioteer. Finally, $\dot{\varepsilon} \gamma \kappa \rho \alpha ́ \tau \epsilon \iota \alpha$ involves a predominance of rational motivation, in which the urge to secure a rationally determined, ultimate benefit for the entire soul outweighs the urge to experience an immediate pleasure.

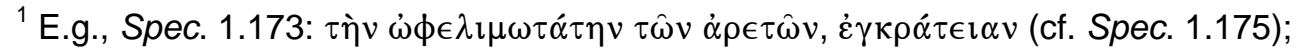

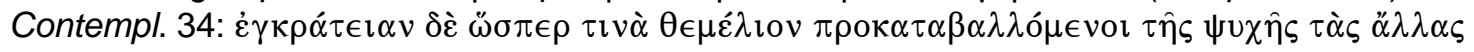

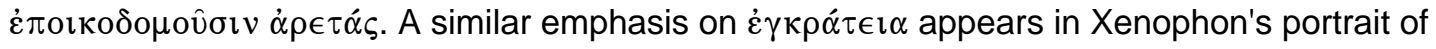




\section{'E $\gamma \kappa \rho \alpha ́ \tau \epsilon \iota \alpha$-- Victory of Rational over Non-Rational}

The Platonic tradition associates $\dot{\varepsilon} \gamma \kappa \rho \alpha \dot{\tau} \tau \in \iota \alpha$ with the victory of reason, but it characterizes reason's opponent in different ways. One broad formulation simply pits reason against the rest of the soul, understood more or less as a single inferior "part" whose inferiority stems from a lack of reasoning capacity. One narrow formulation pits reason against only desire ( $\left.\dot{\varepsilon} \pi \imath \theta \mu i{ }^{\alpha} \alpha\right)$, based on a theoretical correlation of specific virtues with specific elements of the tripartite Platonic soul. Philo uses both of these formulations in his ethical discourse.

The broad formulation appears in Plato's Republic as a reflection on the division within the soul presumed by the term $\dot{\varepsilon} \gamma \kappa \rho \dot{\alpha} \tau \in \iota \alpha$ itself, which commonly

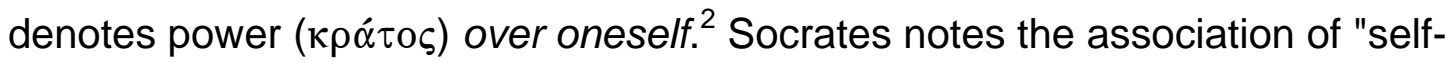

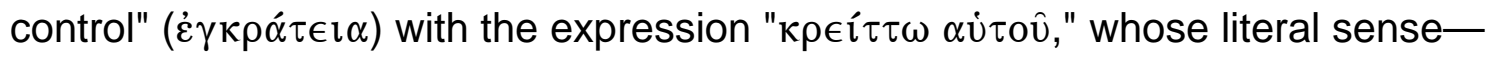
"stronger than himself"—creates confusion:

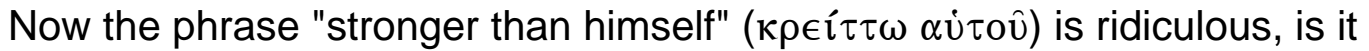
not? For anyone stronger than himself (o $\gamma \grave{\alpha} \rho \dot{\varepsilon} \alpha \nu \tau o \hat{v} \kappa \rho \in i ́ \tau \tau \omega \nu)$ would also be weaker than himself (

\footnotetext{
Socrates in the Memorabilia (see Louis-André Dorion, "Akrasia et enkrateia dans les Mémorables de Xénophon," Dialogue 42 (2003): 645-72, esp. 646-50 [="La prééminence de l'enkrateia"].

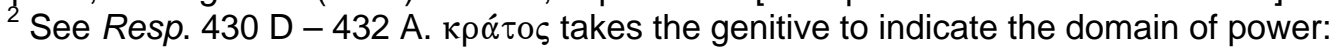
power over someone or something (see LSJ, s.v.). Walter Grundmann suggests that $\dot{\varepsilon} \gamma \kappa \rho \alpha \dot{\tau} \tau \epsilon \alpha$

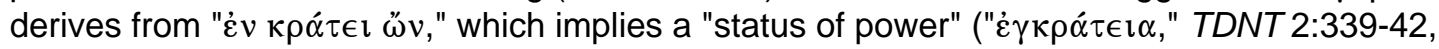

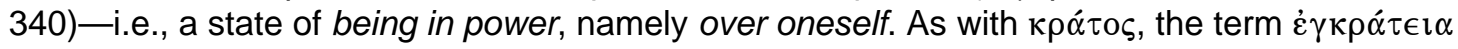
can also take the genitive, at least in earlier usage (e.g., Resp. 390 B: $\dot{\varepsilon} \gamma \kappa \rho \alpha ́ \tau \epsilon \iota \alpha \nu \dot{\varepsilon} \alpha u \tau o \hat{)}$ ). But the reflexive pronoun eventually became unnecessary (see A. A. Long, "Hellenistic Ethics and Philosophical Power," in Hellenistic History and Culture [ed. Peter Green; HCS 9; Berkeley: University of California Press, 1993], 138-56, esp.144. Philo never uses $\dot{\varepsilon} \gamma \kappa \rho \alpha ́ \tau \epsilon \iota \alpha$ with the reflexive pronoun, despite his use of equivalent expressions elsewhere: Post. 42: ôs $\mu \eta \delta$ ' $\alpha \dot{v} \tau o \hat{v}$

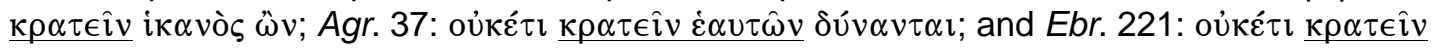

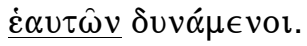




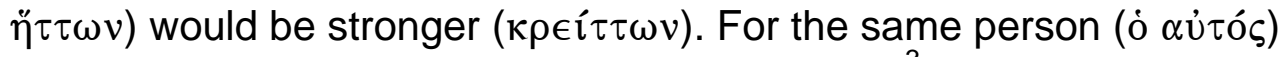
figures in all of these expressions. (Resp. $431 \mathrm{~A})^{3}$

Socrates, however, further explains what people really mean by such

expressions, despite the obscurity:

[T]he soul of man within him has a better part ( $\tau$ ò $\mu \grave{\varepsilon} v \beta \varepsilon \dot{\lambda} \tau \tau \imath o v$ ) and a worse part ( $\tau$ ò $\delta \grave{\varepsilon} \chi \in \hat{\imath} \rho o v)$, and the expression "being stronger than himself" ( $\tau$ ò $\kappa \rho \in i \tau \tau \omega \alpha \dot{u} \tau o \hat{u})$ really means the control of the worse by the

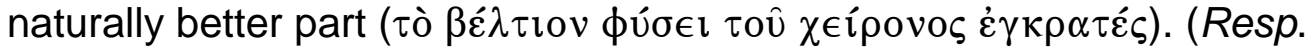
431 A)

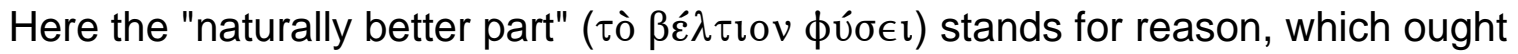
to be in control ( $\dot{\varepsilon} \gamma \kappa \rho \alpha \tau \varepsilon$ s). But Plato never clearly identifies the "worse part" ( $\tau$ ò $\chi \in \hat{\imath} \rho \circ v)$, here or elsewhere, because he never clearly formulates a bipartite model of the soul. ${ }^{4}$ Middle Platonists, however, ultimately preferred a bipartite model of the soul, envisioning simply a "rational part" over a "non-rational part," and they developed a broad conception of $\dot{\varepsilon} \gamma \kappa \rho \alpha \dot{\tau} \tau \epsilon \alpha$ along these lines:

Whenever the rational part of the soul overpowers the non-rational part ( $\tau$ ò

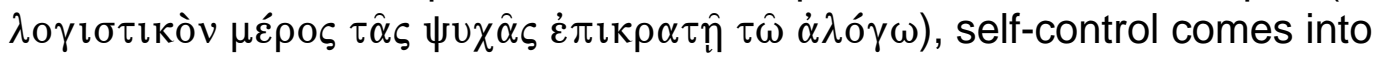
existence $(\gamma \dot{i} v \in \tau \alpha \imath$. . . غ $\gamma \kappa \rho \alpha \dot{\tau} \tau \in \iota \alpha)$. Whenever the non-rational part of the

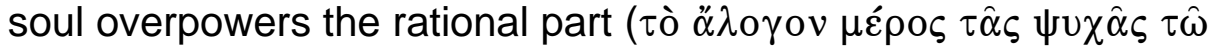

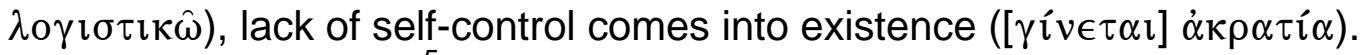
(Ps.-Metop.117.16-18) $)^{5}$

${ }^{3}$ On this passage, see also Plutarch, Virt. mor. 450 D-E. Cf. Leg. 626 E: "[T]he victory

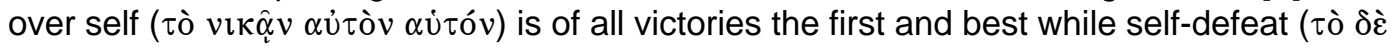

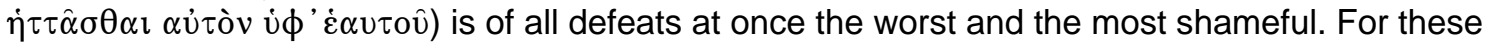

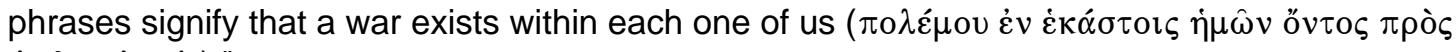
$\dot{\eta} \mu \hat{\alpha} \varsigma \alpha \dot{\tau} \tau o u ́ \varsigma) . "$

${ }_{5}^{4}$ Despite evidence for the concept of bipartition (see Rees, "Bipartition").

${ }^{5}$ My translation. Cf. Plutarch, Virt. mor. 442 A: "[The soul of man] has as one part the

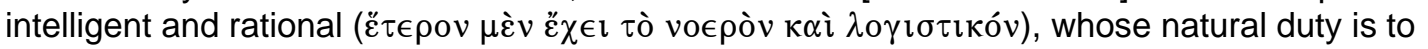

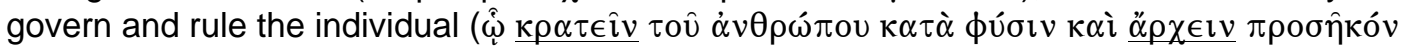

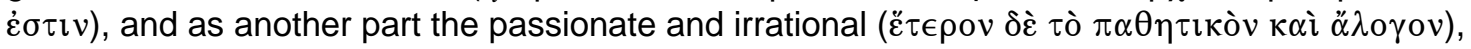
the variable and disorderly ( $\pi 0 \lambda v \pi \lambda \alpha \nu \grave{\varepsilon} \zeta \kappa \alpha \grave{\imath} \ddot{\alpha} \tau \alpha \kappa \tau o \nu)$, which has need of a director $(\dot{\varepsilon} \xi \in \tau \alpha \sigma \tau o \hat{v}$ 
Although Philo never defines $\dot{\varepsilon} \gamma \kappa \rho \alpha \dot{\tau} \tau \epsilon \alpha$ in this way, he presumes this sort of definition when, for example, he interprets biblical references to "shepherding"

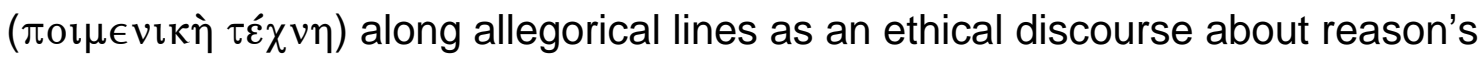
management of the "herd" ( $\dot{\alpha} \gamma \hat{\varepsilon} \lambda \eta)$ of non-rational powers within the soul (Agr. 26-66). ${ }^{6}$ Consistent with Philo's Middle-Platonic moral psychology, this line of interpretation envisions a basic power dynamic in the soul between a rational component fit to govern and a separate, non-rational component in need of governance. ${ }^{7}$ As long as the non-rational component tractably accepts governance, all is well. But when the two components conflict, moral well being hinges on the presence or absence of $\dot{\varepsilon} \gamma \kappa \rho \alpha \dot{\tau \epsilon \iota \alpha}$. Its presence consists in the

$\delta \in o ́ \mu \epsilon v o v)$ " (unless otherwise noted, all translations of Plutarch's writings are from the Loeb

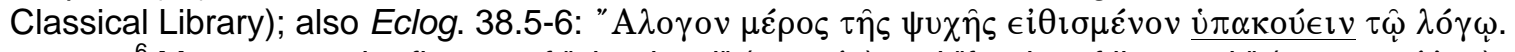

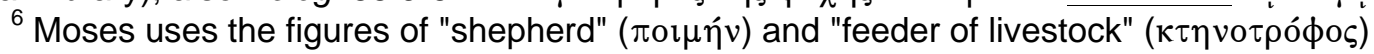
respectively to speak of the rational faculty engaged in either good or bad management of its

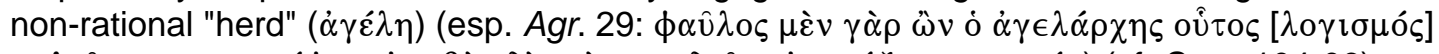

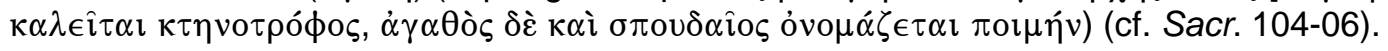
Figurative representations of the soul as a combination of "Man" (rational) and "Beast" (nonrational) suit the Platonic moral psychology particularly well. See Annas, Platonic Ethics, 117-36 [="Humans and Beasts: Moral Theory and Moral Psychology"], esp. 134-36. Cf. Theo Heckel, Der innere Mensch: Die paulinische Verarbeitung eines platonischen Motivs (WUNT 53; Tübingen: J.C.B. Mohr, 1993). Heckel considers the Platonic image of the tripartite soul as "man" (

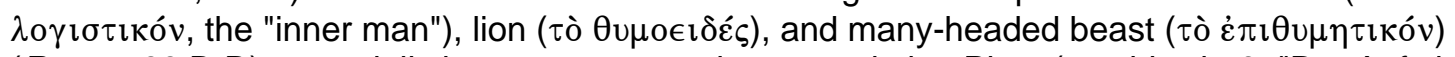
(Resp. 588 B-D), especially its use among authors postdating Plato (see his ch. 3, "Der Aufstieg der Metapher vom 'Inneren Menschen' und die neue Platonhermeneutik ab dem ersten Jh. v. Chr.," 31-88, esp. 42-76 [="Der 'Innere Mensch' bei Philon"]).

7 Philo's subdivision of the non-rational component into five senses, the organs or speech, and the organs of reproduction (Agr. 30) in no way undermines the fundamentally bipartite conception of the soul presumed in his shepherding allegory (see above, 72-77). In this case, the manifold nature of the non-rational part simply fits the characterization of reason as manager of a non-rational "herd." On Philo's conviction that the "better" (rational) part ought to

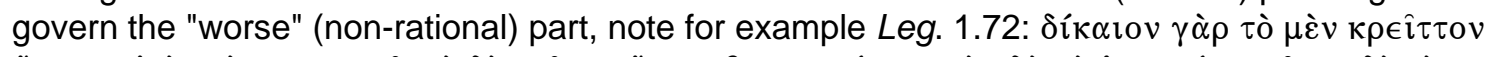

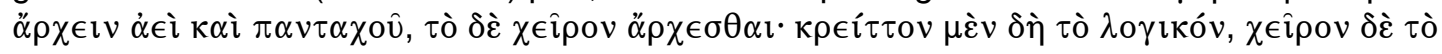

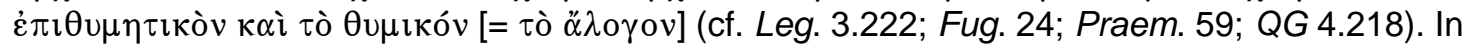


ability of the rational to overpower the non-rational, and Philo attributes precisely

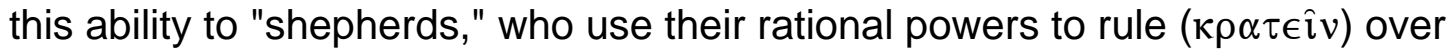
the non-rational forces within. ${ }^{8}$ The absence of $\dot{\varepsilon} \gamma \kappa \rho \dot{\alpha} \tau \in \iota \alpha(\dot{\alpha} \kappa \rho \alpha \sigma i \alpha)$ similarly involves a question of power, but in this case non-rational forces overpower the rational. Philo can use the shepherding allegory to depict this disastrous situation:

$[T]$ he stream of these evils becomes most grievous when the non-rational forces of the soul attack and overpower the forces of reason ( $\dot{\varepsilon} \pi \in \hat{\delta} \dot{\alpha} \nu \alpha i$

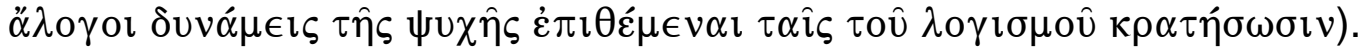

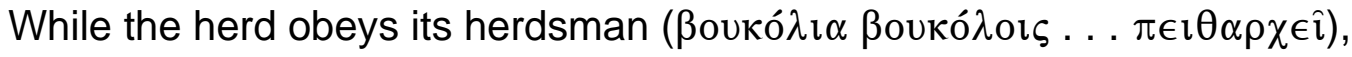
or the flocks of sheep or goats obey the shepherd or goatherd ( $\ddot{\eta} \pi \circ \imath \mu \varepsilon \varepsilon \sigma$

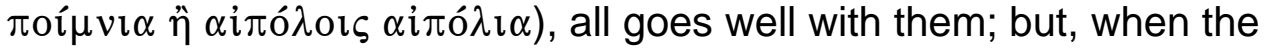
controlling herdsmen $(\dot{\alpha} \gamma \in \lambda \dot{\alpha} \rho \chi \alpha \imath)$ prove weaker than their charges ( $\dot{\alpha} \sigma \theta \epsilon \nu \varepsilon \dot{\sigma} \tau \epsilon \rho \circ \tau \tau \hat{\omega} \nu \theta \rho \epsilon \mu \mu \dot{\alpha} \tau \omega \nu)$, everything goes awry. (Somn. 2.151-52)

Although Philo sees reason engaged in a struggle against certain "powers of the

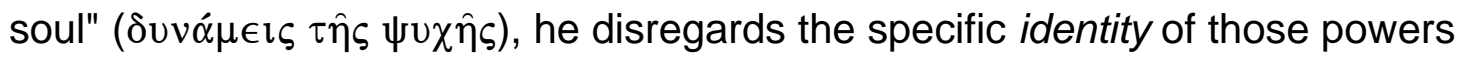

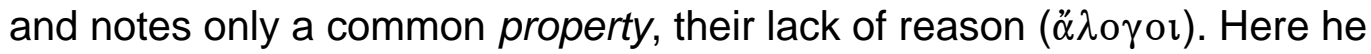
construes $\dot{\varepsilon} \gamma \kappa \rho \dot{\alpha} \tau \epsilon \iota \alpha$ in the broadest possible terms: a variety of distinct opponents may contend with reason (desire, anger, fear, etc.), but they necessarily offer only one type of opposition, non-rational opposition. The value of such a broad formulation lies in its ability to construe the forcible control of any non-rational movement as an instance of $\dot{\varepsilon} \gamma \kappa \rho \alpha \dot{\tau} \tau \epsilon \iota \alpha$.

Opif. 83-86, Philo expresses a similar conviction: human beings (rational) ought to govern animals (non-rational).

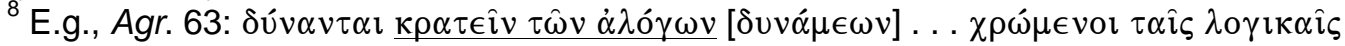

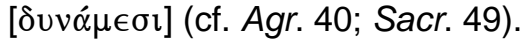


The narrow formulation of $\dot{\varepsilon} \gamma \kappa \rho \alpha ́ \tau \epsilon \iota \alpha$ ultimately derives from a

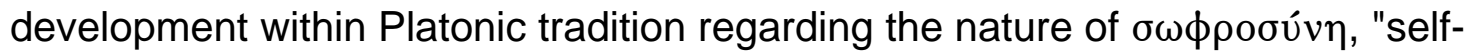

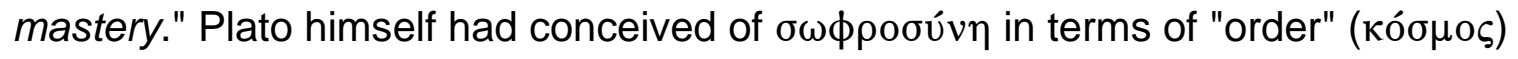
or "concord" ( $\xi u \mu \phi \omega v i \alpha)$ among all parts of the soul as to which part should rule (óđó $\epsilon \in \rho o v \delta \in \hat{\imath} \ddot{\alpha} \rho \chi \in \imath$ ). ${ }^{9}$ But Middle Platonists, dogmatically assigning a single cardinal virtue to each of the soul's parts, narrowed the scope of $\sigma \omega \phi \rho o \sigma u ́ v \eta$ from an agreement involving the entire soul to simply a governance of $\tau \grave{o}$ $\dot{\varepsilon} \pi \imath \theta u \mu \eta \tau \imath \kappa o ́ v$, the seat of $\dot{\varepsilon} \pi \imath \theta u \mu i \alpha .{ }^{10}$ Philo reflects this trend:

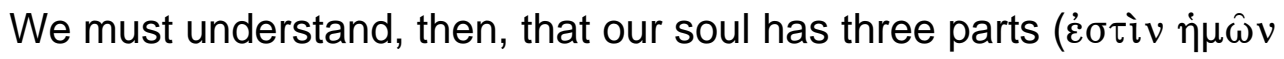

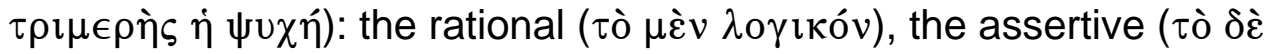

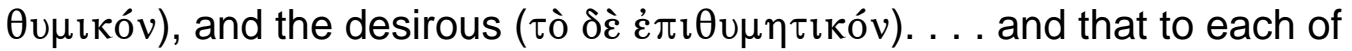
the parts an appropriate virtue has been attached $(\dot{\alpha} \rho \in \tau \grave{\eta} \nu \delta \grave{\varepsilon} \dot{\varepsilon} \kappa \dot{\alpha} \sigma \tau \omega \tau \hat{\omega} \nu$ $\mu \in \rho \hat{\omega} \nu$ oi $\left.\epsilon_{i} \alpha \nu \pi \rho o \sigma \eta \rho \mu o ́ \sigma \theta \alpha \imath\right)$ : prudence to the rational part $(\tau \hat{\omega} \mu \grave{\varepsilon} v$

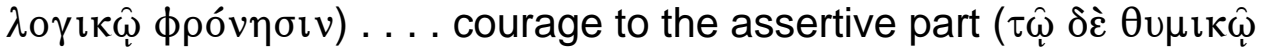
$\dot{\alpha} v \delta \rho \in \dot{\alpha} \alpha v)$; and self-mastery to the desirous part ( $\tau \hat{\omega} \hat{\iota} \delta \dot{\varepsilon} \dot{\varepsilon} \pi \imath \theta u \mu \eta \tau \imath \kappa \hat{\omega}$ $\sigma \omega \phi \rho о \sigma v ́ v \eta v)$. For it is by self-mastery that we heal and cure our desires

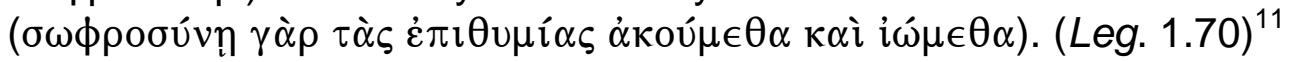

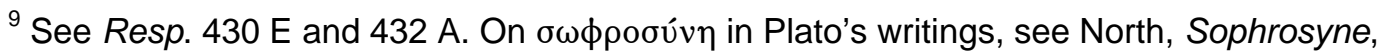
150-96.

${ }^{10} \mathrm{Cf}$. North, Sophrosyne, 173: "[S]ophrosyne must be practiced by all three parts of the soul; it is never, for Plato, as for many later Platonists, solely the virtue of the appetitive part" (cf. Lilla, Clement of Alexandria, 78, n. 2). On the doctrine of virtues for each part in Middle Platonism, see Lilla, Clement of Alexandria, 72-84, esp.80-83. In addition to the passages Lilla

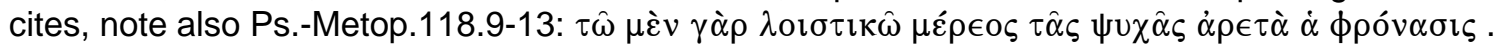

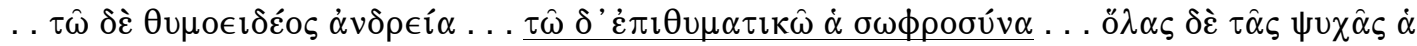

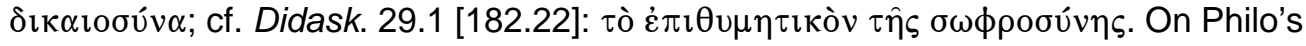
understanding of the cardinal virutes, see Carl Joachim Classen, "Der platonisch-stoische Kanon der Kardinaltugenden bei Philo, Clemens Alexandrinus und Origenes," in Kerygma und Logos: Beiträge zu den geistesgeschichtlichen Beziehungen zwischen Antike und Christentum (ed. Adolf Ritter; Göttingen: Vandenhoeck \& Ruprecht, 1979), 68-88, esp. 70-75; Wofson, Philo, 2:218-35; and in general, Pierre Daubercies, "La vertu chez Philon d'Alexandrie," RTL 26 (1995): 185-210.

${ }^{11}$ My translation.
} 
As the "appropriate virtue" for the $\dot{\varepsilon} \pi \imath \theta u \mu \eta \tau \imath \kappa o ́ v, \sigma \omega \phi \rho о \sigma u ́ v \eta$ accordingly manages the non-rational desires ( $\tau \grave{\alpha} \varsigma \dot{\varepsilon} \pi \imath \theta u \mu i \alpha \varsigma$ ) generated in that part of the soul—and it manages them well. Philo associates $\sigma \omega \phi \rho o \sigma u ́ v \eta$ with the "healing" and "curing" of desire, suggesting a state of moral wellness in which desire operates only as it should. In other words, $\sigma \omega \phi \rho o \sigma u ́ v \eta$ represents the ideal sort of management, in which $\dot{\varepsilon} \pi \imath \theta v \mu i \alpha$ plays the obedient servant of reason, acting only with reason's authorization and never opposing its dictates. Plutarch characterizes the man of self-mastery along similar lines:

And you would say, as you looked at the man, "Then, indeed ceased the gale; a windless calm arose; some god had laid the waves to rest" [Od. 12.168], since by reason the violent, raging, and furious movements of the desires ( $\kappa \imath \nu \eta \mu \alpha \tau \alpha \tau \hat{\omega} \nu \dot{\varepsilon} \pi \imath \theta u \mu \imath \hat{\omega} v)$ had been quenched and those

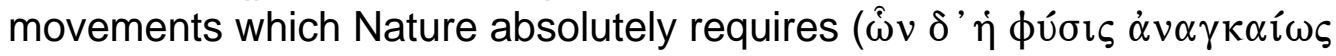

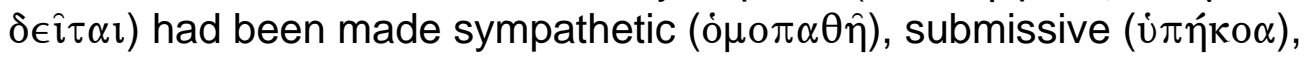
friendly $(\phi i \lambda \alpha)$, and, when the man chose a course of action, willing to cooperate $(\sigma u v \in \rho \gamma \alpha \tilde{\alpha})$, so that they did not outstrip the dictates of reason $(\mu \grave{\eta}$

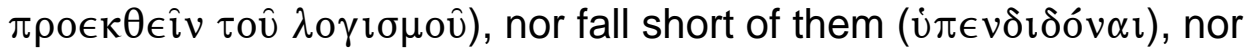
misbehave ( $\dot{\alpha} \tau \alpha \kappa \tau \epsilon \hat{\imath} v)$, nor disobey $(\dot{\alpha} \pi \epsilon \imath \theta \epsilon \hat{\imath} v)$, but so that every impulse

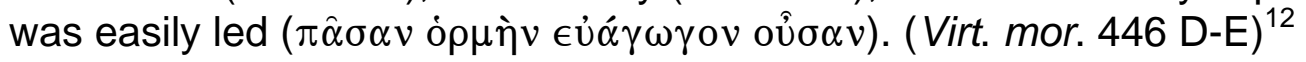

Plutarch situates this concept of self-mastery at the top of a four-point scale depicting four possible relations between reason and desire: reason rules desire without conflict ( $\sigma \omega \phi \rho о \sigma u ́ v \eta)$, reason rules desire with conflict ( $\dot{\varepsilon} \gamma \rho \dot{\alpha} \tau \in \iota \alpha)$, desire rules reason with conflict ( $\dot{\alpha} \kappa \rho \alpha \sigma i \alpha)$, and desire rules reason without

${ }^{12}$ Cf. TL 82: öpos $\sigma \omega \phi \rho o \sigma u ́ v \alpha \varsigma \in \dot{u} \pi \in i ́ \theta \epsilon \iota \alpha$. 
conflict $(\dot{\alpha} \kappa о \lambda \alpha \sigma i \alpha) .{ }^{13}$ Despite occasional lapses in technical precision, Philo demonstrates a fundamental acceptance of this same scale in his ethical theory. For example, he identifies moral "opposites" according to the terms of the scale, correlating the terms denoting absence of conflict ( $\sigma \omega \phi \rho о \sigma u ́ v \eta$ and $\dot{\alpha} \kappa о \lambda \alpha \sigma i \alpha)$ and the terms denoting its presence ( $\dot{\varepsilon} \gamma \kappa \rho \dot{\alpha} \tau \epsilon \iota \alpha$ and $\dot{\alpha} \kappa \rho \alpha \sigma i \alpha) .{ }^{14}$ Furthermore, Philo's ethical theory presumes and depicts, in a variety of ways, the four types of relation between reason and desire outlined by the scale, so he affirms its distinctions by implication if not always by name ${ }^{15}$ Philo's general acceptance of such a well-developed scheme, especially its distinction between self-mastery and self-control, helps to clarify his concept of $\dot{\varepsilon} \gamma \kappa \rho \alpha \dot{\tau} \tau \iota \alpha$.

Like $\sigma \omega \phi \rho o \sigma u ́ v \eta$, which in Middle-Platonic theory deals specifically with the $\dot{\varepsilon} \pi \imath \theta v \mu \eta \tau \imath \kappa o ́ v, \dot{\varepsilon} \gamma \kappa \rho \alpha ́ \tau \epsilon \iota \alpha$ deals specifically with $\dot{\varepsilon} \pi \imath \theta v \mu i \alpha$, but in a different

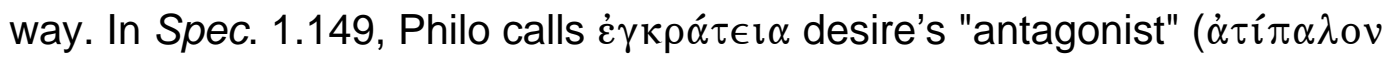
$\dot{\varepsilon} \pi \imath \theta u \mu i \alpha \varsigma)$, and this image captures the essential difference between $\dot{\varepsilon} \gamma \kappa \rho \dot{\alpha} \tau \epsilon \imath \alpha$ and $\sigma \omega \phi \rho о \sigma u ́ v \eta$. In the case of "self-mastery," reason placidly manages an ever docile desiderative faculty. But in the case of "self-control," reason struggles against desire in an active contest of power: reason does manage to assert its

${ }^{13}$ Plutarch gives a detailed overview of this scale in Virt. mor. $445 \mathrm{~B}-446 \mathrm{E}$. The ethical theory underlying the scale comes from Book VII of Aristotle's Nicomachean Ethics (see North, Sophrosyne, 203).

${ }^{14}$ For $\sigma \omega \phi \rho о \sigma u ́ v \eta$ opposed to $\dot{\alpha} \kappa o \lambda \alpha \sigma i \alpha$, see for example Opif. 73: $\tau \dot{\alpha} v \alpha \nu \tau i \dot{\alpha} \ldots$

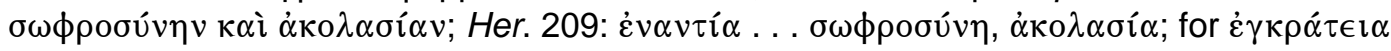

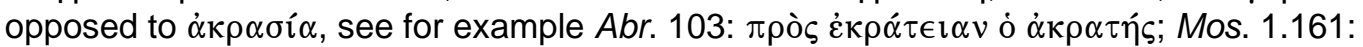

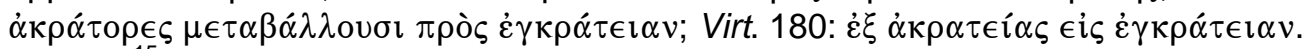

${ }^{15}$ See above, 87-93. 
directives, but only against—and over—desire's positive opposition to those directives. Plutarch characterizes the man of self-control along these lines:

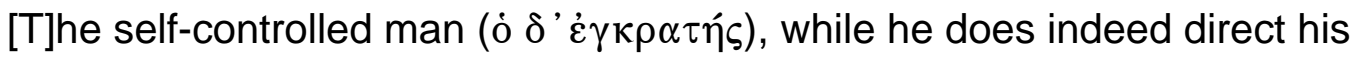

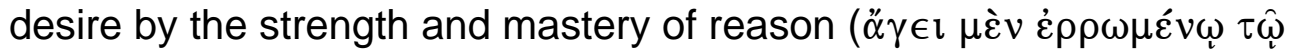

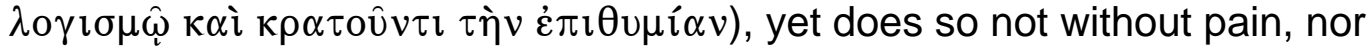

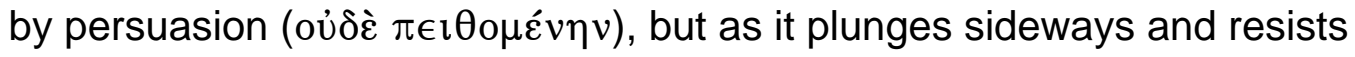

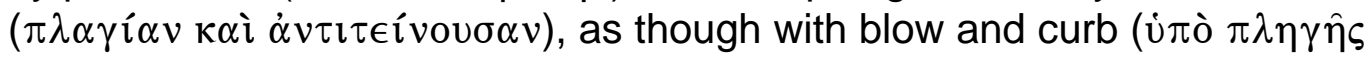

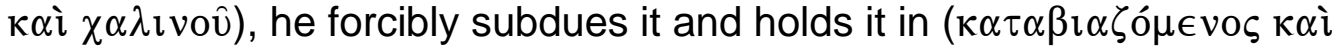
$\dot{\alpha} v \alpha \kappa \rho o v(\omega v)$, being the while himself full of internal struggle and turmoil

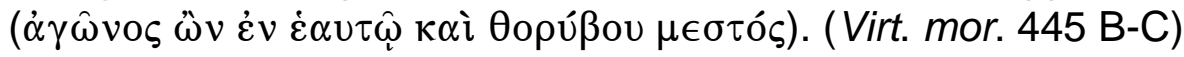

Because self-control involves an active conflict between reason and desire, Plutarch uses terms of strength, force, and violent opposition to characterize it. Philo demonstrates a similar view of self-control and uses similar language in his own characterizations, although he never states his theoretical positions quite as clearly as Plutarch. ${ }^{16}$ He does, however, encapsulate his understanding of $\dot{\varepsilon} \gamma \kappa \rho \alpha ́ \tau \epsilon \iota \alpha$ in an interpretive reflection on the creature known as the "snake-

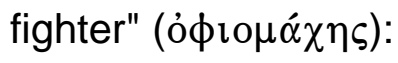

For the snake-fighter is, I think, nothing but a symbolic representation of self-control ( $\sigma u \mu \beta 0 \lambda \imath \kappa \hat{\omega} \varsigma \dot{\varepsilon} \gamma \kappa \rho \dot{\alpha} \tau \epsilon \iota \alpha \in \hat{i} v \alpha \imath)$, waging a fight that never ends and a truceless war against intemperance and pleasure ( $\mu \alpha \dot{\alpha} \eta \nu$

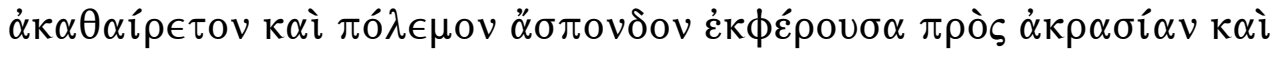

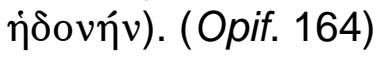

The notions of "never ending fight" ( $\mu \dot{\alpha} \chi \eta v \dot{\alpha} \kappa \alpha \theta \alpha i \rho \in \tau o v)$ and "truceless war" ( $\pi$ ó $\lambda \in \mu o v \ddot{\alpha} \sigma \pi \circ \nu \delta o v)$ obviously convey the element of conflict characteristic of $\dot{\varepsilon} \gamma \kappa \rho \alpha ́ \tau \epsilon \iota \alpha$. And despite Philo's naming here of $\dot{\alpha} \kappa \rho \alpha \sigma i \alpha$ and $\dot{\eta} \delta \circ \nu \eta \dot{~ a s ~ t h e ~}$

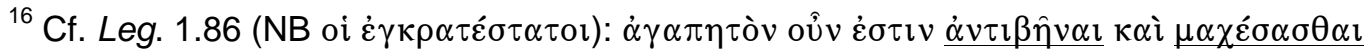

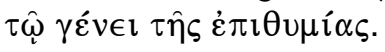


opponents of $\dot{\varepsilon} \gamma \kappa \rho \alpha \dot{\tau} \tau \epsilon \alpha$, he in no way contradicts the notion of a fundamental

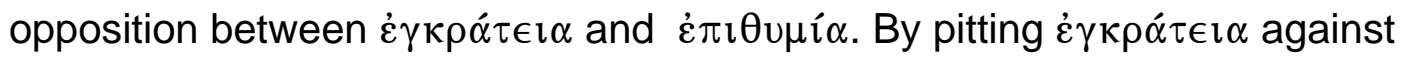
$\dot{\alpha} \kappa \rho \alpha \sigma i \alpha$, Philo simply notes that self-control subverts the victory of desire over

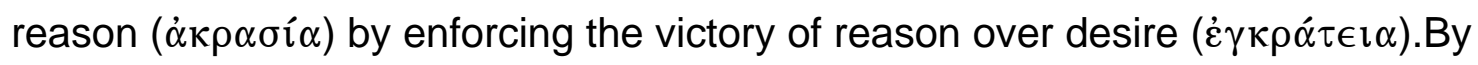
pitting $\dot{\varepsilon} \gamma \kappa \rho \alpha ́ \tau \epsilon \iota \alpha$ against $\dot{\eta} \delta o v \eta ́$, Philo simply recognizes pleasure as the constant and necessary counterpart of desire. Since Platonic $\dot{\varepsilon} \pi \imath \theta u \mu i \alpha$ invariably seeks $\dot{\eta} \delta o v \eta ́$ as its object, pleasure and desire ultimately represent twin aspects of the same phenomenon, and for that reason $\dot{\varepsilon} \gamma \kappa \rho \alpha \dot{\tau} \tau \epsilon \iota \alpha$ interchangeably represents the antagonist of either one. ${ }^{17}$ But in either case $\dot{\varepsilon} \gamma \kappa \rho \dot{\alpha} \tau \epsilon \iota \alpha$ involves active management of one part of the soul, the $\dot{\varepsilon} \pi \imath \theta u \mu \eta \tau \imath \kappa o ́ v$.

Whether formulated broadly as the dominance of rational over non-rational forces or narrowly as the dominance of reason over desire, $\dot{\varepsilon} \gamma \kappa \rho \alpha \dot{\tau} \epsilon \iota \alpha$ always involves a decisive contest of power. Since only reason can successfully direct the soul on a virtuous course of life, moral well being demands an ability to overcome any opposition to reason, no matter the source. Conceiving $\dot{\varepsilon} \gamma \kappa \rho \dot{\alpha} \tau \epsilon \iota \alpha$ along these lines, as simply a power dynamic, rightly identifies self-control with the victory of reason, but it does nothing to define that victory. A more precise

\footnotetext{
${ }^{17}$ In Philo's discussion of $\sigma \omega \phi \rho o \sigma u ́ v \eta$ in Leg. 1, he links self-mastery with the $\dot{\varepsilon} \pi \imath \theta u \mu \eta \tau \imath \kappa o ́ v$ alone (\$§70-71) yet-in line with the Platonic view of $\dot{\varepsilon} \pi \imath \theta u \mu i \alpha$-presumes its

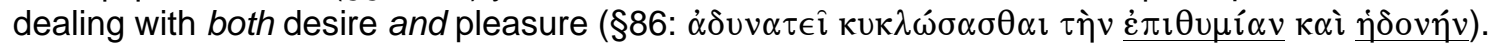
Since it deals with the same part of the soul, $\dot{\varepsilon} \gamma \kappa \rho \alpha \dot{\tau} \tau \iota \alpha$ deals also with both desire and pleasure: either the forcible subjugation of $\dot{\varepsilon} \pi \imath \theta u \mu i \alpha$ or the forcible abstention from $\dot{\eta} \delta o v \eta$ (cf. Ps.-Metop.

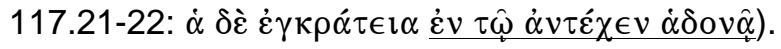


concept of $\dot{\varepsilon} \gamma \kappa \rho \alpha ́ \tau \epsilon \iota \alpha$ emerges through Philo's use of what he and other Middle

Platonists took as a model of self-control in action: the two-horse chariot.

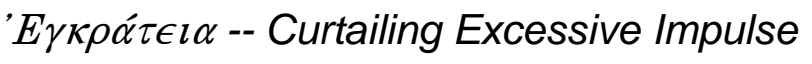

While he owes the analogy between soul and chariot to Plato's Phaedrus

(esp. 246 A-B; 253 D - 256 D), Philo's particular use of the chariot figure to depict غ̇ $\gamma \kappa \rho \alpha ́ \tau \epsilon \iota \alpha$ reflects a decidedly Middle-Platonic moral psychology and a set of didactic aims different from Plato's. ${ }^{18}$ In the Phaedrus, the chariot figure helps to narrate a myth of the soul's journey to transcendent reality, not to expound moral theory. ${ }^{19}$ The struggle between charioteer and horse obviously symbolizes conflict within the soul, but Plato examines this conflict strictly in terms of the myth, not as a separate ethical concern. ${ }^{20}$ In Philo's writings, by contrast, the chariot figure serves as a working model for moral psychology, stripped of any explicit connection with the Phaedrus myth and framed according

${ }^{18}$ On Philo's use of the Phaedrus image, see esp. Méasson, Char ailé, 141-76; also Billings, Platonism of Philo, 88-92. On the broader use of the Phaedrus image in Middle Platonism, see Vander Waerdt, "Moral Psychology," 390 (cf. Lilla, Clement of Alexandria, 92-103, esp. 97). Within Middle Platonism, Philo's use takes precedence, as Méasson notes: "l'œuvre de Philon est sans doute le plus ancien témoignage subsistant de l'utilisation de cette image destiné à devenir un des themes familiers du moyen platonisme" (176). On the chariot as a model of

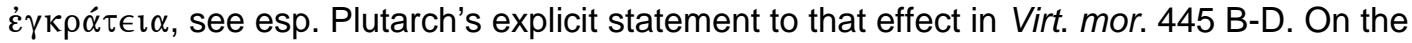
Phaedrus image in Plutarch, see François Fuhrmann, Les images de Plutarque (Paris: C. Klincksieck, 1964), 141, n. 2; cf. Opsomer, "L'âme du monde," 46-47; Rhiannon Ash, "Severed Heads: Individual Portraits and Irrational Forces in Plutarch's Galba and Otho," in Plutarch and his Intellectual World: Essays on Plutarch (ed. Judith Mossman; London: Duckworth, 1997), 189214, 192-96.

${ }^{19}$ See Anne Lebeck, "The Central Myth of Plato's Phaedrus," GRBS 13 (1972): 267-90

${ }^{20}$ See Jacqueline de Romilly, "Les conflits de l'âme dans le Phèdre de Platon" WS 16 (1982): 100-13, esp. 112, where she concludes concerning the conflict depicted through the chariot figure: "Il s'agit, en commandant mieux à l'attelage de notre âme, de pouvoir monter jusqu'au lieu supracéleste, et, pour finir, d'échapper au cycle des incarnations. Ou bien il s'agit, dans le cas contraire, de s'empêtrer dans la matière et les souffrances infinies au'entraîne cette déchéance." 
to Middle-Platonic conceptions of the soul. Gone, for example, are the wings of the chariot-soul so indispensable to the mythical narrative. ${ }^{21}$ And just as MiddlePlatonic bipartition recast $\theta u \mu o ́ \varsigma$ as more of an opponent of reason than an ally, Philo pits both horses against the driver, replacing the Phaedrus notion of a "bad" horse $(\dot{\varepsilon} \pi \imath \theta u \mu i \alpha)$ yoked to an obedient "good" horse $(\theta u \mu o ́ s) .{ }^{22}$ In further agreement with Middle-Platonic moral psychology, which offered variant

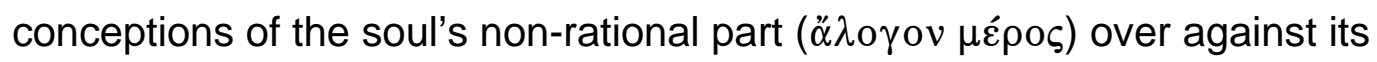

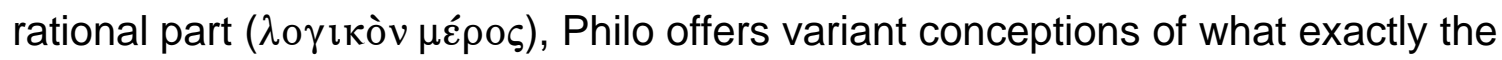
soul's driver, reason, must manage. Reflecting Middle Platonism's configuration of tripartition as bipartition, Philo can speak of either two horses, $\theta u \mu$ ó $\varsigma$ and $\dot{\varepsilon} \pi \imath \theta u \mu i \alpha$, or a single horse, representing simply the non-rational part of the soul. ${ }^{23}$ Elsewhere, he identifies the team of horses more broadly as emotion(s). ${ }^{24}$ He can also envision the team as sense-perception ( $\alpha$ i̋ $\sigma \eta \eta \sigma \iota)$ ). ${ }^{25}$ But no matter what team Philo envisions, he always casts the soul's rational element as the

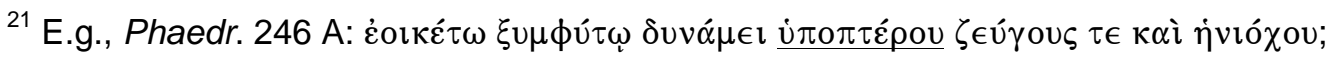

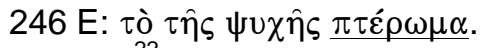

${ }^{22}$ See Méasson, Char ailé, 148-49 [="De l'attelage de Platon à celui de Philon"]; 158-60 [="Le «thumos» chez Platon et chez Philon"].

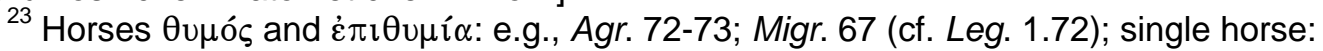
e.g., Leg. 2.99, cited in Inwood, Ethics and Human Action, 142, n. 63. On the single horse variation (142), Inwood writes: "In Plato the two horses represent the two distinct irrational elements in the soul. When a dualistic contrast of reason and the irrational part of the soul in its undifferentiated formulation was preferred, an analogy with only one horse was substituted."

${ }^{24}$ E.g., Leg. 193: ỏ $\chi \dot{\eta} \mu \alpha \tau \imath \pi \alpha \theta \hat{\omega} v$.

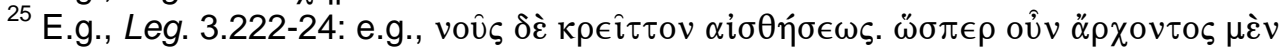

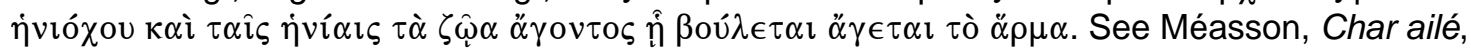
160-63.
} 
charioteer charged with controlling the team. ${ }^{26}$ In this way, his chariot figure always serves as a model of $\dot{\varepsilon} \gamma \kappa \rho \alpha \dot{\tau} \epsilon \iota \alpha$ in action-as a model of reason managing or "driving" the non-rational elements of the soul—and in this respect it perfectly suits the Platonic tradition's broad formulation of $\dot{\varepsilon} \gamma \kappa \rho \alpha \dot{\tau} \tau \epsilon \alpha$ as a power dynamic of rational versus non-rational. But since it can also depict reason managing the discrete movement of those elements—managing, in other words,

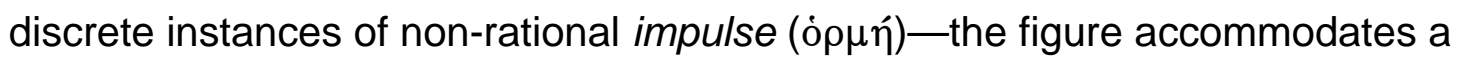
more precise concept of $\dot{\varepsilon} \gamma \kappa \rho \alpha ́ \tau \epsilon \iota \alpha$ tailored to a Middle-Platonic view of "passion."

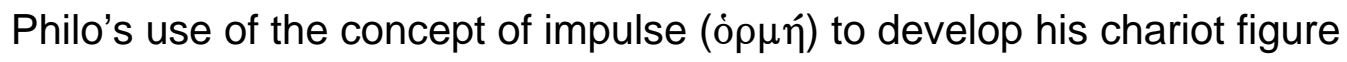
into a more elaborate model of $\dot{\varepsilon} \gamma \kappa \rho \alpha ́ \tau \epsilon \iota \alpha$ presumes a suitable basis in the actual dynamic between horses and drivers: ${ }^{27}$

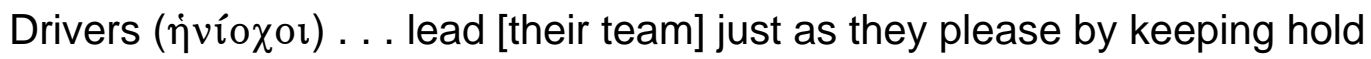
of the reins $(\tau \hat{\omega} v \dot{\eta} v i \hat{\omega} v)$. Sometimes they give rein for a brisk trot

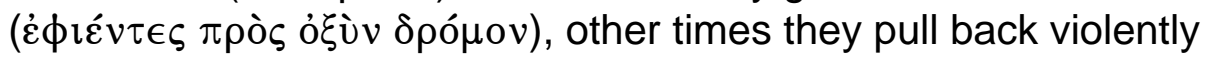

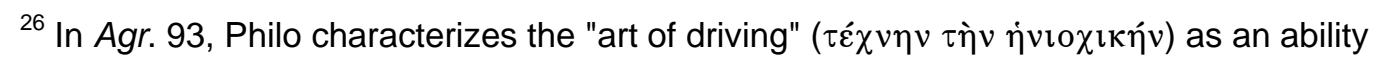

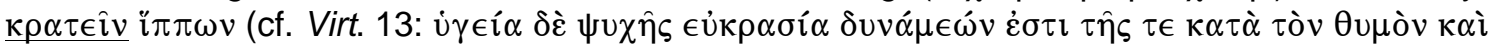

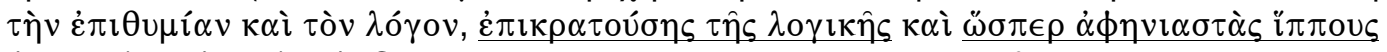

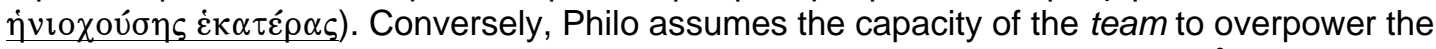
driver (cf. $\dot{\alpha} \kappa \rho \alpha \sigma i \alpha$ ) and bring everything to ruin (see esp. Leg. 3.223: $ّ \sigma \pi \epsilon \rho$ oủv $\alpha \rho \chi o v \tau o \varsigma \mu \varepsilon \grave{\varepsilon} v$

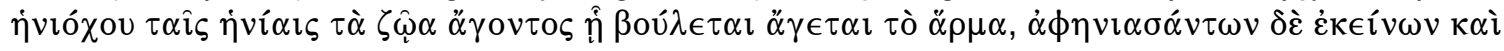

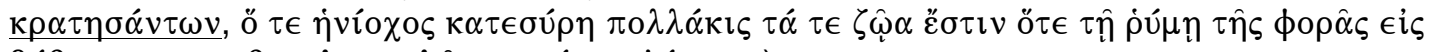

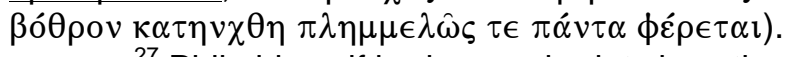

${ }^{27}$ Philo himself had seen chariots in action: "Thus in chariot races ( $\left.\dot{\varepsilon} v i \pi \pi 0 \delta \rho o \mu i \alpha \iota \varsigma\right)$. . I have seen ( $\epsilon \hat{i} \delta o ́ v)$ people giving way to thoughtlessness who, instead of sitting in their places as they should as orderly spectators, stood in the middle of the course and pushed over by the rush of the chariots were crushed under the feet and wheels, a proper reward for their folly" (Prov. 58). Philo's knowledge of chariots included familiarity with obscure technical terminology, on which see H. A. Harris, "The Foot-Rests in Hippolytus' Chariot," CR 18 (1968): 259-60. On Philo's extensive familiarity with a variety of competitive sports, see esp. H. A. Harris, Greek Athletics and the Jews (TSP 3; Cardiff: University of Wales Press, 1976), 51-95. 
( $\dot{\alpha} v \alpha \chi \alpha \imath \tau i \zeta o v \tau \epsilon \varsigma)$, if an excessive surge gets the team running ( $\epsilon \dot{i} \phi \circ \rho \hat{\alpha}$

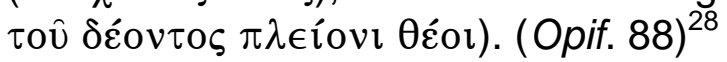

Here Philo reviews the fundamentals of managing an unruly team. Of course, the problem lies not in the team's movement per se, but in its movement beyond what the driver sanctions, in its "excessive surge." Philo uses the term $\phi о \rho \alpha ́-a$ synonym of $\dot{\rho} \mu \eta \dot{\eta}-$ to describe this surge and qualifies it with the expression

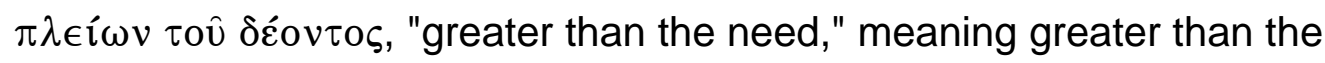
movement needed to accomplish the driver's purpose. Philo elsewhere denotes this type of unruly, excessive movement using a number of specialized terms, most commonly $\dot{\alpha} \phi \eta \nu \imath \dot{\alpha} \zeta \in \imath v$, "to throw off the reins." ${ }^{29}$ To counter this unruliness, drivers must reassert their control, whether by "pulling back violently" ( $\dot{\alpha} v \alpha \chi \alpha \imath \tau i \zeta \in \imath v)$, as Philo indicates here, or by some other technique, such as "curbing" ( $\dot{\varepsilon} \pi \imath \tau \tau \rho \mu \hat{\imath} \zeta \in \imath v)$, as Philo indicates elsewhere. ${ }^{30}$ In any case, Philo envisions controlling a team of horses as a matter of curtailing their excessive movements, which bear description in terms of impulse. Philo's characterization of chariot driving applies also to the mounted horseman:

When the horse goes forward in obedience to the reins ( $\in \dot{\eta} \eta v i \omega \varsigma$ ), the horseman gives a few pats as if to praise the horse, but when the horse gets carried away beyond proper measure by excessive impulse (ö $\tau \alpha \nu \delta \grave{\varepsilon}$

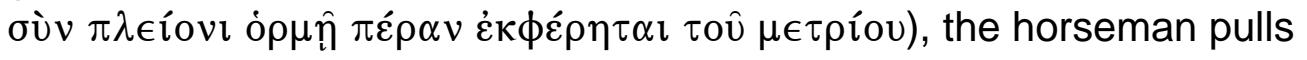

${ }^{28}$ My translation.

${ }^{29} \dot{\alpha} \phi \eta v i \alpha \zeta \in \imath v$ and its variants appear over fifty times in Philo's writings. Méasson (Char ailé, 146) considers it part of a larger vocabulary "inspiré du Phèdre."

${ }^{30} \dot{\alpha} v \alpha \chi \alpha \imath \tau i \zeta \in \imath v$ : lit. to throw back the mane ( $\left.\chi \alpha i \tau \eta\right)$, i.e., to cause to rear up. In other words, the driver pulls back with such violence that the team rears up. $\dot{\varepsilon} \pi \imath \tau \tau \rho \mu \alpha \dot{\alpha} \zeta \in \imath$ : to curb with the bit (cf. $\sigma \tau o ́ \mu \alpha$ ). 
back violently with force $(\mu \in \tau \grave{\alpha} \beta i ́ \alpha \varsigma \in \dot{u} \tau o ́ v \omega \varsigma \dot{\alpha} v \alpha \chi \alpha \imath \tau i \zeta \zeta \in l)$ to slow the horse down. (Agr. 70) ${ }^{31}$

Here again Philo equates control with the curtailing of excessive impulse ( $\pi \lambda \in$ íovı $\dot{\rho} \mu \hat{\eta})$, which involves movement beyond the limit or measure ( $\pi \dot{\varepsilon} \rho \alpha \nu . ~$. . $\tau o \hat{v} \mu \epsilon \tau \rho i ́ o v)$ set by the horseman's purpose. He also highlights a key element of managing any unruly non-rational power, horse or not: the use of brute force $\left(\mu \in \tau \grave{\alpha} \beta i \alpha_{\varsigma}\right)$. By the application of force, a horseman bends the steed to his will, not to eliminate its movement, but simply to control it. Technically, neither of these passages describes the soul, but they clearly allude to the Middle-Platonic definition of "passion" Philo formulates in Spec. 4.79:

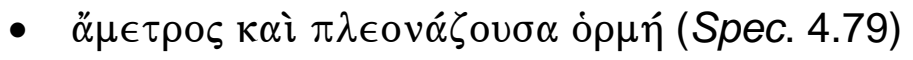

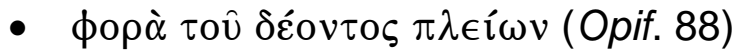

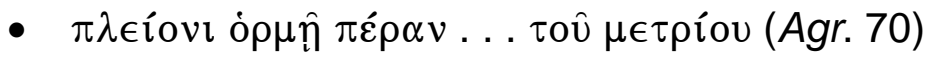

In other words, Philo sees in the management of horses an effective means of representing the management of non-rational impulse, specifically the "excessive" impulse Middle Platonists counted as "passion." Capitalizing on this analogy, Philo applies the language of horsemanship directly to the realm of moral psychology to characterize $\dot{\varepsilon} \gamma \kappa \rho \alpha \dot{\tau} \tau \epsilon \iota \alpha$ as the curtailing of excessive impulse.

Since Middle Platonists defined passion in terms of non-rational impulse, Philo can depict the management of passion strictly in terms of non-rational impulse, without ever naming a specific type of passion (desire, fear, grief, etc.):

\footnotetext{
${ }^{31}$ My translation.
} 
For ["horsemen"] are able, by applying a bridle to the soul's non-rational

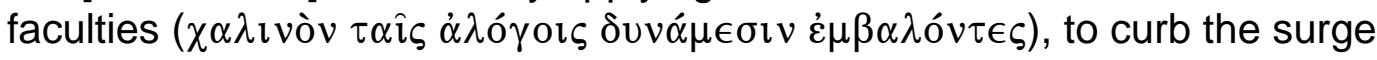

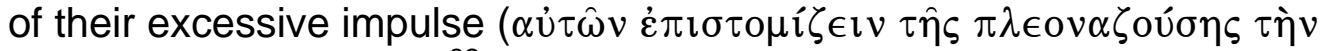
$\phi о \rho \grave{\alpha} \nu$ ò $\rho \hat{\eta} \varsigma) .\left(\right.$ Agr. 94) ${ }^{32}$

As Philo suggests here, the soul has a variety of non-rational faculties ( $\ddot{\alpha} \lambda$ o $\gamma$ or $\delta \cup v \alpha ́ \mu \epsilon \iota \varsigma)$, whose existence in itself poses no problem. But since these faculties can usurp reason's authority and become "passionate," the moral agent must be able to exercise $\dot{\varepsilon} \gamma \kappa \rho \dot{\alpha} \tau \in \imath \alpha$, which Philo depicts here as "applying a bridle" ( $\chi \alpha \lambda$ เvóv . . . $\dot{\varepsilon} \mu \beta \alpha \lambda o ́ v \tau \epsilon \varsigma)$. In particular, the moral agent must be able to curb the surge of excessive non-rational impulses, whatever their source. Desire ( $\dot{\varepsilon} \pi \theta u \mu i \alpha)$, for example, represents a perfectly natural faculty of the soul. But when the impulses of desire become excessive, $\dot{\varepsilon} \pi \imath \theta u \mu i \alpha$ the benign emotion becomes $\dot{\varepsilon} \pi \imath \theta u \mu i \alpha$ the malignant passion. Controlling $\dot{\varepsilon} \pi \imath \theta u \mu i \alpha$ (exercising $\dot{\varepsilon} \gamma \kappa \rho \alpha ́ \tau \epsilon \iota \alpha)$ specifically involves the curtailment of this excess:

But there are others, boastful persons, of the sort that is puffed up by arrogance, who in their craving for high position determine to have nothing to do in any way with the frugal, the truly profitable mode of living. Indeed, if any rebuke them in order to rein in the unruliness of their desires ( $\check{\varepsilon} v \in \kappa \alpha$ $\tau o \hat{v} \tau o ̀ v \dot{\alpha} \phi \eta \nu \imath \alpha \sigma \mu \grave{o} v \tau \hat{\omega} v \dot{\varepsilon} \pi \imath \theta \mu \imath \hat{\omega} v \dot{\alpha} v \alpha \chi \alpha \imath \tau i ́ \sigma \alpha \imath)$, they regard the admonition as an insult. (Spec. 2.18)

The rebuke here stands against passionate desire, since it involves "pulling back violently" ( $\dot{\alpha} v \alpha \chi \alpha \imath \tau i ́ \sigma \alpha \imath)$ not on desire per se but on the "unruliness" of desire

\footnotetext{
${ }^{32}$ My translation. Cf. Leg 3.118: $\dot{\eta}$. . . ó $\rho \mu \grave{\eta} \pi \dot{\alpha} \theta$ ous; Agr. 58: $\tau \grave{\alpha} \pi \epsilon \rho \imath \tau \tau \grave{\alpha} \tau \hat{\eta} \varsigma \epsilon i \varsigma$

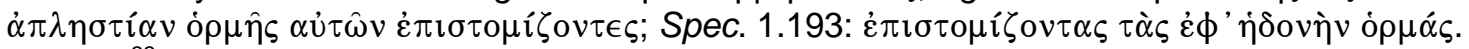

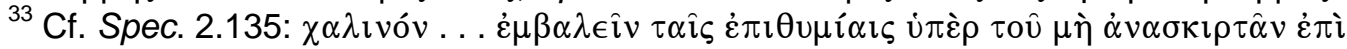

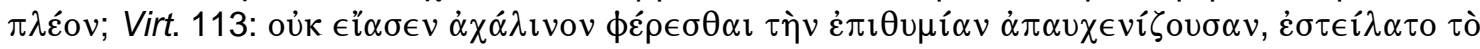

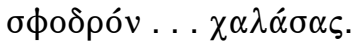


( $\tau o ̀ v \alpha \dot{\alpha} \phi \eta \nu \imath \alpha \sigma \mu o ́ v)$, which represents the movement in excess of the "frugal mode of living" reason would otherwise allow. And the dynamic envisioned here relative to $\dot{\varepsilon} \pi \imath \theta u \wedge$ i $\alpha$ applies in theory to any emotion. In Leg. 3.118-37, for example, Philo uses the chariot figure to represent the work of Aaron, who stands as the allegorical exemplar of the moderation of emotion $(\mu \epsilon \tau \rho \imath \jmath \pi \dot{\alpha} \theta \epsilon \iota \alpha) \cdot{ }^{34}$ While cues in the biblical text prompt Philo to highlight $\theta v \mu$ ó $\varsigma$ in his allegorical consideration of $\mu \epsilon \tau \rho \imath{ }^{\prime} \alpha \dot{\alpha} \theta \epsilon \iota \alpha$, he clearly has all emotions in view. ${ }^{35}$ In general, he portrays

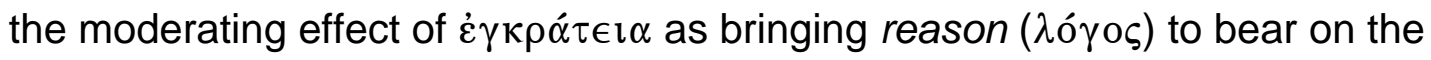
emotions $(\pi \dot{\alpha} \theta \eta)$, "so that [reason] like a charioteer may curb their surge to

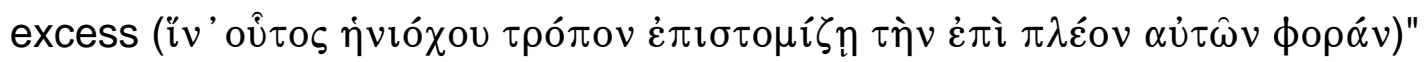
(Leg. 3.134). In other words, reason seeks not to eliminate emotions but simply to curb their excessive impulse. With reason in command, emotion never oversteps the limits of moderate expression—never becomes, in other words, a

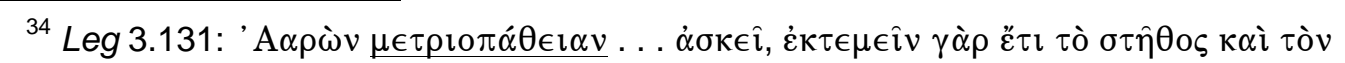

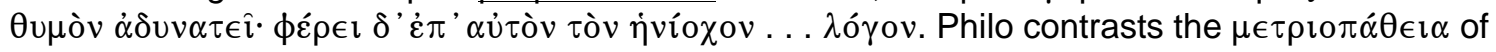
Aaron, a lower ethical stage, with the $\dot{\alpha} \pi \dot{\alpha} \theta \epsilon i \alpha$ of Moses, a higher ethical stage (Leg. 3.128-29). For this distinction between $\mu \epsilon \tau \rho \imath \_\pi \dot{\alpha} \theta \epsilon \iota \alpha$ and $\dot{\alpha} \pi \dot{\alpha} \theta \epsilon \iota \alpha$ in Middle Platonism, see Lilla, Clement of Alexandria, 92-106 (cf. John Dillon, "Plotinus, Philo and Origen on the Grades of Virtue," in Platonismus und Christentum: Festschrift für Heinrich Dörrie [ed. Horst-Dieter Blume and Friedhelm Mann; JACE 10; Münster: Aschendorff, 1983], 92-105, esp. 102-03).

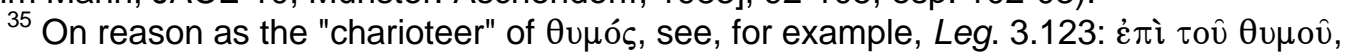

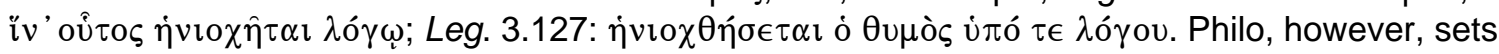
this long discourse on "Aaronic" moderation in the broader context of a Middle-Platonic bipartite opposition between reason ( $\lambda$ ó $\gamma \circ \varsigma$ ) and emotion ( $\pi \dot{\alpha} \theta 0 \varsigma)$. At the outset (Leg. 3.115), he seems to endorse Platonic tripartition, but he immediately reveals his Middle-Platonic affinities in Leg. 3.116 by making bipartition the overarching frame: the soul consists of reason opposed to

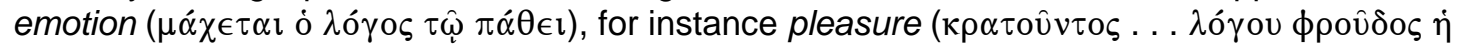

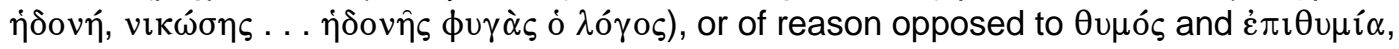

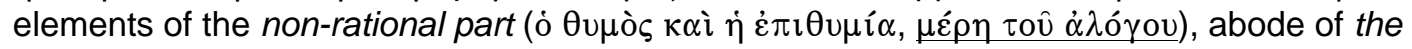
emotions ( $\tau \grave{\alpha} \pi \dot{\alpha} \theta \eta)$. In Philo's Middle-Platonic tripartition as bipartition, $\theta u \mu o ́ s$ and $\dot{\varepsilon} \pi \imath \theta u \mu i ́ \alpha$ 
"passion": a disruptive force that overpowers reason and leads the soul to destruction, like a runaway horse pulling a hapless chariot to ruin. Here again Philo conceives $\dot{\varepsilon} \gamma \kappa \rho \alpha ́ \tau \epsilon \imath \alpha$ as the curtailing of excessive non-rational impulse, and he formulates this concept in light of a Middle-Platonic definition of "passion." While this notion of curtailing excess certainly lends precision to Philo's concept of $\dot{\varepsilon} \gamma \kappa \rho \dot{\alpha} \tau \epsilon \iota \alpha$, his most practical concept of what it means for a rational part to rule over non-rational parts within the soul—especially for reason to rule over desire ( $\dot{\varepsilon} \pi \imath \theta v \mu i \alpha)$-involves the different and often conflicting sources of human motivation.

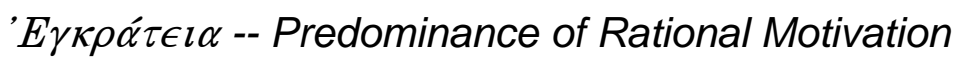

Reason and desire represent two distinct sources of motivation in the human soul, each with its own characteristic aim. ${ }^{36}$ Desire $\left(\dot{\varepsilon} \pi_{\imath} \theta u \mu i ́ \alpha\right)$ represents a source of motivation whose invariable aim is pleasure ( $\dot{\eta} \delta o v \eta ́)$. Given a sensory impression of something pleasurable, desire always responds by motivating the

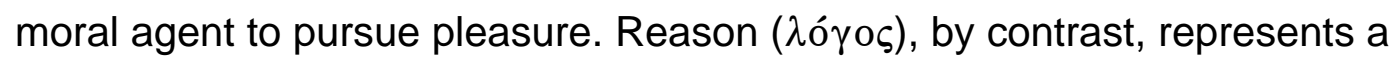
source of motivation whose invariable aim is the good ( $\dot{\alpha} \gamma \alpha \theta$ ó $\varsigma)$. Given a set of circumstances, reason—unless captive to another component of the soulalways responds by motivating the moral agent to do what rational calculation

represent emotions $(\pi \dot{\alpha} \theta \eta)$ stemming from the soul's non-rational part, but they are only two of

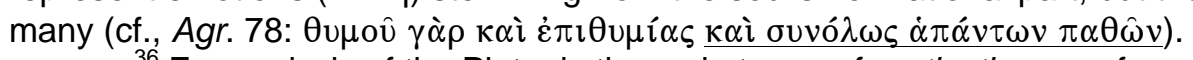

${ }^{36}$ For analysis of the Platonic theory in terms of motivation, see for example Lohrenz, Brute Within, 35: "the embodied human soul is a composite object, composed of a number of parts which (strictly and accurately speaking) are the subjects or bearers of different kinds of 


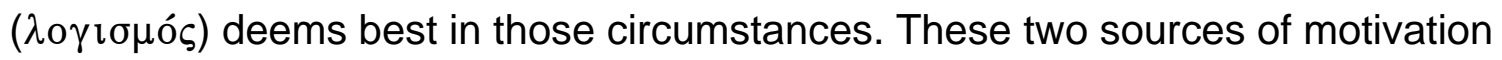
do not necessarily oppose one another, but they obviously can. Desire overcomes reason ( $\dot{\alpha} \kappa \rho \alpha \sigma i \alpha)$ whenever the moral agent acts for the sake of pleasure despite reason's contrary motivation to act for the sake of rational benefit. ${ }^{37}$ Conversely, reason overcomes desire $(\dot{\varepsilon} \gamma \kappa \rho \alpha \dot{\tau} \epsilon \iota \alpha)$ whenever the moral agent acts for the sake of rational benefit despite desire's contrary motivation to act for the sake of pleasure. ${ }^{38}$ Conceived in terms of conflicting motivations, $\dot{\varepsilon} \gamma \kappa \rho \alpha ́ \tau \epsilon \iota \alpha$ imposes onto desire the "measure" of rational benefit: desire may pursue its aim of pleasure, as long as that pursuit serves a rational end and bears rational justification. ${ }^{39}$ The pursuit of pleasure beyond reasonable measure - the pursuit of pleasure for pleasure's sake—represents the triumph of desire (as a source of motivation) over reason (as a source of motivation), and desire at that moment, as its characteristic motivation predominates, becomes "excessive" and so "passionate." While this dynamic applies in theory to any desire, the most basic of desires, the desire for food, illustrates it well. ${ }^{40}$

motivating conditions" (emphasis added; cf. passages in the General Index under "Motivating condition" [218]); see also Cooper, "Human Motivation."

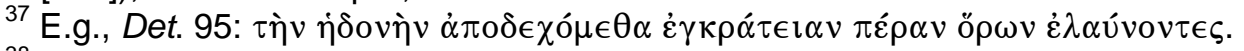

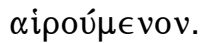

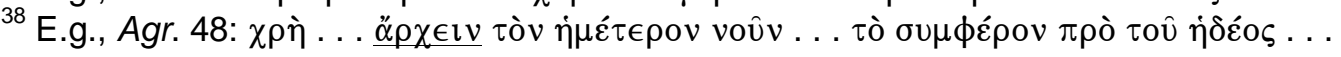

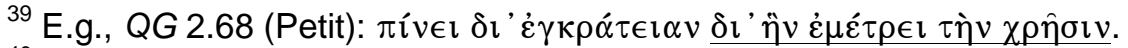

${ }^{40}$ For an illustration of this basic dynamic relative to sexual desire, see Kathy L. Gaca, "Philo's Principles of Sexual Conduct and Their Influence on Christian Platonist Sexual Principles," SPhA 8 (1996): 21-39, esp. 22-27, where Gaca outlines Philo's (Pythagorean) "procreationist principle." Although Gaca does not analyze it in terms of moral psychology, the procreationist principle nevertheless envisions $\dot{\varepsilon} \gamma \kappa \rho \alpha \dot{\tau} \tau \iota \alpha$ as the predominance of rational motivation by endorsing sex for the sake of reproduction (reason as source of motivation) and rejecting sex for the sake of pleasure (desire as source of motivation). Niehoff (Philo on Jewish Identity, 99-102) examines the same principle of limiting sex to reproduction but downplays the 
With regard to food, desire invariably seeks only the pleasure of eating, while reason seeks the moral agent's overall well being. ${ }^{41}$ Desire always urges indulgence, due to its reflexive, non-rational mode of operation-in other words, given an opportunity to eat pleasurably, desire always says "yes." Reason, by contrast, taking all factors into account, can accordingly urge either for or against indulgence on an ad hoc basis. While reason could not in principle categorically endorse a certain type of indulgence, human beings must eat to live, so—barring exceptional circumstances—reason always approves eating for nourishment as the unavoidable indulgence of a "necessary" desire, an indulgence perfectly consistent with the demands of $\dot{\varepsilon} \gamma \kappa \rho \alpha \dot{\tau} \tau \iota \alpha$ :

Mark you not that even the most self-controlled of men (oi $\dot{\varepsilon} \gamma \kappa \rho \alpha \tau \varepsilon ́ \sigma \tau \alpha \tau o$ )

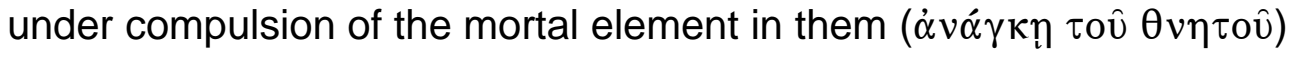

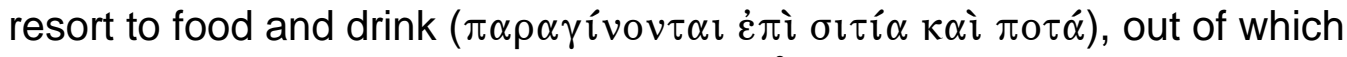
the pleasures of the appetite develop ( $\dot{\varepsilon} \xi \hat{\omega} v \alpha i$ $\gamma \alpha \sigma \tau \rho o ̀ \zeta ~ \dot{\eta} \delta o v \alpha \grave{\imath}$ $\sigma u v \in \sigma \tau \hat{\alpha} \sigma \imath v)$ ? (Leg. 1.86)

Pythagorean associations, instead framing the issue in terms of Philo's ideal of Jewish $\dot{\varepsilon} \gamma \kappa \rho \alpha ́ \tau \epsilon \iota \alpha$.

${ }^{41}$ Much of Philo's discourse on ethical eating reflects elements of the diatribe tradition, especially the works of Musonius Rufus (see Paul Wendland, "Philo und die kynisch-stoische Diatribe," in Beiträge zur Geschichte der griechischen Philosophie und Religion [Berlin: Georg Reimer, 1895], 1-75, esp. 8-15; cf. Bréhier, Idées philosophiques et religieuses, 261-62; Niehoff, Philo on Jewish Identity, 105). Musonius, for example, endorses the standard of need over

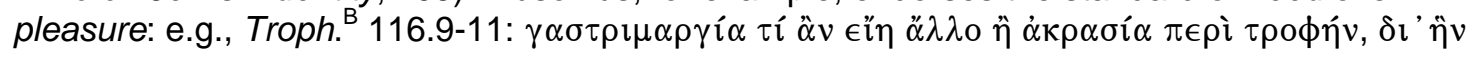

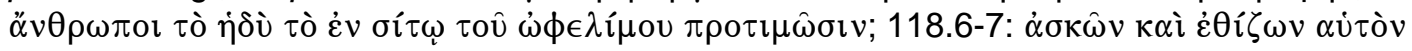

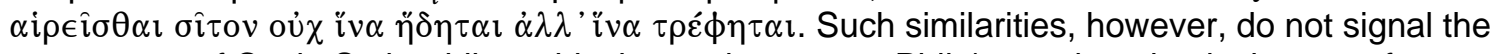
acceptance of Cynic-Stoic philosophical commitments on Philo's part but simply the use of a widespread ethical topos (cf. A. C. van Geytenbeek, Musonius Rufus and Greek Diatribe [trans. B. L. Hijmans; rev. ed.; WTS 8; Assen: Van Gorcum, 1963], 106: "Like nearly all moralists who treat the problem of food, Musonius rejects pleasure as the aim"). Although he sometimes frames ethical discourse in ways comparable to Musonius, Philo presupposes a moral psychology quite different from Musonius or any other Stoic.

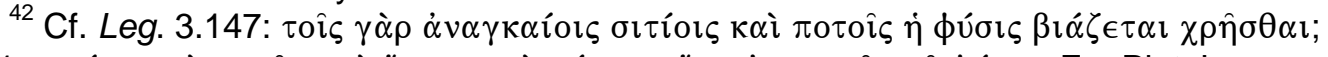

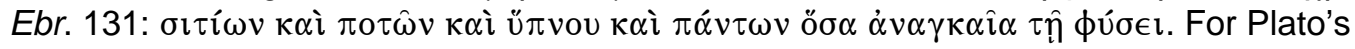
understanding of "necessary desires," see Resp. 558 C - 559 D. 
So a moral agent who genuinely needs to eat can satisfy both reason and desire with a good meal: rational calculation ( $\lambda \circ \gamma \iota \sigma \mu o ́ \varsigma)$ motivates the eating as a logical means of sustaining life and health, while desire $(\dot{\varepsilon} \pi \imath \theta v \mu i ́ \alpha)$ motivates the eating as a pleasurable experience. Of course, rational calculation ( $\lambda \circ \gamma \imath \sigma \mu o ́ s)$ may compel the same hungry moral agent to reject a meal despite desire's pressing motivation to eat for the sake of pleasure-if, for instance, the meal is poisoned or belongs to someone else. But the conflict between reason and desire in matters of food more commonly involves the question of eating in excess of rational necessity. Having eaten enough to survive in good health, and so having no real need to eat, how does the moral agent handle further opportunities to eat? At this point, Philo's moral theory can explain indulgence

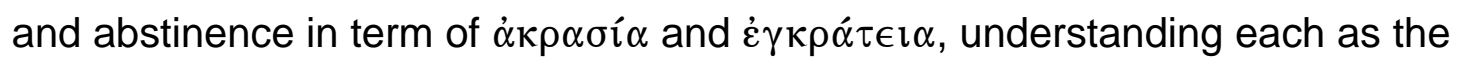
victory of a certain type of motivation. To eat represents a victory of desire over reason ( $\dot{\alpha} \kappa \rho \alpha \sigma i \alpha)$, since the moral agent eats strictly for the sake of pleasure: the motivation for pleasure has in effect overpowered the motivation for rational benefit, which urges abstinence as the reasonable course. Philo understands $\dot{\alpha} \kappa \rho \alpha \sigma i \alpha$ along these lines in Mos. 1.160-61, where he attributes a lack of $\dot{\varepsilon} \gamma \kappa \rho \dot{\alpha} \tau \epsilon \iota \alpha$ to those who incite desires, including the desires of the stomach ( $\tau \grave{\alpha} \varsigma$

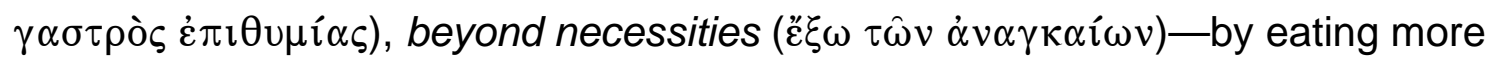
than they need, they eat for pleasure and reflect the predominance of $\dot{\varepsilon} \pi \imath \theta u \mu i \alpha$ 
as a motivating disposition. ${ }^{43}$ Conversely, not to eat represents a victory of reason over desire ( $\dot{\varepsilon} \gamma \kappa \rho \alpha \dot{\tau} \tau \epsilon \alpha)$, since the moral agent controls the desire for food by keeping it within the bounds of rational necessity. Philo equates $\dot{\varepsilon} \gamma \kappa \rho \alpha \dot{\tau} \tau \ell \alpha$ with eating (and drinking) according to need, since it involves reason motivating the moral agent to indulge desire only to the point of need and no further. Commenting on Exodus 23:25b ${ }^{44}$ Philo writes:

In this passage, he symbolically indicates nourishment and health ( $\tau \rho \circ \phi \grave{\eta} v$ $\kappa \alpha i$ ư $\left.i_{\epsilon} \in \_\nu \alpha i v i \tau \tau \epsilon \tau \alpha \imath\right)$ : nourishment through the mention of food and water, and health through the expression "turn away weakness" ( $\delta i \grave{\alpha} \tau o \hat{v}$

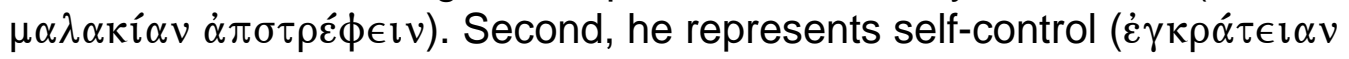
$\epsilon \hat{i} \sigma \eta \gamma \in \hat{\imath} \tau \alpha \iota)$ by talking about the consumption of necessities only ( $\tau \grave{\eta} v \tau \hat{\omega} v$ $\dot{\alpha} v \alpha \gamma \kappa \alpha i \omega v \mu \in \tau o v \sigma i ́ \alpha v$ Hovóv). (QE 2.18) $)^{45}$

Philo's identification here of $\dot{\varepsilon} \gamma \kappa \rho \dot{\alpha} \tau \epsilon \iota \alpha$ with the indulgence of necessary desire enhances the notion of curtailing excess from the chariot figure by further characterizing "excessive" as "unnecessary." Conceived in these terms,

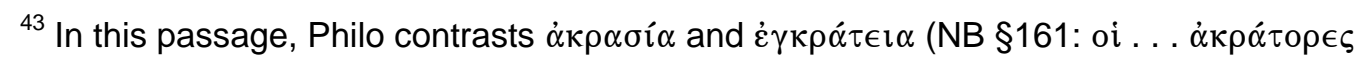

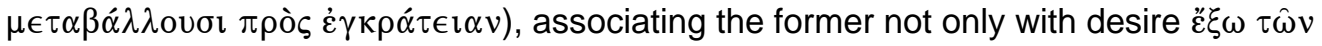

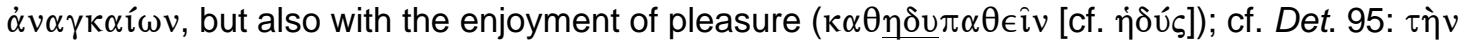

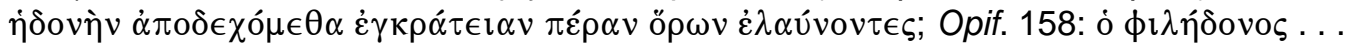

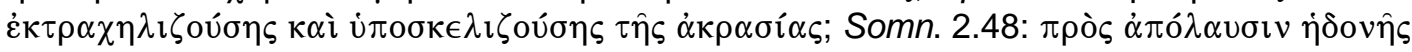

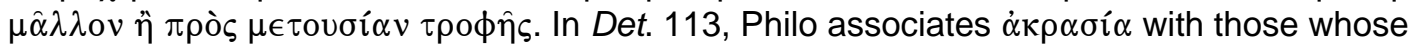
desires continue despite a full stomach. With no rational motivation for eating, only a desire for

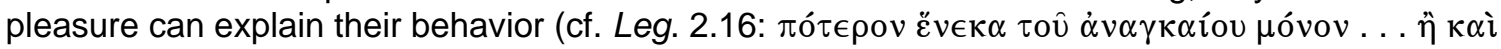

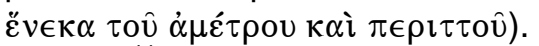

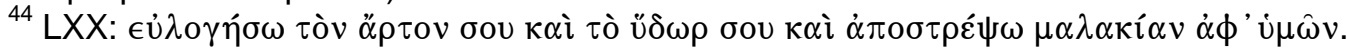
As Marcus notes (PLCL suppl. 2, 56, n. c), "Philo agrees with Heb. against LXX in omitting 'and wine' after 'bread."' (cf. Petit, 254, n. b).

${ }^{45}$ My translation of Petit's text of the Greek fragment (Petit, 254). The passage continues from the Armenian, "for bread is a plain food without anything extra, and flowing water is (a similarly plain) drink, and upon these (depends) health" (trans. Marcus; PLSL suppl. 2, 56). In Leg. 3.154, Philo likewise associates the restraint of desire ( $\sigma v v \in \sigma \tau \dot{\alpha} \lambda \theta \alpha \imath \tau \dot{\alpha} \varsigma \dot{\varepsilon} \pi \imath \theta v \mu i \alpha \varsigma)$ with

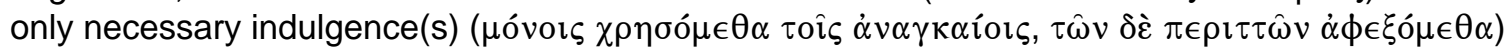

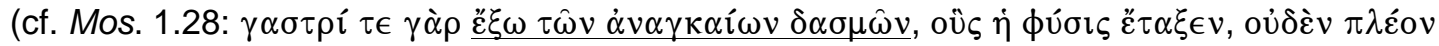

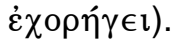




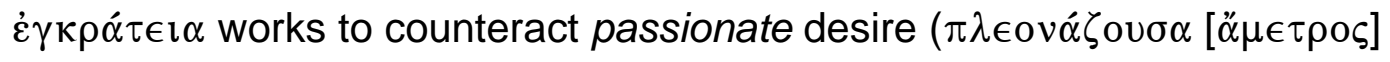
$\dot{\varepsilon} \pi \imath \theta u \mu i \alpha)$ by consistently enforcing the "measure" urged by reason (necessity) over against desire's persistent urge toward pleasure. In other words, $\dot{\varepsilon} \gamma \kappa \rho \dot{\tau} \tau \epsilon \iota \alpha$ eliminates excessive, unnecessary desire and the unnecessary pleasure it entails. Philo symbolically interprets the rite of circumcision along these lines: They say that circumcision of the skin is a symbol, as if (to show that) it is proper to cut off superfluous and excessive desires ( $\tau \grave{\alpha} \varsigma \pi \epsilon \rho \tau \tau \tau \grave{\alpha} \varsigma \kappa \alpha \grave{\imath}$

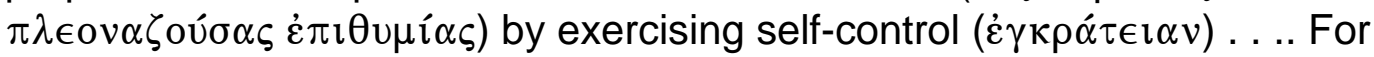
just as the skin of the foreskin is superfluous in procreation ... so the excess of desire is superfluous .... It is superfluous because it is not necessary .... (QG 3.48)

So the moral agent possessed of $\dot{\varepsilon} \gamma \kappa \rho \alpha \dot{\tau} \tau \epsilon \alpha$ moderates $\dot{\varepsilon} \pi \imath \theta u \mu \imath \alpha$ and avoids passion by indulging according to need, curtailing the excess of unnecessary indulgence by ensuring the predominance of a motivation to secure rational benefit (necessity) over a motivation to secure pleasure.

\section{Summary}

Although Philo never offers a direct, extended explanation of $\dot{\varepsilon} \gamma \kappa \rho \alpha ́ \tau \epsilon \iota \alpha$, he nevertheless reveals through incidental remarks a substantive concept of $\dot{\varepsilon} \gamma \kappa \rho \alpha \dot{\tau} \epsilon \iota \alpha$ framed along three distinct but complementary lines. First, $\dot{\varepsilon} \gamma \kappa \rho \alpha ́ \tau \epsilon \iota \alpha$ involves a power dynamic of rational over non-rational forces, understood either broadly as $\lambda$ ó $\gamma$ o $\varsigma$ defeating any challenge from elsewhere in the soul, or narrowly

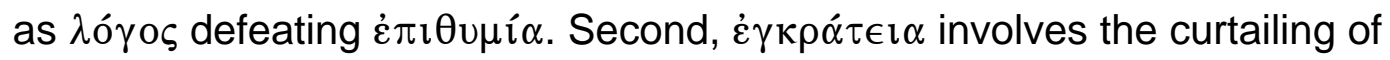
excessive impulse. Finally, $\dot{\varepsilon} \gamma \kappa \rho \alpha ́ \tau \epsilon \mathfrak{} \alpha$ involves the predominance of rational 
motivation over against a non-rational urge toward pleasure. But how, in Philo's view, does the moral agent acquire $\dot{\varepsilon} \gamma \kappa \rho \alpha ́ \tau \epsilon \iota \alpha$ ?

THE ACQUISITION OF 'E $\gamma \kappa \rho \alpha ́ \tau \epsilon \iota \alpha$

Because $\dot{\varepsilon} \gamma \kappa \rho \alpha ́ \tau \epsilon \iota \alpha$ involves the control of non-rational forces, the means of acquiring it have a correspondingly non-rational character, insofar as they do not involve the formulation or deployment of rational argument. Without a capacity for reason, $\dot{\varepsilon} \pi \imath \theta u \mu \imath^{\prime \prime}$ simply cannot accept or reject a moral agent's reasoned guidance. Instead, the moral agent must manage $\dot{\varepsilon} \pi \imath \theta u \mu i^{\prime \prime}$ through the application of force-just as the charioteer does not reason with an unruly team (he cannot), but simply acts to bring it into submission. In other words, $\dot{\varepsilon} \gamma \kappa \rho \alpha ́ \tau \epsilon \imath \alpha$ comes from doing, not thinking: the moral agent becomes good at controlling $\dot{\varepsilon} \pi \imath \theta u \mu i^{\prime \prime}$ only by exerting or practicing control, not by theoretical reflection. ${ }^{46}$ Philo's philosophical contemporaries considered the importance of practice in moral development under the conceptual rubric of $\alpha$ $\sigma \kappa \eta \sigma \iota \varsigma^{47}$ Although the term

${ }^{46}$ Philo clearly distinguishes between theoretical and practical virtue: e.g., Leg. 1.57: $\dot{\eta} \delta \grave{\varepsilon}$

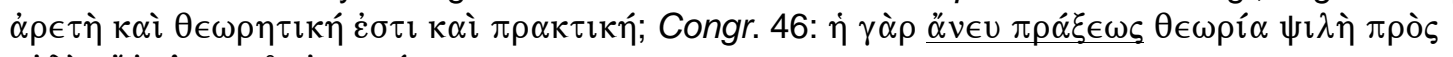

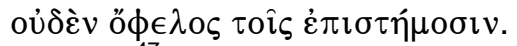

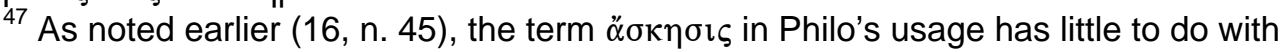
modern terms such as "ascetic" or "asceticism," whose connotations derive mostly from Christian monasticism. The Greek term has no intrinsic association with religious practice (see Dressler,

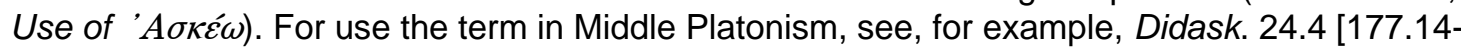

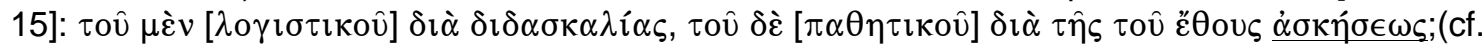

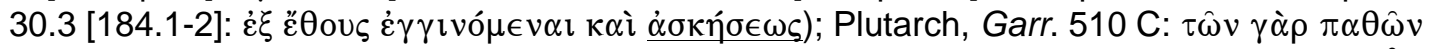

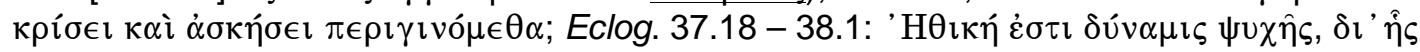

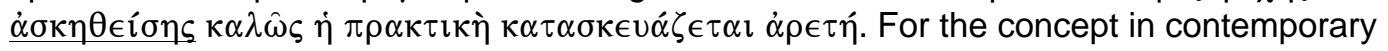
Stoicism, see, for example, Musonius Rufus, "On Training" (Пદ́pı $\dot{\alpha} \sigma \kappa \eta ் \epsilon \omega \varsigma)$ (see also Richard Valantasis, "Musonius Rufus and Roman Ascetical Theory," GRBS 40 [1999]: 207-31; cf. B. L. Hijmans, "A $\Sigma K H \Sigma I \Sigma$ : Notes on Epictetus' Educational System [WTS 2; Assen: Von Gorcum, 


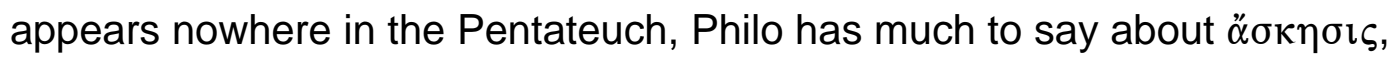
because he believes that Moses considered the topic allegorically under the figure of Jacob.

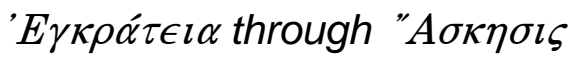

Philo's view of Jacob fits into a broader interpretive scheme involving the three patriarchs Abraham, Isaac, and Jacob, who each represent a different way of acquiring virtue: through instruction ( $\mu \dot{\alpha} \theta \eta \sigma \imath \varsigma)$, nature ( $\phi \dot{\sigma} \sigma \iota \varsigma)$, and practice

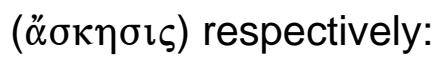

For the holy word seems to be searching into the types of souls ( $\tau \rho$ ó $\pi$ ous $\psi v \chi \eta \hat{\zeta})$, all of them of high worth, one which pursues the good through teaching ( $\dot{\varepsilon} \kappa \delta \imath \delta \alpha \sigma \kappa \alpha \lambda i \alpha \varsigma)$, one through nature ( $\dot{\varepsilon} \kappa \phi \dot{v} \sigma \epsilon \omega \varsigma)$ and one through practice ( $\dot{\varepsilon} \kappa \dot{\alpha} \sigma \kappa \dot{\eta} \sigma \epsilon \omega \varsigma)$. The first called Abraham, the second

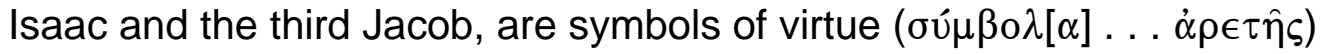

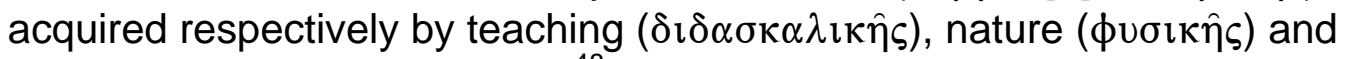

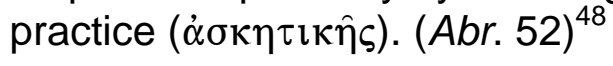

Although Philo ostensibly discovers this threefold scheme through allegorical exegesis of the Pentateuch, the notion of virtue accruing by nature, instruction, and practice comes from Greek philosophy, appearing in systematic formulation at least as early as Aristotle and gaining later acceptance among Philo's philosophical contemporaries, including his fellow Middle Platonists. ${ }^{49}$ Philo's

1959]). For the concept in Cynic philosophy, see Marie-Odile Goulet-Cazé, L'ascèse cynique: un commentaire de Diogène Laërce VI 70-71 (2d ed.; Paris: J. Vrin, 2001).

${ }^{48}$ Cf. Mut. 12; los. 1; Mos. 1.76.

${ }^{49}$ Diogenes Laertius (5.18), attributes the formulation to Aristotle: "Three things he declared to be indispensable for education: natural endowment ( $\phi \dot{v} \sigma \epsilon \omega \varsigma)$, study ( $\mu \alpha \theta \dot{\eta} \sigma \epsilon \omega \varsigma)$, and constant practice ( $\dot{\alpha} \sigma \kappa \eta \dot{\sigma} \sigma \omega \varsigma) "$ (trans. R. D. Hicks). Noting the tripartite method in Didask. 28.4 [182.3-6], Dillon writes (also citing Abr. 52-54) that "it is thus likely to be the basic Middle-Platonic doctrine" (xxiii) (cf. Lilla, Clement of Alexandria, 66-68). For the doctrine among contemporary Stoics, see Geytenbeek, Musonius Rufus, 28-29. 


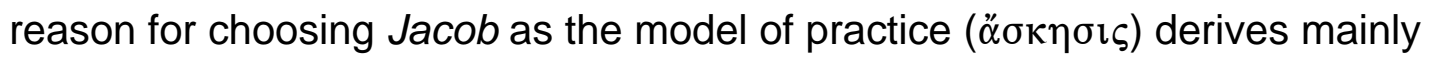
from the patriarch's wrestling match at the ford of the Jabbok (Gen 32:22-32). ${ }^{50}$ Since wrestling plays a definitive role in the life of Jacob, Philo makes it an essential attribute of the type of soul Moses represents through the story of Jacob. Wrestlers are athletes, and in the athletic discourse of antiquity "ळ̈ $\sigma \kappa \eta \sigma \iota \varsigma "$ refers to the practice (i.e., exercise, training) that every athlete-wrestler or not-

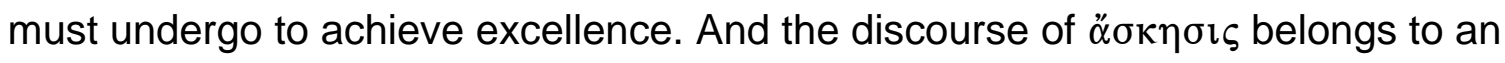
even larger stock of athletic imagery and terminology deployed in connection with the Jacob soul: an "agon motif" that suits Philo's allegorical method well because it operates on two levels. ${ }^{51}$ Literally, the agon motif speaks of an athlete's

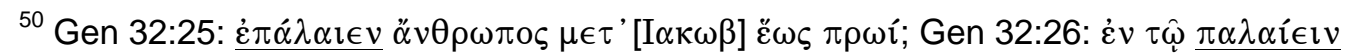
$\alpha \dot{\tau} \tau o ̀ v \mu \in \tau$ ' $\alpha$ $\dot{\tau} \tau$ v̂. For Philo, the etymological tale of Jacob's "heel grabbing" (Gen 25:26: esp. $\dot{\eta}$

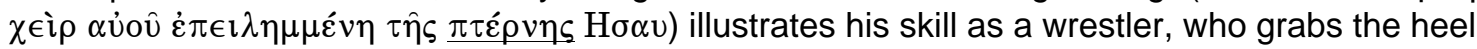
to trip up and overthrow an opponent (e.g., Leg. 3.190; cf. Leg. 3.18, 93; Sacr. 42). On Philo's portrait of Jacob in terms of ancient wrestling, see Harris, Greek Athletics, 68-71. On Philo's understanding of Jacob more broadly, see Petra von Gemünden, "La figure de Jacob à l'époque hellénistico-romaine: l'example de Philon d'Alexandrie," in Jacob: commentaire à plusieurs voix de Gen 25-36 : mélanges offerts à Albert de Pury (ed. Jean-Daniel Macchi and Thomas Römer; MdB 44; Genève: Labor et Fides, 2001), 358-70; C. T. R. Hayward, "Philo, the Septuagint of Genesis 32:24-32 and the Name 'Israel': Fighting the Passions, Inspiration and the Vision of God," JJS 51 (2000): 209-226; Michael Poliakoff, "Jacob, Job, and Other Wrestlers: Reception of Greek Athletics by Jews and Christians in Antiquity," JSH 11 (1984): 48-65, esp. 63-65; Mark Sheridan, "Jacob and Israel: a Contribution to the History of an Interpretation," in Mysterium Christi: Symbolgegenwart und theologische Bedeutung (ed. M. Löhrer and Elmar Salmann; SA 116; Rome: Pontificio Ateneo S. Anselmo, 1995), 219-42.

${ }^{51}$ On the agon motif in Philo, see esp. Martin Brändl, Der Agon bei Paulus: Herkunft und Profil paulinischer Agonmetaphorik (WUNT 222; Tübingen: Mohr Siebeck, 2006), 85-115 [="Die Agon-Metaphorik bei Philo von Alexandrien"]. On Philo's knowledge of agon terminology, Brändl notes: "Dabei handelt es sich nicht nur um das gängige agonistische Wortfeld, sondern auch um detaillierte Einzelheiten und zahlreiche termini technici" (87). As examples of "das gängige

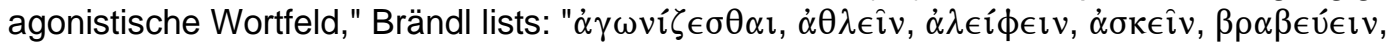

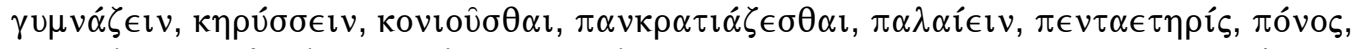

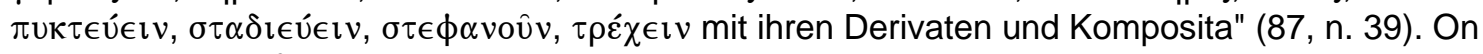
Philo's agon motif, see also Uta Poplutz, Athlet des Evangeliums: Eine motivgeschichtliche Studie zur Wettkampfmetaphorik bei Paulus (HBS 43; Freiburg im Breisgau: Herder, 2004), 174201 [="Die Agonmetaphorik im hellenistischen Judentum: Philo von Alexandrien"]; Victor C. 
struggle to train in pursuit of tangible prizes. But figuratively, the motif speaks of the soul's struggle to train in pursuit of intangible-yet more valuable-prizes,

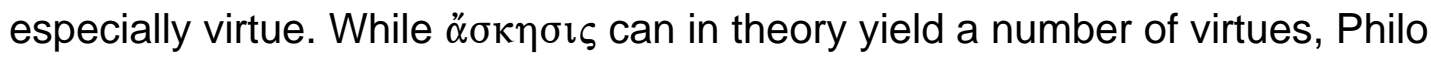
sees it primarily as a means of acquiring $\dot{\varepsilon} \gamma \kappa \rho \alpha ́ \tau \epsilon \iota \alpha .{ }^{52}$ He thematically highlights $\dot{\varepsilon} \gamma \kappa \rho \alpha \dot{\tau} \tau \iota \alpha$ as a prominent goal of the Jacob soul by characterizing its struggle as a contest with non-rational forces-a wrestling match against emotion $(\pi \dot{\alpha} \theta o \varsigma){ }^{53}$

While the patriarch Jacob played the athlete by literally wrestling with a physical opponent, the Jacob soul-the soul possessed of Jacob's athletic

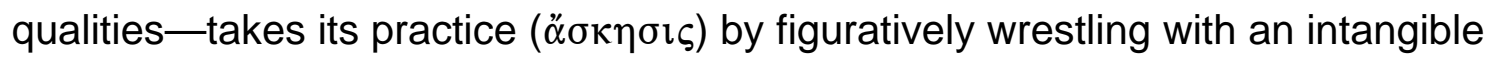

Pfitzner, Paul and the Agon Motif: Traditional Athletic Imagery in the Pauline Literature (NovTSup 16; Leiden: Brill, 1967), 38-48 [="Hellenistic Judaism and the Agon Tradition: Philo"].

${ }^{52}$ When Philo lists the elements of $\ddot{\alpha} \sigma \kappa \eta \sigma \iota \varsigma$, he mentions only the virtue of $\dot{\varepsilon} \gamma \kappa \rho \dot{\alpha} \tau \in \iota \alpha$ :

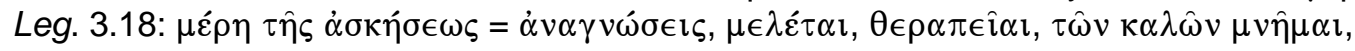

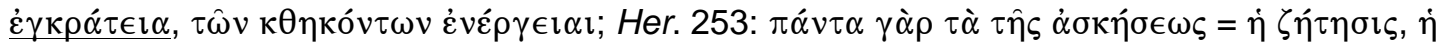

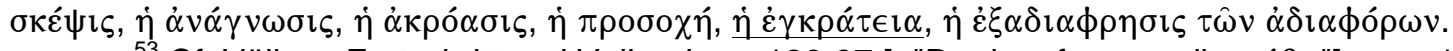

${ }^{53}$ Cf. Völker, Fortschritt und Vollendung, 126-37 [="Der kamf gegen die $\pi \dot{\alpha} \theta \eta$ "], esp. 12930: "Daneben fordert Philo eine willensmäßige Anspannung, um die $\pi \dot{\alpha} \theta \eta$ zu überwinden, ein

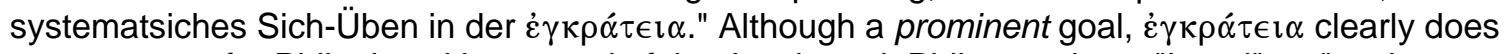
not represent for Philo the ultimate goal of the Jacob soul. Philo translates "Israel" as "seeing

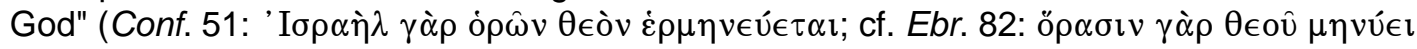

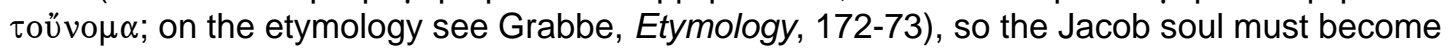
"Israel" and obtain a vision of God to achieve its final end. This ultimate emphasis on seeing God-representing detachment from the sensible world in favor of the intelligible-gives Philo's

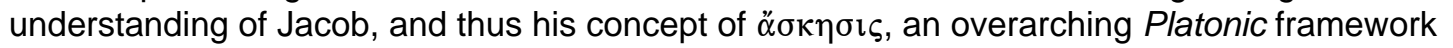
(see esp. Praem. 36-40; cf. Migr. 214; Somn. 1.46; on the Platonic nature of such a vision, see David Bradshaw, "The Vision of God in Philo of Alexandria," ACPQ 72 [1998]: 483-500; Frederick E. Brenk, "Darkly Beyond the Glass: Middle Platonism and the Vision of the Soul," in Platonism in Late Antiquity [ed. Stephen Gersh and Charles Kannengiesser; CJA 8; Notre Dame, Ind: University of Notre Dame Press, 1992], 39-60; cf. Irl Goldwin Whitchurch, The Philosophical Bases of Asceticism in the Platonic Writings and in Pre-Platonic Tradition [CSP 14; New York: Longmans, Green \& Co., 1923]; Sarah J.K. Pearce, The Land of the Body: Studies in Philo's Representation of Egypt [WUNT 208; Tübingen: Mohr Siebeck, 2007], 30-33 [="Migration and

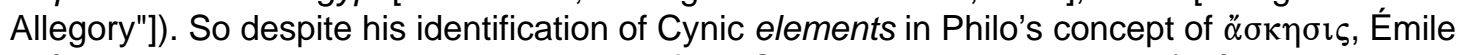
Bréhier's suggestion that it derives entirely from Cynicism must be rejected (Idées philosophiques et religieuses, 261: "L'on ne saurait réduire toute la morale philonienne au cynisme . . . nous allons essayer de montrer que tout son ascétisme en provient" [emphasis added]; see 261-71 [="Le cynisme et l'ascétisme"]). 
yet dangerously real opponent, the emotions $(\pi \dot{\alpha} \theta \eta){ }^{54}$ Philo's vision of the moral agent grappling with, and so struggling against, the emotions reflects above all the division of soul presumed in Middle-Platonic moral psychology, where $\pi \dot{\alpha} \theta$ os has an independent existence over against the rational faculty. The Jacob soul, in other words, contends with distinct, non-rational $\pi \dot{\alpha} \theta \eta$-but how and to what end? Philo clearly depicts the Jacob soul engaged in a contest of power whose outcome rests solely on the relative strength of opponents: the moral agent, exemplified by reason ( $\lambda$ ó ${ }^{\circ} \varsigma$ ), either is or is not stronger than emotion, and so either will or will not succeed in forcibly controlling it. ${ }^{55}$ And the Jacob soul clearly does, in Philo's view, wrestle for control of the emotions, not their elimination or absolute suppression. Specifically, the Jacob soul seeks to moderate emotion and keep it from overstepping the limits or bounds set by reason in a given circumstance.$^{56}$ In Philo's view, the historical patriarch Abraham exhibits this type of soul, as he "wrestles" with the emotion of grief at the loss of Sarah and rightly aims for $\mu \in \tau \rho \imath$ เo $\alpha \theta \epsilon \hat{\imath} v$ (Abr. 257):

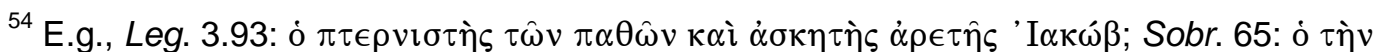

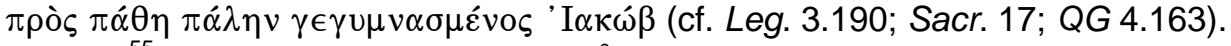

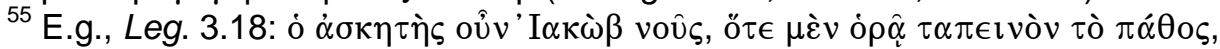

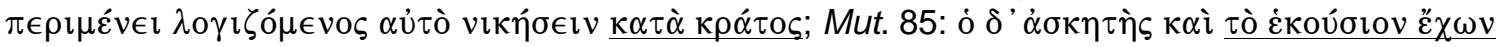

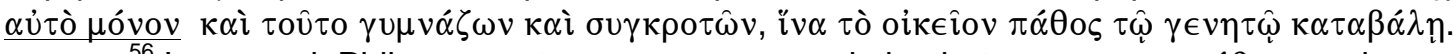

${ }^{56}$ In general, Philo suggests a necessary correlation between $\mu \epsilon \tau \rho \iota 0 \pi \dot{\alpha} \theta \epsilon \imath \alpha$ and $\ddot{\alpha} \sigma \kappa \eta \sigma \iota \varsigma$ as characteristics of a moral agent occupying a lower stage of ethical development (i.e.,

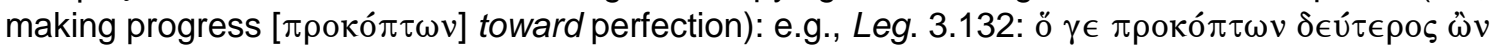

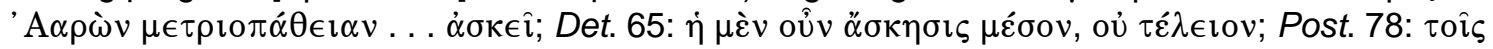

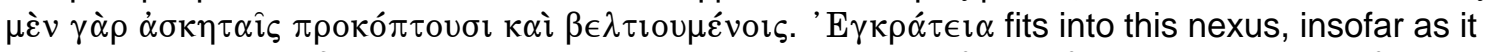
always involves conflict and thus always denotes a measure of imperfection on the part of the moral agent, who has failed at some level to settle the issue of who-or what-shall rule the soul.
} 
[W]hen grief was making itself ready to wrestle with his soul ( $\tau \hat{\eta} \varsigma \lambda \dot{u} \pi \eta \varsigma$

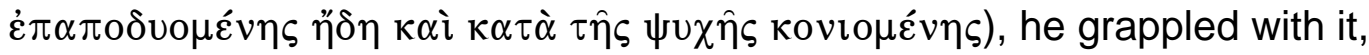

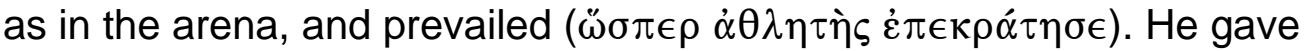
strength and high courage to the natural antagonist of emotion, reason

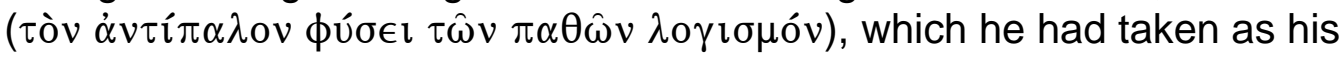
counselor throughout his life and now particularly was determined to obey. $(\text { Abr. 256) })^{57}$

Philo's conception of what the ascetic soul achieves in grappling with the emotions mirrors the Middle-Platonic theory of "passion" sketched elsewhere in his writings. Benign emotions become malignant "passions" by becoming

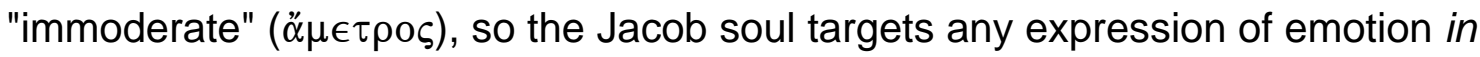
excess of the measure ( $\mu \varepsilon \dot{\tau} \rho \circ v_{)}$set by reason, "wrestling" it down into a more appropriate form. ${ }^{58}$ Allegorically interpreting the "numbing of the broad part"

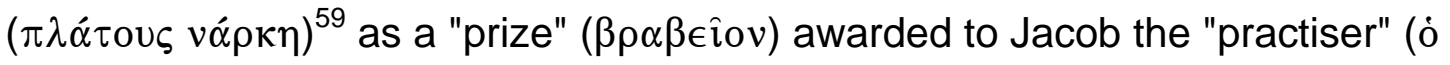
$\dot{\alpha} \sigma \kappa \eta \tau \eta \dot{s)}$ after his wrestling match, Philo writes:

[N]othing is so profitable ( $\sigma u ́ \mu \phi о \rho о v)$ as that the laxity and free play of the

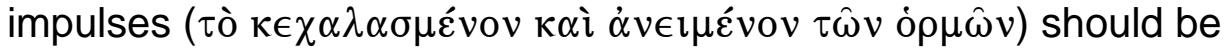
hampered and numbed ( $\dot{\alpha} v \alpha \kappa o \pi \hat{\eta} v \alpha i$ $\tau \epsilon \kappa \alpha \grave{\imath} v \alpha \rho \kappa \hat{\eta} \sigma \alpha \imath$ ) with their vitalizing forces paralyzed so that the inordinate strength of the emotions may be exhausted (iv ' $\dot{\eta} \tau \hat{\omega} v \pi \alpha \theta \hat{\omega} v \not \alpha \mu \epsilon \tau \rho \circ \varsigma$ i $\sigma \chi \grave{v} \varsigma \dot{\varepsilon} \xi \alpha \sigma \theta \epsilon v \dot{\eta} \sigma \alpha \sigma \alpha$ ) and thus provide a breadth in which the better part of the soul may expand ( $\pi \lambda \alpha$ $\alpha$ o $\varsigma$ $\dot{\varepsilon} \mu \pi \alpha \rho \alpha \dot{\alpha} \chi \eta\rceil \psi \chi \chi \eta \hat{\varsigma} \tau \hat{\omega} \beta \in \lambda \tau$ íovı $\mu \varepsilon \dot{\varepsilon} \in \imath)$. (Praem. 48) ${ }^{60}$

${ }^{57}$ Substituting "grief" for Colson's "sorrow," and "emotion" for "passion."

${ }^{58}$ Note also in Abr. 257 Philo's characterization of $\mu \epsilon \tau \rho \iota \pi \alpha \theta \epsilon \hat{\imath} v$ as $\mu \eta \tilde{\tau} \epsilon \pi \lambda \varepsilon$ ov $\tau$ oô $\mu \in \tau \rho i ́ o v ~ \sigma \phi \alpha \delta \alpha \hat{\zeta} \zeta \in \mathfrak{l} v$.

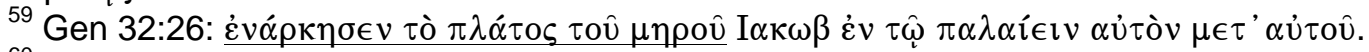

${ }^{60}$ Substituting "impulses" for Colson's "appetites"; "emotions" for "passions"; "paralyzed" for "paralysed." On $\kappa \in \chi \alpha \lambda \alpha \sigma \mu \varepsilon \dot{v} v v$, see Philo's interpretation of "girding the loins" (ó $\sigma \phi \hat{v} \varsigma$ $\pi \epsilon \rho \imath \epsilon \zeta \hat{\omega} \sigma \theta \alpha \mathrm{l})$ which likewise speaks of moderating emotion (e.g., Leg. 3.153-54: $\dot{\alpha} v \epsilon \zeta \hat{\omega} \sigma \theta \alpha \mathrm{l} \gamma \grave{\alpha} \rho$

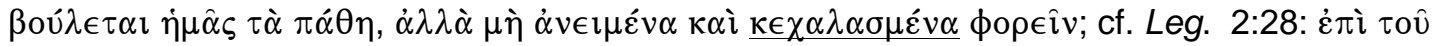

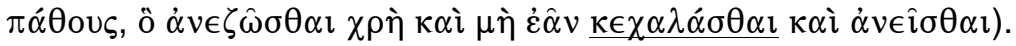


Since curtailing excess stands in Philo's mind as one aspect of $\dot{\varepsilon} \gamma \kappa \rho \dot{\tau} \tau \in \iota \alpha$, he characterizes here the laborious wrestling of the Jacob soul as the practice

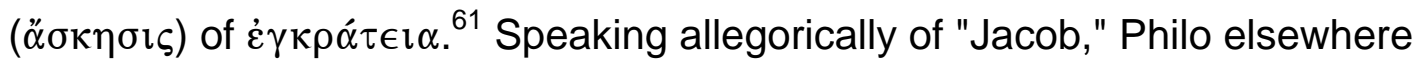
notes:

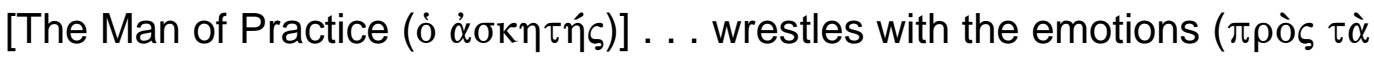
$\pi \alpha \dot{\theta} \eta \pi \alpha \lambda \alpha i \omega v)$ and ... goes into training to gain self-control ( $\pi \rho \grave{\varsigma} \varsigma$ $\dot{\varepsilon} \gamma \kappa \rho \dot{\alpha} \tau \epsilon \iota \alpha \nu \dot{\alpha} \lambda \in \iota \phi o ́ \mu \epsilon \nu \circ \varsigma)$. ... (Congr. 31) ${ }^{62}$

Insofar as he identifies the emotions generically as the wrestling opponent of the Jacob soul, Philo brings a broad formulation of $\dot{\varepsilon} \gamma \kappa \rho \alpha ́ \tau \epsilon \mathfrak{l} \alpha$ ("rational" over "nonrational") to his consideration of $\ddot{\alpha} \sigma \kappa \eta \sigma \imath \varsigma$. But the emotions obviously include $\dot{\varepsilon} \pi \imath \theta u \mu i \alpha$, and the narrow formulation of $\dot{\varepsilon} \gamma \kappa \rho \alpha \dot{\tau} \tau \epsilon \alpha$ singles it out as the principal antagonist of reason. When Philo considers the specific types of practice needed to acquire $\dot{\varepsilon} \gamma \kappa \rho \dot{\alpha} \tau \in \iota \alpha$, he tends to have this narrow formulation-with its emphasis on $\dot{\varepsilon} \pi \imath \theta u \mu i \alpha$-in mind.

\section{'E $\gamma \kappa \rho \alpha ́ \tau \epsilon \iota \alpha$ through Ascetic Precepts}

Based on his understanding of what Jacob represents, Philo sees the

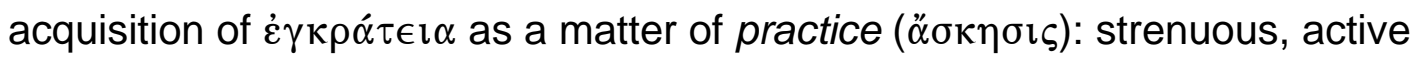
engagement with an opponent $(\dot{\varepsilon} \pi \imath \theta u \mu i \alpha)$, in a contest of power that builds strength and skill. But exactly what sort of practice endows the moral agent with $\dot{\varepsilon} \gamma \kappa \rho \alpha ́ \tau \epsilon \iota \alpha$ ? What sorts of exercises make for good training? In general, Philo

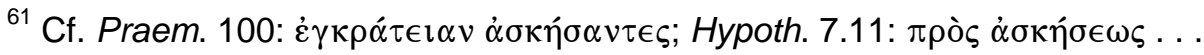

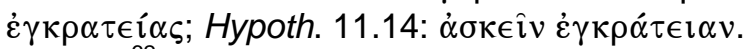

62 Substituting "emotions" for Colson's "passions." 
believes that the Law of Moses promotes virtue among its adherents. ${ }^{63}$ But he also believes that Moses designed specific laws to promote specific virtues, including $\dot{\varepsilon} \gamma \kappa \rho \alpha \dot{\tau} \tau \iota \alpha .{ }^{64}$ In other words, Moses had a clear grasp of the activities of soul capable of effecting $\dot{\varepsilon} \gamma \kappa \rho \alpha \dot{\alpha} \tau \epsilon \iota \alpha$, and-like a good trainer-he prescribed those activities through specific laws. ${ }^{65}$ Apart from any religious significance, such precepts have great philosophical significance, because their formulation

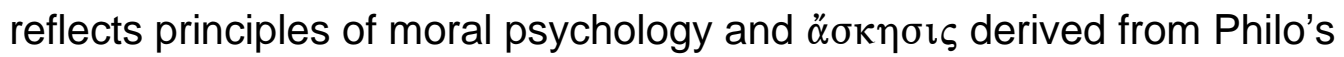
philosophical milieu. ${ }^{66}$ To coin a term, they are "ascetic precepts," and they

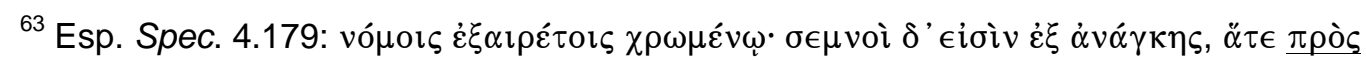

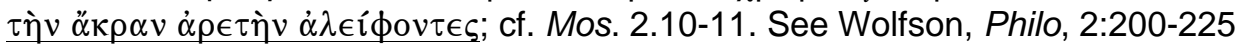
[="Commandments and Virtues"] (cf. John W. Martens, One God, One Law: Philo of Alexandria on the Mosaic and Greco-Roman Law [AMMTC; SPhAMA 2; Boston: Brill Academic Publishers, 2003], 95-99 [="The Law of Moses"]; André Myre, "La loi de la nature et la loi mosaïque selon Philon d'Alexandrie," ScEs 28 (1976): 163-81, esp. 167-71 [="La loi mosaïque et la loi morale"]; Michael Satlow, "Philo on Human Perfection," JTS 59 [2008]: 500-519, 517-18; ). For a consideration of the role of Torah in ethical training in ancient rabbinic Judaism, see Jonathan Wyn Schofer, The Making of a Sage: A Study in Rabbinic Ethics (Madison: University of Wisconsin Press, 2005), esp. 84-115 [="The Heart and Its Formation"].

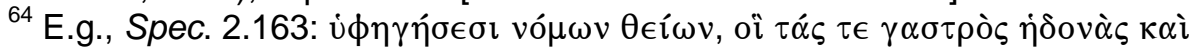

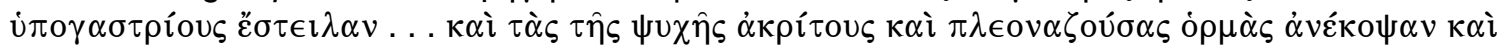
$\dot{\alpha} v \in \chi \alpha i$ i $\_\alpha \nu$. On the valorization of $\dot{\varepsilon} \gamma \kappa \rho \alpha \dot{\tau} \tau \iota \alpha$ among Philo's contemporaries as a context for his own emphasis on $\dot{\varepsilon} \gamma \kappa \rho \alpha \dot{\tau} \epsilon \iota \alpha$ in regard to the Tenth Commandment (and dietary laws), see Stowers, Romans, 46-56; also Niehoff, Philo on Jewish Identity, 75-110 [= "Jewish Values: Religion and Self-Restraint"]; cf. Long, "Ethics and Power."

${ }^{65}$ In Philo's view, Moses could formulate helpful exercises in $\dot{\varepsilon} \gamma \kappa \rho \alpha ́ \tau \epsilon \iota \alpha$ because he himself had mastered desire: "When [Moses] was now passing beyond the term of boyhood, his good sense became more active. He did not, as some, allow the lusts of adolescence to go

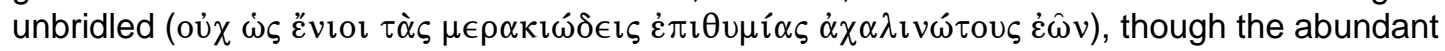
resources which palaces provide supply numberless incentives to foster their flame. But he kept a tight hold on them with the reins, as it were, of temperance and self-control ( $\sigma \omega \phi \rho o \sigma u ́ v \eta$ $\kappa \alpha i$

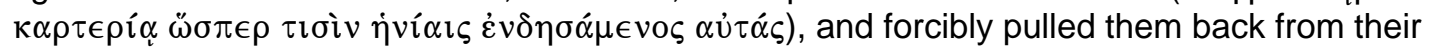

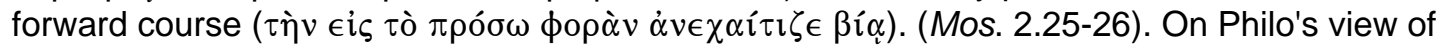
Moses, see Hywel Clifford, "Moses as Philosopher-Sage in Philo," in Moses in Biblical and ExtraBiblical Traditions (ed. Axel Graupner and Michael Wolter; BZAW 372; Berlin: de Gruyter, 2007), 151-67;

${ }^{66}$ These Mosaic philosophical exercises fit the definition of "sittliches Exerzitium" (also "sittliche Übung"), the term Paul Rabbow offers to describe a type of methodical practice popular among philosophers of the early Roman Era: "a particular exertion, a calculated act of self- 
signal Philo's attempt to understand Mosaic legislation in light of contemporary

Middle-Platonic ethical concerns. ${ }^{67}$ Although Philo casts a number of laws as

exercises in $\dot{\varepsilon} \gamma \kappa \rho \alpha ́ \tau \epsilon \iota \alpha$ (ascetic precepts), he never couples an individual law

with a complete explanation of how it works. But considering his remarks on

several such laws provides enough material to create an adequate concept of the ascetic precept.

In the law regarding a year of Sabbath rest for the land (Lev 25:2-7; Exod

23:10-11), the law regarding fasting on the Day of Atonement (Lev 16:29-31;

influence, carried out with the express purpose of achieving a specific ethical effect; it always transcends itself, insofar is it is either repeated or forms part of a larger network of acts designed for the same purpose" (my translation of Paul Rabbow, Seelenführung: Methodik der Exerzitien in der Antike [München: Kösel, 1954], 18).

${ }^{67}$ In general, research into Philo's theory of $\ddot{\alpha} \sigma \kappa \eta \sigma \iota \varsigma$ has overlooked the place of Mosaic legislation within that theory. Studies of Philo that deal directly with $\ddot{\alpha} \sigma \kappa \eta \sigma \iota \varsigma$ but do not consider the ascetic function of precepts include Bréhier, Idées philosophiques et religieuses, 261-71 [="Le

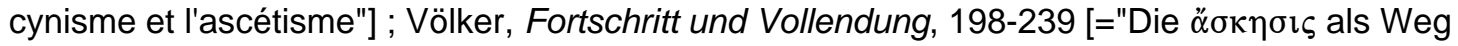
zur Vollkommenheit"]; and Winston, "Philo's Ethical Theory," esp. 405-14 [="Asceticism"]. Similarly, David Charles Aune, "Mastery of the Passions," while he intends in part to "illustrate Philo's ... ascetic program" (128), does not consider the role of precepts. Siegfried, Philo, does speak of "das mosaische Gesetz als das zweckmässigste Anleitungsmittel für . . . sittlichen

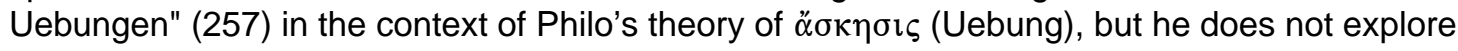

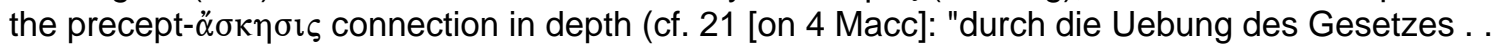
. diese vier Tugenden Entstehen"). In their study of Jacob as Philo's allegorical paradigm of

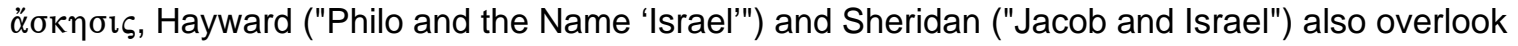
the role of precepts within that paradigm. Steven Fraade notes the role of precepts in his "Ascetical Aspects of Ancient Judaism" (in Jewish Spirituality [ed. Arthur Green; New York: Crossroad, 1986], 253-88, 265: "Such strength is only gradually achieved with the help of the commandments of the Torah, which are often interpreted by Philo as exercises intended to strengthen the soul by repeatedly accustoming it to abstinence from and moderation of desires for food, drink, sex, etc." But Fraade does not explore the precept- $\alpha \sigma \kappa \eta \sigma \iota \varsigma$ connection in depth,

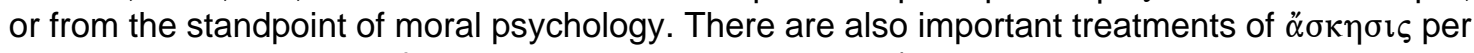
se that mention Philo yet fail to consider ascetic precepts (e.g., Bernhard Lohse, Askese und Mönchtum in der Antike und in der alten Kirche [RKAM; ed. Carsten Colpe and Heinrich Dörrie; Munich and Vienna: R. Oldenbourg, 1969], 102-10). Pierre Hadot, "Spiritual Exercises," provides an excellent survey of therapeutic exercises in Greco-Roman philosophy, including Philo. He

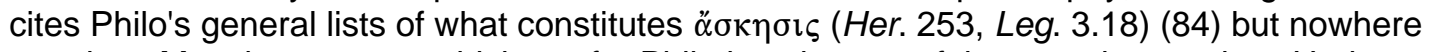
mentions Mosaic precepts, which are for Philo just the sort of therapeutic exercises Hadot seems to have in mind. 
Num 29:7-11), and the law regarding marrying female prisoners of war (Deut 21:10-13), Philo recognizes deliberate efforts on Moses' part to promote

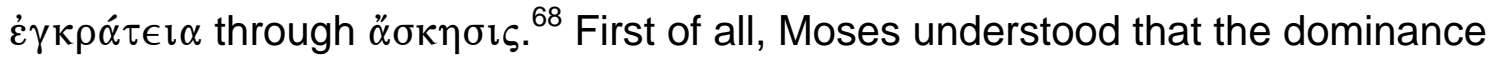
of $\lambda$ ó $\gamma$ o over $\dot{\varepsilon} \pi \imath \theta u \mu i \alpha$ can involve either the complete suppression of desire (no indulgence) or simply the constraint of desire within certain limits (moderate indulgence). In either case, the moral agent controls desire and effectively exercises a capacity for $\dot{\varepsilon} \gamma \kappa \rho \alpha ́ \tau \epsilon \iota \alpha$. The law of Sabbath rest, for example, calls for a moderate indulgence of $\dot{\varepsilon} \pi \imath \theta u \mu i \alpha$, because it prohibits farmers from working their land every seventh year. By enjoining the deliberate forgoing of potential

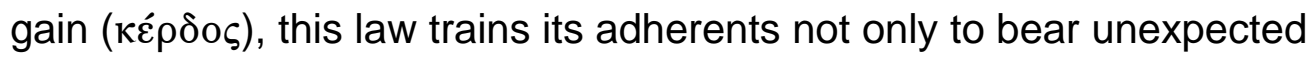
deprivation $(\check{\varepsilon} v \delta \in \imath \alpha)$ but also to keep their desires within moderate bounds. ${ }^{69}$ In Philo's view, the command targets $\pi \lambda \epsilon \mathrm{ov} \epsilon \xi i \alpha$, a form of excessive desire. ${ }^{70}$ Speaking of those who do not observe the law of Sabbath rest, Philo writes:

${ }^{68}$ On the law of Sabbath rest, see esp. Spec. 2.86-109, Spec. 4.212-18, and Praem. 15356 (cf. Hypoth. 7.15-18). On fasting, see esp. Spec. 1.186-88 (cf. Spec. 1.192-93; Mos. 2.23-24) and Spec. 2.193-203 (esp. §195). On female prisoners of war, see Virt. 110-13. Philo himself seems to acknowledge the barbaric setting of a law treating women as spoils of war subject to nonconsensual marriage. He takes an apologetic tack, including this law in his discussion of Mosaic humanity ( $\phi \imath \lambda \alpha \nu \theta \rho \omega \pi i \alpha)$ and highlighting the kindness it enjoins (NB Virt. 110: $\mu \grave{\eta} \dot{\omega} \varsigma$

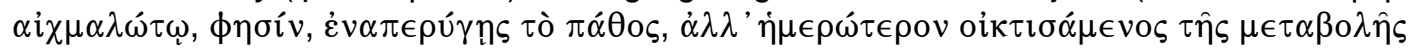

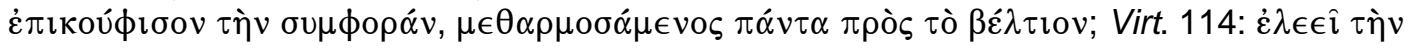
$\alpha i \chi \mu \alpha \dot{\alpha}(\omega \tau o v)$. Unlike the laws of Sabbath rest and fasting, which had practical application in Philo's day, the law regarding marrying female prisoners of war presumably had only a theoretical interest for Philo.

${ }^{69}$ On training for unexpected hardship, see Spec. 2.87-88, where Philo makes the

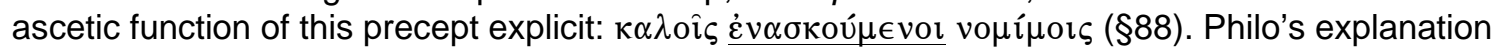
of how this precept works to moderate desire comes in Spec. 4.212-18, as part of an explication of the law against sowing two kinds of seed (Lev 19:19; Deut 22:9), to which Philo attributes the same ascetic function (see esp. Spec. 4.215-18).

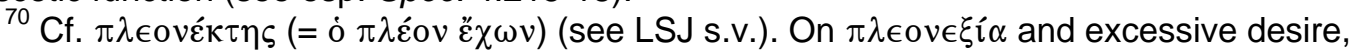

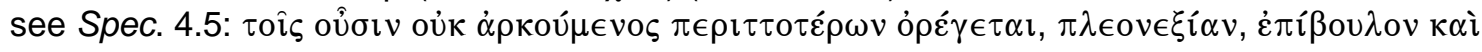


They have burdened the fields by continually pursuing unjust gains based

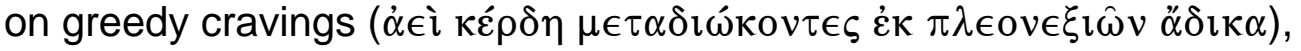
adding to otherwise reasonable desires ( $\tau \alpha \hat{\imath} \varsigma \dot{\varepsilon} \pi \imath \theta u \mu i \alpha \iota \varsigma \dot{\varepsilon} \pi \imath \sigma \tau \dot{\alpha} v \tau \epsilon \varsigma$ ) unbridled and unjust impulses incapable of fulfillment ( $\dot{\alpha} \chi \alpha \lambda i$ vous $\kappa \alpha \grave{\imath}$

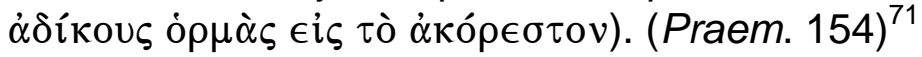

Philo clarifies here the nature of $\pi \lambda \in o v \in \xi i \alpha \imath$ as excessive desires in terms of Middle-Platonic theory. The $\dot{\varepsilon} \pi \imath \theta u \mu i \alpha \iota$ he names represent the unobjectionable emotion desire, whose otherwise benign impulse becomes malignant with the

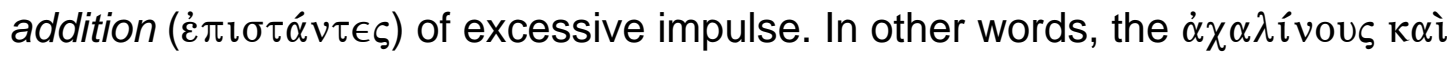

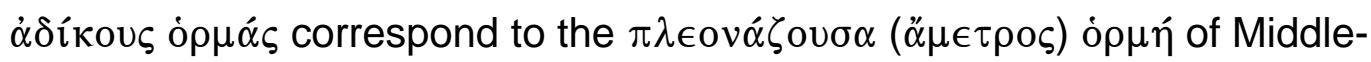
Platonic theory, the quantitative excess constituting passion. To observe the law, farmers need not deny their reasonable desire for produce; they exercise $\dot{\varepsilon} \gamma \kappa \rho \dot{\alpha} \tau \epsilon \iota \alpha$ and curtail their desire within limits prescribed by Moses. ${ }^{72}$ Outright denial—at least for a time—figures in the laws of fasting on the Day of Atonement and marrying female prisoners of war. Here reason cedes nothing to $\dot{\varepsilon} \pi \imath \theta u \mu i \alpha$, compelling it to wait for a fixed interval of time deprived of the pleasure it seeks. The fast, for example, involves one day of "bridling impulses for

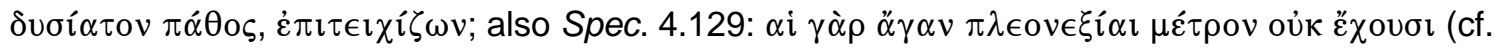
Spec. 1.270, Virt. 100).

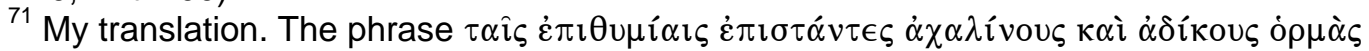

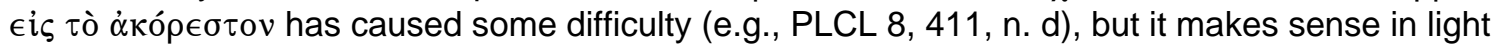
of a Middle-Platonic concept of passion, without Cohn's emendation of present ( $\dot{\varepsilon} \phi \imath \sigma \tau \dot{\alpha} v \tau \epsilon \varsigma)$ for the manuscript aorist $(\dot{\varepsilon} \pi \imath \sigma \tau \alpha \dot{\alpha} \nu \tau \in \zeta)$.

72 In Spec. 4.217, Philo compares violators of the law of Sabbath rest to those who

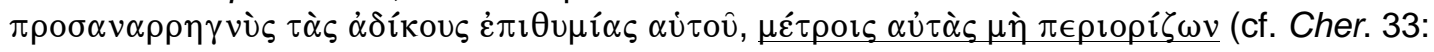
$\left.\mu \varepsilon \dot{\tau} \rho \alpha \tau \alpha \hat{\imath} \varsigma \dot{\varepsilon} \pi \imath \theta u \mu i \alpha_{\imath l \varsigma} \pi \epsilon \rho \imath \theta \epsilon \hat{\imath} v \alpha \imath\right)$. 


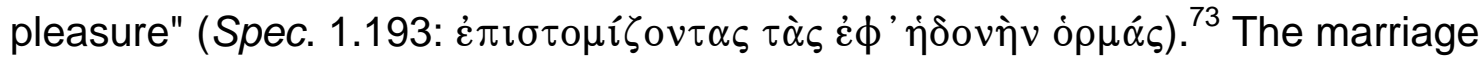
law involves thirty days of postponing consummation, reflecting Moses' unwillingness to "let desire get swept away in unbridled disobedience" (Virt. 113:

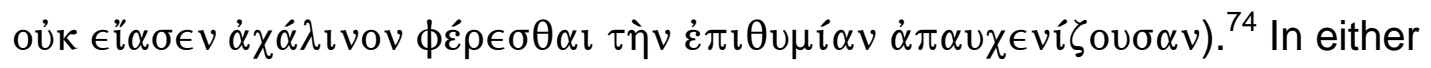
case, Moses has designed an effective exercise in $\dot{\varepsilon} \gamma \kappa \rho \dot{\alpha} \tau \epsilon \iota \alpha$, since obedience requires a stark denial of desire on reason's part. Like the moderation enjoined by the law of Sabbath rest, the abstinence enjoined by these laws of fasting and marriage strengthen the capacity of $\lambda o ́ \gamma o \varsigma$ to subjugate $\dot{\varepsilon} \pi \imath \theta v \mu i \alpha$, which in turn promotes self-control in contexts beyond those contrived by Moses.

In fact, the ascetic value of these laws hinges on their not being ends in themselves, since training exercises necessarily serve as a means for cultivating broader proficiencies. In other words, Philo admires Moses' ascetic precepts not so much for the successful instances of $\dot{\varepsilon} \gamma \kappa \rho \alpha \dot{\tau} \tau \epsilon \iota$ they enjoin as for the successful life of $\dot{\varepsilon} \gamma \kappa \rho \alpha \dot{\tau} \epsilon \iota \alpha$ they collectively promote. The moral capacities derived from observing particular commands transfer broadly to analogous situations Moses never addressed, so those trained by Mosaic legislation can operate apart from law as free moral agents possessed of $\dot{\varepsilon} \gamma \kappa \rho \alpha ́ \tau \epsilon \iota \alpha$. Philo illustrates this principle of transference in Spec. 4.218, where he praises the law

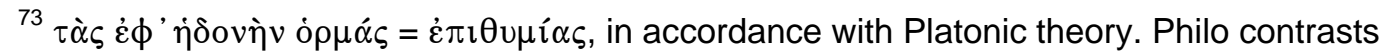
this restraint with the incitements to desire characteristic of pagan holidays (e.g., Spec. 1.192: $\tau \grave{\alpha} \varsigma$

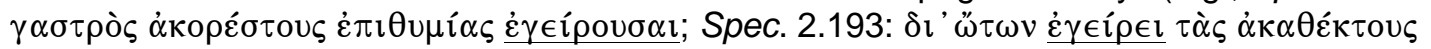
$\dot{\varepsilon} \pi \imath \theta u \mu i \alpha \varsigma)$.

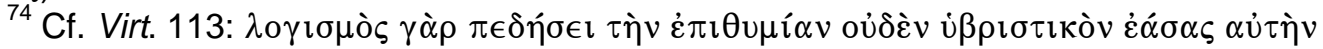

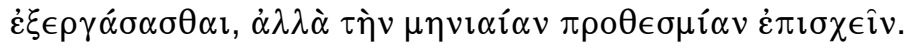


of Sabbath rest for the land as one of two precepts—along with the law against planting two types of seed in a vineyard (Deut 22:9; cf. Lev 19:19)—designed to restrain "by extension" ( $\mu \alpha \kappa \rho o ́ \theta \epsilon \nu)$ the madness of greedy cravings ( $\pi \lambda \epsilon o v \in \xi i \hat{\omega} v$ $\tau \grave{\eta} \nu \lambda \dot{v} \sigma \sigma \alpha \nu)$ aimed at people ( $\left.\dot{\varepsilon} \pi^{\prime} \dot{\alpha} \nu \theta \rho \omega \dot{\pi} \pi \mathrm{ol}\right)$ rather than plants: ${ }^{75}$

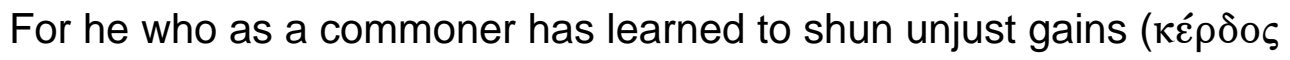
$\left.\alpha{ }_{\alpha} \delta \kappa \circ v\right)$ in the treatment of his plants will, if he becomes a king with greater matters in his charge ( $\lambda \alpha \beta$ ó $\mu \in v o \varsigma \mu \epsilon \iota \zeta o ́ v \omega \nu \pi \rho \alpha \gamma \mu \alpha ́ \tau \omega \nu)$, follow his acquired habit $(\tau \hat{\omega}, \ddot{\varepsilon} \theta \in \imath$ ) when he comes to deal with men and also women. He will not exact a double tribute nor wring the life out of his

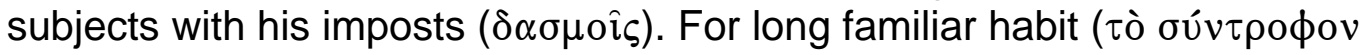
$\check{\varepsilon} \theta$ os) has the power to soften harsh temperaments and in a sense to tutor

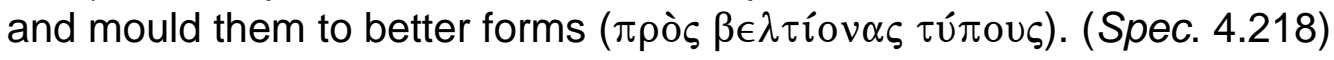

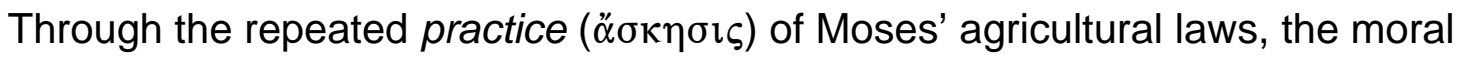
agent develops a "habit" (ع̈ $\theta$ o $)$ of successfully dealing with desire. ${ }^{76}$ Since $\dot{\varepsilon} \gamma \kappa \rho \alpha \dot{\tau} \epsilon \iota \alpha$ per se stands as the ultimate goal, the original context of the precept has little significance, except that it stages a contest of power between $\lambda$ ó$_{0} \varsigma$ and $\dot{\varepsilon} \pi \imath \theta u \mu i \alpha$ whose result is the moral habit of moderating desire. Once acquired

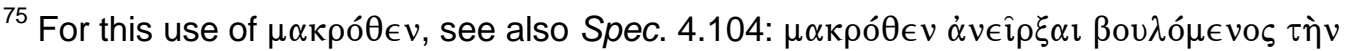
$\dot{\varepsilon} \pi \grave{\imath} \tau \grave{\alpha} \lambda \epsilon \chi \theta \varepsilon \dot{\varepsilon} \tau \tau \alpha \dot{o} \rho \mu \eta \dot{v}$. For the language of restraint Philo uses in Spec. 4.218 to describe the

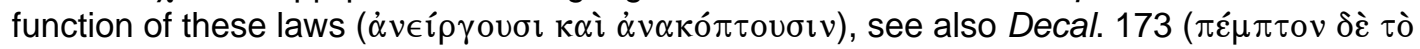

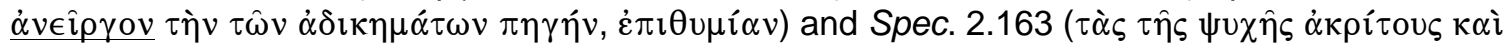

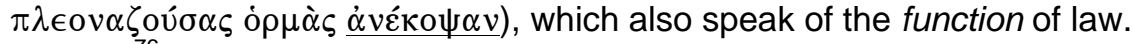

${ }^{76}$ Aristotle clearly articulated a theory of the role played by $\varepsilon$ ध $0 \varsigma$ in the acquisition of

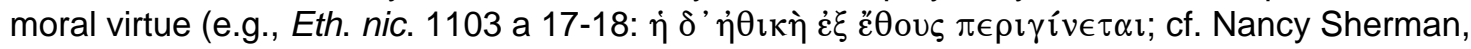
"The Habituation of Character," in Aristotle's Ethics: Critical Essays [ed. Nancy Sherman; CEC; Lanham, Md.: Rowman \& Littlefield, 1999], 231-60). In Middle-Platonic moral theory, the concepts of $\ddot{\alpha} \sigma \kappa \eta \sigma \iota \varsigma$ and $\ddot{\varepsilon} \theta$ o $\varsigma$ bear a close relation, since both involve a process of training non-rational

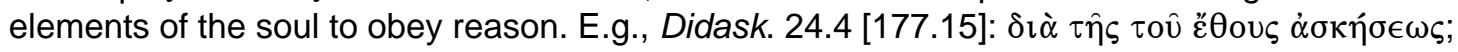

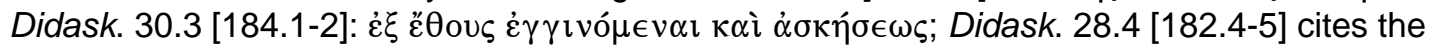

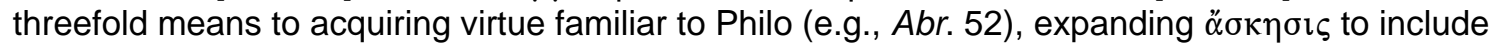

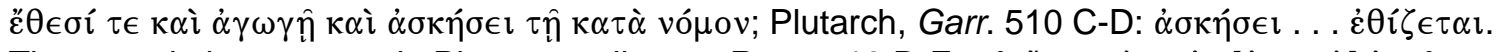

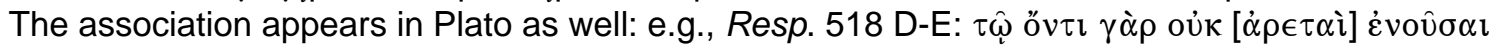

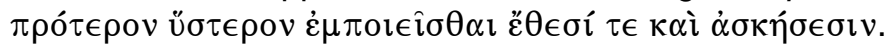


through Moses' ascetic precepts, this habit of moderation transfers to "greater matters" ( $\mu \in \imath \zeta o ́ v \omega v \pi \rho \alpha \gamma \mu \alpha \dot{\tau} \tau \omega \nu)$, such as the duties of a king. Instead of indulging an inordinate desire for revenue, a ruler trained by Moses' regimen will exercise moderation and not exhaust the wealth of his subjects. The same principle of transference appears in Philo's analysis of the fasting prescribed for

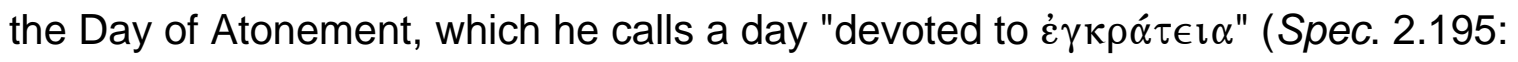

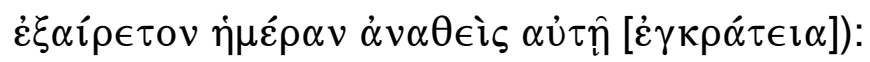

To one who has learnt to disregard food and drink which are absolutely

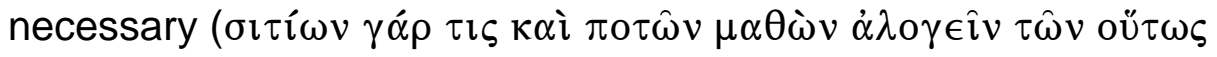

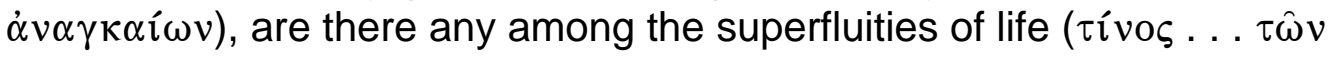
$\pi \epsilon \rho \imath \tau \tau \hat{\omega} v)$ which he can fail to despise, things which exist to promote not

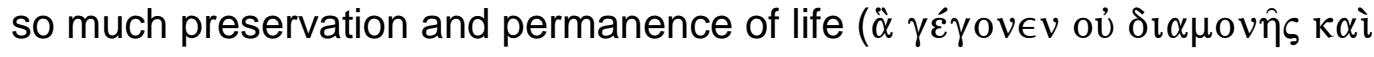
$\sigma \omega \tau \eta \rho i \alpha \zeta \check{\varepsilon} v \in \kappa \alpha)$ as pleasure with all its powers of mischief ( $\mu \hat{\alpha} \lambda \lambda$ ov $\ddot{\eta}$ $\beta \lambda \alpha \beta \epsilon \rho \omega \tau \dot{\alpha} \tau \eta \varsigma \dot{\eta} \delta o v \hat{\eta} \varsigma) ?($ Spec. 2.195)

Philo admires the lifestyle of $\dot{\varepsilon} \gamma \kappa \rho \dot{\alpha} \tau \in \iota \alpha$ this law promotes, not simply the temporary exercise of $\dot{\varepsilon} \gamma \kappa \rho \alpha ́ \tau \epsilon \mathfrak{l} \alpha$ it requires. By practicing on a limited basis the more challenging denial of necessary desires, the moral agent masters the comparatively easy denial of superfluous desires. And this broader capacity for consistent denial of superfluous desires amounts to $\dot{\varepsilon} \gamma \kappa \rho \alpha ́ \tau \epsilon \iota \alpha$, because it involves the enforcement of reason's measure (necessity) over against desire's tendency to pursue pleasure in excess of that measure.

CONCLUSION

Philo has a multi-faceted but theoretically consistent understanding of $\dot{\varepsilon} \gamma \kappa \rho \alpha \dot{\tau} \tau \epsilon \iota$. In essence, $\dot{\varepsilon} \gamma \kappa \rho \alpha ́ \tau \epsilon \iota \alpha$ involves the rule of reason over antagonistic 
non-rational forces within the soul, especially $\dot{\varepsilon} \pi \imath \theta v \mu i \alpha$. In particular, $\dot{\varepsilon} \gamma \kappa \rho \dot{\alpha} \tau \epsilon \iota \alpha$ involves the curtailing of excessive non-rational impulses through the enforcement of limits set by reason. Framed in terms of human motivation, this involves reason's consistent enforcement of its goal, the greatest overall good for the soul, over against desire's goal of pleasure. In any case, $\dot{\varepsilon} \gamma \kappa \rho \alpha ́ \tau \epsilon \iota \alpha$ stands as the indispensable guard against passion, because it keeps the emotion $\dot{\varepsilon} \pi \imath \theta u \mu i \alpha$ from ever usurping reason's authority and overtaking the soul. For this reason, Philo commends the acquisition of $\dot{\varepsilon} \gamma \kappa \rho \alpha \dot{\tau} \epsilon \iota \alpha$, identifying $\ddot{\alpha} \sigma \kappa \eta \sigma \imath \varsigma$ as the principle means to that end. By repeatedly practicing reason's dominance over desire, the moral agent develops a capacity for $\dot{\varepsilon} \gamma \kappa \rho \alpha ́ \tau \epsilon \iota \alpha$. Moses understood this principle and so designed a number of ascetic precepts, which enjoin the subjugation of desire in a limited, artificial setting in order to cultivate a broader lifestyle of $\dot{\varepsilon} \gamma \kappa \rho \dot{\alpha} \tau \in \imath \alpha$ among those trained by his precepts. 


\section{CHAPTER FOUR}

\section{PHILO'S EXPOSITION OF THE TENTH COMMANDMENT: TRANSLATION AND COMMENTARY}

\section{PHILO'S EXPOSITORY AGENDA}

In his exposition of the Tenth Commandment, Philo uses the conceptual nexus of $\dot{\varepsilon} \pi \imath \theta u \mu i \alpha, \dot{\varepsilon} \gamma \kappa \rho \alpha ́ \tau \epsilon \imath \alpha$, and $\ddot{\alpha} \sigma \kappa \eta \sigma \iota \varsigma$ as an overarching frame of reference for his work. Within that frame, his concept of desire figures most prominently, since a serious attempt to explain the prohibition oủк $\dot{\varepsilon} \pi \imath u \mu \eta \dot{\eta} \sigma \in \iota \varsigma$ requires an equally serious concept of $\dot{\varepsilon} \pi \imath \theta u \mu i \alpha$, serious enough to enable a precise statement of what exactly the Tenth Commandment prohibits. For Middle Platonists, the operation of $\dot{\varepsilon} \pi \imath \theta u \mu i \alpha$ can represent either a perfectly natural, amoral emotion $(\pi \dot{\alpha} \theta \circ \varsigma)$ or an immoral passion $(\pi \dot{\alpha} \theta \circ \varsigma)$, depending on whether or not reason stays in control. Reading oủк $\dot{\varepsilon} \pi \imath \theta u \mu \eta \tilde{\sigma \epsilon} \varsigma$ as a categorical prohibition of the emotion desire- $\dot{\varepsilon} \pi \imath \theta v \mu i \alpha$ itself-makes no sense from a Middle-Platonic standpoint for two reasons: (1) the emotion itself involves nothing morally objectionable and (2) human existence requires, at minimum, the indulgence of necessary desires for food and drink. So on theoretical grounds alone, Philo must take oủк $\dot{\varepsilon} \pi \imath \theta \mu \eta ́ \sigma \epsilon \iota \varsigma$ as a prohibition of passionate desire, which in fact he does in the course of his exposition, justifying the prohibition in light of dangers posed by passionate desire itself and its dangerous propensity to 
burgeon into tyrannical desire ( $(\varepsilon \omega \varsigma)$. But how does someone actually observe a prohibition of passionate desire? Here the concept of $\dot{\varepsilon} \gamma \kappa \rho \alpha ́ \tau \epsilon \iota \alpha$ figures into Philo's frame of reference as the solution to the problem addressed by the Tenth Commandment. Because Middle Platonists conceived passionate desire as "immoderate" desire ( $\ddot{\alpha} \mu \in \tau \rho \circ \varsigma \dot{\varepsilon} \pi \imath \theta u \mu i ́ \alpha)$, abstaining from the passion (thereby observing the prohibition) means keeping the emotion within the bounds of moderation, which in turn requires $\dot{\varepsilon} \gamma \kappa \rho \alpha ́ \tau \epsilon \iota \alpha$. For this reason, Philo's exposition programmatically commends $\dot{\varepsilon} \gamma \kappa \rho \dot{\alpha} \tau \epsilon \iota \alpha$ as the means to observing the Tenth Commandment. But Philo also outlines the Mosaic program for acquiring $\dot{\varepsilon} \gamma \kappa \rho \alpha ́ \tau \epsilon \iota \alpha$, which brings $\ddot{\alpha} \sigma \kappa \eta \sigma \iota \varsigma$ into his frame of reference. In particular, he casts the Mosaic dietary laws as a set of ascetic precepts designed to inculcate $\dot{\varepsilon} \gamma \kappa \rho \alpha ́ \tau \epsilon \iota \alpha$ through $\ddot{\sigma} \sigma \kappa \eta \sigma \iota \varsigma$. So Philo's entire exposition can be summarized in terms of these three concepts: (1) the Tenth Commandment prohibits passionate $\dot{\varepsilon} \pi \imath \theta u \mu i \alpha$, (2) obeying the prohibition amounts to the exercise of $\dot{\varepsilon} \gamma \kappa \rho \dot{\alpha} \tau \epsilon \iota \alpha$, and

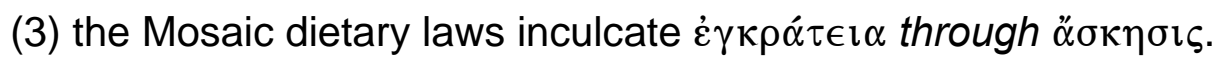

Recognizing $\dot{\varepsilon} \pi \imath \theta u \mu \mathfrak{\imath} \alpha, \dot{\varepsilon} \gamma \kappa \rho \alpha ́ \tau \epsilon \iota \alpha$, and $\ddot{\alpha} \sigma \kappa \eta \sigma \iota \varsigma$ as Philo's ultimate frame of reference helps to explain the various interpretive moves he makes in connection with both the prohibition oủк $\dot{\varepsilon} \pi \imath \theta u \mu \eta \dot{\eta} \sigma \in \imath \varsigma$ and the dietary laws presumed to support its observance. Before composing an exposition of the Tenth Commandment, Philo understood these three concepts to stand in a certain theoretical relationship, conceived along Middle-Platonic rather than 
biblical lines. So when he encounters a biblical prohibition of $\dot{\varepsilon} \pi \imath \theta u \mu i \alpha$, he tries to make sense of it in light of the Middle-Platonic theory at his disposal, framing a philosophical notion of the type of desire proscribed, the reason for its proscription, and the means of observing the proscription. Similarly, once Philo identifies the dietary laws as the legal species of the genus oủк $\dot{\varepsilon} \pi \imath \theta u \mu \eta \dot{\sigma} \sigma \iota \varsigma$, his interest lies not so much in the laws per se as in the Mosaic program of $\ddot{\sigma} \sigma \eta \sigma \iota \varsigma$ they represent. In other words, Philo operates according to a clear expository agenda: a deliberate effort to correlate the Tenth Commandment and its dietary laws with the best of contemporary philosophy (Middle Platonism) by carefully highlighting the principles of $\dot{\varepsilon} \pi \imath \theta u \mu i \alpha, \dot{\varepsilon} \gamma \kappa \rho \alpha \dot{\tau} \tau \in \imath \alpha$, and $\ddot{\alpha} \sigma \kappa \eta \sigma \imath \varsigma$ at work in their formulation. Philo implements this agenda in a variety of ways throughout his exposition, but two particular ways involve his prior knowledge of (1) traditional interpretations of the dietary laws, particularly laws concerning clean and unclean animals, and (2) contemporary genres of philosophical literature. Giving preliminary consideration to these topics clarifies their relevance to Philo's expository agenda.

\section{Traditional Interpretations of Clean and Unclean Animals}

In his extended interpretation of the Mosaic regulations concerning clean and unclean animals (Spec. 4.100-118), Philo demonstrates familiarity with a line of interpretation developed by an earlier generation of Hellenistic Jews in Alexandria—namely, the symbolic interpretation of clean and unclean animals 
attributed to the High Priest Eleazar in the Letter of Aristeas. ${ }^{1}$ Essentially, Eleazar argues that Moses formulated his legislation on clean and unclean animals to

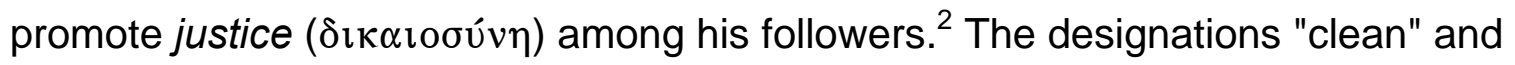
"unclean" have little to do with the properties of animal flesh for eating-instead they derive from physical and behavioral traits that symbolize certain ethical traits among human beings. ${ }^{3}$ Eleazar's most extensive interpretation along these lines involves various species of birds (Let. Arist. 145-50). Unclean birds, for example, "are wild and carnivorous and with their strength oppress the rest and procure their food with injustice" (Let. Arist. 146). As Eleazar explains further:

Through these creatures then, by calling them 'unclean' ( $\dot{\alpha} \kappa \dot{\alpha} \theta \alpha \rho \tau \alpha)$, [Moses] set up a symbol ( $\pi \alpha \rho \alpha \tilde{\sigma} \eta \mu o v)$ that those for whom the legislation was drawn up must practice justice ( $\delta \iota \kappa \alpha$ เoбúvn) in spirit and oppress no one, trusting in their own strength, nor rob anyone of anything, but must

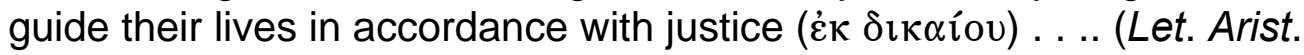
147)

\footnotetext{
${ }^{1}$ See esp. Let. Arist. 144-69. On the question of Philo's knowledge of the Letter of Aristeas, see Moses Hadas, Aristeas to Philocrates: Letter of Aristeas (New York: Harper, 1951; repr., Eugene, Oreg.: Wipf \& Stock, 2007), 21-26. Hadas concludes: "The balance of probability seems to be rather on the side of Philo's having read our Aristeas" (25-26). Cf. Rhodes, "Diet and Desire," 124, n. 10: "Whether or not Philo knew the Letter of Aristeas or simply inherited a similar exegetical tradition is difficult to determine with certainty. The situation is analogous to the famous crux of whether Philo derives his story of the origin of the LXX (Mos. 2.25-44) from Aristeas or an independent tradition. On balance, the wide circulation eventually attained by the Letter of Aristeas favors Philo's knowledge of that document." Berthelot ("L'interprétation symbolique," 253) suggests a shared tradition: "Bien que l'inspiration de Philon soit très proche de celle d'Aristée, il n'est pas sûr que Philon dépende à strictement parler de celui-ci; il semble plutôt que les deux auteurs aient puisé à une tradition commune." On Philo's relation to the Letter of Aristeas, see also Hecht, "Patterns of Exegesis," 112-14.

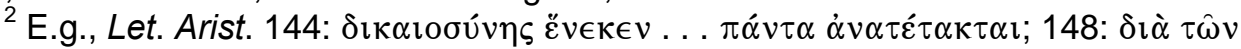

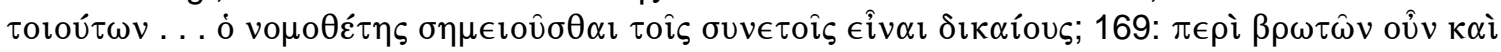

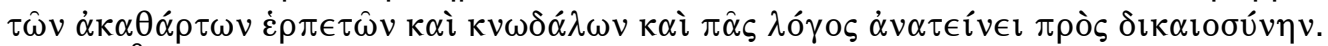

${ }^{3}$ On this sort of ethical interpretation, see Berthelot, "L'interprétation symbolique."
} 
Moses' prohibition functions as a symbolic discourse in which the command to abstain from a certain type of bird translates directly into a moral exhortation to abstain from violent oppression. This line of interpretation makes actual abstinence seem irrelevant, since eating an unclean bird would not in fact undermine Moses' purpose, as long as the moral agent abstains from the type of

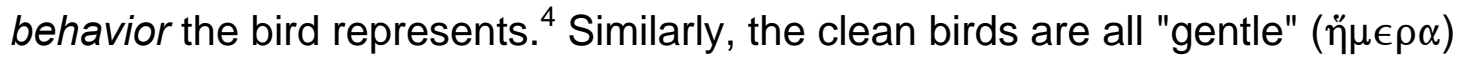
herbivores, which never violently oppress another creature (Let. Arist. 147). By calling them "clean," Moses commends the disposition they represent, again with no real concern for the consumption (or not) of their flesh:

By such examples, then, the lawgiver has commended to men of

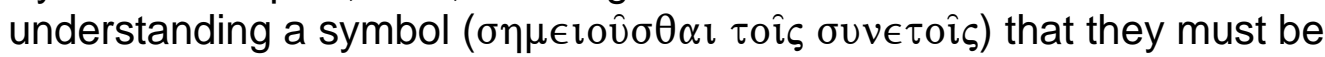

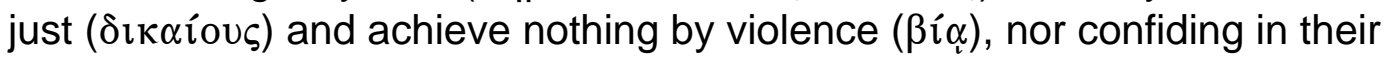

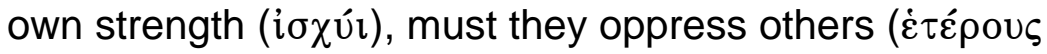
$\kappa \alpha \tau \alpha \delta \cup v \alpha \sigma \tau \epsilon \cup \in \in \iota v)$. (Let. Arist. 148)

In sum, then, the exegetical method of Eleazar involves recognizing in the designations "clean" and "unclean" an animal behavioral trait analogous to a human ethical trait—and further recognizing Moses' primary intention as the commendation or condemnation of ethical traits, not types of meat. As a result of this method-interpreting mainly the traits of "savage" and "carnivorous," "tame"

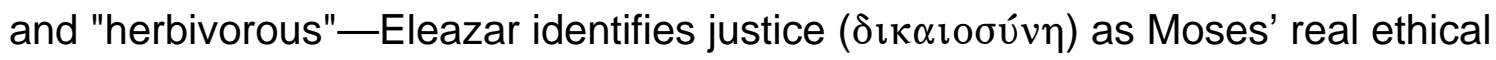
concern.

\footnotetext{
${ }^{4}$ Eleazar downplays the literal significance of the dietary laws at the beginning of his interpretation (Let. Arist. 144): "Do not accept the exploded idea that it was out of regard for 'mice' and the 'weasel' and other such creatures that Moses ordained these laws with such scrupulous care."
} 
Although he uses elements of this traditional interpretation, Philo fundamentally reworks these elements to suit his expository agenda, adapting Eleazar's method and its results to his own particular frame of reference: $\dot{\varepsilon} \pi \imath \theta u \mu i \alpha, \dot{\varepsilon} \gamma \kappa \rho \dot{\alpha} \tau \epsilon \iota \alpha$, and $\ddot{\alpha} \sigma \kappa \eta \sigma \iota \varsigma$. Above all, Philo tries to show that Moses had

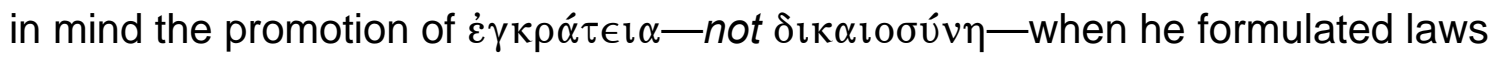
concerning clean and unclean animals. As a result, Philo tends to emphasize the literal significance of Moses' regulations in two important respects: (1) in drawing a connection between the actual eating (or not) of certain meats and the operation of $\dot{\varepsilon} \pi \imath \theta u \mu i \alpha$ in the human soul, and (2) in casting the commands to eat or abstain as the substance of a practical regimen of $\ddot{\sigma} \sigma \kappa \eta \sigma ı \varsigma$, not the dispensable symbolic form of Moses' ethical exhortations. And when Philo does use a symbolic mode of interpretation comparable to Eleazar's, he uses it to demonstrate Moses' ultimate concern for issues of $\dot{\varepsilon} \pi \imath \theta u \mu i ́ \alpha, \dot{\varepsilon} \gamma \kappa \rho \dot{\alpha} \tau \in \imath \alpha$, and $\ddot{\alpha} \sigma \kappa \eta \sigma \iota \varsigma$.

\section{Contemporary Genres of Philosophical Literature}

Philo models his exposition of the Tenth Commandment on a type of philosophical literature whose attention to issues of $\pi \dot{\alpha} \theta o \varsigma, \dot{\varepsilon} \gamma \kappa \rho \dot{\alpha} \tau \epsilon \iota \alpha$, and

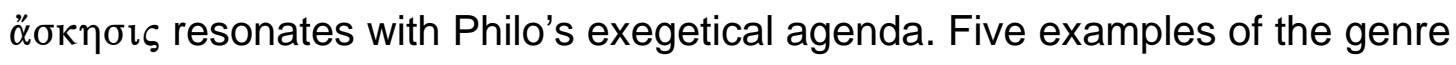
appear among the Moralia of Philo's Middle-Platonic near contemporary Plutarch-treatises Heinz Gerd Ingenkamp calls "praktische 
Seelenheilungsschriften. ${ }^{5}$ Essentially, the Seelenheilungsschrift names one particular passion $(\pi \dot{\alpha} \theta 0 \varsigma)$ as its topic and consists of two parts: a diagnosis

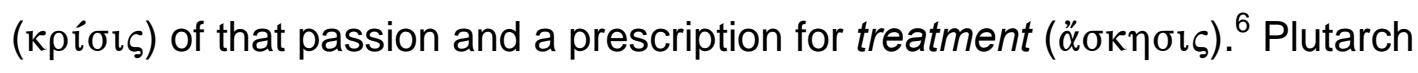
explains the relation between the two parts:

[W] get well by the diagnosis and treatment of our passions ( $\tau \hat{\omega} v \gamma \gamma \grave{\alpha} \rho$ $\pi \alpha \theta \hat{\omega} \nu \kappa \rho i ́ \sigma \epsilon \mathfrak{l} \kappa \alpha \grave{\imath} \dot{\alpha} \sigma \kappa \eta \tilde{\sigma} \sigma \epsilon \mathrm{l})$, but the diagnosis must come first ( $\pi \rho 0 \tau \dot{\varepsilon} \rho \alpha$ $\delta{ }^{\prime} \dot{\eta}$ кpíls); since no one can become habituated to shun or to eradicate

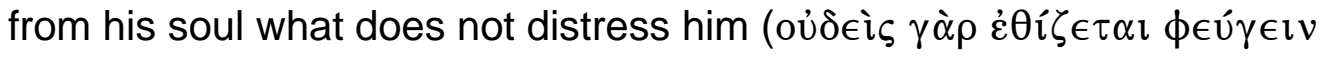

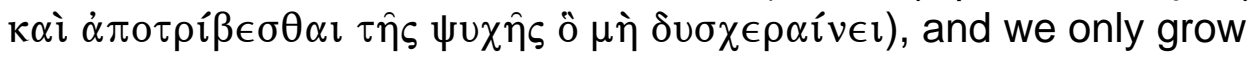
distressed with our passions ( $\tau \dot{\alpha} \pi \dot{\alpha} \theta \eta$ ) when we have perceived, by the exercise of reason, the injuries and shame which result from them ( $\tau \dot{\alpha} \varsigma$ $\left.\beta \lambda \dot{\alpha} \beta \alpha \varsigma \kappa \alpha \grave{\imath} \tau \grave{\alpha} \varsigma \alpha i \sigma \chi u ́ v \alpha \varsigma \tau \grave{\alpha} \varsigma \dot{\alpha} \pi^{\prime} \alpha \dot{v} \tau \hat{\omega} v\right)$. (Garr. 510 C-D)

In other words, a Seelenheilungsschrift tries to convince the reader of the horrible nature of a particular passion, in hopes of motivating the reader to embrace the practical exercises offered as a therapeutic treatment or cure for that passion. Philo most likely encountered the genre through acquaintance with the philosophical milieu of Plutarch's teacher, Ammonius, a contemporary of Philo and native of Alexandria. ${ }^{7}$ In that case, the Seelenheilungsschrift most likely to represent the genre as Plutarch learned it, and thus as Philo knew it, would be the earliest of the five, De garrulitate or On Talkativeness. ${ }^{8}$

${ }^{5}$ See Ingenkamp, Schriften, 7, where he introduces the term and lists the five treatises: De curiositate, De cohibenda ira, De garrulitate, De vitioso pudore, and De se ipsum citra invidiam laudando.

${ }^{6}$ See Ingenkamp, Schriften, 74-124. Cf. Rabbow, Seelenfürung, 340: "Plutarchs System

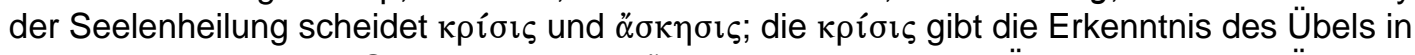

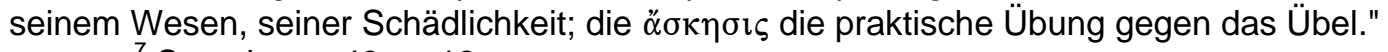

${ }^{7}$ See above, 43, n. 12.

${ }^{8}$ Ingenkamp identifies De garrulitate as the earliest of the five Seelenheilungsschriften, written sometime after A.D. 68 (Schriften, 116-18). And of the five, De garrulitate bears the least 
Although Plutarch makes talkativeness ( $\dot{\alpha} \delta \mathrm{o} \lambda \epsilon \sigma \chi i \alpha)$ the explicit subject of his earliest Seelenheilungsschrift, he ultimately considers the issue of desire ( $\dot{\varepsilon} \pi \theta u \mu i \alpha)$-but desire considered under just one of its aspects, a desire for listeners:

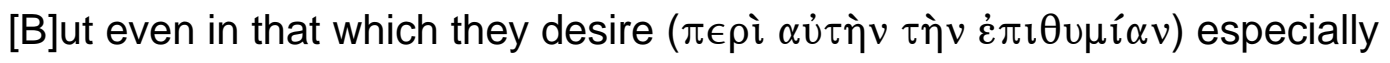
they fail miserably. For in other diseases of the soul (voonj $\alpha \sigma \imath \tau \hat{\eta} s$

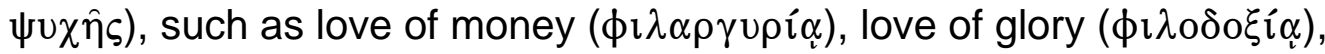
love of pleasure ( $\left.\phi \imath \lambda \eta \delta \delta v^{\prime} \alpha\right)$, there is at least the possibility of attaining

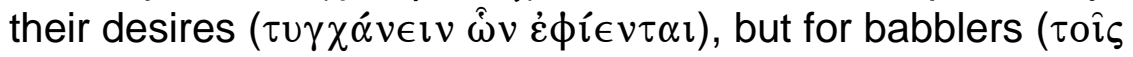

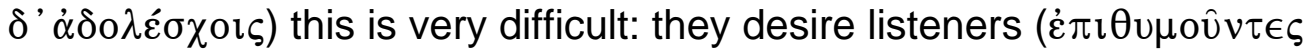
$\dot{\alpha} \kappa \rho о \alpha \tau \hat{\omega} v)$ and cannot get them, since every one runs away headlong. (Garr. $502 \mathrm{E})$

Here Plutarch suggests that $\dot{\varepsilon} \pi \imath \theta u \mu i \alpha$ as it relates to speech can manifest itself in a "diseased" way as talkativeness ( $\dot{\alpha} \delta \circ \lambda \in \sigma \chi i \alpha)$, even though the desire itself involves nothing objectionable. ${ }^{9}$ Thinking along Middle-Platonic lines, Plutarch understands the critical importance of reason's position over against this type of desire, consistently framing his discussion of talkativeness as a matter of selfcontrol $(\dot{\varepsilon} \gamma \kappa \rho \dot{\alpha} \tau \epsilon \iota \alpha)$ or its absence $(\dot{\alpha} \kappa \rho \alpha \sigma i \alpha) .{ }^{10}$ With reason in control, the moral

evidence of Plutarch's personal development of the genre (Schriften, 118, 145). While this particular Middle-Platonic Seelenheilungsschrift postdates Philo, the unmistakable conformity of Philo's exposition with the basic structure and function of De garrulitate indicates Plutarch's use of a preexisting genre known also to Philo. On De garrulitate, see also William A. Beardslee, "De Garrulitate (Moralia 502B-515A)," in Plutarch's Ethical Writings and Early Christian Literature (ed. Hans Dieter Betz; SCHNT 4; Leiden: Brill, 1978), 264-88.

${ }_{9}$ Garr. $504 \mathrm{E}$ : "[S]peech, which is the most pleasant and human of social ties, is made inhuman and unsocial by those who use it badly and wantonly." Philo never explicitly links $\dot{\varepsilon} \pi \imath \theta u \mu i \alpha$ with $\dot{\alpha} \delta \circ \lambda \epsilon \sigma \chi i \alpha$, but he does link the adjective "talkative" ( $\dot{\alpha} \delta \circ \lambda \varepsilon \sigma \chi \eta \varsigma)$ with the "lover of pleasure" (Sacr. 32). He also speaks of desire "overtaking the tongue" (i் $\pi \grave{i} \gamma \lambda \hat{\omega} \tau \tau \alpha \nu \phi \theta \alpha \dot{\alpha} \sigma \alpha \sigma \alpha)$,

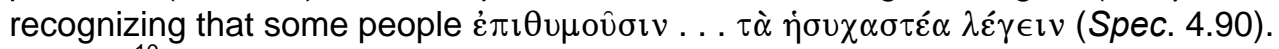

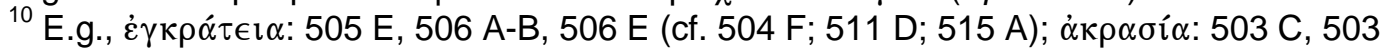

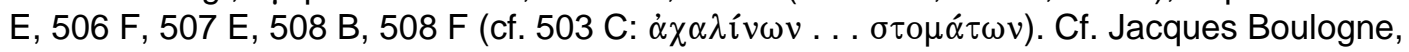
"L'intempérence verbale: L'imaginaire de Plutarche dans la thérapie des maladies de l'âme," in 
agent speaks in an appropriate manner. But if the moral agent's desire for listeners becomes excessive and overcomes reason, a "passion" ( $\pi \dot{\alpha} \theta$ os) results, and since the excessive desire here involves speech, the resulting passion accordingly manifests as an irrational, excessive type of speech, talkativeness. ${ }^{11}$ Following the basic format of a Seelenheilungsschrift, Plutarch's approach to the

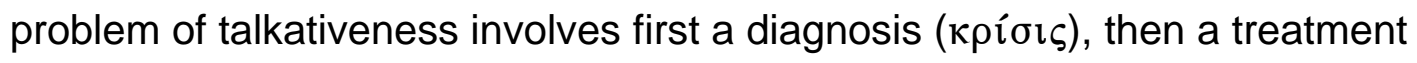

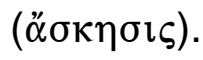

Plutarch's diagnosis of talkativeness includes both broad denouncements of the passion and specific examples of its ill effects. ${ }^{12}$ With chiastic flair, he characterizes $\dot{\alpha} \delta 0 \lambda \epsilon \sigma \chi i \alpha$ as worst among the passions:

Now of the other passions and diseases some are dangerous

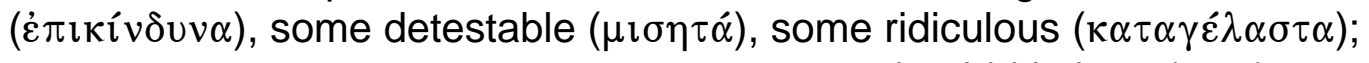

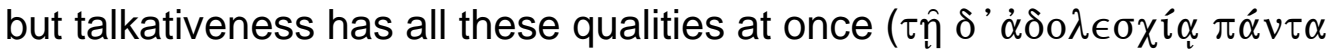

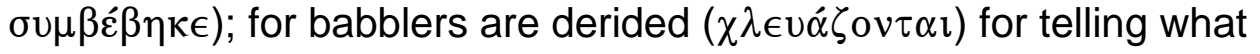
everyone knows, they are hated $(\mu \iota \sigma 0 \hat{v} v \tau \alpha \mathrm{l})$ for bearing bad news, they run into danger ( $\kappa \iota v \delta \cup v \in \cup ́ o v \sigma \iota)$ since they cannot refrain from revealing secrets. (Garr. $504 \mathrm{~F})^{13}$

Plutarch supports his rhetoric with anecdotal evidence of the trouble talkativeness brings, such as the destruction and ruin attending revealed

\footnotetext{
Les passions antiques et médiévales (ed. Bernard Besnier et al.; Paris: Presses universitaires de France, 2003), 161-69.

${ }^{11}$ Plutarch understands "passion" in the Middle-Platonic sense of $\pi \lambda \epsilon o v \alpha \dot{\zeta o v \sigma \alpha}$

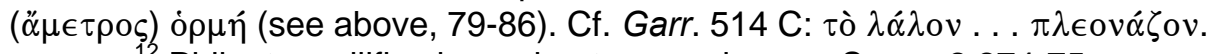

${ }_{12}$ Philo, too, vilifies immoderate speech: e.g., Somn. 2.274-75.

${ }^{13}$ Substituting "passions" for Helmbold's "affections" ( $\left.\pi \alpha \theta \hat{\omega} v\right)$, "diseases" for "maladies"

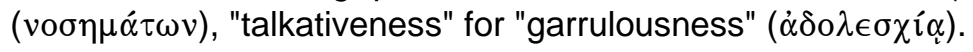


secrets. ${ }^{14}$ King Seleucus, for example, escaping a disastrous battle incognito, received food from a farmer whose $\dot{\alpha} \delta 0 \lambda \epsilon \sigma \chi i \dot{\alpha} \alpha$ brought death (Garr. 508 D-F). The farmer recognized Seleucus and could not restrain himself (oủ $\kappa \alpha \tau \varepsilon ́ \sigma \chi \in v$ ):

[O]n taking leave, [he] said, "Farewell, King Seleucus." And Seleucus, stretching out his right hand to him and drawing him towards himself as though to kiss him, gave a sign to one of his companions to cut off the man's head with a sword. (Garr. $508 \mathrm{E}$ )

Plutarch frames this as a deadly case of $\dot{\alpha} \kappa \rho \alpha \sigma i ́ \alpha$ (508 F), a lack of verbal selfcontrol characteristic of everyone possessed of talkativeness. By this and other examples, framed with disparaging rhetoric, Plutarch hopes to accomplish the express purpose of his diagnosis: revealing the "injuries and shame" ( $\tau \grave{\alpha} \varsigma \beta \lambda \alpha \dot{\alpha} \beta \varsigma$

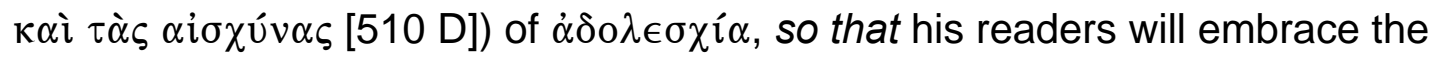
practical treatment he offers in the second part of his treatise. ${ }^{15}$

Having made his diagnostic case against talkativeness, Plutarch turns to a

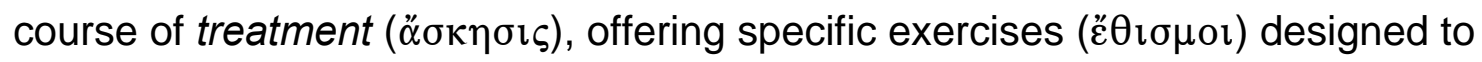
rid the moral agent of talkativeness by inculcating verbal self-control $(\dot{\varepsilon} \gamma \kappa \rho \alpha \dot{\tau} \tau \epsilon \iota)$.These exercises work by orchestrating a contest of power between the soul's rational and non-rational parts—in the case of $\dot{\alpha} \delta \circ \lambda \epsilon \sigma \chi i \alpha$, reason contends against $\dot{\varepsilon} \pi \imath \theta u \mu i \alpha$ as it relates to speech. With each successful

\footnotetext{
${ }^{14}$ Garr. 508 D: "[S]ecrets, when they escape, destroy and ruin ( $\dot{\alpha} \pi 0 \lambda \lambda$ v́ovol $\kappa \alpha \grave{\imath}$ $\delta \iota \alpha \phi \theta \epsilon i$ ovor) those who cannot keep them."

${ }^{15}$ In Garr. 510 D, Plutarch summarizes everything learned from his diagnosis: "Thus, in the case of babblers [we perceive] that they are hated when they wish to be liked, that they cause annoyance when they wish to please, that they are laughed at when they think they are admired, that they spend their money without any gain, that they wrong their friends, help their enemies, and destroy themselves."
} 
exercise, the moral agent's capacity to control this type of desire increases, while the likelihood of desire usurping reason to engender talkativeness correspondingly decreases. Plutarch offers two basic types of $\dot{\varepsilon} \theta \imath \mu$ óc; the first involves refraining from speech for a period of time:

In the first place ( $\pi \rho \hat{\omega} \tau o v)$, then, when questions are asked of neighbors, let him accustom himself to remaining silent ( $\dot{\varepsilon} \theta \iota \zeta \dot{\varepsilon} \tau \omega \sigma \iota \omega \pi \hat{\alpha} v)$ until all

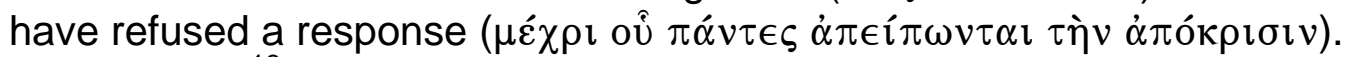
$(\text { Garr. } 511 \mathrm{~F})^{16}$

In other words, the moral agent waits to speak and in so doing subjugates and restrains desire's impulse toward the pleasure(s) of speech. Plutarch again commends the exercise of delayed response when he considers how the moral agent ought to deal with direct questions (Garr. $512 \mathrm{D}-\mathrm{F}) .{ }^{17}$ Neatly summarizing the thrust of his remarks, he identifies the ultimate goal of these exercises as the training of non-rational desire:

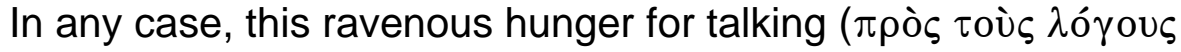
$\dot{o} \xi \dot{u} \pi \epsilon i v o v)$ must be checked so that it may not seem as though a stream $(\dot{\rho} \in \hat{v} \mu \alpha)$ which has long been pressing hard upon the tongue were being gladly discharged at the instance of the question. Socrates, in fact, used to control his thirst in this manner-he would not allow himself to drink after exercise until he had drawn up and poured out the first bucketful, so that his non-rational part might be trained to await the time dictated by reason

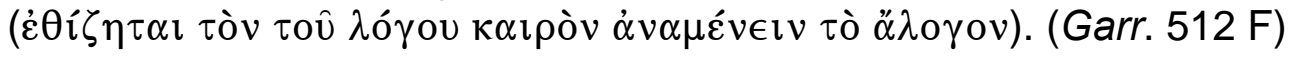

${ }^{16}$ Plutarch indirectly labels this abstention an $\ddot{\alpha} \sigma \kappa \eta \mu \alpha$, because after this first example ( $\pi \rho \hat{\omega} \tau o v)$ he goes on to describe a second ( $\delta \epsilon \dot{\tau} \tau \epsilon \rho o v) \ddot{\alpha} \sigma \kappa \eta \mu \alpha$ in Garr. 512 D. He describes this

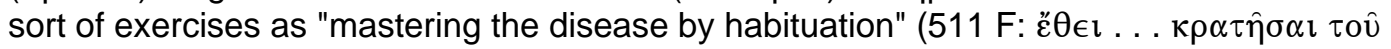
voớ $\mu \alpha \tau \circ \varsigma)$.

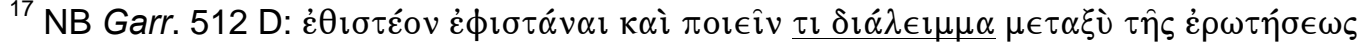

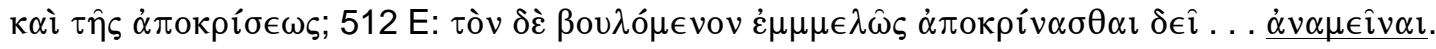


A second type of $\dot{\varepsilon} \theta \imath \sigma \mu$ ó commended by Plutarch involves not the delay of speaking but complete abstinence from speaking on certain topics that incite talkativeness because of the excessive pleasure they afford:

Moreover, just as Socrates used to urge men to be on their guard ( $\phi \cup \lambda \alpha \dot{\tau} \tau \epsilon \sigma \theta \alpha \mathrm{l})$ against those foods which induce us to eat when we are not hungry, and against those liquids which induce us to drink when we are not thirsty, so it is with the babbler as regards subjects for talk ( $\tau \hat{\omega} v$

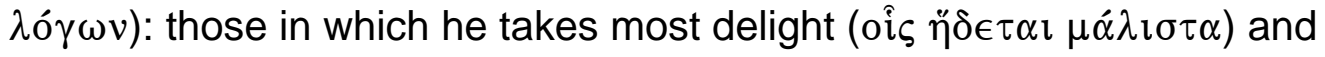
employs ad nauseam he should fear and stoutly resist ( $\alpha \nu \tau \imath \beta \alpha i v \in \imath v)$ when they stream in upon him. (Garr. $513 \mathrm{D})^{18}$

In terms of moral psychology, the danger of especially pleasurable topics lies in their capacity to draw the moral agent into speech for the wrong motive-for pleasure itself and not for good reason, such as a legitimate need to speak. ${ }^{19}$ By avoiding such topics, the moral agent develops verbal $\dot{\varepsilon} \gamma \kappa \rho \alpha ́ \tau \epsilon \iota \alpha$, since rejecting pleasure as a motivation amounts to a subjugation of $\dot{\varepsilon} \pi \imath \theta u \mu i \alpha$ on the part of $\lambda o ́ \gamma o s$. So within Plutarch's therapeutic program, delay and avoidance represent

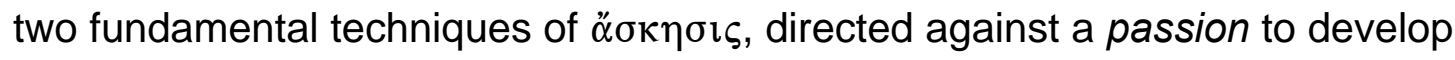
$\dot{\varepsilon} \gamma \kappa \rho \alpha ́ \tau \epsilon \iota \alpha$.

Philo's exposition of the Tenth Commandment exhibits the form and function of a Seelenheilungsschrift. First of all, it has as its topic one particular

${ }^{18}$ Cf. Garr. 514 A: "[H]e that has a greater weakness for one class of subjects than for the other should be on his guard against these subjects and force himself to hold back and

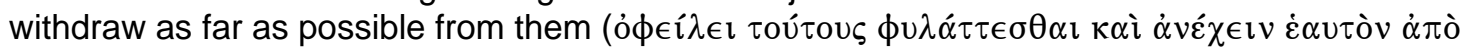
$\tau o u ́ \tau \omega v$ ), since they are always able, because of the pleasure they give ( $\left.\delta \iota^{\prime} \dot{\eta} \delta o v \eta \dot{v}\right)$, to lure him on to dilate upon them."

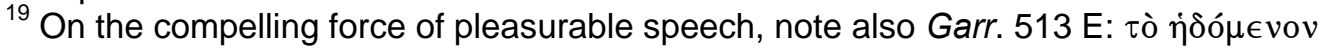

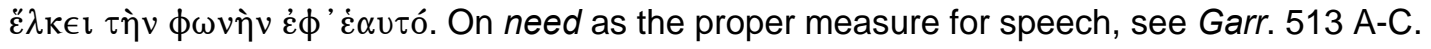


passion, $\dot{\varepsilon} \pi \imath \theta u \mu i \alpha .{ }^{20}$ Second, it essentially divides into the two-part structure

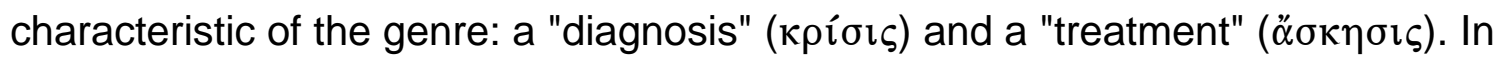
Spec. 4.79-94, Philo considers the horrible nature of desire, offering—like Plutarch—both broad denouncements of the passion and specific examples of its

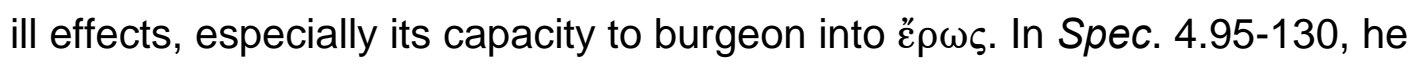
considers the proper treatment of desire, casting the Mosaic dietary laws as therapeutic exercises comparable to those prescribed by Plutarch in De garrulitate. The Mosaic exercises in Philo's exposition mirror not only the ascetic techniques used in De garrulitate—for example, delay and avoidance—but also the overall purpose of Plutarch's "treatment": to cure a passion by cultivating $\dot{\varepsilon} \gamma \kappa \rho \alpha ́ \tau \epsilon \iota \alpha$ through $\ddot{\alpha} \sigma \kappa \eta \sigma \iota \varsigma$.

\section{STRUCTURE OF PHILO'S EXPOSITION ${ }^{21}$}

I. Introduction (\$78b)

II. Diagnosis (Kpíolৎ) (§§79-94)

A. Problem: Every Passion (\$79)

B. Problem: Passionate Desire Burgeoned into Tyrannical Desire (§§80-94)

i. Overview of Tyrannical Desire (\$\$80-83)
a. Origin (§80a)
b. Character (§§80b-83): Insatiable, Oppressive, All- Consuming

\footnotetext{
${ }^{20}$ Not the amoral emotion $\dot{\varepsilon} \pi \imath \theta u \mu i \alpha$, but the immoral passion $\dot{\varepsilon} \pi \imath \theta u \mu i \alpha$.

${ }^{21}$ The structure of the commentary follows the text-units marked with boldface type.
} 
ii. Tyrannical Desire as "Source of All Ills" (\$§84-91)

a. Statement of the Claim (§§84-85)

b. Illustrations (§§86-91)

1. Mode of Operation

2. Tyrannical Desire for Money

3. Tyrannical Desire for Fame

4. Tyrannical Desire for Power

5. Tyrannical Desire for Beauty

6. Tyrannical Desire over the Tongue

7. Tyrannical Desire over the Belly

C. Location of ' $E \pi \imath \theta \mu i^{\prime} \alpha$ (\$§92-94)

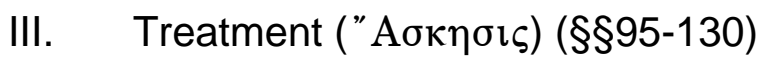

A. Overview of Moses' "Paradigmatic Instruction" (\$§95-97)

B. Elements of Moses' "Paradigmatic Instruction" (§§98-125)

i. First Fruits (\$§98-99)

ii. Clean and Unclean Animals (§§100-118)
a. Introduction (\$100-102)
b. Land Animals (\$§103-109)
c. Aquatic Animals (\$\$110-112)
d. "Reptiles" (§§113-115)
e. Birds (\$§116-117) 


\section{f. Conclusion (\$118)}

iii. Dead Animals (\$§119-121)

iv. Blood and Fat (\$§122-125)

C. Concluding Moral Narrative (\$§126-131)

TRANSLATION AND COMMENTARY

$\S 78 b:$ Introduction

[§78b] Let us turn now to the last of the Ten Words, which like each of the others was delivered in the form of a summary: "You shall not desire."

Philo finally arrives at the Tenth Commandment, after commenting in depth on the other nine in Spec. 1.12 - Spec. 4.78a. He does little more than announce his transition to the last of the "Ten Words," noting only that this Commandment, like the others, has the form of a summary. Naturally, he also cites the Tenth Commandment, providing the basis of his exposition, but he cites an abbreviated version (cf. Exod 20:17; Deut 5:21), placing emphasis on $\dot{\varepsilon} \pi \imath \theta u \mu i \alpha$ itself and not any of its objects.

\section{§79: Problem: Every Passion}

[§79] On the one hand, ${ }^{22}$ every "passion"23 is reprehensible, since we are morally responsible for every unmeasured, "excessive impulse" 24 and for

${ }^{22}$ On the one hand ( $\mu \varepsilon \dot{v}$ ): Philo here compares the passions as a class ( $\left.\Pi \hat{\alpha} \nu \mu \grave{\varepsilon} v \pi \dot{\alpha} \theta 0 \varsigma\right)$ with one particular passion in $\S 80(\tau \hat{\omega} v \underline{\delta \grave{\varepsilon}} \pi \alpha \theta \hat{\omega} v)$.

23 "passion" ( $\pi \dot{\alpha} \theta 0 \varsigma)$ : Philo's use of the terms $\dot{\varepsilon} \pi \hat{\imath} \lambda \eta \pi \tau o v$ (reprehensible) and $\dot{v} \pi \alpha i \tau \imath \iota \varsigma$ (morally responsible) indicates an immoral "passion," not an amoral "emotion" ( $\pi \dot{\alpha} \theta$ os).

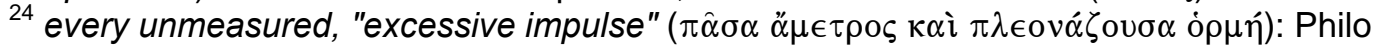
cites the Stoic definition of "passion" ( $\pi \lambda \epsilon o v \alpha ́ \zeta o v \sigma \alpha \dot{o} \rho \mu \eta$ ) but fundamentally recasts it for Middle-

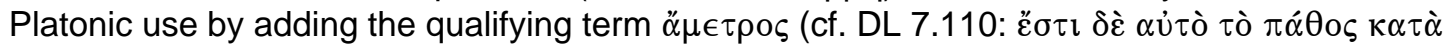
Z $\eta \omega \omega \nu \alpha \ldots \dot{o} \rho \mu \grave{\eta} \pi \lambda \epsilon o v \alpha ́ \zeta o v \sigma \alpha)$. 
the soul's "irrational and unnatural movement." ${ }^{25}$ After all, what do these terms describe if not an unleashing of the emotional part of the soul? ${ }^{26}$ So if anyone fails to place limits on the impulses of emotion, ${ }^{27}$ fails to bridle, so to speak, his team of unruly horses, he ends up indulging a malignant "passion." ${ }^{28}$ And by giving free rein to the team's unruliness, he will careen like an unwitting charioteer into some ditch or chasm, from which he will barely escape-if at all.

To begin his exposition of oủк $\dot{\varepsilon} \pi \imath \theta u \mu \eta ́ \sigma \epsilon \iota$, Philo summarizes the problem posed by every passion ( $\Pi \hat{\alpha} \nu \mu \grave{\varepsilon} v \pi \tilde{\alpha} \theta \circ \varsigma)$ and not just desire, which he will consider at length beginning in $\S 80(\tau \hat{\omega} \nu \delta \grave{\varepsilon} \pi \alpha \theta \hat{\omega} \nu \ldots . \dot{\varepsilon} \pi \imath \theta u \mu i \alpha)$. In agreement with the Stoics, he notes that passions categorically indicate a moral lapse by using the terms $\dot{\varepsilon} \pi \hat{\imath} \lambda \eta \pi \tau o v$ and $\dot{v} \pi \alpha i ́ \tau \imath o{ }^{29}{ }^{29}$ But Philo differs radically in his

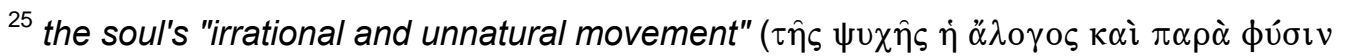

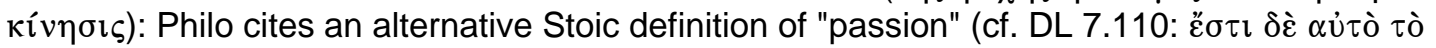

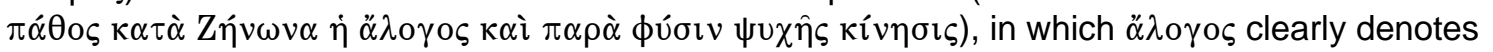
a morally problematic "irrational" (vs. "non-rational") movement.

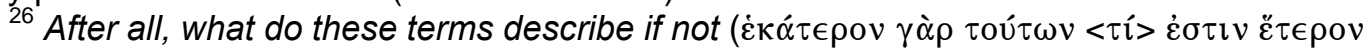

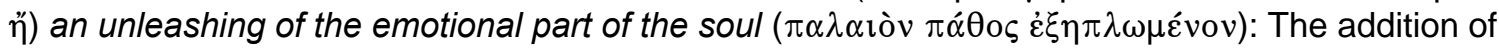
$\tau i$ in PCW seems necessary, since the phrase $\pi \alpha \lambda \alpha$ lòv $\pi \dot{\alpha} \theta$ o $\zeta \dot{\varepsilon} \xi \eta \pi \lambda \omega \mu \varepsilon \dot{\varepsilon} v o v$ further explains, from a Middle-Platonic perspective, the phenomena Philo denotes using Stoic definitions. In the explanatory phrase, $\pi \dot{\alpha} \theta$ o $\varsigma$ refers to the non-rational part of the soul as seat of emotion(s) (i.e.,

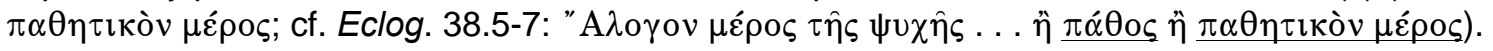
So $\pi \alpha \lambda \alpha$ ló $v$ has the sense of "longstanding," indicating an enduring component of the soul

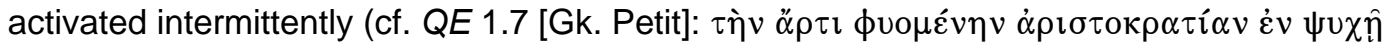

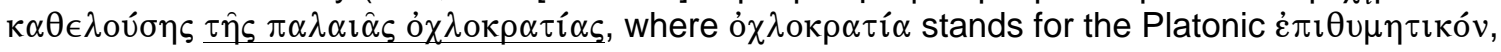
as in Resp. VIII - IX). $\dot{\alpha} \pi \lambda o ́ \omega$ (LSJ, s.v.): to unfold, stretch out.

${ }^{27}$ place limits on the impulses of emotion ( $\mu \varepsilon \varepsilon \tau \rho \alpha \tau \alpha \hat{\imath} \varsigma$ ò $\rho \mu \alpha \hat{\imath} \varsigma$ ó $\hat{\imath} \zeta \in \imath$ ): Philo undoubtedly has in mind non-rational impulses of the emotional part of the soul-in other words, discrete impulses of desire, fear, grief, pleasure, etc. requiring the proper "measure" ( $\mu \varepsilon \dot{\tau} \rho \circ v)$ of reason

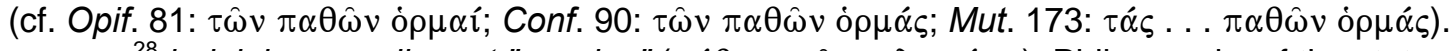

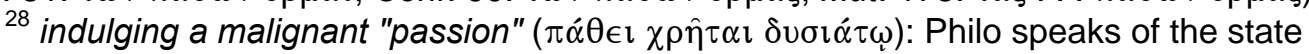
resulting from a lack of measure: an "emotion" ( $\pi \dot{\alpha} \theta \circ \varsigma)$ has become a "passion" ( $\pi \dot{\alpha} \theta$ os).

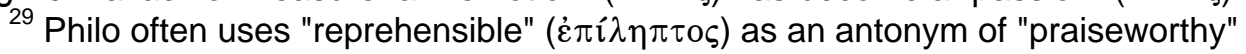

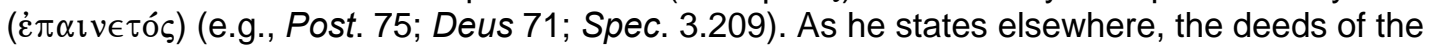
unjust are reprehensible $(\dot{\varepsilon} \pi \hat{\imath} \lambda \eta \pi \tau \alpha)$, due to lack of measure in their emotions $(\delta \imath \dot{\alpha} \ldots \tau \dot{\alpha} \zeta$ $\dot{\alpha} \mu \epsilon \tau \rho i \alpha \varsigma \tau \hat{\omega} \nu \pi \alpha \theta \hat{\omega} v$ ) -i.e., due to "passions" (Spec. 3.209). In addition, the moral agent is "morally responsible" (i $\pi \alpha i \tau \imath o \varsigma)$ not for emotion, but for passion. The moment of moral accountability lies not in the experience of desire, distress, pleasure, or fear, but in the victory of these emotions over reason, which signals reason's failure to properly restrict or measure their 
concept of what those passions fundamentally are. Reworking a standard Stoic

definition, he uses the term $\ddot{\alpha} \mu \in \tau \rho o \varsigma$ to express the Middle-Platonic notion of

passion as a quantitative excess of the non-rational impulses of emotion. ${ }^{30}$ In

similar Middle-Platonic fashion, Philo suggests that the moral agent avoids

passion by moderating these non-rational impulses (metriopatheia), and he uses

the Platonic chariot figure to make his point. ${ }^{31}$ In other words, having framed the

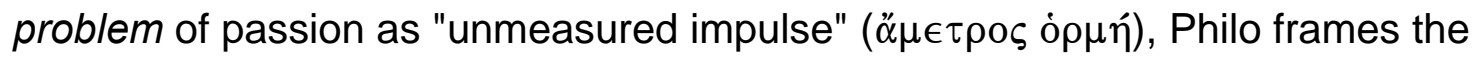

solution as "measured impulse" ( $\mu \varepsilon \dot{\tau} \rho \alpha \tau \alpha \hat{\imath} \varsigma$ ò $\mu \alpha \hat{\imath} \varsigma)$ —only when the charioteer

fails, when emotion oversteps the "measure" of reason's directing authority, only

activity. Cf. Marguerite Harl, "Adam et les deux arbres du paradis (Gen. II-III) ou I'homme milieu entre deux termes ( $\mu \varepsilon ́ \sigma o \varsigma-\mu \in \theta o ́ p r o \varsigma)$ chez Philon d'Alexandrie," RSR 50 (1962): 321-88, 341, n.

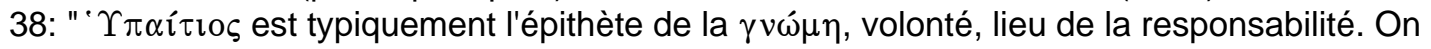

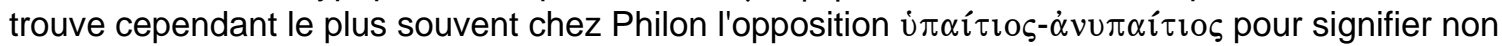
pas « responsable-irresponsable » mais « coupable-innocent »."

${ }^{30}$ In Philo's view, every instance of passion involves an "unmeasured" ( $\left.\alpha \mu \epsilon \tau \rho \varsigma \varsigma\right)$ impulse, one excessive in quantity, not in quality as the Stoics believed. The term $\ddot{\alpha} \mu \in \tau \rho \circ \varsigma$, which appears not a single time in SVF (see index, S.v.), is patently not Stoic, but commentators persist

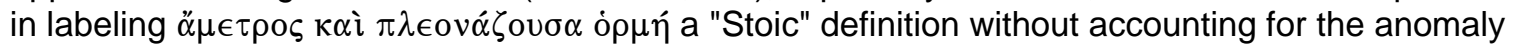
of $\ddot{\alpha} \mu \epsilon \tau \rho \varsigma_{\zeta}$ (e.g., Colson, PLCL 8, 57, n. b; Heinemann, PCH 2, 270, ns. 1-2; Mosès, PAPM 25, 246, n. 2; also David Charles Aune, "Mastery of the Passions," 126; Bréhier, Idées philosophiques et religieuses 253, n. 9; Gaca, Making of Fornication, 200; Lilla, Clement of Alexandria, 92; Pohlenz, Philon, 457; Völker, Fortschritt und Vollendung, 80; Reydams-Schils, "Stoic and Platonist Psycho-Physiology," 193; Wolfson, Philo, 2:230). The other definition of

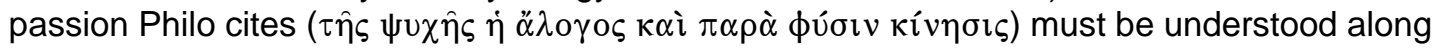
similar Middle-Platonic lines: An unmeasured impulse entails a movement of the soul inconsistent with the dictates of reason and thus "irrational" (vs. non-rational). Such a movement is also "unnatural," since Nature prescribes the rule of the superior over the inferior, in this case reason over the emotions. Philo's reference to an "unleashing of the emotional part of the soul" appears as a clarification of the Middle-Platonic moral psychology underlying the Stoic terminology he has just used. An unmeasured (excessive) impulse of desire, distress, fear, or pleasure indicates not the sudden genesis of passion as something qualitatively distinct within the soul, but instead the "unleashing" ( $\dot{\varepsilon} \xi \alpha \pi \lambda o ́ \omega-i n$ the sense of a "loosening" or removal of restraint) of a preexisting emotional faculty $(\pi \alpha \lambda \alpha$ iòv $\pi \dot{\alpha} \theta o \varsigma)$. Elsewhere, Philo allegorically interprets the biblical prescription for "girded loins" (ỏ $\phi \hat{v} \varsigma \quad \pi \epsilon \rho \imath \epsilon \zeta \hat{\omega} \sigma \theta \alpha \imath$ ) as an injunction against just this sort of "slackening" ( $\chi \alpha \lambda \alpha \omega \omega)$ of the emotions (e.g., Leg. 3.151-54).

${ }^{31}$ Cf. Mosès, PAPM 25, 246, n. 3. On Philo's chariot figure, see above, 111-18. 
then does passion arise in the soul ( $\pi \dot{\alpha} \theta \in \imath \chi \rho \hat{\eta} \tau \alpha \iota \delta v \sigma l \dot{\alpha} \tau \omega)$. Finally, he portrays the disaster in store for all who allow passion to arise in their souls, all who allow otherwise useful emotions to run wild, usurping the directing authority of reason. This lack of restraint ( $\dot{\alpha} \phi \eta \nu \imath \alpha \sigma \mu o ́ v)$ "wrecks" the soul, as the non-rational "horses" are given free rein.

By commending moderation at the outset of his exposition, Philo gives an early indication of how he interprets oủк $\dot{\varepsilon} \pi \imath u \mu \eta \dot{\sigma} \sigma \iota \varsigma$. While obviously a prohibition, the Tenth Commandment does not prohibit $\dot{\varepsilon} \pi \imath \theta u \mu i ́ \alpha$ per se, since Philo recommends the limitation of impulse, not its elimination. In other words, the Tenth Commandment prohibits passionate desire $(\ddot{\alpha} \mu \in \tau \rho \circ \varsigma \dot{\varepsilon} \pi \imath \theta u \mu i \alpha)$, understood as the impulse(s) of the emotion $\dot{\varepsilon} \pi \imath \theta u \mu i \alpha$ exceeding the measure set by reason.

\section{§79 Excursus: Parallel Material in Decal. 142-46}

In Decal. 142-46, Philo introduces his preliminary comments on the Tenth Commandment with similar $\mu \varepsilon \dot{\varepsilon} v \ldots \delta$. comparisons of all $\pi \dot{\alpha} \theta \eta(\pi \dot{\alpha} v \tau \alpha \mu \grave{\varepsilon} v \gamma \gamma \grave{\alpha} \rho$

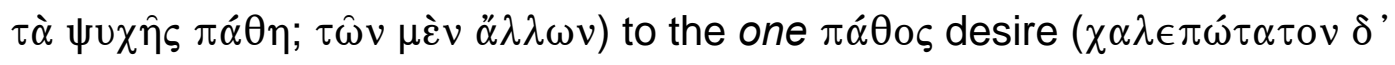
$\left.\dot{\varepsilon} \pi \imath \theta u \mu i \alpha ; \mu o ́ v \eta \delta^{\prime} \dot{\varepsilon} \pi \imath \theta u \mu i \alpha\right)$. But unlike Spec. 4.79, which emphasizes the moral culpability of a failure to moderate the impulses of emotion-in other words, the moral culpability of a "passion"—Philo notes merely that all $\pi \dot{\alpha} \theta \eta$ are 
"troublesome" ( $\chi \alpha \lambda \in \pi \hat{\alpha})$, without condemning them explicitly. ${ }^{32}$ In fact, his

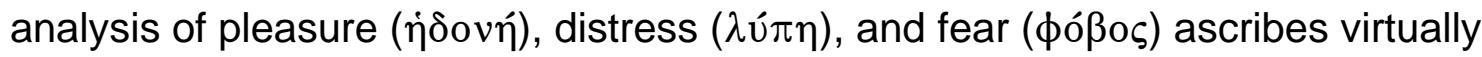
no moral culpability to these $\pi \dot{\alpha} \theta \eta$, since they originate from without and compel

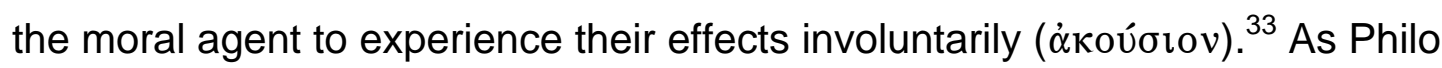
explains in Decal. 143-45, the perceptions of a present good ( $\dot{\alpha} \gamma \alpha \theta$ óv), an

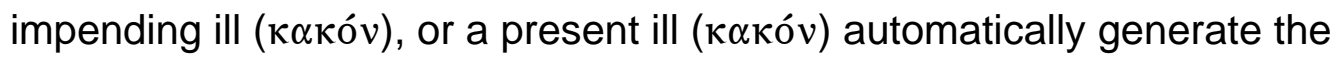
sensations of the corresponding $\pi \dot{\alpha} \theta \eta$. Although Philo's account of the sensations of pleasure, distress, and fear echoes Stoic terminology, his account of the mechanics of these passions flatly contradicts Stoic doctrine. ${ }^{34}$ Above all, Stoics maintained the full accountability of the moral agent for all passions, which all result from voluntary, rational assent $(\sigma \nu \gamma \kappa \alpha \tau \dot{\alpha} \theta \epsilon \sigma \iota \varsigma) .{ }^{35}$ So Philo's association of $\pi \dot{\alpha} \theta \eta$ with involuntary responses to external stimuli clearly reflects a different perspective.

Decal. 142-46 in fact represents a Middle-Platonic account of emotions $(\pi \dot{\alpha} \theta \eta)$, not—as in Spec. 4.79—of passions ( $\pi \dot{\alpha} \theta \eta)$. Philo gives an unusual account of $\dot{\varepsilon} \pi \imath u \mu i \alpha$ because he needs to show why the Decalogue restricts only

${ }^{32}$ Emotions are "troublesome" in their capacity to "unnaturally move and jar the soul,

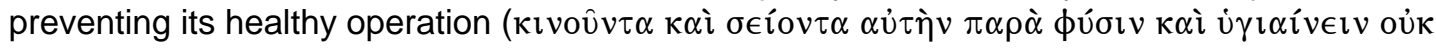
$\dot{\varepsilon} \hat{\omega} v \tau \alpha) "($ Decal. 142).

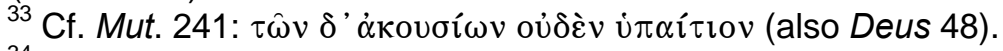

${ }^{34}$ l.e., he does not offer a Stoic account of the passions, pace Colson (PLCL 7, 612).

${ }^{35}$ See Inwood, Ethics and Human Action, 42-101 [="The Psychology of Action"], e.g., 44: "the power to give or withhold assent ... makes men morally responsible for their actions"; 54 : "Man is responsible because of assent"; 72: "Assent . . is vital to the Stoic analysis of action because it is the locus of moral responsibility." The term $\sigma u \gamma \kappa \alpha \tau \alpha \dot{\alpha} \theta \epsilon \iota \varsigma$ appears nowhere in Decal. 142-46 nor anywhere in Philo's analysis of the passions (see Pohlenz, Philon, 456, n. 1). 
this emotion, but he otherwise reflects standard Middle-Platonic views

comparable to Didaskalikos 32.1 [185.24-42]. ${ }^{36}$ For example, both Decal. 142-46

and Didask. 32.1 speak of emotions as movement in the soul, with the

Didaskalikos stating explicitly what Philo certainly presumes: that the movement

occurs in the soul's non-rational part. ${ }^{37}$ Both speak of emotions as involuntary

responses to the perception of an apparent good or ill. ${ }^{38}$ Both speak of four

cardinal emotions, and describe the respective causes of pleasure, distress, and

fear in similar terms. ${ }^{39}$ Since Philo, as a Middle-Platonist, acknowledges the

existence of both emotions ( $\pi \dot{\alpha} \theta \eta)$ and passions $(\pi \dot{\alpha} \theta \eta)$, he attempts to

distinguish $\dot{\varepsilon} \pi \imath \theta u \mu i \alpha$ both from other emotions ( $\pi \dot{\alpha} \theta \eta)$, as in Decal. 142-46, and

from other passions ( $\pi \dot{\alpha} \theta \eta)$, as in Spec. 4.79-80. Given the unique prohibition of

$\dot{\varepsilon} \pi \imath \theta u \mu i \alpha$ over against other $\pi \dot{\alpha} \theta \eta$, Philo must articulate a fundamental difference

between $\dot{\varepsilon} \pi \imath \theta u \mu i \alpha$ and other $\pi \dot{\alpha} \theta \eta$, discernable both at the level of emotion per

${ }^{36}$ Didask. 32.1 clearly speaks of "emotion" ( $\pi \dot{\alpha} \theta$ os), not "passion" ( $\left.\pi \dot{\alpha} \theta 0 \varsigma\right)$, since the Middle-Platonic concept of passion appears later in 32.4 [186.14-29], which contrasts "wild"

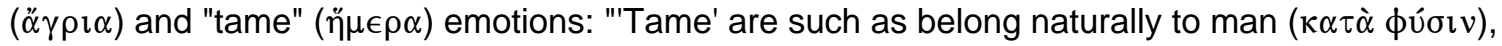

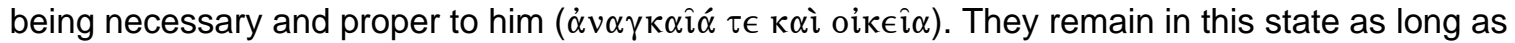
they preserve moderation ( $\check{\varepsilon} \omega \varsigma \ddot{\alpha} \nu \sigma u ́ \mu \mu \epsilon \tau \rho \alpha \dot{v} \pi \dot{\alpha} \rho \chi \eta)$; if they come to exhibit lack of moderation ( $\dot{\alpha} \mu \epsilon \tau \rho \dot{\alpha} \alpha \varsigma)$, they become bad ( $\dot{\eta} \mu \alpha \rho \tau \eta \mu \varepsilon \dot{v} \alpha) "$ (trans. Dillon).

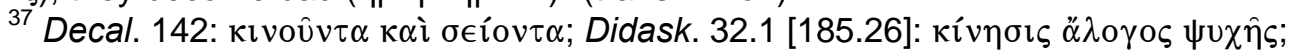

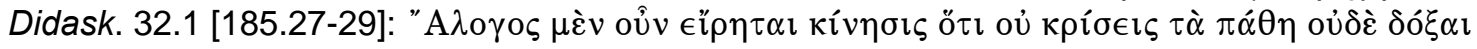
$\dot{\alpha} \lambda \lambda \dot{\alpha} \tau \hat{\omega} v \dot{\alpha} \lambda \hat{\gamma} \gamma \omega v \tau \eta \hat{\varsigma} \varsigma \psi \nu \chi \hat{\eta} \varsigma \mu \epsilon \rho \hat{\omega} v \kappa \iota v \eta ́ \sigma \in \imath \varsigma$.

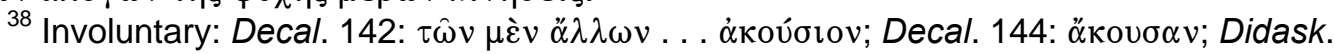

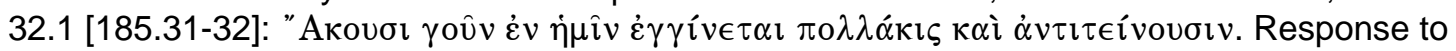

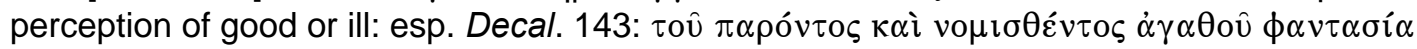

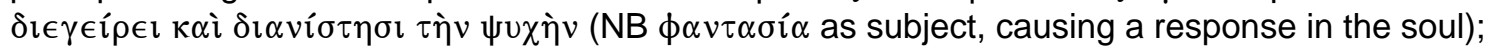

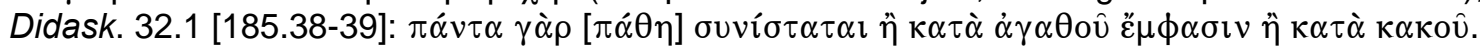

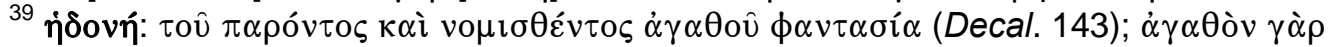

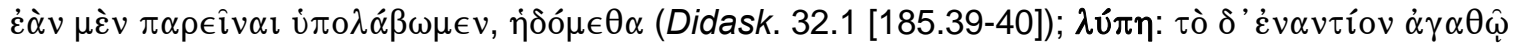

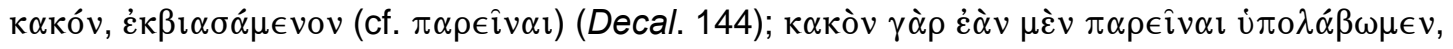


se (Decal. 142-46) and at the level of passion-i.e., the excessive, unmeasured expression of emotion (Spec. 4.79-80).

$$
\S \S 80 \text { - 83: Overview of Tyrannical Desire }
$$

[§80] On the other hand, among the passions, none proves quite so agonizing as a passionate desire for objects of fantasy that seem valuable but really are not, ${ }^{40}$ because longing of this kind eventually gives birth to oppressive tyrannical desires incapable of fulfillment. ${ }^{41}$ And consider the plight of those subject to tyrannical desire $!^{42}$ Free of restraint and fixed on the thought of a beloved object, ${ }^{43}$ desire just keeps stretching and driving the soul farther and farther out into a boundless expanse, pursuing a pesky mocker who flees backwards in a brazen taunt. [§81] The quarry notices desire trying hard to catch up, then stops for a moment-just long enough to provide a teasing hope of capture-only to pull away out of reach, jeering mercilessly. And so desire, constantly eluded, constantly

$\lambda$ u

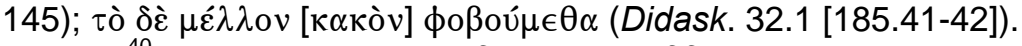

${ }^{40}$ a passionate desire for objects of fantasy that seem valuable but really are not

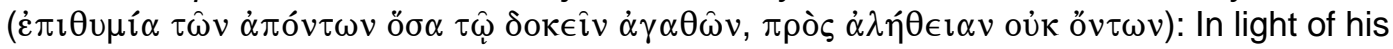
introductory remarks on "passion" (§79), Philo must have in mind passionate desire (پ̋ $\mu € \tau \rho \varsigma$ $\dot{\varepsilon} \pi \imath \theta u \mu i \alpha)$, although he simply refers to it as $\dot{\varepsilon} \pi \imath \theta u \mu i \alpha$. He notes two characteristics of the objects desired: (1) they are not present to the moral agent, and (2) they are "false goods." The first characteristic speaks to how the objects are desired: they are not materially present, so they must

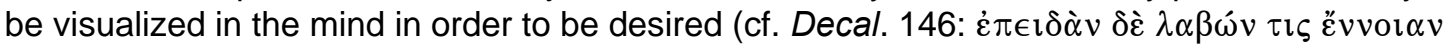

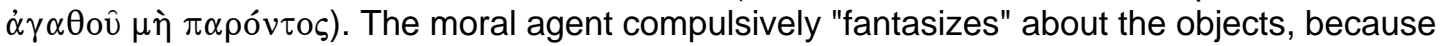
desire has captured the mind, compelling it to incorrectly esteem as "good" (valuable) something that is not. Only people enmeshed in the world and its system of values care about such things-

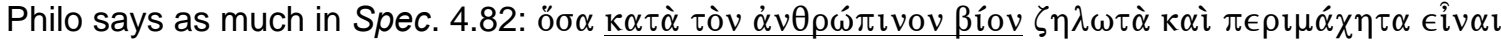

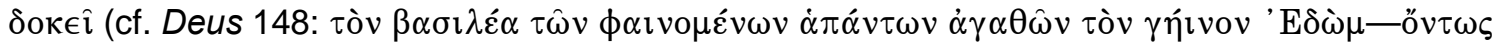

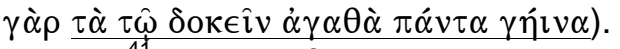

${ }^{41}$ longing of this kind eventually gives birth to oppressive tyrannical desires incapable of

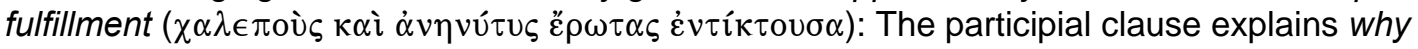
$\dot{\varepsilon} \pi \imath \theta u \mu i \alpha \tau \hat{\omega} \nu \dot{\alpha} \pi \delta ́ v \tau \omega \nu$ (subj. of $\dot{\varepsilon} v \tau i ́ \kappa \tau o v \sigma \alpha)$ proves so "agonizing" ( $\dot{\alpha} \rho \gamma \alpha \lambda \varepsilon \dot{\varepsilon}$ ) -because it gives birth to "tyrannical desires" ( $\rho \omega \tau \alpha \varsigma)$, whose harmful effects ("oppressive . . . incapable of fulfillment") Philo describes in §§80b-83. Mosès also takes the clause as explanatory: "Mais aucune d'entre les passions n'est aussi cruelle que le dèsir des biens absent, biens d'opinion qui n'en sont pas en réalité: car ils engendrent interminablement des caprices tyranniques."

${ }^{42}$ And consider the plight of those subject to tyrannical desire! ( $\left.\gamma \alpha \dot{\alpha} \rho\right)$ : Philo now turns to a detailed characterization of life for those subject to tyrannical desire.

${ }^{43}$ Free of restraint and fixed on the thought of a beloved object: Philo presupposes but does not explicitly state these conditions. Desire has triumphed over reason (cf. Decal. 149: ö $\tau \epsilon$

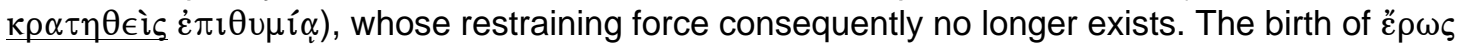
signals the involvement of the mind (see above, 87-93). 
deprived, struggles endlessly in vain, ${ }^{44}$ dooming the poor soul to a Tantalus fate. You remember that wretch. As the story goes, he could never quench his thirst, because the water would instantly recede every time he tried to take a drink. Likewise, whenever he reached for some fruit on the nearby trees, it would all disappear-the loaded branches would suddenly turn barren. [\$82] Now, just as those hard, implacable taskmasters hunger and thirst rack the body more painfully than an inquisitor cranking his torture wheel-often to the point of death, unless someone appeases their savagery with food and drink-desire can create even harsher taskmasters for the soul by creating a grumbling emptiness within. People forget what's right in front of them and become obsessed with what's somewhere off in the distance, working themselves into a frenzied and unending madness. They become just like Tantalus, racked with "hunger" and "thirst," but not for something to fill the void in their bellies - they hunger for money, fame, power, voluptuous bodies, or any of the countless other things that seem to them enviable and worthy of struggle. ${ }^{45}$ And don't think that passionate desire, once indulged, will ever stop short of this full-blown agony. ${ }^{46}$ [\$83] Just as what physicians call the "creeping disease" never stays in one place, but moves about and as its name suggests "creeps" through the whole body, spreading and seeping, taking over the different parts of the body one after another, from head to toe, so too desire spreads quickly and eventually infects every last part of the soul in its drive for absolute tyranny. Think of it as a fire with plenty of fuel, which keeps burning once it's lit until the flames consume everything.

Having sketched briefly the problem posed by passions in general, Philo now considers $\dot{\varepsilon} \pi \imath \theta \mu \hat{\imath} \alpha$ in particular. Any emotion $(\pi \dot{\alpha} \theta 0 \varsigma)$ can become a passion $(\pi \dot{\alpha} \theta$ os) when reason fails to set proper limits—and passion, understood in this way as a failure of restraint, typically brings disaster to the soul (§79). Of course,

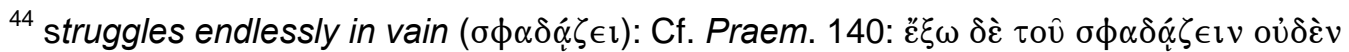

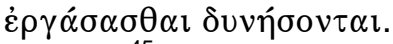

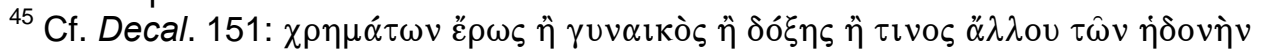
$\dot{\alpha} \pi \epsilon \rho \gamma \alpha \zeta \mathrm{o} \mu \varepsilon \dot{\varepsilon} \omega \omega$.

${ }^{46}$ Some such thought underlies Philo's introduction of disease and fire imagery in §83, which otherwise seems out of place. The agony he has just described inevitably comes once desire oversteps the bounds of reason unchecked. Philo states this more plainly in Decal. 150:

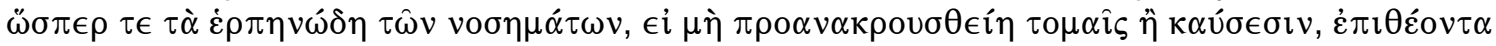

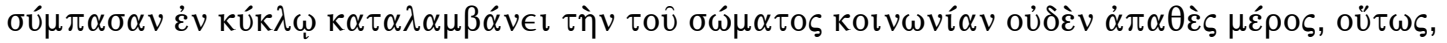


this general rule applies also to $\dot{\varepsilon} \pi \imath \theta v \mu i \alpha$, which turns from useful emotion to destructive passion when it oversteps the measure of reason. But passionate desire ( $\ddot{\alpha} \mu \epsilon \tau \rho \circ \dot{\varepsilon} \pi \imath \theta u \mu i \alpha)$ poses a unique problem and deserves unique censure, because it fosters the awful menace of tyrannical desire (ह̋ $\rho \omega \varsigma)$. Philo wants to describe that menace in detail and so illustrate just how bad $\dot{\varepsilon} \pi \imath \theta u \mu i \alpha$ can be, not $\dot{\varepsilon} \pi \imath \theta u \mu i \alpha$ per se-and certainly not $\dot{\varepsilon} \pi \imath \theta u \mu i \alpha$ the moderated, useful emotion—but $\dot{\varepsilon} \pi \imath \theta u \mu i \alpha$ at its full-blown worst, $\dot{\varepsilon} \pi \imath \theta u \mu i \alpha$ burgeoned into $\varepsilon^{\prime} \rho \omega \varsigma$. In $\S \S 80-83$, Philo introduces the topic of tyrannical desire ( $\varepsilon \rho \omega \varsigma)$ then begins his "diagnosis" (крíбı)) in earnest by explaining its torturous effect on the soul. Philo first makes a precise statement of the type of desire he has in mind (§80a): a longing ( $\dot{\varepsilon} \pi \imath \theta v \mu i \alpha \alpha \hat{\omega} v \dot{\alpha} \pi o ́ v \tau \omega v)$ after false goods gives birth to

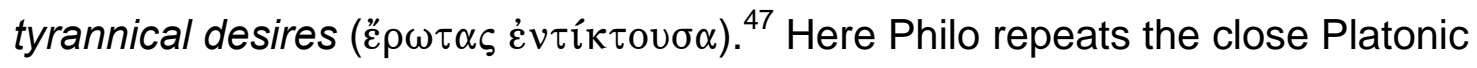
association of ع̋ $\rho \omega \varsigma$ with $\pi$ ó $\theta$ o, a distinct aspect of $\tilde{\varepsilon} \rho \omega \varsigma .{ }^{48}$ Both terms suggest an obsessive desire, but with different emphases. Пó objects not in the subject's physical presence. ${ }^{49}$ As Philo plainly states, the desire

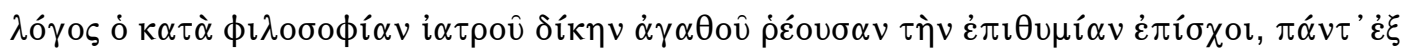

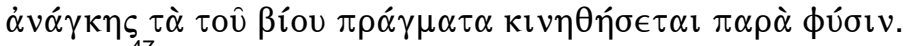

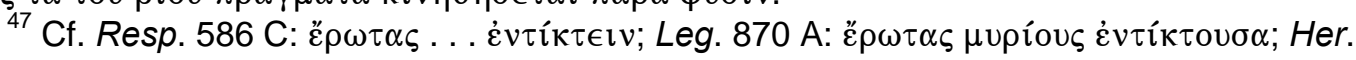

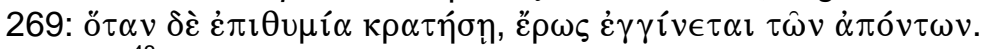

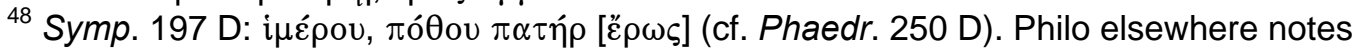

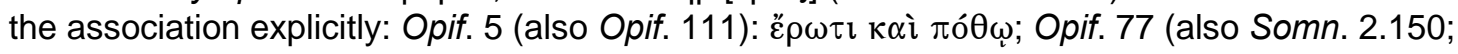

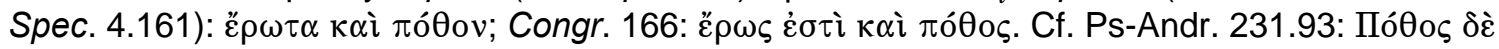

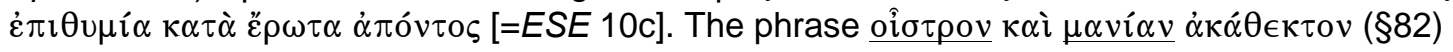

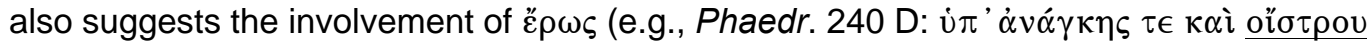

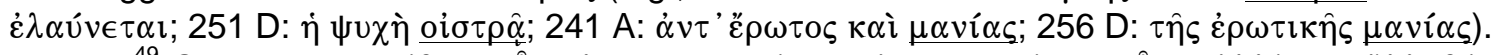

${ }^{49}$ Crat. 420 A: " $\pi$ ó

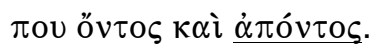


is $\tau \hat{\omega} v \dot{\alpha} \pi o ́ v \tau \omega \nu$, which makes it a longing, a pining, for something remote and invisible. Since there is by definition nothing to perceive through the senses, the moral agent must produce and hold in mind an image of the beloved object. And ع̋ $\rho \omega \varsigma$ specifically involves objects deemed "good" ( $\dot{\alpha} \gamma \alpha \theta$ ós) and thus worthy of ultimate pursuit. So tyrannical desire, as Philo points out, tragically involves a mistaken perception of what is good, compelling the moral agent to pursue

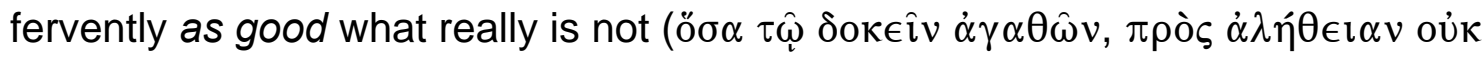
öv $\tau \omega v)$. In terms of Middle-Platonic moral psychology, this happens when the emotion $\dot{\varepsilon} \pi \imath \theta u \mu i \alpha$ not only oversteps the bounds of reason to become passionate desire ( $\ddot{\alpha} \mu \epsilon \tau \rho \circ \varsigma \dot{\varepsilon} \pi \imath \theta u \mu i ́ \alpha)$, but defeats reason entirely, compelling the vanquished moral agent to embrace its false notion of the good-namely, pleasure, which various false goods seem to afford. ${ }^{50}$

Once he identifies tyrannical desire ( $\left.\varepsilon^{\prime} \rho \omega \varsigma\right)$ as his topic, Philo explains its characteristic ill effects, beginning with the tortuous insatiability ع̋ $\rho \omega \varsigma$ creates in the soul (§§80b-82). Philo uses both the image of a maddening, futile chase and the mythical figure of Tantalus to portray vividly the same dreadful experience: fervently, endlessly reaching for something but never getting hold of it. ${ }^{51}$ While

${ }^{50}$ In Phaedr. $237 \mathrm{D}-238 \mathrm{C}$, the term $\check{\rho} \rho \omega \varsigma$ applies to one in whom $\dot{\varepsilon} \pi \mathrm{\imath} \theta u \mu i \mathrm{i}_{\alpha}$ has

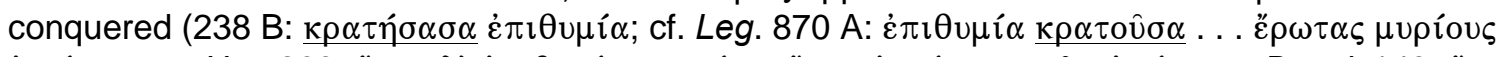

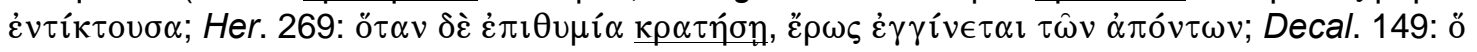

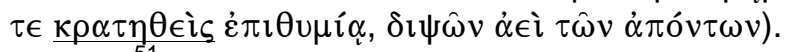

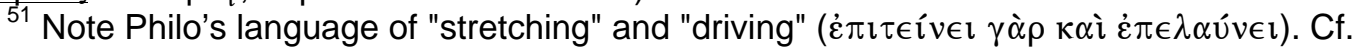

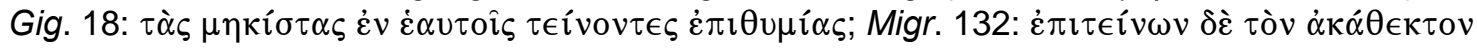

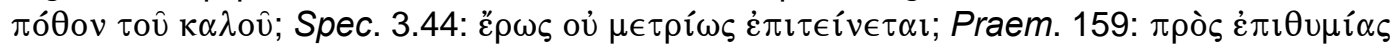

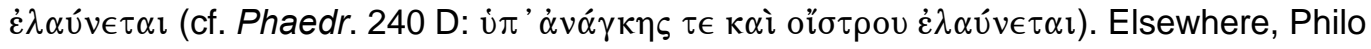


the chase image conveys an impression of the experience, Philo's commentary on Tantalus provides a genuine analysis in terms of moral psychology. Hunger and thirst are desires of the soul especially linked to physical states of

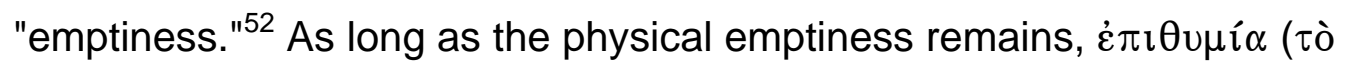
$\dot{\varepsilon} \pi \imath \theta u \mu \eta \tau \imath \kappa o ́ v)$ remains activated, in reflexive pursuit of the pleasure of a physical "filling" with food or water. ${ }^{53}$ The physical emptiness acts as an inherent trigger, constantly goading the "taskmasters" hunger and thirst, which in turn compel the moral agent to eat and drink. But the goading and compelling disappear when the emptiness disappears. Similarly, tyrannical desire creates something like a physical emptiness, insofar as it creates an inherent trigger for the soul's $\dot{\varepsilon} \pi \imath \theta u \mu i \alpha$ ( $\tau o ̀ ~ \dot{\varepsilon} \pi \imath \theta u \mu \eta \tau \imath \kappa o ́ v)$. Obsessed with a false good, the moral agent continually brings an image of that "good" to mind, and because that "good" promises pleasure, $\dot{\varepsilon} \pi \imath \theta u \mu i \alpha$ remains in a state of continual arousal in pursuit of that pleasure. Unlike physical hunger, which can end once the physical emptiness is filled, this "hunger" cannot end, because there is no corresponding

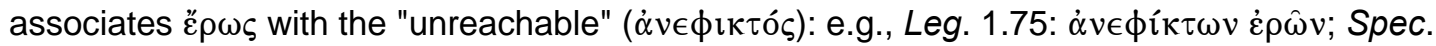

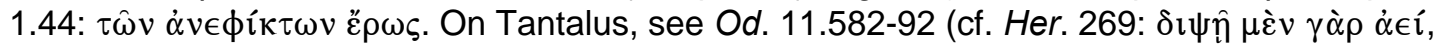

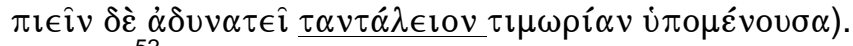

52 On the relation of hunger and thirst, as desires of the soul, to physical states of the body, see Phileb. 31 E - 35 D (cf. Hackforth, Plato's Examination of Pleasure, 61; also 79, n. 4, 112 , n. 2., 140, n. 2).

${ }^{53}$ Of course, reason may or may not authorize the pursuit of food or water, depending on the circumstances. In Resp. 439 C-D, Plato describes the moral agent who simultaneously desires something to drink but refuses to drink, because reason keeps desire in check. 
physical emptiness to fill. ${ }^{54}$ So the soul under tyrannical desire endures an

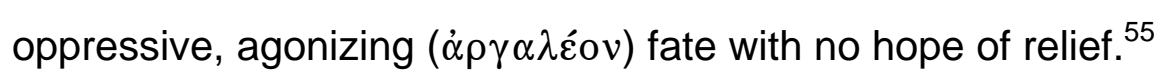

Next, Philo notes the all-consuming nature of tyrannical desire (§83). If left unchecked, desire eventually spreads throughout the entire soul $(\delta \imath$ 'ö $\lambda \eta \varsigma \ldots \tau \hat{\uparrow} \varsigma$

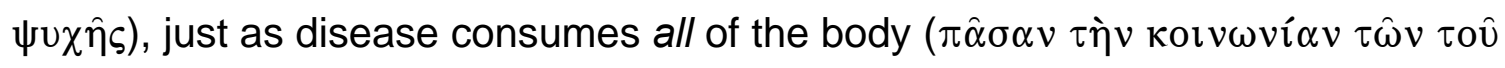

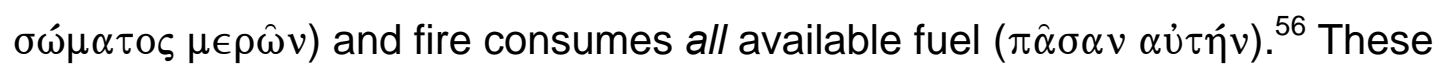
images suit Philo's Middle-Platonic psychology, because they portray desire as a distinct power capable of malignant, independent operation—of spreading its influence from one part of the soul to another. Once desire has broken free of reason's restraint, it settles for nothing less than complete domination. ${ }^{57}$ In this way, tyrannical desire represents the terminal stage of desire's unrestrained activity: $\dot{\varepsilon} \pi \imath \theta u \mu i \alpha$ has "consumed" the rational part of the soul, replacing any proper notion of "the good" with its singular focus on pleasure.

\section{$\S \S 80$ - 83 Excursus: Parallel Material in Decal. 146-50}

In Decal. 146-50, Philo gives a similar account of tyrannical desire, describing its insatiability and all-consuming nature. The initial context, however, deals with desire, pleasure, fear, and distress as emotions $(\pi \dot{\alpha} \theta \eta)$, not passions

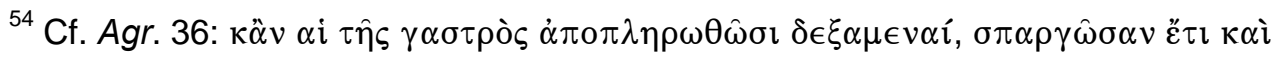

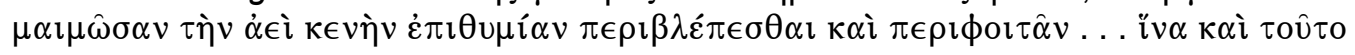

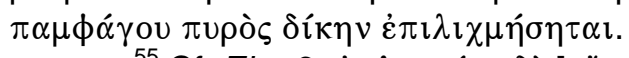

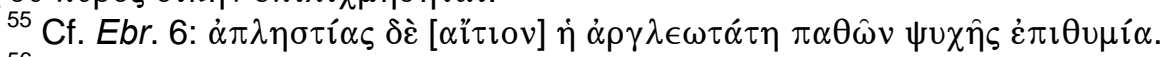

${ }^{56}$ On passion as "disease," see Martha Nussbaum, The Therapy of Desire: Theory and Practice in Hellenistic Ethics (MCL n.s. 2; Princeton: Princeton University Press, 1994), 13-77.

${ }^{57}$ See A. Pelletier, "Les passions à l'assaut de l'âme d'après Philon." REG 78 (1965): 52-

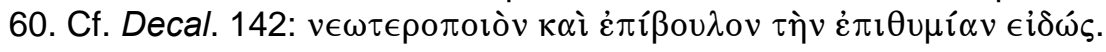


( $\pi \dot{\alpha} \theta \eta)$, addressing the question of how $\dot{\varepsilon} \pi \imath \theta u \mu i \alpha$ (which alone the Decalogue prohibits) differs from the other three (\$142). Philo claims that desire alone is

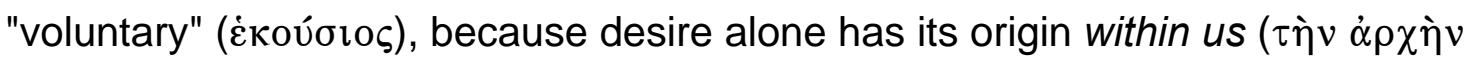
$\dot{\varepsilon} \xi \dot{\eta} \mu \hat{\omega} v \alpha \dot{U} \tau \hat{\omega} v \lambda \alpha \mu \beta \alpha \dot{\alpha} v \in \imath$ ), and he carries this idea into the ensuing descriptions of how each emotion works (§§143-45). ${ }^{58}$ In the case of pleasure, distress, and fear, the perceptions of present good, present ill, or impending ill—perceptions that originate outside the moral agent—cause the corresponding emotion to occur involuntarily, and Philo signals this grammatically by making the perception the subject in each description. ${ }^{59}$ But when he comes to desire (§146), the subject of his description becomes the moral agent ( $\tau / \varsigma)$, who himself brings an

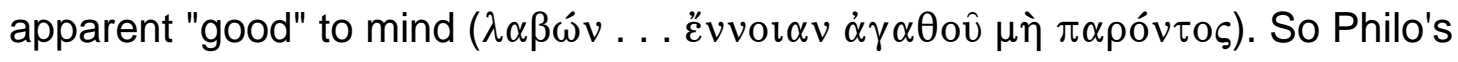
descriptions of the four cardinal emotions do in fact support his initial claim about the unique genesis of desire, but only because he manipulates his account of $\dot{\varepsilon} \pi \imath \theta u \mu i \alpha$ to that end. He elsewhere understands $\dot{\varepsilon} \pi \imath \theta v \mu i \alpha$ to operate according to the same non-rational mechanism of stimulus and response underlying the other emotions. ${ }^{60}$ So consistency of doctrine would have required him to give an account of the emotion desire similar to his accounts of pleasure, distress, and fear. But instead, beginning in $\S 146$ and continuing through $§ 150$, he describes

\footnotetext{
${ }^{58}$ Wolfson (Philo, 2:232-35) explains the unique "voluntary" aspect of desire in light of Philo's concept of human free will (choice). But from a Platonic perspective, non-rational $\dot{\varepsilon} \pi \imath \theta u \mu i \alpha$ moves reflexively and so independently of the moral agent's "will."

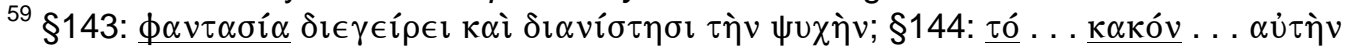

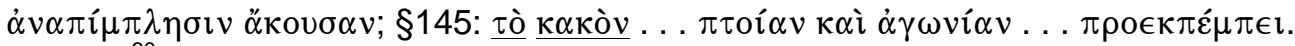

${ }^{60}$ E.g., Leg. 3115: $\dot{\varepsilon} \pi \imath \theta u \mu i \alpha=o ̋ \rho \in \xi ı \varsigma ~ \ddot{\alpha} \lambda o \gamma o \varsigma$ (cf. above, 67, n. 76).
} 
not the emotion $\dot{\varepsilon} \pi \imath \theta u \mu i \alpha$ but its vicious offspring, tyrannical desire (źp $\rho \varsigma)$, in terms that mirror Spec. 4.80-83.

Although Philo does not use the term ह̌ $\rho \omega \varsigma$ in $\$ 146$ when he introduces his topic (as he does in Spec. 4.80 using the term $\check{\varepsilon} \rho \omega \tau \alpha \varsigma$ ), he nevertheless speaks of tyrannical desire. The moral agent holds in mind a concept (žvvor $\alpha v)$ of an

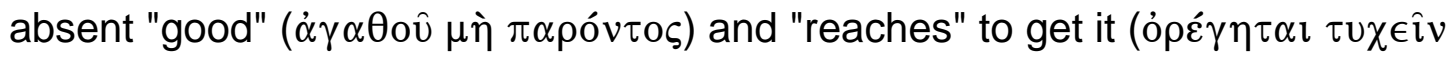
$\alpha$ $\dot{\tau} \tau o \hat{)})$. Setting the mind on what is deemed good signals Platonic $\varepsilon \rho \omega \varsigma$-in particular, a tyrannical desire set on any number of false goods and the pleasures they promise ${ }^{61}$ Philo states the involvement of tyrannical desire

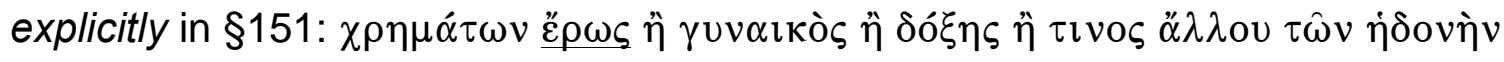
$\dot{\alpha} \pi \epsilon \rho \gamma \alpha \zeta o \mu \varepsilon \dot{\varepsilon} v \omega v$. The absence of the beloved object ( $\mu \grave{\eta} \pi \alpha \rho o ́ v \tau o \varsigma)$ suggests

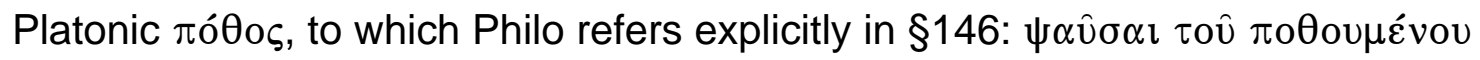

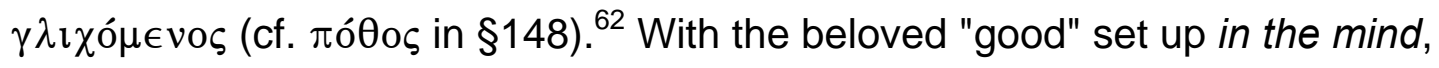

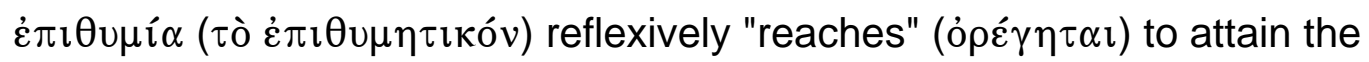
pleasure it offers. ${ }^{63}$ Desire has completely defeated the moral agent, imposing its ultimate "good" of pleasure upon the rational faculty and so establishing an object of hopeless pursuit for the non-rational $\dot{\varepsilon} \pi \imath \theta u \mu i \alpha$ within. ${ }^{64}$ As in Spec.

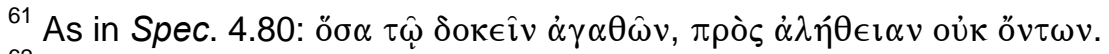

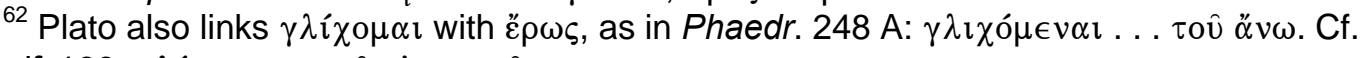

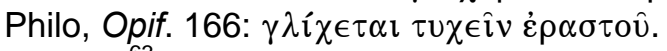

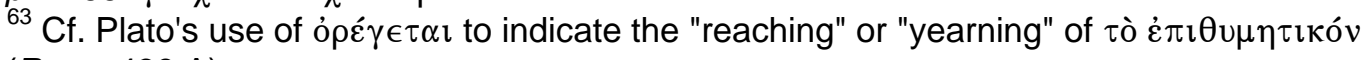
to drink (Resp. 439 A).

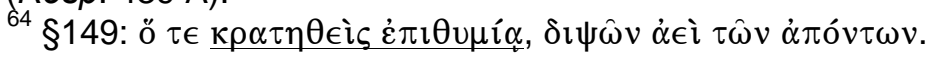


4.80-83, Philo vividly portrays the endless, futile striving to grasp an ever-elusive object.

Instead of elaborating the image of an exasperating, futile chase (mentioned summarily in §146), Philo appeals in §§147-149a to the senses of sight and hearing to illustrate the straining, agonizing, fruitless effort to apprehend the beloved object of tyrannical desire. ${ }^{65}$ The eyes, he says (§147),

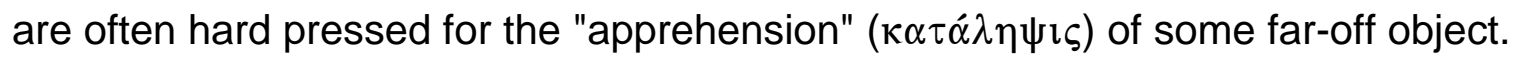
Despite their intense and continued effort, they are unable to get hold of what they "desire" and exhaust themselves.$^{66}$ Likewise, the ears (\$148-149a) can be "aroused" ( $\dot{\alpha} v \in \gamma \in \rho \theta \dot{\varepsilon} v \tau \alpha)^{67}$ by an indistinct, far-off noise, which produces a "longing" ( $\pi$ ó $0 \varsigma$ ) for clarity. The sound, however, remains indistinct, provoking

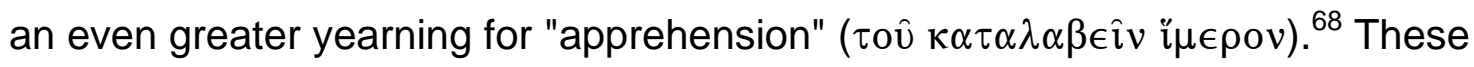
analogies from the realm of sense-perception not only present a novel image of insatiability—-they also reflect the Middle-Platonic moral psychology underlying Philo's exposition. By choosing to compare the mechanism of tyrannical desire

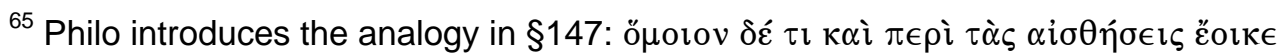
$\sigma u \mu \beta \alpha i v \in i v$.

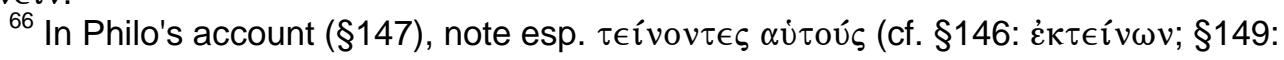

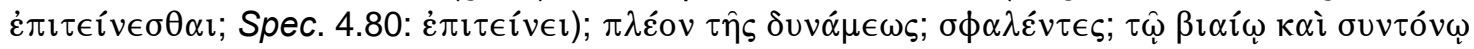

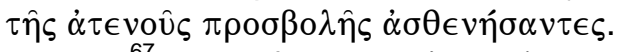

${ }^{67}$ Philo often uses $\dot{\alpha} v \in \gamma \in i \rho \omega$ in connection with the emotions (e.g., Ebr. 98, Fug. 91), which makes sense in light of the moral psychology of है $\rho \omega \varsigma$ : the rational part of the soul, consumed with tyrannical desire, holds in mind an image that continually arouses the emotion $\dot{\varepsilon} \pi \imath \theta u \mu i \alpha$, creating the maddening experience of insatiability (cf. Spec. 1.92: $\dot{\varepsilon} \pi \imath \theta u \mu i \alpha \varsigma$

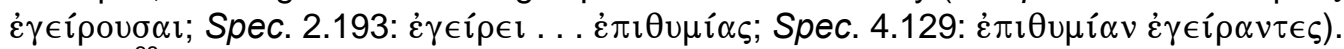

${ }^{68}$ Like $\pi$ ó $\theta$ s, ï $\mu \in \rho \circ \varsigma$ represents an aspect of $\tilde{\varepsilon} \rho \omega \varsigma$ for both Plato and Philo. Examples for

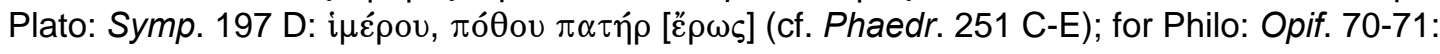


with the non-rational mechanism of sense-perception ( $\alpha$ i̋ $\sigma \eta \eta \iota \varsigma$ ), Philo reaffirms his understanding of $\dot{\varepsilon} \pi \imath \theta u \mu i \alpha$ as a fundamentally non-rational power, which non-rationally pursues the "good" (pleasure) set before it. ${ }^{69}$

As in Spec. 4.81-82, Philo cites the mythical figure Tantalus to illustrate the operation of tyrannical desire (§149b). Although brief, his remarks plainly

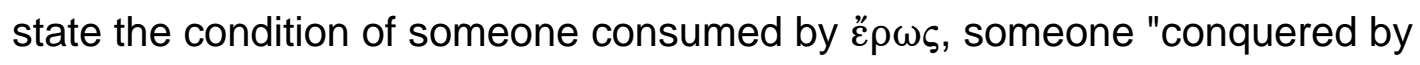

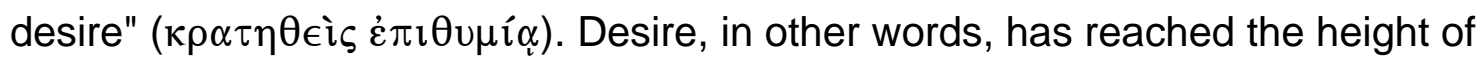
power, supplanting reason and making its own goal of pleasure the goal of the moral agent. In this condition, the moral agent "thirsts" always for what is absent

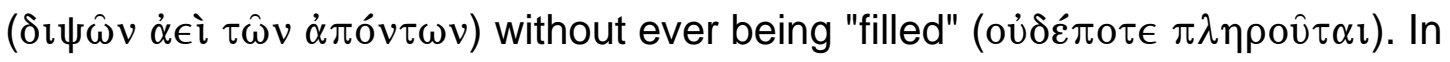
fact, there is no possibility of being filled, since the appetite aroused by an image of false goods has no capacity for fulfillment-it is an "empty," in the sense of

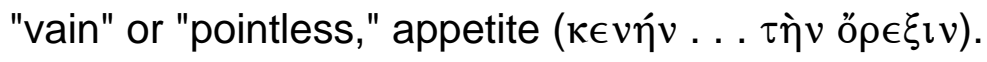

As in Spec. 4.83, Philo compares desire to disease and fire (\$150), both of which spread until they have consumed everything available to them. Again, the imagery reflects Middle-Platonic moral psychology by depicting $\dot{\varepsilon} \pi \imath \theta u \mu i ́ \alpha$ as a destructive force originating in one part (of the body, of the combustible mass, of the soul) and spreading to other parts. ${ }^{70}$ Revealing his Middle-Platonic affinities

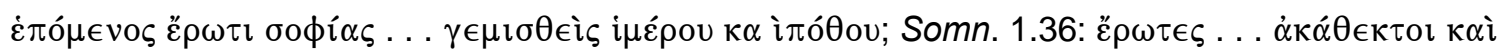

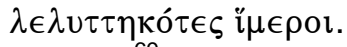

${ }^{69} \mathrm{Cf}$. Philo's bipartite model of reason over against $\alpha$ ĭ $\sigma \eta \eta \sigma \iota \varsigma$ (see above, 72-75).

${ }^{70}$ Philo describes a disease spreading throughout the body leaving no "part" ( $\mu \varepsilon \dot{\rho} \rho \varsigma$ ) unaffected $(\dot{\alpha} \pi \alpha \theta \dot{\varepsilon} \varsigma)(\S 150)$. 
even further, Philo uses this imagery to reflect the adversarial relationship between parts (between reason and desire) so fundamental to the Platonic perspective. He notes that the soul will suffer infection "lest philosophical reason

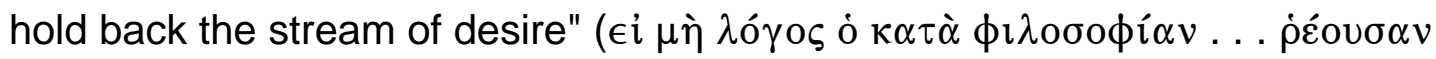
$\tau \grave{\eta} \nu \dot{\varepsilon} \pi \imath \theta v \mu i \alpha \nu \nu \dot{\varepsilon} \pi i ́ \sigma \chi 0 \imath) .{ }^{71}$ Here reason acts to restrain desire, in order to preclude an overpowering of reason by desire. If reason fails to hold back the stream, then desire will have its way, ultimately overrunning the entire soul with the tyranny of $\tilde{\varepsilon} \rho \omega \varsigma$. Similarly, if the "flame" of desire is granted "freedom" $(\ddot{\alpha} \delta \in \imath \alpha)^{72}$ and "leisure" ( $\left.\dot{\varepsilon} \kappa \in \chi \in \imath \rho \mathfrak{i} \alpha\right)^{73}$-in other words, if reason fails to restrain desire and gives it free rein instead—-then it will eventually spread and destroy everything through the tyranny of है $\rho \omega \varsigma$. Philo deploys the imagery in this way because he understands the importance of $\dot{\varepsilon} \gamma \kappa \rho \alpha ́ \tau \epsilon \mathfrak{l} \alpha$ : reason must either impose its rule on non-rational $\dot{\varepsilon} \pi \imath \theta u \mu i_{\alpha}$ or in the end suffer the rule of desire's tyrannical offspring है $\rho \omega \varsigma$.

\section{$\S \S 84$ - 91: Tyrannical Desire as "Source of All IIIs"}

[§84] So great and egregious an ill, then, is passionate desire. In fact, if truth be told, it is the source of all the world's ills. Think for a minute about the underlying cause of looting, robbery, and swindling; of flattery and insult; of seduction, adultery, murder-of all wrongdoing involving matters private or public, sacred or secular. Do these ultimately have any source other than desire? [§85] For this reason, among the passions, only

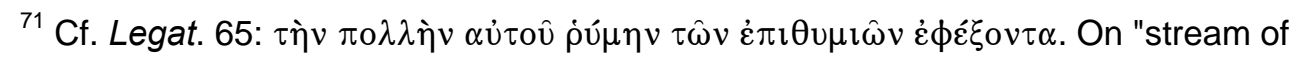
desire," see also Resp. 485 D-E; cf. Crat. 419 E - 420 B.

${ }^{72}$ Cf. esp. Leg. 2.91, where Philo associates this same "freedom" ( $\ddot{\alpha} \delta\llcorner\alpha)$ with the

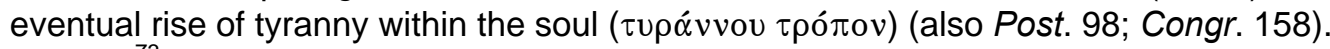

${ }^{73}$ Cf. Philo's use of $\dot{\varepsilon} \kappa \in \chi \in \iota \rho$ í $\alpha$ in connection with the Sabbath (e.g., Mos. 2.22; Spec. 2.69). 
passionate desire deserves the name "Master Vice," whose one little offspring tyrannical desire has repeatedly filled the world with unspeakable disasters ${ }^{74}$ - which, too numerous for land, have spilled out into the sea. Everywhere the vast watery expanse has been filled with ships of war and all the terrible inventions of war. Charging out to sea, their violence runs its course then crashes back like a tide upon the shores of home. [\$86] We can better understand the effect of passionate desire ${ }^{75}$ by thinking of it as a venomous creature or lethal poison, both of which cause an overall change for the worse anytime they take hold of someone. What exactly do I mean by that? Think of tyrannical desire as the fatal "bite" of passionate desire, a terminal "taking hold" akin to a "taking over. ${ }^{176}$ [§87] For example, if a tyrannical desire for money takes over of the soul, ${ }^{77}$ it turns people into thieves and pickpockets, larcenists and burglars-it makes them likely to swindle and scam, to accept bribes, to violate sacred trusts, to perform any other similar act of greed. [§88] If a tyrannical desire for reputation takes over, it makes people pretentious, arrogant, unsteady and unsettled in character. With eager ears they listen for the pronouncements of other people, ${ }^{78}$ becoming at the same time dejected and elated as they

${ }^{74}$ among the passions, only passionate desire deserves the name "Master Vice," whose

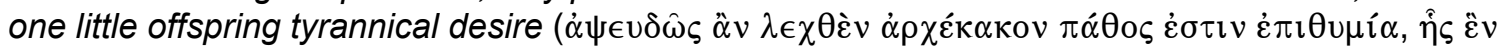

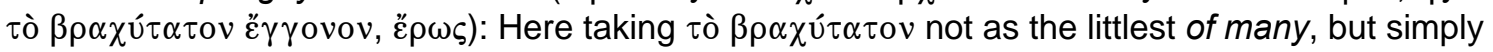

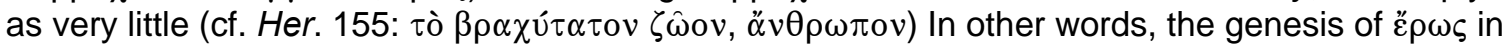
the soul seems slight in comparison with the "unspeakable disasters" ( $\dot{\alpha} \mu \nu \theta \dot{\eta} \tau \omega \nu \ldots$. . б $\mu \phi о \rho \hat{\omega} v)$ it eventually creates.

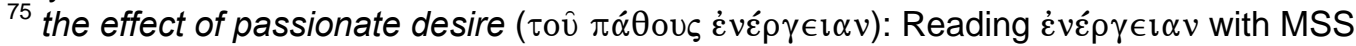
(SM) rather than $\dot{\varepsilon} v \alpha \dot{\alpha} \rho \in \imath \alpha \nu$ proposed by Mangey and adopted by Cohn-Wendland. Philo, after all, explains in §§87-91 the work of desire in the soul (cf. Leg. 2.101: o $\dot{\alpha} \pi 0 \pi i \pi \tau \omega \nu \tau \hat{\omega} \nu \pi \alpha \theta \hat{\omega} v$

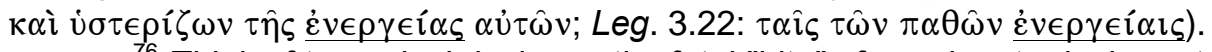

${ }^{76}$ Think of tyrannical desire as the fatal "bite" of passionate desire, a terminal "taking

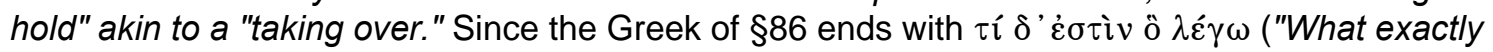
do I mean by that?"), this sentence attempts to clarify the logic of Philo's venom/poison simile in light of the examples given in §§87-91. He presupposes passionate desire as the condition from which tyrannical desire - the worst, terminal grade of desire-is born. Passionate desire represents a genuine danger to the soul, but it fatally "bites" the soul by burgeoning into tyrannical desire, which consumes the moral agent and thoroughly corrupts the character.

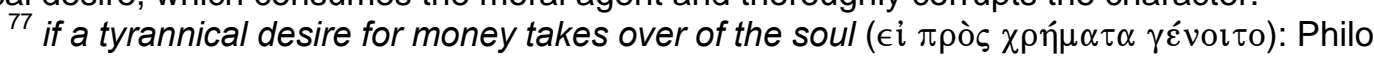

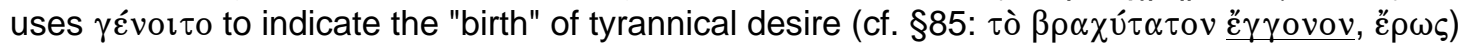
relative to a particular beloved object, in this case $\chi \rho \eta \mu \alpha \tau \alpha$. He envisions the same phenomenon relative to other objects ( $\delta$ ó $\xi \alpha$, etc.) in subsequent paragraphs.

${ }^{78}$ With eager ears they listen for the pronouncements of other people ( $\phi \omega v \alpha \hat{\imath} \varsigma \tau \grave{\alpha} \hat{\omega} \tau \alpha$ $\pi \epsilon \phi \rho \alpha \kappa o ́ \tau \alpha \varsigma)$ : The phrase $\phi \omega \nu \alpha \hat{\imath} \varsigma \tau \grave{\alpha} \hat{\omega} \tau \alpha \pi \epsilon \phi \rho \alpha \kappa o ́ \tau \alpha \varsigma$ most likely represents a play on words. The verb $\underline{\varepsilon} \pi \imath \phi \rho \alpha ́ \sigma \sigma \omega$ with $\tau \grave{\alpha} \hat{\omega} \tau \alpha$ means "to stop one's ears" (see LSJ, s.v.), an idiom attested in Philo (e.g., Leg. 2.25; Migr. 191). But treating $\phi \rho \alpha \dot{\sigma} \sigma \sigma \omega$ as an equivalent of $\dot{\varepsilon} \pi \iota \phi \rho \alpha ́ \sigma \sigma \omega$ yields a sense directly opposite to what the context demands: people concerned with reputation clearly do not "stop their ears"- they want to know what people are saying about them, and because they 
hear from the fickle masses, who deal out praise and blame by indiscriminate whim. Because they care only for what others have to say about them, they readily exchange love for hatred, or hatred for love, depending on what they hear-without a moment's consideration. You'll find them doing other things like this, always for the same reason. [§89] If a tyrannical desire for power takes over, it makes people contentious, inequitable, domineering by nature, cruel at heart. They become enemies of their own land, harsh masters of anyone weaker, irreconcilable enemies of their equals in strength, and deceitful flatterers of anyone stronger. If a tyrannical desire for voluptuous bodies takes over, people become seducers, adulterers, pederasts, devotees of indulgence and lust-they consider the greatest of evils to be the happiest of goods. [§90] Overtaking even the tongue, tyrannical desire has stirred up endless troubles, since we know that people are often gripped with a desire to keep quiet when they ought to speak or a desire to speak when they ought to keep quietand both receive their just deserts. [\$91] And when tyrannical desire seizes the belly, it produces hopeless, insatiable gluttons, devotees of a life of ease and dissipation, people who revel in guzzling and gorging, base slaves of drinks and delicacies, who forage around at parties and banquets like ravenous little dogs. Such people end up with a miserable, accursed life more painful than any death.

Proceeding with his "diagnosis" (крíøı), Philo turns from the agonizing experience tyrannical desire works in the individual (§§80-83) to consider the moral corruption and chaos it works in society through such individuals (§§8491). Philo makes one central claim in this section: that all moral and social ills stem from $\dot{\varepsilon} \pi \imath \theta u \mu i ́ \alpha$. Such a claim both expands the scope of Philo's programmatic condemnation of desire and justifies the Decalogue's prohibition of only one $\pi \dot{\alpha} \theta$ o $\varsigma$ as an efficient preclusion of all wrongdoing. And Philo undoubtedly does mean passionate desire when he calls $\dot{\varepsilon} \pi \imath \theta u \mu i \alpha$ the "source of

are listening intently to praise and blame, their mood rises and falls accordingly. Philo plays with

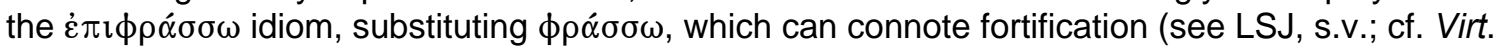
186; Prob. 152). The original effect must have been something like: "Their ears are not stopped, they're propped-eager to hear what people are saying." 


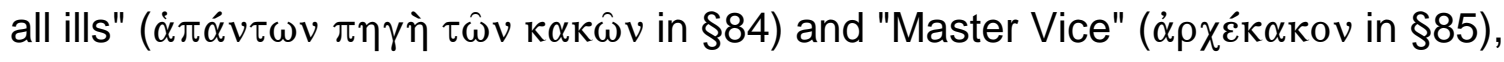
although he means it in a qualified sense ${ }^{79} \mathrm{He}$ indicts passionate desire insofar as it gives birth to tyrannical desire (ह̋ $\rho \omega \varsigma)$, and tyrannical desire then does the real work of corrupting character and engendering corrupt behavior. As Philo puts it in $\S 85, \dot{\varepsilon} \pi \imath \theta u \mu i \alpha$ is the Master Vice, "whose one little offspring tyrannical desire (๕̋ $\rho \omega \varsigma)$ has repeatedly filled the world with unspeakable disasters."

Using a series of concrete examples, Philo goes on to explain in §§86-91 just how tyrannical desire operates. Philo's argument presumes a direct stepwise progression from useful $\dot{\varepsilon} \pi \imath \theta v \mu i \alpha$, to passionate $\dot{\varepsilon} \pi \imath \theta v \mu i \alpha$, to $\tilde{\varepsilon} \rho \omega \varsigma$, which bears full responsibility for the corruption of character. In other words, unrestrained desire gives birth to है $\rho \omega \varsigma$, whose hegemony in turn transforms the moral agent into an evildoer who stops at nothing in pursuit of the beloved object. To clarify the mechanism of this transformation, Philo compares desire to poison, suggesting that both effect an overall change for the worse in whomever they afflict. ${ }^{80}$ Poison, for instance, when introduced into the body (by venomous creatures or lethal drugs), despite its initial localization, eventually transforms the entire body from healthy to sick, from living to dead. Similarly, $\dot{\varepsilon} \pi \imath \theta u \mu i \alpha$, despite the "localization" of its initial break with reason, eventually burgeons into é $\rho \omega \varsigma$ and transforms the entire soul from healthy to sick, from virtuous to vicious. And

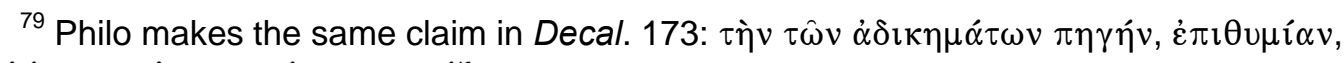

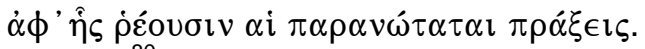

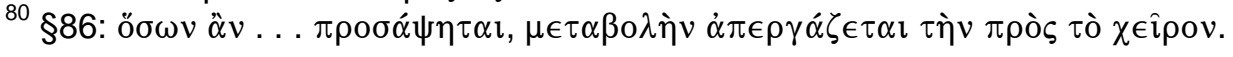


people display different forms of moral corruption depending on which false goods they pursue under tyrannical desire's control: whether money $(\chi \rho \eta \mu \alpha \tau \alpha)$,

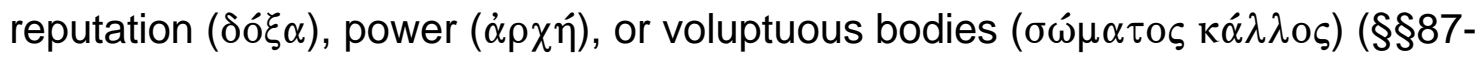
89). ${ }^{81}$ In each case, the moral agent's obsessive drive for that particular "good" ultimately leads to a distinct profile of reprehensible behaviors detrimental to both self and society. For example, an $\tilde{\varepsilon} \rho \omega \varsigma$ for money yields thieves and swindlers (§87); an ع̋ $\rho \omega \varsigma$ for reputation yields pretentious braggarts (§88); ${ }^{82}$ an $\tilde{\varepsilon} \rho \omega \varsigma$ for power yields ruthless oppressors (§89); an ह̋ $\rho \omega \varsigma$ for voluptuous bodies yields sexual offenders (§89). In this way, Philo traces a huge spectrum of wrongdoing to one source, tyrannical desire. To complete this spectrum of wrongdoing, Philo adds to his list of four false goods (§§87-89) two parts of the body over which tyrannical desire can reign (§§90-91): the tongue $(\gamma \lambda \hat{\omega} \tau \tau \alpha)$ and the belly ( $\tau \grave{\alpha} \pi \epsilon \rho \grave{i}$ $\gamma \alpha \sigma \tau \varepsilon \rho \alpha)$.

As for the tongue, Philo mentions the reprehensible desire of some either to keep quiet what ought to be said or to say what ought to be kept quiet (§90). ${ }^{83}$ He describes a situation of desire having "reached" the tongue ( $\dot{\varepsilon} \pi \grave{\imath} \gamma \lambda \hat{\omega} \tau \tau \alpha \nu$ $\phi \theta \dot{\alpha} \sigma \alpha \sigma \alpha)$-that is, desire having extended its influence even so far as to overtake the tongue, causing people to act (speak) contrary to reason. Just as the tyranny of ع̋ $\rho \omega \varsigma$ over people enamored of false goods causes corruption and

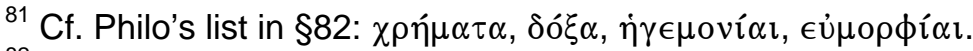

${ }^{82}$ On $\check{\varepsilon} \rho \omega \varsigma$ for $\delta o ́ \xi \alpha$ see also Plutarch, Suav. viv. 1100 B.

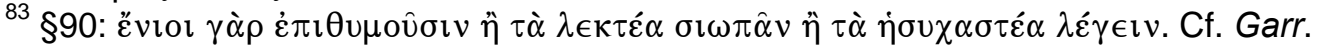


wrongdoing, the tyranny of $\varepsilon^{\prime} \rho \omega \varsigma$ over the tongue causes all sorts of troubles. Philo does not consider at length the immoralities caused by speech and silence, because tracing them to $\dot{\varepsilon} \pi \imath \theta u \mu i \alpha$-turned-ě $\rho \omega \varsigma$ confirms his central claim that all moral and social ills—including these-stem from desire.

Finally, Philo speaks of desire "getting hold of the belly" ( $\dot{\alpha} \psi \alpha \mu \varepsilon \dot{\varepsilon} v \eta \delta \grave{\varepsilon} \tau \hat{\omega} v$ $\pi \in \rho \grave{i} \gamma \alpha \sigma \tau \varepsilon \dot{\varepsilon} \rho)$, which clearly indicates more than just reasonable desires for food and drink. He has in mind people overcome by tyrannical desire (ह̋ $\rho \omega)$, who have established the pleasure derived from eating and drinking as their ultimate

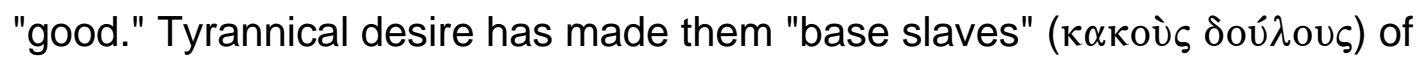

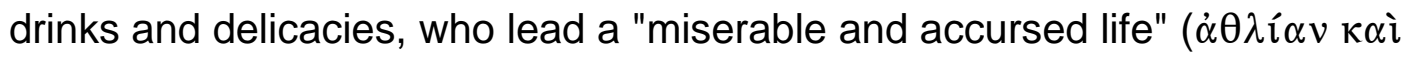
$\dot{\varepsilon} \pi \dot{\alpha} \rho \alpha \tau \sigma \nu . . \zeta \omega \eta \dot{v} v)$ more "agonizing" ( $\dot{\alpha} \rho \gamma \alpha \lambda \epsilon \omega \tau \varepsilon \dot{\varepsilon} \rho \alpha \nu)$ than any death. ${ }^{84}$ As with every case of है $\rho \omega \varsigma$, a particular object of affection produces a particular brand of immorality: those who adore the pleasures of food and drink become, above all, "gluttons" ( $\gamma \alpha \sigma \tau \rho \imath \mu \alpha ́ \rho \gamma o u \varsigma){ }^{85}$

$\S \S 84$ - 91 Excursus: Parallel Material in Decal. 151-53

In Decal. 151-53, Philo likewise indicts desire as the source of countless troubles. He initially asks whether है $\rho \omega \varsigma$ for money, a woman, reputation, or "anything else producing pleasure" becomes the cause of only "small and

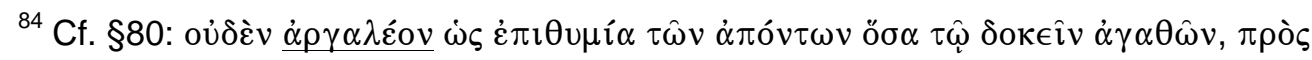

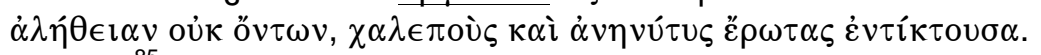

${ }^{85}$ In the course of Phaedr. $237 \mathrm{C}-238 \mathrm{C}$, Socrates labels $\tilde{\varepsilon} \rho \omega \varsigma$ as it relates to food

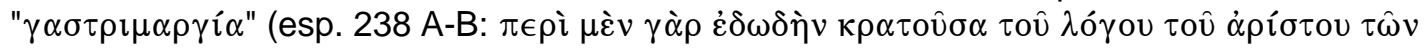


incidental ills." ${ }^{86}$ This rhetorical question functions as the thesis for §§151-53 and reflects real convictions about desire crucial to Philo's exposition of the Tenth Commandment: tyrannical desire $(\varepsilon \rho \omega \varsigma)$, which can arise in connection with any

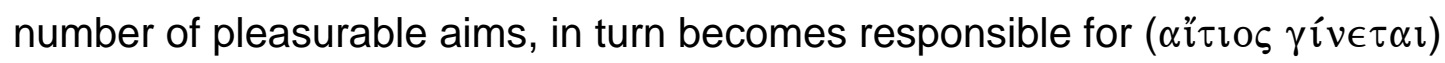
great and innumerable ills. In §\$152-53, Philo considers warfare in particular, ultimately concluding that "all wars flow from one source: desire $(\dot{\varepsilon} \pi \imath \theta u \mu i ́ \alpha)$ for money, or reputation, or pleasure. ${ }^{187} \mathrm{He}$ essentially restates here the thesis of $\S 151$, but with less precision, metonymically replacing the specific term ع̋ $\rho \omega \varsigma$ with the generic term $\dot{\varepsilon} \pi \imath \theta u \mu i \alpha$, replacing also the carefully worded "things that

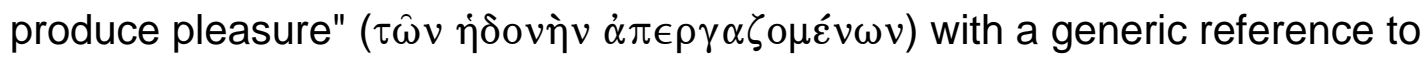

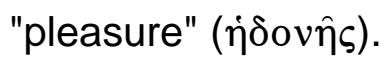

\section{$\S \S 92$ - 94: Location of 'E $E \imath \theta \mu i^{\prime} \alpha$}

[§92] And this overpowering desire for food and drink explains ${ }^{88}$ why those who had not simply "tasted" philosophy but had lavishly "feasted" on its sound doctrines-once they had investigated the nature of the soul and

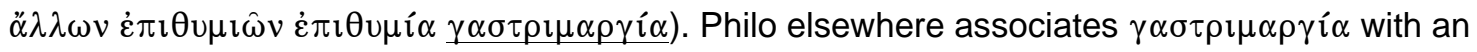
absolute dominance of desire for food (e.g., Agr. 36).

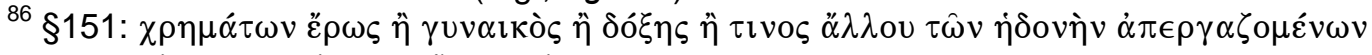

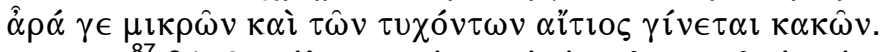
ทंठovทิs.

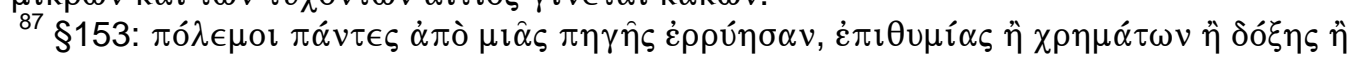

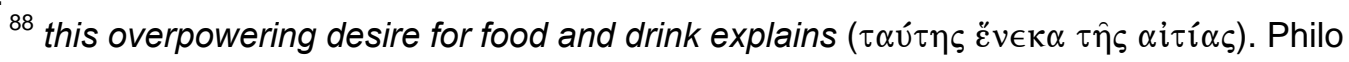
does not name the reason philosophers decided to distribute ( $\dot{\alpha} \pi \dot{\varepsilon} v \in \imath \mu \alpha \nu)$ the soul's parts as they did, but $\tau \alpha \dot{\tau} \tau\rceil$. . . $\tau \hat{\eta} \varsigma \alpha i \tau i \alpha \varsigma$ must refer to some aspect of $\S 91$, because $\S \S 92-94$ bear obvious connections to only that paragraph. Fundamentally, $\S 91$ and $\S \S 92-94$ have in common the association of $\dot{\varepsilon} \pi \imath \theta u \mu \dot{i} \alpha$ with the same general region of the body (§91: $\tau \grave{\alpha} \pi \epsilon \rho \grave{\imath} \gamma \alpha \sigma \tau \hat{\varepsilon} \rho \alpha$; §93: $\dot{o}$

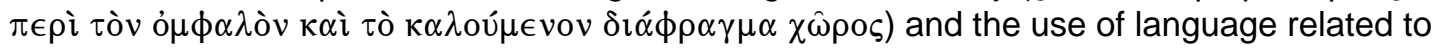

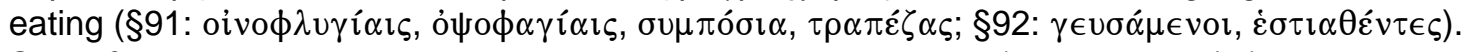
Since $\S 91$ describes corrupt, compulsive eating and drinking, $\tau \alpha u ́ \tau \eta \varsigma \ldots \tau \hat{\eta} \varsigma \alpha i \tau i \alpha \varsigma$ undoubtedly refers to the overpowering desire for food and drink underlying such behavior. 
recognized its tripartite structure ${ }^{89}$ (reason, spirit, desire)—distributed the various parts as they did. They put reason, which rules the soul, in the most appropriate place, the head, which is the topmost part of the body. The head also serves as headquarters for the senses, which together form a sort of entourage for the soul's "king," the mind. [\$93] Next, they determined that spirit must reside in the chest, for two reasons: first, in the chest, spirit wears a breastplate, just like a soldier, and this added protection makes it very difficult to defeat, although certainly not invincible; second, in the chest, dwelling near the mind, spirit receives help from its neighbor, whose wise counsel lulls it into compliance. Finally, they determined that desire must reside in the area around the navel known as the "diaphragm." [\$94] Since desire has the least to do with reason, it clearly must reside as far as possible from reason's royal domainpractically at the outskirts. Naturally, the pasture of this most insatiable and licentious of beasts is the area of the body associated with primal drives for food and sex.

Paragraphs 92-94 represent an excursus framed as a review of Platonic doctrine on the physical location of each of the soul's three parts. ${ }^{90}$ Just before this excursus (§§86-91), Philo had been describing how है $\rho \omega \varsigma$ functions as the source of all wrongdoing, using a series of examples that matched specific false goods pursued under tyrannical desire's hegemony with specific types of moral corruption. His final example (§91) noted the ability of $\dot{\varepsilon} \pi \imath \theta \mu i \alpha$-turned-है $\rho \omega \varsigma$ to "seize the belly" and so corrupt the moral agent in matters of eating and drinking. But in §92, Philo no longer considers the mechanism of $\tilde{\varepsilon} \rho \omega \varsigma$, choosing instead to reflect further on the association of $\dot{\varepsilon} \pi \theta u \mu i \alpha$ with a particular region of the

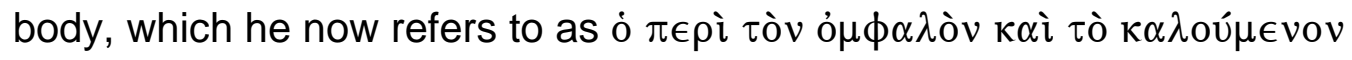

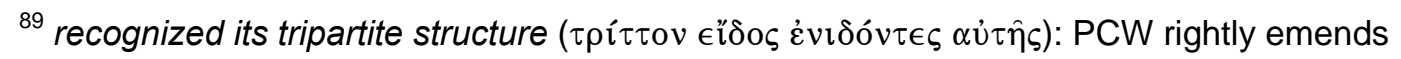

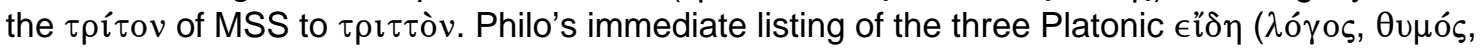
and $\dot{\varepsilon} \pi \imath \theta u \mu i \alpha$ ) indeed suggests an original reference to "threefold [i.e., tripartite] form" rather than

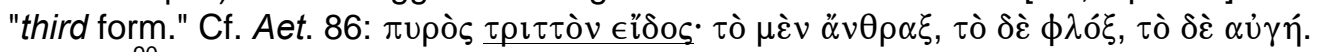

${ }^{90}$ On Plato's theory, see Tim. 69 C - 71 D (cf. Runia, Philo and the Timaeus, 301-14). 


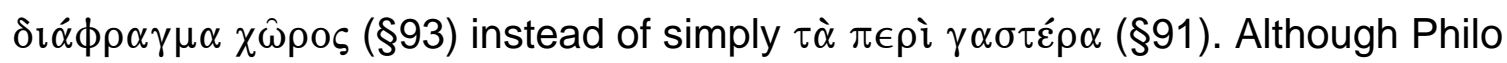
retains from $\S 91$ an interest in the connection between $\dot{\varepsilon} \pi \imath \theta u \mu i \alpha$ and "belly," his question has changed from how $\dot{\varepsilon} \pi \imath \theta u \mu i \alpha$ ( $\tau \grave{\varepsilon} \dot{\varepsilon} \pi \imath u \mu \eta \tau \imath \kappa o ́ v)$ tyrannizes the soul to how knowledgeable philosophers determined its location.

Philo's manner of juxtaposing $\S 91$ and $\S \S 92-94$ implies that philosophers connected the $\dot{\varepsilon} \pi \imath \theta u \mu \eta \tau \imath \kappa o ́ v$ with the the belly because so many people experience an overpowering, tyrannical desire for food and drink. He clearly notes in §§92-94 that these philosophers posited the connection "for this reason"

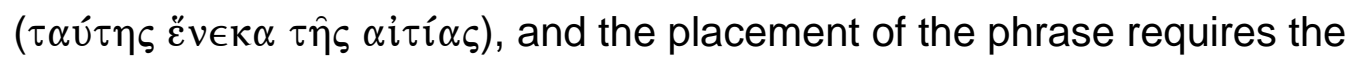
"reason" to be somewhere in §91, most likely in the gluttonous immorality Philo portrays in that paragraph. But when he actually spells out the reason in $\S 94$, he says nothing about gluttonous immorality, merely citing the logical necessity that (1) the faculty having "least to do with reason" reside farthest from reason and (2) the "most insatiable and licentious of beasts" $(\dot{\varepsilon} \pi \imath \theta u \mu i \alpha)$ inhabit the bodily regions associated with food and sex. But Philo does not simply abandon the logic of his transitional phrase in favor of an allusion to Plato's Timaeus ${ }^{91}$-he moves his train of thought in an entirely new direction. And, in fact, when viewed in the context of Philo's entire exposition, §§92-94 do not so much advance the argument as provide a transition within the exposition from the diagnosis section

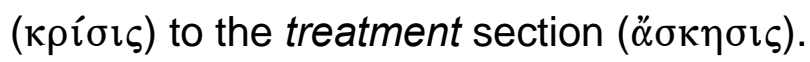

${ }^{91}$ Cf. Tim. 70 D - 71 A. 
Most importantly, §§92-94 function as a transition by introducing new material crucial to Philo's upcoming argument. Part one of his treatise, designed to expose the shameful character of tyrannical desire, essentially ends with $\S 91$, since §§92-94 both derive and digress from that paragraph and bear no direct connection to earlier material. But nothing in part one of his exposition, up to and including §91, gives Philo a theoretical basis for asserting the preeminence of desires for food and drink over against any other type of desire. In fact, the desire for food and drink appears as only part of his list, last among desires for money, reputation, etc.-all of which are equally capable of causing moral ruin after burgeoning into their respective versions of tyrannical desire. Yet in his explanation of the rationale underlying Moses' therapeutic program (§96), Philo will argue that management of "the desire having to do with the belly" ( $\tau \grave{\eta} \nu \pi \epsilon \rho \grave{\imath}$ $\gamma \alpha \sigma \tau \varepsilon \dot{\varepsilon} \rho \alpha \rho \alpha \gamma \mu \alpha \tau \epsilon \cup o \mu \varepsilon \dot{\varepsilon} \eta \eta v \dot{\varepsilon} \pi \imath \theta u \mu i \alpha \nu)$ serves as the paradigmatic model for managing all corruptible desires, since that one desire is fundamental, being the

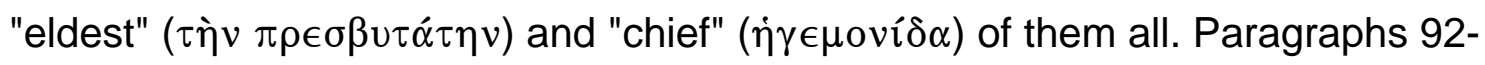
94 give Philo the theoretical justification for such a claim, because they endorse a Platonic view of the soul, which grants preeminence to desires for food and drink while still tracing all corruptible desires to one part of the soul.

In addition, §§92-94 effect a smooth transition from part one (esp. §91) to part two (esp. §§95-97) by considering $\dot{\varepsilon} \pi \imath \theta u \mu i \alpha$ in a new light without disrupting a basic continuity of content involving the nexus of desire, food and drink, and 
the belly. Before $\S \S 92-94$, Philo considers $\dot{\varepsilon} \pi \imath \theta u \mu i ́ \alpha$ in a decidedly negative light, limiting his concern almost exclusively to the disastrous tyranny of $\tilde{\varepsilon} \rho \omega \varsigma$, which represents the terminal stage of $\dot{\varepsilon} \pi \imath \theta \mu i \alpha$ overstepping the bounds of reason. But the treatment section of Philo's exposition concerns itself with how to prevent $\dot{\varepsilon} \pi \imath \theta v \mu i \alpha$ from overstepping the bounds of reason. In other words, the topic of part two is not tyrannical desire, but useful desire-the kind a moral agent may rightly condone and exercise without compromising virtue, provided reason stays in control. By commenting in $\S \S 92-94$ on the location of $\dot{\varepsilon} \pi \imath v u \mu i \alpha$ within Platonic tripartition, Philo shifts the emphasis from desire as raging tyrant to desire as a natural component of the soul, without entirely losing sight of its dangerous

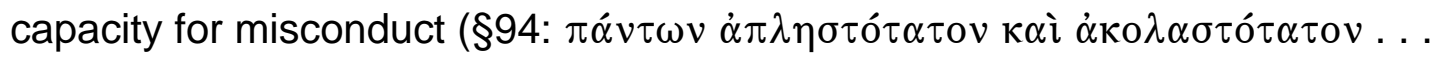
$\theta \rho \epsilon \mu \mu \alpha \dot{\tau} \tau \nu)$. He can then begin in $\S \S 95-97$ his consideration of how best to manage $\dot{\varepsilon} \pi \imath \theta u \mu i \alpha$, particularly the $\dot{\varepsilon} \pi \imath \theta u \mu i \alpha$ for food and drink, which—though prone to excess_-forms a natural part of every human life.

\section{$\S \S 95$ - 97: Overview of Moses' "Paradigmatic Instruction"}

[§95] Now, the most holy Moses, in my view, took all of this into account when he designed a special set of laws for managing desire. ${ }^{92}$ His goal was to eliminate passionate desire, ${ }^{93}$ having come to detest it as both a horrible disgrace in itself and-as I just explained—the ultimate cause of disgraceful behavior, a sort of siege-engine within us, bent on overtaking

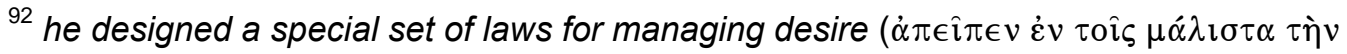
$\dot{\varepsilon} \pi \imath \theta u \mu i \alpha v)$ : Unlike the Tenth Commandment itself, which categorically prohibits passionate desire, Moses' prohibition ( $\dot{\alpha} \pi \epsilon \hat{\imath} \pi \epsilon v)$ operates through the cumulative effect of a whole set of dietary laws promoting virtuous management of the emotion desire.

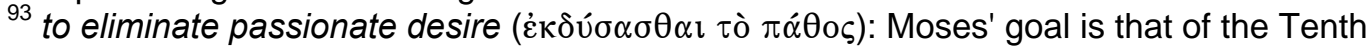

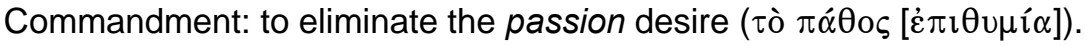


and corrupting the soul. ${ }^{94} \mathrm{He}$ understood that a life free of passionate desire, in which desire obeys the commanding authority of reason, ${ }^{95}$ would be filled with peace, order, and genuine prosperity, resulting in perfect happiness. [§96] And since Moses cherishes brevity and tends to address innumerable cases with just one paradigmatic instruction, he builds a comprehensive therapeutic program on the chastisement and training of just one desire, desire involving the belly. ${ }^{96} \mathrm{He}$ reasons that once the most primal and commanding desire has learned to submit to the laws of selfmastery, all other desires will likewise become obedient to the rein and accept the authority of reason. [\$97] So what sort of instruction lies at the heart of Moses' therapeutic program? Obviously, its two fundamental concerns are food and drink, and Moses left neither of these unregulated. Instead, he curtailed their use by means of dietary laws whose observance leads to self-control, not to mention philanthropy and-most important of all-piety.

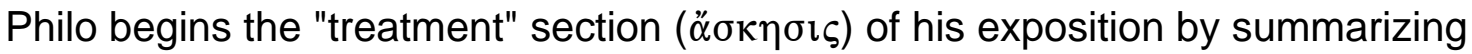

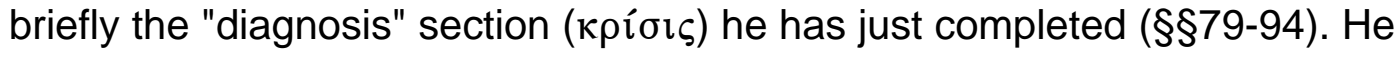

${ }^{94}$ a sort of siege-engine within us, bent on overtaking and corrupting the soul (ڤ̆ৎ $\tau \imath v \alpha$ $\tau \hat{\eta} \varsigma \psi \cup \chi \hat{\eta} \varsigma \dot{\varepsilon} \lambda \dot{\varepsilon} \pi \mathrm{o} \lambda \mathrm{\imath v}$ ): A $\dot{\varepsilon} \lambda \dot{\varepsilon} \pi \mathrm{o} \partial \mathrm{l} \varsigma$ was a machine of war, designed for hostile assault of an enemy fortification. By using this term, Philo suggests that $\dot{\varepsilon} \pi \imath \theta \mu i \alpha$ seeks to overthrow reason. By "storming the citadel" and taking over the soul, $\dot{\varepsilon} \pi \imath \theta u \mu i \alpha$-turned-ž $\rho \omega \varsigma$ becomes the cause of

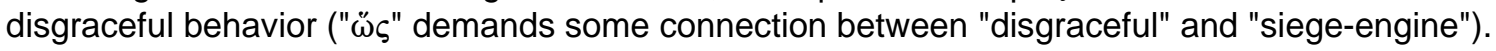
The independent, hostile agency of $\dot{\varepsilon} \pi \imath \theta u \mu i \alpha$ conveyed by the metaphor illustrates Philo's fundamentally Platonic perspective. See Pelletier, "Passions à l'assaut de l'âme," esp. 57-58. Cf. Abraham Malherbe, "Antisthenes and Odysseus, and Paul at War," HTR 76 (1983): 143-73, esp. 145-47.

${ }^{95}$ a life free of passionate desire, in which desire obeys the commanding authority of

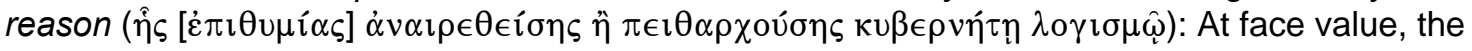
Greek suggests two ways of managing $\dot{\varepsilon} \pi \imath \theta u \mu i \alpha$ to achieve peace and happiness: abolish

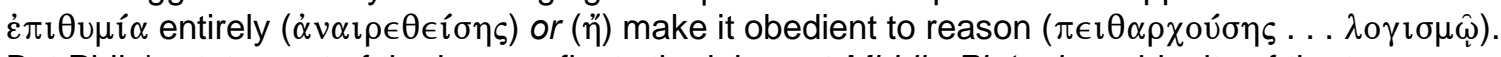
But Philo's statement of the issue reflects the inherent Middle-Platonic ambiguity of the term $\dot{\varepsilon} \pi \imath \theta u \mu i^{\alpha}$, which refers either to the passion desire or the emotion desire. He clearly calls for the

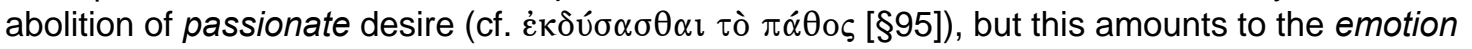
desire obeying reason. In other words, the $\eta$ indicates not an alternative solution to the problem of desire but an alternative formulation of a single solution: the elimination of passionate desireid est, the obedience of desire to reason.

${ }^{96}$ he builds a comprehensive therapeutic program on the chastisement and training of

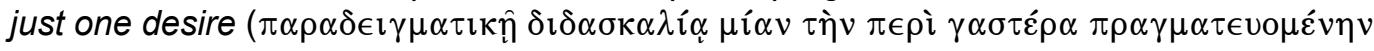

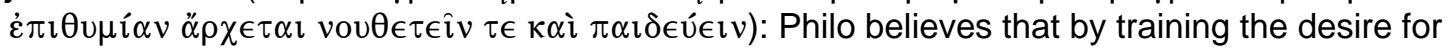
food and drink Moses expected to train all desire(s). So the training of this one desire stands as the foundation ( $\not \rho \rho \in \tau \alpha \imath)$ for what amounts to a "comprehensive therapeutic program," insofar as all desires are in view. 
attributes to "the most holy Moses" (o i $\epsilon \rho \omega \tau \alpha \tau \circ \zeta \mathrm{M} \omega v \sigma \hat{\eta} \varsigma)$ an understanding of everything $(\pi \dot{\alpha} \nu \tau \alpha)$ he has just explained about the nature, function, and problematic malfunction of $\dot{\varepsilon} \pi \imath \theta u \mu i \alpha$. This philosophical insight created in Moses a determination that Philo expects the reader to share at this point in the

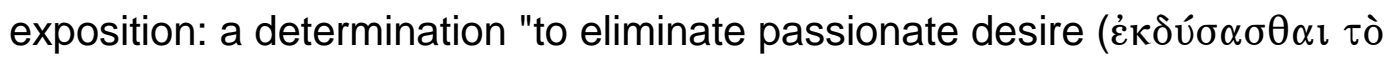
$\pi \dot{\alpha} \theta$ os), having come to detest it ( $\mu \nu \sigma \alpha \xi \dot{\alpha} \mu \epsilon \nu \circ \varsigma)$ as both a horrible disgrace in

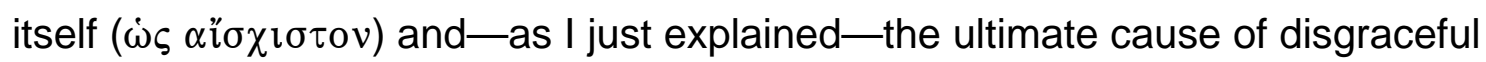
behavior ( $\tau \hat{\omega} v \alpha i \sigma \chi i ́ \sigma \tau \omega v \alpha i \iota \tau o v) .{ }^{97}$ Passionate desire, in other words, proves not only reprehensible in itself-it also generates reprehensible behavior whenever it overtakes and tyrannizes the soul. For this reason, Moses sought to eliminate the passion desire by training the emotion to obey the commanding

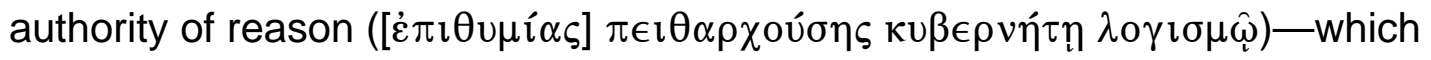

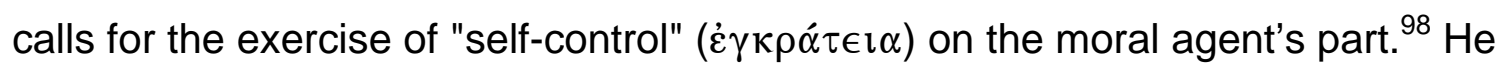
addressed this critical need for self-control through his legislation, as Philo explains in §§96-97.

${ }^{97}$ Cf. Garr. 510 C-D: "[W]e get well by the diagnosis and treatment of our ailments ( $\tau \hat{\omega} \nu$

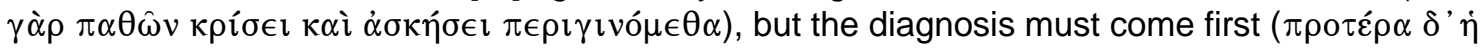

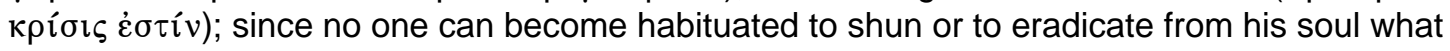

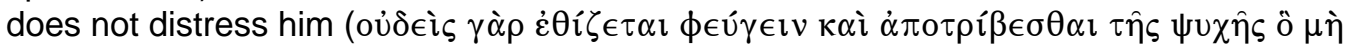
$\delta v \sigma \chi \epsilon \rho \alpha i v \in \imath$ ), and we only grow distressed with our ailments ( $\delta v \sigma \chi \epsilon \rho \alpha i v o \mu \epsilon \nu \delta \grave{\varepsilon} \tau \grave{\alpha} \pi \dot{\alpha} \theta \eta$ ) when we have perceived, by the exercise of reason, the injuries and shame which result from them

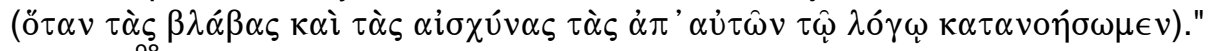

${ }^{98}$ The term $\kappa \nu \beta \epsilon \rho v \eta \dot{\tau \eta} \varsigma$ invokes Philo's premier model of $\dot{\varepsilon} \gamma \kappa \rho \dot{\alpha} \tau \epsilon \iota \alpha$, the chariot figure

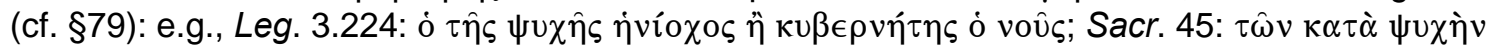

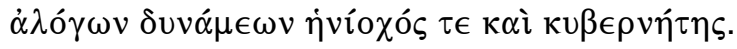


According to §96, Moses ingeniously crafted one "paradigmatic

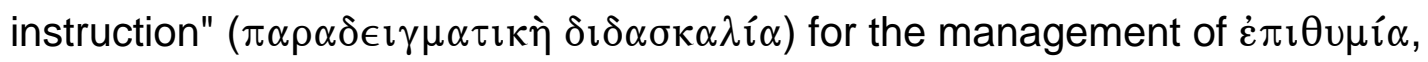
which—though ostensibly geared only to the desire for food and drink—applies in fact to every type of desire. ${ }^{99}$ Of course, this "instruction" appears nowhere in the Pentateuch as a distinct, coherent, continuous discourse. Instead, Philo must gather the scattered elements of Moses' instruction and cobble them together into a meaningful unit. He believes that as a set the various precepts governing food and drink reveal, upon careful examination, an ulterior motive on Moses' part: to inculcate self-control relative to gastric desire, which extends in turn to all desire. And because the dietary laws promote the management of $\dot{\varepsilon} \pi \imath \theta u \mu i \alpha$, Philo identifies them as the specific laws falling under the generic heading oủ $\dot{\varepsilon} \pi \imath \theta u \mu \eta \dot{\sigma} \sigma \iota \iota$.

To explain a single therapeutic program whose benefits extend throughout the whole range of desires, Philo relies on the principle of transference, which gives him a much-needed warrant for reconciling parts one and two of his exposition. ${ }^{100}$ Without it, he is left "diagnosing" in part one a problem involving many desires (for money, reputation, etc.), while "treating" in part two only one desire (for food and drink). By casting the Mosaic dietary laws as a paradigmatic instruction, Philo effectively accounts for all of the desires mentioned in part one,

${ }^{99}$ Cf. Philo's notion of circumcision as a sort of "paradigmatic instruction" in Spec. 1.9:

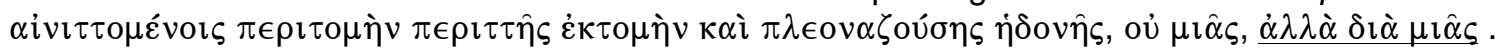
. . $\alpha \dot{\imath} \tau \hat{\omega} \nu \ddot{\alpha} \lambda \lambda \omega \nu \dot{\alpha} \pi \alpha \sigma \hat{\omega} v$; also QG 3.48.

${ }^{100}$ On the principle of transference, see above, 135-37. 
since their successful management follows from the successful management of gastric desire. This approach not only solves a practical problem for Philo—it also makes good sense in light of Middle-Platonic theoretical principles. First, the idea that gastric desire predominates—being, as Philo puts it, $\tau \grave{\eta} \nu \pi \rho \epsilon \sigma \beta v \tau \alpha ́ \tau \eta \nu$ $\kappa \alpha \grave{~} \dot{\omega} \varsigma \dot{\eta} \gamma \in \mu o v i ́ \delta \alpha$-comes from Plato himself, who highlights desires for food and drink in his characterizations of $\dot{\varepsilon} \pi \imath \theta u \mu i \alpha .{ }^{101}$ Second, Philo believes that

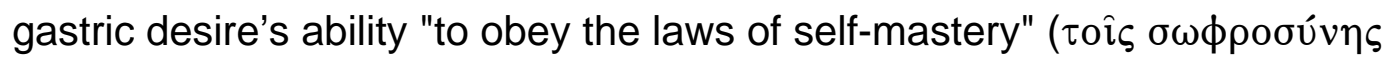

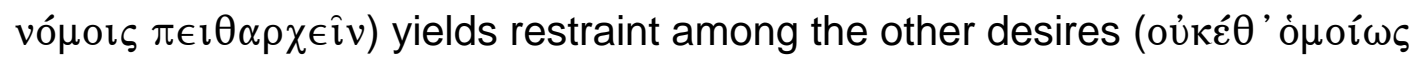
$\dot{\alpha} \phi \eta \nu \imath \dot{\alpha} \sigma \in \imath \nu \ldots \sigma \tau \alpha \lambda \eta \dot{\eta} \sigma \in \sigma \theta \alpha \imath)$, reasoning that because desires for food and drink are most powerful, their compliance necessarily engenders compliance among other desires stemming from the $\dot{\varepsilon} \pi \imath \theta u \mu \eta \tau \imath \kappa o ́ v$, which are by definition less powerful. ${ }^{102}$ Plutarch envisions a similar transference of the moral agent's capacity to manage desire—but in his method of training, restraint develops first in less difficult situations then applies stepwise to progressively more difficult situations. ${ }^{103}$ Moses' method exhibits greater efficiency by reversing the

${ }^{101}$ E.g., Resp. 437 D.

102 Philo's language of restraint in this passage-esp. his use of $\dot{\alpha} \phi \eta \nu \imath \dot{\alpha} \sigma \in \imath v$ and $\sigma \tau \alpha \lambda \eta \dot{\eta} \sigma \epsilon \theta \alpha \imath$ ( $\sigma \tau \varepsilon \dot{\lambda} \lambda \lambda \omega)$-reflects his Middle-Platonic view of passion. For example, within the model of $\dot{\varepsilon} \gamma \kappa \rho \alpha \dot{\alpha} \tau \epsilon \iota \alpha$ posed by Philo's chariot figure, the term $\dot{\alpha} \phi \eta \nu \imath \dot{\alpha} \zeta \omega$ (cf. $\dot{\alpha} \phi \eta \nu \imath \alpha \sigma \mu o ́ \varsigma)$ denotes "excess"-namely, the excess movement responsible for transforming an emotion into a passion (see above, 111-18). By claiming that all other types of $\dot{\varepsilon} \pi \imath \theta v \mu i \alpha$ will no longer $\alpha \dot{\alpha} \phi \nu \imath \alpha \dot{\alpha} \sigma \in \imath$ upon successful implementation of Moses' therapeutic dietary program, Philo means that they will become moderate in the Middle-Platonic sense of measured or without excesss. In other words, they will become restrained $(\sigma \tau \alpha \lambda \eta \tilde{\sigma} \epsilon \sigma \theta \alpha \imath)$ in the very sense he suggests elsewhere in his

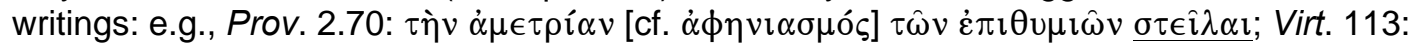

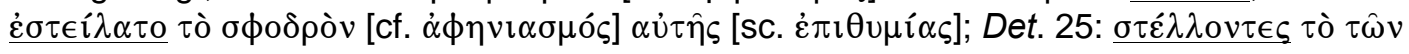
$\dot{\varepsilon} \pi \imath \theta u \mu \imath \hat{\omega} v \mu \varepsilon \dot{\gamma} \in \theta o \varsigma$ [cf. $\dot{\alpha} \phi \eta \nu \imath \alpha \sigma \mu o ́ s]$ ]

${ }^{103}$ See Ingenkamp, Schriften, 105, esp. the first on his list of three $\dot{\varepsilon} \theta \imath \sigma \mu о i ́$. 
progression, training the most difficult desire first and so removing the need to address less demanding calls for self-control from less difficult desires.

In §97, Philo summarizes the method of Moses' paradigmatic instruction. Clearly, the instruction must deal with food and drink, since they are the objects of gastric desire. As Philo explains, Moses restricted their use ( $\dot{\varepsilon} \pi \epsilon \tau \tau o ́ \mu \iota \sigma \epsilon)$ with specific ordinances whose observance leads to self-control ( $\delta \imath \alpha \tau \dot{\gamma} \gamma \mu \alpha \sigma \imath \ldots$ $\pi \rho \grave{\varsigma} \dot{\varepsilon} \gamma \kappa \rho \dot{\alpha} \tau \epsilon \iota \alpha \nu \ldots \dot{\alpha} \gamma \omega \gamma o \tau \dot{\alpha} \tau o \imath \varsigma) .{ }^{104}$ In other words, Moses designed the dietary laws as ascetic precepts to promote $\dot{\varepsilon} \gamma \kappa \rho \alpha \dot{\tau} \tau \iota \alpha$ among members of his commonwealth—first with respect to food and drink, but ultimately with respect to every object of desire. ${ }^{105}$ Viewed in terms of moral philosophy, Moses' method looks much like the recommendation of practical exercises aimed at eliminating a

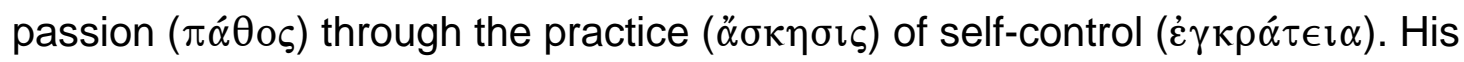
"ordinances" ( $\delta \iota \alpha \tau \alpha ́ \gamma \mu \alpha \tau \alpha)$ serve the same function as the $\dot{\varepsilon} \theta \imath \sigma \mu o i ́$ of Plutarch's Seelenheilungsschriften. In the case of De garrulitate, followers of Plutarch's philosophy will eliminate the passion of talkativeness $(\dot{\alpha} \delta \circ \lambda \epsilon \sigma \chi i \alpha)$ from their lives

${ }^{104}$ Philo's use of $\dot{\varepsilon} \pi \epsilon \sigma \tau o ́ \mu \imath \sigma \epsilon$ again suggests the chariot figure (see above, 111-18). Along with the inculcation of $\dot{\varepsilon} \gamma \kappa \rho \alpha \dot{\tau} \tau \in \mathfrak{l} \alpha$, Philo mentions also philanthropy and piety, but these do not figure prominently in his exposition until the end, where he revisits the notion of piety in $\S \S 128-131$. He mentions them here because he sees each of the Ten Commandments as promoting the more generic virtues, although each has its special purpose(s). On Philo's view of piety $(\epsilon \dot{v} \sigma \varepsilon \hat{\beta} \in \imath \alpha)$, see esp. Gregory E. Sterling, "'The Queen of the Virtues': Piety in Philo of Alexandria," SPhA 18 (2006): 103-23.

${ }^{105}$ Philo actually names $\dot{\varepsilon} \gamma \kappa \rho \dot{\alpha} \tau \epsilon \iota \alpha$ here, but note further indications of $\dot{\varepsilon} \gamma \kappa \rho \dot{\alpha} \tau \epsilon \iota \alpha$ in

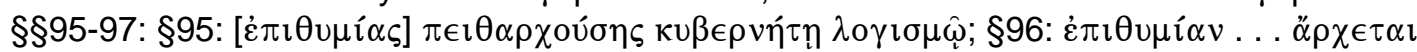

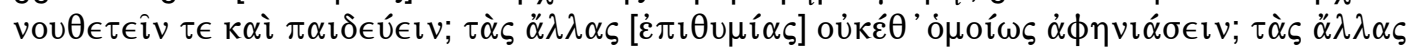

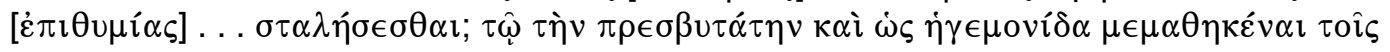

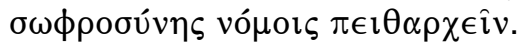


by developing $\dot{\varepsilon} \gamma \kappa \rho \alpha ́ \tau \epsilon \iota \alpha$ with respect to speaking, as they engage in behaviors enjoined by his $\dot{\varepsilon} \theta \imath \sigma \mu o i ́$. Similarly, followers of Moses' philosophy will eliminate the passion of gluttony ( $\gamma \alpha \sigma \tau \rho \iota \alpha \gamma i \alpha)$ from their lives by developing $\dot{\varepsilon} \gamma \kappa \rho \alpha \dot{\tau} \tau \imath \alpha$ with respect to eating and drinking, as they engage in behaviors enjoined by his $\dot{\varepsilon} \theta \imath \sigma \mu o i ́$, the dietary laws. But with Moses' ingenious program, as Philo presents it, the elimination of gluttony entails the elimination of all passions similarly characterized by excessive desire for a certain object (wealth, reputation, etc.). While Plutarch treats passions one at a time, Moses treats passions all at once.

$$
\S \S 98 \text { - 99: First Fruits }{ }^{106}
$$

[§98] For example, Moses commands the people to bring as first fruits some of their grain, wine, oil, livestock, and other goods. They are instructed to designate one portion of these first fruits for sacrifice and another portion for the priests - the former out of gratitude to God for bountiful produce and abundance of goods, the latter out of gratitude for the sacred temple-service, in order that the priests might receive a reward for their performance of holy duties. [§99] He completely forbids anyone to sample these goods or take hold of them until the first fruits are duly apportioned. This command functions as an exercise in the self-control that proves so beneficial to all of life. ${ }^{107}$ You see, Moses knew that by learning to restrain their eager rush to enjoy the season's harvest, by waiting for the consecration of the first fruits, the people were in fact training themselves to check the unruliness of their impulses, quieting any passionate desire within.

Philo begins his study of Moses' "paradigmatic instruction" with the law of First

Fruits, which of course involves food and drink: Philo lists "grain, wine, oil, and

\footnotetext{
${ }^{106}$ See Deut 18:4.

107 This command functions as an exercise in the self-control that proves so beneficial to

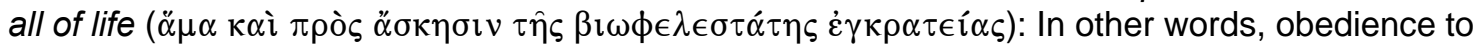

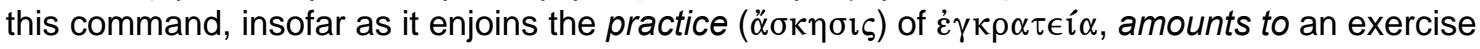
in self-control-i.e., an ascetic precept.
} 
livestock" as items falling under the commandment's purview. His reference here to "wine" (oîvos) stands alone in the treatment portion of the exposition, which cites no other laws mentioning wine or any other drink. ${ }^{108}$ So despite his earlier

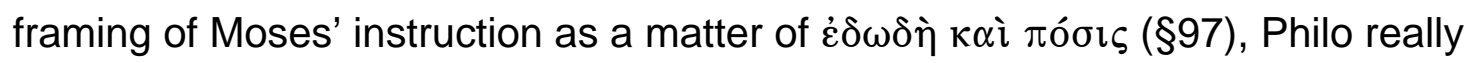
ends up discussing only food. He mentions both because he knows that $\dot{\varepsilon} \pi \imath \theta u \mu i \alpha$ of the belly theoretically involves both eating and drinking, a fact duly noted in the diagnostic portion of his exposition (\$91). But Philo does not see any significant role for laws governing drink(s) or drinking in Moses' instruction on desire.

Philo explicitly identifies the law of First Fruits as an exercise in self-

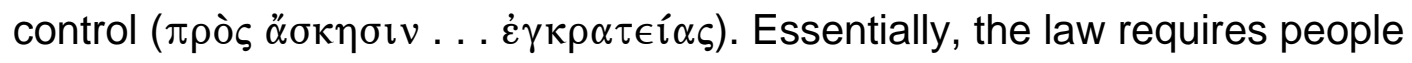
eager to consume fresh stores of food and drink to wait ( $\dot{\alpha} v \alpha \mu \varepsilon \dot{\varepsilon} v \omega v)$ until a ceremonial dedication has first taken place. In terms of moral psychology, this involves $\dot{\varepsilon} \pi \mathrm{l} \theta u \mu i \alpha$ activated by the pleasurable prospect of consuming a variety of goods but forcibly restrained for a time by reason. To indulge the initial impulse to eat and drink, ignoring the law, would be to act strictly on a motive for pleasure, which amounts to indulging an unmeasured, excessive impulse—or, in this case, indulging a passionate desire. By waiting until reason authorizes the indulgence of desire, the moral agent effectively removes the excessiveness of

${ }^{108}$ Cf. Colson 67, n. b: "This is the only way in which restraint in drinking is enjoined throughout these sections." But note liquor ( $\dot{\alpha} \kappa \rho \alpha ́ \tau o v)$ in $\$ 113$. 


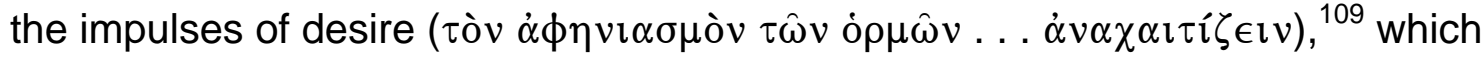

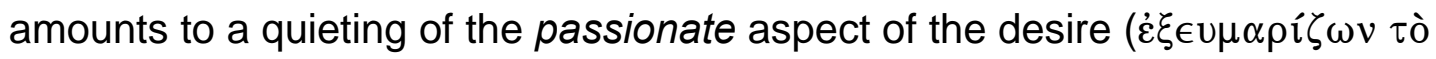
$\pi \dot{\alpha} \theta$ os). ${ }^{110}$ This exercise clearly employs a delay technique, which appears both elsewhere in Philo's writings and in Plutarch's De garrulitate. ${ }^{111}$ $\S \$ 100$ - 102: Introduction to Clean and Unclean Animals ${ }^{112}$ [§100] As for foods not otherwise regulated by the law of First Fruits, ${ }^{113}$ Moses did not in the least allow members of the sacred commonwealth simply to eat whatever they wanted without restriction. In fact, he strictly prohibited all of the richest, most succulent types of meat-meat that tickles and teases our treacherous foe pleasure-by prohibiting just the right animals from land, sea, and sky. He knew that these meats could bring about the insatiability of tyrannical desire, once they had ensnared the most slavish of the senses, taste. ${ }^{114}$ And insatiability represents a practically incurable problem not only for souls but also for bodies, since an insatiable desire for food naturally leads to overeating, which in turn leads to indigestion, a foundation and wellspring of diseases and infirmities. [\$101] Now, the most obvious prohibitions of pleasurable fare involve the pig, whose meat everyone acknowledges as the most delectable among land animals, and scaleless sea creatures. ${ }^{115}$ In these

${ }^{109}$ Cf. Spec. 2.18: $\tau o ̀ v ~ \dot{\alpha} \phi \eta v \imath \alpha \sigma \mu o ̀ v ~ \tau \hat{\omega} v \dot{\varepsilon} \pi \imath \theta u \mu \imath \hat{\omega} v \dot{\alpha} v \alpha \chi \alpha \iota \tau i ́ \sigma \alpha \imath$. With $\dot{\alpha} \phi \eta v \imath \alpha \sigma \mu o ́ v$ and $\dot{\alpha} v \alpha \chi \alpha \imath \tau i \zeta \in \imath v$, Philo again invokes the chariot figure (see above, 111-18).

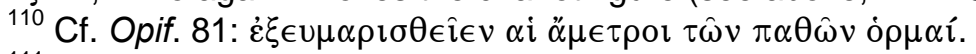

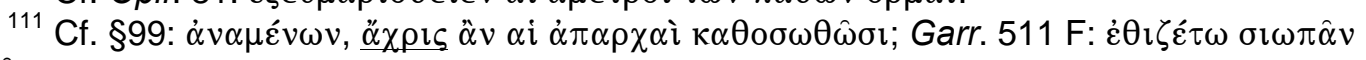

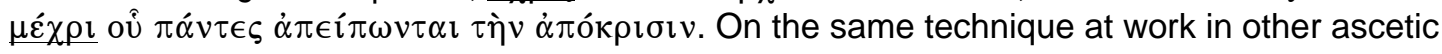
precepts, see above, 130-35.

112 See Lev 11; Deut 14:1-21

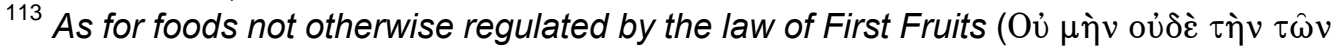
$\ddot{\alpha} \lambda \lambda \omega \nu \mu \in \tau o v \sigma i \alpha v)$ : Philo moves on to foods not under the purview of the First Fruits regulation (cf. Mosès 259, n.10: "Ceux qui ne sont pas assujettis à une offrande préalable").

${ }^{114} \mathrm{He}$ knew that these meats could bring about the insatiability of tyrannical desire, once they had ensnared the most slavish of the senses, taste ( $\epsilon \dot{i} \delta \grave{\omega} \varsigma$ ö $\tau \imath \tau \grave{\eta} v \dot{\alpha} v \delta \rho \alpha \pi 0 \delta \omega \delta \epsilon \sigma \tau \dot{\alpha} \tau \eta \nu \tau \hat{\omega} v$

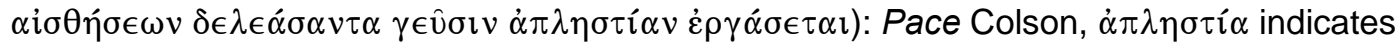
"insatiability," not "gluttony" (cf. Heinemann: "Unersättlichkeit"; Mosès: "l'insatiabilité"). And $\dot{\alpha} \pi \lambda \eta \sigma \tau i \alpha$ signals the presence of tyrannical desire ( $(" \rho \omega \varsigma)$ in the soul-in this case, $\varepsilon^{\prime} \rho \omega \varsigma$ as it relates to food.

${ }^{115}$ PCW posits a lacuna in the Greek text of $\S 101: \dot{\varepsilon} v v ́ \delta \rho \omega v \delta \grave{\varepsilon} \tau \grave{\alpha} \gamma \varepsilon \dot{\varepsilon} v \eta \tau \hat{\omega} v \dot{\alpha} \lambda \in \pi \hat{\imath} \delta \omega v$

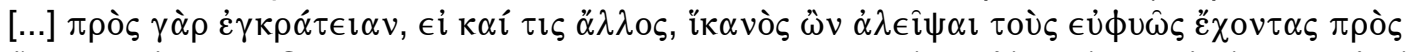

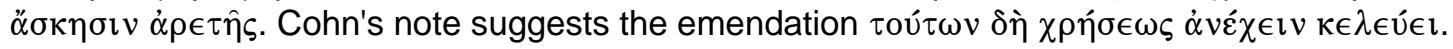
The text, however, makes sense as it stands. Philo mentions the prohibitions of pork and 
and other restrictions, self-control was Moses' ultimate concern, and heif anyone-had the philosophical expertise to train those with natural aptitude in the practice of virtue. He accomplishes this inculcation of selfcontrol by training and drilling people to be sparing and easily satisfied, targeting the removal of extravagance. [\$102] Determined to promote neither a life of austerity, like the Lacedaemonian lawgiver, nor of daintiness, like the man who introduced habits of feebleness and luxury to the Ionians and Sybarites-cutting instead a straight path right between the two-Moses relaxed what was too severe in one and tightened what was too lax in the other. As with a musical instrument, he sought to blend the excesses of either end of the scale into a moderate tone, promoting a life of harmony and blameless integrity. So he was not at all haphazard when he drew up his legislation on dietary matters. On the contrary, he took the utmost care in determining foods to be eaten and foods to be avoided.

Philo devotes by far the majority of his discussion of the content of Moses' "paradigmatic instruction" to the legislation governing various species of clean $(\kappa \alpha \theta \alpha \rho \dot{\alpha})$ and unclean $(\dot{\alpha} \kappa \dot{\alpha} \theta \alpha \rho \tau \alpha)$ animals $(\zeta \hat{\omega} \alpha) .{ }^{116}$ The designations "clean" and "unclean" of course refer to an animal's legal status as either a permitted or prohibited food source. ${ }^{117}$ So with this new topic Philo abides by his initial framing

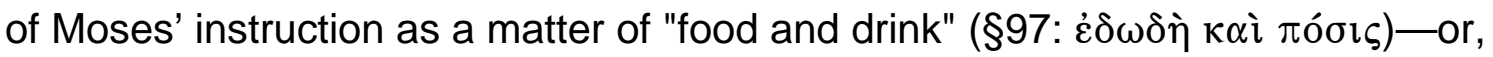
in this case, only food-but the issue now becomes whether or not the people may eat a certain meal, not how or when, as with the law of First Fruits. In any case, his exegetical task remains the same: to explain how these dietary laws

scaleless sea creatures, emphasizing the pleasure they afford, because they illustrate Moses' real purpose for the dietary laws: the promotion of $\dot{\varepsilon} \gamma \kappa \rho \alpha \dot{\tau} \tau \in \iota \alpha$.

${ }^{116}$ Compare Clean-Unclean Animals (§§100-118) to First Fruits (§§98-99), Dead Animals (§§119-121), and Blood and Fat (§§122-125). On Philo's discussion of clean-unclean animals in $\S \S 100-118$, see especially Rhodes, "Diet and Desire."

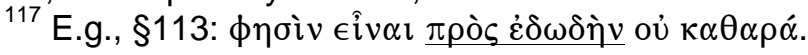


promote $\dot{\varepsilon} \gamma \kappa \rho \alpha \dot{\tau} \tau \epsilon \iota$ in service to the Tenth Commandment's prohibition of

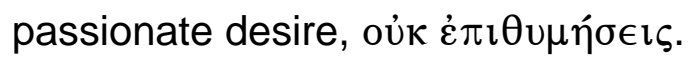

According to Philo, the legislation on clean and unclean animals reflects in general an unwillingness on Moses' part to permit the "unrestricted use" ( $\chi \rho \hat{\eta} \sigma \iota v$ $\dot{\alpha} \delta \in \hat{\alpha})$ of foods not otherwise regulated by the law of First Fruits. ${ }^{118}$ In particular, Moses selected for prohibition the "fattest" ( $\epsilon \dot{\sigma \sigma \alpha \rho \kappa o ́ \tau \alpha \tau \alpha) \text { and "richest" ( } \pi \text { ló } \tau \alpha \tau \alpha)}$ animals from land, sea, and sky, knowing that they yield the tastiest meats. He did this because he understood the dangerous capacity of delicious foods to "ensnare" ( $\delta \in \lambda \in \dot{\alpha} \sigma \alpha \nu \tau \alpha)$ the palate and, in so doing, cause people to eat strictly for the pleasure of eating. ${ }^{119}$ In terms of moral psychology, eating for pleasure represents a victory of $\dot{\varepsilon} \pi \imath \theta v \mu i \alpha$ over reason: in particular, a victory of $\dot{\varepsilon} \pi \imath \theta v \mu i \alpha$ as motivating disposition (whose aim is pleasure) over reason as motivating disposition (whose aim is rational benefit: survival, good health, etc.). The victory of $\dot{\varepsilon} \pi \imath \theta v \mu i \alpha$ produces in the soul an "insatiability" ( $\dot{\alpha} \pi \lambda \eta \sigma \tau i \alpha)$, which in turn causes overeating and leads to indigestion, a "foundation and wellspring" ( $\dot{\alpha} \rho \chi \eta$ $\tau \epsilon \kappa \alpha i ̀ ~ \pi \eta \gamma \eta \dot{)}$ of diseases and infirmities. Philo's incidental remark here on the danger of tasty meat echoes and corroborates his earlier, extended remarks in §79-91 on the danger, broadly speaking, of passionate desire. In either case, he envisions a torturous Tantalus fate of insatiable desire-the mark of tyrannical

${ }^{118}$ Cf. $\chi \rho \hat{\eta} \sigma \iota v \dot{\alpha} \delta \epsilon \hat{\alpha}$ in Prov. 2.70, where Philo also speaks of restricting desires for food

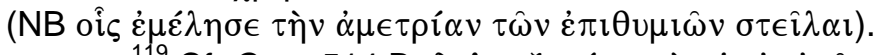

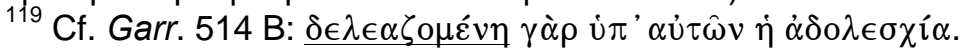


desire ( $\varepsilon \rho \omega \varsigma)$-looming as the eventual outcome of $\dot{\varepsilon} \pi \imath \theta u \mu i \alpha$ gaining the upper hand over reason. And just as he earlier associated the terminal grade of desire with a condition of soul generating further moral decline (§§86-91), Philo here associates the terminal grade of eating for pleasure with a condition of body generating further physical decline. ${ }^{120}$ These parallels suggest an attempt on Philo's part to coordinate the "diagnosis" and "treatment" portions of his exposition by using similar terms to frame both problem and solution. Here, the solution Moses offers amounts to a simple principle: avoiding especially pleasurable meats eliminates the risk of indulging passionate desire, which in turn eliminates the even greater risk of suffering tyrannical desire. ${ }^{121}$ But understood in this way, Moses' prohibitions only steer the moral agent away from a specific —and thus limited—set of dietary incitements to passionate desire, without addressing the broader concern of cultivating $\dot{\varepsilon} \gamma \kappa \rho \dot{\alpha} \tau \in \iota \alpha$ in observance of the general prohibition oủк $\dot{\varepsilon} \pi \imath \theta u \mu \eta ́ \sigma \in \iota \varsigma$. In §§101-102, Philo traces a broader connection between avoiding tasty meats and a lifestyle of $\dot{\varepsilon} \gamma \kappa \rho \alpha ́ \tau \epsilon \iota \alpha$.

He begins by citing two examples, presumably his best, of prohibited animals commonly acknowledged "by those who partake" ( $\pi \alpha \rho \grave{\alpha} \tau o i ̂ \varsigma \chi \rho \omega \mu \varepsilon ́ v o r \varsigma)$

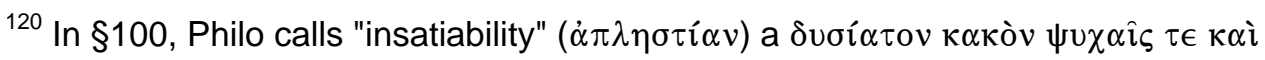
$\sigma \omega \mu \alpha \sigma \iota v$. Philo described its harm to souls at length in the diagnosis portion of his exposition, using images like the frustrated pursuit and Tantalus (§£80-81). He describes its harm to bodies in $\S 100$, where he links it to indigestion.

${ }^{121}$ Philo earlier described those enslaved to a tyrannical desire for food and drink in $\S 91$. 


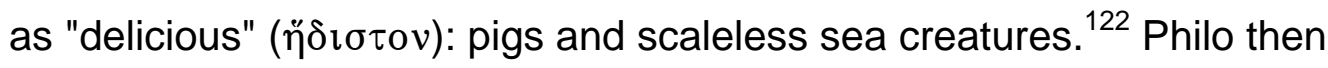
immediately deploys the agon motif in order to cast these prohibitions as exercises designed by Moses to train moral athletes in the practice of $\dot{\varepsilon} \gamma \kappa \rho \alpha \dot{\tau} \epsilon \iota \alpha .{ }^{123}$ But how exactly does Moses' training program work? Since Moses prescribed these exercises in an effort to remove extravagance ( $\dot{\alpha} \phi \in \lambda \in \hat{\imath} v$ $\pi \circ \lambda \cup \tau \varepsilon \dot{\varepsilon} \epsilon \in \alpha \nu$ ), he evidently considered anything done for pleasure's sake to be an extravagance by definition. No one, in other words, ever needs to eat something delicious—one only needs to eat. By prohibiting delicacies, Moses in effect trained the people to eat according to their need —not their pleasure-

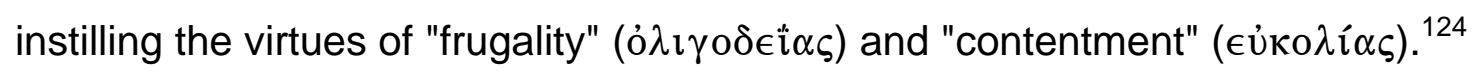
And the consistent practice of living according to need amounts to the consistent practice of $\dot{\varepsilon} \gamma \kappa \rho \alpha \dot{\tau} \tau \epsilon \alpha$, since it represents, in terms of moral psychology, the consistent dominance of reason (as motivating disposition seeking the rational

${ }^{122}$ Philo's reference to creatures of both land (pigs) and sea (scaleless creatures) proves that he still speaks in general, introductory terms at this point (cf. §100: $\chi \epsilon \rho \sigma \alpha i \omega v \hat{\eta} \dot{\varepsilon} v u ́ \delta \rho \omega \nu \grave{\eta}$ $\pi \tau \eta \nu \hat{\omega} v)$. His failure to give an example of an especially tasty bird may stem from his not having one to give. Cf. Heinemann PCH 2, 276, n. 2: "Auf die Vögel wird hier nicht eingegangen, da bekanntlich, was Philo $\$ 100$ allerdings ausser acht lässt, sehr wohlschmeckende Vögel zum genusse erlaubt sind." His discussion of each distinct domain of creatures begins in earnest with land animals in $\$ 103$.

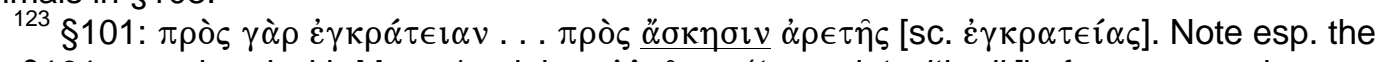
terms in $\S 101$ associated with Moses' training: $\dot{\alpha} \lambda \in \hat{\imath} \psi \alpha \mathrm{l}$ (to anoint with oil [before gymnastic

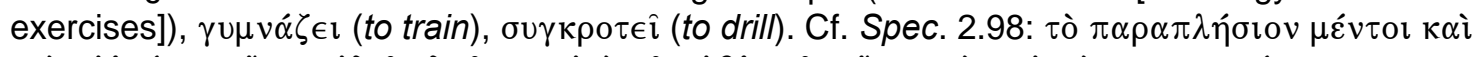

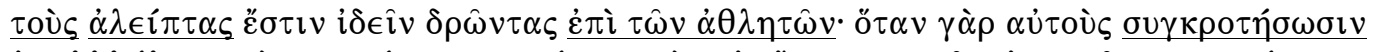

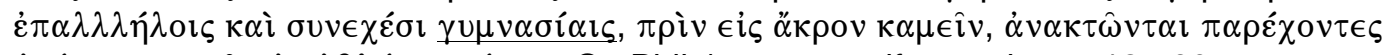

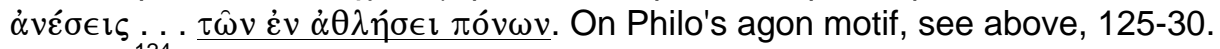

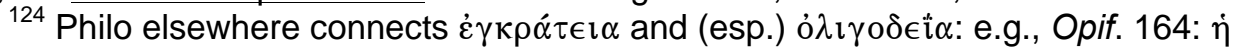

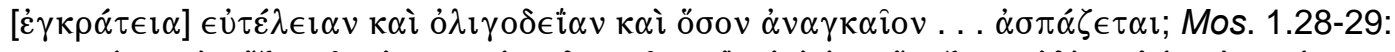

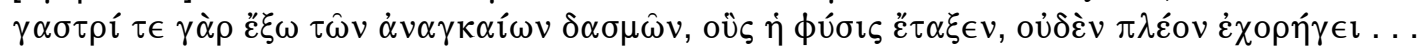

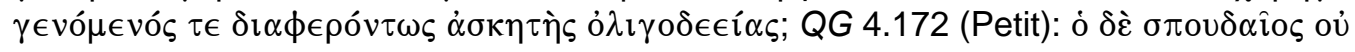


benefit of sustenance) over desire (as motivating disposition seeking the pleasure of delicious food). In other words, $\dot{\varepsilon} \pi \imath \theta v \mu i \alpha$ trained to accept the measure set by reason never becomes passionate. At the same time, since the challenge of limiting indulgence to reasonable need accompanies any expression of $\dot{\varepsilon} \pi \imath \theta u \mu i \alpha$ (for food, wealth, etc.), the habits of $\dot{\varepsilon} \gamma \kappa \rho \alpha \dot{\tau} \tau \in \imath \alpha$ Moses cultivates by prohibiting voluptuous foods apply more broadly to any situation requiring the moral agent to abstain from extravagant (i.e., unnecessary) pleasures.

According to Philo, the lifestyle of $\dot{\varepsilon} \gamma \kappa \rho \alpha \dot{\tau} \epsilon \iota \alpha$ Moses promotes through his legislation on clean and unclean animals strikes a perfect balance between two extreme positions. On the one hand, Moses avoids the overly austere approach

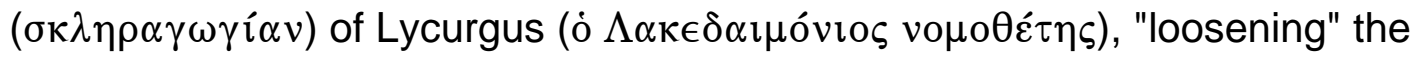

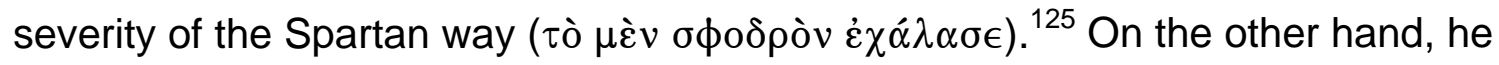

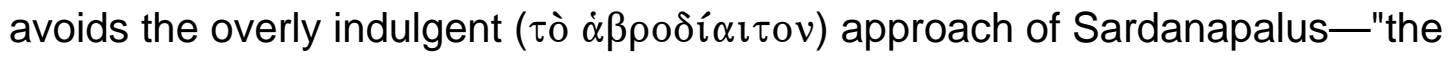
man who introduced habits of feebleness and luxury to the lonians and

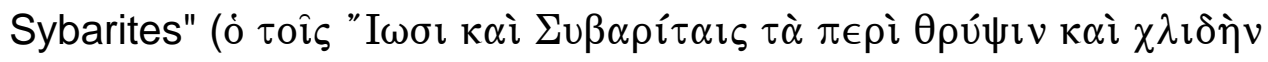
$\epsilon \mathfrak{i} \sigma \eta \gamma \eta \sigma \dot{\alpha} \mu \in \nu \circ \varsigma$ ) - "tightening" the laxity of his dissolute way of life ( $\tau \grave{o}$

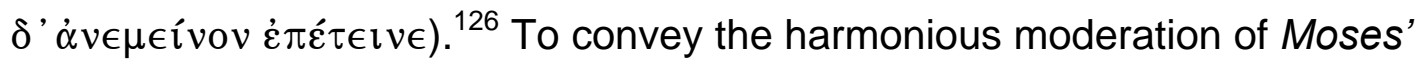

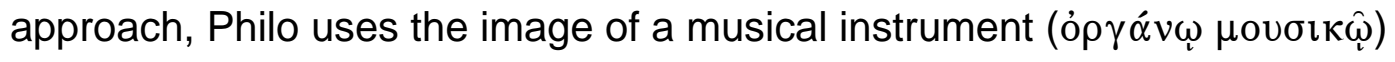

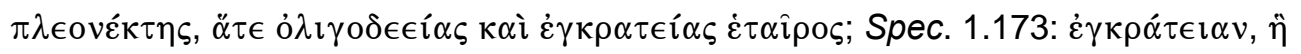

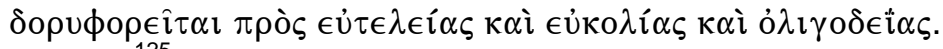

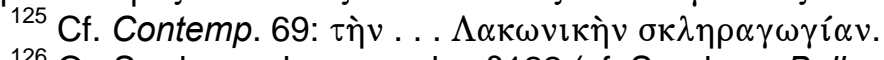

${ }^{126}$ On Sardanapalus, see also $§ 122$ (cf. Sandnes, Belly and Body, 65-68; Abraham Malherbe, "The Beasts of Ephesus," JBL 87 (1968): 71-80, esp. 76-77). The tomb of 


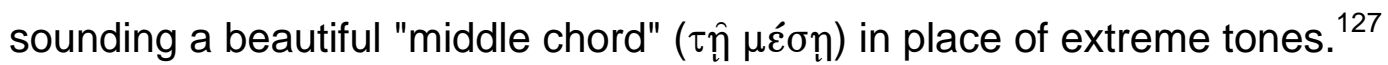
Despite the obvious rhetorical function of these appeals, Philo has in mind genuine ethical concerns. Moral agents of the Sardanapalus type, for example, would eat the delicious foods Moses prohibited, indulging in pleasure for pleasure's sake because desire rules their souls without the restraint or "measure" of reason. Moral agents of either the Lycurgus or Moses type would of course avoid overly pleasurable foods, but Philo gives no clear indication of what would otherwise distinguish their respective dietary habits. Presumably, Philo envisions the Spartan approach as determined avoidance of any pleasure: food serves only to sustain life, and pleasure-because it contributes nothing to that purpose—-has no place in the Spartan diet. ${ }^{128}$ Philo seems to envision Moses' approach as less severe, but similarly geared toward eating for sustenance over pleasure. While strictly opposed to eating for pleasure's sake, Moses nevertheless allows for the incidental pleasures accompanying a healthful diet. After all, he prohibits only the most delectable meats, generously allowing the people to enjoy a variety of other meats as they choose.

Sardanapalus supposedly read: "̌̋ $\sigma \mathrm{\imath} \epsilon, \pi \hat{\imath} v \epsilon, \pi \alpha \hat{\imath} \zeta \epsilon$ (see Sandness, Belly and Body, 66; Malherbe, "Beasts of Ephesus," 76). On the Sybarites, see also Spec. 3.43.

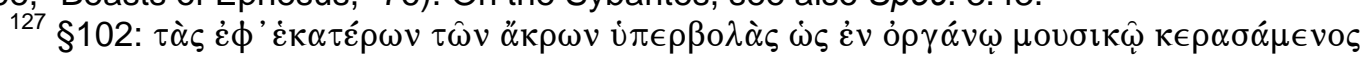

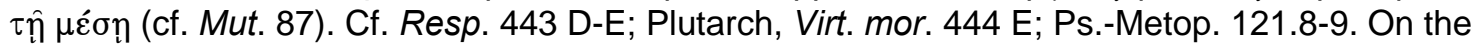
relevant music theory, see Martin L. West, Ancient Greek Music (Oxford: Oxford University Press, 1994), 219-23. More generally, see also Louis Feldman, "Philo's Views on Music," JJML 9 (1986): 36-54.

${ }^{128}$ Some Spartan dishes notoriously offered no pleasure to the palate, esp. "black broth" ( $\mu \varepsilon ́ \lambda \alpha \varsigma \zeta \omega \mu o ́ \varsigma)$, a pork stew (e.g., see Plutarch Lyc. 12.6-7). 
Plutarch offers similar praise of balanced moderation in De garrulitate, though he has in mind $\dot{\varepsilon} \pi \imath \theta v \mu i \alpha$ affecting the tongue, not the stomach. ${ }^{129}$ Just as Philo acknowledges three basic approaches to eating, Plutarch acknowledges three basic approaches to answering questions: "the barely necessary" ( $\tau \grave{o}$

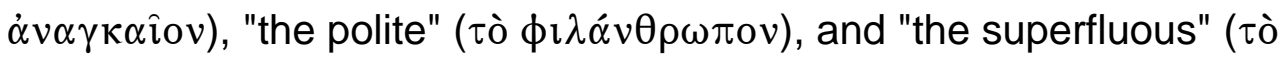
$\pi \in \rho \imath \sigma \sigma o ́ v) .{ }^{130}$ And, like Philo, Plutarch associates the "barely necessary" with Spartan austerity:

For example, if someone asks, "Is Socrates at home?" one person may

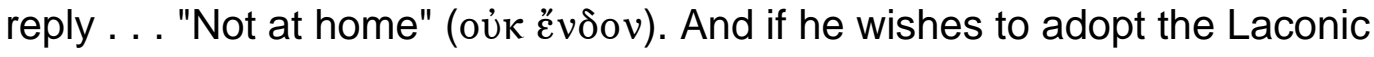
style ( $\lambda \alpha \kappa \omega v i \zeta \in \imath v)$, he may omit the "At home" ("̋voov) and only utter the

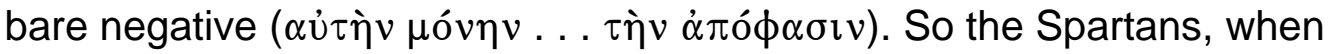
Philip wrote to ask if they would receive him into their city, wrote a large "No" on the paper and sent it back. (Garr. $513 \mathrm{~A}$ )

Plutarch disapproves of the Spartan refusal to speak beyond what absolute necessity requires, just as Moses disapproves of the austere Spartan diet's emphasis on necessity at the expense of pleasure. But Plutarch disapproves also of excessive indulgence in speech, which involves a failure of "the indulgent and

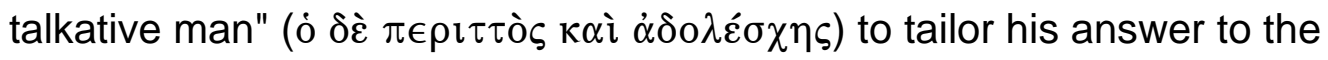

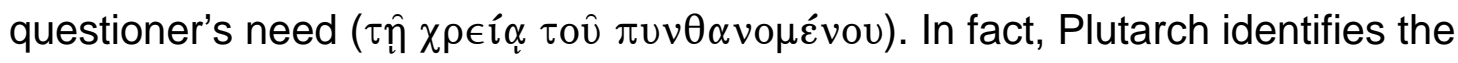
questioner's "need" ( $\chi \rho \in i \alpha)$ as the "measure" ( $\mu \varepsilon \dot{\tau} \rho \circ \nu)$ of a proper response (Garr. 513 C). Here Plutarch deploys the same Middle-Platonic concept of $\dot{\varepsilon} \pi \imath \theta u$ í $\alpha$ attested in Philo's writings, understanding "passionate" desire as

\footnotetext{
129 Garr. 513 A-C.

130 Garr. 513 A.
} 
immoderate desire ( $\ddot{\alpha} \mu \epsilon \tau \rho \varsigma \varsigma \dot{\varepsilon} \pi \imath \theta u \mu i \alpha)$. In Plutarch's example, a desire to speak becomes passionate when it oversteps the reasonable measure ( $\mu \varepsilon \dot{\tau} \rho \circ \nu$ ) of politely providing needed information and motivates the moral agent to indulge in speaking for the sake of speaking, in particular for the pleasure derived from

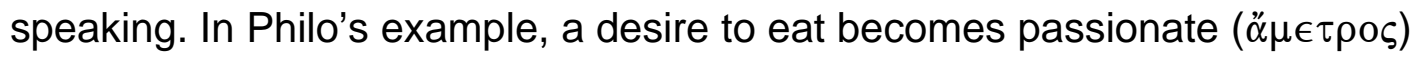
when it oversteps the reasonable measure ( $\mu \varepsilon \dot{\tau} \tau \rho \nu$ ) of amply providing needed sustenance and motivates the moral agent to indulge in eating for the sake of eating, in particular for the pleasure derived from eating.

Taken as a unit, $\S \S 100-102$ undoubtedly serve as a thesis governing all of Philo's comments on Moses' legislation concerning clean and unclean animals. Not only do §§100-102 form a discrete text-unit preface to the detailed analyses of specific laws, but they also speak in the broad, synoptic terms characteristic of an overarching claim. Philo asserts, in sum, that Moses recognized throughout the animal kingdom (land, sea, and sky) the dangerous incitement to $\dot{\varepsilon} \pi \imath \theta u \mu i \alpha$ posed by delicious meats, and he obviated the risk by declaring those animals "unclean." By removing the incitement, he sought to lessen the incidence of passionate desire, which so easily burgeons into tyrannical desire. Although Philo explains how such prohibitions promote also a lifestyle of $\dot{\varepsilon} \gamma \kappa \rho \alpha ́ \tau \epsilon \iota \alpha$ (§§101-102)—-thereby subsuming all of §§100-118 under his earlier, express purpose of showing how all dietary laws promote $\dot{\varepsilon} \gamma \kappa \rho \dot{\alpha} \tau \in \imath \alpha(\S \S 95-97)$ —his thesis regarding the legislation on clean and unclean animals specifically asserts 
Moses' intention to eliminate passionate desire by prohibiting delicious meats. He makes this claim prospectively in $\S \S 100-102$, but also retrospectively in $\S 118$, where he recapitulates it, creating an unmistakable interpretive frame for §§103117. ${ }^{131}$ So Philo ostensibly draws just one fundamental conclusion from his investigation of clean and unclean animals-a conclusion he prompts the reader to accept by placing it prominently at both the beginning and end of his work. Composing §§100-118 in this way, Philo inadvertently offers a criterion for assessing his work, since each consideration of a certain animal or type of animal either does or does not support the overarching thesis. If it does, then Philo reveals consistency in his analysis of the clean and unclean animals. If it does not, then Philo reveals an inconsistency, which calls for some sort of explanation. And a consideration of the inconsistencies in Philo's work helps to illustrate his underlying expository agenda.

$$
\S \S 103 \text { - 109: Land Animals }{ }^{132}
$$

[\$103] Take the case of man-eating beasts. Someone might easily consider it perfectly just for them to endure from man the same fate they impose. But Moses, carefully considering what befits a gentle soul, thinks we should abstain from enjoying the meat of such creatures-which do provide, by the way, a most suitable and delicious feast. You see, while perpetrators certainly deserve to suffer in kind, it should not be at the hands of their victims, lest we become beasts unknowingly by indulging a passionate desire for revenge against man-eaters. ${ }^{133}$ [§104] In fact, Moses

${ }^{131}$ Rhodes ("Diet and Desire," 133) notes the "inclusio" formed by §§100-102 and §118.

132 See Lev 11:1-8; Deut 14:3-8

${ }^{133}$ lest we become beasts unknowingly by indulging a passionate desire for revenge

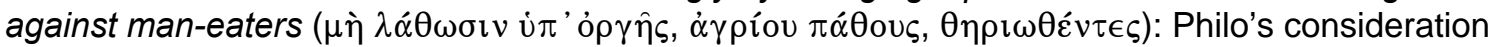

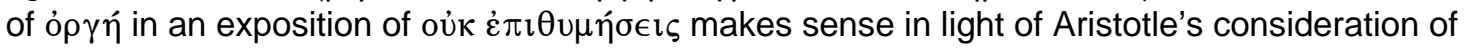
ó $\gamma \gamma \eta$ in Rhetoric 1378a30 - 1378b10, where he defines it as an appetite (o’ $\epsilon \xi_{1 \varsigma}$ ) for retribution 
makes so extreme an effort to prevent such behavior as to forbid categorically the eating of all carnivorous animals, wanting to restrain preemptively the impulse for revenge against man-eaters. ${ }^{134} \mathrm{He}$ designated instead the herbivores as suitable livestock fit for eating, since they are tame by nature and eat only the gentle yield of the earth. Such creatures never plot mischief against anyone. [\$105] Now, of the herbivores, Moses lists ten approved for eating: the calf, the lamb, the kid, the deer, the gazelle, the fallow deer, the ibex, the addax, the oryx, and the giraffe. Because of his constant devotion to numerical theory, which he acutely understood as being of the greatest possible significance in every matter, Moses legislates nothing great or small without first considering the appropriate number and, as it were, affixing that number to the precepts. And of the numbers following the monad, the decad represents absolute perfection-a most holy and sacred number, as Moses declares. Here he places it on the various types of clean animals as a seal of approval, once he decided to grant their use to members of his commonwealth. [\$106] He also provides a simple way of authenticating and approving these ten animals, based on a pair of traits they all exhibit: each has split hooves and chews its cud. Animals that exhibit neither of these traits, or only one of them, are in Moses' view unclean. You see, these two traits are really symbolic representations of the most enlightened methods of teaching and learning, which can, when put into practice, lead to the clear discernment of moral excellence from its opposite. [§107] Consider the ruminating animal. After taking a few initial bites, the food settles in its gullet. Then after a short while, bringing it up again, the animal works it into a smoother substance, before finally sending it down into the stomach. In the same way, a student takes in through his ears various philosophical doctrines and theories from his teacher. But unable to comprehend immediately and grasp the lesson

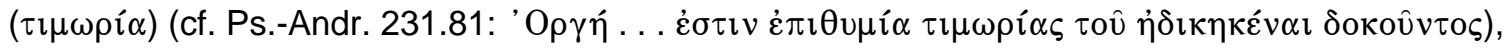

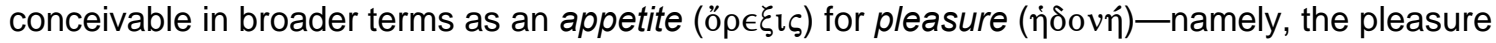
of retribution (cf. Spec. 3.85). The issue here is not a desire for revenge per se, but the danger of such a desire becoming excessive (passionate) due to the personal involvement of the agent of justice. On ó $ү \gamma$ ́ and other terms for "anger," see William V. Harris, Restraining Rage: The Ideology of Anger Control in Classical Antiquity (Cambridge, Mass.: Harvard University Press, 2001), 50-70 [="The Greek and Latin Terminology"]. On the likelihood of Philo's concept of ópүi being similar to Aristotle's, note esp. Harris, Restraining Rage, 61: "All or most of the many definitions of orge which later writers offer are more or less simplified versions of the one in Aristotle's Rhetoric, not that most of their authors will have know the Aristotelian text."

${ }^{134}$ wanting to restrain preemptively the impulse for revenge against man-eaters

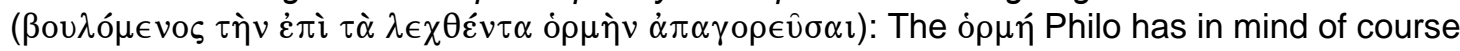
involves eating the meat of man-eaters, but for him such eating amounts to an act of revenge. In

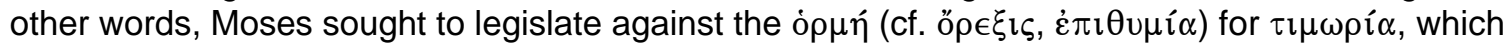
could too easily become excessive (passionate) when killing and eating this type of animal. 
firmly, he continues to hold onto it, until by bringing it up again over and over in his memory through repeated exercises, which act as a sort of cement for ideas, he imprints it securely onto his soul. [\$108] But the firm grasp of ideas, it seems, does no good at all without the added ability of sorting through them and making decisions about which to accept and which to reject. This ability to discriminate appears under the symbol of the split hoof, indicating that there are just two roads in life: one leading to vice and one leading to virtue. Of course we must turn from one and never leave the other. [§109] So animals whose hooves are either not split at all or split more than once are equally unclean, but for different reasons. The first kind represents the idea that good and evil have one and the same nature-in the sense that one spherical surface has both a concave and a convex aspect, or one road runs both up and down a hill at the same time. The second kind, far from offering no choice at all, deceives the traveler by presenting many different roads in life. With a multitude of options, finding the best and most productive path becomes difficult.

Philo's consideration of land animals begins at $\S 103$, continues through $\S 109$, and divides easily into three sections: (1) an explanation of why Moses did not sanction the slaughter of man-eating animals (or any carnivores) for food (§§103104a), (2) an introduction and listing of the ten "clean" herbivores, with special emphasis on the number ten (§§104b-105), and (3) a symbolic interpretation of Moses' criteria for designating a land animal "clean" (§§106-109). ${ }^{135}$ Of these, only his discussion of man-eating animals bears any clear relation to the issues of $\dot{\varepsilon} \pi \imath \theta \nu \mu i \alpha, \dot{\varepsilon} \gamma \kappa \rho \alpha \dot{\tau} \tau \imath \alpha$, and $\ddot{\alpha} \sigma \kappa \eta \sigma \imath \varsigma$ raised more broadly throughout his exposition—but even here the relation seems contrived in two respects. First, Moses never explicitly prohibits man-eating animals—or any carnivorous land animals, for that matter-despite their obvious failure to meet the criteria for

${ }^{135}$ Philo gives no formal introduction to this section, but note his retrospective comment

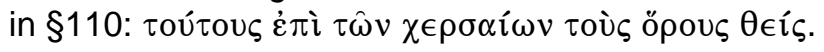


clean animals. ${ }^{136}$ So Philo's decision to make any comment at all on man-eating animals stems from his own agenda, not an exegetical imperative. Second, the case of man-eaters does not, strictly speaking, confirm the thesis Philo has just formulated in $\S 100$ about how Moses' dietary restrictions promote $\dot{\varepsilon} \gamma \kappa \rho \alpha ́ \tau \epsilon \iota \alpha$. But the "prohibition" of man-eaters does resemble the type of restriction, and the accompanying strategy for promoting $\dot{\varepsilon} \gamma \kappa \rho \alpha \dot{\tau} \tau \in \alpha$, that Philo's thesis attributes to Moses. All of this suggests an effort on Philo's part to find at least one other example, in addition to the pig, of a land animal whose flesh incites $\dot{\varepsilon} \pi \imath \theta u \mu i \alpha$ and whose removal from the diet is meant therefore to obviate passion.

While man-eating animals, in Philo's estimation, no doubt make "a most suitable and delicious feast" (§103), he evidently does not consider them as dangerously delicious as pigs and scaleless sea creatures (\$101), because he explains their prohibition on different-though analogous—grounds. Because these animals kill and eat human beings, retributive justice warrants their being killed and eaten in return. ${ }^{137}$ Moses, however, recognized a great moral danger whenever victims take the place of dispassionate agents of justice in executing a sentence, since victims easily succumb to their own desire for revenge-

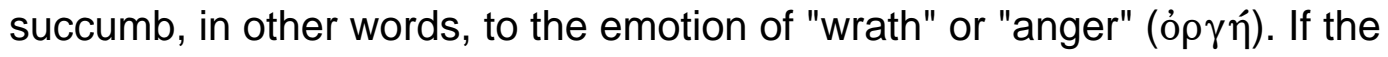
followers of Moses were, for example, allowed to eat lions, they might do so not

\footnotetext{
${ }^{136}$ Which Philo reviews in $\S \S 106-109$. This technicality may account for Philo's wording:

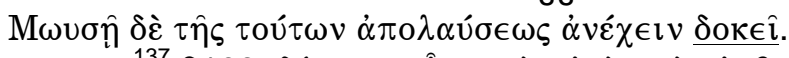

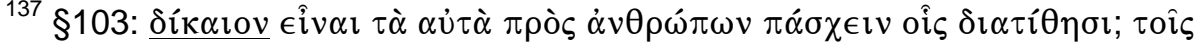

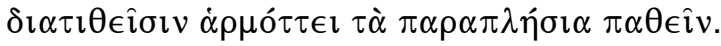


from a reasonable desire to nourish their bodies but from a passionate desire to avenge all who have fallen prey to lions. As Philo puts it, they might "become

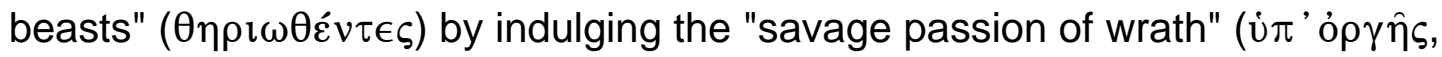
$\dot{\alpha} \gamma \rho \operatorname{oiou} \pi \dot{\alpha} \theta$ ous). So the lion, like the pig, represents a delectable meal, but in a fundamentally different sense. The pig incites $\dot{\varepsilon} \pi \imath \theta u \mu i \alpha$ by promising abundant pleasure through the sweet taste of delicious meat. The lion incites $\dot{\varepsilon} \pi \imath \theta v \mu i \alpha$ by promising abundant pleasure, too, but through the sweet taste of revenge. Moses, understanding the meat of man-eating animals to be especially pleasurable in this qualified sense, recognized a danger and did not allow his followers to consider such animals a source of food. In fact, as Philo goes on to explain in §104, Moses was so eager to protect against the dangerous "impulse"

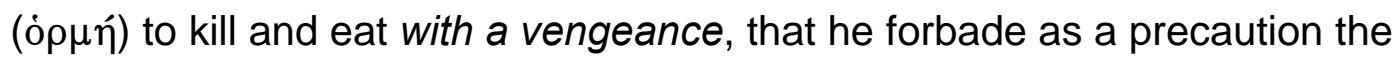
consumption of any animal that kills and eats other animals-let alone human beings. ${ }^{138}$ Herbivores, Moses reasoned, never plot mischief against anyone, man

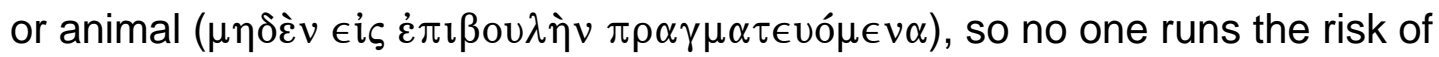
eating them with a vengeance. In other words, no one could ever reasonably perceive herbivores as reprehensible aggressors, so no one could ever reasonably harbor a dangerous, potentially overwhelming desire to punish them. In some respects, Philo's discussion of man-eating land animals, including his ensuing remarks on carnivores and herbivores, invites comparison with

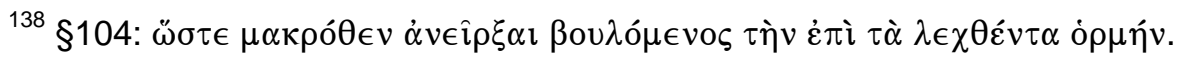


Eleazar's discussion of clean and unclean birds in the Letter of Aristeas. ${ }^{139}$ Both discussions highlight the contrasting characteristics of carnivores and herbivores,

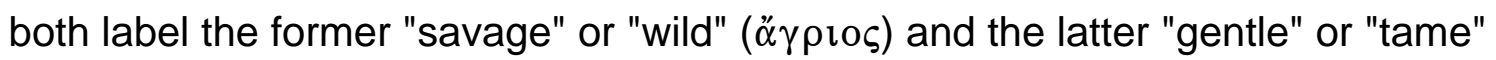

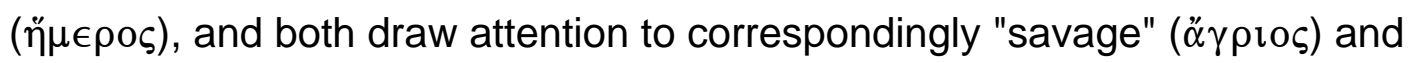

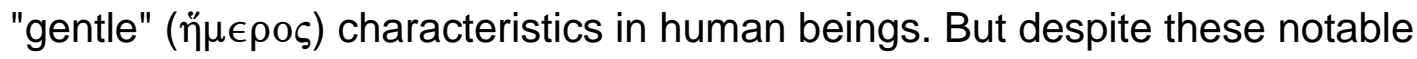
similarities, the two discussions represent radically different understandings of what Moses sought to accomplish through his dietary legislation. ${ }^{140}$ The Letter of Aristeas, on the one hand, believes that the ethical benefit of Moses' legislation on unclean, savage, carnivores and clean, gentle, herbivores derives from a symbolic application. ${ }^{141}$ The animals exemplify certain noble and ignoble character traits, which Moses either commends or condemns symbolically through the designations "clean" and "unclean." To eat or abstain as prescribed does not in itself affect the character of the moral agent, who must first correctly discern and then embrace the moral exhortations Moses expresses symbolically through his legislation. Philo, on the other hand, believes that the ethical benefit of the carnivore-herbivore legislation derives from a strictly literal application. ${ }^{142}$

\footnotetext{
${ }^{139}$ See esp. Rhodes, "Diet and Desire," 123-25.

140 Pace Rhodes, "Diet and Desire," esp. 125: "[B]oth Philo and Aristeas discern a similar logic operative in the dietary legislation."

${ }^{141}$ Let. Arist. 148-49: "By such examples, then, the lawgiver has commended to men of understanding a symbol ( $\sigma \eta \mu \in \imath o v ̂ \sigma \theta \alpha \imath)$ that they must be just and achieve nothing by violence, nor, confiding in their own strength, must they oppress others. For if it is lawful not even to touch the creatures aforementioned because of their several natures, how must we not in every way guard our characters from degenerating to a similar state."

${ }^{142}$ In other words, Philo attributes no symbolic significance to Moses' legislation on unclean, savage, carnivores and clean, gentle, herbivores. Philo obviously does engage in symbolic interpretations through much of §\$100-118: namely, §§106-109 (criteria for clean land
} 
Man-eating animals do not, in Philo's view, represent a reprehensible character trait. They actually eat human beings—who might actually eat them in return, indulging an actual vengeance that overshadows reason. By literally abstaining from the meat of man-eaters, the soul literally abstains from a troublesome passion. Similarly, Moses does not prohibit carnivores as a class because they represent violence, oppression, or some other vicious trait, but because a person accustomed to eating all sorts of carnivores will have difficulty abstaining from one particular sort, the man-eaters. ${ }^{143}$ As for herbivores, both Eleazar and Philo

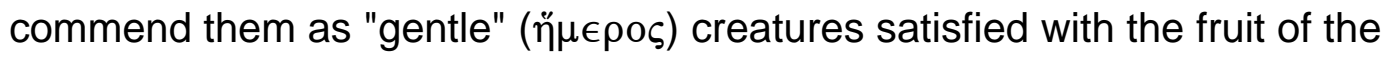

animals), §§110-112 (criteria for clean aquatic animals), §§113-115 (clean and unclean "creeping" animals). But he invariably announces his symbolic interpretations: $\tau \alpha \nu \tau i ̀ ~ \delta \grave{\varepsilon} \tau \grave{\alpha} \sigma \eta \mu \epsilon i \alpha$

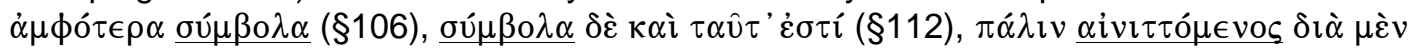

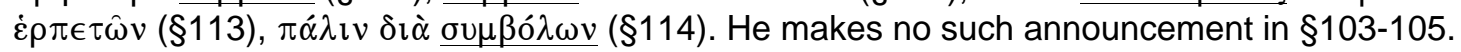
Heinemann (Bildung, 161) acknowledges: "Philon kennt für die Speisegesetze allegorische und wörtliche Begründungen"-and he gives examples of the two approaches (161-66). Under "wörtliche Begründungen," Heinemann mentions first the prohibition of "besonders wohlschmeckende Tiere" (such as pork), recognizing Moses' goal of "zur Selbstbeherrshung anregen" (163). In Heinemann's view, the prohibition of man-eaters involves "wörtliche Begründungen" as well, but he does not situate this prohibition within the larger context of promoting self-control in service to the Tenth Commandment.

${ }^{143}$ Pace Rhodes, "Diet and Desire," 123: "Philo advances an allegorical argument that explains why no carnivores are among those permitted for food." Unlike Eleazar (Let. Arist. 146149), Philo attributes to Moses no objection to carnivores per se, on allegorical, symbolic, or any other grounds. In Philo's view, Moses prohibits all carnivores only to increase the likelihood of his followers successfully abstaining from the one type of carnivore whose meat endangers the soul—namely, man-eaters (cf. Heinemann, Bildung, 164: "Das Verbot anderer Fleischfresser betrachtet Philon als Schutzmaßnahme, um die Begier nach menschenfressenden Tieren zu unterdrücken). In other words, Moses' tacit prohibition of all carnivores really only targets creatures that grievously offend human beings. The behavior of carnivores as carnivores has at best an incidental significance. Eleazar, by contrast, understands Moses to have concerned himself first with the nature of carnivores per se, whose aggression happens to affect human beings in some cases: "But of the winged creatures which are forbidden you will find that they are wild and carnivorous and with their strength oppress the rest and procure their food with injustice at the expense of the tame fowl mentioned above. And not only these, but they also seize lambs

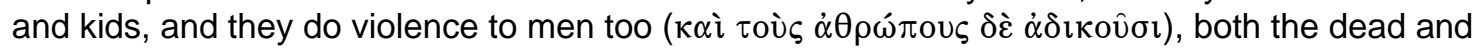
the living" (Let. Arist. 146). 
earth. ${ }^{144}$ But they again differ as to the symbolic or literal significance of this disposition. For Eleazar, a person who merely follows Moses' instruction to eat only herbivores misses Moses' real purpose, which was to promote the sort of life herbivores represent: a life of justice that oppresses no one. ${ }^{145}$ For Philo, the person who eats only herbivores_even with no reflection on the significance of the rule-fulfills Moses' purpose, which was to safeguard his followers from a passionate desire for revenge by allowing them to eat only harmless creatures.

So despite superficial similarities, Philo's remarks in §§103-104 represent a radical departure from Eleazar's discussion of clean (herbivorous) and unclean (carnivorous) birds in the Letter of Aristeas. Eleazar, for his part, understood the dietary laws in terms of moral exhortation. Once decoded properly, obscure regulations about "clean" and "unclean" animals become straightforward ethical maxims_-such as, "Be just and achieve nothing by violence" (Let. Arist. 148). But while they inform a moral agent's theoretical conception of what virtue requires, actual observance of the dietary laws yields no practical benefit, no training in

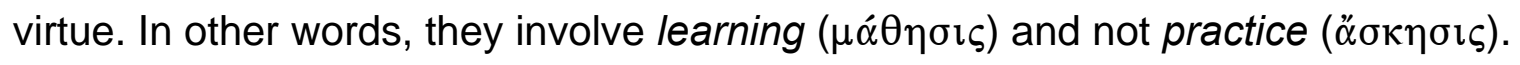
Philo, by contrast, understands these dietary laws in terms of moral psychology, construing them as practical exercises designed to eliminate passionate desire

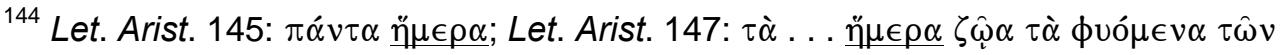

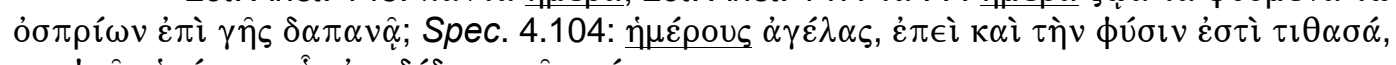

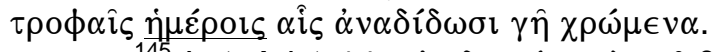

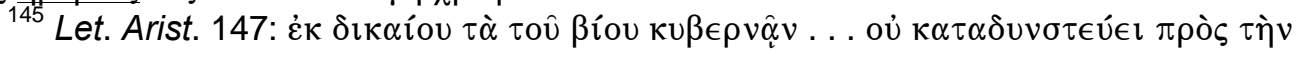
$\dot{\varepsilon} \pi \alpha \nu \alpha i \rho \in \sigma l v \tau \hat{\omega} \nu \sigma u \gamma \gamma \in \nu \iota \kappa \hat{\omega} v$. 
and promote $\dot{\varepsilon} \gamma \kappa \rho \alpha \dot{\tau} \tau \iota \iota .{ }^{146}$ Everyone who puts them into practice benefits from them, with or without an awareness of the ethical theory Moses used to formulate them. ${ }^{147}$ In fact, only those who put them into practice benefit from them. The relative unimportance of knowledge and understanding stems from the fact that these laws involve the training and management of the soul's non-rational part. In

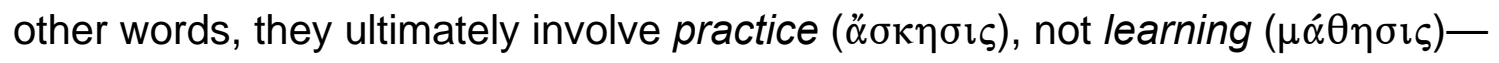
and this fits Philo's overall agenda in the exposition. In fact, his effort to construe

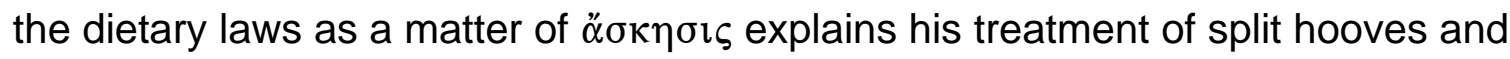
rumination.

After a brief listing of the ten species of clean herbivores (§105), Philo considers the two authenticating "signs" ( $\sigma \eta \mu \in \hat{\imath} \alpha)$ common to all ten: split hooves and rumination (§§106-109) ${ }^{148}$ Because he ascribes a symbolic significance to these two traits, Philo's commentary begins at this point to resemble more closely the Letter of Aristeas, which also interprets split hooves and rumination symbolically (Let. Arist. 150-60). But despite his application of the same mode of interpretation to the same material, Philo manages to draw different conclusions because of his different interpretive agenda. Although Philo cannot make split hooves and rumination speak directly to issues of $\dot{\varepsilon} \pi \imath \theta u \mu i \alpha$ and $\dot{\varepsilon} \gamma \kappa \rho \alpha \dot{\tau} \tau \epsilon \alpha$, he

${ }^{146}$ This fits the overall purpose(s) of his exposition. NB the discourse of moral psychology

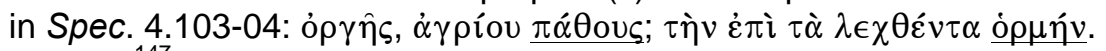

${ }^{147}$ In other words, not eating man-eaters helps to eliminate passionate desire for revenge, whether or not someone understands why it helps.

${ }_{148}$ See Rhodes, "Diet and Desire," 125-27. Philo considers the same "signs" in a similar way in Agr. 131-45. 


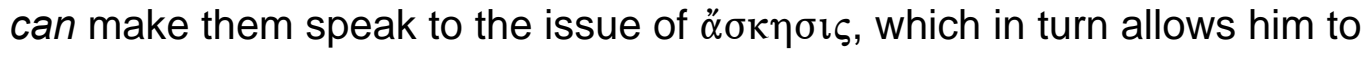
maintain the coherence of his work by tying this particular portion to his broader expository agenda. ${ }^{149}$ Philo engages the notion of $\ddot{\alpha} \sigma \eta \sigma \iota \varsigma$ primarily through his remarks on rumination, which both he and Eleazar identify as a symbol of "memory" ( $\mu \nu \eta \dot{\mu \eta) .}{ }^{150}$ But unlike Eleazar-who interprets rumination in terms of the content of memory: namely, remembrance of God $^{151}$ —Philo interprets rumination in terms of the faculty of memory per se: namely, memory as a type of

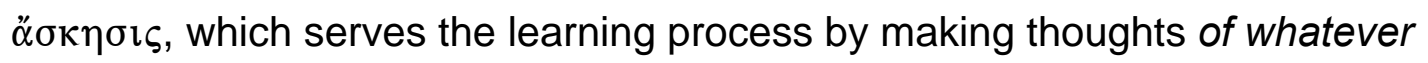
content secure in the mind through repetition (§107). ${ }^{152}$ This type of $\ddot{\alpha} \sigma \kappa \eta \sigma r \varsigma$

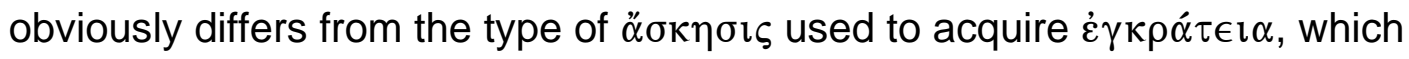
involves forcibly training a non-rational power $(\dot{\varepsilon} \pi \imath \theta v \mu i \alpha)$ to obey reason. But in both cases the moral agent must actively engage certain faculties to achieve

${ }^{149}$ So §§106-109 fit sensibly into Philo's exposition, even though he seems to have lost all sight of issues pertinent to the Tenth Commandment-namely, $\dot{\varepsilon} \pi \imath \theta u \mu i \alpha$ and $\dot{\varepsilon} \gamma \kappa \rho \alpha \dot{\alpha} \tau \epsilon \iota$. Because Colson misses the importance of $\ddot{\alpha} \sigma \kappa \eta \sigma i \varsigma$ to Philo's expository agenda, he does not see the relevance of §§106-109: "In [§§100-105] the prohibition of certain kinds of beasts, fishes, and birds is based on the supposition that they are the most appetizing and to abstain from them encourages self-control. It will be seen that from \$106 onwards a totally different line of argument is adopted, viz. that philosophical and moral lessons are intended by the distinctions" $(68, n$. a); cf. Rhodes, "Diet and Desire," 127: "One cannot help but think that in his discussion of rumination and cloven hooves, Philo has wandered from his initial theme of desire and self-control." Rhodes, however, does not miss the relevance of Philo's other symbolic interpretations (§§110-115) to issues of $\dot{\varepsilon} \gamma \kappa \rho \alpha ́ \tau \epsilon \iota \alpha$ and $\dot{\varepsilon} \pi \imath \theta u \mu i \alpha$ ("Diet and Desire," 127-31).

150 Philo's special interest in memory comes through in the ordering of his commentary on the two traits: first rumination (memory), then the split hoof, despite his initial listing of first the

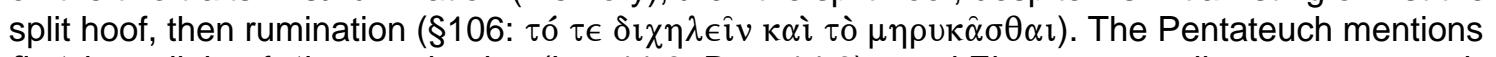
first the split hoof, then rumination (Lev 11:3; Deut 14:6)—and Eleazar naturally comments on the traits in that order. Philo's reversal suggests a deliberate reorganizing of the material.

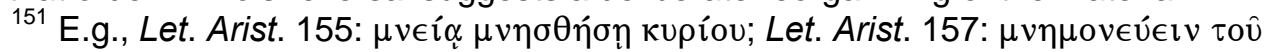

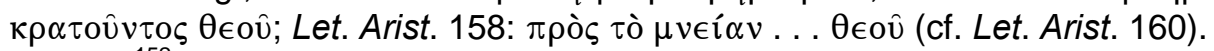

152 In Leg. 3.18, Philo lists $\tau \hat{\omega} v \kappa \alpha \lambda \hat{\omega} v \mu v \hat{\eta} \mu \alpha \mathrm{l}$ among the $\mu \varepsilon \hat{\varepsilon} \rho \tau \hat{\eta} \varsigma \dot{\alpha} \sigma \kappa \eta \dot{\eta} \sigma \omega \varsigma$. On Philo's understanding of the role of $\mu \nu \eta \dot{\eta} \mu \eta$ in the learning process, see Post. 148-49 (cf. Agr. 131-35). 
certain ends. Furthermore, in both cases the engagement takes the form of

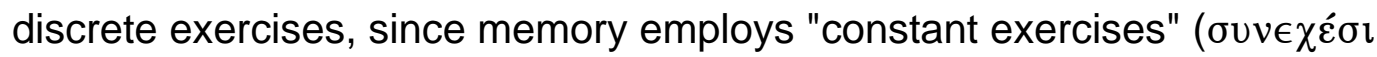

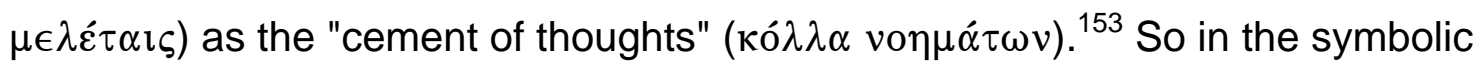
interpretations that follow ( $\S 110-115)$, Philo does not construe the dietary laws as practical exercises designed to inculcate $\dot{\varepsilon} \gamma \kappa \rho \dot{\tau} \tau \epsilon \iota \alpha$, as he did, for example, with the prohibition of pork. Rather, he construes them as repositories for the principles of $\dot{\varepsilon} \gamma \kappa \rho \alpha \dot{\tau} \tau \in \boldsymbol{\imath} \alpha$, which—once properly discerned—are indeed mastered and secured in the mind through practice. ${ }^{154}$ Here Philo's symbolic method corresponds to that of the Letter of Aristeas, which likewise extracts ethical principles from the dietary laws with little concern for the practical implications of their literal observance. Yet even when Philo does replicate Eleazar's technique, the technique serves a different agenda. Philo ultimately has in mind a very practical program of desire management, which the theoretical principles outlined in $\S \S 110-115$ commend. ${ }^{155}$

${ }^{153}$ On the association of $\mu \in \lambda \dot{\varepsilon} \tau \eta$ with $\ddot{\alpha} \sigma \kappa \eta \sigma \iota \varsigma$, see, e.g., Leg. 3.18: $\mu \varepsilon \dot{\rho} \eta \tau \hat{\eta} \varsigma \dot{\alpha} \sigma \kappa \eta \dot{\eta} \sigma \epsilon \omega$.

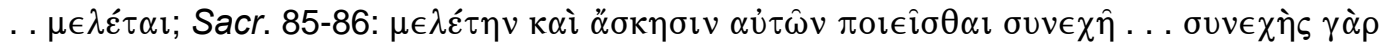

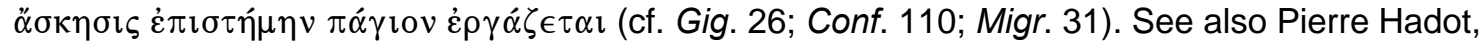
"La philosophie antique: une éthique ou une pratique?," in Problèmes de la Morale Antique (ed. Paul Demont; Amiens: Université de Picardie-Jules Verne, 1993), 7-37, esp. 23-24; and Mosès,

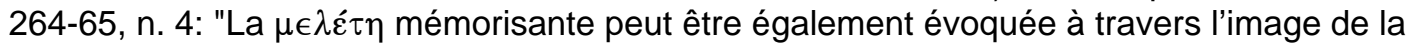
simple mastication (Leg. I, 98) ou à travers le symbole de la manne concassée (Sacrif. 86). Ce type d'exercice mental appartient à la plupart des ascèses philosophiques de l'époque."

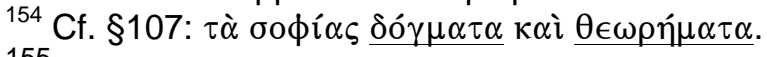

155 Cf. Somn. 1.169: "There being, then, three methods by which virtue accrues, it is the

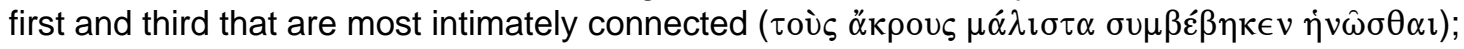
for what comes by practice is the offspring and product of that which comes by learning ( $\tau \grave{\alpha} \gamma \grave{\alpha} \rho$

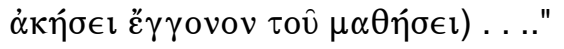




\section{$\S \S 110$ - 112: Aquatic Animals ${ }^{156}$}

[§110] After establishing these restrictions for land animals, Moses begins to list aquatic animals that are clean and approved for eating. Here again he clearly marks the clean species with a pair of traits-fins and scalesrejecting with disapproval any animal that exhibits neither or only one of them. Now, this requires an accurate explanation. [\$111] You see, creatures lacking either or both of these traits get dragged along by the current, unable to withstand the force of its movement. But creatures equipped with both face the current head-on and repel it. Eager to contend with the opponent, they train themselves with zeal and invincible daring: pushed they push back, chased they turn and charge, hemmed in they clear wide swaths for an easy escape. [§112] As with the land animals mentioned earlier, these two types of aquatic creatures are also symbols: the first represents the soul of a lover of pleasure, the second represents the soul enamored of endurance and self-control. After all, the road to pleasure is downhill all the way-easier than any other. So instead of a path for walking, it ends up being more like a slippery slope. By contrast, the road to self-control is a steep uphill climb-laborious, to be sure, but more beneficial than any other. The road to pleasure whisks us away and compels our descent, bearing us down headlong until at last it flings us off into the lowest depths. But the other road leads upward to heaven, granting immortality to those who do not grow weary, who have the strength to endure its rough and challenging climb.

In his symbolic interpretation of the criteria for clean land animals, Philo had to reckon with a traditional, perhaps even authoritative, understanding of the significance of rumination and split hooves, but his interpretation of fins and scales, the criteria for clean aquatic animals, seems like a novel venture. While he does use the traditional technique of correlating animal behavior with human character-just as Eleazar did in the case of carnivorous birds (Let. Arist. 14549)—Philo's results seem original, given their tailored fit to his expository agenda. He begins with a characterization of the unclean aquatic animal, which

${ }^{156}$ See Lev 11:9-12; Deut 14:9-10. 
lacks fins, or scales, or both. Such a creature, he notes, get swept away by the current, "unable to withstand the force of its movement" ( $\dot{\alpha} v \tau \varepsilon \dot{\varepsilon} \chi \in \iota v \dot{\alpha} \delta v v \alpha \tau o \hat{v} v \tau \alpha$

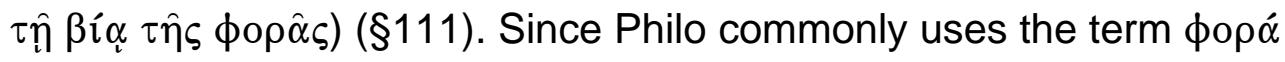
("movement") as a synonym for the technical term ó $\mu \eta ́$ ("impulse"), his wording here mirrors the discourse of moral psychology deployed elsewhere in his writings. ${ }^{157}$ In particular, he portrays the plight of someone mastered by the nonrational impulse(s) of $\dot{\varepsilon} \pi \imath \theta u \mu i \alpha$, someone identified explicitly in $\S 112$ as the

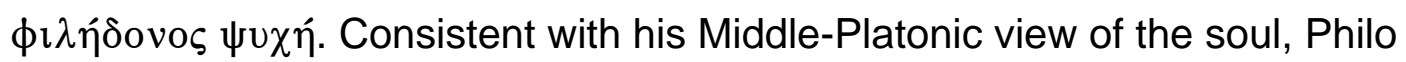
portrays a contest of power within the moral agent whose reason ( $\lambda$ ó ${ }^{\circ} \varsigma$ ) suffers

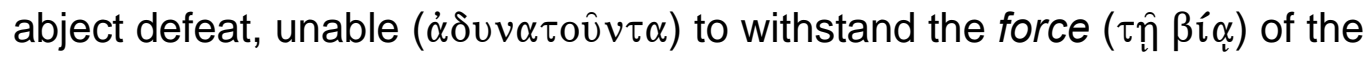
dominating non-rational power $(\dot{\varepsilon} \pi \imath \theta u \mu i \alpha)$. Just as the current absolutely directs the movement of a finless, scaleless creature, so $\dot{\varepsilon} \pi \imath \theta u \mu i \alpha$-turned-ě $\rho \omega \varsigma$

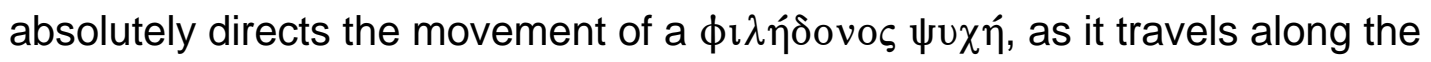
easy path to pleasure ( $\left.\dot{\varepsilon} \phi^{\prime} \eta \dot{j} \delta \nu^{\prime} \eta \dot{v}\right) .{ }^{158}$ By contrast, aquatic animals with fins and

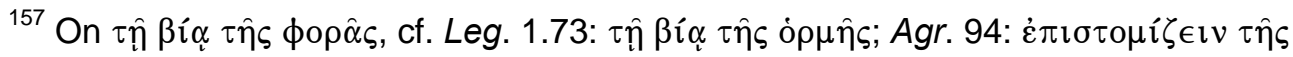

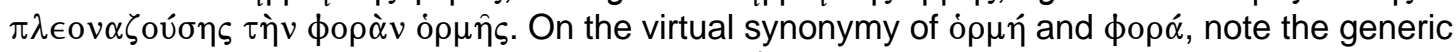

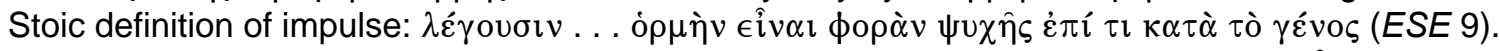

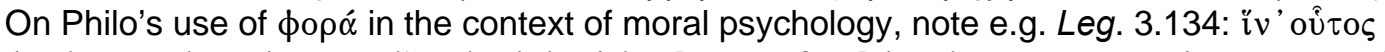

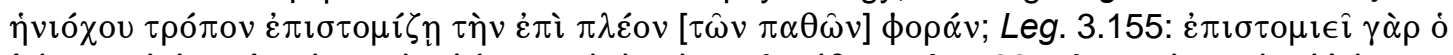

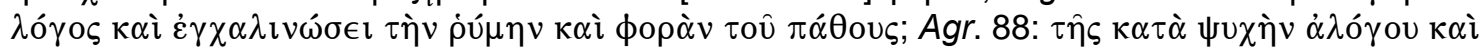

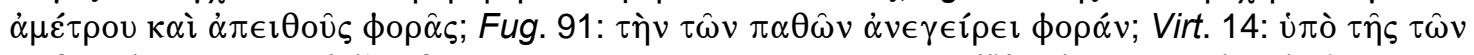

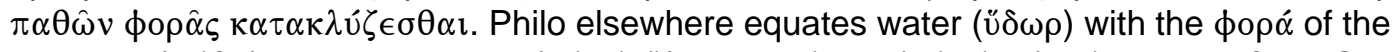

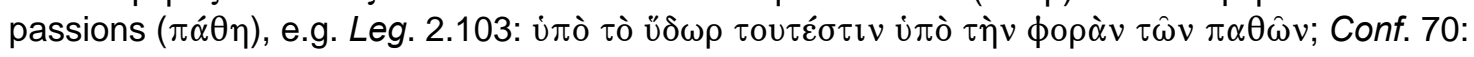

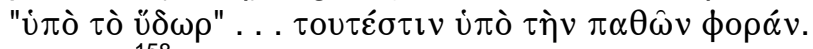

${ }^{158}$ The $\phi \imath \lambda \eta ́ \delta o v o \varsigma \psi \nu \chi \eta \dot{\eta}$, mastered by tyrannical desire (ह̋ $\left.\rho \omega \varsigma\right)$, orients its life toward the

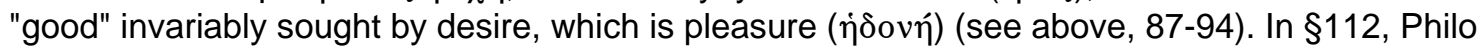

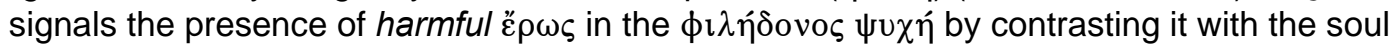

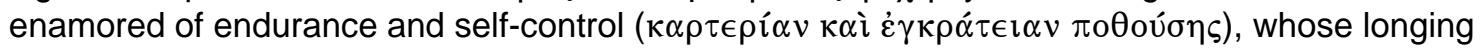


scales stoutly oppose the current (\$111). Philo characterizes their behavior using the agon motif, portraying the sort of struggle against $\dot{\varepsilon} \pi \imath \theta u \mu i \alpha$ engaged by

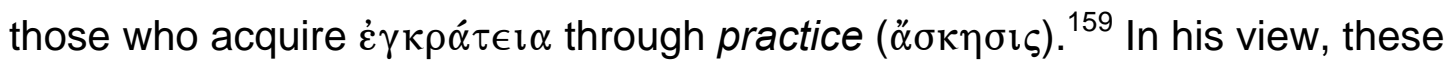
creatures symbolize the soul that yearns for endurance and self-control

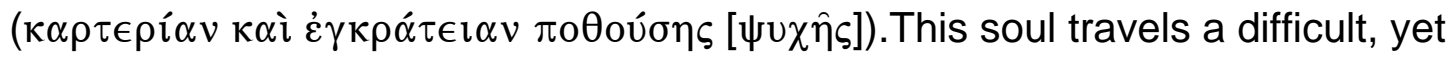
profitable, path, which leads not only to $\dot{\varepsilon} \gamma \kappa \rho \dot{\alpha} \tau \epsilon \iota \alpha$ but ultimately to heaven ( $\epsilon \dot{i} \varsigma$ oủpavóv) for those strong enough to endure it. By highlighting issues of $\dot{\varepsilon} \pi \imath \theta u \mu i \alpha, \dot{\varepsilon} \gamma \kappa \rho \alpha \dot{\tau} \tau \iota \alpha$, and $\ddot{\alpha} \sigma \kappa \eta \sigma \iota$, Philo incorporates his interpretation of clean aquatic animals into the larger purpose of his exposition.

$$
\S \S 113 \text { - 115: "Reptiles"160 }
$$

[§113] Moses applies the same idea to reptiles, declaring both creatures with no feet, which wriggle about by sliding on their stomach, and fourlegged creatures with many feet unclean for eating - but he is once again hinting here at something else. Reptiles with no feet represent people who live for their bellies, who gorge themselves like cormorants, bringing a series of endless tributes to their sovereign ruler, the wretched belly. With liquor, pastries, seafood, and in general whatever baked treat or tasty relish the exacting culinary arts produce for every sort of dish, these people fan and stoke their boundless and insatiable desires. Reptiles with four legs and many feet represent the miserable slaves of not just one passion, desire, but of all passions, which generically are four in number, each having many species. The tyranny of one passion is hard enoughhow oppressive and unbearable the tyranny of many! [§114] But among reptiles, Moses designates as "clean" creatures with legs above their feet enabling them to leap up off of the ground. These are the various kinds of grasshoppers, along with the creature known as the "snake fighter." Once

( $\pi$ ó $0 \varsigma$ ) indicates the presence of beneficial $\tilde{\varepsilon} \rho \omega \varsigma$ (on the $\varepsilon \rho \omega \varsigma$ - $\pi$ ó $0 \varsigma$ connection, see above, 161, n. 48).

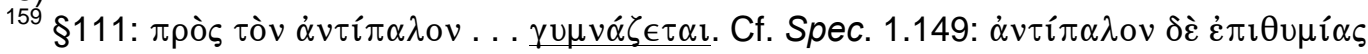
$\dot{\varepsilon} \gamma \kappa \rho \alpha ́ \tau \epsilon \imath \alpha$. For "resisting current," the passions, and the agon motif, see esp. Mut. 214-15.

${ }^{160}$ See Lev 11:2-23, 41-45. Here "reptiles" in the broad sense of creatures that "creep" ( $\tau \hat{\omega} \nu \dot{\varepsilon} \rho \pi \epsilon \tau \hat{\omega} \nu)$ (cf. Lat. repere). 
again, Moses is using symbols to carefully examine the different habits and dispositions of a rational soul. In this case, we learn that the powerful pull of the body naturally weighs foolish people down, strangling and crushing them as it adds its force to the great sinking mass of mortal existence. [\$115] Some happy souls, however, can resist the downward force of that pull with a superior counterforce. Taught by the principles of proper instruction to leap upward from earth and all earthly concerns into the ethereal circuits of heaven, these souls glimpse a vision deemed worthy of envy and struggle by all who forgo half-hearted efforts and attain it through determined resolve.

In his explicit references to the structure of his commentary on clean and unclean animals, Philo acknowledge only three major elements—animals of land, sea, and sky—leaving no place in his outline for the reptiles ( $\tau \grave{\alpha} \dot{\varepsilon} \rho \pi \epsilon \tau \dot{\alpha})$ of $\S \S 113-$ 115 , except as part of his discussion of aquatic animals $(\S \S 110-112) \cdot{ }^{161} \mathrm{He}$ obviously does not place reptiles in the same physical domain, but they do, in his view, share with aquatic creatures the same symbolic domain, which justifies their standing together with aquatic creatures under the same rubric. In Philo's view, Moses formulated dietary restrictions for the reptiles using "the same idea"

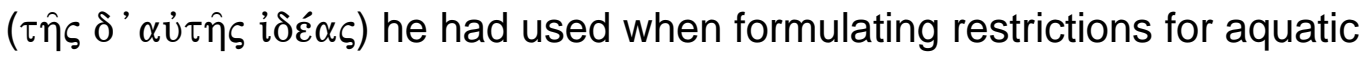
creatures (§113) ${ }^{162}$ Generally speaking, Moses' "idea" involved the correlation of animal behavior with human character, a correlation noted also by Eleazar in the Letter of Aristeas (esp. 145-49). But specifically, Moses saw in both aquatic

${ }^{161}$ When he finally begins his discussion of birds in $\S 116$, Philo claims to have considered only two classes of animal (land and aquatic) up to that point, so apparently none of the creatures mentioned in §§113-115 represent a distinct class (§116: ' $E \pi \in \lambda \eta \lambda v \theta \dot{\omega} \varsigma$ oủv $\tau \hat{\omega}$

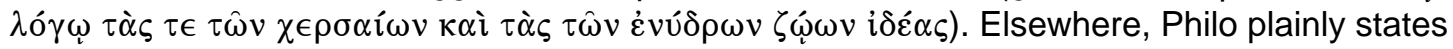
that his discussion of clean and unclean animals involves only three distinct varieties of creature:

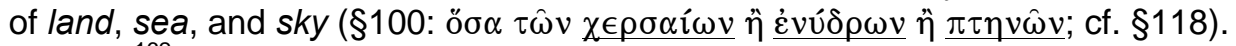

${ }^{162}$ Cf. §113: $\pi \dot{\alpha} \lambda l v \alpha i v \imath \tau \tau o ́ \mu \epsilon v o \varsigma \delta \delta \grave{\alpha} \mu \grave{\varepsilon} v \dot{\varepsilon} \rho \pi \epsilon \tau \hat{\omega} v$. 
creatures and reptiles certain physiological traits indicative of $\dot{\varepsilon} \gamma \kappa \rho \alpha ́ \tau \epsilon \iota \alpha$ : either its abject absence, amounting to $\phi \imath \lambda \eta \delta \delta$ ví $\alpha$, or its salutary presence. By designating creatures either "clean" or "unclean" in accordance with their traits, Moses instructs students of his dietary laws in matters bearing on the Tenth Commandment, either commending the vigorous management of $\dot{\varepsilon} \pi \imath \theta u \mu i \alpha$ ( $\dot{\varepsilon} \gamma \kappa \rho \alpha \dot{\tau} \tau \epsilon \iota \alpha)$ or denouncing enslavement to $\dot{\varepsilon} \pi \imath \theta u \mu i^{\alpha} \alpha(\phi \imath \lambda \eta \delta \delta$ ví $\alpha)$. In the case of aquatic creatures, Moses explores the symbolic significance of fins and scales, while in the case of reptiles, he considers the symbolic significance of feet.

Philo subdivides the unclean reptiles into those "with no feet" ( $\alpha \pi \circ \delta \alpha)$ and those "with four legs and many feet" ( $\tau \in \tau \rho \alpha \sigma \kappa \in \lambda \hat{\eta} \kappa \alpha \grave{\imath} \pi 0 \lambda u ́ \pi \circ \delta \alpha$ ), and both represent souls utterly devoid of $\dot{\varepsilon} \gamma \kappa \rho \dot{\alpha} \tau \epsilon \iota \alpha(\$ 113) .{ }^{163}$ By creatures "with no feet," Philo clearly means serpents, which of necessity "wriggle about by sliding on

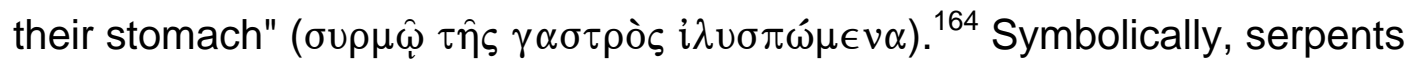

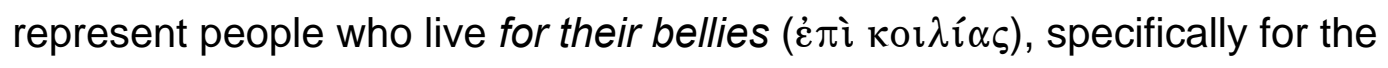
pleasure derived from eating and drinking. Holding pleasure as their ultimate aim, such people embody $\phi \imath \lambda \eta \delta o v i ́ \alpha$, the condition of soul indicative of tyrannical

${ }^{163}$ The actual terms Philo uses to classify unclean reptiles do not appear in the biblical

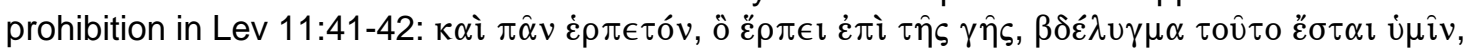

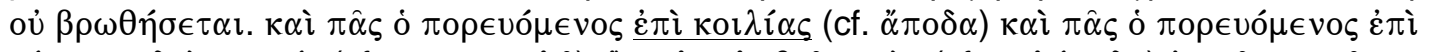

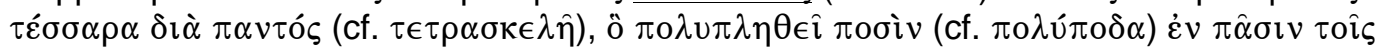

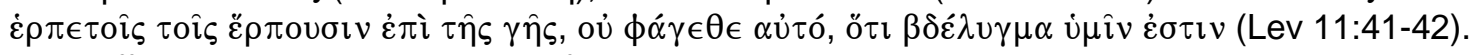
Philo offers a similar interpretation of Lev 11:42 in Leg. 3.139.

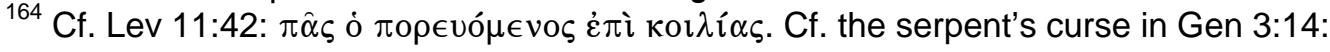

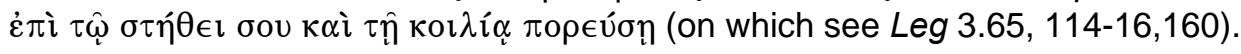


desire. ${ }^{165}$ Philo further suggests the involvement of tyrannical desire with his description of those who live "for their bellies," echoing his earlier description of those consumed by tyrannical desire affecting the belly (§91). ${ }^{166}$ Instead of controlling desire with $\dot{\varepsilon} \gamma \kappa \rho \alpha ́ \tau \epsilon \iota \alpha$, such people end up constantly stimulating desire, which in their case can never reach satiety because the deposed rational faculty sets no limit. ${ }^{167}$ Similarly, creatures "with four legs and many feet" represent people who, in general, fail to master the soul's non-rational forces through $\dot{\varepsilon} \gamma \kappa \rho \alpha ́ \tau \epsilon \iota \alpha$ and become instead mastered by those forces. In particular, Philo has in mind souls dominated by all of the passions $(\pi \dot{\alpha} \theta \eta)$ : not just the four

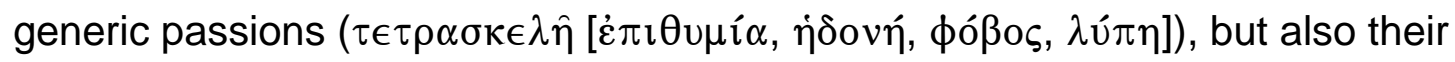

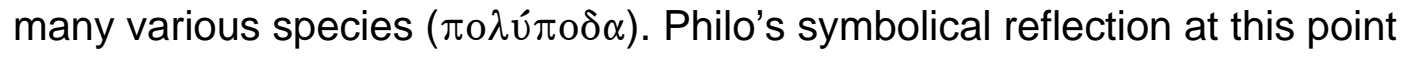
involves all passions, clearly transcending the scope of his overarching topic, the

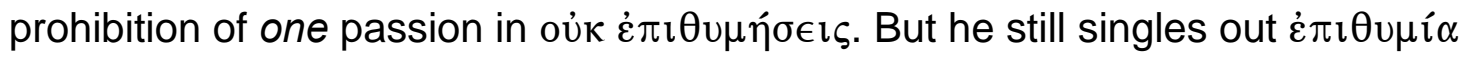
for special mention in his description of reptilian souls, comparing their subjugation to many passions to the miserable slavery and harsh despotism

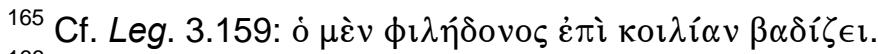

${ }^{166}$ Apart from general similarities, note especially the terms common to both passages:

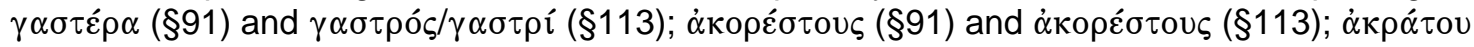

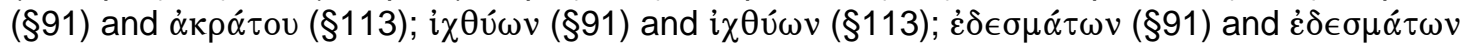
(§113); $i \lambda v \sigma \pi \omega \mu \varepsilon \dot{v o v \varsigma}(\S 91)$ and $i \lambda v \sigma \pi \omega \mu \epsilon v \alpha$ (\$113). Philo does, however, compare gluttonous people to other sorts of animals in the two passages: dogs in $\S 91$ ( $\tau \rho \circ \operatorname{\pi ov} \kappa u v i \delta i \omega v$ ) and

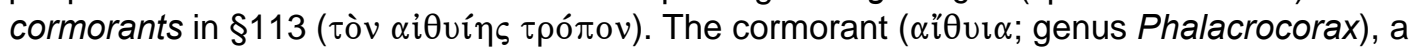
voracious bird emblematic of gluttony (see also Leg. 3.155; Det. 101; Contemp. 55), would have fit perfectly into Philo's discussion of birds (\$§116-117), had Moses designated it "unclean." $\dot{\varepsilon} \pi \imath \theta u \mu i \alpha \varsigma$.

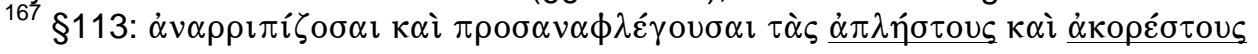


imposed by one passion, $\dot{\varepsilon} \pi \imath \theta u \mu i \alpha$, whose tyranny brings trouble enough. ${ }^{168}$ By framing such a comparison, Philo presumes to have already spoken on the nature and effects of tyrannical desire. And indeed he has, in both his symbolic interpretations (§§110-113) and the theoretical reflections of the exposition's "diagnosis" portion (esp. §§80-91). So even though Philo's remarks on fourlegged multipeds deny a particular significance to tyrannical desire in the interpretation of that restriction, they nevertheless confirm the preeminence of tyrannical desire in Philo's exposition.

Philo interprets also the clean reptiles symbolically (§§114-115), exploring the significance of their distinguishing trait: legs above their feet enabling them to leap from the ground $(\pi \eta \delta \hat{\alpha} \nu \dot{\alpha} \pi \grave{~} \tau \hat{\eta} \varsigma \gamma \hat{\eta} \varsigma \delta \dot{v} v \alpha \sigma \theta \alpha \imath) .{ }^{169}$ Like their unclean counterparts, these reptiles represent for Philo a certain type of soul, which in this case Moses sought to commend, not condemn. ${ }^{170}$ In particular, Philo correlates their ability to leap from the ground ( $\pi \eta \delta \hat{\alpha} \nu \dot{\alpha} \pi \grave{o} \tau \hat{\eta} \varsigma \gamma \hat{\eta} \varsigma)$ with the ability of souls to "leap" upward from the earth and from all earthly concerns ( $\alpha \nu \omega$ $\pi \eta \delta \hat{\alpha} \nu \ldots \dot{\alpha} \pi \grave{o} \gamma \hat{\eta} \varsigma \kappa \alpha \grave{\imath} \tau \hat{\omega} v \chi \alpha \mu \alpha \iota \zeta \dot{\eta} \lambda \omega \nu)$, which secures for them a vision of the

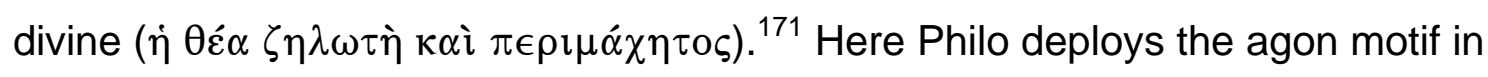

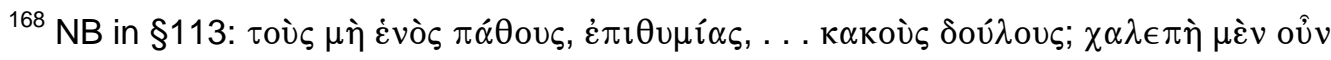

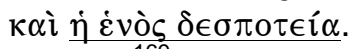

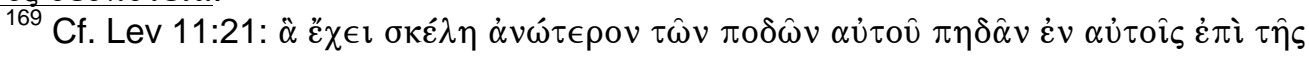
$\gamma \hat{\eta} \varsigma$. NB Philo's emendation of $\underline{\dot{\varepsilon} \pi \hat{\imath}} \tau \hat{\eta} \varsigma \gamma \gamma \hat{\eta} \varsigma$ to $\dot{\alpha} \pi \grave{o} \tau \hat{\eta} \varsigma \gamma \hat{\eta} \varsigma$ to suit his exegetical purpose.

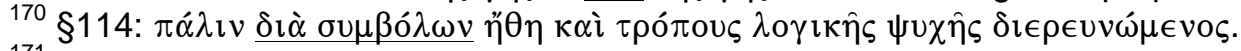

${ }^{171}$ Cf. Her. 239: "Conversely Moses gives high approval to those reptiles which can leap upwards ( $\ddot{\alpha} v \omega \delta \dot{v} v \alpha \tau \alpha \imath \pi \eta \delta \hat{\alpha} v)$. Thus he says, 'These shall ye eat of the flying reptiles which go

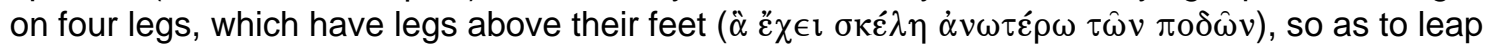


its distinctively Platonic aspect, casting the practice of $\dot{\varepsilon} \gamma \kappa \rho \alpha ́ \tau \epsilon \iota \alpha$ as a means of escaping the body's entanglement with the sensible realm. ${ }^{172}$ While he does not use the term $\dot{\varepsilon} \gamma \kappa \rho \alpha \dot{\tau} \tau \imath \alpha$, the concept undoubtedly informs his notion of a "leaping" soul that wrestles successfully against the "pull of the body" (i $\tau$

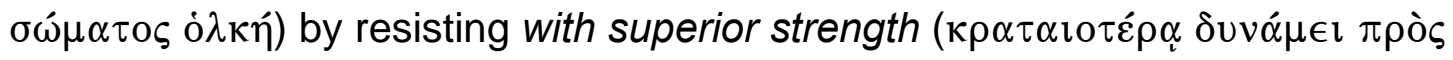

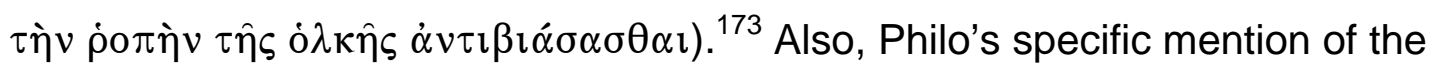

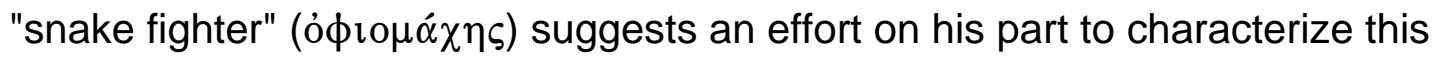
type of soul as a model of $\dot{\varepsilon} \gamma \kappa \rho \alpha \dot{\tau} \tau \imath \alpha$, since he elsewhere interprets the snake fighter in precisely those terms:

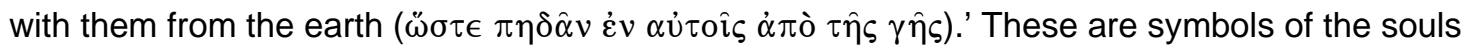

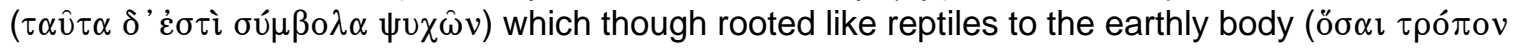
$\dot{\varepsilon} \rho \pi \epsilon \tau \hat{\omega} \nu \pi \rho \circ \sigma \epsilon \rho \rho \iota \zeta \omega \mu \varepsilon \dot{v} \alpha \iota \tau \hat{\omega} \gamma \eta \dot{\imath} v \omega \sigma \omega \mu \alpha \tau \imath)$ have been purified and have strength to soar on

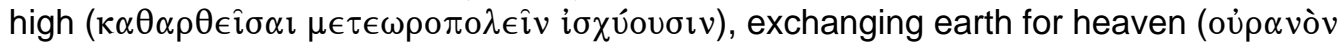
$\dot{\alpha} v \tau \imath \kappa \alpha \tau \alpha \lambda \lambda \alpha \xi \dot{\alpha} \mu \epsilon v \alpha \imath \gamma \hat{\eta} \varsigma)$, and corruption for immortality ( $\phi \theta$ op $\hat{\alpha} \varsigma \dot{\alpha} \theta \alpha v \alpha \sigma i \alpha v) . "$

${ }^{172}$ On the Platonic aspect of Philo's agon motif, see above, 127, n. 53.

${ }^{173}$ On "escaping the body," see Gig. 31; Somn. 1.43-44. By the term "pull of the body" ( $\dot{\eta}$

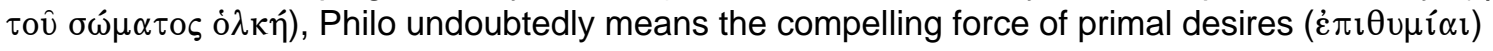
for pleasure (i்ovin) closely associated with the body yet residing in the soul (cf. Gig. 33: $\tau \alpha \hat{\imath} \varsigma$

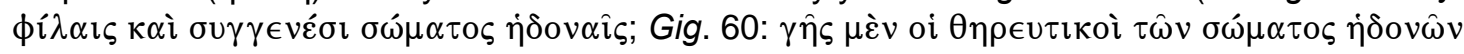

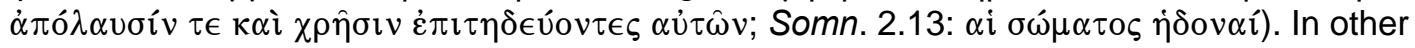
words, Philo envisions in this passage a moral agent resisting $\dot{\varepsilon} \pi \imath \theta u \mu i \alpha$, which amounts to a

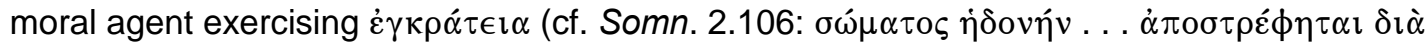
$\pi o ́ \theta$ ov $\dot{\varepsilon} \gamma \kappa \rho \alpha \tau \in i \alpha \varsigma)$. On Philo and the body, see Pierre Courcelle, "Tradition platonicienne et traditions chrétiennes du corps-prison (Phédon 62 b; Cratyle 400 c)," REL 43 (1965): 406-43, esp. 413-14; Kenneth Fox, "Paul's Attitude toward the Body in Romans 6-8: Compared with Philo of Alexandria" (Ph.D. diss., University of St. Michael's College, 2001), 215-58 [="Philo's Double Attitude toward the Body"]; Josef Groß, Philons von Alexandreia Anschauungen über die Natur des Menschen (Inaugural Dissertation, University of Tübingen, 1930), 10-21 [="Der Körper des Menschen"]; Runia, Philo and the Timaeus, 258-78 [="(M)an's descent into the body"], 321-22; Alexander Sand, Der Begriff "Fleisch" in den paulinischen Hauptbriefen (BU 2; Regensburg: Pustet, 1967), 281-84 [="Philo von Alexandrien"]; Eduard Schweizer, "Die hellenistische

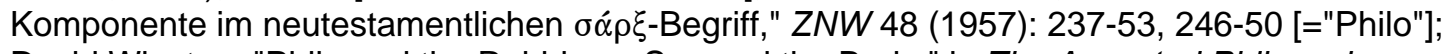
David Winston, "Philo and the Rabbis on Sex and the Body," in The Ancestral Philosophy: Hellenistic Philosophy in Second Temple Judaism: Essays of David Winston (ed. Gregory Sterling; SPhM 4; BJS 331; Providence: Brown Judaic Studies, 2001), 199-219. 
For the snake-fighter is, I think, nothing but a symbolic representation of

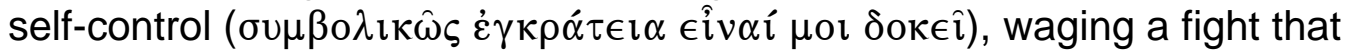
never ends and a truceless war against intemperance and pleasure ( $\pi \rho \grave{s} \varsigma$

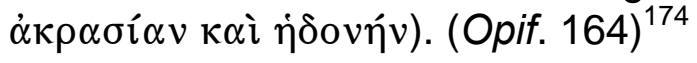

So Philo equates the clean reptiles with souls possessed of $\dot{\varepsilon} \gamma \kappa \rho \dot{\alpha} \tau \epsilon \iota \alpha$, which prove themselves superior to their unclean counterparts by rejecting pleasure instead of embracing it ( $\phi \lambda \lambda \eta \delta o v i ́ \alpha)$.

$$
\S \S 116-117: \text { Birds }^{175}
$$

[§116] Having provided a rational account of the nature of land-based and aquatic animals, and having made the most appropriate distinctions among them by the laws he enacted, Moses begins to examine the essence of the last type of creature - the myriad kinds of winged creatures. He rejects a great number of birds, in particular those that prey either on other animals or on human beings. The prohibition includes every carnivorous, every venomous bird, and in general every bird that uses aggressive force of any kind. [§117] But Moses includes ring-doves, pigeons and turtle-doves, and the various types of cranes, geese, and birds of that sort all in one class of tame and gentle creatures. He allows these birds without restriction to anyone who chooses to use them for food.

Philo completes his survey of clean and unclean animals from land, sea, and sky with a short consideration of the legislation governing birds ( $\gamma \varepsilon \dot{\varepsilon} \nu \tau \hat{\omega} \nu \pi \tau \eta \nu \hat{\omega} v)$. Philo's brevity contrasts sharply with Eleazar's elaborate interpretation of these same laws in the Letter of Aristeas. ${ }^{176}$ While Philo does recognize along with

${ }^{174}$ Cf. Leg. 2.105. Philo's symbolic interpretation of the snake fighter, although modeled on Eleazar's method, reveals Philo's unique appropriation of that method. Eleazar's method assumes some animal trait reasonably analogous to a human ethical trait. Nothing about "fighting snakes," as an animal trait, suggests a comparison with human self-control. The snake-fighter can only represent self-control if the "snake" represents pleasure (see Calabi, "Il serpent e il cavaliere"; Siegfried, Philo, 247), and this identification involves Philo's allegory of the soul (on which see Tobin, Creation of Man, 135-76).

${ }^{175}$ See Lev 11:13-19; Deut 14:11-18.

${ }^{176}$ Let. Arist. 145-49. 
Eleazar the Mosaic correlation of "clean" with docility (herbivores) and "unclean" with aggression (carnivores), he does not make Eleazar's connection between these behavioral traits and similar character traits. In fact, Philo makes no application to the realm of ethics at all, taking the laws neither literally as practical exercises in $\dot{\varepsilon} \gamma \kappa \rho \alpha \dot{\tau} \tau \epsilon \alpha$ nor symbolically as theoretical promotions of $\dot{\varepsilon} \gamma \kappa \rho \alpha ́ \tau \epsilon \iota \alpha$. Such an omission clearly defeats the purpose of Philo's exposition, which presumes to show how Moses' dietary laws promote the observance of oủк $\dot{\varepsilon} \pi \imath \theta u \mu \eta \dot{\sigma} \sigma \in \varsigma \zeta$ by fostering proper management of $\dot{\varepsilon} \pi \imath \theta u \mu i \alpha$ within the soul. By citing a set of dietary laws and tracing no connection to his overall expository agenda ( $\dot{\varepsilon} \pi \imath \theta u \mu i \alpha, \dot{\varepsilon} \gamma \kappa \rho \alpha \dot{\tau} \tau \iota \iota, \ddot{\alpha} \sigma \kappa \eta \sigma \iota)$ ), Philo seems to deny the existence of any connection.

But Philo earlier proved his creative ability to find such connections for the sake of his expository agenda, using a variety of literal and symbolic techniques. ${ }^{177}$ So his failure to produce an interpretation here along lines of moral psychology hardly stems from an inability to do so, but more likely from an unwillingness. The reluctance makes sense, if in fact Philo knew the Letter of Aristeas, or at least the symbolic interpretation of clean and unclean birds it contains. After all, the careful explication of how Moses ingeniously used obscure regulations about eating birds to commend justice and condemn violent

${ }^{177}$ In fact, the logic of Philo's interpretation of the prohibition of man-eaters (§§103-104), however strained, could just as well apply here to the prohibition of carnivorous birds, since they too-as both Philo and Eleazar acknowledge-injure human beings and could therefore incite 
oppression stands as the highlight of Eleazar's discourse on the dietary laws. Such a notable interpretation probably either was standard before its inclusion in the Letter of Aristeas or became standard as a result. In either case, a wellestablished traditional understanding of the laws governing birds, especially one at odds with his expository agenda, would put Philo in an awkward exegetical position. According to Eleazar, Moses had one clear objective in prohibiting or

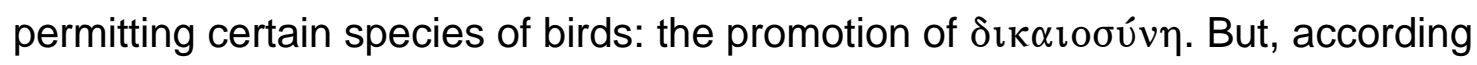
to Philo, Moses formulated the dietary laws in an effort to promote $\dot{\varepsilon} \gamma \kappa \rho \alpha ́ \tau \epsilon \iota \alpha$,

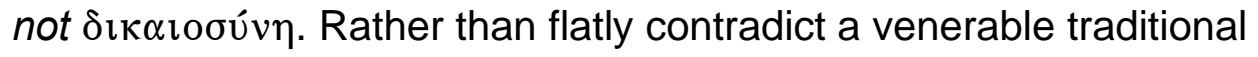
interpretation, Philo offers no interpretation at all. As a result, he gives absolutely no support to one element of his original thesis about the laws of clean and unclean (§§100-102), which states that Moses regulated the consumption of animals from land, sea, and sky with a view to eliminating passionate desire. Yet when he summarily concludes his discussion of the laws of clean and unclean, he speaks as if he had.

\section{§118: Conclusion of Clean and Unclean Animals}

[§118] So, as you can see, Moses withdrew from our use certain animals from every region of the earth: creatures from the land, from the sea, and from the sky. He was, in a sense, withdrawing fuel from a fire, intending all along to extinguish passionate desire. ${ }^{178}$

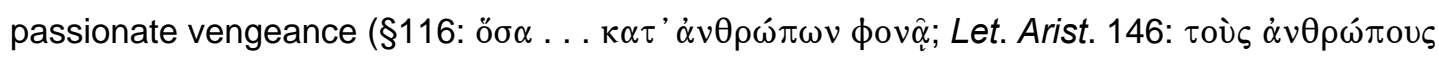

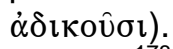

${ }^{178}$ He was, in a sense, withdrawing fuel from a fire, intending all along to extinguish

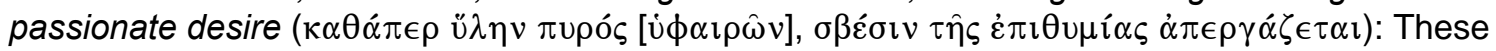
restrictions do nothing to "extinguish" $\dot{\varepsilon} \pi \imath \theta u \mu i \alpha$ itself, since even those who abstain from prohibited animals indulge the amoral emotion $\dot{\varepsilon} \pi \imath \theta u \mu i \alpha$ when they eat, and Philo nowhere 
In §118, Philo completes the interpretive frame he began in $\S \S 100-102$, suggesting that Moses crafted his legislation on clean and unclean animals primarily to remove incitements to $\dot{\varepsilon} \pi \imath \theta u \mu i \alpha$ and obviate the risk of passionate

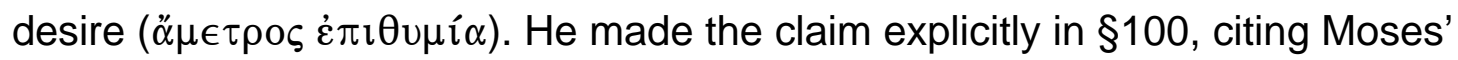

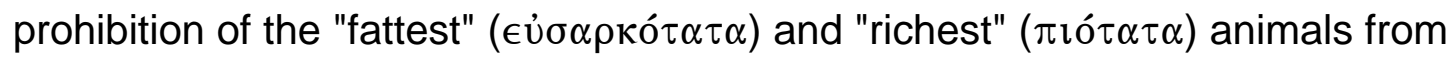
land, sea, and sky—animals with especially delicious meats likely to cause the moral agent to eat strictly for the sake of pleasure. Here in §118, Philo uses more general terms to make the same essential point: Moses' strategic prohibition of certain animals from land, sea, and sky amounts to the withdrawal of "fuel from a fire" in order to "extinguish" passionate desire. ${ }^{179}$ By framing his entire discussion of the laws governing clean and unclean animals with one distinct claim about the purpose of those laws, Philo implies that each one of his analyses corroborates, or at least should corroborate, that claim. But only two of the animals he considers in fact support his claim: pigs and scaleless sea creatures, both of which Philo clearly identifies as especially pleasurable to eat and morally dangerous for that reason. He does manage to fit one other type of prohibited animal, the land carnivores, into his interpretive scheme, but only through a

advocates the elimination (extinguishing) of $\dot{\varepsilon} \pi \imath \theta u \mu i \alpha$ per se. The $\dot{\varepsilon} \pi \imath \theta u \mu i \alpha$ Philo has in mind must be passionate desire, which Moses' dietary regulations are designed to eliminate.

${ }^{179}$ Cf. Gemünden, "Culture des Passions," 341: "[L]es homes imparfaits doivent lutter, ils doivent faire des efforts pour avancer (Her. 275). Dans cette lutte, c'est surtout le logos qui combat les passions. Pour cette lutte, le prokoptôn doit se référer à la philosophie et à la Loi. Cette dernière peut éteindre par exemple le désir (epithumia), comme Philon le démontre dans De specialibus Legibus IV, 118 au sujet des lois alimentaires qui peuvent éteindre le désir 
strained notion of man-eaters being delicious (\$103-104). Otherwise, he offers strictly symbolic interpretations of the various clean and unclean species, avoiding any sort of claim about how they actually taste. He discontinues the symbolic mode when he gets to the legislation concerning birds, but instead of interpreting that legislation in light of his claim about delicious fare, he offers no interpretation at all. So Philo hardly succeeds in demonstrating a systematic tendency on Moses' part to designate delicious animals "unclean" in an effort to combat passionate desire.

But in §§100-118 Philo does succeed in promoting the broader expository agenda he brings to all of the dietary laws, despite his failure to unite the laws of clean and unclean animals under one interpretive claim. In other words, Philo finds a way of making this subset of the dietary laws speak to issues of $\dot{\varepsilon} \pi \imath \theta u \mu i \alpha$, $\dot{\varepsilon} \gamma \kappa \rho \alpha ́ \tau \epsilon \iota \alpha$, and $\ddot{\sigma} \sigma \kappa \eta \sigma \iota \varsigma$, confirming their essential relation-as species to genus - to the Tenth Commandment's prohibition of desire. In particular, he shows how the Mosaic legislation on clean and unclean species, with almost perfect consistency, addresses the problem of $\ddot{\alpha} \mu \epsilon \tau \rho \circ \varsigma \dot{\varepsilon} \pi \imath \theta v \mu i \alpha$ by posing the solution of $\dot{\varepsilon} \gamma \kappa \rho \alpha \dot{\alpha} \tau \epsilon \iota \alpha$ acquired through $\ddot{\alpha} \sigma \kappa \eta \sigma \iota \varsigma .{ }^{180}$ The prohibitions of pork and scaleless sea creatures of course support not only Philo's specific thesis for

«comme un feu auquel on refuse du bois»." Note fire imagery also in Spec. 4.83; Decal. 150, 173 (cf. Fug. 158; Mos. 2.58; Sobr. 43; Congr. 55; Provid. 2.40).

${ }^{180}$ With two significant exceptions: the laws regarding rumination and split hooves (§§106-109) and the laws governing birds (§§116-117). In the case of rumination, Philo does the best he can, turning the interpretation toward his exegetical agenda by highlighting the role of 
$\S \S 100-118$ but also his general thesis about the dietary laws overall, since the consistent avoidance of excessive pleasure fosters a lifestyle of $\dot{\varepsilon} \gamma \kappa \rho \dot{\alpha} \tau \epsilon \iota \alpha$, which accepts only rational (moderate) indulgences of $\dot{\varepsilon} \pi \imath v u \mu i \alpha$. The prohibition of land carnivores promotes $\dot{\varepsilon} \gamma \kappa \rho \alpha ́ \tau \epsilon \iota \alpha$ through a similar mechanism, even though no one-including Philo—considers the meat of such animals especially tasty. Philo ascribes a symbolic function to all of the other regulations, explaining how the designations "clean" and "unclean" respectively either commend $\dot{\varepsilon} \gamma \kappa \rho \alpha \dot{\alpha} \tau \iota \alpha$ and $\ddot{\alpha} \sigma \kappa \eta \sigma \iota \varsigma$ or condemn the excessive indulgence of $\dot{\varepsilon} \pi \imath \theta u \mu i \alpha$, quite apart from the palatability of the animals involved.

$$
\S \S 119-121: \text { Dead Animals }{ }^{181}
$$

[§119] In other regulations concerning food, Moses commands the avoidance of dead animals, whether dead by natural causes or savaged by a predator. As the second prohibition suggests, a human being should not dine with wild beasts, all but feasting with them on their meal of flesh. As for the first prohibition, there seem to be at least two possible reasons. To begin with, eating a creature dead by natural causes is harmful and likely to cause disease, since the vital fluid of the creature has died inside the body along with the blood. Also, a creature already claimed by death should be left untouched out of respect for the forces of nature to which it succumbed. [\$120] Now, great hunters, the kind trained as expert marksmen who down their prey with rarely a miss, receive praise from most lawgivers among Greeks and barbarians. Such men boast in their successful exploits, especially when they share some of the catch with the dog handlers and even with the dogs themselves. They are praised for their character, as men who are not only brave but also generous. But the architect of our sacred commonwealth would obviously condemn such behavior, having forbidden outright the consumption of animals either dead by natural causes or-as applies in this case-savaged by a predator, for the reasons previously stated. [\$121] Suppose, however, one

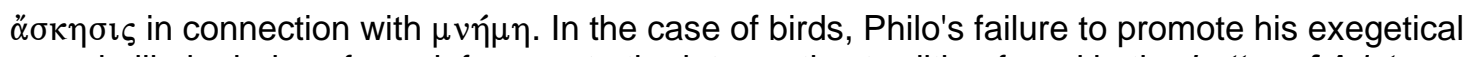
agenda likely derives from deference to the interpretive tradition found in the Letter of Aristeas.

${ }^{181}$ See Exod 22:30; Lev 17:15; Deut 14:21. 
of our commonwealth's athletes of virtue becomes fond of physical training and the hunt, ${ }^{182}$ expecting in this way to undergo exercises and preparations for wars and dangerous engagements with his enemies. Whenever he has a successful expedition, he should simply give the catch to his dogs for them to feast on, as a payment or prize for their courage and impeccable service. He himself should never even touch the dead animals, so as to learn in his dealings with non-rational creatures a proper attitude toward human enemies. In particular, he should never do battle with them in order to gain something he does not already own, which is the business of robbers, but in an effort either to avenge past wrongs or to deal with ones he considers imminent.

As part of an overarching thesis for $\S \S 100-118$, Philo claimed that Moses prohibited animals yielding delicious meats in order to promote $\dot{\varepsilon} \gamma \kappa \rho \alpha ́ \tau \epsilon \iota \alpha$, but his discussion in §§119-121 of animals dead from either natural causes $(\theta v \eta \sigma \iota \mu \alpha \hat{\imath} \nu v)$ or violent attack $(\theta \eta \rho \imath \alpha ́ \lambda \omega \tau o v)$ clearly requires a different approach. ${ }^{183}$ Since these prohibitions presume edibility under different circumstances of death, they must involve only the moderately tasty "clean" animals, whose demise from old age, disease, or mauling can only make them less appetizing. Philo can no longer broach the topic of moral psychology, as he did earlier, by analyzing the dietary laws in terms of the pleasure (jंoví) certain

${ }^{182}$ Suppose, however, one of our commonwealth's athletes of virtue becomes fond of

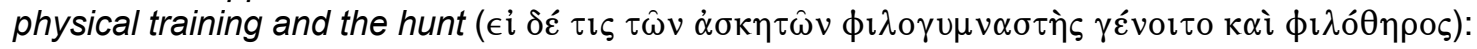
Philo considers the case of a moral athlete ( $\tau \imath \varsigma \tau \hat{\omega} \nu \dot{\alpha} \sigma \kappa \eta \tau \hat{\omega} v)$ who becomes enamored of

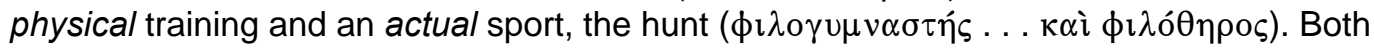
Heinemann and Mosès read the passage in this way: "Wenn aber ein tugendbeflissener Mann auch Freund von Körperübungen und Jagd ist"; "Et si tel athlète de la vertu est aussi un amateur des exercices physiques et de la chasse"). Colson does not identify $\tau \imath \varsigma \tau \hat{\omega} v \dot{\alpha} \sigma \kappa \eta \tau \hat{\omega} \nu$ with a

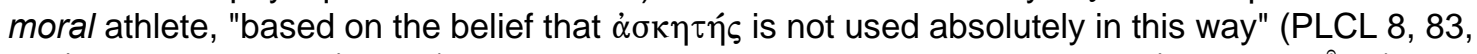

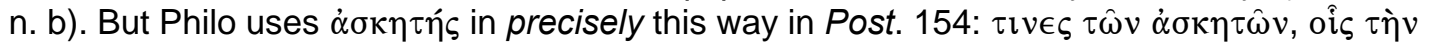

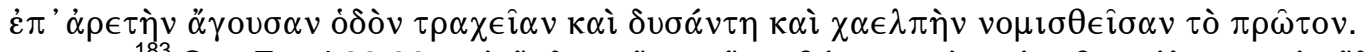

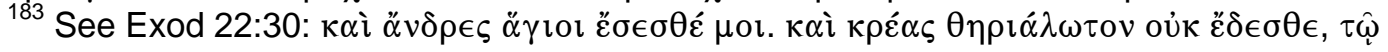

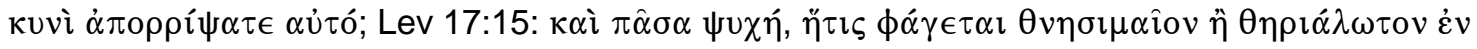


animals afford when eaten. In fact, nothing in his initial explanation of why Moses prohibited the $\theta v \eta \sigma \iota \mu \alpha i ̂ v$ and the $\theta \eta \rho \iota \alpha ́ \lambda \omega \tau o v(\S 119)$ speaks at all to the issues of $\dot{\varepsilon} \pi \imath \theta u \mu i \alpha, \dot{\varepsilon} \gamma \kappa \rho \alpha \dot{\tau} \tau \imath \alpha$, and $\ddot{\alpha} \sigma \kappa \eta \sigma \iota \varsigma$ raised elsewhere in his exposition. To create a connection between these two prohibitions and his exegetical agenda, Philo uses a convoluted bit of legal reasoning to derive from them a brand new prohibition, found nowhere in the Pentateuch, which in his view counts as an exercise in $\dot{\varepsilon} \gamma \kappa \rho \alpha ́ \tau \epsilon \iota \alpha$.

Philo contrasts Greek and barbarian lawgivers, who praise the generosity of expert huntsmen who share the catch even with their hounds ( $\left.\sigma \kappa u ́ \lambda \alpha \xi_{\imath}\right)$, with Moses, who presumably would find fault with such a practice based on his

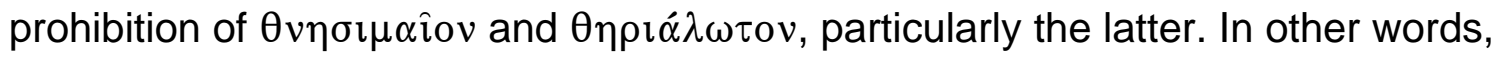
Moses' prohibition of mauled animals ( $\theta \eta \rho \imath \alpha \dot{\alpha} \omega \tau \tau \nu)$, which Philo characterized in

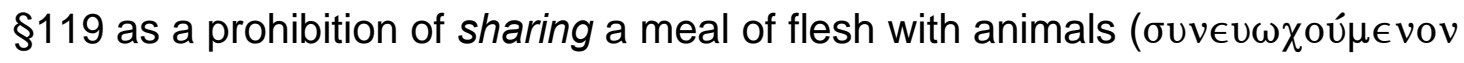
$\tau \alpha \hat{\imath} \varsigma \sigma \alpha \rho \kappa о \phi \alpha \gamma i \alpha(\varsigma)$, would forbid a hunter from sharing with his dogs. But Philo still has no clear application to moral psychology, so he poses yet another scenario, which holds at best a tertiary relation to Moses' original prohibition of $\theta \eta \rho \iota \alpha ́ \lambda \omega \tau$ ov. Suppose, says Philo, someone fond of training becomes an avid hunter ( $\phi \imath \lambda o ́ \theta \eta \rho \circ \varsigma)$, in order to train for warfare. ${ }^{184}$ Philo suggests that such

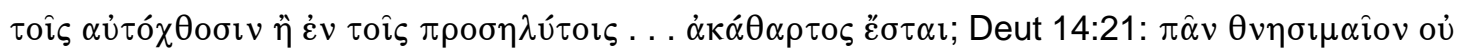
$\phi \dot{\alpha} \gamma \epsilon \sigma \theta \epsilon ;$ cf. Lev 5:2; 11:39-40, 22:8.

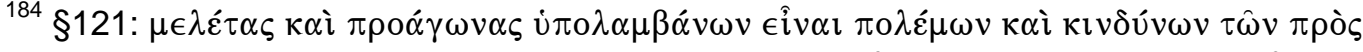
$\dot{\varepsilon} \chi \theta \rho o u ́ c$. In other words, Philo poses the very specialized case of someone who hunts not for food, but for martial training. 
hunters should not even touch their dead quarry ( $\mu \grave{\eta} \psi \alpha \nu \varepsilon ́ \tau \omega)$, but simply give the dogs a well-deserved feast. And because he characterized the hunt as strictly a preparation for warfare, Philo can interpret the practice of abstaining from the catch in a brand new way, which does not involve the condition of the deceased animal(s) but does_-at long last-involve the moral condition of the hunter.

By avoiding all contact with the dead quarry, the hunter as moral agent learns through practice with animal opponents to battle human enemies not for

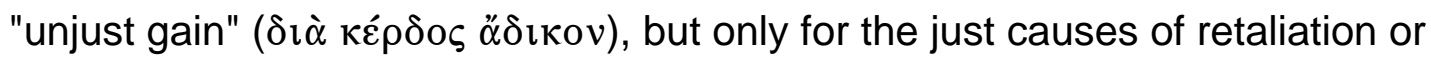
preemptive self-defense. Since he has painstakingly managed to cast the law of

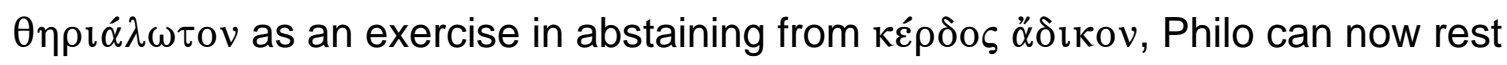
assured of its relevance to moral psychology and the management of $\dot{\varepsilon} \pi \imath u \mu i \alpha$, though he chooses not to explore that relevance in detail. Elsewhere, however,

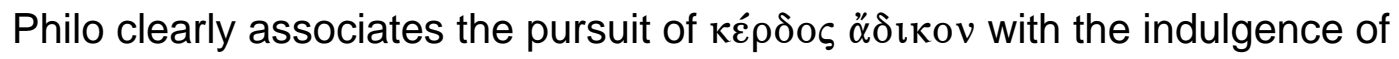
passionate desire, with a failure to limit $\dot{\varepsilon} \pi \imath \theta v \mu i \alpha$ properly, particularly in his interpretation of the law against sowing more than one type of seed in a vineyard. ${ }^{185}$ Trying to get more than one crop from one piece of land represents an act of egregious avarice. ${ }^{186}$ Whoever makes the attempt incites unjust desires

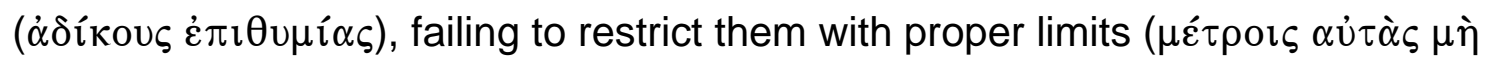

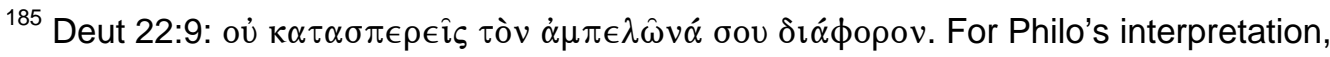
see esp. Spec. 4.212-18.

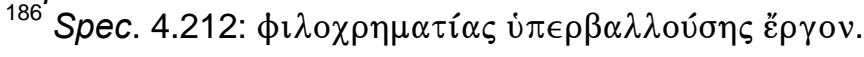




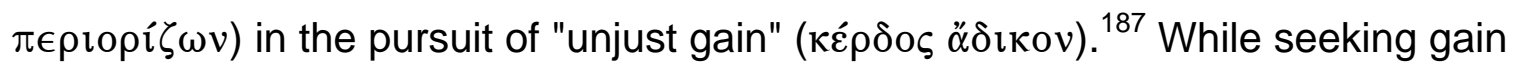
from one crop represents a just and reasonable course of action, seeking more represents an overstepping of reason's authority on the part of desire. Philo's case of the just warrior suggests a similar dynamic: while going to war for a just cause represents a reasonable course of action, going to war for gain represents a triumph of $\dot{\varepsilon} \pi \imath \theta u \mu i \alpha$ over $\lambda o ́ \gamma o \varsigma$, since the violence no longer bears justification on rational grounds. ${ }^{188}$ So in Philo's mind, a hunter training for battle who gives his catch to the dogs not only obeys a semblance of Moses' prohibition of $\theta \eta \rho \imath \alpha ́ \lambda \omega \tau o v-h e$ also, more importantly, is training himself in going to war with a rational motivation, not a motivation based on $\dot{\varepsilon} \pi \imath \theta u \mu i \alpha$. And by encouraging the dominance of reason over desire, such training promotes $\dot{\varepsilon} \gamma \kappa \rho \alpha ́ \tau \epsilon \iota \alpha$.

$$
\S \S 122-125: \text { Blood and Fat }{ }^{189}
$$

[§122] Of course, some devotees of Sardanapalus, greedily extending their ever dainty lack of self-control beyond all bounds and limits, cleverly devise new kinds of pleasure. For their culinary delight, they prepare meat unfit for any sacrifice by strangling and choking the animals to death. In this way, they entomb the blood, the essence of the soul, within the body - blood that should have been liberated and released from the body. They should be content to enjoy the flesh alone, without touching anything akin to the soul. [\$123] This explains Moses' decision to legislate elsewhere concerning blood, as he does when he prohibits the consumption of both blood and fat. Blood is prohibited for the reason I mentioned: it is the essence of the soul. I do not mean the intelligent and rational soul, but the soul that operates through the senses-the soul that

\footnotetext{
${ }^{187}$ Spec. 4.217-18.

${ }^{188}$ Philo suggests in $\S 121$ that those who go to war for unjust gain essentially engage in

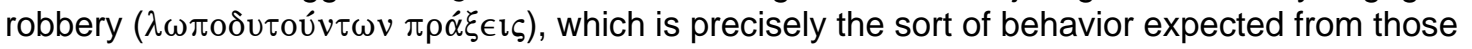

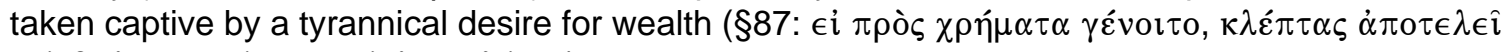

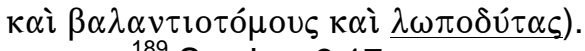

${ }^{189}$ See Lev 3:17.
} 
provides both to us and to non-rational animals the same capacity for life in the sensible world. But the essence of the other type of soul is divine spirit, especially from Moses' perspective. In his account of the creation of the world, Moses states that God infused the first man and founder of our race with a "breath of life" into his "face," the most commanding part of the body, where the senses are stationed like an entourage for the mind as for a great king. Clearly, what God infused was ethereal spirit, and, if you will, something better than ethereal spirit: an effulgence of the blessed, the triply blessed, Nature. [\$124] As for the fat of the animal, Moses prohibits its consumption because it is most succulent. Here again he wants to teach self-control and zeal for an austere life-a life that forgoes what is easiest and convenient and instead endures voluntarily the mental efforts and other labors needed to acquire virtue. [\$125] For this reason, the blood and the fat are taken from every sacrificial animal and given as a whole burnt offering, as a sort of first fruits. The blood is poured out onto the altar as a drink offering, while the fat, on account of its richness, is brought instead of oil to fuel the flame of the sacred and holy fire.

Philo now turns to the prohibitions of blood and fat, taking first the prohibition of blood (§§122-123). ${ }^{190}$ In the case of unclean animals, Philo cast the dietary laws as exercises in '̇ं $\gamma \rho \alpha \dot{\tau} \tau \epsilon \iota \alpha$ by presuming to identify Moses' tacit rationale for prohibiting certain species-the pig, for example, tastes delicious and incites $\dot{\varepsilon} \pi \imath \theta u \mu i \alpha$, and Moses prohibits the pig for that reason. In the case of blood, however, Philo must account for a dietary prohibition whose explicit rationale has little or nothing to do with $\dot{\varepsilon} \pi \imath \theta u \mu i \alpha$, $\dot{\varepsilon} \gamma \kappa \rho \dot{\alpha} \tau \epsilon \iota \alpha$, or $\ddot{\alpha} \sigma \kappa \eta \sigma \imath \varsigma$. Moses instead forbids blood because of its unique relation to the soul $(\psi v \chi \eta) \cdot{ }^{191}$ But despite biblical data at odds with his expository agenda, Philo still broaches the topic in terms of moral psychology, characterizing the consumption of blood as one of the

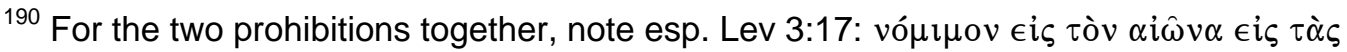

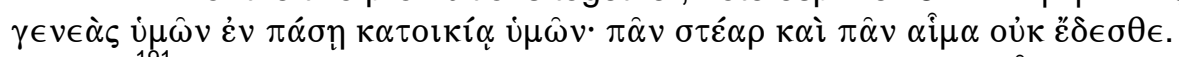

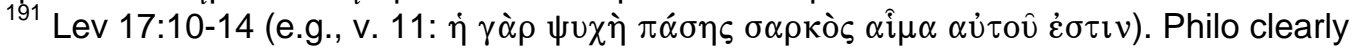

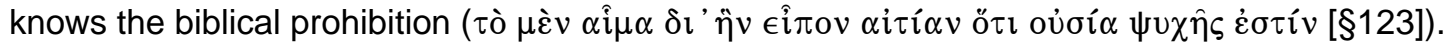


decadent pleasures ( $\dot{\eta} \delta$ ovás) enjoyed by some "Sardanapalus types" $(\Sigma \alpha \rho \delta \alpha \nu \alpha \dot{\pi} \alpha \lambda \lambda \mathrm{\jmath}) \cdot{ }^{192}$ These people strangle the animals they eat, "entombing" the blood within the body, and so demonstrate an egregious, effeminate lack of self-control. ${ }^{193}$ The reprehensible luxury of such a practice lies in its being done strictly for the sake of pleasure by those unwilling to content themselves with the more reasonable indulgence of eating only the flesh drained of blood. ${ }^{194}$ So Philo effectively frames the prohibition of blood as a deterrent to passionate desire, deploying the same $\lambda o ́ \gamma o \varsigma-\dot{\varepsilon} \pi \imath \theta v \mu i \alpha$ dynamic that informs his exposition of the laws of clean and unclean animals. He implies that reason, imposing proper measure ( $\mu \dot{\varepsilon} \tau \rho o v$ ) on $\dot{\varepsilon} \pi \imath \theta u \mu i \alpha$, would in fact endorse the eating of meat properly

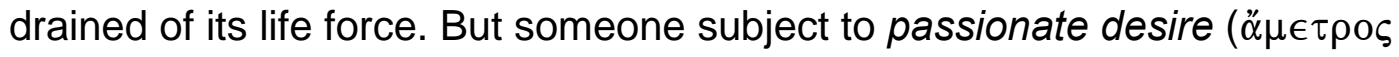
$\dot{\varepsilon} \pi \imath \theta u \mu i \alpha)$, acting on the basis of desire's motivation for pleasure, oversteps this reasonable limit in order to enjoy the delectable but unreasonable indulgence of blood-infused meat. By avoiding such meat, the moral agent learns by practice

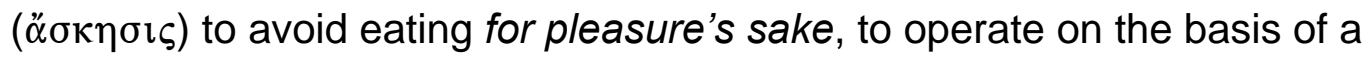
rational motivation, and to develop the moderate lifestyle possessed of $\dot{\varepsilon} \gamma \kappa \rho \alpha ́ \tau \epsilon \iota \alpha$. Of course, Philo must acknowledge, as he clearly does, that Moses did not have the pleasures of blood in mind when he made the prohibition, but

192 On Sardanapalus, see $\$ 102$.

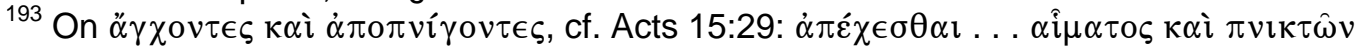
(see A. J. M. Wedderburn, "The 'Apostolic Decree': Tradition and Redaction," NovT 35 [1993], 362-89, esp. 366-68).

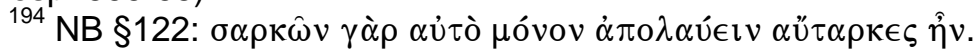


rather its property of kinship with the soul. But Philo cannot limit his commentary to the biblical data without losing the overall thrust of his exposition, which programmatically seeks to draw some connection between the individual dietary laws and the management of $\dot{\varepsilon} \pi \imath \theta \mu i^{\alpha} \alpha$. And Philo does draw the connection-in fact, he highlights it by discussing it first. Although the "Sardanapalus types" Philo mentions ought to abstain from blood primarily because it carries life, they clearly would also derive the secondary benefit of a more moderate lifestyle. And followers of Moses, who would first avoid the meat of strangled animals because it still contains the essence of life, nevertheless derive the same benefit of eliminating a dangerously titillating food from their diet.

The Mosaic prohibition of fat, by contrast, perfectly suits Philo's expository agenda, since it corresponds exactly to the prohibition of pork in its theoretical mechanism. ${ }^{195}$ As Philo explained in §100, Moses prohibited animals, like the pig, whose flesh is "most succulent" ( $\pi$ ló $\tau \alpha \tau \alpha)$, knowing that abstinence from delectable fare facilitates proper management of $\dot{\varepsilon} \pi \imath \theta \mu i \alpha$. Echoing these remarks, Philo attributes the prohibition of fat ( $\tau$ ò $\sigma \tau \varepsilon \dot{\varepsilon} \alpha \rho)$ to its being "most succulent" ( $\pi \imath o ́ \tau \alpha \tau o v)$, noting that Moses here "again" ( $\pi \alpha \dot{\lambda} \lambda \imath v)$-with this dietary restriction-offers a lesson in self-control ( $\delta \imath \delta \alpha \sigma \kappa \alpha \lambda i \alpha \nu \dot{\varepsilon} \gamma \kappa \rho \alpha \tau \epsilon i \alpha \varsigma)$. By abstaining from fat, the moral agent learns to reject the life of luxury, which pursues pleasure for pleasure's sake at the prompting of $\dot{\varepsilon} \pi \imath \theta u \mu i \alpha$. Of course,

${ }^{195}$ Noted also by Heinemann, Bildung, 163. 
the life of $\dot{\varepsilon} \gamma \kappa \rho \alpha \dot{\tau} \tau \iota \alpha$, which pursues only necessities at the prompting of reason,

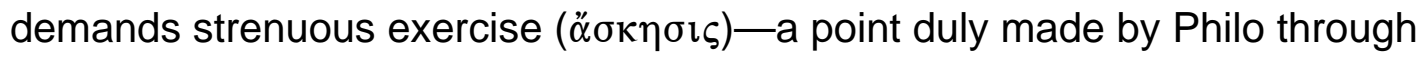
deployment of the agon motif. In particular, the command to abstain from fat

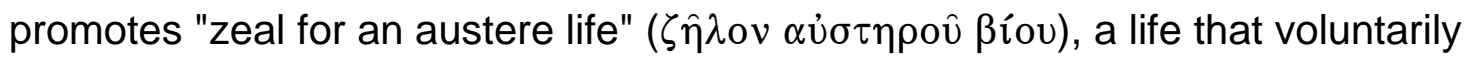

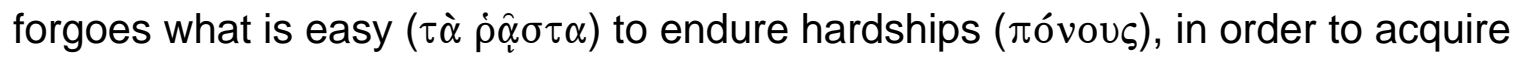

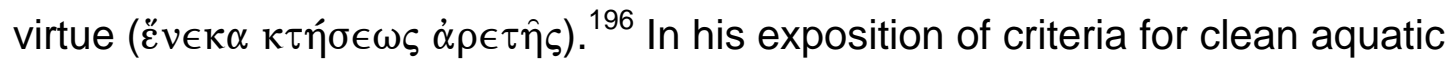
creatures (\$112), Philo deployed the same figure in the same way, contrasting

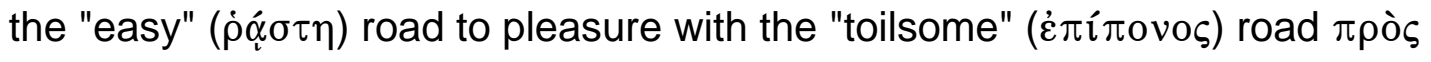
$\dot{\varepsilon} \gamma \kappa \rho \alpha ́ \tau \epsilon \iota \alpha \nu$.

$$
\S \S 126 \text { - 131: Concluding Moral Narrative }{ }^{197}
$$

[§126] Finally, remember that Moses condemns some of his contemporaries as gluttons, as people who consider the experience of pleasure to be the pinnacle of happiness. A luxurious life in the city was not enough for them, where the supplies and provisions for all their necessities were inexhaustible. They wanted the same thing in the desolate, trackless wilderness, expecting to find vendors of fish, meat, and every kind of seasonable produce. [\$127] When scarcity did come, they joined forces in shouting down, denouncing, and disparaging their leader with shameless audacity. And they did not stop their revolt until they got what they wanted. Their demands were met for two reasons: first, to show that all things are possible for God, who finds a way in the midst of impossible and irresolvable situations; second, to punish the people, who were slaves of their belly and shirkers of holiness. [\$128] As the story goes, a great cloud of quail, swept in from over the sea, poured out of the sky at dawn. So thick was this mass of birds that the encampment and the surrounding area-in every direction, as far as a fit man could walk in a day - were overshadowed. In addition, they were flying only a few feet off of the ground, which made them easy to capture. [\$129] Now, you would

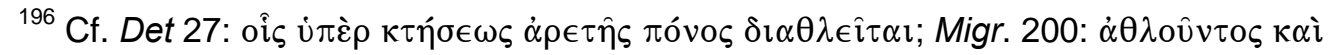

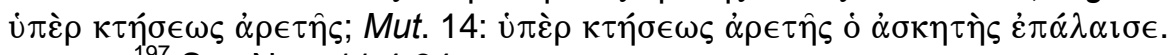

${ }^{197}$ See Num 11:4-34. 
think that the people, struck with amazement by such a marvelous demonstration of power on God's part, would have been satisfied simply with what they saw-that filled with reverence, and amply fed by reverence ${ }^{198}$ they would have abstained from eating any of the meat. Instead, goading their desire to an even greater pitch, they went after what seemed to them the greatest possible good fortune. Raking in the quail with both hands, they packed the folds of their garments. Storing those birds away in their tents, they went back outside to catch others, demonstrating that greedy cravings for more have no limit. Preparing their game in a variety of ways, they gorged themselves insatiably, about to be destroyed — the fools—by their bloat. [§130] And, in fact, they did perish before long in a pool of noxious discharges. So in keeping with the passion that destroyed them, that place was named "Tombs of Desire." Clearly, as our story teaches, there is no evil in the soul greater than desire. [\$131] Taking all of this into consideration, we can admire what Moses so admirably says in his exhortations, "Let no one do what is pleasing in his own sight." He is saying, in effect, "Let no one indulge his own desire." If a person expects to become truly noble, let him be pleasing to God, the world, Nature, laws, and wise men by rejecting the love of self.

At §126, Philo abruptly turns from his serial treatment of discrete dietary laws to a moralized retelling of God's provision of quail to the Israelites in the wilderness. Philo's narrative ends in $\S 130$ with an explicit statement of what the story ultimately teaches: that "there is no greater evil ( $\mu \in \hat{\imath} \zeta o v \kappa \alpha \kappa o ́ v)$ in the soul than desire. ${ }^{199}$ This sweeping indictment of $\dot{\varepsilon} \pi \imath \theta u \mu i \alpha$ clearly resembles earlier

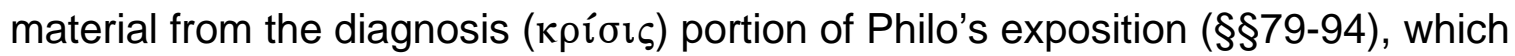
sought above all to illustrate the reprehensible nature and harmful effects of

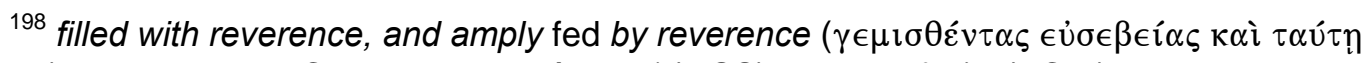

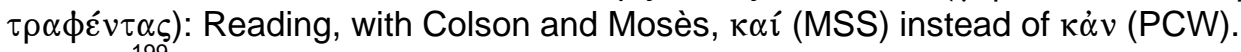

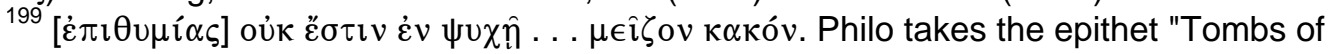

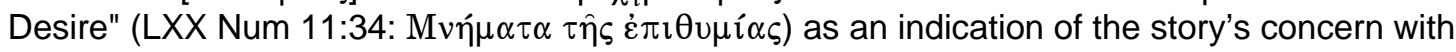
the passion $(\pi \dot{\alpha} \theta \circ \varsigma)$ desire (§130). Cf. Philo's comments on Num 11:4 in Migr. 155, esp. his

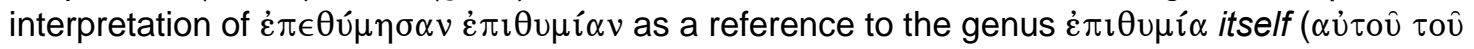

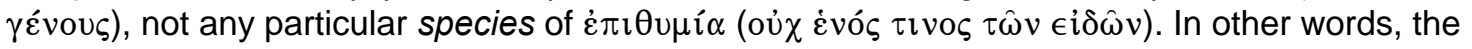
story from Numbers speaks in Philo's view to more than just gastric desire, and for this reason it 
desire, particularly of its most egregious manifestation, tyrannical desire ( $\left.\varepsilon^{\prime} \rho \omega \varsigma\right)$. Insofar as the material in $\S \S 126-130$ serves to depict tyrannical desire in a negative light, it too bears analysis as part of Philo's diagnosis, although it appears at the very end of his exposition.

Philo undoubtedly sees tyrannical desire as the distinct manifestation of $\dot{\varepsilon} \pi \imath \theta v \mu i \alpha$ at work in the people's clamoring for meat and later gorging themselves with quail. In particular, they suffered from tyrannical desire affecting the belly, which turned them into "gluttons" (§126: $\gamma \alpha \sigma \tau \rho \iota \alpha \dot{\rho} \rho \gamma o u \varsigma)$, the very effect Philo described as part of the exposition's first and more extensive diagnosis. ${ }^{200}$ But despite the incidental involvement of the stomach as the sphere of desire's influence, the real issue —as with any instance of tyrannical desire-is the involvement of the rational faculty, in particular its being overthrown by desire, which results in the moral agent designating pleasure as "the good." As

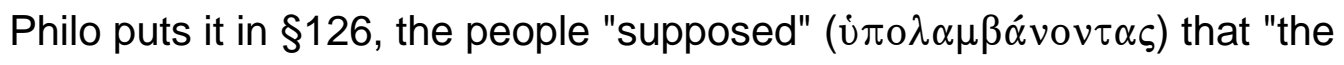

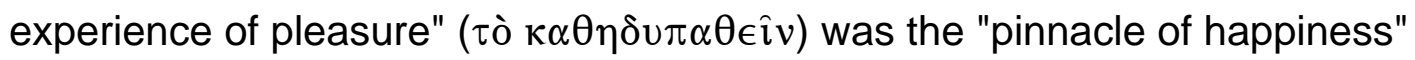

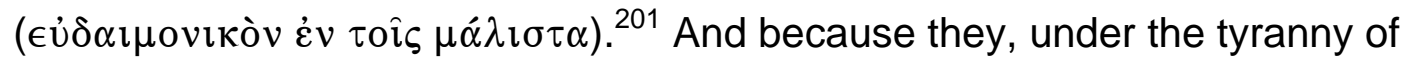
$\dot{\varepsilon} \pi \imath \theta u \mu i \alpha$-turned-ह̌ $\rho \omega \varsigma$, sought the experience of pleasure per se, instead of a clear, rational objective such as maintaining life, their desire for meat had no limit 
$(\mu \varepsilon \dot{\tau} \rho \circ)$ ) ${ }^{202}$ They literally ate themselves to death, illustrating the destruction attending tyrannical desire. ${ }^{203}$ Consistent with the generic aims of a "diagnosis"

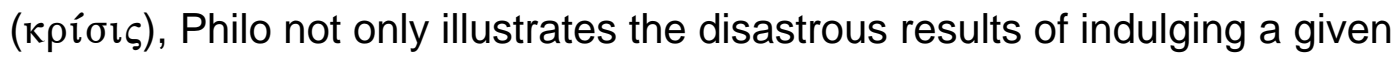
passion (in this case, $\dot{\varepsilon} \pi \imath \theta u \mu i \alpha$ ), but also emphasizes the morally reprehensible nature of such indulgence. ${ }^{204}$ In this way, $§ \S 126-130$ essentially restate the case made in §79-94, but through a biblical narrative rather than a philosophical discourse. This change in literary vehicle allows Philo to explore for the first time the relation between $\dot{\varepsilon} \pi \imath \theta v \mu i \alpha$ and piety—a relation he only hinted at in $\S 97$, when he claimed that observance of the dietary laws leads not only to $\dot{\varepsilon} \gamma \kappa \rho \dot{\alpha} \tau \in \iota \alpha$

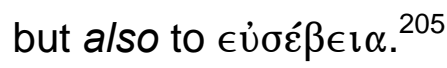

Philo's retelling of Numbers 11:4-34 portrays the states of tyrannical desire and piety as radically incompatible, if not mutually exclusive. He recognizes two distinct breaches of piety within the story, and both stem from the hegemony of desire within the soul. First, because tyrannical desire compelled Moses' followers to seek pleasure per se, they unreasonably craved—and demanded-the luxury of meat in a trackless desert. In Philo's view, this made

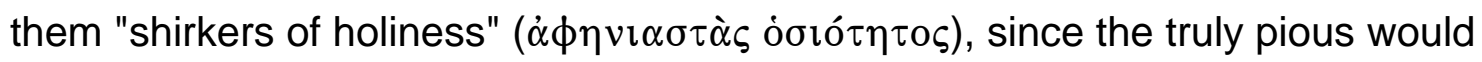

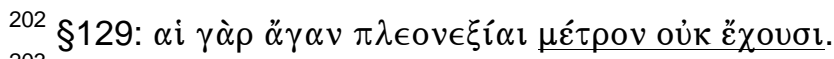

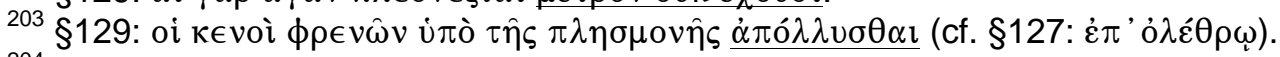

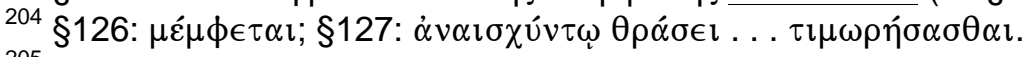

205 On Philo's understanding of $\epsilon \dot{\sigma} \sigma \varepsilon \hat{\beta} \in 1 \alpha$ ("piety"), see esp. Sterling, "'Queen of the

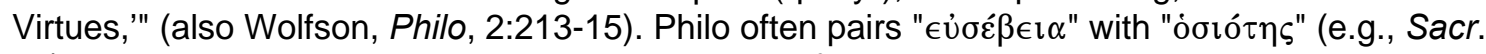
37). The two terms are practically synonymous, insofar as they both denote piety in a general sense (Sterling, "QQueen of the Virtues," 113: "Philo used the two terms as virtual synonyms to refer to the human response to and perception of God."). 
have gratefully sated their necessary desires for food with the manna God provided. ${ }^{206}$ Second, after God's miraculous provision of quail the people ought to have abstained from eating any meat, getting instead a nourishing fill of piety

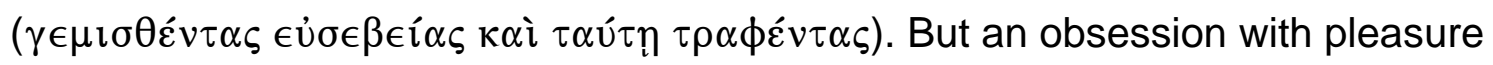
kept them from properly recognizing both the provision and the power of Godthey were unable to see any greater good beyond their own myopic indulgence of $\dot{\varepsilon} \pi \imath \theta u \mu i \alpha$. In other words, as the story illustrates, those ruled by $\dot{\varepsilon} \pi \imath \theta u \mu i \alpha$ cannot count anything or anyone, including God, as more valuable than their personal experience of pleasure ( $\dot{\eta} \delta \circ v \eta$ ), since $\dot{\varepsilon} \pi \imath \theta u \mu i \alpha$ compels them to

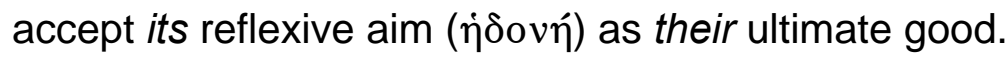

Philo concludes his analysis of the quail narrative, and his entire exposition of the Tenth Commandment, with a brief reflection on Deuteronomy 12:8, which he paraphrases as, "Let no one do what is pleasing in his own sight." ${ }^{207}$ To make the passage more directly relevant to both the biblical story

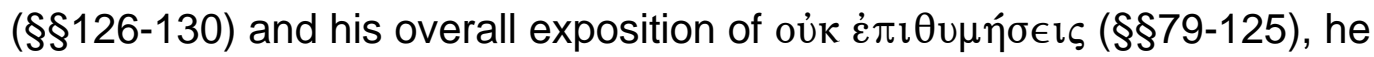
interprets its meaning as, "Let no one indulge his own desire ( $\left.\dot{\varepsilon} \pi \imath u \mu i_{\llcorner} \alpha\right) . " 208$

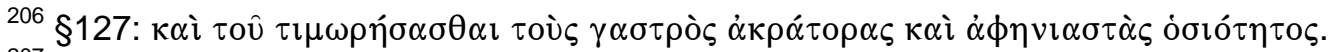

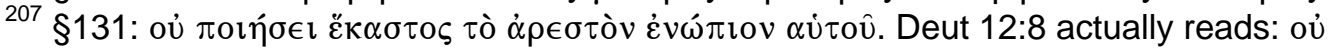

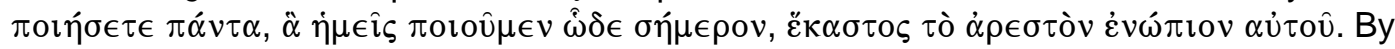
opening $\S 131$ with $\delta$ ió, Philo signals a logical connection with the preceding narrative, which began in §126. §§126-131 stand as the final text unit in Philo's exposition, since he announces in $\S 132$ the completion of his commentary on laws pertaining to the Tenth Commandment, which in turn signals the end of his entire commentary on the Decalogue: "In these remarks we have discussed the matters relating to desire or lust ( $\tau \hat{\omega} v \in \dot{\epsilon} \zeta \dot{\varepsilon} \pi \imath \theta u \mu i \alpha \nu \dot{\alpha} v \alpha \phi \epsilon \rho o \mu \varepsilon \dot{\varepsilon} v \omega v$ ) as adequately as our abilities allow, and thus completed our survey of the ten oracles, and the laws which are dependent on them."

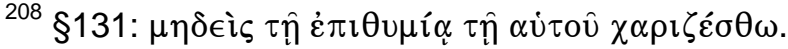


Obviously, such an exhortation applies to the cautionary tale Philo has just related in $\S \S 126-130$, since that indulgence led unmistakably to a shameful, impious death. And just as the exhortation makes sense in light of Philo's biblical "diagnosis" (§§126-130), it makes sense also in light of his earlier philosophical "diagnosis" (§§79-94). In fact, the earlier case against desire represents a more extensive elaboration of the threats to moral and physical well being posed by $\dot{\varepsilon} \pi \imath \theta v \mu i ́ \alpha$, so Philo's version of Deuteronomy 12:8 pertains at least as much to the first (roughly) third of his exposition as it does to the last few paragraphs-if not more.

But Philo apparently intends this simple proscription against indulging desire to conclude his entire exposition of the Tenth Commandment, not just the

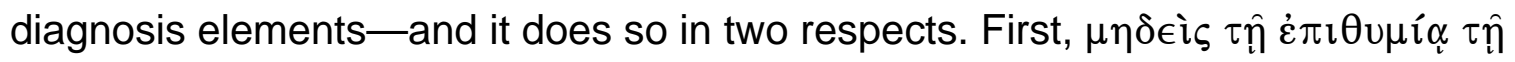

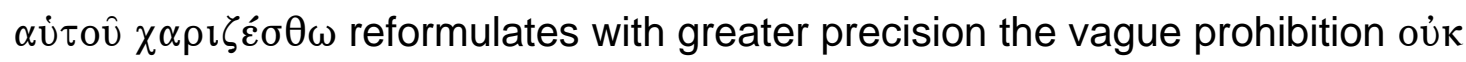
$\dot{\varepsilon} \pi \imath \theta u \mu \eta \dot{\sigma} \sigma \iota \varsigma$, offering the reader a final, more definitive encapsulation of what the Tenth Commandment actually prohibits. When Philo speaks elsewhere of "indulging" desire, or other emotions, he has in mind an indulgence at the expense of reason —in other words, a "giving in" to emotion that signals the overpowering of reason and the moral agent's consequent departure from rational motivation. In los. 153, for example, Philo explains how for the sake of pleasure (desire's aim) the masses disregard virtue (reason's aim) and instead indulge ( $\chi \alpha \rho \imath \zeta o ́ \mu \in v o \imath)$ their "unbridled desires," yielding to whatever those 


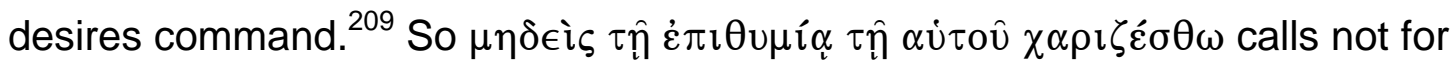
the elimination of desire but for its moderation, for a management of $\dot{\varepsilon} \pi \imath \theta u \mu i \alpha$ that forbids its indulgence beyond the measure set by reason. In other words, Philo takes Moses' Deuteronomy exhortation as a prohibition of passionate

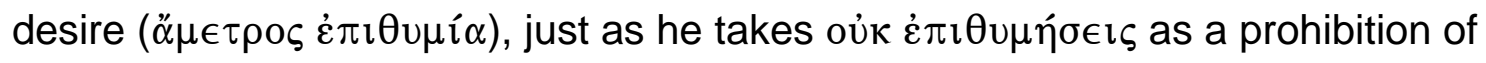
passionate desire ( $\ddot{\alpha} \mu \epsilon \tau \rho \varsigma \varsigma \dot{\varepsilon} \pi \imath \theta v \mu i \alpha)$. So here at the end of his exposition, Philo appropriately offers a compact summary of what he understands the Tenth Commandment to mean in terms of moral psychology. But Philo adds one final thought on what he understands the Tenth Commandment to mean in terms of the overall orientation of the moral agent's life. To indulge one's own desire ( $\imath \hat{\eta}$ $\left.\dot{\varepsilon} \pi \imath \theta u \mu i \alpha_{\iota} \tau \hat{n} \alpha \dot{\tau} \tau o u ̂\right)$, Philo suggests, amounts to a reprehensible love of self

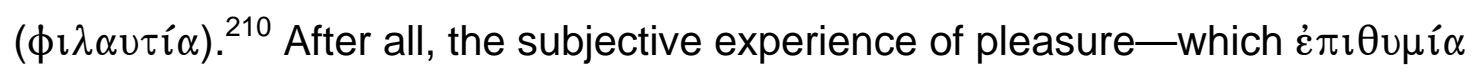
invariably seeks_involves only one person, the self. So valuing pleasure above all other concerns, as those tyrannized by desire must do, truly represents a self-

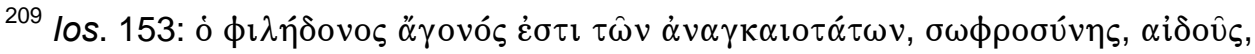

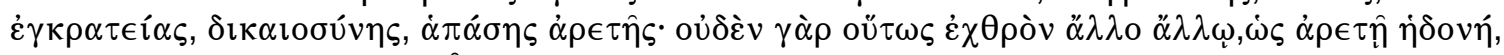

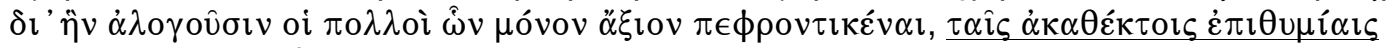

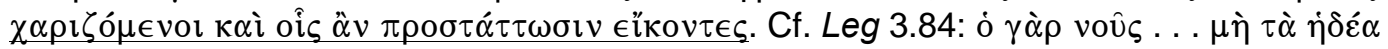

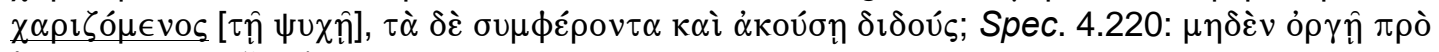

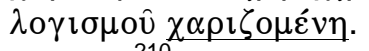

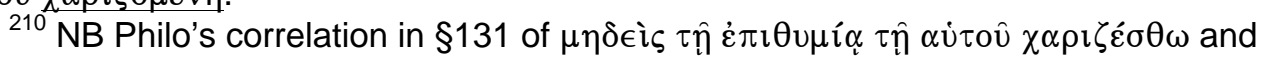
$\phi \imath \lambda \alpha u \tau i \alpha \nu \pi \alpha \rho \alpha \imath \tau o u ́ \mu \epsilon v o \zeta$. On Philo's concept of $\phi \imath \lambda \alpha u \tau i \alpha$, see esp. Frédéric Deutsch, "La philautie chez Philon d'Alexandrie," in Philon d'Alexandrie et le langage de la philosophie (ed. Carlos Lévy; Turnhout: Brepolis, 1998), 87-97; also Walter Warnach, "Selbstliebe und Gottesliebe im Denken Philons von Alexandrien," in Wort Gottes in der Zeit: Festschrift Karl Hermann Schelkle (ed. Helmut Feld and Josef Nolte; Düsseldorf: Patmos, 1973), 198-214. Cf. Pearce, Land of the Body, 149-51. 
centered life, since the chief aim necessarily involves only the self. ${ }^{211}$ Captive to self-interest, the $\phi i ́ \lambda \alpha u \tau o \varsigma$ lacks a proper concern not just for other people, but also for God. ${ }^{212}$ In fact, love of self and love of God represent for Philo two radically opposed and incompatible modes of life. ${ }^{213}$ And by drawing this contrast here at the end of his exposition, Philo revisits and substantiates his earlier claim that Moses' dietary laws lead to self-control $(\dot{\varepsilon} \gamma \kappa \rho \alpha \dot{\tau} \tau \epsilon \iota)$, philanthropy

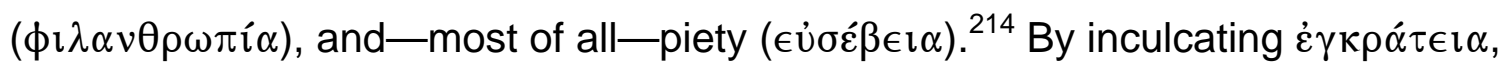
the dietary laws promote observance of the Tenth Commandment, which forbids

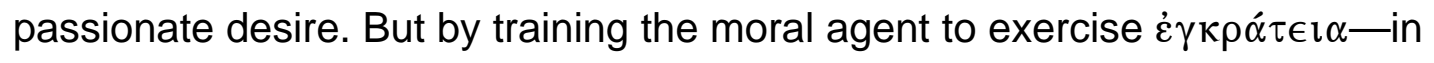
other words, not to indulge in $\dot{\varepsilon} \pi \imath \theta u \mu i \alpha$-those laws also undermine love of self, allowing instead a life of devotion to God.

\footnotetext{
${ }^{211}$ In Post. 180, Philo pairs $\phi \imath \lambda \alpha v \tau i ́ \alpha$ and $\phi \imath \lambda \eta \delta o v i ́ \alpha$, suggesting an equivalence.

${ }^{212}$ Cf. Q.G. unidentified fragments 11 (Marcus) [cf. Petit], which begins, oi $\dot{\varepsilon} \alpha \nu \tau \hat{\omega} v \mu o ́ v o v$

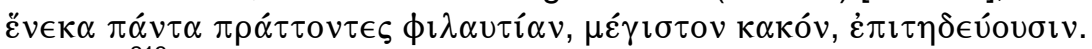

${ }^{213}$ E.g., Spec. 1.344: نं Praem. 12: $\phi \imath \lambda \alpha u \tau i ́ \alpha \nu \pi \rho o ̀ ~ \epsilon u ̉ \sigma \epsilon \beta \epsilon i \alpha \varsigma \alpha \dot{\alpha} \sigma \pi \alpha \sigma \alpha \dot{\alpha} \mu \epsilon v o u$. Allegorically, Philo identifies Abel as the

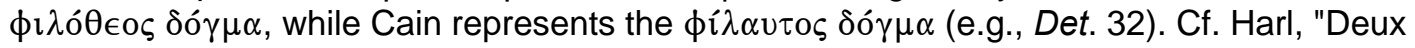
arbres," 379: "[L]'homme est libre d'opter pour l'un ou l'autre movement, pour l'amour de luimême et ce qui est proche de lui, la $\phi \imath \lambda \alpha \nu \tau i \alpha$, , ou au contraire pour l'attitude proprement

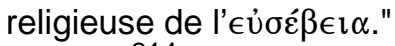

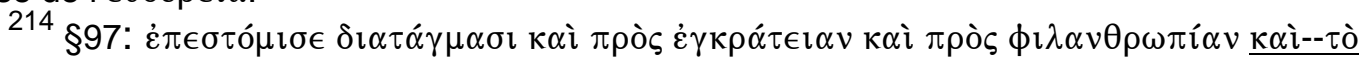

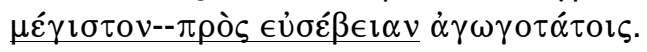




\section{CHAPTER FIVE \\ SUMMARY AND LINES OF FURTHER RESEARCH}

SUMMARY

In the course of larger, systematic exposition of the Decalogue, Philo offers in Spec. 4.78b-131 an extended, detailed exposition of the Tenth Commandment, which he reads—despite its clear biblical formulation as a prohibition of desire for the goods of a neighbor-as a prohibition of desire itself

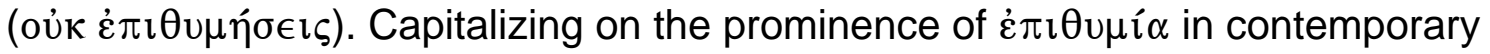
ethical discourse about the "passions" ( $\pi \dot{\alpha} \theta \eta)$, Philo frames his interpretation of the Tenth Commandment along philosophical lines, justifying the prohibition in light of Middle-Platonic conceptions of how desire operates within, and endangers, the human soul. Philo couples this theoretical reflection with a consideration of the Mosaic dietary laws, which in his view fall under the rubric of the Tenth Commandment (as species under genus) and promote its observance by design. This two-part structure-(1) theoretical reflection on a problem $\left(\dot{\varepsilon} \pi \imath \theta \mu i \alpha^{\alpha}\right)$ and (2) practical consideration of a solution (dietary laws)—signals an effort on Philo's part to frame his philosophical exposition of the Tenth Commandment in an appropriately philosophical way: as a "Seelenheilungsschrift," a type of philosophical literature consisting of (1) the 


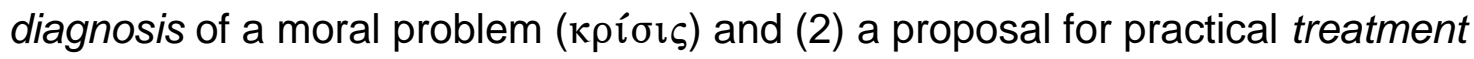

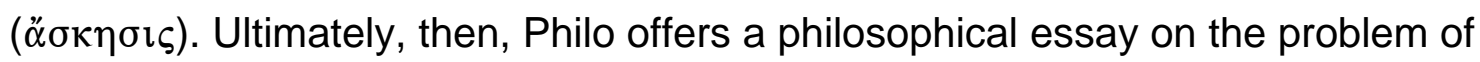
$\dot{\varepsilon} \pi \imath \theta u \mu i \alpha$, but he never loses sight of the biblical warrant for his essay, the simple prohibition oủк $\dot{\varepsilon} \pi \imath \theta u \mu \eta ́ \sigma \in \iota \varsigma$. In fact, by answering the two fundamental questions raised by this prohibition, the essential points of Philo's essay on $\dot{\varepsilon} \pi \imath \theta u \mu i^{\alpha}$ emerge:

1. In Philo's view, what does the Tenth Commandment prohibit? (All desire? A certain type? What type?)

2. In Philo's view, how is the Tenth Commandment observed? (What are the mechanics of its observance? What role do the dietary laws play in its observance?)

The first question deals with Philo's concept of $\dot{\varepsilon} \pi \imath \theta u \mu i \alpha$, especially its problematic malfunction. The second question deals with Philo's concept of

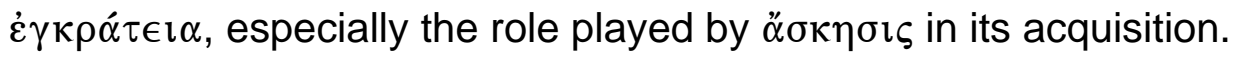

What, then, does the Tenth Commandment prohibit? From a strictly verbal

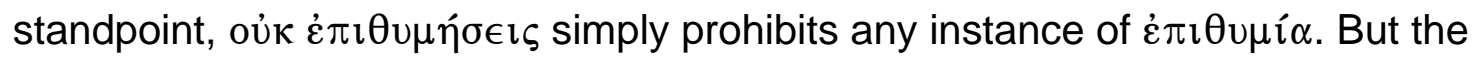
term $\dot{\varepsilon} \pi \imath \theta u \mu i \alpha$ has a fundamental ambiguity in Philo's Middle-Platonic system of thought, due to the ambiguity of the broader rubric $\pi \dot{\alpha} \theta$ os, which designates either an amoral emotion or an immoral passion. In other words, the abbreviated Tenth Commandment offers no clear moral imperative, except in the context of Philo's interpretation. And Philo clearly interprets it as a prohibition of passionate desire, which—by his own definition—means excessive desire ( $\pi \lambda \epsilon$ ová $\zeta o v \sigma \alpha$ 
$\dot{\varepsilon} \pi \imath \theta u \mu i \alpha)$, understood as immoderate desire $(\ddot{\alpha} \mu \in \tau \rho \circ \varsigma \dot{\varepsilon} \pi \imath \theta u \mu i ́ \alpha)$. So the Tenth Commandment prohibits any instance of the non-rational emotion desire

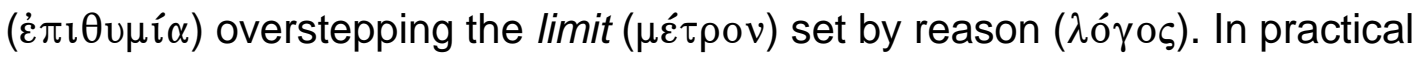
terms, the moral agent violates the Tenth Commandment whenever desire's

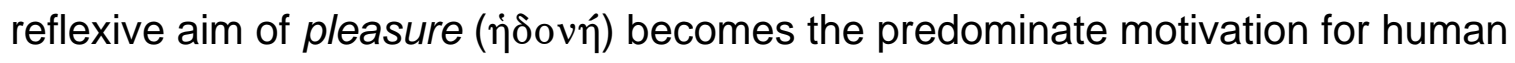
action over against rational considerations such as necessity. By indulging passionate desire in this way, the moral agent not only violates the Tenth Commandment but also risks a much greater ill, tyrannical desire (है $\rho \omega \varsigma)$, which Philo sees as the final ruinous outcome of letting desire usurp reason. From an initial break with reason's hegemony, $\dot{\varepsilon} \pi \imath \theta v \mu i \alpha$ proceeds to overtake the entire soul, including the rational faculty, which tragically sets desire's aim of pleasure as the moral agent's ultimate good. Philo makes such a strong presumption of the eventual progression from passionate to tyrannical desire that his theoretical reflection on the ills of $\dot{\varepsilon} \pi \imath \theta u \mu i \alpha$, in part one of his exposition (the "diagnosis"), deals mainly with the ills of ع̋ $\rho \omega \varsigma$. So despite his explicit identification of oủk

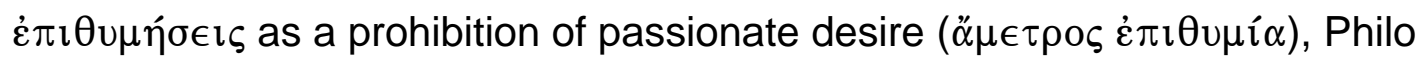
sees it in effect as a preemptive prohibition of tyrannical desire (है $\rho \omega \varsigma)$ as well. And how is the Tenth Commandment observed? Essentially, obedience to the Tenth Commandment requires the exercise of $\dot{\varepsilon} \gamma \kappa \rho \alpha \dot{\tau} \tau \ell \alpha$, since regular enforcement of the dictates of $\lambda o ́ \gamma o \varsigma$ over against $\dot{\varepsilon} \pi \imath \theta u \dot{i} \alpha$ (when the two conflict) precludes the sort of passionate desire prohibited by the injunction oủ 
$\dot{\varepsilon} \pi \imath \theta v \mu \eta \dot{\sigma} \sigma \iota \iota$, while eliminating also the risk of tyrannical desire. In other words, the Tenth Commandment's proscription of $\ddot{\alpha} \mu \epsilon \tau \rho \circ \varsigma \dot{\varepsilon} \pi \imath \theta u \mu i \alpha$ amounts to a prescription of $\dot{\varepsilon} \gamma \kappa \rho \alpha \dot{\tau} \epsilon \iota \alpha$. Moses understood this, so he devised a way of equipping his followers with $\dot{\varepsilon} \gamma \kappa \rho \alpha ́ \tau \epsilon \iota \alpha$, by formulating a set of dietary laws that

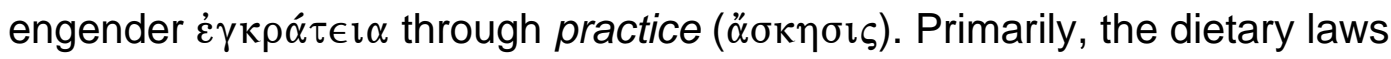
promote $\dot{\varepsilon} \gamma \kappa \rho \alpha ́ \tau \epsilon \imath \alpha$ through specific practical exercises: either the temporary restraint of desire or the avoidance of especially pleasurable foods. The first type of exercise orchestrates a subjugation of desire that increases the moral agent's capacity for $\dot{\varepsilon} \gamma \kappa \rho \dot{\alpha} \tau \in \imath \alpha$-just as weight training builds physical strength and so increases a wrestler's capacity to overthrow an opponent in a contest. The second type of exercise obviates the risk of passionate desire by eliminating incitements to passionate desire—but more broadly it promotes a lifestyle of $\dot{\varepsilon} \gamma \kappa \rho \dot{\alpha} \tau \in \iota \alpha$ by training the moral agent to act from a motive of necessity rather than a motive of pleasure, which amounts to the rule of reason over desire. Secondarily, the dietary laws_-in particular, certain laws regarding clean and unclean animals—symbolize broader ideals and principles of $\dot{\varepsilon} \gamma \kappa \rho \alpha \dot{\tau} \tau \iota \iota \alpha$, reinforcing and promoting the goal of Moses' practical regimen. Taken as one comprehensive program, the dietary laws represent a course of "treatment" for the problem of passionate desire "diagnosed" in part one of Philo's exposition, even though they ostensibly deal only with the desire for food and drink. This apparent limitation actually reveals to Philo the genius of Moses' plan: due to the 
preeminence of this one type of desire among all others, its successful management through $\dot{\varepsilon} \gamma \kappa \rho \dot{\alpha} \tau \in \imath \alpha$ necessarily—a maiore ad minus—entails successful management of any other type of desire.

\section{LINES OF FURTHER RESEARCH}

A detailed study of Philo's exposition of the Tenth Commandment suggests various lines of further research. Citing one desideratum for the respective fields of Philonic studies, Hellenistic Judaism, early Christianity, and Middle Platonism illustrates the range of possibilities.

In order to understand the moral psychology presumed in his exposition of

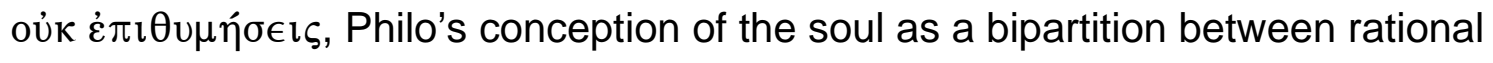
and non-rational parts received considerable attention. The significance of this basic, bipartite model lies in its ability to accommodate every other model of the soul Philo cites. In other words, Philo does not endorse different—even contradictory-models of the soul according to exegetical necessity. He instead endorses one model of the soul, which he then cites ad hoc in various equivalent formulations. ${ }^{1}$ The idea of Philo's having just one coherent model of the soul should be further tested and either confirmed or discarded. Settling the issue in favor of one model would provide a helpful framework for further research.

Philo's exposition relates also to Hellenistic Judaism broadly, especially the issue of Alexandrian exegetical traditions. Philo undoubtedly reworks a

${ }^{1}$ Cf. Dillon, Middle Platonists, 174-75, on Philo's reference to different soul divisions: "This is not chaotic eclecticism ....; for Philo each of these divisions expresses some aspect of the truth, but the most basic truth remains the division into rational and irrational." 
prominent traditional interpretation of clean and unclean winged creatures from the Letter of Aristeas to suit his own exegetical agenda. With respect to the animal traits of carnivorous (vs. herbivorous) and wild (vs. tame), Philo turns an originally symbolic interpretation promoting justice ( $\delta\llcorner\kappa \alpha \iota \sigma o ́ v \eta)$ into a literal

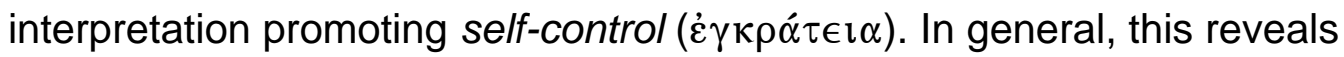
something about the communal aspect of biblical exegesis in Alexandria, but it specifically reveals a nexus of text, interpretation, and cultural—especially philosophical-milieu worth investigating further. ${ }^{2}$ The Letter of Aristeas found significance in otherwise obscure dietary laws by correlating its interpretation with current trends in contemporary philosophy, namely Pythagorean philosophy and its symbolic interpretation of dietary laws. ${ }^{3}$ Philo correlated his interpretation with what he knew as current trends in contemporary philosophy, namely MiddlePlatonic philosophy. Both reflect an apologetic aspect of the relation between exegesis and cultural milieu, as they attempt to demonstrate the parity of Mosaic legislation with the highest cultural achievements of their Gentile contemporaries. ${ }^{4}$

\footnotetext{
${ }^{2}$ Thomas Tobin investigated this nexus in The Creation of Man-i.e., studying different levels of interpretation "involves the analysis of the thought patterns used in the interpretations, and the relationship of those thought patterns to the biblical text and to the philosophical milieu of Alexandria during the period" (9). Philo's interaction with an earlier level of interpretation in the case of dietary laws represents precisely the sort of interaction Tobin identifies in the case of the story of man's creation. The call for further research into this nexus amounts to a call for further corroboration and refinement of Tobin's approach.

${ }^{3}$ See Berthelot, "L'interprétation symbolique."

${ }^{4}$ On the valorization of $\dot{\varepsilon} \gamma \kappa \rho \alpha \dot{\tau} \tau \epsilon \iota \alpha$ among Philo's contemporaries as a context for his own emphasis on $\dot{\varepsilon} \gamma \kappa \rho \alpha \dot{\tau} \tau \in \mathfrak{l} \alpha$ in regard to the Tenth Commandment (and dietary laws), see Stowers,
} 
In terms of early Christianity, Philo's exposition of the Tenth Commandment relates most directly to the letters of Paul, especially to issues raised in Galatians and Romans about the role and purpose of Mosaic law. Paul's proclamation of Christ involves at some level a marginalization, if not

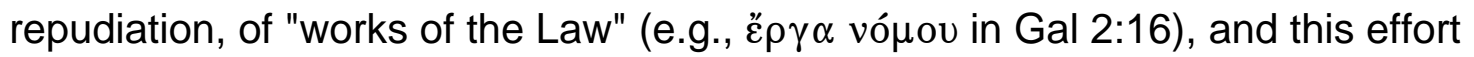
on Paul's part implies the existence of an opposing viewpoint in which "works of the Law" figure prominently. So properly understanding Paul requires a historically plausible reconstruction of a role for "works of the Law" that accounts for their valorization within first-century Judaism. James Dunn's "new perspective on Paul" correctly rejects anachronistic and theologically loaded notions of हैp $\gamma \alpha$ vó $\mu$ ov, such as "works which earn God's favour, as merit-amassing observances," arguing instead for the notion of cultural "badges" that "mark out the Jews as God's people." ${ }^{5}$ The food laws, for example, as "works of the Law," establish an ethnic identity—and Paul ultimately disputes the foisting of this identity on Gentiles as an addendum to their faith in Christ. ${ }^{6}$ Without undermining Dunn's assessment, Philo's view of the food laws nevertheless calls for the consideration of another possibility. Clearly for some Jews of the first century, "works of the Law" functioned as a means to virtue, in particular the virtue of

Rereading of Romans, 46-56; also Niehoff, Philo on Jewish Identity and Culture, 75-110 [="Jewish Values: Religion and Self-Restraint"]; cf. Anthony Long, "Philosophical Power."

5 James D. G. Dunn, "The New Perspective on Paul," in The New Perspective on Paul (rev. ed.; Grand Rapids: Eerdmans, 2008), 99-120, 111.

${ }^{6}$ On the food laws as identity markers, see Dunn, "New Perspective," 109-10 (e.g., 108: "[B]y 'works of the law' Paul intended his readers to think of particular observances of the law like circumcision and the food laws" [original emphasis]). 
$\dot{\varepsilon} \gamma \kappa \rho \alpha \dot{\tau \epsilon \iota \alpha .}{ }^{7}$ Further research into first-century perspectives on the Law that Paul

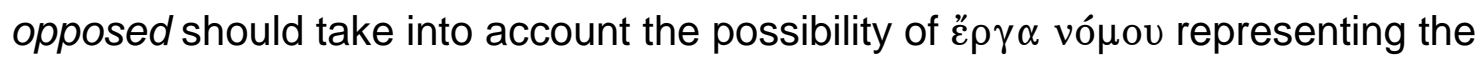
sort of ascetic exercises Philo describes in his exposition. ${ }^{8}$

Finally, Philo's exposition of the Tenth Commandment brings to light not just a Middle-Platonic concept of "passion," but a distinct Middle-Platonic

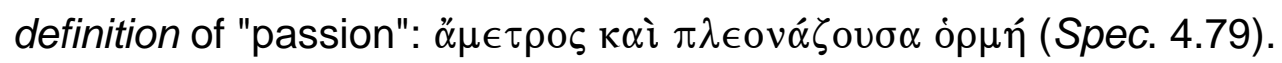

Understanding this as a deliberately revised Stoic definition, which uses $\ddot{\alpha} \mu \epsilon \tau \rho \circ \varsigma$ to reinterpret $\pi \lambda \epsilon \operatorname{ov} \alpha_{\zeta} \mathrm{ov \sigma} \alpha_{\alpha}$ in light of a radically different moral psychology, reveals not a superficial eclecticism within Middle Platonism but a thoughtful effort to appropriate terminology without compromising principles. Furthermore, Philo provides extensive evidence not only for the definition $\pi \lambda \epsilon o v \alpha ́ \zeta o v \sigma \alpha$

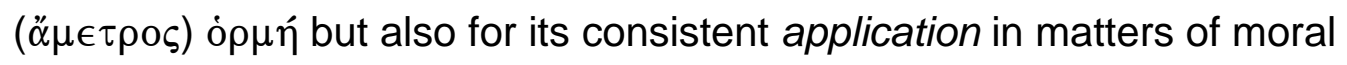
psychology in first-century Alexandrian Middle Platonism—-for example, in connection with the Phaedrus chariot figure. Philo's use of a working MiddlePlatonic definition of passion holds significance for further research into the historical development of ethical theory within Middle Platonism.

${ }^{7}$ Stowers makes this point in Romans, esp. 58-65 [="Judaism as a School for SelfMastery] (cf. idem, "Paul and Self-Mastery," 531-34). The scope of Stowers work, however, does not allow him to consider in depth either the moral psychology of Philo or precisely how the observance of Mosaic law leads to $\dot{\varepsilon} \gamma \kappa \rho \alpha \dot{\tau} \tau \iota \alpha$.

${ }^{8}$ Cf. Stowers, Romans, 66-74 [="Audience, Opponents, and Self-Mastery in Paul"]; e.g., 67: "Paul's attack on these opponents who taught judaizing practices to gentiles suggests that their appeal may have centered on claims that gentiles could learn self-mastery by association with the Jewish community and by adopting certain practices that were described as methods of self-mastery." 


\section{BIBLIOGRAPHY}

\section{PRIMARY SOURCES}

Alcinoos, Enseignement des doctrines de Platon. Edited by John Whittaker. Translated by Pierre Louis. 2d ed. Paris: Belles Lettres, 2002.

Alcinous: The Handbook of Platonism. Translated with introduction and commentary by John M. Dillon. Oxford: Clarendon, 1993.

Aristeas to Philocrates: Letter of Aristeas. Edited and translated by Moses Hadas. New York: Harper, 1951. Repr., Eugene, Oreg.: Wipf \& Stock, 2007.

Aristotle, Nicomachean Ethics. Translated by H. Rackham. Rev. ed. Loeb Classical Library. Cambridge: Harvard University Press, 1934.

. On the Soul. Translated by W. S. Hett. Loeb Classical Library. Cambridge: Harvard University Press, 1936.

. Art of Rhetoric. Translated by J. H. Freese. Loeb Classical Library. Cambridge: Harvard University Press, 1926.

Arius Didymus, Epitome of Stoic Ethics. Edited and translated by Arthur J. Pomeroy. Texts and Translations 44. Greco-Roman Series 14. Atlanta, $\mathrm{Ga}$.: Society of Biblical Literature, 1999.

Diogenes Laertius, Lives of Eminent Philosophers. Translated by R. D. Hicks. 2 vols. Loeb Classical Library. Cambridge: Harvard University Press, 1925.

Eudorus (fragments). In "Raccolta e interpretazione delle testimonianze e dei frammenti del medioplatonico Eudoro di Alessandria: Parte prima: Testo e traduzione delle testimonianze e dei frammenti sicuri." By Claudio Mazzarelli. Rivista di Filosofia Neo-Scolastica 77 (1985): 197-209.

Filone di Alessandria, De Decalogo. Edited and translated by Francesca Calabi. Philosophica 24. Pisa: ETS, 2005. 
Galen, On the Doctrines of Hippocrates and Plato. Edited and translated by Phillip De Lacy. 3 vols. 2 d ed. Corpus Medicorum Graecorum 5.4.1.2. Berlin: Akademie-Verlag, 1980-84.

Homer, Odyssey. Translated by A. T. Murray. Revised by George E. Dimock. 2 vols. Loeb Classical Library. Cambridge: Harvard University Press, 1919.

Long, Anthony A., and David N. Sedley. The Hellenistic Philosophers. 2 vols. Cambridge: Cambridge University Press, 1987.

Musonius Rufus, On Training. In Musonius Rufus: The Roman Socrates. By Cora E. Lutz. Yale Classical Studies 10. New Have: Yale University Press, 1947.

Philo. Translated by F. H. Colson et al. 12 vols. Loeb Classical Library. Cambridge: Harvard University Press, 1929-1962.

Philon D'Alexandrie: Quæstiones: Fragmenta Græca. Edited and translated by Françoise Petit. Les œvres de Philon d'Alexandrie 33. Paris: Cerf, 1978.

Philonis Alexandrini opera quae supersunt. Edited by L. Cohn, P. Wendland, S. Reiter. 6 vols. Berlin: de Gruyter,1896-1915.

Plato. Translated by Harold North Fowler et al. 12 vols. Loeb Classical Library. Cambridge: Harvard University Press, 1914-1927.

Plutarch, Moralia. Translated by F. C. Babbitt et al. 16 vols. Loeb Classical Library. Cambridge: Harvard University Press, 1927-1976.

Pseudopythagorica Ethica: I trattati morali di Archita, Metopo, Teage, Eurifamo. Edited and translated by Bruno Centrone. Elenchos 17. Naples: Bibliopolis, 1990.

Stobaeus, Ioannes. Anthologii libri duo priores. 2 vols. Edited by Curt Wachsmuth. Berlin: Weidmann, 1884.

Stoicorum veterum fragmenta. Edited by $\mathrm{H}$. von Arnim. 4 vols. Leipzig: Teubner, 1903-1924.

Timaeus of Locri, On the Nature of the World and the Soul. Edited and translated by Thomas H. Tobin. Texts and Translations 26. Greco-Roman Religion Series 8. Chico, Calif.: Scholars Press, 1985. 
SECONDARY SOURCES

Abel, Karlhans. "Das Propatheia-Theorem: Ein Beitrag zur stoischen Affektenlehre." Hermes 111 (1983): 78-97.

Amir, Yehoshua. "Philo and the Bible." Studia Philonica 2 (1973): 1-8.

. "Irrationales Denken in rationalem Gewande bei Philon von

Alexandrien." Pages 189-199 in Die hellenistische Gestalt des Judentums bei Philon von Alexandrien. Forschungen zum jüdisch-christlichen Dialog 5. Neukirchen-Vluyn: Neukirchener Verlag, 1983.

. "Philon und die jüdische Wirklichkeit seiner Zeit." Pages 3-51 in Die hellenistische Gestalt des Judentums bei Philon von Alexandrien. Forschungen zum jüdisch-christlichen Dialog 5. Neukirchen-Vluyn: Neukirchener Verlag, 1983.

. "The Transference of Greek Allegories to Biblical Motifs in Philo." Pages 15-25 in Nourished with Peace: Studies in Hellenistic Judaism in Memory of Samuel Sandmel. Edited by Frederick E. Greenspahn, Earle Hllgert, and Burton L. Mack. Homage Series. Chico, Calif.: Scholars Press, 1984.

. "The Decalogue According to Philo." Pages 121-160 in The Ten Commandments in History and Tradition. Edited by Ben-Zion Segal and Gershon Levi. Jerusalem: Magnes Press, 1990.

Annas, Julia. An Introduction to Plato's Republic. Oxford: Clarendon Press, 1981. . Hellenistic Philosophy of Mind. Hellenistic Culture and Society 8. Berkeley: University of California Press, 1992.

. "The Hellenistic Version of Aristotle's Ethics." Pages 392-408 in Aristotle's Ethics. Edited by Terrence Irwin. Classical Philosophy: Collected Papers 5. New York: Garland, 1995.

. Platonic Ethics, Old and New. Ithaca: Cornell University Press, 1999.

Apelt, Mathilda. De rationibus quibusdam quae Philoni Alexandrino cum Posidonio intercedunt. Inaugural Dissertation, University of Jena, 1907.

Arbesmann, Rudolf. Das Fasten bei den Griechen und Römern. Religionsgeschichtliche Versuche und Vorarbeiten 21, part 1. Giessen: A. Töpelmann, 1929. 
Arnaldez, Roger. "Introduction Generale." Pages 2-112 in De Opificio Mundi. Introduction, translation, and notes by Roger Arnaldez. Vol. 1 of Les Ervres de Philon D'Alexandrie. Edited by Roger Arnaldez, Jean Pouilloux, ad Claude Mondésert. Paris: Éditions du Cerf, 1961.

Arthur, E. P. "The Stoic Analysis of the Mind's Reactions to Presentations." Hermes 111 (1983): 69-78.

Ash, Rhiannon. "Severed Heads: Individual Portraits and Irrational Forces in Plutarch's Galba and Otho." Pages 189-214 in Plutarch and his Intellectual World: Essays on Plutarch. Edited by Judith Mossman. London: Duckworth, 1997.

Aune, David C. "Mastery of the Passions: Philo, 4 Maccabees and Earliest Christianity." Pages 125-158 in Hellenization Revisited: Shaping a Christian Response within the Greco-Roman World. Edited by Wendy E. Helleman. Lanham: University Press of America, 1994.

Aune, David E. "Human Nature and Ethics in Hellenistic Philosophical Traditions and Paul: Some Issues and Problems." Pages 291-312 in Paul in His Hellenistic Context. Edited by Troels Engberg-Pedersen. Minneapolis: Fortress, 1995.

Babut, Daniel. Plutarque et le Stoïcisme. Paris: Presses universitaires de France, 1969.

Baltes, Matthias. Timaios Lokros, Über die Natur des Kosmos und der Seele. Philosophia Antiqua 21. Leiden: Brill, 1972.

Barclay, John M. G.. Jews in the Mediterranean Diaspora: From Alexander to Trajan (323 BCE - 117 CE). Edinburgh: T\&T Clark, 1996.

Barker, Andrew. "Timaeus on Music and the Liver." Pages 85-99 in Reason and Necessity: Essays on Plato's Timaeus. Edited by M. R. Wright. London: Duckworth, 2000.

Barnes, Jonathan. "Antiochus of Ascalon." Pages 51-96 in Philosophia Togata: Essays on Philosophy and Roman Society. Edited by Miriam Griffin and Jonathan Barnes. Oxford: Clarendon Press, 1989.

Baudry, Gérard-Henry. "Le péché original chez Philon d'Alexandrie." Mélanges de science religieuse 50 (1993): 99-115.

. "La théorie du 'penchant mauvais' et la doctrine du 'péché original."' Bulletin de litérature ecclésiastique 95 (1994): 271-301. 
Beardslee, William A. "De Garrulitate (Moralia 502B-515A)." Pages 264-288 in Plutarch's Ethical Writings and Early Christian Literature. Edited by Hans Dieter Betz. Studia ad corpus hellenisticum Novi Testamenti 4. Leiden: Brill, 1978.

Becchi, Francesco. "Platonismo medio ed etica Plutarchea." Prometheus 7 (1981): 125-145, 263-284.

. "Plutarco tra Platonismo e Aristotelismo: La Filosofia come ПIAI $\Delta$ EIA dell'Anima." Pages 25-43 in Plutarco, Platón y Aristóteles: Actas del V Congreso Internacional de la I.P.S. : Madrid-Cuenca, 4-7 de mayo de 1999. Edited by Aurelio Peréz Jiménez, José García López, and Rosa M Aguilar. Madrid: Ediciones Clásicas, 1999.

Benson, John. "Varieties of Desire." Aristotelian Society Supplementary Volume 50 (1976): 177-192.

Bentwich, Norman. Philo-Judaeus of Alexandria. Philadelphia: Jewish Publication Society of America, 1910.

Berchman, Robert M. "Philo and Philosophy." Pages 49-70 in Judaism in Late Antiquity: Where We Stand: Issues and Debates in Ancient Judaism. Part 3 of vol. 3 of Judaism in Late Antiquity. Edited by Alan J. Avery-Peck and Jacob Neusner. Handbook of Oriental Studies, section one: The Near and Middle East 53. Leiden: Brill, 2000.

Berger, Klaus. Die Gesetzesauslegung Jesu: Ihr historischer Hintergrund im Judentum und im Alten Testament: Teil I: Markus und Parallelen. Wissenschaftliche Monographien zum Alten und Neuen Testament 40.1. Neukirchen-Vluyn: Neukirchener, 1972.

Berthelot, Katell. "L'interprétation symbolique des lois alimentaires dans la Lettre d'Aristée: une influence pythagoricienne." Journal of Jewish Studies 52 (2001): 253-268.

Billings, Thomas H. The Platonism of Philo Judaeus. Chicago: University of Chicago Press, 1919. Repr., New York: Garland, 1979.

Birnbaum, Ellen. "What Does Philo Mean by 'Seeing God'? Some Methodological Considerations." Pages 535-552 in Society of Biblical Literature 1995 Seminar Papers. Edited by Eugene H. Lovering. Society of Biblical Literature Seminar Papers Series 34. Atlanta, Ga.: Scholars Press, 1995. 
"Allegorical Interpretation and Jewish Identity among Alexandrian

Jewish Writers." Pages 307-329 in Neotestamentica et Philonica:

Studies in Honor of Peder Borgen. Edited by David E. Aune, Torrey

Seland, and Jarl Henning Ulrichsen. Leiden: Brill, 2003.

Bonazzi, Mauro. "Eudoro di Alessandria alle origini del platonismo imperiale."

Pages 117-160 in L'eridità platonica: studi sul platonismo da Arcesilao a Proclo. Edited by Mauro Bonazzi and Vincenza Celluprica. Elenchos 45. Naples: Bibliopolis, 2005.

. "Eudorus' Psychology and Stoic Ethics." Pages 109-132 in Platonic Stoicism - Stoic Platonism: The Dialogue between Platonism and Stoicism in Antiquity. Edited by Mauro Bonazzi and Christoph Helmig. Ancient and Medieval Philosophy 39. Leuven: Leuven University Press, 2007.

. "Towards Transcendence: Philo and the Renewal of Platonism in the Early Imperial Age." Pages 233-51 in Philo of Alexandria and PostAristotelian Philosophy. Edited by Francesca Alesse. Studies in Philo of Alexandria 5. Leiden: Brill, 2008.

Booth, Peter A. "The Voice of the Serpent: Philo's Epicureanism." Pages 159-72 in Hellenization Revisited: Shaping a Christian Response within the Greco-Roman World. Edited by Wendy E. Helleman. Lanham: University Press of America, 1994.

Borgen, Peder. "Philo of Alexandria." Pages 233-282 in Jewish Writings of the Second Temple Period: Apocrypha, Pseudepigrapha, Qumran Sectarian Writings, Philo, Josephus. Edited by Michael E. Stone. Vol. 2 of The Literature of the Jewish People in the Period of the Second Temple and the Talmud. Compendia Rerum ludaicarum ad Novum Testamentum 2. Assen: Van Gorcum, 1984.

. "Philo of Alexandria." Pages 333-342 in vol. 5 of The Anchor Bible Dictionary. Edited by David Noel Freedman. 6 vols. New York: Doubleday, 1992.

"Heaven Ascent in Philo: An Examination of Selected Passages." Pages 246-268 in The Pseudepigrapha and Early Biblical Interpretation. Edited by James H. Charlesworth and Craig A. Evans. Journal for the Study of the Pseudepigrapha: Supplement Series 14. Studies in Scripture in Early Judaism and Christianity 2. Sheffield: Journal for the Study of the Old Testament Press, 1993. 
"Philo of Alexandria-A Systematic Philosopher or an Eclectic

Editor?" Symbolae Osloenses 71 (1996): 115-134.

Philo of Alexandria: An Exegete for His Time. Leiden: Brill, 1997.

Borgen, Peder, Kare Fuglseth, and Roald Skarsten. The Philo Index: A Complete Greek Word Index to the Writings of Philo of Alexandria. Grand Rapids: Eerdmans, 1999.

Bos, Abraham P. "Philo of Alexandria: A Platonist in the Image and Likeness of Aristotle." The Studia Philonica Annual 10 (1998) 66-86.

. '"Aristotelian' and 'Platonic' Dualism in Hellenistic and Early Christian Philosophy and in Gnosticism." Vigiliae Christianae 56 (2002): 273-91.

Boughton, Jesse Scott. "The Idea of Progress in Philo Judaeus." Ph.D. diss., Columbia University, 1932.

Boulogne, Jacques. "L'intempérence verbale: L'imaginaire de Plutarche dans la thérapie des maladies de l'âme." Pages161-169 in Les passions antiques et médiévales. Edited by Bernard Besnier, Pierre-François Moreau, and Laurence Renault. Paris: Presses universitaires de France, 2003.

Bourfartigue, Jean. "La structure de l'âme chez Philon : terminologie scolastique et métaphores." Pages 59-75 in Philon d'Alexandrie et le langage de la philosophie: actes du colloque international organisé par le Centre d'études sur la philosophie hellénistique et romaine de l'Université de Paris XII-Val de Marne, Créteil, Fontenay, Paris, 26-28 octobre 1995. Edited by Carlos Lévy. Turnhout: Brepolis, 1998.

Bousset, Wilhelm. "Philo." Pages 438-455 in Die Religion des Judentums im Späthellenistischen Zeitalter. Edited by Hugo Gressmann. Handbuch zum Neuen Testament 21. Tübingen: J.C.B. Mohr (Paul Siebeck), 1966.

Boyancé, Pierre. "Études philoniennes." Revue des études grecques 76 (1963): 64-110.

. "Écho des exégèses de la mythologie grecque chez Philon." Pages 169-186 in Philon d'Alexandrie, Lyon, 11-15 Septembre 1966. Colloques nationaux du Centre national de la recherche scientifique, Paris: Éditions du Centre national de la recherche scientifique, 1967.

Bradshaw, David. "The Vision of God in Philo of Alexandria." American Catholic Philosophical Quarterly 72 (1998): 483-500. 
Brändl, Martin. Der Agon bei Paulus: Herkunft und Profil paulinischer Agonmetaphorik. Wissenschaftliche Untersuchungen zum Neuen Testament 222, 2d series. Tübingen: Mohr Siebeck, 2006.

Bréhier, Emile. Les idées philosophiques et religieuses de Philon d'Alexandrie. Études de philosophie médiévale 8. 3d edition. Paris: J. Vrin, 1950.

Brenk, Frederick E. "Darkly Beyond the Glass: Middle Platonism and the Vison of the Soul." Pages 39-60 in Platonism in Late Antiquity. Edited by Stephen Gersh and Charles Kannengiesser. Christianity and Judaism in Antiquity 8. Notre Dame, Ind.: University of Notre Dame Press, 1992.

Brennan, Tad. "The Old Stoic Theory of the Emotions." Pages 21-70 in The Emotions in Hellenistic Philosophy. Edited by Juha Sihvola and Troels Engberg-Pedersen. New Synthese Historical Library 46. Dordrecht: Kluwer Academic Publishers, 1998.

. "Stoic Moral Psychology." Pages 257-294 in The Cambridge Companion to the Stoics. Edited by Brad Inwood. Cambridge: Cambridge University Press, 2003.

Butterweck, A. Jakobs Ringkampf am Jabbok: Gen. 32,4 ff in der jüdischen Tradition bis zum Frühmittelalter. Judentum und Umwelt 3. Frankfurt am Main: Peter Lang, 1981.

Calabi, Francesca. "Il serpente e il cavaliere: piacere e 'sophrosyne' in Filone di Alessandria." Annali di scienze religiose 8 (2003): 199-215.

Chadwick, Henry. "Philo." Pages 137-157 in The Cambridge History of Later Greek and Early Medieval Philosophy. Edited by A. H. Armstrong. Cambridge: Cambridge University Press, 1967.

Centrone, Bruno. "La letteratura pseudopitagorica: origine, diffusione e finalità." Pages 429-452 in La letteratura pseudepigrafa nella cultura greca e romana: atti di un incontro di studi, Napoli, 15-17 gennaio 1998. Edited by Giovanni Cerri. Annali dell'Istituto universitario orientale di Napoli 22. Naples: Istituto universitario orientale, 2000.

Classen, Carl Joachim. "Der platonisch-stoische Kanon der Kardinaltugenden bei Philo, Clemens Alexandrinus und Origenes." Pages 68-88 in Kerygma und Logos: Beiträge zu den geistesgeschichtlichen Beziehungen zwischen Antike und Christentum. Edited by Adolf Martin Ritter. Göttingen: Vandenhoeck \& Ruprecht, 1979. 
Clifford, Hywel. "Moses as Philosopher-Sage in Philo." Pages 151-67 in Moses in Biblical and Extra-Biblical Traditions. Edited by Axel Graupner and Michael Wolter. Beihefte zur Zeitschrift für die alttestamentliche Wissenschaft 372. Berlin: de Gruyter, 2007.

Cohn, Leopold. "Einteilung und Chronologie der Schriften Philos." Philologus: Supplementband 7 (1899): 387-436.

Cohen, Naomi. "The Greek Virtues and the Mosaic Laws in Philo: An Elucidation of De Specialibus Legibus 133-135." Studia Philonica Annual 5 (1993): 9-23.

. Philo Judaeus: His Universe of Discourse. Beiträge zur Erforschung des Alten Testaments und des antiken Judentum 24. Frankfurt am Main: Peter Lang, 1995.

Collins, John J. "Hellenistic Judaism in Recent Scholarship." Pages 1-20 in Jewish Cult and Hellenistic Culture: Essays on the Jewish Encounter with Hellenism and Roman Rule. Supplements to the Journal for the Study of Judaism 100. Leiden: Brill, 2005.

Cooper, John M. "Plato's Theory of Human Motivation." Pages 118-137 in Reason and Emotion: Essays on Ancient Moral Psychology and Ethical Theory. Princeton: Princeton University Press, 1999. Repr. from History of Philosophy Quarterly 1 (1984): 3-21.

. "Pleasure and Desire in Epicurus." Pages 485-514 in Reason and Emotion: Essays on Ancient Moral Psychology and Ethical Theory. Princeton: Princeton University Press, 1999.

. "Posidonius on Emotions." Pages 449-484 in Reason and Emotion: Essays on Ancient Moral Psychology and Ethical Theory. Princeton: Princeton University Press, 1999. Repr. from pages 71-111 in The Emotions in Hellenistic Philosophy. Edited by Juha Sihvola and Troels Engberg-Pedersen. New Synthese Historical Library 46. Dordrecht: Kluwer Academic Publishers, 1998.

"Reason, Moral Virtue, and Moral Value." Pages 253-280 in Reason and Emotion: Essays on Ancient Moral Psychology and Ethical Theory. Princeton: Princeton University Press, 1999. Repr. from pages 81-114 in Rationality in Greek Thought. Edited by M. Frede and G. Striker. Oxford: Clarendon, 1996. 
. "Some Remarks on Aristotle's Moral Psychology." Pages 237-52 in Reason and Emotion: Essays on Ancient Moral Psychology and Ethical Theory. Princeton: Princeton University Press, 1999. Repr. from Southern Journal of Philosophy 27 Supplement (1988): 25-42.

Courcelle, Pierre. "Tradition platonicienne et traditions chrétiennes du corpsprison (Phédon 62 b; Cratyle 400 c)." Revue des études latines 43 (1965): 406-443.

"Le corps-tombeau (Platon, Gorgias 493a, Cratyle 400c, Phèdre 250c)." Revue des études anciennes 68 (1966): 101-122.

Cummins, W. Joseph. "Eros, Epithumia, and Philia in Plato." Apeiron 15 (1981): 10-18.

Daniélou, Jean. Philon D'Alexandrie. Paris: A. Fayard, 1958.

Daubercies, Pierre. "La vertu chez Philon d'Alexandrie." Revue théologique de Louvain 26 (1995): 185-210.

Decharneux, Baudouin. "Interdits sexuels dans l'œuvre de Philon d'Alexandrie dit 'Le Juif." Pages 17-31 in Religion et Tabou Sexuel. Edited by Jacques Marx. Problèmes d'histoire des religions 1. Bruxelles: Editions de l'Université de Bruxelles, 1990.

De Lacy, Phillip. "Galen's Platonism." American Journal of Philology 93 (1972): 27-39.

. "The Third Part of the Soul." Pages 43-63 in Le Opere Psicologiche di Galeno: Atti del Terzo Colloquio Galenico Internazionale, Pavia, 10-12 Settembre 1986. Edited by Paola Manuli and Mario Vegetti. Elenchos 13. Naples: Biblipolis, 1988.

Delling, Gerhard. "The 'One Who Sees God' in Philo." Pages 27-41 in Nourished with Peace: Studies in Hellenistic Judaism in Memory of Samuel Sandmel. Edited by Frederick E. Greenspahn, Earle HIlgert, and Burton L. Mack. Homage Series. Chico, Calif.: Scholars Press, 1984.

Dent, N. J. H. "Varieties of Desire." Proceedings of the Aristotelian Society Supplementary Volume 50 (1976): 153-175

Deuse, Werner. Untersuchungen zur mittelplatonischen und neuplatonischen Seelenlehre. Abhandlungen der Geistes- und Sozialwissenschaftlichen Klasse: Einzelveröffentlichung 3. Mainz: Akademie der Wissenschaften und der Literatur, 1983. 
Deutsch, Frédéric. "La philautie chez Philon d'Alexandrie." Pages 87-97 in Philon d'Alexandrie et le langage de la philosophie: actes du colloque international organisé par le Centre d'études sur la philosophie hellénistique et romaine de l'Université de Paris XII-Val de Marne, Créteil Fontenay, Paris, 26-28 octobre 1995. Edited by Carlos Lévy. Turnhout: Brepolis, 1998.

Dey, Lala Kalyan Kumar. The Intermediary World and Patterns of Perfection in Philo and Hebrews. Society of Biblical Literature Dissertation Series 25. Edited by Howard C. Kee and Douglas A. Knight. Missoula, Mont.: Scholars Press, 1975.

Dierauer, Urs. Tier und Mensch im Denken der Antike: Studien zur Tierpsychologie, Anthropologie und Ethik. Studien zur antiken Philosophie 6. Amsterdam: Grüner, 1977.

Dihle, Albrecht. "Posidonius' System of Moral Philosophy." Journal of Hellenic Studies 93 (1973): 50-57.

Dillon, John M. "The Academy in the Middle Platonic Period." Dionysius 3 (1979): 63-77. Repr. The Golden Chain: Studies in the Development of Platonism and Christianity. Collected Studies 333. Aldershot, Hampshire; Brookfield, Vt.: Variorum, 1990.

"The Descent of the Soul in Middle Platonic and Gnostic Thought." Pages 357-364 in The Rediscovery of Gnosticism. Vol. 1. Edited by B. Layton. Leiden: Brill, 1980.

Preface to Philo of Alexandria: The Contemplative Life, The Giants, and Selections. Translated with an introduction by David Winston. Classics of Western Spirituality. Mahwah, N.J.: Paulist, 1981.

. "Self-Definition in Later Platonism." Pages 60-75 in Self-Definition in the Greco-Roman World. Vol. 3 of Jewish and Christian Self-Definition. Edited by Ben E. Meyer and E. P. Sanders. London: SCM Press, 1982. Repr. The Golden Chain: Studies in the Development of Platonism and Christianity. Collected Studies 333. Aldershot, Hampshire; Brookfield, Vt.: Variorum, 1990.

"'Metriopatheia and Apatheia': Some Reflections on a Controversy in Later Greek Ethics." Pages 508-517 in Essays in Ancient Greek Philosophy II. Edited by John Anton and Anthony Preus. Albany: SUNY Press, 1983. Repr. The Golden Chain: Studies in the Development of Platonism and Christianity. Collected Studies 333. Aldershot, Hampshire; Brookfield, Vt.: Variorum, 1990. 
. "Plotinus, Philo and Origen on the Grades of Virtue." Pages 92105 in Platonismus und Christentum: Festschrift für Heinrich Dörrie. Edited by Horst-Dieter Blume and Friedhelm Mann. Jahrbuch für Antike und Christentum, Ergänzungsband 10. Münster: Aschendorff, 1983.

. "Plutarch and Second Century Platonism." Pages 214-229 in Classical Mediterranean Spirituality: Egyptian, Greek, Roman. Edited by A. H. Armstrong. Vol. 15 of World Spirituality: An Encyclopedic History of the Religious Quest. New York: Crossroad, 1986. Repr. The Golden Chain: Studies in the Development of Platonism and Christianity. Collected Studies 333. Aldershot, Hampshire; Brookfield, Vt.: Variorum, 1990.

. "'Orthodoxy' and 'Eclecticism': Middle Platonists and NeoPythagoreans." Pages 103-125 in The Question of "Eclecticism": Studies in Later Greek Philosophy. Edited by J. M. Dillon and A. A. Long. Hellenistic Culture and Society 3. Berkeley: U of California Press, 1988.

. "Rejecting the Body, Refining the Body: Some Remarks on the Development of Platonic Asceticism." Pages 80-87 in Asceticism. Edited by Vincent L. Wimbush and Richard Valantasis. New York: Oxford University Press, 1995. 1996.

The Middle Platonists. Rev. ed. Ithaca: Cornell University Press, "The Pleasures and Perils of Soul-Gardening." Studia Philonica Annual 9 (1997):190-197.

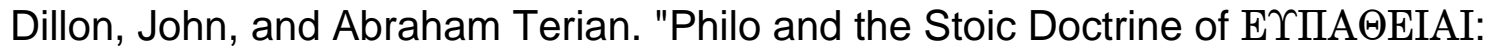
A Note on Quaes Gen 2.57." Studia Philonica 4 (1976-77): 17-24.

Dogniez, Cécile and Marguerite Harl, eds. Le Pentateuque d'Alexandrie: text grec et traduction. Paris: Cerf, 2001.

Donini, Pierluigi. "The history of the concept of eclecticism." Pages 15-33 in The Question of "Eclecticism": Studies in Later Greek Philosophy. Edited by J.M. Dillon and A.A. Long. Hellenistic Culture and Society 3. Berkeley: $U$ of California Press, 1988.

Donini, Perluigi, and Brad Inwood. "Stoic Ethics." Pages 675-738 in The Cambridge History of Hellenistic Philosophy. Edited by Keimpe Algra, Jonathan Barnes, Jaap Mansfeld, and Malcolm Schofield. Cambridge: Cambridge University Press, 1999. 
Dorion, Louis-André. "Akrasia et enkrateia dans les Mémorables de Xénophon." Dialogue 42 (2003): 645-672.

Dörrie, Heinrich. "Der Platoniker Eudorus von Alexandreia." Hermes 79 (1944): 25-38. Repr., pages 297-309 in Platonica Minora. Studia et Testimonia Antiqua 8. München: W. Fink, 1976.

. "Die Erneuerung des Platonismus im ersten Jahrhundert vor Christus." Pages 17-33 in Le Néoplatonisme. Colloque international sur le néoplatonisme, Royaumont, France, 1969. Paris: Éditions du Centre national de la recherche scientifique, 1971. Repr. pages 154-165 in Platonica Minora. Studia et Testimonia Antiqua 8. München: W. Fink, 1976.

Dressler, Hermigild. The Use of 'A $A \kappa \varepsilon \dot{\varepsilon} \omega$ and Its Cognates in Greek Documents to 100 AD. Catholic University of America Patristic Studies 78. Washington: Catholic University of America Press, 1947.

Duff, Tim. Plutarch's Lives: Exploring Virtue and Vice. Oxford: Clarendon Presss, 1999.

Dunn, James D.G. "The New Perspective on Paul." Pages 99-120 in The New Perspective on Paul. Rev. ed. Grand Rapids: Eerdmans, 2008.

Elsky, Martin, trans. "Erich Auerbach, 'Passio as Passion' ['Passio als Leidenshaft']" Criticism 43 (2001): 288-308.

Feldman, Louis H. "Philo's Views on Music." Journal of Jewish Music and Liturgy 9 (1986): 36-54.

Firmage, Edwin. "The Biblical Dietary Laws and the Concept of Holiness." Pages 177-208 in Studies in the Pentateuch. Edited by J. A. Emerton. Supplements to Vetus Testamentum 41. Leiden: Brill, 1990.

Fitzgerald, John T. Cracks in an Earthen Vessel : An Examination of the Catalogues of Hardships in the Corinthian Correspondence. Society of Biblical Literature Dissertation Series 99. Atlanta, Ga.: Scholars Press, 1988.

Fitzmyer, Joseph A. Romans: A New Translation with Introduction and Commentary. Anchor Bible 33. New York: Doubleday, 1993. 
Fortenbaugh, William M. "The Antecedents of Aristotle's Bipartite Psychology." Pages 303-320 in Essays in Ancient Greek Philosophy. Edited by John P. Anton and Anthony Preus. Vol. 2. Albany: State University of New York Press, 1983.

Fox, Kenneth Allan. "Paul's Attitude toward the Body in Romans 6-8: Compared with Philo of Alexandria." Ph.D. diss., University of St. Michael's College, 2001.

Fraade, Steven. "Ascetical Aspects of Ancient Judaism." Pages 253-288 in Jewish Spirituality : From the Bible through the Middles Ages. Edited by Arthur Green. World Spirituality: An Encyclopedic History of the Religious Quest 13. New York : Crossroad, 1986.

Francis, James A. Subversive Virtue: Asceticism and Authority in the Second-Century Pagan World. University Park, Pa.: Pennsylvania State University Press, 1995.

Frede, Michael. "The Stoic doctrine of the affections of the soul." Pages 93110 in The Norms of Nature: Studies in Hellenistic Ethics. Edited by Malcolm Schofield and Gisela Striker. Cambridge: Cambridge University Press, 1986.

Froidefond, Christian. "Plutarque et le platonisme." Aufstieg und Niedergang der römischen Welt 36.1: 184-233. Part 2, Principat, 36.1. Edited by W. Haase and $\mathrm{H}$. Temporini. New York: de Gruyter, 1987.

Fuhrmann, François. Les images de Plutarque. Paris: C. Klincksieck, 1964.

Gaca, Kathy L. "Philo's Principles of Sexual Conduct and Their Influence on Christian Platonist Sexual Principles." Studia Philonica Annual 8 (1996): 21-39.

. The Making of Fornication: Eros, Ethics, and Political Reform in Greek Philosophy and Early Christianity. Hellenistic Culture and Society. Edited by Anthony W. Bulloch, Erich S. Gruen, A. A. Long, and Andrew F. Stewart. Berkeley: University of California Press, 2003.

Ganson, Todd Stuart. "Appetitive Desire in Later Plato." History of Philosophy Quarterly 18 (2001): 227-237.

Gardiner, H. N. "The Psychology of the Affections in Plato and Aristotle." Philosophical Review 27 (1918): 469-488. 
. "The Psychology of the Affections in Plato and Aristotle."

Philosophical Review 28 (1919): 1-26.

Geljon, A. C., and David Runia. "An Index Locorum to Billings, The Platonism of Philo Judaeus." Studa Philonica Annual 7 (1995): 169-185.

Gemünden, Petra von. "La culture des passions à l'époque du Nouveau Testament: une contribution théologique et psychologique." Études théologiques et religieuses 70 (1995): 335-348.

. "La femme passionnelle et l'homme rationnel? Un chapitre de psychologie historique." Biblica 78 (1997): 457-480.

. "La figure de Jacob à l'époque hellénistico-romaine: l'example de Philon d'Alexandrie." Pages 358-70 in Jacob: commentaire à plusieurs voix de Gen 25-36 : mélanges offerts à Albert de Pury. Edited by JeanDaniel Macchi and Thomas Römer. Le Monde de la Bible 44. Genève: Labor et Fides, 2001.

. "Der Affekt der $\dot{\varepsilon} \pi \imath \theta u \mu i ́ \alpha$ und der vó $\mu$ o $:$ Affektkontrolle und soziale Identitätsbildung im 4. Makkabäerbuch mit einem Ausblick auf den Römerbrief." Pages 55-74 in Das Gesetz im frühen Judentum und im Neuen Testament: Festschrift für Christoph Burchard zum 75. Geburtstag. Edited by Dieter Sänger and Matthias Konradt. Novum Testamentum et Orbis Antiquus / Studien zur Umwelt des Neuen Testaments 57.

Göttingen: Vandenhoeck \& Ruprecht; Fribourg: Academic Press, 2006.

Geytenbeek, Anton Cornelis van. Musonius Rufus and Greek Diatribe.

Translated by B. L. Hijmans. Rev. ed. Wijsgerige Teksten en Studies 8. Assen: Van Gorcum, 1963.

Gilbert-Thirry, Anne. "La théorie stoïcienne de la passion chez Chrysippe et son evolution chez Posidonius." Revue philosophique de Louvain 75 (1977): 393-435.

Gill, Christopher. "Did Chrysippus Understand Medea?" Pages 410-423 in Hellenistic Philosophy. Edited by Terence Irwin. Philosophy: Collected Papers 8. New York: Garland, 1995. Repr. Phronesis 23 (1983): 136-149.

. "Plato and the Education of Character." Archiv für Geschichte der Philosophie 67 (1985): 1-26.

. "The Emotions in Greco-Roman Philosophy." Pages 5-15 in The Passions in Roman Thought and Literature. Cambridge: Cambridge University Press, 1997. 
. "Did Galen Understand Platonic and Stoic Thinking on

Emotions?" Pages 113-148 in The Emotions in Hellenistic Philosophy. Edited by Juha Sihvola and Troels Engberg-Pedersen. New Synthese Historical Library 46. Dordrecht: Kluwer Academic Publishers, 1998.

. The Structured Self in Hellenistic and Roman Thought. Oxford: Oxford University Press, 2006.

Glucker, John. Antiochus and the Late Academy. Hypomnemata 56. Göttingen: Vandernhoeck \& Ruprecht, 1978.

Goodenough, Erwin R. The Jurisprudence of the Jewish Courts in Egypt. New Haven: Yale University Press, 1929.

"Philo's Exposition of the Law and His De Vita Mosis." Harvard Theological Review 26 (1933): 109-125.

By Light, Light: The Mystic Gospel of Hellenistic Judaism. New Have: Yale University Press, 1935.

Gosling, Justin. "The Stoics and 'Akrasia."' Apeiron 20 (1987): 179-202.

Gould, Carol S. "A Puzzle about the Possibility of Aristotelian enkrateia." Phronesis 39 (1994): 174-186.

Goulet-Cazé, Marie-Odile. L'ascèse cynique: un commentaire de Diogène Laërce VI 70-71. 2d ed. Paris: J. Vrin, 2001.

Grabbe, Lester L. Etymology in Early Jewish Interpretation: The Hebrew Names in Philo. Atlanta: Scholars Press, 1988.

."Hellenistic Judaism." Pages 53-83 in Historical Syntheses. Part 2 of Judaism in Late Antiquity. Edited by Jacob Neusner. Handbook of Oriental Studies 16. Leiden: Brill, 1995.

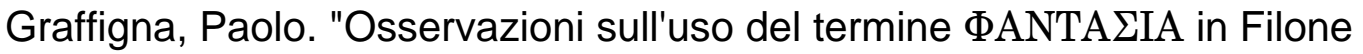
d'Alessandria." Koinonia 16 (1992): 5-19.

Grant, Robert M. "Dietary Laws among Pythagoreans, Jews, and Christians." Harvard Theological Review 73 (1980): 299-310. 
Graver, Margaret. "Philo of Alexandria and the Origins of the Stoic

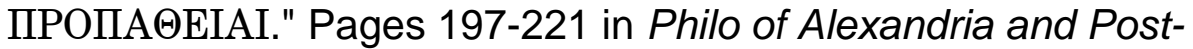
Aristotelian Philosophy. Edited by Francesca Alesse. Studies in Philo of Alexandria 5. Leiden: Brill, 2008. Repr. from Phronesis 44 (1999): 300325.

Groß, Josef. Philons von Alexandreia Anschauungen über die Natur des Menschen. Inaugural Dissertation, University of Tübingen, 1930.

Hackforth, R. Plato's Examination of Pleasure. Cambridge: Cambridge University Press, 1945.

Hadas-Lebel, Mireille. Philon d'Alexandrie: un penseur en diaspora. Paris: Fayard, 2003.

Hadot, Pierre. "La philosophie antique: une éthique ou une pratique?" Pages 737 in Problèmes de la morale antique. Edited by Paul Demont. Amiens: Université de Picardie-Jules Verne, 1993. . "Spiritual Exercises." Pages 81-125 in Philosophy as a Way of Life: Spiritual Exercises from Socrates to Foucault. Edited by Arnold Davidson. Translated by Michael Chase. Oxford: Blackwell, 1995.

Hahm, David E. "The Ethical Doxography of Arius Didymus." Aufstieg und Niedergang der römischen Welt 36.4:2935-3055, 3234-3243 [indices]. Part 2, Principat, 36.4. Edited by H. Temporini and W. Haase. New York: de Gruyter, 1990.

Halperin, David M. "Platonic Erôs and What Men Call Love." Ancient Philosophy 5 (1985): 161-204.

. "Plato and the Metaphysics of Desire." Proceedings of the Boston Area Colloquium in Ancient Philosophy 5 (1989): 27-52.

Hammerton-Kelly, Robert G. "Sources and Traditions in Philo Judaeus." Studia Philonica 1 (1972): 3-26.

Hankinson, James. "Galen's Anatomy of the Soul." Phronesis 36 (1991): 197233.

. "Actions and Passions: Affection, Emotion, and Moral SelfManagement in Galen's Philosophical Psychology." Pages 184-222 in Passions and Perceptions. Edited by J. Brunschwig and M. Nussbaum. Cambridge, 1992. 
Harl, Marguerite. "Adam et les deux arbres du paradis (Gen. II-III) ou

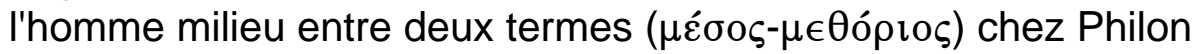
d'Alexandrie." Recherches de science religieuse 50 (1962): 321-388.

Harris, Harold A. "The Foot-Rests in Hippolytus' Chariot." Classical Review 18 (1968): 259-260.

. Greek Athletics and the Jews. Trivium: Special Publications 3. Cardiff: University of Wales Press, 1976.

Harris, William V. Restraining Rage: The Ideology of Anger Control in Classical Antiquity. Cambridge: Harvard University Press, 2001.

Hay, David M. "The Psychology of Faith in Hellenistic Judaism." Aufstieg und Niedergang der römischen Welt 20.2:881-925. Part 2, Principat, 20.2. Edited by H. Temporini and W. Haase. New York: de Gruyter, 1987.

. "Philo of Alexandria." Pages 357-379 in The Complexities of Second Temple Judaism. Vol. 1 of Justification and Variegated Nomism. Edited by D. A. Carson, Peter T. O'Brien, and Mark A. Seifrid. Grand Rapids: Baker Academic, 2001.

Hayward, C.T.R. "Philo, the Septuagint of Genesis 32:24-32 and the Name 'Israel': Fighting the Passions, Inspiration and the Vision of God." Journal of Jewish Studies 51 (2000): 209-226

Hecht, Richard D. "Preliminary Issues in the Analysis of Philo's De Specialibus Legibus." Studia Philonica 5 (1978): 1-56.

. "Patterns of Interpretation in Philo's Interpretation of Leviticus." Studia Philonica 6 (1979-80): 77-155.

Heckel, Theo K. Der innere Mensch: die paulinische Verarbeitung eines platonischen Motivs. Wissenschaftliche Untersuchungen zum Neuen Testament 53, 2d series. Tübingen: J.C.B. Mohr, 1993.

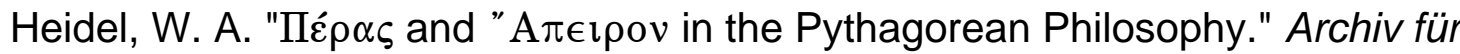
Geschichte der Philosophie 14 (1901): 384-399.

Heil, Christoph. Die Ablehnung der Speisegebote durch Paulus: Zur Frage nach der Stellung des Apostels zum Gesetz. Bonner biblische Beiträge 96. Weinheim: Beltz Athenäum, 1994. 
Heinemann, Isaak. Philons griechische und jüdische Bildung;

Kulturvergleichende Untersuchungen zu Philons Darstellung der jüdischen Gesetze. Darmstadt: Wissenschafgtliche Buchgesellschaft, 1962.

Herrmann, Johannes. "Das zehnte Gebot." Pages 69-82 in Sellin-Festschrift: Beiträge zur Religionsgeschichte und Archäologie Palästinas Ernst Sellin zum 60. Geburtstage dargebracht. Leipzig: Deichert, 1927.

Hijmans, B. L. " $A \Sigma K H \Sigma I \Sigma$ : Notes on Epictetus' Educational System. Wijsgerige Teksten en Studies 2. Assen: Von Gorcum, 1959. . "Posidonius' Ethics." Acta Classica 2 (1959): 27-42.

Himbaza, Innocent. Le Décalogue et l'histoire du texte: Etudes des formes textuelles du Décalogue et leurs implications dans l'histoire du texte de l'Ancien Testament. Orbis biblicus et orientalis 207. Fribourg: Academic Press, 2004.

Hoek, Annewies van den. Clement of Alexandria and His Use of Philo in the Stromateis: An Early Christian Reshaping of a Jewish Model. Supplements to Vigiliae Christianae 3. Leiden: Brill, 1988.

Hoffman, Paul. "Plato on Appetitive Desires in the Republic." Apeiron 36 (2003): 171-174.

Houston, Walter J. "Towards an Integrated Reading of the Dietary Laws of Leviticus." Pages 142-161 in The Book of Leviticus: Composition and Reception. Edited by Rolf Rendtorff and Robert A. Kugler. Supplements to Vetus Testamentum 93: Formation and Interpretation of Old Testament Literature 3. Leiden: Brill, 2003.

Hunter, David G. "The Language of Desire: Clement of Alexandria's Transformation of Ascetic Discourse." Pages 95-111 in Discursive Formations, Ascetic Piety and the Interpretation of Early Christian Literature. Part 1. Semeia 57. Edited by Vincent L. Wimbush. Atlanta: Scholars Press, 1992.

Hursthouse, Rosalind. "Plato on the Emotions." Proceedings of the Aristotelian Society Supplementary Volume 58 (1984): 81-96.

Ingenkamp, Heinz Gerd. Plutarchs Schriften über die Heilung der Seele. Hypomnemata: Untersuchungen zur Antike und zu ihrem Nachleben 34. Göttingen: Vandernhoeck \& Ruprecht, 1971. 
Inwood, Brad. Ethics and Human Action in Early Stoicism. New York: Oxford University Press, 1985.

. "Seneca and Psychological Dualism." Pages 150-183 in Passions and Perceptions. Edited by J. Brunschwig and M. Nussbaum. Cambridge, 1992.

and Pierluigi Donini. "Stoic Ethics." Pages 675-738 in The Cambridge History of Hellenistic Philosophy. Edited by Keimpe Algra, Jonathan Barnes, Jaap Mansfeld, and Malcolm Schofield. Cambridge: Cambridge University Press, 1999.

Jackson, Bernard S. "Liability for Mere Intention in Early Jewish Law." Pages 202-34 in Essays in Jewish and Comparative Legal History. Studies in Judaism in Late Antiquity 10. Edited by Jacob Neusner. Leiden: Brill, 1975.

Jastram, Daniel N. "Philo's Concept of Generic Virtue." Ph.D. diss., University of Wisconsin—Madison, 1989.

. "Philo's Concept of Generic Virtue." Pages 323-347 in Society of Biblical Literature 1991 Seminar Papers. Edited by Eugene H. Lovering. Society of Biblical Literature Seminar Papers Series 31. Atlanta, Ga.: Scholars Press, 1991.

Johansen, Thomas. "Body, Soul, and Tripartition in Plato's Timaeus." Oxford Studies in Ancient Philosophy 19 (2000): 87-111.

Jones, C. P. "The Teacher of Plutarch." Harvard Studies in Classical Philology 71 (1967): 205-213.

Kahn, Charles H. "Plato's Theory of Desire." Review of Metaphysics 41 (1987): 77-103.

Kellerman, Ulrich. "Der Dekalog in den Schriften des Frühjudentums." Pages 147-226 in Weisheit, Ethos, und Gebot: Weisheits- und Dekalogtraditionen in der Bibel und im frühen Judentum. Edited by Henning Graf Reventlow. Biblisch-Theologische Studien 43. Neukirchen-Vluyn: Neukirchener, 2001.

Keyser, Paul T. "Orreries, the Date of [Plato] Letter ii, and Eudoros of Alexandria." Archiv für Geschichte der Philosophie 80 (1998): 241-267. 
Kidd, I. G. "Posidonius on Emotions." Pages 200-215 in Problems in Stoicism. Edited by A. A. Long. London: Athlone Press, 1971.

Kirk, Kenneth E. The Vision of God: The Christian Doctrine of the Summum Bonum. New York: Harper \& Row, 1966.

Kittel, G., and G. Friedrich, eds. Theological Dictionary of the New Testament. Translated by G. W. Bromiley. 10 vols. Grand Rapids: Eerdmans, 19641976.

Klauck, Hans-Josef. 4. Makkabäerbuch. Jüdische Schriften aus hellenistischrömischer Zeit 3.1. Edited by Hermann Lichtenberger et al. Gütersloh: Gerd Mohn, 1989.

Klosko, George. "The 'Rule' of Reason in Plato's Psychology." History of Philosophy Quarterly 5 (1988): 341-356.

Knuth, Werner. Der Begriff der Sünde bei Philon von Alexandria. Inaugural Dissertation, University of Jena, 1934.

Knuuttila, Simo, and Juha Sihvola. "How the Philosophical Analysis of the Emotions was Introduced." Pages 1-19 in The Emotions in Hellenistic Philosophy. Edited by Juha Sihvola and Troels Engberg-Pedersen. New Synthese Historical Library 46. Dordrecht: Kluwer Academic Publishers, 1998.

Kornfeld, Walter. "Reine und unreine Tiere im alten Testament." Kairos 7 (1965): 134-147.

Kuntz, Paul Grimley. "Philo Judaeus: A Decalogue in Balance." Pages 11-26 in The Ten Commandments in History: Mosaic Paradigms for a WellOrdered Society. Edited by Thomas d'Evelyn. Emory University Studies in Law and Religion. Grand Rapids: Eerdmans, 2004.

Lamberton, Robert. Homer the Theologian: Neoplatonist Allegorical Reading and the Growth of the Epic Tradition. Berkeley: University of California Press, 1986.

Le Boulluec, Alain. "La place des concepts philosophiques dans la réflexion de Philon sur le plaisir." Pages 129-152 in Philon d'Alexandrie et le langage de la philosophie: actes du colloque international organisé par le Centre d'études sur la philosophie hellénistique et romaine de l'Université de Paris XII-Val de Marne, Créteil, Fontenay, Paris, 26-28 octobre 1995. Edited by Carlos Lévy. Turnhout: Brepolis, 1998. 
Lebeck, Anne. "The Central Myth of Plato's Phaedrus." Greek, Roman and Byzantine Studies 13 (1972): 267-290.

Leighton, Stephen R. "Aristotle and the Emotions." Pages 248-278 in Aristotle's Ethics. Edited by Terrence Irwin. Classical Philosophy: Collected Papers 5. New York: Garland, 1995. Repr. from Phronesis 27 (1982): 144-174.

. "The Value of the Passions in Plato and Aristotle." Southwest Philosophy Review 11 (1995): 41-56.

Leipoldt, Johannes. Griechische Philosophie und früchristliche Askese. Berichte über die Verhandlungen der Sächsischen Akademie der Wissenschaften zu Leipzig, philologisch-historische Klasse 106, part 4. Berlin: AkademieVerlag, 1961.

Lévy, C. "Le concept de doxa des Stoïciens à Philon d'Alexandrie: essai d'étude diachronique." Pages 250-284 in Passions and Perceptions. Edited by J. Brunschwig and M. Nussbaum. Cambridge, 1992.

. "Deux problèmes doxographiqes chez Philon d'Alexexandrie:

Posidonius et Enésidème." Pages 79-102 in Philosophy and Doxography of the Imperial Age. Edited by Aldo Brancacci. Accademia Toscana di Scienze e Lettere "La Colombaria": Studi 228. Florence: Leo S. Olschki, 2005.

. "Philon d'Alexandrie et les passions." Pages 27-41 in Réceptions antiques: lecture, transmission, appropriation intellectuelle. Edited by Lætitia Ciccolini, Charles Guérin, Stéphane Itic, and Sébastien Morlet. Études de littérature ancienne 16. Paris: Éditions Rue d'Ulm, 2006.

. "Philo's Ethics." Pages 146-171 in The Cambridge Companion to Philo. Cambridge: Cambridge University Press, 2009.

Lilla, Salvatore. Clement of Alexandria: A Study in Christian Platonism and Gnosticism. Oxford Theological Monographs. London: Oxford University Press, 1971.

Lluch Baixauli, Miguel. "El tratado de Filón sobre el Decálogo." Scripta Theologica 29 (1997): 415-441.

Loader, William. "The Decalogue." Pages 5-25 in The Septuagint, Sexuality, and the New Testament: Case Studies on the Impact of the LXX in Philo and the New Testament. Grand Rapids, Mich.: Eerdmans, 2004. 
Löhr, Hermut. "Speisenfrage und Tora im Judentum des Zweiten Tempels und im entstehenden Christentum." Zeitschrift für die Neutestamentliche Wissenschaft 94 (2003): 17-37.

Lohse, Bernard. Askese und Mönchtum in der Antike und in der alten Kirche. Religion und Kultur der alten Mittelmeerwelt in Parallelforschungen 1. Edited by Carsten Colpe and Heinrich Dörrie. Munich and Vienna: R. Oldenbourg, 1969.

Long, Anthony A. "Hellenistic Ethics and Philosophical Power." Pages 138-156 in Hellenistic History and Culture. Edited by Peter Green. Hellenistic Culture and Society 9. Edited by A. Bulloch, E. Gruen, A. A. Long, and F. Stewart. Berkeley: University of California Press. 1993.

. "Aristotle's Legacy to Stoic Ethics." Pages 378-391 in Aristotle's Ethics. Edited by Terrence Irwin. Classical Philosophy: Collected Papers 5. New York: Garland, 1995. Repr. from Institute of Classical Studies Bulletin 15 (1968): 72-85.

. "Soul and Body in Stoicism." Phronesis 27 (1982): 34-57. Repr. pages 154-177 in Hellenistic Philosophy. Edited by Terence Irwin. Philosophy: Collected Papers 8. New York: Garland, 1995. Repr. pages 224-249 in Stoic Studies. Cambridge: Cambridge University Press, 1996.

. "Stoic Psychology." Pages 560-584 in The Cambridge History of Hellenistic Philosophy. Edited by Keimpe Algra, Jonathan Barnes, Jaap Mansfeld, and Malcolm Schofield. Cambridge: Cambridge University Press, 1999.

. "Philo on Stoic Physics." Pages 121-140 in Philo of Alexandria and Post-Aristotelian Philosophy. Edited by Francesca Alesse. Studies in Philo of Alexandria 5. Leiden: Brill, 2008.

Lorenz, Hendrik. "Desire and Reason in Plato's Republic." Oxford Studies in Ancient Philosophy 27 (2004): 83-116.

. The Brute Within: Appetitive Desire in Plato and Aristotle. Oxford Philosophical Monographs. Oxford: Oxford University Press, 2006.

Lugo, Wolfgang Gil. "El vicioso deseo del tirano platónico." Apuntes Filosóficos 15 (1999): 9-22. 
Lyonnet, S. "'Tu ne convoiteras pas' (Rom. vii 7)." Pages 157-165 in Neotestamentica et Patristica: Eine Freundesgabe, Herrn Professor Dr. Oscar Cullmann zu seinem 60. Geburtstag überreicht. Supplements to Novum Testamentum 6. Leiden: Brill, 1962.

Mack, Burton L. "Philo Judaeus and Exegetical Traditions in Alexandria." Aufstieg und Niedergang der römischen Welt 21.1:227-271. Part 2, Principat, 21.1. Edited by H. Temporini and W. Haase. New York: de Gruyter, 1984.

Malherbe, Abraham. "The Beasts at Ephesus." Journal of Biblical Literature 87 (1968): 71-80.

. "Antisthenes and Odysseus, and Paul at War." Harvard Theological Review 76 (1983): 143-173.

Martens, John W. "Philo and the 'Higher Law.'" Pages 309-321 in Society of Biblical Literature 1991 Seminar Papers. Edited by Eugene H. Lovering. Society of Biblical Literature Seminar Papers Series 31. Atlanta, Ga.: Scholars Press, 1991.

. "Unwritten Law in Philo: A Response to Naomi G. Cohen." Journal of Jewish Studies 43 (1992): 38-45.

. One God, One Law: Philo of Alexandria on the Mosaic and GrecoRoman Law. Studies in Philo of Alexandria and Mediterranean Antiquity 2. Boston: Brill Academic Publishers, 2003.

Massebieau, Louis, and Émile Bréhier. "Essai sur la chronologie de la vie et des œvres de Philon." Revue de l'histoire des religions 53 (1906): 25-64.

Mattila, Sharon Lea. "Wisdom, Sense Perception, Nature, and Philo's Gender Gradient." Harvard Theological Review 89 (1996): 103-129.

Mealand, David L. "Philo of Alexandria's Attitude to Riches." Zeitschrift für die neutestamentliche Wissenschaft 69 (1978): 258-264.

Méasson, Anita. Du char ailé de Zeus à l'Arche d'Alliance: Images et mythes platoniciens chez Philon d'Alexandrie. Paris: Études Augustiniennes, 1987.

Mendelson, Alan. Philo's Jewish Identity. Brown Judaic Studies 161. Atlanta, Ga.: Scholars Press, 1988. 
Metzner, Rainer. "Paulus und der Wettkampf: Die Rolle des Sports in Leben und Verkündigung des Apostels (1 Kor 9.24-7; Phil 3.12-16)." New Testament Studies 46 (2000): 565-583.

Milgrom, Jacob. "The Biblical Diet Laws as an Ethical System." Pages 104118 in Studies in Cultic Theology and Terminology. Studies in Judaism in Late Antiquity 36. Leiden: Brill, 1983. Repr. from Interpretation 17 (1963): 288-301.

. "Ethics and Ritual: The Foundations of the Biblical Dietary Laws." Pages 159-191 in Religion and Law: Biblical-Judaic and Islamic Perspectives. Edited by Edwin B. Firmage, Bernard G. Weiss, and John W. Welch. Winona Lake: Eisenbrauns, 1990.

Miller, F. D. "Plato on the Parts of the Soul." Pages 48-65 in Plato's Middle Period: Psychology and Value Theory. Vol. 3 of Plato: Critical Assessments. Edited by Nicholas D. Smith. London: Routledge, 1998.

Moehring, Horst R. "Arithmology as an Exegetical Tool in the Writings of Philo of Alexandria." Pages 141-176 in The School of Moses: Studies in Philo and Hellenistic Religion: In Memory of Horst R. Moehring. Atlanta, Ga.: Scholars Press, 1995.

Mondésert, C. "Philo of Alexandria." Pages 877-900 in The Early Roman Period. Edited by William Horbury, W. D. Daview, and John Sturdy. Vol. 3 of The Cambridge History of Judaism. Cambridge: Cambridge University Press, 1999.

Montgomery, James A. "Ascetic Strains in Early Judaism." Journal of Biblical Literature 51 (1932): 183-213.

Moravcsik, J. M. E. "Reason and Eros in the 'Ascent'-Passage of the Symposium." Pages 285-302 in Essays in Ancient Greek Philosophy. Edited by John P. Anton and George L. Kustas. Albany: State University of New York Press, 1971.

Moreau, Pierre-François. "Les passions: continuités et tournants." Pages1-12 in Les passions antiques et médiévales. Edited by Bernard Besnier, Pierre-François Moreau, and Laurence Renault. Paris: Presses universitaires de France, 2003.

Moreschini, Claudio. "Considerazioni sulla dottrina del pathos nel Medioplatonismo." Studi filosofici 8-9 (1985-86): 23-33. 
Morris, Jenny. "The Jewish Philosopher Philo." Pages 809-889 in Emil Schürer, The History of the Jewish People in the Age of Jesus Christ (175 B.C.-A.D. 135): A New English Version Revised and Edited by Geza Vermes, Fergus Millar, and Martin Goodman. Vol. 3, part 2. Edinburgh: T\&T Clark, 1987.

Moskala, Jirí. "Categorization and Evaluation of Different Kinds of Interpretation of the Laws of Clean and Unclean Animals in Leviticus 11." Biblical Research 46 (2001): 5-41.

Moss, Jessica. "Pleasure and Illusion in Plato." Philosophy and Phenomenological Research 72 (2006): 503-535

Myre, André. "La loi dans l'ordre moral selon Philon d'Alexandrie." Science et esprit 23 (1971): 93-113.

. "La loi et le Pentateuque selon Philon d'Alexandrie." Science et esprit 25 (1973): 209-225.

. "Les caractéristiques de la loi mosaïque selon Philon d'Alexandrie." Science et esprit 27 (1975): 35-69.

. "La loi de la nature et la loi mosaïque selon Philon d'Alexandrie." Science et esprit 28 (1976): 163-181.

Napolitano, Linda M. "Il Platonismo di Eudoro: tradizione protoaccademica e medioplatonismo Alessandrino." Museum Patavinum 3 (1985): 27-49.

Newmyer, Stephen T. "Philo on Animal Psychology: Sources and Moral Implications." Pages 142-155 in From Athens to Jerusalem: Medicine in Hellenized Jewish Lore and in Early Christian Literature: Papers of the Symposium in Jerusalem, 9-11 September 1996. Edited by Samuel Kottek, Manfred Horstmanshoff, Gerhard Baader, and Gary Ferngren. Pantaleon Reeks 33. Rotterdam: Erasmus Publishing, 2000.

Niehoff, Maren R. Philo on Jewish Identity and Culture. Texte und Studien zum antiken Judentum 86. Tübingen: Mohr Siebeck, 2001.

Nikiprowetzky, Valentin. Le commentaire de l'écriture chez Philon d'Alexandrie. Arbeiten zur Literatur und Geschichte des hellensitischen Judentums 11. Leiden: Brill, 1977. 
North, Helen. Sophrosyne: Self-knowledge and Self-restraint in Greek Literature. Cornell Studies in Classical Philology 35. Ithaca: Cornell University Press, 1966.

Nussbaum, Martha. "Plato on Commensurability and Desire." Proceedings of the Aristotelian Society Supplementary Volume 58 (1984): 55-80.

. "Therapeutic Arguments and Structures of Desire." Differences: $A$ Journal of Feminist Cultural Studies 2 (1990): 46-66.

. The Therapy of Desire: Theory and Practice in Hellenistic Ethics. Princeton: Princeton University Press, 1994.

Olphe-Galliard, Michel. "Ascèse, Ascétisme: II. — Développement Historique." Columns 938-60 in vol. 1 of Dictionnaire de spiritualité. Edited by Marcel Viller. 16 vols. Paris: G. Beauchesne, 1937.

Opsomer, Jan. "L'âme du monde et l' âme de l'homme chez Plutarque." Pages 33-49 in Estudios sobre Plutarco: Ideas religiosas: Actas del III Simposio Internacional sobre Plutarco, Oviedo 30 de abril a 2 de mayo de 1992. Edited by Manuela García Valdés. Madrid: Ediciones Clásicas, 1994.

. "Plutarch's Platonism Revisited." Pages 163-200 in L'eridità platonica: studi sul platonismo da Arcesilao a Proclo. Edited by Mauro Bonazzi and Vincenza Celluprica. Elenchos 45. Naples: Bibliopolis, 2005.

Palumbo, Lidia. "Sull'ottavo e il nono libro della Repubblica: A proposito della natura del desiderio." Pages 60-87 in Eros, Phobos, Epithymia: Sulla natura dell'emozione in alcuni dialoghi di Platone. Napoli: Loffredo, 2001.

Papathomas, Amphilochios. "Das agonistishce Motiv 1 Kor 9.24 ff. Im Spiegel zeitgenössischer dokumentarischer Quellen." New Testament Studies 43 (1997): 223-241.

Pearce, Sarah J.K. The Land of the Body: Studies in Philo's Representation of Egypt. Wissenschaftliche Untersuchungen zum Neuen Testament 208. Tübingen: Mohr Siebeck, 2007.

Pelletier, A. "Les passions à l'assaut de l'âme d'après Philon." Revue des études grecques 78 (1965): 52-60.

Peters, F. E. Greek Philosophical Terms: A Historical Lexicon. New York: New York University Press, 1967. 
Pfitzner, Victor C. Paul and the Agon Motif: Traditional Athletic Imagery in the Pauline Literature. Supplements to Novum Testamentum 16. Leiden: Brill, 1967

Phillips, Thomas E. "Revisiting Philo: Discussions of Wealth and Poverty in Philo's Ethical Discourse." Journal for the Study of the New Testament 83 (2001): 111-121.

Pohlenz, Max. Philon von Alexandreia. Nachrichten von der Akademie der Wissenschaften in Göttingen 5. Göttingen: Vandenhoeck \& Ruprecht, 1942.

Poliakoff, Michael. "Jacob, Job, and Other Wrestlers: Reception of Greek Athletics by Jews and Christians in Antiquity." Journal of Sport History 11 (1984): 48-65.

Poplutz, Uta. Athlet des Evangeliums: Eine motivgeschichtliche Studie zur Wettkampfmetaphorik bei Paulus. Herders Biblische Studien 43. Freiburg im Breisgau: Herder, 2004.

Rabbow, Paul. Seelenfürung: Methodik der Exerzitien in der Antike. München: Kösel, 1954.

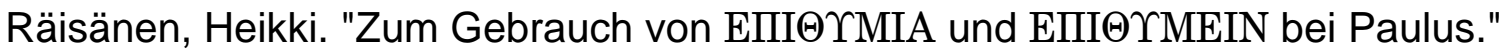
Studia Theologica 33 (1979): 85-99.

Ranocchia, Graziano. "Moses against the Egyptian: The Anti-Epicurean Polemic in Philo." Pages 75-102 in Philo of Alexandria and Post-Aristotelian Philosophy. Edited by Francesca Alesse. Studies in Philo of Alexandria 5. Leiden: Brill, 2008.

Reale, Giovanni. "Philo of Alexandria and Mosaic Philosophy." Pages 169204 in A History of ancient Philosophy. Vol. 4. Edited and translated by J.R. Catan. Albany: State University of New York Press, 1990.

Rees, D. A. "Bipartition of the Soul in the Early Academy." Journal of Hellenic Studies 77 (1957): 112-118.

Reinhartz, Adele. "The Meaning of Nomos in Philo's Exposition of the Law." Sciences religieuses 15 (1986): 337-345.

. "Philo's Exposition of the Law and Social History: Methodological Considerations." Pages 6-21 in Society of Biblical Literature 1993 Seminar Papers. Edited by Eugene H. Lovering. Society of Biblical Literature Seminar Papers Series 32. Atlanta, Ga.: Scholars Press, 1993. 
Reydams-Schils, Gretchen. "Posidonius and the Timaeus: Off to Rhodes and Back to Plato?" Classical Quarterly 47 (1997): 455-476.

. "Philo of Alexandria on Stoic and Platonist Psycho-Physiology: The Socratic Higher Ground." Pages 169-195 in Philo of Alexandria and PostAristotelian Philosophy. Edited by Francesca Alesse. Studies in Philo of Alexandria 5. Leiden: Brill, 2008. Repr. from Ancient Philosophy 22 (2002): 125-147.

Rhodes, James N. "Diet as Morality: Tracing an Exegetical Tradition." M.A. thesis, Catholic University of America, 2000.

. "Diet and Desire: The Logic of the Dietary Laws According to Philo." Ephemerides Theologicae Lovanienses 79 (2003): 122-133.

Rofé, Alexander. "The Tenth Commandment in the Light of Four Deuteronomic Laws." Pages 45-65 in The Ten Commandments in History and Tradition. Edited by Ben-Zion Segal and Gershon Levi. Jerusalem: Magnes Press, 1990.

Romilly, Jacqueline de. "Les conflits de l'âme dans le Phèdre de Platon." Wiener Studien 16 (1982): 100-113.

Rosen, Stanley. "The Role of Eros in Plato's Republic." Review of Metaphysics 18 (1965): 452-475.

Roskam, Geert. On the Path to Virtue: The Stoic Doctrine of Moral Progress and its Reception in (Middle-) Platonism. Ancient and Medieval Philosophy 33. Leuven: Leuven University Press, 2005.

Runia, David T. Philo of Alexandria and the Timaeus of Plato. Philosophia Antiqua 44. Leiden: Brill, 1986.

. "How to Read Philo." Pages 185-198 in Exegesis and Philosophy: Studies on Philo of Alexandria. Collected Studies 332. Aldershot, Hampshire; Brookfield, Vt.: Variorum, 1990.

. "Philo, Alexandrian and Jew." Pages 1-18 in Exegesis and Philosophy: Studies on Philo of Alexandria. Collected Studies 332. Aldershot, Hampshire; Brookfield, Vt.: Variorum, 1990. 
. "Redrawing the Map of Early Middle Platonism: Some Comments on the Philonic Evidence." Pages 85-104 in Hellenica et Judaica:

hommage à Valentin Nikiprowetzky. Edited by A. Caquot, M. Hadas-lebel, and J. Riaud. Leuven: Peeters, 1986. Repr. in Exegesis and Philosophy: Studies on Philo of Alexandria. Collected Studies 332. Aldershot, Hampshire; Brookfield, Vt.: Variorum, 1990.

. "Witness or Participant? Philo and the Neoplatonic Tradition." Pages 36-56 in The Neoplatonic Tradition: Jewish, Christian and Islamic Themes. Edited by Arie Johan Vanderjagt and Detlev Pätzold. Köln: Dinter, 1991. 112-140.

"Was Philo a Middle Platonist?" Studia Philonica Annual 5 (1993):

. "Why Does Clement Call Philo "The Pythagorean?'" Pages 54-76 in Philo and the Church Fathers: A Collection of Papers. Supplements to Vigiliae Christianae 32. Leiden: Brill, 1995. Repr. from Vigiliae Christianae 49 (1995): 1-22.

. "A Brief History of the Term Kosmos Noétos from Plato to Plotinus." Pages 151-171 in Traditions of Platonism: Essays in Honour of John Dillon. Edited by John J. Cleary. Aldershot: Ashgate, 1999.

. "Philon d'Alexandrie devant le Pentateuque." Pages 99-105 in Le Pentateuque d'Alexandrie: text grec et traduction. Edited by Cécile Dogniez and Marguerite Harl. Paris: Cerf, 2001.

. Review of Kathy L. Gaca, The Making of Fornication. Studia Philonica Annual 17 (2005): 237-243.

. "Etymology as an Allegorical Technique in Philo of Alexandria." Studia Philonica Annual 15 (2004): 101-121.

Sand, Alexander. Der Begriff "Fleisch" in den paulinischen Hauptbriefen. Biblische Untersuchungen 2. Regensburg: Pustet, 1967.

Sanders, E. P. Jewish Law from Jesus to the Mishnah: Five Studies. London: SCM Press; Philadelphia: Trinity Press International, 1990.

Sandmel, Samuel. "Confrontation of Greek and Jewish ethics: Philo: De Decalogo." Pages 163-176 in Judaism and Ethics. Edited by Daniel J. Silver. New York: Ktav, 1970. 
. "Virtue and Reward in Philo." Pages 217-223 in Essays in Old Testament ethics (J. Philip Hyatt, in memoriam). Edited by James L. Crenshaw and John T. Willis. New York: Ktav, 1974.

. "Philo Judaeus: An Introduction to the Man, his Writings, and his Significance." Aufstieg und Niedergang der römischen Welt 21.1:3-46. Part 2, Principat, 21.1. Edited by H. Temporini and W. Haase. New York: de Gruyter, 1984.

Sandnes, Karl Olav. Belly and Body in the Pauline Epistles. Society for New Testament Studies Monograph Series 120. Cambridge: Cambridge University Press, 2002.

Santas, Gerasimos. "Passionate Platonic Eros in the Phaedrus." Pages 58-80 in Plato and Freud: Two Theories of Love. Oxford: Basil Blackwell, 1988.

. "Plato's Theory of Eros in the Symposium." Pages 14-57 in Plato and Freud: Two Theories of Love. Oxford: Basil Blackwell, 1988.

Satlow, Michael L. "Philo on Human Perfection." Journal of Theological Studies 59 (2008): 500-19.

Schibli, Hermann S. "Xenocrates' Daemons and the Irrational Soul." Classical Quarterly 43 (1993): 143-167.

Schmidt, Helmut. Die Anthropologie Philons von Alexandreia. Würzburg: Konrad Triltsch, 1933.

Schofer, Jonathan Wyn. The Making of a Sage: A Study in Rabbinic Ethics. Madison: University of Wisconsin Press, 2005.

Schweizer, Eduard. "Die hellenistische Komponente im neutestamentlichen

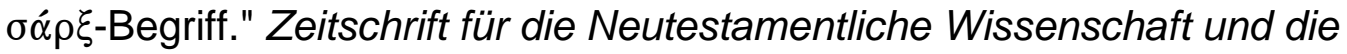
Kunde der älteren Kirche 48 (1957): 237-253.

Seland, Torrey. "The Moderate Life of the Christian paroikoi: A Philonic Reading of 1 Pet 2:11." Pages 241-264 in Philo und das Neue Testament: Wechselseitige Wahrnehmungen: I. Internationales Symposium zum Corpus Judaeo-Hellenisticum 1.-4. Mai 2003, Eisenach/Jena. Edited by Roland Deines and Karl-Wilhelm Niebuhr. Wissenschaftliche Untersuchungen zum Neuen Testament 172. Tübingen: Mohr Siebeck, 2004. 
Sheridan, Mark. "Jacob and Israel: a Contribution to the History of an Interpretation." Pages 219-41 in Mysterium Christi: Symbolgegenwart und theologische Bedeutung. Edited by M. Löhrer and Elmar Salmann. Studia Anselmiana 116. Roma: Pontificio Ateneo S. Anselmo, 1995.

Sherman, Nancy. "The Habituation of Character." Pages 231-260 in Aristotle's Ethics: Critical Essays. Edited by Nancy Sherman. Critical Essays on the Classics. Lanham, Md.: Rowman \& Littlefield, 1999.

Siegfried, Carl. Philo von Alexandria als Ausleger des Alten Testament. Jena: Hermann Dufft, 1875.

Sihvola, Juha. "Emotional Animals: Do Aristotelian Emotions Require Beliefs?" Pages 50-82 in Psychology and Ethics. Edited by Lloyd P. Gerson. Vol. 3 of Aristotle: Critical Assessments. London: Routledge, 1999.

Sissa, Giulia. "Du desir insatiable au plaisir captive." Pages 33-48 in Religion et tabou sexuel. Edited by Jacques Marx. Problèmes d'histoire des religions I/1990. Bruxelles: Editions de l'Université de Bruxelles, 1990.

Sorabji, Richard. "Chrysippus-Posidonius-Seneca: A High-Level Debate on Emotion." Pages 149-169 in The Emotions in Hellenistic Philosophy. Edited by Juha Sihvola and Troels Engberg-Pedersen. New Synthese Historical Library 46. Dordrecht: Kluwer Academic Publishers, 1998.

. Emotion and Peace of Mind: From Stoic Agitation to Christian Temptation: The Gifford Lectures. Oxford: Oxford University Press, 2000.

. "The Mind-Body Relation in the Wake of Plato's Timaeus." Pages 152-162 in Plato's Timaeus as Cultural Icon. Edited by Gretchen J. Reydams-Schils. Notre Dame: University of Notre Dame Press, 2003.

Spanneut, Michel. "Apatheia ancienne, apatheia chrétienne. Ière partie: L'apatheia ancienne." Aufstieg und Niedergang der römischen Welt 36.7: 4641-4717. Part 2, Principat, 36.7. Edited by W. Haase and H. Temporini. New York: de Gruyter, 1994.

Stamm, Johann Jakob. The Ten Commandments in Recent Research. Translated by M.E. Andrew. 2d ed. Studies in Biblical Theology 2. Naperville, III.: Allenson, 1967.

Stein, S. "The Dietary Laws in Rabbinic and Patristic Literature." Studia Patristica 2 (1957): 141-154. 
Stemberger, Günter. "Der Dekalog im frühen Judentum." Pages 91-103 in Gesetz als Thema Biblischer Theologie. Jahrbuch für Biblische Theologie 4. Neukirchen-Vluyn: Neukirchener Verlag, 1989.

Sterling, Gregory E. "Platonizing Moses: Philo and Middle Platonism." Studia Philonica Annual 5 (1993): 96-111.

. "'The School of Sacred Laws': The Social Setting of Philo's Treatises." Vigiliae Christianae 53 (1999): 148-164.

. "'The Queen of the Virtues': Piety in Philo of Alexandria." Studia Philonica Annual 18 (2006): 103-123

Stevens, John A. "Preliminary Impulse in Stoic Psychology." Ancient Philosophy 20 (2000): 139-168.

Stowers, Stanley K. A Rereading of Romans: Justice, Jews, and Gentiles. New Haven: Yale University Press, 1994.

. "Paul and Self-Mastery." Pages 524-550 in Paul in the GrecoRoman World: A Handbook. Edited by J. Paul Sampley. Harrisburg, Pa.: Trinity Press International, 2003.

Teodorsson, Sven-Tage. "The Psycholgy of De Facie and De Virtute Morali." Pages 115-122 in Estudios sobre Plutarco: Ideas religiosas: Actas del III Simposio Internacional sobre Plutarco, Oviedo 30 de abril a 2 de mayo de 1992. Edited by Manuela García Valdés. Madrid: Ediciones Clásicas, 1994.

Terian, Abraham. "A Philonic Fragment on the Decad." Pages 175-182 in Nourished with Peace: Studies in Hellenistic Judaism in Memory of Samuel Sandmel. Edited by Frederick E. Greenspahn, Earle Hilgert, and Burton L. Mack. Homage Series. Chico, Calif.: Scholars Press, 1984.

. "Some Stock Arguments for the Magnanimity of the Law in Hellenistic Jewish Apologetics." Jewish Law Association Studies 1 (1985): 141-149.

Termini, Cristina. "Taxonomy of Biblical Laws and $\Phi I \Lambda$ OTEXNIA in Philo of Alexandria: A Comparison with Josephus and Cicero." Studia Philonica Annual 16 (2004): 1-29.

. "Philo's Thought within the Context of Middle Judaism." Pages 95-123 in The Cambridge Companion to Philo. Cambridge: Cambridge University Press, 2009. 
Theiler, Willy. "Philo von Alexandria und der Beginn des kaiserzeitlichen Platonismus." Pages 484-501 in Untersuchungen zur antiken Literatur. Berlin: de Gruyter, 1970. Repr. from pages 199-218 in Parusia: Studien zur Philosophie Platons und zur Problemgeschichte des Platonismus: Festgabe für J. Hirschberger. Edited by Kurt Flasch. Frankfurt/Main: Minerva, 1965.

. "Philo von Alexandria und der hellenisierte Timaeus." Pages 52-63 in Der Mittelplatonismus. Edited by Clemens Zintzen. Wege der Forschung 70. Darmstadt : Wissenschaftliche Buchgesellschaft, 1981. Repr. from pages 27-35 in Philomathes: Studies and Essays in the Humanities in Memory of Philip Merlan. Edited by Robert B. Palmer and Robert H. Kelly. The Hague: Nijhoff, 1971.

Thesleff, Holger. "Notes on Eros in Middle Platonism." Arctos 28 (1994): 115128.

Tobin, Thomas H. The Creation of Man: Philo and the History of Interpretation. Catholic Biblical Quarterly Monograph Series 14. Washington: Catholic Biblical Association of America, 1983.

. "Was Philo a Middle Platonist? Some Suggestions." Studia Philonica Annual 5 (1993): 147-150.

. Paul's Rhetoric in Its Contexts: The Argument of Romans. Peabody, Mass.: Hendrickson, 2004.

Turowski, Edmund. Die Widerspiegelung des stoischen Systems bei Philon von Alexandreia. Inaugural Dissertation, University of Königsberg, 1927.

Vaage, Leif E. and Vincent L. Wimbush, ed. Asceticism and the New Testament. New York: Routledge, 1999.

Valantasis, Richard. "Constructions of Power in Asceticism." Journal of the American Academy of Religion 63 (1995): 775-821.

. "Musonius Rufus and Roman Ascetical Theory." Greek, Roman, and Byzantine Studies 40 (1999): 207-231.

Vander Waerdt, P. A. "The Peripatetic Interpretation of Plato's Tripartite

Psychology." Greek, Roman and Byzantine Studies 26 (1985): 283-302.

. "Peripatetic Soul-Division, Posidonius, and Middle Platonic Moral Psychology." Greek, Roman and Byzantine Studies 26 (1985): 373-394. 
. "Aristotle's Criticism of Soul-Division." American Journal of Philology 108 (1987): 627-643.

Vian, Giovanni Maria. "Purità e culto nell'esegesi giudaico-ellenistica." Annali di storia dell'esegesi 13 (1996): 67-84.

Völker, Walther. Fortschritt und Vollendung bei Philo von Alexandrien: Eine Studie zur Geschichte der Frömmigkeit. Texte und Untersuchungen zur Geschichte der altchristlichen Literatur 49.1. Edited by Erich Klostermann and Carl Schmidt. Leipzig: J.C. Hinrichs, 1938.

Warnach, Walter. "Selbstliebe und Gottesliebe im Denken Philons von Alexandrien." Pages 198-214 in Wort Gottes in der Zeit: Festschrift Karl Hermann Schelkle zum 65.Geburtstag dargebracht von Kollegen, Freunden, Schülern. Edited by Helmut Feld and Josef Nolte. Düsseldorf: Patmos, 1973.

Warne, Graham J. Hebrew Perspectives on the Human Person in the Hellenistic Era: Philo and Paul. Mellen Biblical Press Series 35. Lewiston, N.Y.: Mellen Biblical Press, 1995.

Watson, Francis. Paul and the Hermeneutics of Faith. London: T \& T Clark, 2004.

Wasserman, Emma. The Death of the Soul in Romans 7. Wissenschaftliche Untersuchungen zum Neuen Testament 256. Tübingen: Mohr Siebeck, 2008.

Weber, Reinhard. "Eusebeia und Logismos: zum philosophischen Hintergrund von 4. Makkabäer." Journal for the Study of Judaism in the Persian, Hellenistic and Roman Period 22 (1991): 212-234.

. Das "Gesetz" bei Philon von Alexandrien und Flavius Josephus: Studien zum Verständnis und zur Funktion der Thora bei den beiden Hauptzeugen des hellenistischen Judentums. Arbeiten zur Religion und Geschichte des Urchristentums 11. Edited by Gerd Lüdemann. Frankfurt am Main: Lang, 2001.

Wedderburn, A. J. M. "The 'Apostolic Decree': Tradition and Redaction." Novum Testamentum 35 (1993): 362-89.

Weinfeld, Moshe. "The Decalogue: Its Significance, Uniqueness, and Place in Israel's Tradition." Pages 3-47 in Religion and Law: Biblical-Judaic and Islamic Perspectives. Edited by Edwin B. Firmage, Bernard G. Weiss, and John W. Welch. Winona Lake: Eisenbrauns, 1990. 
Wendland, Paul. "Philo und die kynisch-stoische Diatribe." Pages 1-75 in Beiträge zur Geschichte der griechischen Philosophie und Religion. Berlin: Georg Reimer, 1895.

West, Martin L. Ancient Greek Music. Oxford: Oxford University Press, 1994.

Whitchurch, Irl Goldwin. The Philosophical Bases of Asceticism in the Platonic Writings and in Pre-Platonic Tradition. Cornell Studies in Philosophy 14. New York: Longmans, Green \& Co., 1923.

Whittaker, John. "Ammonius on the Delphic E." Classical Quarterly 19 (1969): 185-192.

. "Platonic Philosophy in the Early Centuries of the Empire." Aufstieg und Niedergang der römischen Welt 36.1: 81-123. Part 2, Principat, 36.1. Edited by W. Haase and H. Temporini. New York: de Gruyter, 1987.

. "The Terminology of the Rational Soul in the Writings of Philo of Alexandria." Studia Philonica Annual 8 (1996): 1-20.

Williamson, Ronald. Jews in the Hellenistic World: Philo. Cambridge

Commentaries on Writings of the Jewish and Christian World, $200 \mathrm{BC}$ to AD 200 1.2. Cambridge: Cambridge University Press, 1989.

Wimbush, Vincent L. "Sophrosyne: Greco-Roman Origins of a Type of Ascetic Behavior." Pages 89-102 in Gnosticism and the Early Christian World: In Honor of James M. Robinson. Edited by James E. Goehring, Charles W. Hedrick, Jack T. Sanders, with Hans Dieter Betz. Forum Fascicles. Sonoma, Ca.: Polebridge Press, 1990.

Winston, David. Introduction to Philo of Alexandria: The Contemplative Life, The Giants, and Selections. Translated with an introduction by David Winston. Classics of Western Spirituality. Mahwah, N.J.: Paulist, 1981.

. "Philo's Ethical Theory." Aufstieg und Niedergang der römischen Welt 21.1:372-416. Part 2, Principat, 21.1. Edited by $\mathrm{H}$. Temporini and W. Haase. New York: de Gruyter, 1984.

. "Philo and the Contemplative Life." Pages 198-231 in Jewish Spirituality : From the Bible through the Middles Ages. Edited by Arthur Green. World Spirituality: An Encyclopedic History of the Religious Quest 13. New York : Crossroad, 1986.

141-146.

. "Response to Runia and Sterling." Studia Philonica Annual 5 (1993): 
. "Hellenistic Jewish Philosophy." Pages 11-32 in The Ancestral

Philosophy: Hellenistic Philosophy in Second Temple Judaism: Essays of David Winston. Edited by Gregory E. Sterling. Brown Judaic Studies 331. Studia Philonica Monographs 4. Providence, R.I.: Brown Judaic Studies, 2001. Repr. from Routledge History of World Philosophies 2 (1997): 3861.

. "Philo and the Rabbis on Sex and the Body." Pages 199-219 in The Ancestral Philosophy: Hellenistic Philosophy in Second Temple Judaism: Essays of David Winston. Edited by Gregory E. Sterling. Studia Philonica Monographs 4. Brown Judaic Studies 331. Providence: Brown Judaic Studies, 2001.

. "Philo of Alexandria on the Rational and Irrational Emotions." Pages 201-220 in Passions and Moral Progress in Greco-Roman Thought. Edited by John T. Fitzgerald. New York: Routledge, 2008.

Wolfson, Harry Austryn. Philo: Foundations of Religious Philosophy in Judaism, Christianity, and Islam. 2 vols. $2 \mathrm{~d}$ rev. print.; Structure and Growth of Philosophic Systems from Plato to Spinoza 2. Cambridge, Mass.: Harvard University Press, 1948.

Ziesler, J. A. "The Role of the Tenth Commandment in Romans 7." Journal for the Study of the New Testament 33 (1988): 41-56.

Zeller, Dieter. Charis bei Philon und Paulus. Stuttgarter Biblestudien 142. Stuttgart: Verlag Katholisches Bibelwerk, 1990. 
VITA

Hans Svebakken grew up in Davenport, lowa. Before attending Loyola University Chicago, he earned a Bachelor of Arts in Theology (1994), summa cum laude, from Concordia University Chicago, where he minored in Biology. At Loyola, he first earned a Master of Arts in Ancient Greek (1999), receiving a distinction award on his comprehensive translation exam. He then earned a Master of Arts in Biblical Languages and Literature (2001) before entering the doctoral program in New Testament and Early Christianity. After completing coursework, Hans received the Pre-Doctoral Teaching Scholar Award (2002 2003) and the Arthur J. Schmitt Dissertation Fellowship (2004 - 2005). 